
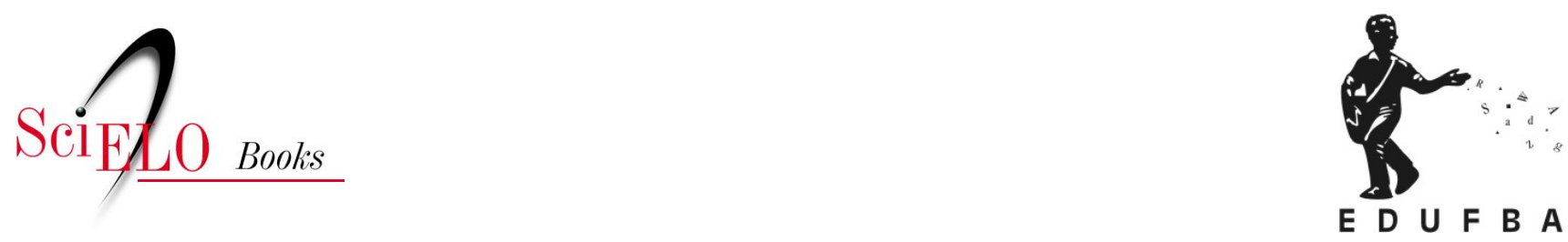

\title{
As donas do canto \\ o sucesso das estrelas-intérpretes no carnaval de Salvador
}

\author{
Marilda Santanna
}

\section{SciELO Books / SciELO Livros / SciELO Libros}

SANTANNA, M. As donas do canto: o sucesso das estrelas-intérpretes no carnaval de Salvador [online]. Salvador: EDUFBA, 2009. 488 p. ISBN 978-85-2320-885-1. Available from SciELO Books

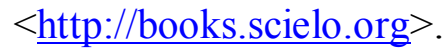

\section{(2)(1)(2)}

All the contents of this chapter, except where otherwise noted, is licensed under a Creative Commons Attribution-Non Commercial-ShareAlike 3.0 Unported.

Todo o conteúdo deste capítulo, exceto quando houver ressalva, é publicado sob a licença Creative Commons Atribuição Uso Não Comercial - Partilha nos Mesmos Termos 3.0 Não adaptada.

Todo el contenido de este capítulo, excepto donde se indique lo contrario, está bajo licencia de la licencia Creative Commons Reconocimento-NoComercial-Compartirlgual 3.0 Unported. 


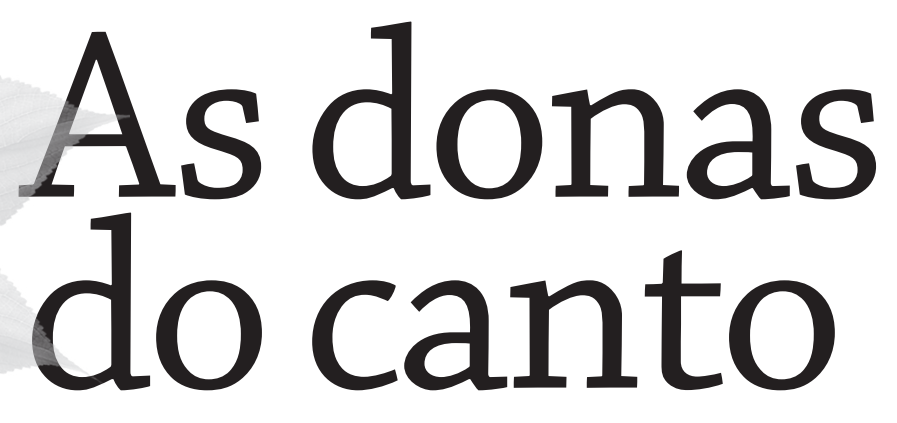

O sucesso das estrelas-intérpretes no Carnaval de Salvador 
UNIVERSIDADE FEDERAL DA BAHIA

Reitor

Naomar Monteiro de Almeida Filho

Vice Reitor

Francisco José Gomes Mesquita

EDITORA DA UNIVERSIDADE FEDERAL DA BAHIA

Diretora

Flávia Goullart Mota Garcia Rosa

CONSELHO EDITORIAL

Titulares

Ângelo Szaniecki Perret Serpa

Caiuby Alves da Costa

Charbel Ninõ El-Hani

Dante Eustachio Lucchesi Ramacciotti

José Teixeira Cavalcante Filho

Maria do Carmo Soares Freitas

Suplentes

Alberto Brum Novaes

Antônio Fernando Guerreiro de Freitas

Armindo Jorge de Carvalho Bião

Evelina de Carvalho Sá Hoisel

Cleise Furtado Mendes

Maria Vidal de Negreiros Camargo

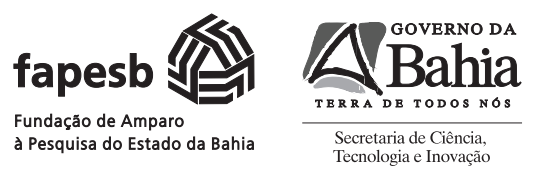


MARILDA SANTANNA

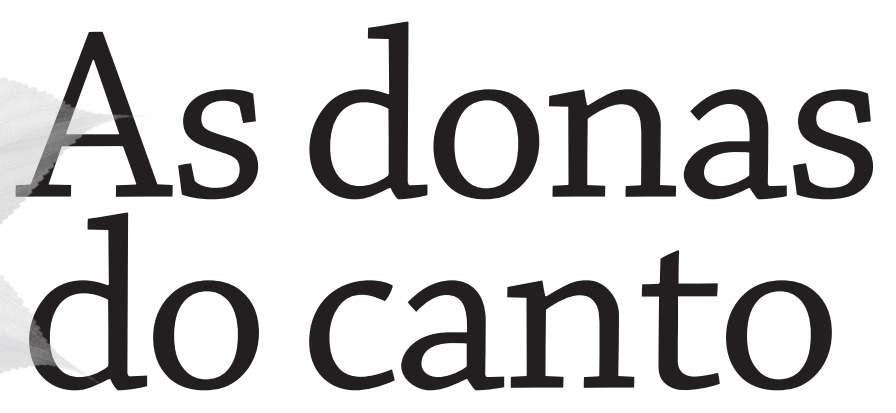

O sucesso das estrelas-intérpretes no Carnaval de Salvador

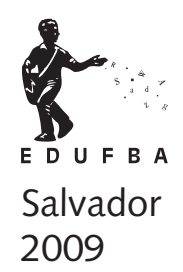


(C) 2009, by autor

Direitos para esta edição cedidos à EDUFBA.

Feito o depósito legal.

PROJETO GRÁFICO, CAPA \& DIAGRAMAÇÃO

Genilson Lima Santos

REVISÃO DE TEXTO

Cida Lopes

Cristiane Porto

Sistema de Bibliotecas - UFBA

Santanna, Marilda.

As donas do canto : o sucesso das estrelas-intérpretes no carnaval de Salvador / Marilda Santanna. - Salvador : EDUFBA, 2009.

488 p. : il.

ISBN 978-85-232-0625-3

1. Mercury, Daniela, 1965- 2. Menezes, Margareth, 1962- 3. Sangalo, Ivete, 1972- 4. Música - Salvador (BA) - Anos 1980. 5. Axé-Music. 6. Cantoras. 7. Empresários artísticos. 8. Carnaval - Salvador (BA). 9. Música - Influência. I. Título.

Editora filiada à:

\section{exex} de America Latina y it Caril $x$.

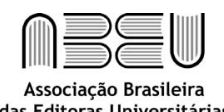

das Editoras Universitárias
$\mathrm{CBaL}$

EDUFBA Rua Barão de Jeremoabo, s/n Campus de Ondina, Salvador - Bahia CEP 40170115 Tel/fax 7132836164 www.edufba.ufba.br edufba@ufba.br 
Dedico este trabalho a todas as intérpretes brasileiras que me ajuda(ra)m através dos seus trinados a compreender as diferenças e singularidades da música nacional. 


\section{AGRADECIMENTOS}

Amigos, professores, funcionários e instituições foram muito importantes para que este processo se concretizasse. Entre eles, o meu orientador Milton Moura pelo carinho, paciência e compreensão em todos os momentos e os professores do Programa, Antônio Câmara e Cecília Sardenberg.

Às amigas e companheiras de todas as horas: Cláudia Santana (amiga-irmã), Chris Georges, Eveline Abreu e Carlos Barros pela ajuda inestimável ao enriquecimento deste trabalho. A Cida Lopes e Cris Porto, pela criteriosa revisão com comentários e sugestões. Duas novas amigas entram para o meu rol.

A Asa Branca, Marquinho de Carvalho, Márcio Dhiniz e Neto Costa pela cumplicidade com a música;

À FAPESB pelo financiamento da bolsa que muito me ajudou no decorrer da pesquisa.

Às produtoras Canto da Cidade e sua equipe atenciosa e respeitosa nas pessoas de Daniela Mercury, Kitty Mercury, Clínio Bastos, Muriel, Valter, Fabiana Santana, Lícia Fábio e Nil Pereira, Marcelo Dantas (um príncipe) e aos músicos de Daniela e demais funcionários; à Central de Produções e a Margareth Menezes e equipe pela atenção; a todos os membros de fãs-clubes que me concederam entrevistas, bem como material para coleta de dados a exemplo de Janaina e Juliana Wândega.

A todos os artistas que me concederam entrevistas para o enriquecimento luminoso do trabalho e, principalmente, aos espíritos e mentores que muito me ajuda(ra)m neste percurso.

À Nina, Tuca e Cristiano pelo carinho e pela vibração em todos os momentos, o meu agradecimento especial.

A meus Pais Geonildo e Aurelina, referência de vida 
Já estou até vendo Meu nome brilhando E o mundo aplaudindo Ao me ver cantar Ao me ver passar I wanna be a star!

Rádio, televisão, revistas, muito mais, ah Meu rosto, meu sorriso, à venda nos jornais Paris Match, N.Y.Times, Look, Life, BBC of London ....

Abram alas Eu vou passar Sucesso, aqui vou eu! Abram alas I wanna be a star! Sucesso, aqui vou eu! Sucesso, aqui vou eu! Ah!

Sucesso aqui vou eu (Build up) Rita Lee e Arnaldo Baptista 


\section{Sumário}

Prefácio 15

\section{Primeiros acordes 15}

2 A formação da estrela na cena musical de Salvador a partir da década de oitenta 29

Troféu Caymmi: fábrica de talentos 30

Outras fábricas 36

Panorama local para o surgimento da axé music $\quad 40$

Artistas na cena do Carnaval 43

Os blocos de trio e a organização empresarial do Carnaval 44

As puxadoras/vocalistas de blocos/bandas 52
As aspirantes a estrela 53
O construto da estrela 61

3 Bahia, Brasil, axé music 73

As estrelas: da Época de Ouro à era do DVD 74

A construção de uma referência baiana no contexto

da brasilidade 102

A figura da baiana 107 
As tias baianas no Rio de Janeiro 107

O Teatro de Revista - Oba! 113

Araci Cortes, ou simplesmente, Linda Flor 122

Carmen Miranda: a Pequena Notável 128

Quem é mesmo a baiana consagrada na ribalta? 137

A representação da figura da baiana pelos compositores 143

A axé music e a construção de uma identidade cultural

baiana/brasileira 152

\section{Aspectos artísticos, técnicos e profissionais na construção da carreira das} estrelas/intérpretes da axé music 171

Aspectos propriamente artísticos: o artista como intérprete e criador 175

As intérpretes e seus músicos, arranjadores e diretores musicais 189

Empresários e produtores culturais: os intermediários

da cultura 196

As donas do canto 210

Os patrocinadores 219

A mídia 223

O público: fãs-clubes 230

O talento e o sucesso musical como cartão-postal 249

\section{A singularidade das intérpretes 259}

Daniela Mercury: uma voz que dança 262

A branquinha mais neguinha da Bahia 269

A rainha da axé music 281 
Sou de qualquer lugar: a cor do som 287

O Carnaval eletrônico da Rainha 296

Clássica: o retorno 299

Margareth Menezes: a força que vem da Terra 306

Maga: o senso de justiça 321

Afropopbrasileira 327

O Carnaval e o bloco Os Mascarados 331

Afropopbrasileiro: o bloco 335

A trajetória de Ivete Sangalo: liberdade na voz dela que ecoa 337

De vocalista a empresária 338

A sorte grande de (piri)guete Sangalo 348

O eu-mercadoria 358

O canto barroco da axé music: Daniela, Margareth e Ivete 372

6 Acordes finais 397

Lista de abreviaturas $\quad 411$

Referências 413

Anexos 431 


\section{Prefácio}

Prezado leitor, anuncio uma novidade. O trabalho de Marilda Santanna acrescenta um traço novo ao estudo das práticas musicais e empresariais associadas ao Carnaval de Salvador. Nos últimos vinte anos, um bom número de pesquisadores tem procurado oferecer, ao público constituído de acadêmicos, curiosos e fãs, aportes diferenciados a este acervo. O item que vinha predominando, tendo desacelerado um pouco nos últimos anos, é a dimensão étnica desses processos. Outro item de destaque é aquele referido às questões administrativas, organizacionais e técnicas. Nos últimos anos, o conceito de identidade também tem sido uma tentação quase inevitável, ensejando a produção de não poucos ensaios sobre diferentes processos de construção identitária em torno da grande festa dos baianos.

Este trabalho inaugura um enfoque no cenário acima resumido. Trata-se das três estrelas que se construíram na recente história do nosso Carnaval. Carnaval que já transita nos circuitos pop. A cultura carnavalesca mantém interseções com outras dinâmicas musicais, empresariais, mercadológicas, propagandísticas. A cantora de Carnaval não é mais somente cantora de Carnaval. É uma operária de sua própria divinização, zeladora permanente de seu próprio estrelato.

Diversas discussões poderiam ser desdobradas então. Integrando-se ao mundo da grande mídia, dos grandes negócios, o perfil dessas artistas não estaria condenado a ser determinado pela engrenagem do sucesso? Onde estaria, então, a originalidade e a autenticidade da intérprete? Restaria que espaço para que pudesse ser verdadeira? 
Aos efeitos de enfrentar estes desafios, a empreitada de Marilda Santanna se baseia em artes múltiplas. A sombra benfazeja de Edgard Morin lhe conferiu um instrumento especial na condução de tantos relatos, tantos cadernos de campo, tantas leituras. E a compreensão da carreira da estrela vai se construindo, então, a partir de três trajetórias muito singulares. Baianas, carnavalescas, brasileiras, midiáticas.

As três carreiras se confundem, num certo sentido, com a história da axé music. Esta vertente poderosa da música produzida na Bahia para o verão e o Carnaval, nos anos oitenta, vai se desdobrar, nos anos noventa, em uma diversidade maior de formas musicais para o entretenimento e a diversão. No século XXI, a axé music já não se refere tanto à cidade que a engendrou, alcançando considerável autonomia com relação às temáticas iniciais. É um nicho da música produzida no Brasil que vibra, juntamente com outras tradições locais e regionais no mundo inteiro, em frequências que vêm conectá-la com a música do mundo. Não somente aquela do Terceiro Mundo. O pop é universalizado a partir de Elvis Presley e a própria classificação dos mundos em Primeiro e Terceiro fica relativizada diante de sucessos como Elton John, Michael Jackson e Madonna. Mais ainda quando se observa a história recente do funk e do hip hop.

Para botar tudo isto no papel, Marilda Santanna revisitou trajetórias de intérpretes de diversas origens e épocas. Manteve-se próxima das gregas, espanholas, portuguesas e outras brasileiras que se faziam baianas no palco, reconstruindo a cada vez a saga da baiana que Manuel Antônio de Almeida já reporta no Rio de Janeiro de D. João VI. Além dessas baianas todas, a autora acompanhou cuidadosamente as carreiras de Araci Cortes e Carmem Miranda. Estas viagens vêm ajudar o leitor a compreender a arte dessas cantoras como recriações do repertório a elas associado. A grande cantora recria a canção, confere-lhe um toque especial que permanece como máscara colada à face.

Quando se aproxima das três estrelas do Carnaval de Salvador, a autora já disse que a intérprete não pode não ser singular. Até mesmo para se inserir exitosamente na máquina pop do sucesso, é preciso ser original, coincidir consigo mesma enquanto se modifica constan- 
temente. Nesta dinâmica de diversos pólos, um deles é o tipo de fã que a intérprete não apenas cativa e constrói, como também satisfaz e contempla. Afinal, que dia mesmo aconteceu uma estrela sem suas legiões de fãs?

Cada uma dessas estrelas acontece neste livro, então, como num palco em que cada pormenor tem o papel de revelá-la inteira. A autora é figurinista, iluminadora, contra-regra, técnica vocal. Gostaria de concluir esta breve entrada com uma suposição. Marilda Santanna manteve uma relação privilegiada com as intérpretes que estuda no seu livro. Primeiro, porque também é cantora, conhece o mundo do palco, do sucesso, da relação com empresários, produtores, fãs, jornalistas. Por outro lado, como cantora de outros estilos musicais, pôde apreciar a cena estudada, que corresponde à axé music, com o saudável recurso da alteridade e da distância técnica. Intérprete de MPB, especialista no repertório de Tom Jobim e dos autores que o têm como referência, Marilda aproxima-se do seu objeto de pesquisa sem com ele se confundir. Permite, assim, que o leitor possa chegar bem perto da cena das carreiras de Ivete Sangalo, Margareth Menezes e Daniela Mercury, alcançando uma nitidez visual que os melhores telões não conseguem passar, uma acuidade sonora que os melhores microfones ficam a dever aos públicos. Somos aqui convidados especiais que, junto às cortinas do sucesso, podemos gozar de tudo isto bem de pertinho. Prezado leitor, fique à vontade para conferir.

Milton Moura 


\section{1 \\ Primeiros acordes}

As estrelas o são porque aprendemos a chamá-las com este nome e nos habituamos a este procedimento? Afirmamos que são estrelas em função de determinadas características? São todas iguais? Quem sabe, diferem no tamanho ou na intensidade do brilho... Afinal, o que é mesmo uma estrela? De onde vem seu brilho? Como se mantêm? E quando já não se mantêm com a mesma intensidade? Esse brilho tem fim? Questões como estas ocuparam sábios e cientistas por séculos. Referimo-nos, neste livro, a um tipo de estrela. De certa forma, próximo, porquanto podemos vê-la com relativa facilidade. Por outro lado, muito distante, já que subsiste como estrela em virtude de sua singularidade brilhante, até ofuscante, por vezes.

Este texto trata das estrelas da axé music, das estrelas da música do Carnaval de Salvador. Estudamos sua participação na construção de um tipo de representação da sociedade baiana, entendendo aí a Bahia como a capital e seu Recôncavo, que alcançou notável visibilidade nas últimas décadas, e que vem sendo chamada, tanto na mídia como no próprio campo acadêmico, de baianidade.

Estão entrelaçadas e interatuantes, aqui, a axé music e a baianidade. Sendo assim, é importante desde já assinalar a participação especial, insubstituível - no proscênio mesmo do processo - das estrelas/intérpretes do/no Carnaval. A maneira como se difundem as imagens - entendendo-se aí imagens em sentido amplo, de referências iconográficas - da Bahia inclui freqüentemente a cena do Carnaval. Aí, suas estrelas comparecem à frente. E pode-se afirmar também que é com estas suas estrelas que a Bahia se perfila no panteão da brasilidade. 
As estrelas/intérpretes Daniela Mercury, Margareth Menezes e Ivete Sangalo podem representar, de maneira singular, modelos a serem seguidos na mídia e fora delas? Esta pergunta, que toca o núcleo do tema do livro, será construída progressivamente. Ora, é o desempenho dessas artistas diante de seus grandes públicos e o sucesso que aí se realiza que arremata e dá sentido a toda uma malha de possibilidades, circunstâncias, definições e projetos.

Desde este capítulo introdutório, ao mesmo tempo em que estará sendo construído o objeto, elementos da metodologia comparecerão à página, incluindo o anúncio das diversas discussões com os autores que contribuem para o desenvolvimento da reflexão. A metodologia consistirá, portanto, no estabelecimento de uma interface fecunda destas discussões, na busca da construção de um aparelho conceitual que permita colocar, da forma mais precisa e criativa possível, os termos do problema e as tentativas de solução.

Um trabalho que envolve práticas artísticas abarca fontes variadas. Tomamos como fontes principais discografias, entrevistas, matérias de jornais e revistas em meio impresso e eletrônico, fotografias, além do olhar atento aos desfiles, shows e ensaios nos carnavais de Salvador, de 2003 a 2007.

Passemos, então, às precisações, sendo que a maneira que pareceu mais adequada de dispô-las nesta Introdução é seguir aproximadamente a ordem em que as discussões respectivas são realizadas nos diversos capítulos do livro.

A primeira destas discussões remete ao que é o sucesso. Este pode ser entendido como um acontecimento, como um resultado exitoso, podendo ser aplicado a uma pessoa, artista ou autor de grande prestígio ou popularidade, ou ainda a um empreendimento ou obra que alcance grande êxito. Poderíamos nos perguntar, então: O que pode levar alguém ou algum empreendimento ao sucesso? Quais os fatores que o deflagram? Como o sucesso é construído, inventado, potencializado, mantido?

Assim, buscamos situar o sucesso das estrelas baianas no Carnaval como um ambiente que se descortina de forma multidimensional. E 
já nas primeiras páginas, tomamos como inspiração fundamental a interlocução com Edgar Morin (1989) - mais exatamente, sua construção do conceito de estrela.

Este corpo celeste dotado de luz própria se constitui como pessoa notável, como astro e enquanto fenômeno estético/artístico/ religioso a partir da "desteatralização" da representação. No entanto, esta desteatralização só se tornou possível com o desenvolvimento das técnicas e da câmera, que, de imóvel, passou a se locomover, levando assim o ator de cinema a se liberar dos limites da atuação teatral. Assim, a interpretação passou a ser uma técnica entre tantas outras que constituem o filme ou similar (montagem, fotografia, iluminação), que, juntas, possibilitaram a valorização de atributos e artifícios tais como beleza, jovialidade e dom, além de reforçar o processo de projeção-identificação que se estabelece entre público e personagem.

Por outro lado, a relação entre público e estrela é indissociável da noção de mito e mercadoria que se processa pelo entrelaçamento de vida real embebida do imaginário e do imaginário de vida real. Por sua vez, estas semidivindades só se tornam possíveis em sociedades modernizadas, urbanas, cujos aspectos podem ser compreendidos de forma multidimensional, de modo que possam se interrelacionar com os aspectos sócio-econômicos-culturais.

Heróis, astros, estrelas, reis e rainhas são expressões normalmente utilizadas pelos veículos de comunicação para se referirem àqueles que ocupam um lugar de destaque na realidade e na imaginação do mundo contemporâneo. Assim, o rei do futebol, a rainha dos baixinhos, as rainhas do rádio, a rainha da axé music, as estrelas de cinema e de TV são mitos da atualidade.

É importante situar a noção de mito na atualidade através da apreensão destas estrelas simultaneamente como mito e mercadoria, divinas e mortais, públicas e privadas, amadas como irmãs e desejadas como amantes. Estas estrelas singulares têm muito a dizer sobre a sociedade contemporânea baiana. Assim, para Morin (1989), quando se fala em mito da estrela, "trata-se, portanto, em primeiro lugar, do 
processo de divinização a que é submetido o ator de cinema, e que faz dele ídolo das multidões" (p. 26).

O presente livro não pretende discutir antropologicamente a noção de mito. $\mathrm{O}$ sentido do termo mito aqui apontado serve, tão somente, para ilustrar condutas e situações pelas quais passam estas estrelas na sociedade contemporânea. Os mitos da era tecnológica podem ser representados pelas estrelas veiculadas pelos meios de comunicação, tornando-se assim personagem central da narrativa. Então, ao ver a imagem destas estrelas/intérpretes nestes veículos, podemos afirmar que elas tornam-se mito diante de uma legião de fãs/ fiéis que as acompanham em suas diversas e diferentes aparições.

Diferentemente das narrativas míticas tradicionais, nas quais não é possível precisar as origens, a era das estrelas, no entanto, é historicamente determinada a partir de 1913, tanto dos Estados Unidos quanto na Europa, com a consolidação do star system. No Brasil, este fenômeno é deflagrado não só no cinema, com os padrões de beleza inicialmente norte-americano e posteriormente europeu, mas também nas companhias de revistas espanholas, portuguesas e francesas que aportavam principalmente no Rio de Janeiro, com suas vedetes inatingíveis ao contato físico, mas acessíveis aos olhos dos fãs.

Diversamente do mundo dos mitos das sociedades chamadas tradicionais, o mundo das estrelas é como um Olimpo, constituído pelos meios de comunicação; entretanto, aí o culto é profano, podendo se consubstanciar numa infinidade de objetos que vão desde um simples autógrafo, fotografias, bottoms, revistas, CD e DVD, sites, blogs etc.

Estas estrelas cinematográficas das quais trata Morin (1989) podem servir para construir estas singularidades com elementos importantes em sua composição como apontado anteriormente. Veremos como podemos caracterizar estas singularidades artísticas a partir destes elementos que serão depoimentos e fotos retirados de revistas, jornais, entrevistas, suas respectivas biografias, sites etc.

À luz do conceito da padronização-individuação-criação, Morin (1969) pretende dar conta de que nem a divisão do trabalho nem a padronização são em si obstáculos à individualização da obra. Ao con- 
trário, esta relação dialética desemboca numa superindividualidade representada pela figura da vedete. E estas vedetes se constituem em personalidades estruturadas e individualizadas ao mesmo tempo.

De forma análoga à afirmação de Morin $(1989 ; 1969)$ podemos observar que, no âmbito da cidade do Salvador - mais particularmente, do seu Carnaval -, a partir da segunda metade da década de 1980, se constitui num novo modelo de organização das práticas artísticas, contribuindo para uma nova configuração da indústria da música e do Carnaval e, conseqüentemente, para o aparecimento da estrelaintérprete neste ambiente.

A criação de diversos blocos carnavalescos e trios elétricos; atuações de órgãos públicos, sobretudo a criação da Empresa de Turismo da Bahia S/A - BAHIATURSA enquanto órgão estadual destinado a gerir as atividades do turismo e da Empresa de Turismo de Salvador - EMTURSA, enquanto seu correspondente municipal; a assimilação de novas condições tecnológicas que possibilitaram a subida dos tambores para o trio elétrico, impulsionado pelo aperfeiçoamento de captação do som dos instrumentos heteróclitos e da voz humana; a realização semanal dos ensaios dos blocos afro como celeiro de criação desta nova configuração; o desempenho da imprensa, que realiza a efemeridade e como que dá mais velocidade do acontecimento. Neste sentido, assim como "o cinema procura a vedete que une o arquétipo ao individual, a partir daí compreende-se que a vedete seja o melhor anti-risco da cultura de massa, e, principalmente, do cinema" (MORIN, 1969, p. 31).

No Carnaval de Salvador, procura-se, então, a puxadora dos blocos de Carnaval para dar conta da padronização-individuação deste novo modelo, com a ascensão da axé music. É o embrião do surgimento da estrela. Poder dar conta de uma jornada longa em cima dos trios animando foliões, e além dessa energia ser bela, jovem, ter punch, eram requisitos considerados importantes no recrutamento das puxadoras/ vocalistas desde aqueles anos.

Antes de se tornarem estrelas, porém, estas vocalistas carregavam em sua performance o nome do bloco e da banda, não se configurando 
nos moldes em que hoje conhecemos a estrela-intérprete. Eram vocalistas, ou ainda, puxadoras de bloco. Não se pode deixar de destacar a atuação de algumas vocalistas como Márcia Freire, que já carregava em sua performance elementos de estrela, com preocupações com o figurino, a forma física, a maquiagem e o trato com uma legião de fãs que participavam do bloco Cheiro de Amor, embalados pelos seus sucessos veiculados nas rádios locais. Contudo, o desenvolvimento da axé music e do Carnaval de Salvador passa a valorizar cada vez mais o papel da intérprete já "descolada" do bloco e da banda, o que aconteceu nítida e explosivamente com a ascensão da carreira solo de Daniela Mercury em 1991, quando se deu o sucesso do seu primeiro álbum solo.

É deste processo de estabelecimento da intérprete no Carnaval de Salvador que trata o capítulo 2. Abordam-se aí, também, as interrelações entre o artista e sua obra neste ambiente específico, da indústria da música do Carnaval e suas singularidades, bem como do panorama musical e fonográfico de Salvador no período.

Problematizar como o sucesso se estrutura numa sociedade contemporânea cujas características confluem de forma singular para o trânsito entre o tradicional e o moderno, é do que vai tratar o capítulo 3 .

Para compreender a construção desta estrela cujo perfil perseguimos, é preciso ir buscar seus anúncios desde as elaborações da figura da baiana no século XIX, por artistas não baianas e mesmo não brasileiras nos palcos dos teatros de revista da então Capital Federal. Ao longo deste século e meio, estes artistas e seus produtores nos aportam uma representação de sociedade baiana centrada em ícones de etnicidade, sensualidade e ancestralidade. Com efeito, a constituição de um perfil da nacionalidade brasileira na mídia e de um perfil da localidade (ou regionalidade) baiana toma como referência um dos elementos que ocupa o centro da cena, a figura da baiana.

Neste sentido, a figura da baiana merece já nesta Introdução uma rápida referência. A entrada desta figura na cena artística pode ser remetida ao gênero do teatro ligeiro - particularmente, a revista mu- 
sical República, na qual Arthur Azevedo, o autor, coloca em cena em 1889, o tango As laranjas de Sabina, inspirado no incidente policial envolvendo uma preta vendedora de laranjas (TINHORÃO, 1972, p.17), interpretado pela atriz e cantora grega Ana Manarezzi. É a referência mais antiga que temos, na ribalta, do tipo denominado baiana. A espanhola Pepa Ruiz também se tornou sucesso cantando o lundu Mungunzá, na figura da baiana levada pela revista portuguesa Tin tin por tin tin, em agosto de 1892. Entretanto, o que perpetuaria e internacionalizaria a figura da baiana seria a performance extraordinária de Carmem Miranda, interpretando o samba de Caymmi O que éque a baiana tem, quase 40 anos depois.

Não é demais sublinhar que, além da grega Ana Manarezzi, da espanhola Pepa Ruiz e da portuguesa Carmem Miranda, outras representantes "estrangeiras" desse novo tipo traduziram com graça, segundo a crítica da época, o que já se chamava de espírito baiano, com seus atributos tradicionais de malemolência, sensualidade, musicalidade, etc. Quanto às brasileiras, também se esmeravam na graça e picardia ao representar este tipo no teatro ligeiro. Dentre elas, destacamos aquela que serviu de inspiração para Carmem Miranda. Falamos de Araci Côrtes, a primeira artista brasileira a montar sua própria companhia, tornando-se, assim, empresária e artista de sucesso.

Além da figura da baiana que habitava este universo das revistas musicais, a música carnavalesca se fazia presente já ditando sucessos que viriam se difundir através do rádio que a processava industrialmente, diante de grandes públicos de consumidores, tornando-a assim popular e, como não é difícil de imaginar, sucesso no Carnaval. Podemos afirmar que a música popular brasileira, associada ao teatro ligeiro e ao rádio, construiu seu sucesso baseado na trilogia teatro/ Carnaval/rádio.

Voltando à música produzida para o Carnaval de Salvador a partir dos anos de 1980, observamos que fenômeno semelhante aconteceu ao associar a axé music à radiofonia, o que equivale a dizer: à tecnologia. A versão da sociedade baiana chamada baianidade é indissociável 
dessas intérpretes, porta-vozes da axé music. Assim, o ambiente do Carnaval de forma geral e a axé music e suas estrelas - Daniela Mercury, Margareth Menezes e Ivete Sangalo - nos servem de contexto para compreender como a figura destas artistas baianas/brasileiras correspondem a uma contínua (re)configuração, envolvendo tradição e modernidade e redimensionando o "lugar" da Bahia no concerto da brasilidade.

Os recursos teórico-metodológicos tomados nesta discussão correspondem a autores como Canclini (2003), com a dinâmica que chama de hibridismo, e Canevacci (1996), que por sua vez fala em sincretismo. A manipulação desses conceitos nesta pesquisa é temperada com os toques do sujeito múltiplo e descentrado de Stuart Hall (1992), cujo trânsito entre a tradição e a modernidade se delineia de forma multidimensional, por vezes complementar, jamais concluída.

Outro recurso relevante no estudo destas formações identitárias é o conceito de texto tal como formulado por Moura (2001). Para o autor, a baianidade pode ser percebida/estudada como um texto, o que pode ser compreendido no gerúndio (na acepção de tecimento) no particípio (na concepção de tecido) e no infinitivo (como numa tessitura). Sumarizando a baianidade como arranjo historicamente construído de referências identitárias, diz o autor: "Parece um arranjo tecido de familiaridade, religiosidade, sensualidade, reunindo os elementos mais díspares num sistema que se baseia justamente na adjacência do desigual, dita de forma aparentemente não problemática" (p.7).

Quanto à conceituação de Carnaval, o mesmo autor responde a estas indagações no sentido de tomá-lo "como o drama encenado de modo vário e desigual pela população de Salvador e os visitantes, turistas, jornalistas e outros que compõem o contingente de milhões de pessoas [...]”, ( p. 12). A própria montagem da sociedade baiana toma como uma referência de especial importância o seu Carnaval, que por sua vez se coloca como espetacularização da baianidade.

Outro item importante na discussão sobre os processos de construção de identidades, inclusive no caso particular de Salvador, é o próprio papel da mídia, sendo um elemento, especialmente, relevante 
às noções de pertencimento (KELLNER, 2001) em relação à classe, gênero, idade, geração e grupo étnico.

O capítulo 4 discute como a estrela-intérprete se constitui como criador e empresário - como criadora e empresária, no caso - no ambiente do Carnaval de Salvador. Aos efeitos de realizar esta discussão com rigor metodológico, buscamos conceitualizar o intérprete como um sujeito tomado como intermediário na compreensão entre indivíduos que falam idiomas diferentes; pode-se também definir intérprete como aquele que está sempre permutando, reformulando suas indagações e/ou convicções. Intérprete pode também ser considerado aquele que busca interpretar o outro ou mesmo uma obra que foi composta pelo outro (no caso uma canção, poesia, discurso), de maneira idiossincrática. Enfim, o intérprete pode ser considerado o mediador por definição e excelência.

No âmbito da música, o termo intérprete denomina tanto aquele ou aquela que canta/ interpreta, que leva ao público uma canção de forma singular, única, própria, e que não necessariamente é o/a autor/a da obra que interpreta.

Interpretar, por sua vez, nos conduz a uma visão aberta, particular, única, jamais solitária. Neste sentido é que destacamos a figura e o termo intérprete para dar conta de uma personagem/agente/ator social, ou, como queiramos denominá-lo, da forma como este indivíduo traduz o seu cantar em constante transformação por conta do espaço em que se relaciona e se move. Este mesmo intérprete se identifica em função da relação com os outros, configurando-se por vezes em arauto de uma classe (aqui, no sentido profissional - a profissão de músico), tendo como uma de suas funções intermediar, interpretar a enunciação do autor, do compositor. Este, por sua vez, imprime em sua obra sua forma de dizer, de ver o mundo, de se comunicar.

O artista como intérprete e criador, na acepção de Paul Zumthor, são "portadores da voz poética" (1993, p. 57). Estes portadores se estendem não somente a cantores, músicos, trovadores, menestréis, compositores, jogralescos, dentre outros detentores do dom da oratória; segundo o autor, 
[...] o que os define juntos, por heterogêneo que seja seu grupo, é serem (analogicamente, como os feiticeiros africanos de outrora) os detentores da palavra pública. É, sobretudo, a natureza do prazer que eles têm a vocação de proporcionar: o prazer do ouvido; pelo menos de que o ouvido é o órgão. O que fazem é o espetáculo (p. 57).

Estes cantores, recitadores e leitores, a depender do estilo de vida que levavam, se tornavam frágeis no modo como se inseria na ordem feudal ou urbana. Só cabia a estes profissionais "uma modalidade de integração social: a que se opera pelo lúdico" (ZUMTHOR, 1993, p. 66).

Podemos observar, com Zumthor, que estes profissionais intérpretes medievais carregam graus de similitude com o que costumamos denominar de intérprete da canção popular brasileira/baiana nos moldes da indústria da música contemporânea.

No Brasil, o construto desta nova intérprete pode ser reportado às transformações operadas no ambiente da música popular brasileira, principalmente a partir da década de 1920, quando da passagem da mudança do sistema de gravação mecânica para a gravação elétrica e do aparecimento e expansão do primeiro veículo de comunicação de massa - o rádio. No entanto, esta intérprete nos moldes em que a indústria cultural se constitui apresenta graus de similitude com a organização e formatação do teatro de revista (neste sentido, antes do advento do rádio e da televisão) no Brasil e na Europa (particularmente Portugal, Espanha e França).

O artista como intérprete criador nos leva a refletir sobre o próprio conceito de estrela (MORIN, 1969; 1989) e intérprete (ZUMTHOR, 1993), buscando uma interface entre ambos no sentido de compreender a construção de um artista que possa dialogar com o mercado da música sem sufocar o seu poder de criação, negociando assim sua carreira no sentido de poder ajustar, aparar, repensar, avançar, recuar, traçar estratégias de forma reflexiva, de maneira a poder gerenciar com sucesso a sua criação/criatividade num mercado competitivo e efêmero. 


\section{A formação da estrela na cena musical de Salvador: 1985-2007}

Salvador, na segunda metade da década de oitenta, poderia ser caracterizada por dois grandes mo(vi)mentos no campo da música: a ascensão da axé music em 1987 e o surgimento do projeto Troféu Caymmi em 1985. Estes mo(vi)mentos tinham objetivos distintos. O primeiro, devido ao grande avanço tecnológico e racionalização da cultura, oportunizou um diálogo bastante significativo em novas sínteses musicais propiciadas por experimentações de sonoridades e instrumentos heteróclitos, que, juntos fizeram surgir o que se convencionou denominar de axé music; este movimento foi proporcionado também pela fragmentação do processo produtivo da indústria fonográfica, terceirizando as etapas de gravação, fabricação e distribuição do produto (DIAS, 200o, p.17), ambientado no Carnaval.

O segundo, o Troféu Caymmi, surgiu num momento em que o ambiente musical de Salvador, neste período, se resumia a poucos artistas. Estes, imbuídos mais de idealismo do que propriamente de profissionalismo, se autoproduziam, mostrando um show por ano em palcos alternativos da cidade, tais como o Teatro do Instituto Cultural Brasil Alemanha - e o Teatro Vila Velha, que os recebiam normalmente tendo como público amigos, familiares e uns poucos admiradores que contribuíam de forma simbólica na compra do bilhete de entrada, cujo valor era repassado para os músicos que tocavam no show. 
A "noite", com bares cuja música ao vivo se fazia presente, também se constituía em espaço de circulação de artistas que durante o final de semana se apresentavam em espaços que alimentavam a chamada MPB, com formações que alternavam de voz e violão a bandas pequenas. Bares como Dama da Noite, Bilhostre, Luz de Velas, Vagão, Cheiro de Mar, no Rio Vermelho, e Canteiros, Caneco e Travessia, na Pituba, soam hoje como os mais representativos dessa época.

A música instrumental também se fazia presente com alguns grupos, tais como o Sexteto do Beco, o Raposa Velha e o Grupo Garagem, que se revezavam na cena instrumental baiana/soteropolitana, além do Festival de Música Instrumental, criado em 1982 pelos maestros Zeca Freitas e Fred Dantas, contando com o apoio insuficiente da Fundação Cultural do Estado e do Teatro Castro Alves, que cedia o espaço para o evento. O Festival não acontecia como um calendário anual; entretanto, proporcionava uma grande movimentação para a cena instrumental local, com músicos que se tornariam futuramente os grandes instrumentistas, arranjadores e diretores musicais dos maiores nomes da cena axé music, dentre tantos: Cesário Leone, baixista e diretor musical de Daniela Mercury; Letieres Leite, saxofonista e arranjador de Ivete Sangalo e de Daniela Mercury; Luciano Silva, diretor musical e saxofonista de Margareth Menezes; Alfredo Moura, tecladista, produtor e arranjador de outros grandes nomes da cena do axé.

Em linhas gerais, o Troféu Caymmi surge neste cenário.

\section{Troféu Caymmi: fábrica de talentos}

Diante deste quadro idealista e sem um mercado que pudesse alimentar esta produção "alternativa", o Caymmi foi idealizado em 1985 pelo compositor e violonista Tuca de Morais, que, insatisfeito pela falta de repercussão dos poucos shows apresentados em teatro, cria o projeto tendo como objetivo maior estimular, reconhecer e revelar a produção musical alternativa baiana, de forma a contemplar a di- 
versidade musical da cidade. Inicialmente, era premiada a modalidade show em diversas categorias, tais como: intérprete, instrumentista, arranjo, produção, diretor musical e composição; é a partir de 1988 que a modalidade disco passa a ser também premiada, devido ao crescimento da produção fonográfica local. Entretanto, segundo o seu idealizador,

[...] o objetivo maior do projeto no seu nascedouro (era) é estimular uma crítica musical nos jornais que circula(va)m na cidade, provocando uma curiosidade no âmbito da imprensa acerca do que se produz(ia) nos palcos da cidade na área musical' ${ }^{1}$.

O projeto dispunha de uma comissão julgadora - formada em sua grande maioria por jornalistas dos cadernos de cultura, além de músicos, poetas e produtores - eleita pela própria classe musical com duração de um ano, que acompanha(ria) os shows nos teatros e palcos alternativos da cidade.

Esta comissão assistia a todos os shows inscritos previamente na produtora do projeto Prisma Produções e contou durante dez anos de 1985 a 1995 - com o patrocínio da Companhia Petroquímica do Nordeste - COPENE (atual BRASKEM), num ato pioneiro de parceria empresa privada/projeto cultural, já que não se configurava em rotina patrocinar projetos culturais, pois as leis de incentivo em nível municipal ${ }^{2}$, estadual ${ }^{3}$ e federal ${ }^{4}$ ainda não existiam.

Sendo indicados, os artistas se apresentavam na Concha Acústica do Teatro Castro Alves, tendo no encerramento da noite uma grande atração nacional. Nomes como Tim Maia, Gilberto Gil, Alceu Valença, Paulinho da Viola, Joyce, Léo Gandelman, Ed Motta e Fernanda Abreu, dentre outros, passaram pelo projeto.

Além destes eventos semestrais, acontecia anualmente a entrega do prêmio na sala principal do Teatro Castro Alves, também com atrações nacionais de peso como Marisa Monte, Maria Bethânia, Caetano Veloso, a Família Caymmi (Nana, Danilo e Dory) e o mestre Dorival Caymmi, dentre outros. O prêmio (tinha) tem como símbolo uma estatueta $^{5}$ e a gravação do $\mathrm{CD}$ solo do melhor show. 
Dentre algumas premiadas na categoria intérprete, Margareth Menezes, Daniela Mercury e Ivete Sangalo, respectivamente em 1985, 1988 e 1992, revelam a importância do projeto em depoimentos a seguir. Ivete Sangalo pontua: "Eu não precisei, no início de minha carreira, gravar um disco para ser reconhecida nacionalmente. O Troféu Caymmi cumpriu o papel de me dar o devido respaldo"'. Daniela Mercury agradece o prêmio da seguinte maneira: "Obrigado Troféu Caymmi, o meu sucesso é o sucesso da Bahia, é o sucesso da nossa música. Que o Troféu Caymmi continue incentivando novos talentos, novos artistas, como me incentivou; meu orgulho é fazer parte dessa história"7. Por sua vez, Margareth Menezes diz: "Foi com o Troféu Caymmi de melhor intérprete no início do projeto que mudou muita coisa em minha carreira a nível de divulgação e apoio que eu recebi do mesmo"8.

Assim, estas intérpretes apontam a importância de terem sido premiadas pelo projeto, diferenciando, no entanto, o tipo de estímulo conferido pelo projeto em relação ao próprio mercado fonográfico, ratificado pelo cantor e compositor Gerônimo. "Eu fui um dos primeiros a concorrer ao Troféu Caymmi, e com esse projeto tive uma ascensão pela imprensa muito grande, eu não digo através do rádio, porque o Troféu Caymmi é um trabalho de base, um trabalho de estrutura que se faz". Neste sentido, o compositor distingue o tipo de projeção apontada pelo projeto, que tem como objetivo maior, referendado pelos artistas premiados, o reconhecimento artístico mais do que o mercadológico. Este acontece em virtude da própria visibilidade provocada pela premiação.

Podemos observar que a própria premiação pode estimular o alavancamento da carreira destes artistas e, consequentemente, conferir uma maior visibilidade e propiciar contratos com gravadoras e blocos, como aconteceu com a cantora Margareth Menezes ao ser premiada nos anos de 1985 como melhor intérprete no show Banho de Luz; em 1988, como melhor show para Beijo de flor; e possibilitando, com estas premiações, a apresentação na noite do Troféu "Caymmi" no projeto Astral ${ }^{9}$, sendo ali contratada pela Polygram para produzir o seu primeiro álbum. 
Por sua vez, Ivete Sangalo também colhe frutos com sua premiação de revelação no projeto em 1992, ao se apresentar na micareta da cidade baiana de Morro do Chapéu e ser convidada para ser vocalista da Banda Eva, através de um dos sócios do bloco - Jonga Cunha. Assim, prenunciando o êxito do projeto nascido em 31 de março de 1985, o seu patrono escreveu para o catálogo de premiação em 8 de março de 1986:

Em princípio, a idéia de reunir sob o mesmo teto de uma competição de grande porte novas gerações de músicos, compositores e cantores da música popular em particular da música popular da Bahia, é realmente uma idéia louvável. Sabemos como é difícil e trabalhosa a tarefa de procurar convencer, selecionar e estimular jovens que despontam em busca do sucesso. E como também é gratificante encontrar entre selecionados novos valores e novos nomes, para reeditarem o sucesso dos brilhantes baianos que há tantas décadas vêm levando o nome da Bahia pelo Brasil e pelo mundo afora. A escolha de meu nome para o troféu, que premia os novos valores baianos, muito me honrou e aqui agradeço comovido [...] Resta-nos o prazer de assistir, ao correr dos anos o crescente êxito do Projeto Troféu Caymmi para o bem dos jovens de nossa terra e o estímulo dos novos talentos (CAYMMI, 1986).

Para concluir o rol de depoimentos sobre a importância do projeto para a comunidade musical soteropolitana, capturamos o depoimento do artista Gilberto Gil, que, em passagem pelo projeto, afirma que "outros estados deveriam criar projetos baseados no formato do Troféu Caymmi, para que pudessem valorizar e estimular o surgimento de novos talentos"10. Ao longo dos seus vinte anos de existência, o projeto passou por momentos de dificuldades de patrocínio, com a saída do patrocinador durante dez anos - a COPENE, ficando suspenso por cinco anos. Em 1999, o projeto reinicia com o apoio de artistas do porte de Margareth Menezes, Ivete Sangalo, Márcia Short, Saul Barbosa, Sidney Magal, Compadre Washington, Danilo Caymmi e muitos outros que foram prestigiar o seu retorno, como afirmou o produtor cultural do projeto Tuca de Morais em entrevista ao Jornal 
Gazeta da Bahia ao repórter Marcos Pierry "O meu termômetro é a classe musical. Esse período sem o [troféu] Caymmi foi importante para constatarmos que ele realmente fez falta" (PIERRY, 1999, p.6).

Danilo Caymmi, cantor, compositor e instrumentista, também presente no momento da retomada do projeto em Salvador, contribuiu de forma determinante para a sua volta ao se encontrar com o produtor no Rio de Janeiro, estimulando-o a retomar o projeto. Em depoimento ao mesmo repórter, diz ele: "Estou aqui porque foram dez anos de credibilidade e competição sadia; eu mesmo fui revelado como artista em um festival e fiquei muito sensibilizado quando Tuca me disse que o Troféu estava parado" (PIERRY, 1999, p.6).

Assim, a volta do projeto se efetiva pelas mãos da classe musical que se mobiliza para sua retomada, culminando com um show de Ivete Sangalo (em 1999) na Concha Acústica, para angariar fundos. Neste ano, o projeto premia a intérprete Noeme Bastos nas categorias melhor show e melhor intérprete com um álbum solo.

Em 2002, o projeto volta à cena com o patrocínio das Lojas Insinuante e do Serviço Social da Indústria - SESI, através da Lei Estadual de Incentivo à Cultura e um novo design para o troféu, que recria sua marca pelas mãos do artista plástico Tati Moreno. A intérprete Stella Maris recebe o prêmio de melhor show, gravando o álbum solo.

Em 2004, com o patrocínio da TIM pelo FazCultura, o projeto premia a Banda Scambo que grava o álbum solo ${ }^{11}$.

Em 2007, o projeto contou com o patrocínio da CHESF se adequou a um novo momento do mercado, tendo tão somente três etapas em sua estrutura: a Terça Caymmi, no teatro ACBEU, cujos artistas se apresentam para a comissão e o grande público; a solenidade de premiação dos melhores do ano; e a gravação do $\mathrm{CD}$, prêmio maior do projeto. $\mathrm{O}$ Projeto comemorou 20 anos em 2007, no TCA, tendo como tema os Festivais da Canção, e como convidados para o encerramento Daniela Mercury e Danilo Caymmi, além de artistas locais que foram premiados, tais como: Andréa Daltro, Noeme Bastos, Grupo Garagem, Márcia Castro, Joatan Nascimento, dentre outros. Além deste evento, uma 
exposição fotográfica retrospectiva, com curadoria de Vera Milliotti, ficou em cartaz na cidade. Ainda como parte desta comemoração, o Projeto inaugura a Casa de Cultura Troféu Caymmi, que promove saraus temáticos, oficinas e encontros acerca do panorama da música produzida na Bahia.

Procuramos destacar a dificuldade de um produtor independente para a manutenção de projetos que fomentem e estimulem a produção cultural local, tendo que competir com empresas que criam e administram seus próprios projetos, bem como alguns produtores e artistas que transitam tanto no ambiente público quanto no privado, com privilégios que potencializam a realização dos seus respectivos projetos. Assim, Tuca de Morais aponta, numa entrevista a Kátia Borges, no jornal A Tarde:

A Bahia vive uma situação contraditória, uma realidade em que
o papel da iniciativa privada mudou muito. Eu diria que os
valores mudaram. As empresas que há dez ou quinze anos eram
patrocinadoras, hoje são grandes concorrentes dos produtores
culturais. Somos formigas sendo devorados por dragões. As
empresas têm seus próprios projetos culturais, cuja importância
não cabe questionar, mas é preciso que a verba destinada a
incentivo seja repartida com projetos como o Troféu Caymmi,
que tem grande importância no meio musical baiano em todos
os aspectos. [...]. Acho que as empresas chegaram à conclu-
são de que é melhor criar seus próprios projetos. E não foram
apenas as empresas. Hoje temos concorrência com blocos que
tem seus artistas, com os artistas que contratam outros artistas
e até com as agências de publicidade que também invadiram o
mercado de produção. (BORGES, 2000, p. 8)

Ainda na mesma entrevista, o produtor, ao ser indagado sobre a solução para minimizar o problema, responde:

O Fazcultura deveria atentar para essas questões. É uma lei muito importante para a Bahia. Já viabilizou inúmeros bons projetos, mas é preciso criar mecanismos que possibilitem a sobrevivência de produtores independentes, que também possuem projetos interessantes, importantes. 
Por outro lado, a verba no âmbito estadual - destinada tanto ao FazCultura quanto ao Fundo Estadual de Cultura, e da Fundação Cultural do Estado da Bahia - e no âmbito municipal, tal como o edital publicado pela Fundação Gregório de Mattos, continuam insuficientes para atender a demanda de produtores independentes e artistas que se habilitam a preencher planilhas e acompanhar a tramitação dos processos cujas verbas são insuficientes para atender a demanda ${ }^{12}$.

Outras opções se apresentam em sites de empresas estatais e privadas nos editais de concorrência a projetos culturais que pululam via Internet, mas que contemplam uma quantidade mínima de artistas e produtores nordestinos de maneira geral, e baianos de forma particular.

Editais de empresas como Petrobras, Banco do Brasil, Caixa Econômica Federal, Itaú, dentre outras, destinam um número pouco significativo de recursos aprovados para outras regiões do Brasil que não seja o Centro-Sul, provocando um desequilíbrio na balança cultural dos recursos destinados àquela região em relação às outras.

Voltemos então, ao ambiente local, no sentido de compreender outros espaços que estimula(ra)m a produção musical local.

\section{Outras fábricas}

No que diz respeito a cursos de especialização e formação de músicos, arranjadores, intérpretes e afins, a Academia Música Atual - AMA, posteriormente Academia de Música de Salvador - AMUSA, fundada pelo Maestro Sérgio Souto e pelos violonistas Aderbal Duarte e Thomas Gruetz, todos formados pela Escola de Música da UFBA, e fundadores do grupo Sexteto do Beco, contribui na formação de alguns profissionais da área, bem como no estímulo à música instrumental. Alguns nomes que passaram pela AMUSA: Jussara Silveira, Marilda Santanna e Lui Rabelo, dentre outros.

A Escola de Música ${ }^{13}$ da Universidade Federal da Bahia - UfBA e a da Universidade Católica do Salvador - Ucsal também contribuíam 
na formação destes novos profissionais que saíam para um mercado ainda em formação. Ainda buscando um panorama musical profissional de Salvador neste novo milênio, podemos nos reportar a dois instrumentistas, arranjadores e diretores musicais das estrelas do axé music - Daniela Mercury e Ivete Sangalo -, que são Letieres Leite e Gerson Silva, respectivamente. Ambos são músicos que se tornam empresários da música e inauguram em 2004 a Academia de Música da Bahia - AMBAH, cujo objetivo é formar instrumentistas, cantores e arranjadores que já estejam no mercado e buscam uma metodologia de ensino cuja aproximação com o ambiente de trabalho é o mote para a aprendizagem. Nomes como Joelma Silva, Gil Santos (ambos vocalistas de Daniela Mercury), e Ângela Lopo (vocalista de Cláudia Leitte), dentre outros, foram alunos desta Escola, que teve suas atividades encerradas em 2008.

Como podemos observar, a cena musical e cultural soteropolitana começava a se delinear de forma a refletir uma inquietação nos diversos segmentos musicais da cidade, retratando assim uma produção musical marcada pela diversidade. Assim se configurava o ambiente para o surgimento de uma grande indústria que se formava, cujo maior palco de divulgação para o grande público é a maior festa ao ar livre do mundo segundo o Guiness Book - o Carnaval baiano.

Assim, apesar desta diversidade musical, circulando em vários ambientes, a axé music e o samba reggae tornam-se a grande referência da produção musical de Salvador, com especificidades apontadas na própria criação do estúdio WR, de propriedade do produtor musical Wesley Rangel, cujo objetivo primeiro era criar o seu próprio mercado na área de propaganda, compondo e gravando jingles e spots para rádio e TV. Este empreendimento tinha como band leader e diretor musical Luiz Caldas, além de contar com a participação de grandes músicos locais, em sua maioria autodidatas, bem como técnicos, também autodidatas, que serviram de matriz na criação do novo modelo musical que estava por vir.

O estúdio, como um ambiente de experimentação técnica e artística, se torna um espaço ideal para plasmar uma nova sonoridade 
híbrida na construção de uma nova síntese musical que passava a ser denominada de axé music. Esta tecnicização provoca uma relativa autonomia no mercado desta música, pois o próprio estúdio WR produzia nomes como o Olodum, Banda Mel, Gerônimo, Sarajane, Chiclete com Banana, Luiz Caldas, Margareth Menezes, Luiz Caldas, Banda Cheiro de Amor, Banda Reflexu's, É o Tchan, dentre outros, estabelecendo uma nova ordem de negociação com as majors, que recebiam o produto pronto para circular no mercado. Esta tarefa ficava com as multinacionais, tais como a Polygram, Continental, Sony, Warner, Universal, dentre outras. Entretanto, outros empresários baianos como Ricardo Cavalcanti possuíam seu próprio selo - Stallo, que também utilizava as majors para a divulgação dos seus produtos artísticos/musicais, além de suas lojas de discos que vendiam estes produtos.

É sabido que a fragmentação do processo produtivo da indústria fonográfica contribui de forma determinante para a terceirização da produção como conseqüência de uma autonomia crescente dos setores produtivos e consumidores. Assim, vejamos como se processa a industrialização da música em Salvador a partir da segunda metade da década de oitenta, através do depoimento de um dos maiores responsáveis por esta transformação, Wesley Rangel, um pioneiro na experimentação deste novo modelo:

A WR foi fundada em 1975, especificamente para trabalhar com spot de rádio, e, a partir de oitenta, começou a trabalhar com jingles. Foi quando nós começamos a montar equipes de música, uma banda que depois veio se chamar Acordes Verdes, e que acompanhou o Luís Caldas no seu primeiro sucesso a ao nível de Brasil. A primeira música que nós colocamos na rádio com a banda foi uma versão de "Mrs Robinson" em 1982. Aí fizemos mais umas três ou quatro músicas dentre elas, "No Why", "Visão do cíclope", "Magia", ai veio "Nega do cabelo duro", que foi a música de Luís Caldas que deu o efeito que a gente queria [...] então, a entrada da WR neste circuito comercial da música baiana foi circunstancial, porque tínhamos 
esta banda e começamos a trabalhar (já que a rádio era fechada ao produto baiano). Começamos um trabalho com o Carnaval a partir da década de oitenta, com o "Nega do cabelo duro", e em 84 gravamos efetivamente o disco de Luís Caldas e o disco de Gerônimo Mensageiro da alegria. Logo depois, no ano seguinte, gravamos o primeiro disco na Bahia do Chiclete com Banana [...], Sementes, que aí resolveu ser uma seqüência de discos. Aí veio nessa mesma onda a Sarajane...Virgílio... Zé Paulo... em 88, veio Margareth Menezes, com quem fiz a música "Faraó"... O Olodum também em 88. [...] Em 90, começamos a trabalhar com Daniela Mercury. Lançamos Daniela, já nesta linha de axé, misturando o Olodum com o trio elétrico, com a música "Swing da cor". E ela começou a fazer um sucesso maior e a música baiana começou então a ter mais prestígio nacional (LEME, 2003, p. 72-73).

Este ambiente propício para a ascensão da axé music é também indissociável da profissionalização do Carnaval, que a partir deste momento contribui para a divulgação desta nova cena profissional/ artística de Salvador, também alavancada pela execução dos sucessos nas das FM e TV locais.

Vejamos, ainda o que o empresário Wesley Rangel tem a dizer sobre este fenômeno:

A diferença entre a WR e qualquer estúdio musical do Rio e de São Paulo é que a WR teve que criar o seu próprio mercado, já que na Bahia não existia um mercado, pois o artista baiano sempre acreditava no eixo Rio-São Paulo para fazer o seu trabalho. [...] Talvez a Bahia tenha dado certo porque nós sofremos muito pouca influência externa. Ao contrário, nós influenciamos a música nacional com músicos que aqui foram formados como o baterista Cezinha (músico do estúdio WR), que trabalhou com grandes artistas como Cássia Eller, Marisa Monte; [...] Ramiro Mussoto (percussionista argentino que trouxe a programação de bateria para as máquinas; [...] hoje o próprio Gil usa os nossos músicos como as vocalistas do estúdio Ângela e Tita e o 
sanfoneiro Cicinho). O sucesso do Eu, Tu, Eles foi feito aqui no estúdio. [...] Então, o mercado é comprador de bons produtos e produtos com identidade, e a Bahia neste período lançou muitos produtos que não existiam. [...] Ela lançou moda... e lançando moda conseguiu um sucesso de mercado. E isso é importante porque a Bahia abriu as portas para o novo. [...] (LEME, 2003, p. 53-54).

Uma nova ordem de mercado se estabelece, diminuindo o êxodo de artistas baianos para o Centro-Sul e aos poucos outros estúdios, em sua grande maioria de propriedade dos artistas locais, vão surgindo em Salvador, como os de Daniela Mercury, Carlinhos Brown, Durval Lélis e Ivete Sangalo, dentre outros, que negociam diretamente com as gravadoras os seus produtos.

Atualmente, o estúdio WR perdeu sua grande fatia no mercado, gravando em média cinco CDs por ano, quando, até a década de 9o, além de gravar artistas, produziu grandes estrelas tais como É o Tchan, Timbalada e As Meninas, até que a sua atuação foi perdendo fôlego por conta de uma nova configuração de concorrência no mercado de estúdios de gravação, bem como o advento da pirataria e de uma maior autonomia dos artistas, que, além de se tornarem proprietários dos seus estúdios, negociam o tape gravado diretamente com as majors.

Entretanto, não só os empresários contribuíam para a expansão e profissionalização deste mercado. A dinâmica da indústria cultural ${ }^{14}$ também se realizava através do rádio, da televisão e da mídia impressa na produção, divulgação e consumo destes produtos artísticos.

Vejamos então como a música e seus agentes podem servir de panorama para retratar um ambiente propício no processo de industrialização de uma cidade como Salvador.

\section{Panorama local para o surgimento da axé music}

O mercado da música se transforma, paulatinamente, a partir do processo de modernização/urbanização/industrialização, respecti- 
vamente representado pelos anos cinquenta, sessenta e setenta, não de forma estanque, mas de forma a desembocar no que hoje podemos denominar de "indústria do axé".

Este processo que vem se transformando cada vez mais veloz e desigual pode ser ilustrado pela fala de Miguez Oliveira (1998).

Apoiada fundamentalmente nos elementos da conjunção musical afro-elétrico-carnavalesca e na sua rica dimensão multicultural, passa a existir uma complexa e extensa rede de produtores de bens e serviços simbólico-culturais, que, inserida tanto no setor formal como informal da economia, alimenta um mercado praticamente permanente que extrapola os limites da cidade e do seu ciclo de festas de verão (apud MOURA; GUERREIRO, 2004, p. 5).

Neste sentido, a "indústria do axé" se auto-sustenta independente do eixo Rio-São Paulo, que serve apenas de suporte para a circulação desses bens simbólicos, sem a necessidade do êxodo dos artistas, que ao contrário, necessitam deste ambiente para manter a chama da criação (MORIN, 1969).

Este panorama altera-se a partir da segunda metade da década de oitenta. Efetivamente, é em 1987, quando uma nova sonoridade passou a invadir os lares através das ondas sonoras das FM locais. Estas, que até então se limitavam a reproduzir o modelo do eixo-sul, passam a veicular as produções musicais locais gravadas no estúdio WR, tornando-se um marco para o mercado da música produzida na Bahia, particularmente em Salvador. Até então, as gerações anteriores saíam de suas cidades para "tentar a sorte" no eixo Rio-São Paulo. É o caso de Assis Valente e Dorival Caymmi, nos anos trinta e quarenta; de Glauber Rocha nos anos sessenta; de João Gilberto, nos cinquenta/sessenta; de Gil, Caetano, Bethânia, Gal, Tom Zé, como de Raul Seixas, nos anos sessenta; dos Novos Baianos - Moraes Moreira, Pepeu Gomes, Paulinho Boca de Cantor... - nos setenta; de Chico Evangelista, Jorge Alfredo, Marcelo Nova, Luis Brasil e A Cor do Som, no início dos oitenta. E certamente esta breve relação poderia ser completada com muitos outros artistas. 
Vejamos como se processa em linhas gerais estas transformações, principalmente a partir dos anos setenta, com a subida dos "Novos Baianos" ao trio elétrico, levando como influência musical a síntese do rock com o samba, o ijexá com o frevo e, principalmente, a poética musical nas letras de Moraes Moreira, um dos integrantes do grupo que, já em carreira solo compôs canções imortalizadas pelo repertório do Carnaval, como: Chame gente, Vassourinha elétrica, Pombo correio e Assim pintou Moçambique.

Neste sentido, a música do Carnaval baiano já se fazia presente para além do seu território. Importante destacar a contribuição de Caetano Veloso neste processo, principalmente com o frevo Atrás do trio elétrico, composto em 1969, popularizando assim o frevo baiano.

Uma nova síntese musical se plasma a partir da segunda metade da década de oitenta, precisamente em 1987 com o fenômeno Faraó ${ }^{15}$. Era a música percussiva produzida na periferia que passava a ocupar um lugar de destaque em Salvador e no Brasil. A mídia do Centro-Sul, curiosa com o fenômeno, passa a dar destaque e a observar in loco o que realmente estava acontecendo e se ocupa em opinar a respeito do fenômeno. Observemos a citação:

Pela primeira vez, uma estrela de sucesso popular, ao explodir com a venda de um milhão de discos, atravessou a fronteira. Era a bonita e branca Daniela Mercury, lançada pela Sony para sair do Pelourinho e animar a platéia no vão do Museu de Arte de São Paulo, na Avenida Paulista. Pela porteira aberta por Daniela, passaram o Olodum e demais grupos que tocavam a música de Carnaval baiana, que recebeu, no mercado fonográfico, o rótulo de axé music (MASSON; FERNANDES, 1997, p. 83).

Ainda nesta matéria, podemos perceber um tom eivado de preconceito no que se refere a estes artistas que atravessam a "fronteira" e a "porteira" do Sul para fazer sucesso longe de sua terra natal, mantendo seus vínculos com as origens. Por outro lado, este sucesso é "permitido" em parte por conta de se ter uma representante bonita e branca. No caso, Daniela Mercury é considerada por muitos estudiosos uma personagem chave no processo de mestiçagem da nova música afro-baiana. 
Poderíamos nos perguntar então: Como estas intérpretes assumem o proscênio no processo de mestiçagem desta música? Ou melhor: como estas artistas assumem o comando vocal do Carnaval? Ou ainda: quem pode ser considerado porta voz do fenômeno Faraó? O público crescente, mas ainda incipiente que frequentava as quadras dos blocos afros e divulgava boca-a-boca essa nova música? Os autores destas canções? Os programadores de rádio e a gravadora/ estúdio WR? A subida dessa música para o trio elétrico na voz da vocalista Jaciara, da Banda Mel, em plena terça-feira de Carnaval, que paralisou uma multidão que pulava atrás do trio? O binômio baianidade/Carnaval? Os empresários como mediadores fundamentais da produção cultural e como personagens-chave na construção do sucesso?Todos esses elementos imbricados? Vejamos.

\section{Artistas na cena do Carnaval}

Tracemos então, em linhas gerais, de que maneira a participação destas artistas se constitui num novo momento na atual configuração do Carnaval, tomando como desafio e estímulo a provocação de Antônio Risério em Carnaval Ijexá: "que as mulheres se movimentem e marquem presença na transa do afrocarnaval" (1981, p.128).

Vale ressaltar que o trio elétrico, no seu nascedouro ${ }^{16}$, não incluía a voz humana em sua apresentação, possivelmente pela falta de condições tecnológicas para sua amplificação, que não tinha como competir com as guitarras (paus elétricos) amplificadas. Neste sentido, o trio elétrico se lança para o mercado, sem a presença do cantor (a).

No entanto, a primeira cantora a empunhar o microfone no Carnaval em cima do trio elétrico foi Baby Consuelo (hoje Baby do Brasil), que cantou o Hino do Esporte Clube Bahia nos idos do Carnaval de 1976, com os Novos Baianos (GóES, 2000, p.164). A partir daí, o trio elétrico se aliou ao cantor numa assimilação progressiva de recursos tecnológicos, numa simbiose perfeita na qual saiu ganhando o folião, que se beneficiou com a melhor qualidade técnica do som. Neste sentido, a participação da mulher na cena do Carnaval pode ser 
referida como um fato de certa maneira recente em relação ao próprio surgimento do trio elétrico e do frevo elétrico.

Cantoras como Sarajane, Laurinha, Simone Moreno, Janete e Jaciara (vocalistas da Banda Mel na primeira formação), Márcia Short e Alobêned (na segunda formação), Cátia Guimma, Emanuelle Araújo ${ }^{17}$, Marinês (Banda Reflexu's), Márcia Freire, Gilmelândia ${ }^{18}$ (Gil da Banda Beijo), Ivete Sangalo e Daniela Mercury, dentre outras, podem ser consideradas como vigoroso núcleo embrionário das puxadoras/vocalistas de blocos que se plasmam a partir de uma nova configuração no Carnaval, não se tornando, entretanto, um momento estanque, brusco, na passagem de um período para o outro. Ao contrário, estas configurações se constroem de maneira bastante sutil, mas não de forma lenta e gradual.

O surgimento destas artistas da nova música que se associa também ao aparato tecnológico é a alavanca para a subida da música afrobaiana ao palco do trio elétrico. A percussão tocada em conjunto com outros instrumentos heteróclitos realiza um som que, se não bem equalizado/mixado, não permite a audibilidade da voz do intérprete. Hoje, tão importante quanto os músicos, o diretor musical e os/as intérpretes, o técnico/engenheiro de som com seus equipamentos, são aliados na reprodução dessa nova música não só em cima do trio, como também em outros palcos pelo mundo afora.

O ambiente propício para o surgimento e ascensão destas estrelas de axé music ${ }^{19}$ no Carnaval, é traçado com o surgimento dos blocos de trio.

\section{Os blocos de trio e a organização empresarial do Carnaval}

O surgimento e organização deste empreendimento enquanto balcão de negócios começa a se delinear a partir dos anos setenta, quando os trios passaram a animar os associados de blocos ditos de elite como Os Corujas, Trás os Montes e Os Internacionais, que começaram a se or- 
ganizar no sentido de padronizar as fantasias e delimitar o espaço dos associados por meio de cordas, com o intuito de proteger aqueles que contribuíram com um carnê anual com direito a brincar três dias no bloco. Entretanto, só no final dos anos oitenta é que se constitui uma nova configuração, com a organização enquanto empresa de quarenta blocos com trios particulares, provocando assim uma demanda de foliões que queriam brincar com "comodidade" e "segurança", protegidos por cordas. Atraiu-se, assim, um grande fluxo de turistas que se sentiam mais à vontade nesta nova modalidade, em contraposição aos foliões que "brincavam" atrás dos trios independentes, normalmente patrocinados pela prefeitura e pelo governo do Estado.

Este novo modelo plasmado a partir do final dos anos oitenta é representado pelas bandas de trio tais como: Camaleão, Beijo, Cheiro de Amor, Eva, Papa Léguas, Pike, Pinel, dentre outros, cuja indumentária chamada "abadá" serve para distinguir um bloco do outro de forma a padronizar os associados. Entretanto, esta padronização se processa não só pelo desenho e cor de cada abadá, que a cada dia do desfile muda (para dificultar a fraude), mas pelo próprio repertório executado, dentre outros padrões. A corda que separa o folião comum dos associados permite considerável comodidade dentro do bloco, equipado com banheiros e bares, nos chamados carros de apoio.

Joaquim $\mathrm{Nery}^{20}$, um dos sócios da Central do Carnaval, gerencia, juntamente com mais dois sócios, 24 blocos que se apresentam nos Circuitos Osmar (Campo Grande) e Dodô (Barra/Ondina) com valores que normalmente vão de $\mathrm{R} \$ 180,00$ (cento e oitenta reais) a $\mathrm{R} \$ 800,00$ (oitocentos reais), divididos em até doze parcelas mensais. A Central do Carnaval é uma empresa criada em 2000, com a proposta fundadora de tornar possível a comercialização integrada de blocos de Carnaval, em que o folião pode montar o seu próprio produto, mesclando dias diferentes, com atrações diferentes e preços diferenciados. A empresa surge da síntese dos blocos Camaleão e Nana Banana, que se juntaram ao Bloco Beijo, a pedido do seu sócio Misael Tavares, que gerenciava a carreira do cantor Netinho. Como não estava dando conta da demanda de trabalho, propôs ao Camaleão gerenciar o bloco. Assim nasce a 
Central do Carnaval. "O objetivo da Central do Carnaval não é ficar restrito ao produto Carnaval. Hoje, a empresa trabalha com eventos não só na Bahia, mas em outros estados" ${ }^{21}$. Tem sede nos shoppings Iguatemi e Shopping Barra com lojas que comercializam produtos como souvenires, camisetas, shorts, mochilas, bonés, dentre outros, com a logomarca da empresa.

O mercado se torna cada vez mais competitivo, com a entrada de empresas concorrentes. Outro grupo que tem crescido de forma cada vez mais veloz neste ambiente é a Axé Mix, criada em 2002 como fruto de um grupo de empresários que, sentindo a necessidade de agregar os blocos Coruja e Cerveja \& Cia., criados em 1963 e 1998, respectivamente, a uma única marca. A empresa tem como objetivo administrar e comercializar blocos e camarotes, festas e Carnavais fora de época, dentre outros eventos. "Seu negócio é o entretenimento e seu objetivo maior é proporcionar lazer aos mais diversos públicos através de serviços oferecidos". ${ }^{22}$ Com uma estrutura composta de um escritório com diretoria geral, financeiro, administrativo, vendas/Internet, produção, criação, informática, bandas e bar mix, além de balcão de venda de ingressos no Shopping Iguatemi, a Axé Mix possui um case de produtos como o camarote Axé Mix, o camarote Cerveja e Cia Brasil e a festa Cerveja e Cia Folias, que acontece nas principais cidades do Brasil, os ensaios de verão de Ivete Sangalo no Píer Bahia (de 2003 a 2004), além da boutique Axé Music, na qual se comercializam roupas e souvenires com a sua marca.

Pode-se citar, também, a parceria firmada em 2005 entre os blocos Cerveja e Cia e Cocobambu nos Carnavais fora de época, surgindo o bloco Cerveja e Coco. Com apenas três anos de existência, a empresa consta no seu currículo parcerias com empresas do mesmo ramo como Reino da Folia, o bloco Eu Vou, o camarote Salvador, além de administrar seis blocos; diversos artistas, como Ivete Sangalo, Asa de Águia, Banda EVA, Rapazolla e Tribahia, dentre outros; e cinco camarotes, dentre eles o Axé Mix, situado na Casa d'Itália ${ }^{23}$ numa área de 2.000 mil metros quadrados composto de praça de alimentação, piscina, salão de beleza, massagem, etc. 
No entanto, este modelo já começa a provocar insatisfação por parte dos consumidores. As centrais de vendas tais como Central do Carnaval, Reino da Folia e Axé mix, ligadas respectivamente a Chiclete com Banana, Ivete Sangalo e Asa de Águia receberam constantes reclamações por parte dos consumidores que se recusam a comprar pacotes fechados de fantasias, bem como ingressos e outros serviços em quantidade limitada pela empresa. O modelo empresarial que ambienta o surgimento da estrela é tematizado a seguir.

Os produtores/empresários culturais no ambiente da axé music se constroem de forma bastante particular. Inicialmente, pela própria maneira como explode no ambiente do Carnaval, esta música corresponde a um jogo de interesses e poder que circula em ambientes diversos tais como o rádio, com os seus programadores, produtores fonográficos, assessores de imprensa/jornalistas e donos de banda e/ ou de bloco; todos estes agentes, circulando em diversos territórios, tramam no sentido de se construir um mercado com know-how na propagação e perpetuação desta música. Agentes de outros campos também se arvoram na empreitada de empresariar artistas ou bandas. É o caso do jogador de futebol Edilson, que, além de manter uma banda de pagode, $\mathrm{Oz}$ Bambaz, mantém um estúdio de gravação e uma casa de shows. Este mercado se encontra imbricado com os veículos de comunicação, gravadoras e selos, bem como patrocinadores, todos, contribuindo para a eclosão e profissionalização desta festa da música baiana que derrama sua alegria para outras plagas, de forma a vender o seu negócio como franchising.

Jonga Cunha, que durante mais de dez anos foi sócio do bloco Eva exerceu o cargo de Coordenador do Carnaval na Empresa de Turismo de Salvador - EMTURSA, em 2005, afirma que o Carnaval de Salvador é um grande negócio: "O bloco Eva já teve uma casa, um galpão, um trio elétrico e 50 funcionários. Associou-se à Central do Carnaval e hoje opera com 10 funcionários"24.

Outro grande empreendimento deste porte que circula em Salvador é o Pida - misto de site, revista e programa de TV exibido aos sábados na TV Aratu, constitui-se como divulgador em potencial das 
festas e badalações em torno da axé music, patrocinado pelos blocos e empresas ligados ao "esquema da indústria do Carnaval".

Outro tipo de empreendimento de porte que acontece em Salvador de outubro até o Carnaval são os eventos de domingo a domingo em bares, casas de shows e nos mais variados espaços da cidade, movimentado um número substancial tanto de artistas quanto de público local e turistas, bem como o comércio informal que aflui cada vez em maior número neste período.

Neste contexto, contudo, é a grade da programação do Festival de Verão realizado pela produtora iContent no Parque de Exposições, incluindo, a partir de 2007, atrações internacionais como Gloria Gaynor, musa do público GLS; Ben Harper e o cantor de reggae Matsyahu. Este último se apresentou na abertura do Festival, em 2007, juntamente com Chiclete com Banana, Timbalada, Banda Eva e atrações nacionais como Cidade Negra. Em 2008, a atração internacional foi o cantor sueco EagleEye Cherry. Já em 2009, tivemos a apresentação da canadense Alanis Morissette, e de atrações nacionais e locais, ao longo da sua história.

Segundo dados do Jornal A Tarde de 24 jan.2007, na coluna Sotaque Baiano, a infraestrutura do festival que acontece no Parque de Exposições é montada numa área com 90 mil metros quadrados, com segurança de 4,8 mil homens da Polícia Militar, além de 2.770 seguranças extras de empresas privadas; postos médicos; 200 sanitários químicos; área de alimentação com mais de 20 restaurantes e bares; estacionamento com 500 vagas para venda antecipada e mais 1,1 mil avulsas; além de reforço na frota de ônibus e linhas exclusivas.

Passemos, pois, à configuração do Carnaval. O que importa é pontuar as possibilidades organizacionais dos atores e do Carnaval enquanto balcão de negócio estratégico que se desenvolve através das donas, suas vozes e seus pares.

A respeito da teia de negócios que envolvem o Carnaval baiano, Miguez Oliveira afirma:

Partindo da aparição do Bloco Camaleão na cena do Carnaval no inicio dos anos setenta, precisamente em 1978, ano de sua fundação, dá-se o inicio da profissionalização dos blocos de trio, 
fenômeno que se multiplica de forma cada vez mais quantitativa e empresarial neste panorama (1996, p.120).

O autor destaca ainda que, dentre os quase cem blocos de trio em atividade, alguns blocos - Os Internacionais, Os Corujas, Cheiro de Amor - podem refletir a configuração do Carnaval, considerando-se as estratégias por que têm passado, como resultado de modelos exitosos de adaptação.

Passando de entidades sem fins lucrativos a empresas que além de administrar blocos, shows, ensaios, artistas, festas, micaretas, balcões de vendas de ingressos destes eventos a exemplo do Pida e do Ticket Mix e Carnavais temporãos, estes blocos e suas produtoras impulsionam de tal maneira o mercado da música, de forma enxuta, terceirizando os mais diversos serviços que, ainda segundo Miguez Oliveira (1996, p. 126) "podem incluir trio elétrico, som, banda, atrações artísticas, músicos, segurança, serviços de apoio (fiscais, vendedores, recepcionistas, garçons, pessoal médico), etc" imprimindo assim inovações tanto em sua organização quanto nas mudanças na configuração física e tecnológica na engenhoca criada por Dodô e Osmar, que passa de uma fobica reformada a gigantescas carretas sofisticadas com tecnologia de ponta. E, continua Miguez:

Assim, as condutas dos blocos de trio, não apenas potencializam o processo de transformação do Carnaval numa mercadoria, como também passam a ditar os padrões de organização e atuação nesse negócio, estimulando a que outros atores e organizações, a exemplo de blocos afro como Olodum ${ }^{25}$, Ilê Aiyê e Araketu, adotem estratégias semelhantes (p.130).

Além das empresas de blocos de trio que se organizam e desdobram sua atuação de forma cada vez mais profissional, os suportes institucionais são de fundamental importância na difusão da imagem da Bahia e do Carnaval como cartão postal para o turista ver ${ }^{26}$.

É importante observar o mercado crescente na profissionalização da alegria e da festa gerenciada também por artistas/empresários 
que disputam cada vez mais espaço junto aos donos de blocos, ao se tornarem também donos e/ou sócios. Assim, uma nova forma de fortalecer o seu produto se institui no mercado. São as sociedades entre as empresas dos artistas que se fortalecem ao vender os seus blocos em outras praças.

Este modelo da indústria de Carnaval desenvolvido a partir da década de noventa vem sofrendo transformações significativas no campo da economia, do turismo e da cultura, no sentido de transformar o Carnaval num grande balcão de negócios. Este, por sua vez, se constitui em algo bastante lucrativo, não só para a economia local, como também para outros espaços que se constituem em Carnavais foras de época, ensaios, festas e afins que movimentam uma economia bastante significativa neste empreendimento.

Assim, este modelo que permitiu a formação de um mercado musical local vem ratificar a predisposição de uma cidade para elaborar sua vida social pela linguagem musical. No entanto, estes códigos musicais remetem a questões estetizadas na afrodescendência, que se reportam ao plano da sensualidade, da historicidade, num trânsito entre a tradição e o moderno organizados numa narrativa de forte apelo estético e turístico.

Colocadas estas informações no sentido de contextualizar progressivamente nossa reflexão, podemos então nos perguntar: $\mathrm{O}$ que efetivamente atrai os grandes investidores e os turistas? Quem funciona como o mediador deste fenômeno catártico, alucinógeno, dionisíaco? É a música, é o Carnaval enquanto festa popular de grandes proporções? São as vozes tecnológicas/amplificadas das estrelas vindas de cima do trio, representadas em sua grande maioria por mulheres jovens, belas e singulares? É um novo modelo de bloco de trio que inaugura este fenômeno?

O novo modelo de bloco de trio é o salto, é o trampolim da carreira de artistas que viriam a alcançar o sucesso. É daí que saem Márcia Freire, Daniela Mercury, Ivete Sangalo, Márcia Short e Cláudia Leitte, dentre outras. No repertório dessas artistas já se encontra a síntese plasmada de todas as matrizes que, desde o inicio do trio elétrico 
e principalmente a partir dos anos setenta, compõem o cenário do Carnaval de Salvador.

A criação dos blocos alternativos dilata consideravelmente o número de apresentações e a captação de foliões, para não falar nas oportunidades de trabalho. Neste sentido, a associação de entidades se dá também na alternância do comando do trio a cada dia. O mesmo bloco pode apresentar uma banda de bloco afro e uma banda de axé music, pagode, atrações nacionais, DJs, dentre outros. É, porém, no âmbito da composição que melhor se verifica o trânsito intermitente de energia musical no universo do Carnaval. Alguns artistas têm composto para vários perfis de blocos. Hoje, os blocos se apresentam indistintamente como atrações em eventos dos mais variados estilos.

$\mathrm{O}$ afro e o frevo elétrico, com um toque de lambada como tempero, bem como o galope, ocuparam o centro da cena do Carnaval de Salvador até o início dos anos oitenta, quando Daniela Mercury imprime o samba reggae com uma nova sonoridade a partir de Swing da Cor, em 1991. Daí em diante, inúmeras sonoridades se interfaciam. A Timbalada, com a batida do funk nos timbaus, passa a apontar mais uma síntese que vem desembocar a partir de 2000 em canções como Maria sem vergonha, gravada por Carlinhos Brown. Dandalunda e Toté de Maianga, gravadas por Margareth Menezes, e Maimbê Dandá e Olha o Gandhy aí, gravadas por Daniela Mercury, já apontam temáticas e sonoridade do universo do candomblé. Outros estilos, como o pagode, também participam da concepção deste modelo.

No Carnaval, os espaços são ininterruptamente (re)negociados, num clima de ajuda/ concorrência. Há espaços também para manifestações tradicionais como a Mudança do Garcia $^{27}$, e espaços cada vez mais sofisticados como os camarotes que proliferam a cada dia em ambos os circuitos, e espaços cada vez menores para o folião pipoca, que se encontra cada vez mais confinado em becos e vielas por onde podem "admirar" a festa e seus ídolos, ou ainda se contentar em ficar nos bairros periféricos de origem, onde a prefeitura monta palcos e contrata atrações locais de pouca projeção para tentar "segurar" aí uma parte da população. 
Misturando, juntando as diferenças e reconfigurando a cada ano o significado de existirmos juntos num mundo tão múltiplo, o Carnaval também pode se configurar em "nossa cara". E esta "nossa cara" pode ser reconhecida pelos rostos e vozes que representam de forma múltipla e volátil estas diferentes identidades presentes nos palcos e no ambiente do Carnaval, pelas vozes das musas/rainhas da axé music - Daniela Mercury, Margareth Menezes e Ivete Sangalo.

\section{As puxadoras/vocalistas de blocos/bandas}

Já foi dito que o frevo elétrico, no seu nascedouro, não teve a participação da voz humana pela impossibilidade da captação e amplificação do seu som. Entretanto, depois de meio século da invenção do trio elétrico e mais de 30 anos da aparição de Baby do Brasil no Carnaval, é impossível pensar não só o Carnaval, mas a própria música produzida na Bahia sem as suas representantes.

Assim, a presença da figura feminina no Carnaval de Salvador é de certa maneira recente em relação à própria criação do trio elétrico. No entanto, é nos moldes em que se encontra hoje a indústria do Carnaval e da música de Salvador que se caracteriza este novo diálogo não somente de guitarras e paus elétricos, mas também de tambores, timbaus, vozes e samplers, numa interface polifônica e polirítmica.

Depois de Baby do Brasil no trio dos Novos Baianos, muitas seguidoras se arvoravam a cantar no palco de um trio elétrico, competindo com a amplificação ensurdecedora das guitarras elétricas, que, executando marchas, frevos, merengues, salsas e galopes, em sua grande maioria só instrumental, já conferiam o tom da diversidade sonora do Carnaval de Salvador.

Estas vocalistas, originárias em sua grande maioria de bandas de baile e dos palcos dos bares de Salvador, carrega(va)m no seu canto um decalque de cada canção executada nas FMs por artistas do cenário nacional. Este era o controle de "qualidade" do trabalho apresentado 
nos clubes e bares de Salvador. Assim, as chamadas crooners dessas bandas e as cantoras da noite seriam as futuras puxadoras/vocalistas de bloco/banda.

O cenário do Carnaval, na década de oitenta, não se configurava com um mercado de grande concorrência. O panorama apontava uma disputa saudável entre a loura - Sarajan $\mathrm{e}^{28}$ - e a morena - Laurinha ${ }^{29}$ - que dominavam o mercado em sua grande maioria povoado por vocalistas do sexo masculino como Lui Muritiba, Carlos Pita, Zé Paulo, Zé Honório, Marcionílio, Virgílio, Luiz Caldas e a banda Chiclete com Banana.

Estes artistas, em sua grande maioria vindos do interior baiano, já carregavam em suas respectivas bagagens musicais os bailes que animavam os clubes nos seus municípios de origem. Bandas como Scorpius e Mike Five, dentre outras, circulavam pela Bahia e por Salvador lotando clubes e espaços afins. O próprio Luiz Caldas, nascido em Feira de Santana, assim como a banda Chiclete com Banana, ainda como Banda Scorpius, são exemplos desta experiência em bailes.

São estes crooners que se tornam vocalistas/puxadores de bandas que, ainda nos anos setenta e oitenta, animavam os bailes da cidade em clubes como o Cruz Vermelha e Casa d'Itália, cantando os sucessos executados pelas FMs, e tinham como objetivo divertir os jovens que gostavam de dançar ao vivo os sucessos da época, de forma a reconhecer, exatamente como executados no rádio, os arranjos. O cantor também reproduzia fielmente a canção numa atitude de "competência" da banda, sendo aclamado assim pela audiência.

\section{As aspirantes a estrela}

As puxadoras/vocalistas de banda/bloco tinham uma função semelhante ao do crooner de orquestra, que satisfazia o público animando, divertindo e entoando canções de sucesso, só que num ambiente diferente daquele dos salões de festas. Neste sentido, ao mesmo tempo em que o crooner se assemelha ao puxador/vocalista de banda/ bloco, possui características distintas, pois, além de animar os foliões/ associados que acompanham o bloco, apresenta-se para uma câmera 
de TV de várias emissoras que transmitem em tempo real a festa, o Carnaval. Além de cantarem seus respectivos sucessos tocados nas FMs, os puxadores/vocalistas se apresentam para o público e para a máquina simultaneamente.

Se observarmos fotografias de álbuns daquele período, bem como fotografias e vídeo tapes de algumas puxadoras/vocalistas ${ }^{30}$ de bloco ou bandas de axé, podemos perceber que já havia uma preocupação com o que se veste, maquiagem, cabelo etc. Entretanto, estes profissionais se apresentam como portavozes da proposta ou mensagem do bloco e dos seus empresários/proprietários, inclusive nas próprias canções que levam o nome do bloco. Tomemos como exemplo deste fenômeno três representantes desta categoria: Márcia Freire, Carla Vizi e Emanuelle Araújo ${ }^{31}$.

Cabe então a pergunta: Efetivamente, é possível se fabricar uma estrela? Quais as condições indispensáveis para o lançamento de uma estrela no mercado? Mais ainda: como se dá seu êxito e permanência?

Nas práticas artísticas, o papel que a intérprete feminina ocupa neste ambiente da música de forma geral, e na axé music de forma particular, funciona de diferentes formas, obedecendo, porém, a uma padronização-individuação que a indústria cultural utiliza para lançar no mercado o "novo" com referências antigas.

Sobre o tema, Morin aponta que:

A concentração técnico-burocrática pesa universalmente sobre a produção cultural de massa. Donde a tendência à despersonalização da criação à predominância da organização racional de produção (técnica, comercial, política) sobre a invenção, à desintegração do poder cultural. No entanto, essa tendência, exigida pelo sistema industrial, se choca com uma exigência radicalmente contrária, nascida da natureza mesma do consumo cultural, que sempre reclama um produto individualizado, sempre novo.[...] No entanto, a indústria cultural precisa de unidades necessariamente individualizadas. Um filme pode ser concebido em função de algumas receitas-padrão (intriga amorosa, happy end) mas, deve ter sua personalidade, sua 
originalidade, sua unicidade. Do mesmo modo, um programa de rádio, uma canção. Por outro lado, a informação, a grande imprensa pescam cada dia, o novo, o contingente, o "acontecimento", isto é, o individual. Fazem o acontecimento passar nos seus moldes para restituí-lo em sua unicidade. A indústria cultural deve, pois, superar constantemente uma contradição fundamental entre suas estruturas burocratizadas-padronizadas e a originalidade (individualidade e novidade) do produto que ela deve fornecer. Seu próprio funcionamento se operará a partir desses dois pares antitéticos: burocracia-invenção, padrãoindividualidade (1969, p. 28-29).

Neste sentido, o artista-intérprete, de forma paradoxal, torna-se sim um criador que busca a originalidade e a inventividade como forma de superar a padronização pura e simplesmente, ao mesmo tempo em que busca a invenção como forma de se distinguir da padronização com certa autonomia no seio da produção artística. Assim, podemos afirmar que a originalidade e a individualidade são intrínsecas à criação do artista.

Este artista criador-autor surge no século XIX, afirmando-se no início da era industrial, ao mesmo tempo em que se desagrega de sua produção com as técnicas industriais da cultura. Esta desagregação, no entanto, não se processa de forma mecânica. Pelo contrário, a divisão industrial do trabalho artístico faz surgir a unicidade da criação artística pelo nome do artista intérprete, ele mesmo mediador deste produto.

Esta divisão do trabalho não resulta incompatível com a "individualização da obra", que, por sua vez, também passa a ser padronizada, seguindo regras e formatos compatíveis com o mercado. Assim é que estas puxadoras/vocalistas dos blocos/bandas preenchem os requisitos necessários para dar conta da substituição de uma "peça" que repete o modelo/protótipo anterior, mas de forma a não provocar "estranheza" no público.

Cátia Guimma, Carla Vizi ${ }^{32}$, Simone Moreno, Emanuelle Araújo e Márcia Freire são algumas destas puxadora/vocalistas que se limitaram a seguir o padrão com uma pequena dose de individuação. Entretanto, 
esta dose não foi suficiente para provocar uma ruptura no modelo vigente e transformá-las em novos protótipos.

Depois de todo este processo, se as aspirantes forem notadas, obtêm um papel secundário e sua personalidade se amplia e enriquece. Entretanto, elas só se tornam efetivamente uma estrela no dia em que os fãs as reconhecem como tal, pedindo autógrafos e tirando fotos. É o sucesso. E o sucesso é o reconhecimento, a visibilidade, a superexposição. Assim, o construto da estrela é indissociável do sucesso. Observemos o que nos tem a dizer Márcia Freire, em entrevista à autora, sobre o sucesso:

Se eu pudesse definir isso aí [...] Mas eu, eu vi a história do sucesso e depois a crise. O sucesso a gente aprende. São etapas. Mas você precisa estar com o pé no chão para ter humildade, não é? Porque quando vem a queda, que é natural, você tem que aprender como lidar com isso, isso é que é difícil. (FREIRE, 2005).

Uma figura bastante emblemática do desempenho de "criar" estrelas é o empresário Jonga Cunha. Vejamos o que nos diz quando perguntado pela autora sobre qual o critério para escolher estas cantoras para puxar esses blocos.

Olha, não houve uma criteriosa escolha em que tenha sido cientificamente pesado qualquer tipo de fator. Não em relação a uma mulher ou outra. Mas, a postura, a beleza, a voz, o punch. A gente sempre entendeu que as cantoras baianas de axé, elas têm, somam vários predicados. O de entreter, de conseguir segurar uma massa, de dominar o povão, que é uma resistência de tocar 6 horas em cima de um trio elétrico. Eu acho que assim, o Brasil tem alguns poucos exemplos, exceto baianos, de esboçar este tipo de comportamento. De mulheres, que tem além de cantar bem qualquer gênero, também segurar um rock'n'roll, uma música pop, em cima de um trio elétrico pra cem mil pessoas, com 6 horas de duração. A gente cita Elba Ramalho, Clara Nunes, talvez. E as baianas surgem em cada es- 
quina. Fez-se uma escola na Bahia de cantoras que tenham esse perfil, que saiba cantar [ele cita Cláudia Leitte, a ex-vocalista da Babado Novo], interpretar, que saiba ser rock'n'roll. Eu acho que surgiu aqui na Bahia essa escola, e eu acho muito legal. Os critérios de escolha sempre foram esses. Beleza sim, porque bloco sempre foi uma coisa de jovens, porque ficam querendo ver alguém bonito lá em cima mesmo, mas também, gente que segure o pique, que não é mole não. Acho que também essas coisas foram importantes. (CUNHA, 2005).

Este punch apontado pelo empresário refere-se à energia necessária para fazer chegar ao público.

Veremos agora como se constrói a estrela axé em termos de voz.

A voz feminina, na axé music, utiliza o registro de peito, grave; propõe uma voz de comando, de poder. Assim, as multidões obedecem às indicações coreográficas/vocais no sentido de seguir com mais facilidade o diálogo com os tambores e demais tecnologias nas vozes das estrelas. Os harmônicos ecoam mais na região grave, imprimindo mais "volume" nas vozes, que podem assim "competir" em pé de igualdade com a massa sonora dos instrumentos que ecoam.

Sobre o que é necessário para ser uma intérprete no Carnaval e uma intérprete de axé music, vejamos o que nos tem a dizer o especialista Neto Costa, professor de Margareth Menezes.

Primeira coisa: prá você ser uma intérprete, você precisa ter uma inteligência musical muito grande. Porque muitas vezes você tem a voz, mas o que fazer com ela? Uma grande intérprete, como uma grande cantora, tem que, antes de mais nada, saber qual é o recurso que ela tem e os limites da sua voz. Esse é o primeiro ponto. Eu acho que uma grande cantora, e uma grande intérprete, tem que saber até onde ela pode ir. E no axé isso não é diferente. Cantar é você ter conhecimento do seu próprio organismo, antes de mais nada. Então assim, você vai cantar na avenida. Seu corpo informa se você está bem ou não está bem. Pronto, você pode administrar aquela voz. É lógico que a comunicação é importante. Pra você ser uma grande 
comunicadora, você não precisa ficar feito uma barata tonta. Se acabar lá em cima, você precisa se administrar, como eu falei e manter a energia no olhar, na voz, no braço, no corpo. Então, o corpo comunica, você não precisa ficar só na voz. Eu acho que uma grande cantora é aquela que não precisa se estressar pra poder levantar o público. (NETO COSTA, 2005).

Podemos observar, no depoimento, uma necessidade, por parte da estrela, de conhecer o seu corpo/aparelho vocal. Este autoconhecimento é possível desde que haja um controle de sua própria carreira e se possam estabelecer limites de shows, de aparições, de contratos. Como ilustração de uma superexposição, citamos o acontecido em abril de 2006, no Carnabelô (Carnaval fora de época de Belo Horizonte) com a então vocalista/puxadora da banda Babado $\mathrm{Novo}^{33}$, Cláudia Leitte ${ }^{34}$, em fase de recuperação vocal devido ao abuso durante o Carnaval de Salvador, cantou com sérios problemas vocais, sacrificando assim sua performance e sua saúde. Entretanto, como vocalista de banda e com contratos a cumprir, este problema revela-se de pouca relevância tanto para o contratante quanto para o empresário da banda contratada.

Ora, a "autonomia" do artista em poder fazer uso de sua agenda de maneira a preservar sua saúde como um todo não é um procedimento usual no ambiente do sucesso e da visibilidade.

A história mostra que a cantora/atriz Carmem Miranda faleceu precocemente também em virtude do excesso de trabalho e contratos exaustivos, que não permitiam sua recuperação de estafas sucessivas. Não afirmamos com isto que as estrelas que administram sua carreira/ sucesso também não sejam acometidas de estafas e outros males. No entanto, usualmente, os empresários aproveitam um produto novo no mercado para que a superexposição lhe renda dividendos de forma a substituir o protótipo com defeito por outro mais novo e sem problemas aparentes, caso o primeiro protótipo comece a apresentar defeitos/problemas constantes.

Assim funciona o mercado da indústria da música, que de forma 
sazonal coloca novos modelos fundamentados no antigo nas prateleiras, para que os fãs e os empresários donos de bloco, ao se cansarem daquela estrela, possam substituí-la por outra, sem prejuízo para quem pode "escolher".

Outra característica apontada pelo empresário Jonga Cunha na constituição da estrela é o que se convencionou denominar de pop. Tomamos como pop a música de caráter popular divulgada pelos meios massivos a partir da década de sessenta, cujas características se revelam tanto no formato médio para execução em no máximo três minutos como na timbragem de instrumentos elétricos/eletrônicos e letras com refrões que se repetem, para atingir um público potencialmente jovem. O pop também se caracteriza pela vertigem da obsolescência, além da autonomia em relação a todas as origens.

Diversos artistas do ambiente da axé music, ao serem indagados acerca do que é o pop, imprimem graus de similitude ao rótulo. Ivete, no entanto, responde: "Eu tô esperando até hoje que alguém me mande uma cartinha me explicando. Eu tô por fora do que é pop. Eu não tô sabendo quem sou eu..." (Entrevista à autora em 6 out. 2005). Mesmo sendo considerada pela revista Roling Stone como uma artista pop da atualidade, ela rejeita o rótulo. Radamés Venâncio (diretor musical de Ivete) aponta que o pop:

[...] é popular né, é o que tá tocando no rádio. Dizem que o título pop é americano né? Mas o pop vem do popular, é o que ta tocando no rádio, é o que o povo aceita mais fácil, é o que ela [lvete] canta no show e o povo responde na hora. É isso que eu acho de pop. (2005).

Margareth vincula o pop também ao popular.

Popular moderno. Música popular nos EUA é o pop, música popular no Brasil é o pop. E nós temos aqui o nosso pop reggae, temos o afro pop. Eu estou cada vez mais enfatizando esta questão do afropop porque eu acho um descaso a gente ter pop rock e não ter afro pop como rótulo de identificação. (MENEZES, 2005). 
Neste sentido, buscamos situar o pop também como um dos ingredientes da composição da estrela.

Discutiremos agora, com mais detalhe, o artista original, os elementos fundamentais para se construir uma estrela. Efetivamente, a estrela, ao se constituir, necessita de uma série de atributos que correspondem ao já apontado anteriormente. Entretanto, falta-lhe algo que consiste essencialmente em... personalidade. É o que nos aponta Morin quando enumera "a distância interestelar que vai da jovem bonita à estrela" (1989, p. 37).

A maneira como esta artista se apresenta para o público chega a um estágio em que a puxadora/vocalista começa a se descolar do bloco e da banda, não necessitando mais desses itens para ser cultuada. Por outro lado, o próprio bloco e a banda servem de instrumento para reforçar o seu culto. Neste momento dá-se o descolamento que transforma a puxadora/vocalista em estrela. Esta transformação se dá na própria preocupação da aspirante a estrela com o seu corpo - o que veste, como se penteia, como fala com o "seu" público, como é assediada pelos veículos com entrevistas e fotos, dentre outras características.

Como o público se identifica e elege a estrela? O que seria uma estrela autêntica? O que a faz tornar-se estrela? O fato de carregar consigo o hic et nunc, a aura?

Os protótipos criados para alimentar/ilustrar a "indústria axé" tornam-se modelos para o público e para as novas aspirantes a estrela, que copiam com fidelidade o que faz sucesso estimulado pelo mercado e seus empresários, que se contentam em reproduzir o previsível. Entretanto, alguns desses artistas, ao se descolarem de um rótulo, no caso dos blocos e suas respectivas bandas, adquirem vida própria e fazem uso de um sentimento exclusivo do ser humano - a criação (MORIN, 1969). Estes fãs/fiéis que seguem o modelo são os que a elegem como modelos a serem seguidos. Assim, a indústria cria a estrela e os fãs/fiéis, por sua vez, a elegem.

Isto não significa que o construto da puxadora/vocalista de banda/ bloco não carregue em sua apresentação autenticidade ou mesmo a 
aura do seu self. Entretanto, o que falta a estas vocalistas/puxadoras se tornarem efetivamente uma estrela é o reconhecimento como tais pelo público e pela mídia. "A estrela, quanto mais partilhada, mais endeusada" (MORIN, 1989).

Morin, inicialmente, contrapondo-se ao pensamento de Adorno e Horkheimer de que algo não poderia ser arte se fosse indústria, demonstra como a divisão do trabalho e a mediação tecnológica não são incompatíveis com a criação artística. Não nega a existência do pensamento das classes dominantes na indústria cultural, havendo assim uma alienação por parte dos "receptores". Entretanto, converter o processo industrial em si mesmo na operação constitutiva da alienação é uma distância muito grande. Morin aponta que a verdadeira mediação, a função de meio que cumpre no cotidiano a cultura de massa se efetiva na comunicação do real com o imaginário. Neste sentido, para dar conta deste fenômeno, Morin encontra elementos em "Freud e sua proposta sobre os mecanismos de identificaçãoprojeção, para pensar os modos como a indústria cultural responde, na era da racionalidade instrumental, à demanda de mitos e de heróis" (MARTIN BARBERO, 2003, p.95).

\section{O construto da estrela}

Estes "personagens", "vultos", "mitos", divulgados através dos livros, do rádio, do cinema, dos jornais, da televisão, que se apropriam desta forma de representação para se referirem àqueles que por seus feitos ocupam um lugar de destaque na realidade e na imaginação contemporânea, são reconhecidos pela mídia pelos seus feitos de caráter artístico, esportivo, etc. na condição de estrelas e ídolos.

Assim, nas sociedades contemporâneas, a cultura da mídia tem um papel fundamental na veiculação deste fenômeno que se utiliza destas expressões para conferir um papel de destaque às estrelas de cinema, enfim, às celebridades que normalmente povoam os meios de comunicação aprovadas pelo senso comum, que "elegem" como modelo estas "personalidades" do cotidiano. 
Podemos nos perguntar, então: Como as figuras heróicas dos mitos contemporâneos, Daniela Mercury, Margareth Menezes e Ivete Sangalo podem representar singularidades, modelos a serem seguidos na mídia e fora delas?

Os mitos contemporâneos são representados por estas estrelas que só ganham visibilidade por força da mídia; sem seus dispositivos, o mito não acontece. Necessário ressaltar que a mídia - mais especificamente, a indústria da mídia/música -, não fabrica estes mitos segundo o termo cunhado por Lipovetski: paixonite de massa (1989). As agências da indústria cultural fabricam o star system produzindo a tal paixonite de massa, alimentando o funcionamento da engrenagem da cultura da mídia. Esta teoria apóia-se unicamente no fenômeno da produção, não levando em consideração a heterogeneidade da recepção, não considerando o público como agente pensante e crítico, co-autor da obra, e o próprio artista como agente criador que se utiliza do seu poder simbólico para "enfeitiçar" com suas vozes de sereias, os fãs/fiéis.

Tomemos o conceito de Morin - o mito das estrelas - como "o processo de divinização a que é submetido o ator de cinema, e que faz dele ídolo das multidões" (1987, p. 26). O autor utiliza a analogia entre mito e religião para dar conta do fenômeno das estrelas de cinema. Parece que esta analogia refere-se ao que mantém e fortalece o vínculo social, estreitando os laços que se estabelecem entre os membros da sociedade através do processo de identificação que se verifica entre o público e os heróis midiáticos, e que este fenômeno não deixa de ser um modo laico de re-ligação. Re-ligação entre o herói midiático e o público.

Assim, uma nova categoria de mito é desenvolvida no âmbito da sociedade contemporânea. Estas estrelas tornam-se mito pela capacidade de agregar certos valores do imaginário de determinados segmentos sociais reproduzido pelos fãs que se identificam com elas, elegendo-as como modelo de conduta. O ritual de adoração é verificado pelo culto às revistas, que revelam desde a sua intimidade até o pensamento referente a determinado assunto, a fofocas e mexericos 
que lhe dizem respeito, ou ainda, o novo álbum ou DVD lançado no mercado, bem como sites e blogs. Estes rituais, no entanto, têm caráter eminentemente profano.

O templo das estrelas são os fãsclubes, com os santinhos distribuídos entre os fãs/fiéis, as fotografias, de preferência autografadas, ou mesmo o último CD ou DVD com uma dedicatória única e exclusiva para cada um dos fãs/fiéis; são os blogs cada vez mais visitados pelos fãs/fiéis que de maneira interativa dialogam com seu ídolo e acompanham sua carreira passo a passo.

Assim, o caráter do culto às estrelas é profano, só sendo possível o seu avatar pela mão branca do fenômeno da tierce culture ou mass culture (MORIN, 1969), ou cultura da mídia (KELLNER, 2001). "Essas novas mercadorias são as mais humanas de todas, pois vendem a varejo os ectoplasmas de humanidade, os amores e os medos romanceados, os fatos variados do coração e da alma" (MORIN, 1969, p. 16).

Este fenômeno mítico/midiático transmitido pelas ondas sonoras digitais e imagéticas e transmitido de forma cada vez mais veloz, contudo, é provocado por uma cultura que:

Fornece pontos de apoios imaginários à vida prática e por pontos de apoio práticos à vida imaginária: ela alimenta o ser semi-real, semi-imaginário que cada um secreta no exterior de si (sua alma), e o ser semi-real, semi-imaginário que cada um secreta no exterior de si e no qual se envolve (sua personalidade) (MORIN, 1969, p. 16).

Vejamos como se constrói este mito estelar. Ainda para Morin (1989), o fenômeno da estrela só aparece onde ela possa brilhar. Assim, os empresários, bem como seus produtos em forma de blocos de Carnaval, de filmes, de revistas, da mídia são os grandes "aliados" para a fabricação da estrela.

Assim, voltemos às características essenciais formuladas por Morin para se tornar uma estrela.

A beleza é uma característica essencial à estrela. Qualquer mulher considerada bonita é uma aspirante a se tornar estrela. Por outro lado, 
existem recursos técnicos que propiciam a fabricação da beleza, tais como maquiagens, plásticas reparadoras, iluminação adequada (no caso específico da estrela de cinema), dentre outros. Sendo assim, a maquiagem das estrelas é essencialmente uma maquiagem de beleza que "acentua, estiliza e realiza definitivamente a beleza sem falhas, harmoniosa e pura" (MORIN, 1989, p. 29). Ricardo Almeida, maquiador de Daniela e Margareth Menezes, destaca que, na primeira, procura utilizar cores de sombra que possam destacar sua pele branca, enquanto em Margareth os tons ocres e dourado acentuam sua pele negra.

O mesmo acontece com o seu corpo perfeito (talhado em cirurgias plásticas e silicone) e cheio de curvas. Ainda segundo Morin (1989, p. 30) "Seu vestuário é um adorno" e seu toilette, perfeito no corte, no caimento, no feitio" Por mais simples que a estrela esteja vestida, ostenta em sua simplicidade grandes griffes. Ao mesmo tempo, quebram tabus de etiquetas fazendo combinações despretensiosas que ajudam a realçar sua real beleza.

Ao se disfarçarem atrás de grandes óculos escuros, ostentam neste disfarce a marca da "distinção" de uma grande grife de óculos, ou mesmo capas e roupas que ajudem a disfarçar suas formas e identidade.

"Produto moda, a estrela deve agradar; a beleza, ainda que não seja absolutamente necessária nem suficiente, é um de seus atributos principais" (LIPOVETSKI, 1989, p.214). Ainda para o mesmo autor: "O 'tipo' que personifica a estrela é sua griffe do mesmo modo que o estilo de um costureiro" (p. 215). Assim: "O visual não é mais um elemento decorativo, é constitutivo do posicionamento, da originalidade dos grupos, e sem dúvida ganhará cada vez mais importância com o desenvolvimento dos videoclipes" (p.216).

Indissociável da beleza, a juventude é fundamental na "criação" da estrela. Esta juventude, entretanto, torna-se cada vez mais duradoura associada a cosméticos e institutos de beleza que se dedicam com eficácia a eliminar rugas e gorduras localizadas numa juventude sem idade. Estas estrelas, cada vez mais "sem idade", também passam a atingir um espectro cada vez mais amplo de gerações, bem como uma 
beleza cada vez mais fora dos padrões hegemônicos, imprimindo aí outros atributos tais como o punch, já apontado antes, e a sensualidade, dentre outros.

Assim, este corpo ideal revela em si uma "alma ideal35".A estrela é uma conselheira para todos os tipos de aflições, sejam eles íntimos, sejam morais ou ainda sentimentais. Esta alma ideal da estrela implica uma "espiritualização" mostrada através de fotografias, entrevistas, vídeos; imagens lendo clássicos da literatura, fazendo compras em Miami, passeando na Disney ou na ilha de Caras, fazendo ginástica, passeando em família ou de férias com amigos, ou em temas ainda mais distante do seu universo existencial.

Assim, os componentes como a beleza, a jovialidade e a espiritualidade são elementares para atingir o estrelato. Qualquer moça bonita, jovem e boa pode ser aspirante a estrela. Pois nenhuma técnica é necessária para ser estrela. Sendo assim, "ser estrela é, precisamente, o impossível possível, o possível impossível" (MORIN, 1989, p. 34). Para Morin, o mito se instala neste momento, no coração da realidade. Para o autor, "o acesso ao estrelato depende do acaso. Este acaso é uma sina, esta sina é uma graça. [...] O que importa em primeiro lugar: o $d_{0 m}{ }^{36}$. O dom, isto é, o dom intrínseco, que é também miraculoso, transcendente: o dom da graça" (p.35).

Entretanto, este dom da graça, como apontado anteriormente, pode ser criado, recriado, aperfeiçoado ou mesmo "fabricado". Assim, em última instância, quem elege, quem outorga à estrela o título de estrela é a multidão de admiradores. É o público que coloca a etiqueta de estrela no mercado. Por mais que sejam contratados produtores, empresários, maquiadores, estilistas, cursos e professores de etiqueta e de técnicas específicas na arte de cantar, representar, dançar, lançamento de produtos com seus rostos e marcas, entrevistas, fotos e fofocas envolvendo seu nome, dentre outros aparatos da indústria do entretenimento, estas estrelas efetivamente só atingem o Olimpo pelas mãos dos seus fãs/fiéis. Isto não significa que seja dispensável o aparato mercadológico, industrial, publicitário na fabricação do sucesso. Contudo, trata-se ainda do penúltimo degrau; o último degrau, quem a faz galgar é o público. 
Assim, a estrela "pertence" ao seu público. Sua vida privada deve ser pública e sua vida pública, publicitária. Quanto mais é consumida, mais é adorada, partilhada. Seus fãs não têm ciúme dos seus amores, casamentos, casos, de sua vida social cheia de festas, jantares, recepções. A estrela leva uma vida sem fronteiras, em trânsito e lúdica.

Vejamos um exemplo das estrelas na indústria do axé:

Vida de estrela é assim. Ivete Sangalo acabou de voltar de uma baita turnê pelos Estados Unidos - com Miami, Nova York e Boston num roteiro digno de super star. Na volta, nem teve tempo de desfazer as malas, porque voltou para brilhar no Grammy Latino no início deste mês (FOLLONI, 2003, p. 142-145).

Assim, sem fronteiras, quebrando barreiras de tempo-espaço, as estrelas se locomovem pelo ar; seu ambiente é o céu estrelado, assim como o palco iluminado para que ela possa brilhar para o seu público. Neste sentido, já temos subsídios para criar a tipologia de três estrelas da axé music: Daniela Mercury, estrela lunar; Ivete Sangalo, estrela solar; e Margareth Menezes, estrela telúrica. ${ }^{37}$

Para este artista/criador poder competir no mercado da música, diversas estratégias são necessárias para a construção do deste sucesso. Juventude, beleza e dom são elementos indispensáveis, já citados. Entretanto, no ambiente específico da axé music, além destes três prérequisitos, acrescentamos o punch, o elemento pop, o empreendedorismo. Esta construção, em qualquer ambiente, é um acontecimento faustoso, sendo talvez o ingrediente mais importante no lançamento de um produto da indústria do Carnaval e da música.

A indústria da música produzida em Salvador a partir da década de oitenta se constitui, assim, num panorama para se compreender como o sucesso destas intérpretes baianas se configura como um fenômeno de caráter multidimensional. É o que veremos no capítulo seguinte. 


\section{Notas}

1 Entrevista à autora em 10 dez. 2005.

2 O Decreto n. 16.208, de 28 de dezembro de 2005 regulamenta a Lei $6.800 / 2005$, que dispõe a concessão de incentivo fiscal para financiamento de projetos culturais e dá outras providências.

3 Lei 7.015 de dezembro de 1996. O FazCultura tem como objetivo de incrementar o desenvolvimento e promover a cultura baiana em parceria com o empresário. Ver htpp://www.cultura.ba.gov.br/\#

4 Lei 8313/91, conhecida como Lei Rouanet, permite que os projetos aprovados pela Comissão Nacional de Incentivo à Cultura - CNIC recebam patrocínio e doações de empresas e pessoas que poderão abater, ainda que parcialmente, os benefícios concedidos do imposto de renda devido. Para maiores informações, ver htpp://www.cultura.gov.br/ props/propsb.htm

5 A primeira estatueta do projeto foi idealizada pelo artista plástico Márcio Lucena. A estatueta atual foi confeccionada pelo artista plástico Tati Moreno.

6 Depoimento coletado na coletiva com a artista no Restaurante Barbacoa em 2001, quando se tornou madrinha do projeto.

7 Depoimento coletado no especial dos 10 anos do Troféu Caymmi, exibido pela TV Educativa em 1995 .

8 Depoimento também coletado no especial da TV Educativa.

9 Projeto criado pelo empresário José Medina, o mesmo criador do Rock in Rio, cuja proposta era apresentar artistas nacionais durante o verão na área aberta do Centro de Convenções em Salvador durante os anos oitenta. Na noite do Caymmi no Projeto Astral, apresentaram-se os vencedores em diversas categorias, dentre eles: Gerônimo, Margareth Menezes e o Grupo Garagem, abrindo o show de Geraldo Azevedo.

10 Depoimento registrado quando da passagem do artista como convidado especial no show de encerramento na entrega do prêmio em 1994, realizada no Hotel Quatro Rodas.

11 Importante destacar que, até o ano de 1991, os artistas premiados em show nas diversas categorias gravavam a coletânea em disco. A partir de 1992, o Projeto passou a premiar o melhor show com um álbum solo. A primeira artista agraciada foi Tita Alves (1992), sucedida pelo percussionista Wilson Café (1993), e em seguida, pelo reggaeman Dionorina (1994). 
Encontra-se em tramitação no Congresso Nacional a reforma da Lei Rouanet.

13 Inaugura um curso de graduação em Música Popular, que teve seu primeiro vestibular em 2009.

14 É importante destacar que o próprio teatro já se debruça nesta discussão através da peça Pague pra ver. Numa montagem do grupo Tribo do XVIII, com concepção e direção de João Sanches, que também assina o texto ao lado de Leandro Araújo, a peça discute a indústria cultural e a relação da arte com dinheiro, passeando pela cultura pop e pelas referências culturais de massa. O espetáculo ficou em cartaz durante o ano de 2006 em teatros tais como o Molière e Teatro XVIII. Outro espetáculo que discute a relação da indústria do Carnaval como o comércio informal é "Esse Glauber", com texto de Aninha Franco e encenado por Rita Assemany e Diogo Lopes, retrata o universo dos "cordeiros" no ambiente do Carnaval de maneira a perceber a dura exploração sofrida pela mão de obra informal no ambiente do Carnaval, através particularmente dos blocos de Carnaval, que pode ser estendida a outros profissionais tais como vendedores ambulantes e barraqueiros.

15 Faraó, composição de Luciano Gomes gravada em 1987 por Margareth Menezes e Djalma Oliveira e pela Banda Mel, tendo nos vocais Book Jones, Janete e Jaciara, pode ser considerada a primeira canção que subiu ao trio elétrico já com a sonoridade do samba reggae, em síntese com instrumentos elétrico/eletrônicos.

16 Criado na década de 1950 pela dupla Dodô e Osmar, torna-se um fator decisivo para a atual configuração do Carnaval de Salvador. Para se compreender o Carnaval contemporâneo, o trio elétrico é um elemento fundamental em que diversas matrizes musicais, de repertórios, de ritmos, de temáticas, de performances se interfaciam formando novas sínteses musicais.

17 Vocalista da Banda EVA após a saída de Ivete Sangalo, Emanuelle Araújo, atriz de formação, permanece na banda um curto período, migrando para o Rio de Janeiro e retomando a profissão de atriz, além de cantar no grupo Moinho, formado com Lanlan e Tony Costa, em apresentação no Rio de Janeiro. Em 2008 participou da novela "A favorita”, da Rede Globo.

18 Gil começou a carreira cantando reggae, forró e MPB em barzinhos, até ir para o Carnaval como vocalista na banda Pinote, depois na bandas Jóia e Laranja Mecânica. Tem visibilidade em 1998, ao substituir Netinho na Banda Beijo. O primeiro CD como vocalista da Banda Beijo 
Ao vivo lhe rendeu um disco de ouro e um de platina. Além do Ao vivo, a artista gravou ainda como vocalista da banda os CDs Apaixonada (1999), e Meu nome é Gil (2000). Partindo para a carreira solo lança três álbuns: Movimento (2002), Gilmelândia (2003), e Canto da sereia (2005). Em 2007, comanda o programa Viva a noite, aos sábados, no SBT.

$19 \mathrm{Na}$ acepção de Moura (2001), é o nome de uma interface de repertório que se remete e, em contrapartida, organiza uma formulação de identidade cultural baiana, que passou a ser convencionalmente chamada baianidade. Este repertório tem como referência central o próprio Carnaval. Para Guerreiro (2000), axé music é o encontro da música dos blocos de trio com a música dos blocos afro (frevo baiano + samba reggae). É um estilo mestiço, cuja linguagem mistura sonoridades harmônicas e percussivas.

20 Entrevista concedida à autora em 18 maio 2005.

21 Dados extraído do site <www.centraldocarnaval.com.br>

22 Informação extraída do site <www.axemix.com.br>

23 A Casa d'Itália é um prédio antigo misto de consulado da Itália e espaço de shows, particularmente de pagodes na década de 9o, cuja localização propicia uma visibilidade estratégica no período do Carnaval, tornando-se assim um camarote com localização privilegiada.

24 Entrevista concedida à autora em 18 maio 2005

25 Maiores informações sobre o Olodum em Marcelo Dantas , 1994; 1996. Neste último, o autor aponta que as organizações afro-baiana também contribuem de forma impactante neste ambiente, "expandindo-se como produto artístico cultural e ideológico no Brasil e no exterior, através do mercado internacional da World Music" (p. 67), imprimindo assim um novo modelo cunhado por três organizações - os blocos afro do Carnaval da Bahia, Olodum, Ilê Ayiê, e Apaches do Tororó.

26 Ver Bahia Análise\&Dados v. 5. n. 4, mar. 1996, edição totalmente dedicada ao Carnaval.

27 O Bloco surgiu com o nome Arranca-Toco no período final da Segunda Guerra, quando músicos da polícia militar resolvem sair às ruas tocando seus respectivos instrumentos de sopro e percussão. Em 1950, passou a se chamar "faxina do Garcia" cuja multidão formada em sua grande maioria pelos moradores portavam vassouras, baldes e panos para uma faxina no bairro e nas ruas. Só em 1959 passou a se chamar de "Mudança do Garcia", desfilando sempre no próprio bairro do Garcia e no Circuito Osmar (Campo Grande). Misto de bloco de sujos e troça, 
tem sempre como característica as críticas aos governos de maneira geral e a maneira irreverente e jocosa como desfila, portando alegorias criativas.

28 Sarajane pode ser considerada a primeira rainha da música popular baiana. Vocalista do Trio Tapajós e do Novos Bárbaros na década de oitenta, fez muito sucesso no início da axé music, gravando seu primeiro álbum solo pela Odeon (EMI) em 1985, cujo repertório incluía Água de Coco, de Carlinhos Brown. A cantora e Luiz Caldas são considerados "os pais" da axé music, levando este "gênero" ainda em gestação para o centro-sul, particularmente no programa de Chacrinha, divulgando as danças e as fusões rítmicas que começavam a despontar no Carnaval de Salvador.

29 Foi vocalista do Bloco Cheiro de Amor de 1982 a 1984, dividindo posteriormente os vocais com Sarajane no Trio Novos Bárbaros, onde ficou até 1986, partindo depois para a arreira solo. Em 1988 recebeu o Troféu Caymmi de melhor intérprete pelo show "Pura Ousadia", partindo em 1990 para a Espanha, onde permaneceu até 1994. Dos seus sucessos, podemos destacar Pipoca louca, de Zelito Miranda e Helson Hart, e Flor nos cabelos, de Carlos Pita.

30 Tomamos por puxadora aquelas vocalistas contratadas pelas bandas e blocos, representando assim os interesses dos seus respectivos empresários. Estas artistas servem de chamariz para atrair um maior número possível de foliões/associados, e ao público de uma maneira geral, sem, no entanto, se descolar do vínculo contratual. Entretanto, é de fundamental importância para sua contratação alguns requisitos para este papel tais como beleza, juventude e voz de comando (punch), dentre outros.

31 Márcia Freire, vocalista da banda e bloco Cheiro de Amor; Carla Vizi, vocalista da banda Cheiro de Amor em substituição a Márcia Freire e Emanuelle Araújo, vocalista da Banda Eva em substituição a Ivete Sangalo.

32 Juntamente com Cátia Guimma e Márcia Short participam do grupo vocal EME XXI, sob a produção de Jonga Cunha e André Simões.

33 A banda Babado Novo surgiu em 2003. Com 5 álbuns lançados e puxando o bloco Papa (antigo Papa Léguas) no Carnaval de Salvador e o bloco Uau em Carnavais fora de época.

34 Cláudia Leite é uma vocalista/puxadora que foge dos padrões instituídos por Márcia Freire, Carla Vizi e outras. Ao lado dos empresários Cal Adam (que já foi dono do É o Tchan) e Manoel Castro (ex Cheiro 
de Amor). Seu álbum, Ver-te mar vendeu 45 ooo mil cópias, sendo apontada pela mídia como uma potencial substituta de Ivete Sangalo. Ver Martins (2007, p. 130) e o site http://www.babadonovo.com.br/ portal_babado/self_print.asp?id=227.

35 Morin considera "alma" os sentimentos cultivados pelas estrelas tais como: amor, compaixão, solidariedade, compreensão, dentre outros. (1989, p. 32)

36 A acepção de dom em Morin se refere a "algo dado", incomum, portanto, no ambiente das Ciências Sociais. Tomamos aqui dom,talento,desenvoltura extraordinária, percebendo que esta "aptidão", habilidade, também pode ser construída, aprimorada, aperfeiçoada.

37 Esta tipologia será discutida no capítulo 5. 


\section{Bahia, Brasil, Axé Music}

No capítulo anterior foi traçado um rápido panorama musical de Salvador nos anos oitenta, no sentido de compreender a configuração para o surgimento tanto do Troféu Caymmi como da axé music, tendo como nascedouro o mundo musical de Salvador e sua estrutura empresarial/organizacional, que passa a tomar cada vez mais fôlego a partir da década de noventa, através da proliferação de Carnavais fora de época, blocos alternativos, ensaios, festas e eventos. Isto vem culminar no acontecimento mais faustoso da indústria do Carnaval - o surgimento das puxadoras de bloco, apoiado no binômio apontado por Morin (1969) padronização/individuação até atingir a ascensão da estrela com ingredientes tais como (1989) beleza, juventude e dom além de punch e do elemento pop. Este fenômeno não se encontra descolado da dinâmica da indústria cultural, que através do rádio, das gravadoras, dos empresários/proprietários de blocos e de órgãos governamentais, passa a integrar plenamente o campo artístico na música de Salvador deste período, contribuindo para plasmar o surgimento da estrela, e consequentemente, o seu sucesso.

As diversas formas do fazer artístico são consideradas relevantes no engendramento das identidades. Alguns autores com os quais dialogamos abordam esta problemática como um processo, uma construção, um fluxo dinâmico em tempos contemporâneos pelo qual o ator social, com suas diferentes identificações, se desloca continuadamente.

Antes de tratar da plêiade de intérpretes que participam dos processos aqui estudados, convém esclarecer brevemente o que se 
entende por intérprete nesta pesquisa, discussão a ser retomada no capítulo 4. Inicialmente, procuramos situar no âmbito da música o que poderá significar o termo intérprete como um mediador, intermediário de informações musicais (a melodia, o ritmo, a relação entre corporeidade e emissão de voz, a forma, a mensagem poética) com um público num determinado espaço-lugar que pode ser um teatro, um trio elétrico (palco móvel), programa de TV, Rádio, CD, DVD etc. Intérprete também pode ser considerado(a) aquele(a) que serve de intermediário(a) na compreensão entre indivíduos que falam idiomas diferentes. Pode-se também definir intérprete como aquele que está sempre trocando, reformulando suas indagações e/ou convicções, ou ainda, o que busca compreender o outro através de sua obra de maneira idiossincrática. Enfim, o(a) intérprete pode ser considerado o mediador por definição e excelência. Vamos então ao intérprete - no nosso caso, de preferência, às intérpretes - e seus contextos.

\section{As estrelas:da Época de Ouro à era do DVD}

O período entre guerras atinge também a produção musical no Brasil que tinha o rádio como veículo difusor, interrompendo constantemente sua programação diária para irradiar boletins e notícias referentes aos combates entre as nações envolvidas. Enquanto a Europa sofria os efeitos da guerra, os Estados Unidos viam crescer seu poderio político, econômico e cultural, conquistando mercados dantes sob as mãos da Europa, exportando toda uma cultura do entretenimento que se fortalecia através do cinema, da música e dos costumes e bens de consumo como refrigeradores, refrigerantes, televisores, automóveis, produtos alimentícios como maionese Hellmann's, comprimidos efervescentes como Alka-Seltzer, tecidos sintéticos como o nylon, tergal, valisère, etc, bem como um comportamento de um público jovem cada vez mais ávido por novos modelos de consumo.

No Brasil, a própria transição do modelo europeu, com suas influências dos musicais music hall, féerie, café cantante, revista, vê 
seu poderio diminuir diante da entrada avassaladora da produção norteamericana. A indústria cultural expandia seus tentáculos para outros continentes através do cinema, da música, das revistas que imprimiam novos modelos de "bem estar", cujos produtos, tais como eletrodomésticos e de toucador, de beleza, servem para imprimir um novo modelo de comodidade a uma população ávida por bens de consumo e de protótipos exibidos nos filmes e revistas tendo as estrelas como modelo a ser seguido.

Assim, o construto da própria intérprete brasileira é indissociável do modelo da indústria cultural implantado no mundo a partir do advento do cinema e do rádio, que serve de divulgador destes produtos artísticos. Neste sentido, as negociações que deslocaram a hegemonia do modelo de cultura europeia para o modelo norteamericano trazem para o mundo consequências até hoje presentes, no que se refere à velocidade e efemeridade das informações, atingindo o sucesso como meta e fugacidade dos tempos contemporâneos.

A própria Carmem Miranda foi atingida de forma retumbante neste processo. A figura de Carmem serve também para reforçar junto aos yankees a imagem do Brasil como um país exótico e cheio de luxúria. Ao afirmar que Bananas is my Business, efetiva-se a situacionalidade de onde vem o exotismo deste lugar cheio de danças e mulheres sensuais e passionais, de animais selvagens e indumentárias folclóricas.

A obra artística como mercadoria e construção identitária pode ser destacada nos trabalhos de inúmeros artistas. Entretanto, tomamos a intérprete como portavoz desta construção em nomes representativos como Araci Cortes, fazendo do samba um símbolo de brasilidade no teatro de revista, com sua graça e malemolência; a própria Carmem Miranda, que imortalizou o traje e trejeitos da baiana, com a ajuda inestimável de Dorival Caymmi; ou mesmo a pop star Madonna, que possibilita a criação de um novo "eu-mercadoria" (KELLnER, 2001), podem nos servir para traçar uma elaboração de como se constitui e se constrói a intérprete no Brasil. Esta construção é indissociável, evidentemente, dos meios de comunicação de massa, que, através inicialmente do teatro de revista musicado, dos impressos tais como 
jornais, revistas e partituras, e posteriormente dos sulcos, através do gramofone e do acetato, bem como das ondas sonoras do rádio e da imagem televisiva e do DVD, possibilitam narrativas que se tornam hegemônicas e que podem ser identificadas no trabalho de algumas intérpretes emblemáticas nesta construção.

Importa destacar a década de 30 como um momento simbólico para a música popular brasileira. Destacam-se aí as transformações do samba $^{3}$ - particularmente no Rio de Janeiro -, até se constituir como um gênero genuinamente brasileiro, inclusive o evento das escolas de samba que a partir de 1935 se integram de forma definitiva aos festejos do Carnaval ${ }^{4}$ carioca, além da popularização das emissoras de rádio, que ampliam e diversificam cada vez mais sua programação, criando talentos que se tornam referência para a posteridade, particularmente a partir de 1932, com o decreto que permitiu a comercialização da rádio, proporcionando assim contar com patrocinadores, ampliar seus elencos e a valorizar cada vez mais a música nacional. Vale lembrar que, neste período, a grande quantidade de cantores era infinitamente maior que as cantoras. Nomes como Francisco Alves, Sílvio Caldas, Carlos Galhardo e Orlando Silva detinham a preferência nacional de forma esmagadora.

A própria temática que gravitava em torno destes artistas, segundo Faour (2006), até o final dos anos cinquenta:

Não eram tanto as de amor inatingível, mas sim do amor não realizado ou mal resolvido. As letras traziam com mais freqüência a mulher como inimiga em potencial do homem - a culpada por tudo que desse errado no relacionamento. Ela poderia ser a traidora, a perdulária, a exigente demais, a excessivamente crítica, a não compreensiva, e em linhas gerais uma "perdida", sem coração. (2006, p.31)

Por outro lado, tinha-se o Carnaval como ambiente para amenizar esta temática, mas vez por outra o próprio Carnaval sucumbia ao tema. A própria Carmem, com o seu primeiro sucesso - Ta-hí, de Joubert de Carvalho - passou pela temática da dor de cotovelo, sua- 
vizada pelo seu jeito brejeiro e debochado de interpretar. Vejamos, então, o surgimento de algumas destas intérpretes no cenário artístico brasileiro, cujas trajetórias servem para delinear uma elaboração de identidades culturais associada ao fenômeno do surgimento das estrelas na indústria da música.

Primeiramente, tomamos como exemplo as irmãs Linda e Dircinha Batista, que começaram a carreira artística ainda muito cedo. Depois de Carmem Miranda, foram as primeiras estrelas de grande popularidade no país. Conhecidas como as irmãs Batista, Linda aprendeu violão na adolescência e acompanhava a irmã Dircinha nas apresentações nos programas de rádio, até que um incidente arranjado pelo seu pai e pelo cantor Francisco Alves, que mantinha um programa na rádio Cajuti, a obrigou a cantar sem a presença da irmã, iniciando assim uma carreira de muito sucesso cantando sambas, marchas e sambas-canções.

Em 1937, Linda Batista foi eleita a primeira rainha do rádio, título mantido até 1948, quando é substituída por Marlene. Chegava à Rádio Nacional em carros importados, vestindo casacos de pele e usando jóias de grande valor. Ambas, como era comum na época, cantavam números musicais em filmes, a exemplo de Banana da terra, com produção de Wallace Downey, em 1938. Dircinha Batista gravou mais de 300 discos de $78 \mathrm{rpm}$, além de LPs. Intérprete também de marchinhas e sambas, a artista se consagra com seu primeiro sucesso no Carnaval de 1938, com a marchinha Periquito Verde, de Nássara e Sá Róris. Mas é com Vingança, de Lupicínio Rodrigues, que alcança um sucesso estrondoso, carregando em seus versos um discurso extremamente vingativo e machista.

Estas intérpretes podem ser consideradas portavozes de compositores da época que tinham o Carnaval também como grande veículo de divulgação para ilustrar a crônica de costumes cujo texto se reportava muitas vezes a temas corriqueiros como a falta d'água, ou ainda brincadeiras da época ou mitos infantis, como Pirata da perna de pau.

A respeito deste fenômeno, tomamos como ilustração dois grandes ídolos das décadas de quarenta/cinquenta nos idos da Era de Ouro do 
Rádio, com a ascensão de duas grandes intérpretes da música brasileira: Emilinha Borba e Marlene, bem como na grande referência da formação da intérprete/estrela no Brasil, alavancada principalmente pelo rádio e pelo cinema, que exibia as estrelas em películas patrocinadas pela Atlântida e pela Vera Cruz, além do Carnaval.

As disputas se travavam, sobretudo, entre as favoritas da Marinha - a carioca Emilinha - e da Aeronáutica - a paulista Marlene. Esta, estrela absoluta do programa de Manoel Barcelos; aquela, do programa de César de Alencar. Ambas serviam de modelo para uma infinidade de fãsclubes espalhados pelo Brasil através do disco, do rádio, do cinema e das revistas que divulgavam à exaustão seus sucessos, provocando uma disputa tão acirrada entre seus fãs que se chegou a sugerir um Tratado de Tordesilhas musical dos anos cinquenta "dividindo o Brasil entre fãs de Emilinha e Marlene" (ALBIN, 2004, p.160). Assim, as jovens fãs que viam nestas estrelas/rainhas a realização de seus sonhos, de um dia poderem também alcançar o sucesso como o seu ídolo, alimentavam na época a frustração da derrota de Martha Rocha no concurso de Miss Universo por duas polegadas a mais, além da perda da Copa do Mundo "dentro de casa" para o Uruguai, no Maracanã (p. 160).

Emilinha Borba gravou inúmeros sucessos em marchinhas carnavalescas tais como a emblemática Chiquita Bacana, de João de Barro e Alberto Ribeiro, no Carnaval de 1949, bem como Tomara que chova (de Paquito e Romeu Gentil), no Carnaval de 1951. Além das marchinhas e dos programas de rádio ${ }^{5}$, a artista também participou de inúmeros filmes tais como Estou aí, Aviso aos navegantes e Poeira de estrelas.

Marlene, de origem italiana, começa sua carreira profissionalmente na rádio Tupy de São Paulo, mudando posteriormente para o Rio, onde estreia no cassino Icaraí, em Niterói. Mais tarde, assina contrato com a rádio Mayrink Veiga e o Cassino da Urca, até 1946, quando a casa fecha devido à proibição de jogos de azar. Apresenta-se também em boites, passando de crooner a estrela no Copacabana Palace. No entanto, sua carreira ascende com a ida para a Rádio Nacional, em 1948, no programa de César de Alencar. Eleita pela primeira vez 
Rainha do Rádio em 1949, ganha seu próprio programa de nome Duas Majestades, permanecendo como estrela absoluta até o fechamento da emissora.

1950 é um ano emblemático na carreira de Marlene. Eleita Rainha do Rádio mais uma vez, inicia-se uma disputa, alimentada também pela mídia, entre as duas estrelas. Dentre os sucessos da artista, destacamos os sambas que estouraram no Carnaval, tais como Lata d'água, Zé Marmita, Sapato de pobre e Mora na filosofia, gravado em 1955. O cinema também está presente em sua trajetória em películas tais como Pif-paf, Caídos do céu e Tudo azul, dentre outros.

Outras duas grandes representantes da construção da intérprete no Brasil da época de ouro foram Dalva de Oliveira e Ângela Maria.

A primeira, anunciada como a menina prodígio da voz de ouro (ALBIN, 2004, p. 171) inicia-se na música ainda criança, ao ser descoberta pelo maestro que a observava se sentar ao piano tentando tirar melodias, após a limpeza do salão de dança. Assim, convidada pelo maestro, "apresenta-se num cirquinho de tablado" (p. 171). A artista inicia sua carreira, como era de praxe na época, em programas de rádio, mas também devido ao seu potencial vocal e afinação perfeita, faz participações em operetas no Teatro Glória, no Rio de Janeiro. Ao conhecer, no teatro, o futuro marido e parceiro Herivelto Martins, se junta à dupla Preto e Branco até trocar o nome do trio, por sugestão de César Ladeira para Trio de Ouro. Sua gravação antológica de Ave Maria no Morro (Herivelto Martins e Grande Otelo) e a marcha-rancho Praça Onze (Herivelto) são ilustrações emblemáticas do trio.

Com o casamento em crise, transformando as brigas e acusações em crônicas musicais, fez inúmeros sucessos entre 1950 e 1954, como Errei sim, de Ataulfo Alves, Tudo acabado, de J. Piedade e Osvaldo Martins, Que será?, de Marino Pinto e Mário Rossi, tema corriqueiro em seu repertório, tornando-se assim uma das primeiras intérpretes brasileiras a assumir publicamente sua separação, o que, para a época, era inusitado. Assim, levando o passional para sua vida artística, Dalva torna-se referência para outras grandes intérpretes, a exemplo de Maria Bethânia e Ângela Maria. 
Temas sobre a Bahia também são recorrentes na obra de Dalva, como a famosa $A$ Bahia te espera (David Nasser). Seu último sucesso gravado na década de setenta para o Carnaval foi a marcha-rancho Bandeira Branca, cujo tema reporta-se a um pedido de paz ao amado que a abandonou.

Ângela Maria é outra grande intérprete da chamada Época de Ouro. Carioca, é considerada por especialistas a intérprete mais popular dos anos cinquenta. Também chamada de Sapoti (apelido dado pelo então presidente Getúlio Vargas), surge nos programas de calouros, depois se torna crooner no Dancing Avenida, até ser convidada para integrar o cast na rádio Mayrink Veiga. Inicia sua carreira imitando Dalva de Oliveira, até encontrar seu estilo próprio, sendo eleita Rainha do Rádio em 1954. Interpreta em sua grande maioria sambas-canções cujos temas versavam sobre o perfil feminino estereotipado, seus amores, afazeres domésticos, o posto de rainha do lar etc. Canções como Mamãe, de Herivelto Martins e David Nasser, gravada em 1956, bem como Esmeralda, Garota Solitária e Cinderela, gravadas respectivamente em 1960, 1962 e 1966, todas três de Adelino Moreira, eram representações bastante presentes no imaginário da sociedade da época. Mas Ângela também gravou sambas que faziam elegia à pancada na mulher, como o seu primeiro sucesso Meu dono, meu rei, de Cyro Monteiro e Dias da Cruz. Gravou também composições que fugiam das temáticas da violência, como o samba-canção de Caymmi, Nem eu, em 1953.

Tanto Dalva quanto Ângela podem ser consideradas intérpretes com características vocais do bel canto, cuja extensão permitia um repertório recheado de choros, lamentações e despedidas sofridas, bem como representante - no caso de Ângela - do sonho feminino de busca da felicidade através do casamento.

Estas artistas como Dalva de Oliveira, Ângela Maria, Nora Ney, Linda e Dircinha Batista, Dóris Monteiro, Maysa, Carmem Costa, Dolores Duran, Elizeth Cardoso, Lana Bittencourt, Isaurinha Garcia, Alaíde Costa e Ellen de Lima, foram eleitas Rainhas do Rádio em diferentes décadas. Suas vozes ecoaram carregadas ainda de textos 
cujos temas vão de uma ingênua brincadeira com jogos de palavras - presente nas emboladas - até desilusões amorosas, sonhos de um amor ideal, violência doméstica contra a mulher, bem como temas cotidianos daquela época, sempre retratados pelo ponto de vista do compositor, que detinha quase cem por cento das canções registradas.

Entretanto, a década de cinquenta se apresenta de forma bastante profícua para a música brasileira, não só em gêneros gestados nesta época, como a Bossa Nova ${ }^{6}$, mas também por compositoras e intérpretes femininas que se lançam no mercado fonográfico e fogem ao ambiente do Carnaval, dos sambas e marchinhas, cujo cenário se situava nos bairros da Lapa e Vila Isabel, dentre outros; bem como do rádio como um dos únicos e mais importantes veículos de difusão.

Nora Ney, Maysa e Dolores Duran são três grandes representantes da denominada música de fossa, cujos temas apontam para a desilusão amorosa, as angústias e solidão do pós-guerra adornados por gêneros como o samba-canção, de preferências nos bairros da Zona Sul do Rio de Janeiro, de forma geral, e em Copacabana de forma particular, sede emblemática das classes média e alta naquele período. As boites se tornam os lugares mais apropriados para este momento da música brasileira, regado a cigarros e bebidas para destilar uma desilusão amorosa adornada por cálidas vozes que falam de adeus e solidão. Mesmo porque, com a proibição de jogos de azar e o fechamento de todos os cassinos, boa parte dos artistas e boêmios migram para as boites.

Compositora e intérprete, Dolores Duran - que compõe Por Causa de você, em 1957, em parceria com Tom Jobim, também gravada pela compositora e intérprete Maysa -, lançou também sambas no Carnaval, apesar de se constituir numa compositora e intérprete de fossa em composições antológicas tais como Se é por falta de adeus, gravada por Dóris Monteiro, A noite do meu bem, Fim de caso e Castigo, dentre outras.

Com Nora Ney, que iniciou a carreira cantando sucessos estrangeiros por conta de um defeito articulatório que dificultava sua dicção nos erres, a música de fossa continua com a gravação antológica de 
Ninguém me ama, de Antônio Maria, que conquista o primeiro disco de ouro ${ }^{7}$ da história fonográfica do Brasil.

Maysa, paulista de nascimento, foi outra grande intérprete que se consagrou também como compositora de sambas-canções, como as antológicas Ouça e Meu mundo caiu. Dona de uma beleza hollywoodiana que seria bastante explorada pela televisão, já em competição com o rádio como vitrines para os artistas, torna, assim como Dalva de Oliveira, sua vida privada em pública. Aos 18 anos, casa-se com André Matarazzo, de família tradicional paulista, que se opunha à carreira artística da jovem cantora. Desquita-se ainda muito jovem e passa a se embriagar cada vez mais, além de se envolver em escândalos amorosos. Muda-se para o Rio de Janeiro, envolvendo-se com a "turma da Bossa Nova" gravando o seu segundo álbum, já LP e não mais $78 \mathrm{rpm}$, com O barquinho, de Menescal e Bôscoli, o que lhe valeu o título de primeira divulgadora internacional da Bossa Nova. Além desta canção, outras do repertório da Bossa Nova se tornam clássicos em sua voz, como Meditação, Dindi e Se todos fossem iguais a você.

Maysa torna-se uma grande estrela da música popular brasileira, emprestando sua beleza em participações de teatro e em novelas como O Cafona, da Rede Globo, em 1971. Fez turnês internacionais, morou durante certo tempo na Espanha e apresentava-se sempre descalça, sendo chamada pela imprensa de a condessa descalça.

Assim, o final da década de cinquenta e início de sessenta se configura num momento especial da música brasileira, em que a música romântica, a fossa emblematizada também na voz da divina Elizeth Cardoso, cujo álbum antológico Canção do amor demais (1958), com arranjos de Tom Jobim, violão de João Gilberto e letras de Vinicius de Moraes, plasma uma nova forma de interpretar sambas-canções.

Silvinha Telles é outra artista advinda da Bossa Nova, que, ao lançar o álbum Amor de gente moça, que traz apenas compositores já considerados do movimento do final dos anos cinquenta. É outra cantora que teve morte precoce.

Como era de se esperar, soa estranho o novo estilo que se formatava em 1958 também pela batida do violão de João Gilberto, do 
seu canto falado e da harmonia mais dissonante para os padrões auditivos da época, provocando uma tempestade de críticas, que reagem de forma passional ao novo, embalado também pelo governo de Juscelino Kubitschek, ele próprio cognominado o Presidente Bossa Nova, que tem também como meta um Brasil cosmopolita, do desenvolvimento.

Neste sentido, a Bossa Nova torna-se ideal como novo produto musical no mercado internacional, feito só conseguido até o momento por Carmem Miranda, assumindo o proscênio da representação da brasilidade, tendo o Rio de Janeiro como paraninfo.

Assim, o final da década de cinquenta vê o ocaso dos sambas e marchinhas de cunho carnavalesco. Estes são substituídos pelos sambas-enredos das escolas de samba do Rio de Janeiro. Temas como vingança e violência contra a mulher conviviam, sendo paulatinamente substituídos. Composições como Você e eu, Samba de verão, Fotografia e Amazonas traziam o amor, o sorriso e a flor como tônica. O poeta da Bossa Nova, Vinicius de Morais, também transitava por temas românticos revelados em Minha namorada, Eu sei que vou te amar, Sem você e Garota de Ipanema, gravadas por intérpretes masculinos e femininos, mas imprimindo um tom mais coloquial, mas não menos sofrido.

Ainda de forma tímida, mas não menos importante, as compositoras e intérpretes no Brasil começam a extravasar sua produção poética em parcerias com músicos e movimentos como o que antecedeu a Jovem Guarda, passando dos "anos dourados" para os "anos rebeldes", na figura emblemática de Celly Campello, depois Sônia Delfino, embaladas por versões ou letras originais cuja temática variava do comportamento dos bad boys americanos à vida romântica infantil das garotas e seus relacionamentos com os namorados. Assim, por mais que se sonhasse com "o bom rapaz" com "um pão" ou com "um brotinho ajuizado", no fundo, todas elas buscavam o casamento.

A Jovem Guarda acontece como representante da música pop/rock no Brasil, nas vozes de Roberto Carlos, Erasmo Carlos e Wanderléa, Vanusa, Waldirene, Martinha, Meire Pavão, Lílian (da dupla Leno e Lílian), cujas versões eram cada vez mais frequentemente embaladas 
pela indústria fonográfica e pela televisão, já como um novo símbolo de integração nacional. Estes artistas falavam para uma juventude farta de guerras, que, já prenunciando a Guerra do Vietnã e a Guerra Fria, buscava identidade(s) que também expressassem uma visão romântica do mundo e normas de comportamento contra o consumismo. Além disto, tomava fôlego o apelo pela liberação sexual, relacionada ao surgimento da pílula anticoncepcional e expressa através dos cortes de cabelo e das mini-saias, além da música dos Beatles e de gírias que sugeriam um Brasil plugado nos EUA e no mundo; um Brasil transmitido via intelsat.

Wanderléa, "a Ternurinha", torna-se uma figura bastante representativa deste período, ditando moda, seja nas coreografias sensuais que imprimia, ao dançar com a mão na pélvis, no uso de mini-saias com botas e as pernas de fora, ou ainda com roupas coladas ao corpo. Wanderléa, além de cantar dor-de-cotovelo e amor adolescente, também se mostra dona do seu nariz ao interpretar do amigo Erasmo Carlos Prova de fogo, em 1967; ou ainda em rocks como Estou com raiva de você e Pare o casamento, que revela o desespero do amor que está prestes a se casar com outra. A rebeldia estética assumia contornos políticos no mundo como rebeliões na França e na Tchecoslováquia, bem como movimentos contra as ditaduras militares instauradas em diversos países latino-americanos.

Entretanto, temos em Vanusa um perfil um pouco diferenciado, que, além de intérprete, compunha a grande maioria das letras dos seus álbuns, passando por temáticas que iam do questionamento dos casamentos fracassados à mulher submissa e à violência do homem contra a mulher, numa atitude que para a época se configurou em quebra de tabus. Canções como Manhãs de setembro (1973) e Rotina, ambas com música de Mário Campanha, além de S.O.S. Mulher (1982), já apontava para uma intérprete incomodada com o papel da mulher na sociedade. Em Mudanças, um marco em sua carreira em parceria com Sérgio Sá, gravada em 1979, a intérprete se torna, segundo relato da mesma, em " uma exímia lutadora nas palavras" (apud FAOUR, 2006, p.141), nos versos: 
Hoje eu vou mudar/vasculhar minhas gavetas

[...]

Deixar de ser menina pra ser mulher

Hoje eu vou mudar

Pôr na balança a coragem

Me entregar no que acredito

Pra ser o que sou sem medo

Dançar e cantar por hábito

E não ter cantos escuros pra guardar os meus segredos

$[\ldots]$

Mudanças, Sérgio Sá e Vanusa, 1979

Entre os anos sessenta e setenta, além de Vanusa, outras compositoras e intérpretes ousaram expor seu ponto de vista em canções que começavam a expor o universo feminino de forma mais contundente. Dentre elas: Rita Lee, Cláudia Barroso, Isolda, Marlui Miranda.

As intérpretes e a música brasileira, mais uma vez, comparecem para retratar a crônica social do período embalada pelos Festivais da Canção que se incumbiram de lançar nomes e movimentos emblemáticos na moderna música popular brasileira como a Tropicália ${ }^{8}$, já carregada de elementos pop, também ilustrada pelo trio paulista $O s$ Mutantes, dos irmãos Sérgio e Arnaldo Batista e da compositora e intérprete Rita Lee. Esta, na próxima década, se tornaria a maior representante da música pop brasileira, criando canções que imprimem malícia, deboche e bom humor sem perder de vista a crítica social ao papel da mulher, como podemos observar nos álbuns lançados um após o outro como Baila comigo e Lança Perfume, ambos em 1981, já em dupla com o guitarrista e marido Roberto de Carvalho.

Rita Lee é uma artista que coloca em questão o papel da mulher de diferentes maneiras, seja aquela que vive atrás do marido rico, como em Locomotivas, seja a relação sexual entre um casal como em Lança perfume, Mania de você e Banho de espuma; sejam as contradições da mulher como em Fonte da juventude; seja ainda criticando a high so- 
ciety com Alô, alô marciano, gravada por Elis Regina, ou ainda em Cor de rosa choque, que toca em temas como a menstruação.

Como seguidora de Rita Lee, podemos reconhecer, já no século XXI, a aparição da revelação feminina nacional do rock na baiana Pitty, que se lança no mercado do eixo-sul depois de certa visibilidade em Salvador, conquistando prêmios e público de forma a apontar, no mercado, que mulheres também sabem falar sobre si mesma e outros assuntos neste universo de forma irreverente, multifacetada. "Aclamada pelo maior prêmio no Brasil pelo canal MTV - especializado em videoclipes de música pop/rock, desbancando nomes do rock nacional a exemplo do Skank, Marcelo D2, dentre outros" (SILVA, 2002, p.168).

Entretanto, é do Sul, ainda muito jovem, que aos dezoito anos, parte para o Rio de Janeiro uma intérprete considerada das maiores de todos os tempos - Elis Regina, que revoluciona o próprio conceito de intérprete. Desembarca no Rio de Janeiro em março de 1964 com contrato com a CBS (gravou o seu primeiro álbum, Viva a Brotolândia, aos 15 anos), sendo logo depois contratada pela gravadora Philips e pela TV Rio e participando da edição de vários programas Noite de Gala, sustentando assim, a casa e o pai no Rio, bem como o resto da família em Porto Alegre.

A chegada da artista ao Rio de Janeiro coincide com um novo momento político e social do Brasil. O tema "o amor, o sorriso e a flor" cede espaço para temas com cunho social não só na música, mas no cinema de Glauber, no Centro Popular de Cultura - CPC, ligas camponesas, reforma agrária, Universidade de Brasília, enfim, a utopia de um Brasil democrático e de valorização da cultura popular.

Em Copacabana, o famoso Beco das Garrafas, recheado de bares, era um ambiente ideal para experimentar novas fórmulas do show business. E foi neste ambiente que estreou Elis. Era assessorada pela dupla Luiz Carlos Miéle e Ronaldo Bôscoli, ainda inexperientes, mas cheios de vontade de produzir musicais baseados na Broadway. Sem recursos, pois os bares do Beco eram minúsculos, usavam a criatividade para dar conta das dificuldades. Assim, Elis estreia no Bottle's dirigida por Miéle e Bôscoli e assessorada pelo bailarino americano 
Lane Dale, que a ensinou a usar os braços que ficariam famosos ao girar como hélice, o que lhe valeu o apelido de Eliscoptéro.

O seu gestual e jeito de cantar fugiam de maneira marcante à postura impressa no canto da Bossa Nova. Assim, artistas como Caetano Veloso, ao vê-la em programas de TV na época, disse: "Eu a achei muito talentosa e muito vulgar [...] E como eu era bossanovista - era muito João Gilberto, aquela coisa cool e de bom gosto e cores mais discretas -, Elis me pareceu cafona, mas cheia de talento" (apud ECHEVERRIA, 1994, p.21).

Elis emigra para São Paulo já num clima estimulado pelos estudantes de centros acadêmicos universitários na época, que arrendam o teatro Paramount com o nome de uma série de shows que se tornariam emblemáticos: $O$ fino da bossa, posteriormente transformado em programa pela TV Record, um novo discurso se formatava com compositores contra a ditadura, mesmo que de forma velada. Neste programa, Elis era acompanhada pelo Zimbo Trio (Luiz Chaves, Amilton Godoy e Rubinho), que a considerava como um músico (fato raro entre a categoria, que não considera o cantor como tal).

Além disso, a artista defende, no I Festival de Música Popular da TV Excelsior (pois o da Record havia terminado), uma canção que se tornaria emblemática em sua carreira não só pelo canto visceral, mas pelo gestual já apontado: Arrastão, de Edu Lobo e Vinicius de Moraes, vencedora do primeiro lugar. Era a consagração que viria a galope em shows memoráveis, como na dupla constituída com Jair Rodrigues, que durou três anos e meio, troféus, shows e contrato com a TV Record, já empresariada pelo argentino Marcos Lázaro. Este negociou seu passe por uma soma equivalente hoje a 15.760 dólares, o salário mais alto pago a um artista na televisão brasileira daquela época.

Assim, a artista torna-se uma grande estrela reconhecida nacionalmente e com fãclube - Elis em movimento. Em 1967, Elis defende a canção de Dori Caymmi e Nelson Motta - O Cantador -, levando o prêmio de melhor intérprete no III Festival de Música da Record, conhecido como o "festival da virada". 
O trânsito da intérprete por diversos gêneros musicais mostra que uma gaúcha também sabe cantar samba com ginga e vence como intérprete a I Bienal do Samba, promovida pela Rede Record com a canção Lapinha, de Baden Powell e Paulo César Pinheiro. Em 1971, Elis aceita presidir o júri do VI Festival Internacional da Canção, promovido pela TV Globo. Neste festival, artistas como Chico Buarque, Tom Jobim, Edu Lobo e Paulinho da Viola aproveitam a transmissão ao vivo para protestarem contra a censura.

Sua carreira é marcada por 28 álbuns, além de coletâneas. Tendo traçado uma vida pontuada por declarações bombásticas, contraditórias, por um temperamento estourado e intolerante e repertório plural, além de uma voz privilegiada, a artista, a cada álbum lançado e espetáculo estreado, se superava em musicalidade e performance, reforçada também pela assessoria inestimável do pianista, arranjador e marido de 1971 a 1980, César Camargo Mariano.

Mas é em 17 de dezembro de $1975^{\circ}$ que a música brasileira é brindada com a estreia de um espetáculo musical que ficou na história do show business brasileiro: Falso Brilhante. Apesar do espetáculo ter sido apresentado só em São Paulo, permaneceu 14 meses em cartaz (fato inédito na época), com 257 apresentações e público de 280.000 mil pessoas. Além do Falso Brilhante, o show e álbum homônimo Transversal do Tempo, gravado ao vivo no Teatro Ginástico, Rio de Janeiro, em abril de 1978, é outro marco em sua carreira. Neste show, a artista retrata a angústia, a claustrofobia da cidade grande, tudo isto presente no repertório de letristas como Aldir Blanc e Maurício Tapajós. Em depoimento ao programa do show, diz ela: "A partir do momento em que resolvi que minha arte deve ter ligação com a realidade em que vivo, mínima que seja, lamento imensamente a cara amarrada, a falta de espaço, a falta de amigos" (apud ECHEVERRIA, p.103), numa alusão à canção citada Aos nossos filhos.

Neste sentido, a artista adorada por muitos e odiada por tantos outros, imprime em seu canto um novo momento na música brasileira, cuja personalidade se confunde com o artístico. Seu canto sintetiza a técnica e a emoção de forma por vezes visceral, por vezes 
contida, brejeira, satírica; ao mesmo tempo, de maneira debochada, diz que "O ser humano está na maior fissura porque está cada vez mais down no high society" (Alô, Alô Marciano, de Rita Lee ${ }^{10}$ e Roberto de Carvalho).

Assim, a intérprete decalca em sua voz não mais a doçura e a submissão do canto feminino impresso na voz de sua musa Ângela Maria, mas a agressividade na voz e no corpo, exibindo assim uma postura política e engajada. Seu canto revolucionário para os padrões estéticos da época, já que a artista surge no miolo da Bossa Nova, está carregado de movimento nos braços e ombros. Ao cantar ${ }^{11}$, exibe sempre sua arcada dentária completa, demonstrando que o canto tímido de Nara Leão já não correspondia unicamente a um jeito de protestar e de mostrar insatisfação pelo poder vigente.

A interrupção precoce de sua carreira, em janeiro de 1982, não calou sua influência sobre as novas intérpretes que surgiriam, espelhando-se inclusive em sua musicalidade, emissão, fraseado, ritmos perfeitos. Isto se verifica inclusive no caso de Daniela Mercury, como veremos no capítulo 5 .

Tomando como referência mais duas grandes representantes da $\mathrm{MPB}^{12}$, podemos ilustrar com o advento de duas baianas um novo momento na música brasileira, que aponta para uma transgressão nos padrões não só musicais como também em termos de apresentação visual de Gal Costa e Maria Bethânia, que em vez de turbantes e trajes da baiana tradicional, condizentes com uma Bahia cristalizada como um ambiente de tradição e pobreza, propõem uma Bahia também contemporânea, que utiliza elementos que coincidem com o pop. Assim, Gal e Bethânia imprimem seus respectivos discursos não unicamente pela voz, como também pelo desempenho corporal e pelo discurso. Diz Bethânia: "Gosto de minha pele e de minhas mãos percorrendo seus contornos”. E Gal... "Sou sexy desde o começo, só que agressiva”. (apud FAOUR, 2006, p.147).

Com estes artistas, a Bahia reassume o proscênio da MPB não somente nas representações da Bahia e do Brasil presentes nas obras de Gil e Caetano, como também nas figuras dessas baianas/intérpretes 
que trazem uma Bahia transitando no binômio tradição/modernidade. Vejamos um pouco de suas trajetórias para compreender o próprio ambiente em que suas respectivas carreiras se plasmam na MPB.

Gal Costa surge no cenário musical ainda na década de sessenta. Inicialmente influenciada pelo canto de João Gilberto, rompe com esta estética buscando um canto mais gutural e gritado, tornando-se musa da Tropicália e portavoz do movimento na ausência dos seus mentores Caetano e Gil, à época do exílio em Londres. A intérprete passa de agressiva ${ }^{13}$ a moderna com álbuns emblemáticos como $\mathrm{Fa}$ Tal - Gal a todo vapor, Cantar, Índia ${ }^{14}$ (1973), retoma a Bahia tradicional com Gal Canta Caymmi (1976), apresenta-se tropical com Gal Tropical (1979) e romântica com álbuns emblemáticos como Água Viva e Mina d'água do meu canto, sem deixar em momento algum seu canto cristalino embaçado. Gal Costa pode ser rotulada como a voz que canta e serve de referência para as novas gerações.

Maria Bethânia torna-se uma representação de canto revolucionário para os padrões vigentes da época em que surge. Convidada para substituir Nara Leão no musical Opinião, com direção de Augusto Boal e direção musical de Dori Caymmi, cujo tema versava sobre o morro, teve seu êxito coroado pela canção Carcará, de João do Vale e José Cândido. Com uma força interpretativa impressa mais na palavra do que na melodia, a intérprete de voz grave e dramática, a cada álbum lançado, imprime novas maneiras de mostrar uma Bahia tradicional, ancestral. Seu repertório busca incessantemente uma dramaticidade carregada de elementos estéticos, poéticos, seja nos cenários, figurinos ou iluminação, utilizados como elementos cênicos, ou na sua própria opção religiosa ilustrada também pelo seu figurino e acessórios, bem como no repertório.

As boites foram o seu palco durante um longo tempo, registrada em álbuns antológicos ao vivo como Recital na Boite Barroco (1968), além de Rosa dos Ventos (1971), e Drama - a luz da noite. Encontros musicais também são frequentes em sua trajetória, como no álbum Bethânia e Edu (1967) e Chico Buarque e Maria Bethânia (1975). Em 1976, a intérprete recebe seu primeiro disco de ouro com Pássaro proibido. Para Oliveira (2005, p. 51), 
Bethânia protagoniza a primeira década de sua trajetória afirmando-se a partir da confluência de habitus, discursividades e reticularidade, como uma mulher marcada por um ideal de liberdade individual que transparece no proscênio de sua performance artística.

Na década de oitenta, a compositora Sueli Costa tem em outra intérprete baiana de nascimento, Simone, uma grande representante. Esta, entretanto, não carrega em seu campo esta marca de territorialidade e da Bahia tradicional presente no canto de Bethânia, e muito menos a voz cristalina de Gal Costa. Ao contrário, com uma voz grave e quente, Simone se coloca como uma intérprete que rompe barreiras, ao assumir publicamente sua orientação sexual.

O final da década de setenta e início da década de oitenta se configuram como um momento bastante representativo para as intérpretes brasileiras, que colocam sua libido em público, seja através de figurinos cada vez mais sensuais com decotes e pernas de fora (já utilizados há muito nos palcos das "revistas") exibidos nas capas dos seus álbuns. É o caso de Simone, com Pedaços e Corpo e alma; de Fafá de Belém, com Banho de cheiro, Estrela radiante e Essencial; e de Alcione, Joanna, Zizi Possi, Beth Carvalho, Rosemary, Fernanda Abreu e Rita Lee, dentre outras ${ }^{15}$. Ou ainda ao vivo, como no show de Simone Delírios, delícias (1983), cantando a balada paixão dos gaúchos Kleiton e Kleidir, cujo cenário era uma cama redonda rodeada de almofadas que insinuava uma masturbação, antes mesmo de Madonna se tornar um escândalo com suas simulações sexuais em cena no emblemático show Like a virgin (1984).

Simone se lança em 1977 com a canção O que será (À flor da pele), de Chico Buarque, além de Medo de amar número 2, de Sueli Costa e Tite de Lemos. Ambas as canções simulam um ato sexual com gemidos e sussurros, exaltando a força e a sensualidade da mulher. No seu repertório recheado de letras com esta temática, destacamos Mulher da vida, Coisa Feita, Condenados, Um desejo só não basta, Tô que tô e Bárbara. 
Em depoimento em relação à escolha do repertório, Simone diz:

Não havia esquema predeterminado para eu ter acesso às músicas, recebê-las e incluí-las em meus discos...O tema das músicas, sua abordagem, não norteava a escolha isoladamente, e sim um conjunto de fatores e, claro, aquelas com as quais eu e a minha voz se identificassem (apud FAOUR, 2006, p. 220).

Como destaque neste ambiente, pontuamos também a presença de Ângela Rô Ro, que revela publicamente sua orientação sexual em escândalos frequentes. Em 1981, de forma ainda considerada agressiva para os padrões da época, lança um álbum com letras bem marcadas pelo homoerotismo, com o nome Escândalo, o mesmo de uma canção de Caetano Veloso; cinco composições em parceria com Náila Skorpio têm também este apelo. Sua voz com um timbre rouco e bluesy, além de grave, torna-se uma referência para artistas que se identificavam com o tema.

Neste mesmo período, outras compositoras e intérpretes surgem no cenário nacional da MPB, a exemplo de Fátima Guedes com Condenados, Cheiro de mato, Mais uma boca (1980), presentes no seu álbum de estreia Lápis de cor, lançado em 1981, quando ela contava apenas 20 anos. Segundo relato próprio, sua grande influência foi Dolores Duran. "Mas quando descobri que ela era uma eterna sofredora, vi que não era só aquilo que eu queria para as minhas letras. Posso ser sofredora, mas não eterna" (apud FAOUR, 2006, p.145). Elis Regina gravou a canção Onze fitas, de sua autoria, além de cantar em seus shows a canção Meninas da cidade ${ }^{16}$.

Outra compositora e intérprete original surgida também na geração setenta/oitenta foi Joyce, com as composições Feminina e Clareana, ambas de 1980, e Essa Mulher (gravada por Elis Regina em 1979 num álbum homônimo), que se apresentam para o mercado como cronistas de uma sociedade em que o papel da mulher se transformou de dona de casa a ativista social, mãe solteira, em competição no mercado de trabalho, buscando outros valores sociais que não valorizam tanto o corpo, mas sim o pensamento e o seu papel na sociedade. Diferente 
um pouco de Fátima Guedes, sua identificação maior passa pela figura de Chiquinha Gonzaga, primeira maestrina e compositora brasileira, que ousou assumir a batuta dos seus arranjos, além de tocar, compor e liderar a orquestra. Enfim, posicionar-se não somente como intérprete e compositora, mas como músico.

Outra artista e compositora que comparece na transformação da MPB para a música pop brasileira a partir dos anos oitenta é Marina Lima, que estreia em 1979, alavancada pela mão de Caetano Veloso, com quem faz dueto no seu disco de estreia. Neste disco, a foto da capa exibe uma artista moderna, plugada com o pop, o que pode ser observado pela guitarra preta empunhada. Seu sucesso vai sendo construído pela linhagem e postura homoerótica ${ }^{17}$ ainda subliminarmente assumida não só pelos códigos de figurino e gestual, como também através das letras de suas canções em parceria com o irmão e poeta Antônio Cícero. Isto pode ser observado no seu quinto álbum, Fullgás ${ }^{18}$, cuja canção se torna emblemática no universo pop embalada pela sua voz pequena e sensual, que viria a se deteriorar ao longo dos anos, retirando-a do mercado.

A esta altura, podemos observar que o Brasil, plugado cada vez mais no mundo da sonoridade dos instrumentos elétricos e das atitudes darks, punks, rockers, pop, impregna o ambiente musical social de tal maneira que grupos como Kid Abelha, Blitz, Barão Vermelho, e intérpretes como Lulu Santos e Ritchie, dentre outros, convivem com artistas que buscam em seus respectivos territórios o sêmen da criação como a "turma do Nordeste", também representada nas composições de Zé Ramalho, Alceu Valença, Belchior, Ednardo, Geraldo Azevedo, e na voz da paraibana Elba Ramalho, que retoma a influência de Marinês e imprime em seu canto um Nordeste agreste, vigoroso, em diálogo com o pop no que se refere à interpretação, à sonoridade e arranjos, como pode ser conferido no frevo Banho de cheiro (1983), de Carlos Fernando.

Elba Ramalho surge no cenário nacional, segundo a crítica especializada, como uma intérprete de canto agreste e estranho aos ouvidos acostumados com a suavidade da voz de Gal Costa. Entretanto, 
Elba traz um dado novo para a MPB: o frevo cantado e dançado no palco, além dos lamentos do sertão impregnado de dor. A alegria e a dor são dois sentimentos bastante recorrentes em sua trajetória. Em Banho de cheiro, um diálogo com a Bahia é recorrente quando enuncia: Eu quero um banho de cheiro/eu quero um banho de lua/eu quero navegar/ eu quero uma menina que me ensine noite e dia o valor do bê-a-bá. $O$ bê-a-bá dos baianos/morena bonita da Boca do Rio/o bê-a-bá do Senhor do Bonfim.... O diálogo com conterrâneos como Geraldo Azevedo está presente na canção Aconchego, gravada pela intérprete em 1985.

Elba é uma intérprete brasileira que transita com propriedade no clima do Carnaval da Bahia através de Moraes Moreira e Luiz Caldas, bem como no Carnaval pernambucano de Alceu Valença e Nando Cordel, dentre outros. O seu vigor no palco se assemelha ao da tríade central de intérpretes baianas deste estudo, levando a alegria, a dança, o molejo, o punch, a força deste canto; sem, no entanto, revelar ainda o elemento pop nos moldes em que a indústria e o mercado fonográfica mundial apontam. Entretanto, carregando o estigma de ser nordestina.

A década de oitenta se constitui num momento bastante representativo para a música brasileira.

Assistimos hoje aos desdobramentos dessa abertura à pluralidade de gêneros, fontes, ritmos e talentos individuais que tão bem marcaram a passagem para a década de oitenta, acompanhando tanto a descompressão de costumes quanto a democratização do país. (ALBIN, 2004, p. 343).

Como exemplo ilustrativo do domínio assumido pelas mulheres de uma maneira geral e das intérpretes e compositoras de forma particular, temos o programa Mulher 8o, veiculado pela Rede Globo, com números musicais ilustrados por nomes como Elis Regina, Rita Lee, Gal Costa, Joyce, Bethânia, Zizi Possi, Fafá de Belém, Joanna, dentre outras.

Entre a década de setenta/oitenta, pontuamos a presença de grandes compositoras e sambistas como D. Ivone Lara, Beth Carvalho, 
Alcione, Lecy Brandão e Clara Nunes, sendo que todas estas imprimem como característica a voz encorpada. Esta última, seguidora da Umbanda, leva também em seu vestuário uma baiana carregada de signos da Bahia tradicional em canções como Ê baiana. Alcione também demonstra um trânsito bastante próximo desta Bahia tradicional em canções como Ilha de maré, de Walmir Lima e Lupa. Com uma voz profunda, destaca-se gravando sambistas tradicionais e modernos como o baiano Edil Pacheco. Lecy Brandão, outro grande expoente do samba, guarda íntima relação com o samba carioca, integrando a ala de compositores da Mangueira. Entretanto, não se pode deixar de registrar o seu diálogo com o samba reggae, quando da gravação da música de Tonho Matéria, Maravilha Araketu-Semente da memória, peça mais executada do CD Cidadã Brasileira, em 1990, que lhe valeu dois prêmios Sharp ${ }^{19}$.

A década de noventa oportunizou a convivência/concorrência de diversos gêneros. Ao mesmo tempo em que sacramenta o pop rock como a música da juventude urbana, que por sua vez já se fazia presente como consumidora desde os anos sessenta, a música sertaneja passa a competir, em termos mercadológicos, com a axé music. É a própria brasilidade que se manifesta no âmbito da música, nem sempre de forma pacífica. Sua expressão se torna crescentemente múltipla, estando os gêneros ou estilos musicais referidos a tradições diferenciadas, que, em conexão com os influxos internacionais, imputam noções de pertencimento. Observa-se cada vez mais a consolidação da mídia eletrônica de várias maneiras associada à indústria da música, com papel fundamental na informação, na divulgação, na circulação de novos ritmos, novos intérpretes, novas bandas, participando do complexo processo de construção de identidades.

Continuemos, pois, em linhas gerais, no ambiente musical nacional, para compreender a consolidação da ascensão da axé music neste contexto. Inicialmente, tracemos o surgimento de uma artista que se tornou unanimidade nacional quando do seu aparecimento em 1988: Marisa Monte. Contemporânea de Daniela Mercury, inicia sua carreira, interpretando canções já gravadas numa pluralidade de 
ritmos e gêneros comum a uma intérprete em busca de um estilo próprio no seu primeiro álbum Marisa Monte ao vivo (1988).

Entretanto, a partir dos seus próximos álbuns, Mais (1991), Verde anil amarelo cor de rosa e carvão (1994), Barulhinho bom (1996), Marisa se exercita também como compositora/intérprete de suas canções em parcerias mais comum com Carlinhos Brown, Arnaldo Antunes, Nando Reis, revelando-se a cada álbum uma intérprete de temas que perpassam o cotidiano, a relação a dois, de forma lírica e doce, característica comum em seu timbre vocal. Buscando um diferencial no mercado da música cuja tônica se reporta à superexposição, Marisa se recolhe cada vez mais da visibilidade, passando anos sem lançar um álbum solo, ou ainda recusando-se a aparecer em programas de televisão. Lançou, ao lado de Carlinhos Brown e Arnaldo Antunes, o disco Os Tribalistas (2002), com recorde de vendas, sem que o trio realizasse um único show ou concedesse uma única entrevista referente ao mesmo sem a expressa presença dos três.

Assim, Marisa Monte traça sua trajetória fazendo o antimarketing de sua imagem. Resguardou-se e produziu outros álbuns, como fez com a Velha Guarda da Portela, o Omelete man de Carlinhos Brown, ou pesquisando sonoridades e ritmos como o samba para servir de referência na construção dos dois álbuns lançados em 2006: Infinito Particular e Universo ao meu redor ${ }^{20}$, depois de seis anos sem gravar um disco solo. Estes álbuns já atingiram a marca de 300.000 mil cópias. Para a artista, o álbum Infinito Particular

[...] é a continuação de meu projeto autoral de compositora. De uma forma mais ampla, posso dizer que faço música contemporânea brasileira, e os dois discos se encaixam nessa classificação [...]. Enquanto em Universo ao meu redor a atmosfera do samba vai muito além do ritmo. É a maneira de lidar com a música como um meio de celebração da vida, uma forma de preservar valores e agregar pessoas (REZENDE; MEIRELLES, 2006, p.29-30). 
Pelo menos no seu álbum de estreia, Carmem Miranda aparece como influência na canção South american way, gravada pela Pequena Notável em 1940, além de Billye Holliday, na canção Speak low. Mas é em Gal Costa que encontramos grandes influências vocais em Marisa Monte, particularmente do álbum de Gal Cantar, bem como em Baby do Brasil, na sua versão mais telúrica em regravações dos Novos Baianos, como se pode ver em A menina dança, no álbum Barulhinho bom, ou em canções próprias como em Vilarejo, presente no seu Infinito Particular (2006). Aos poucos, a intérprete passa a imprimir personalidade cada vez mais singular aos seus trabalhos, bem como nas composições autorais, e nos shows cada vez mais concorridos, em virtude da sensibilidade com que se destacam o figurino, o cenário e a iluminação. Assim, criadora do seu visual e autora de sua própria imagem, ao mesmo tempo em que tem parceiros, mas assume toda a responsabilidade pela sua trajetória. "Gostem ou não gostem, sou mais eu. É assim que me sinto inteira”, diz a artista em entrevista a Barros e Simões (1998, p. 77). Na mesma entrevista, credita sua trajetória em termos de estratégia artística e não de marketing. Assim, "ao mirar um alto padrão artístico e estabelecer um eficiente esquema empresarial, Marisa Monte traçou a mais bem sucedida trajetória da música brasileira contemporânea" (p. 71).

Seguindo o caminho traçado por Marisa Monte, sem, contudo, alcançar sua projeção e unanimidade de crítica, pontuamos nomes como Adriana Calcanhoto, Ana Carolina e Zélia Duncan, para destacar as mais representativas desta geração.

Adriana Calcanhotto, gaúcha de nascimento, com uma postura mais cool, apesar de contundente, revela-se como uma intérprete/ compositora mais concertista, que se apresenta, na maioria das vezes, só com seu violão, mostrando-se influenciada pela Tropicália na temática de suas canções. Ana Carolina, mineira, surge também como compositora que se vale da percussão para alimentar uma interpretação mais visceral e barroca.

Zélia Duncan, além de compositora, carrega em seu timbre vocal uma semelhança com a região da tessitura masculina, sugerindo um 
canto mais andrógino. Ana Carolina também imprime timbre grave, mas, diferentemente de Zélia Duncan, percebe-se pelo timbre uma mulher cantando.

Juntamente com Cássia Eller, estas três últimas são representantes da geração de compositoras e intérpretes da denominada Nova música popular brasileira, que, mais do que uma mensagem poética musical impressa em suas performances vocais e corporais, trazem impregnado em seu canto a sua orientação sexual, levando legiões de fãs homossexuais aos espaços em que se apresentam, demonstrando cada vez mais um país plural, não só no que se refere a gêneros musicais e costumes, como também a orientações sexuais.

Outras intérpretes que surgem no novo milênio podem ser sumarizadas em dois nomes que despontam no mercado: Maria Rita e Vanessa da Matta ${ }^{21}$.

Maria Rita já surge no mercado com uma carga de responsabilidade singular. Filha de Elis Regina e César Camargo Mariano lança o primeiro álbum gravado ao vivo num show que contempla canções de Milton Nascimento, Marcelo Camelo (guitarrista do grupo Los Hermanos), buscando uma sonoridade acústica com pegada ${ }^{22}$ pop. Incensada pela mídia como substituta da mãe, apesar do timbre bastante parecido, a artista busca novos caminhos, apesar de se configurar, juntamente com Vanessa da Matta e Marisa Monte, como representantes da denominada Nova MPB. No segundo álbum, gravado ao vivo no estúdio, diz a artista, no encarte:

Essas canções foram todas ensaiadas e gravadas ao vivo no estúdio Toca de Bandido, no Rio de Janeiro, nos meses de junho e julho de 2005, com a intenção de captar a emoção dos músicos envolvidos. Foram mixadas posteriormente, sem emendas ou consertos, por Álvaro Alencar, também na toca. MR. (MARIA RITA, 2005).

Com um canto quase falado, mas diferente do de João Gilberto, impregnado de um certo temor pelo futuro, Maria Rita aponta para uma intérprete em forma(ta)ção, preocupada com o social quando 
diz na canção Minha alma (a paz que eu não quero), de Marcelo Yuka: A minha alma tá armada/E apontada para a cara do sossego/Pois paz sem voz, paz sem voz/Não é paz é medo... Com o álbum Samba meu, de 2007, Maria Rita traz o samba como tema, contemplando novos compositores como Arlindo Cruz, Serginho Meriti, Edu Krieger, Franco, além do consagrado compositor Gonzaguinha.

Vanessa da Matta, que desponta no novo século sem ter alcançado o sucesso de Marisa Monte, imprime em sua performance referências pontuais de intérpretes como Clara Nunes, Adriana Calcanhoto e Gal Costa. Assim como estas, constituiu-se como uma intérprete autoral, como pode ser conferido na canção $A$ força que nunca seca, gravada por Maria Bethânia, quando a artista contava com apenas 19 anos. Regravou Nossa canção, de Luiz Ayrão, inicialmente gravada por Roberto Carlos (1966), estourando nas emissoras de rádio. Mas é também como compositora que se apresenta nos seus álbuns: Vanessa da Mata (2002), Esta boneca tem manual (2004) e Sim (2007).

Assim,Vanessa torna-se referência para uma legião de aspirantes a intérpretes que pleiteiam se lançar no mercado. Para Nelson Motta, em entrevista ao jornal A Tarde este mercado é marcado também pela democratização musical provocada pelas novas mídias, a pirataria e a Internet, que disponibiliza produtos para o largo consumo, como um ponto importante na facilidade de se mostrar um trabalho. No entanto, diz ele: "É uma oportunidade para todo mundo. Nunca foi tão fácil mostrar um trabalho.Ao mesmo tempo, nunca foi tão difícil ser notado.Essa é uma consequência da democratização musical" (ALVES, 2006b, p.8).

Martins;Vitale (2007) apontam que, em 2006, mais de 100 intérpretes femininas chegaram às lojas, enquanto que, do sexo masculino, apenas 34 foram lançados. Segundo o autor, este boom de vozes femininas se deve a três fatores: 1) o aumento do apuro técnico das cantoras, que buscam cada vez mais tornar a voz um instrumento; 2) a dedicação das mulheres em especial na arte de interpretar; e, por fim, 3) o diálogo constante que estas novas aspirantes a estrela mantêm com as suas precursoras. 
Ainda para Martins;Vitale (2007), esta horda que vem surgindo pode ser agrupadas em três vertentes como grandes influenciadoras da nova geração: a recordista em número de discípulas é Elis Regina ${ }^{23}$, que tem no seu canto uma carga interpretativa em cada nota emitida. Dentre elas o autor cita a paulista Daniela Procópio, Bruna Caran e Giana Viscardi. A segunda vertente tem como referência João Gilberto $^{24}$, reunindo nomes como Luciana Alves e Érika Machado; na terceira, a influência vem de Marisa Monte, em nomes como Roberta Sá, Anna Luisa e Luísa Maita, cujo treinamento no canto lírico leva a uma emissão mais segura e cuja obsessão com a técnica, bem como a maneira de compor um repertório, "são duas lições básicas" (p.124).

Entre estas influenciadoras, o autor cita ainda a "escola de Clara Nunes ${ }^{25}$ ", cujas características do "canto encorpado e um repertório que varia de sambas a música do início do século passado” (p. 124), "misturando sentimentos de alegria e de tristeza que caracteriza o samba de raiz" (p. 123), têm como seguidoras nomes como Mônica Salmaso, Paula Lima, Mariana Baltar e Mariana Aydar, dentre outras. Convém observar que o "mapeamento" destas intérpretes femininas que surgem no cenário "nacional" se refere unicamente aos talentos do centro-sul não, contemplando, portanto, a pluralidade de intérpretes que habita este Brasil musical.

Assim, as múltiplas possibilidades de um país mestiço podem ser observadas na mensagem poética e no canto destas intérpretes carregado de significados de vários lugares. Pode-se observar que as representações que articula identidades formadoras do texto-nação Brasil também se encontram presente na produção musical/vocal destas intérpretes que contribuem de forma determinante para a construção do texto da brasilidade/baianidade.

Após esta longa relação de intérpretes brasileiras, aos efeitos de compor uma caracterização de sua diversidade tanto quanto de alguns eixos comuns de seus desempenhos e de suas posturas, pode-se afirmar que o sujeito da música/canção - especialmente o sujeito feminino, no caso desta pesquisa - se traduz como um representante 
em potencial na mediação/relação entre artista e sociedade. A contemporaneidade, por sua vez, pode traduzir um ambiente propício para um estudo dessa natureza, na medida em que a crise da modernidade se torna mais visível com o ocaso de formulações antinômicas simples, dando lugar à percepção mais evidente da fragmentação e da descontinuidade.

Por outro lado, esta problematização também pode ser encontrada em outras linguagens tais como a literatura, o futebol e a televisão na constituição de um quadro de referências da brasilidade. É neste sentido que se revela interessante recorrer ao pensamento transdisciplinar dos Estudos Culturais, cuja problemática sobre identidade toma o proscênio em nomes como Stuart Hall e Paul Gilroy.

Stuart Hall (1992) interroga se as mudanças em processo tomadas de forma grupal, em conjunto, não corresponderiam à própria modernidade que está se transformando. O autor argumenta com a insinuação e desdobramento de uma nova dimensão: naquilo que é descrito, algumas vezes, como nosso mundo pós-moderno, somos "pós" relativamente a qualquer concepção essencialista ou fixa de identidade - algo que, desde o Iluminismo, se supõe definir o próprio núcleo ou essência de nosso ser e fundamentar nossa existência como sujeitos humanos. Para explorar estas afirmações, o autor primeiramente examina as definições de identidade e o caráter da mudança na modernidade tardia.

Assim como na inspiração de Hall, este estudo se apropria da noção de identidade que se organiza de forma fluida e dinâmica, como num concerto, simpatizando com o sujeito pós-moderno, cuja identidade assume contornos diferentes em diferentes fenômenos, sendo definida historicamente e não biologicamente de forma não unificada ao redor de um "eu" coerente. Seria fora de sentido pensar a identidade como algo dado. Mais pertinente seria pensá-la de forma múltipla, como um texto, que tanto pode se referir a um perfil de um indivíduo, ou milhões deles (MOURA, 2001). 


\section{A construção de uma referência baiana no contexto da brasilidade}

A partir do que foi discutido na seção anterior, podemos afirmar, então, que alguns espaços se constroem historicamente como referências na trama da brasilidade que tem o rádio, a música, bem como o teatro de revista e o cinema, como grandes difusores de um discurso nacionalista. A Bahia comparece como o lugar por excelência da tradição, da ancestralidade, da familiaridade (MOURA, 2001). Como lugar emblematizado qual nascedouro do Brasil, configura-se também como sede do elemento ou fator étnico. Sua legião de intérpretes, compositores, romancistas, cronistas, cineastas, dentre outros profissionais, contribuem para plasmar esta representação.

Jorge Amado, na área da literatura, se firma com a referência de Bahia tradicional, com tipos imortalizados a exemplo de Tieta do Agreste, Gabriela Cravo e Canela, Mar Morto, Dona Flor e seus dois maridos, etc.

Temos como uma das figuras mais paradigmáticas deste padrão de representação a figura de Dorival Caymmi, ao representar uma Bahia praieira, paradisíaca, contribuindo de forma decisiva para a configuração de uma Bahia ancestral, religiosa, em harmonia com a natureza, de forma a contribuir para plasmar uma Bahia tradicional, ratificada também na obra de não baianos tais como Ari Barroso, Vinicius de Morais e Carmem Miranda, dentre outros.

Indo além, diríamos que as construções identitárias sobre a Bahia não se resumem unicamente aos baianos e tampouco aos brasileiros. A dinâmica destas construções identitárias pode ser construída por estrangeiros que nunca estiveram na Bahia, bem como brasileiros em igual situação, buscando num diálogo entre tradição e modernidade sua construção. Para Moura (2001) a origem do texto da baianidade se encontra não na Baía de Todos os Santos, mas na Baía de Guanabara.

No âmbito da música, antes ainda que esta construção se faça presente pela obra de Dorival Caymmi, buscamos referências da 
construção desta identidade em nomes conhecidos e consagrados do cancioneiro popular, tais como Xisto Bahia, artista baiano com trânsito no teatro e na música. Nascido em Salvador, teve um papel fundamental na construção e perpetuação de nossa música com a gravação do lundu Isso é bom pelo cantor também baiano Manoel Pedro dos Santos, conhecido simplesmente por Baiano.

Este artista foi o responsável provavelmente pela gravação do primeiro disco brasileiro; o zonophone número 10.001 com gravação em uma só face. Ele consta com o número de ordem 01, no catálogo da Cada Edison em 1902 (LISBOA JR., 1990, p. 19).

Para Lisboa Jr., a indústria fonográfica brasileira nasceu sob as bênçãos dos orixás, pois o primeiro disco brasileiro foi gravado por um intérprete baiano, de um autor baiano.

Canções com temas culinários da Bahia, imortalizadas na obra de Caymmi, já eram corriqueiros desde 1904, quando da gravação do lundu de autor anônimo de nome $O$ Caruru, registrado na voz do cantor carioca Mário Pinheiro. Além disto, consta um sem número de canções com o mesmo temário que contribuíram para a construção desta identidade, tais como A farofa (1907), também gravada por Baiano, e $O$ vatapá, gravada por uma dupla gaúcha de nome Os Geraldos, formado por Geraldo Magalhães e Nina Teixeira - trata-se de uma cançoneta anônima, picante, que descreve como se faz um vatapá. Vale a pena transcrever um pequeno trecho:

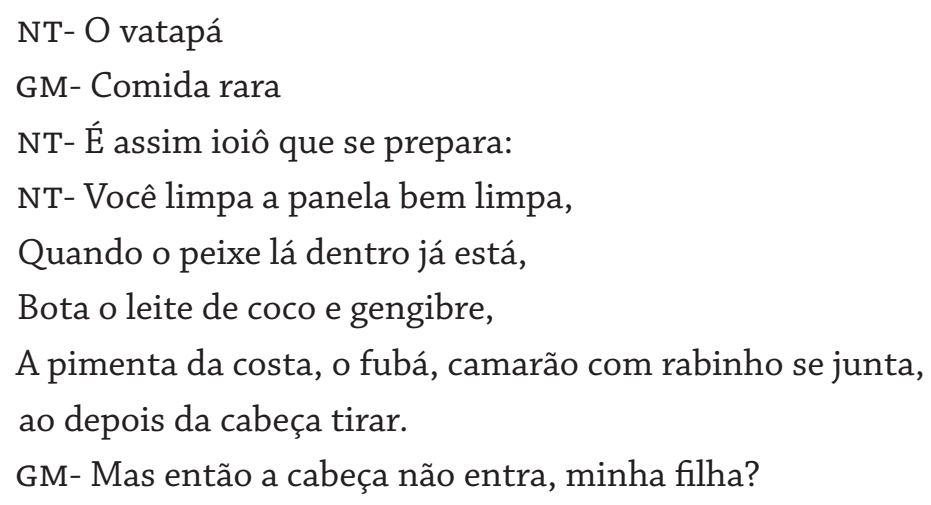


NT- Ah! Que cabeça, seu moço, que nada!

NT- Mexe direito prá não queimar,

GM- Pra não queimar

NT- Pegue com jeito o vatapá

$[\ldots]$

Podemos citar mais um exemplo no que se refere à música como construção do texto da baianidade na voz de Francisco Alves, que teve sua primeira gravação com um tema sobre a Bahia, bem como de Orlando Silva, que iniciou sua carreira fonográfica gravando o samba Olha a baiana, de 1935 .

Vale a pena destacar o papel relevante dos ranchos inaugurados pelo diálogo entre baianos e cariocas na construção da marca que correspondente à Bahia impressa nessas manifestações, sob a égide da religiosidade negra, da lascívia, da malemolência que caracterizam um texto identitário da Bahia tradicional. Tomemos como exemplo o texto de Moura:

É na própria história do Carnaval carioca que vamos encontrar, de forma mas fartamente documentada, a presença dos baianos no Rio de Janeiro [...] A importância de relacionar estes elementos decorre do próprio fato de o texto da baianidade ter se originado do contraste entre os padrões civilizatórios que se tornaram emblemáticos do Rio de Janeiro e da Bahia, já no século XIX [...] Não é somente o número dos baianos no Rio de Janeiro, as qualidades de sua atuação e a frequência com que são referidos que impressiona; são também os conteúdos reunidos e organizados por este termo. Seriam todos estes personagens baianos mesmo? Tratar-se-ia de uma sinédoque que, de tão usual, sequer parece sê-lo? É nome de que esta palavra? Assim, encontro motivos mais que suficientes para supor que baiano, é tanto quanto o pátrio de uma província, o nome de um ethos que acontece, num universo hegemonizado pelo elemento branco, suposta e/ou pretensamente ocidental, como étnico (MOURA, 2001, p. 138). 
Neste sentido, o cenário do Carnaval se constitui num ambiente ideal no campo da música, seja através do lundu, do samba, do maxixe, do tango brasileiro, da marcha, da marcha rancho, do samba reggae, ou qualquer outro gênero sincrético (CANEVACCI, 1996) composto para a festa, para a construção identitária da Bahia.

Retomando a reflexão de Moura sobre o caráter de Salvador como uma cidade para o Carnaval, ou seja, uma cidade que produz festa durante quase todo o ano:

[...] seja para consumo próprio seja para o dos adventícios, a cidade está continuamente produzindo e vendendo sua máscara, que se refere sobretudo à sua pele, sua voz, seus movimentos, sua capacidade de criar. Esses atributos têm sujeitos e esses sujeitos correspondem à própria sociedade soteropolitana, de que os artistas, empresários e políticos não são que representantes e administradores. Seja porque o Carnaval de Salvador é um trabalho que envolve muitos milhares de indivíduos, seja porque este trabalho toma como substrato a representação da identidade da cidade e retoma continuamente essa representação, a discussão sobre a organização da festa não pode deixar de considerar a festa de uma cidade ( MOURA, 1996, p.68).

Convém lembrar que o Carnaval não diz respeito apenas à festa que tem esse nome, mas a todo um universo de processos, vivências, experiências e produção empresarial e artística que alcança, na realização do próprio Carnaval, o seu apogeu. Neste sentido, a malha extensa de micaretas, ensaios, Festival de Verão, Carnaval temporão, etc, integra também o que chamamos aqui de Carnaval.

Moura (2001) considera a baianidade como um texto representacional baseado em três pilares: familiaridade, religiosidade e sensualidade. Neste sentido, seria pertinente pensá-la de forma múltipla, como um texto, que tanto pode se referir a um perfil de um indivíduo, ou milhões deles (MOURA, 2001, p.13). Assim, a cidade do Salvador se especializou em vender sua própria imagem, embalada pelo fazer musical que tem o Carnaval como uma grande vitrine desta representação. 
Este texto pode nos servir para delinear o que chamamos de territorialidade, baseada nas noções de lugar e região como constitutivos de identidades do binômio Bahia/Brasil. Afirma-se que o Recôncavo toma o proscênio na construção de uma identidade baiana no Brasil seja através de artistas como Assis Valente, Baiano e as tias - Ciata, Perciliana Maria Constança e Amélia de Aragão.

Décadas depois, outros representantes da construção da imagem da Bahia se fariam presentes, tais como os Caetano, Gil, Gal e Bethânia, que também migram para tentar a sorte no eixo-sul. Estes artistas representam uma nova configuração sócio-cultural da Bahia e do Brasil a partir da década de sessenta, contribuindo assim para a construção não de uma Bahia, mas de Bahias representadas através das singularidades de cada um (OLIVEIRA, 2005), contribuem para plasmar a imagem veiculada da Bahia de forma plural, principalmente pela voz/composição de Caetano Veloso, Atrás do trio elétrico, em 1969, divulgando para o Brasil o Carnaval da Bahia e a engenhoca inventada pela dupla Dodô e Osmar na década de cinquenta. O Carnaval da Bahia, assim como o trio elétrico, se torna então conhecido em outras regiões.

$\mathrm{Na}$ década de setenta, mais baianos contribuem para plasmar a imagem da Bahia fora do seu território. É o caso dos Novos Baianos, que, promovendo a síntese de choro, rock e samba, divulgam uma Bahia em diálogo da tradição dos choros e sambas com a modernidade do som das guitarras distorcidas de Pepeu Gomes. Uma das figuras emblemáticas deste grupo é o compositor e cantor Moraes Moreira, que sai para a carreira solo na década de oitenta e contribui de forma determinante para plantar a nova síntese musical que desembocaria na axé music, já promovendo aproximações com ritmos do candomblé, a exemplo do ijexá, com parceiros tais como Antônio Risério e Fausto Nilo. Antes, porém, passemos a considerar a figura da baiana como representação de uma baianidade tradicional que, por sua vez, desempenha um papel especial na configuração da própria brasilidade. 


\section{A figura da baiana}

A organização de um acervo nacional de identidades se dá ao longo das décadas de forma indissociável da formação de um repertório que consubstancia o que chamamos, inclusive na linguagem do senso comum, de música popular brasileira, também representada nos palcos das revistas musicais pelas figuras da baiana e da mulata, como do malandro, do matuto e outros tipos criados neste ambiente e encontrados também nos filmes da Atlântida e suas chanchadas. Nestes espaços constantemente negociados por atrizes/intérpretes, nem sempre brasileiras, e muito menos baianas, percebe-se uma multiplicidade de identidades se apresentando num construto variável e complexo de elementos.

Neste sentido, a música, assim como o teatro de revista, particularmente, e o próprio cinema nacional também podem ser elencados como fatores relevantes na construção de uma identidade nacional. Estes elementos configuram perfis artísticos que marcam na música, no seu jeito de cantar e dançar, um "lugar" demarcado territorialmente, cuja presença no cenário cultural se processa mediante a síntese de culturas que se hibridizam constantemente em sua mulatez, ao mesmo tempo em que buscam nesta síntese a diferença.

Vejamos em linhas gerais como podemos construir estes perfis, buscando desde o final do século XIX, com o estabelecimento no Rio de Janeiro das tias baianas e a consolidação da figura da baiana no teatro de revista, a construção de uma identidade de intérprete baiana/brasileira. Logo após, isto será completado pela observação da trajetória de algumas intérpretes no cenário artístico/teatral brasileiro que servem para delinear uma elaboração de identidades culturais associada ao fenômeno do surgimento das estrelas na indústria da música.

\section{As tias baianas no Rio de Janeiro}

O século XIX assiste a uma progressiva crise da economia baiana. Neste contexto, boa parte de trabalhadores rurais migra para o vale 
do Paraíba, que vivia o apogeu do café. A partir do final do século, a própria capital brasileira torna-se foco de emigração desta mão-deobra que se junta aos demais num processo de industrialização que começava a se instalar na capital do Império.

Tinhorão (1998), aponta que:

Desde a década de 1870 os baianos constituíam, em verdade, a segunda maior colônia de emigrados da capital do país [...]: eram os baianos 2.120 numa população local de $274.972 \mathrm{em}$ 1870; 10.633 na população de 522.651 em 1890, e 12.926 entre 1.157.873 de habitantes recenseados em 1920. (p.264).

Entretanto, além dos baianos, encontra-se em menor escala, na vida urbana do Rio de Janeiro, agrupamentos de núcleos vizinhos de diferentes regiões tais como pernambucanos, alagoanos, sergipanos, e em maior número, baianos, que, tendo afinidades nas diversas formas de diversão, transforma "a cidade do Rio de Janeiro de fins do século XIX e inícios do século XX, num verdadeiro laboratório de experiências fragmentadas de usos e costumes de origem rural" (p.265).

Desde a Primeira República, em virtude das perseguições sistemáticas por parte da polícia em diversos pontos de aglomeração - rodas de batuque, capoeiras, dentre outras manifestações -, as casas das famílias dos baianos mais bem sucedidos torna-se o local mais seguro para as reuniões da comunidade, introduzindo assim o costume destes patrícios e agregados se reunirem nas casas das "tias".

A presença dos afro-baianos na capital da província a partir do século XIX tem em Hilária Batista de Almeida, a famosa Tia Ciata, uma representante singular, formando, com o seu clã, um pedaço da pequena África (MOURA, 1995) no Rio de Janeiro. Nascida em Santo Amaro da Purificação, no Recôncavo Baiano, em 1854, chega ao Rio de Janeiro ainda mocinha e tinha sua residência na rua Visconde de Itaúna, na região da Praça Onze, mudando-se depois para a rua da Alfândega. A Praça Onze "é tradicionalmente aceito como sendo o local onde teria nascido Pelo telefone, tido como o primeiro samba com autoria registrada e gravado em disco" (LOPES, 2003, p.32). 
Vejamos, a seguir, o depoimento do cronista Francisco Guimarães, na década de 1930.

Outro samba afamado era na casa da tia Ciata, que nestes últimos tempos foi, sem dúvida, a baiana de maior nome na baía de Guanabara [...] Os sambas na casa de tia Ciata eram importantíssimos porque, em geral, quando eles nasciam no alto do morro, na casa dela é que se tornavam conhecidos na roda. Lá é que eles se popularizavam, lá é que eles sofriam a crítica dos catedráticos, com a presença das sumidades do violão, do cavaquinho, do pandeiro, do reco-reco e do atabaque. (GUIMARÃES, 1930 apud LOPES, 2003, p. 35).

Além da famosa Tia Ciata, outras tias de tornaram famosas. Uma delas é Prisciliana de Santo Amaro, tendo como nome de batismo Perciliana Maria Costança, mãe de onze filhos, dentre eles o caçula conhecido como João da Baiana. Outra dessas mulheres singulares foi Tia Amélia, mãe do famoso Donga, apontado como o autor de Pelo telefone, a primeira canção registrada como samba. Outra ainda foi Tia Dadá, em cuja casa o compositor Caninha afirmou ter ouvido samba pela primeira vez. Estes são alguns dos redutos familiares cujo funcionamento até a década de 1920 se tornaram "verdadeiros centros de diversão popular" (TINHORÃO, 1998, p. 275).

Tinhorão (1998) aponta que o tratamento de "tia" ${ }^{26}$ conferido a estas mulheres se deve também à maior experiência delas por conta da idade e pelo sucesso financeiro pessoal como vendedora de doces e comedorias feitas na hora, ao fogareiro, normalmente expostos em tabuleiros ornados em panos de renda e expostos nas esquinas do centro comercial, como se vê em quantidade em Salvador.

Os proventos conseguidos com este ofício forneciam uma ajuda substancial aos seus companheiros, possibilitando assim que elas assumissem o aluguel dos casarões em velhas ruas, que no Segundo Reinado haviam se constituído em moradia de burgueses, cuja arquitetura longitudinal possibilitava uma estratificação social assim descrita: 
Sala de entrada seguida de vários cômodos dando para o longo corredor que conduzia ao quintal, após passar pela sala de jantar e a cozinha. [...] na sala, ficavam os mais velhos e bem sucedidos, que constituíam o partido alto da comunidade, cultivavam seus versos improvisados entre ponteados de violão, lembrando sambas sertanejos de roda à viola; os mais novos, já urbanizados, tiravam seu samba corrido cantando em coro na sala de jantar, aos fundos; e no quintal, os brabos amantes da capoeira e da pernada, divertiam-se em rodas de batucada ao ritmo de estribilhos marcados por palmas e percussão (TINHORÃO, 1998, p. 276).

Estas festas tinham uma frequência bastante diversificada. Além da comunidade baiana, os cariocas também participavam, seja por laços de parentesco, seja por proximidade cultural ou social. Frequentavam estes espaços artesãos, militares de baixo escalão, músicos, boêmios, repórteres, dentre outros. Assim, a casa não era frequentada apenas por negros e pobres, mas também por integrantes de outras etnias, como o cigano Saudade ${ }^{27}$.

Moura (2001) aponta que o texto da baianidade se constrói pelo tripé religiosidade, sensualidade e familiaridade. Entretanto, poderíamos acrescentar a este tripé a culinária e a festividade, tão presente nestes encontros nas casas das tias, também como berço da construção de uma identidade nacional que tem a música brasileira como um dos ícones mais vigorosos - em particular, o samba.

Além da figura da baiana que habitava este universo das revistas musicais, a música carnavalesca se fazia presente, já ditando sucessos que viriam a se difundir através do rádio que a processava industrialmente, diante de grandes públicos de consumidores, tornando-a assim popular e, consequentemente, ser sucesso no Carnaval. Como já destacado anteriormente, a música popular brasileira, associada ao teatro ligeiro e ao rádio, construiu seu sucesso baseado na trilogia teatro/Carnaval/rádio.

O "ser baiano" no Brasil ou "brasileiro" fora dele se constitui num arranjo de narrativas singulares cuja organização pode ser reportada 
à terceira década do século $\mathrm{XX}$, sobretudo a partir do advento do rádio como veículo de difusão de nossa música, seguido do futebol e da televisão, que, ecoando pelo país afora, unificam o país de uma forma múltipla.

Nesse momento, gostaríamos de nos deter de forma mais específica na construção de um texto que organiza de forma paradigmática a "identidade baiana", partindo da construção das atrizes/cantoras do teatro de revista, que se constitui num perfil bastante significativo desta representação nos palcos. Entretanto, não podemos deixar de registrar, com base em Lopes (2003), o êxodo de negros/baianos para a capital do Império a partir de 1860, devido ao declínio da cafeicultura no vale do Paraíba, contribuindo assim para a construção de narrativas identitárias da Bahia, e da Bahia no Rio de Janeiro também pelos trabalhadores da zona portuária e do comércio, bem como pelas tias que serviram de mediadoras na forma(ta)ção do samba. É preciso completar esta informação lembrando que boa parte dos negros/escravos que trabalhavam nos cafezais do Vale do Paraíba eram baianos. Inclusive a grande Tia Ciata.

Como se costuma rememorar na narrativa fundante da identidade brasileira, a Bahia carrega no seu ventre o nascimento do Brasil. E é muito significativo que isto se constitua numa cidade feminina não só pelo gênero - $a$ Bahia -, como também pela predisposição para o inaugural; o dar à luz, enfim.

Os palcos cariocas e suas revistas de ano retrataram inúmeros tipos populares, dentre eles a baiana, encontrado também nos romances da época através de personagens como Rita Baiana ou mesmo na descrição do romance Memórias de um sargento de milícias, de Manoel Antônio de Almeida (2004), que começa sua narrativa situando historicamente que o mesmo se passa no tempo do rei, referindo-se à permanência de D. João VI no Rio de Janeiro juntamente com a corte portuguesa entre 1808 e 1821. Assim, citaremos um trecho um pouco extenso deste romance para ilustrar a presença deste tipo no imaginário social do Brasil desde os tempos do rei ao descrever, num dia de procissão, a passagem de um rancho de nome As baianas. 
Queremos falar de um grande rancho chamado das - baianas -, que caminhava adiante da procissão, atraindo mais ou tanto como os santos, os andores, os emblemas sagrados, os olhares dos devotos, era formado este rancho por um grande número de negras vestidas à moda da província da Bahia, donde lhe vinha o nome, e que dançavam nos intervalos do Deo gratias uma dança lá a seu capricho.[...] Todos conhecem o modo por que se vestem as negras da Bahia; é um dos modos de trajar mais bonito que temos visto, não aconselhamos porém que ninguém o adote; em país em que todas as mulheres usassem desse traje especialmente se fosse desses abençoados em que elas são alvas e formosas seria uma terra de perdição e de pecado. Procuremos descrevê-lo.

As chamadas baianas não usavam de vestido; traziam somente umas poucas saias presas à cintura, e que chegavam pouco abaixo do meio da perna, todas elas ornadas de magníficas rendas; da cintura para cima apenas traziam uma finíssima camisa, cuja gola e mangas eram também ornadas de rendas; ao pescoço punham um cordão de ouro ou um colar de corais, os mais pobres eram de miçangas; ornavam a cabeça com uma espécie de turbante a que davam o nome de trunfas, formado por um grande lenço branco muito teso e engomado; calçavam umas chinelinhas de salto alto, e tão pequenas, que apenas continham os dedos dos pés, ficando de fora todo o calcanhar; e além de tudo isso envolviam-se graciosamente em uma capa de pano preto, deixando de fora os braços graciosamente ornados de argolas de metal simulando pulseiras (ALMEIDA, 2004, p. 55-56).

Tempos depois, não seria tão elogioso o registro da presença das baianas no centro do Rio de Janeiro por Machado de Assis, em uma de suas crônicas na gazeta A Semana. Trata-se da abundância de tias baianas na Rua Direita no final do século XIX:

[...] dominavam as quitandeiras de um lado e, de outro, africanas e crioulas. Destas, as baianas eram conhecidas pela trunfa - um lenço interminavelmente enrolado na cabeça, fazendo 
lembrar o famoso retrato de Mme de Staël. Mais de um Lord Oswald do lugar achou ali a sua Corina. Ao lado da Igreja da Cruz, vendiam-se folhetins de várias espécies, pendurados em barbantes. Os pretos minas teciam e cosiam chapéus de palha. Havia mais... Que é que não havia na rua Direita? (ASSIS, s/d, p. 278).

Em direção contrária deste breve trecho de Machado de Assis está a construção da personagem Rita Baiana em O Cortiço, de Aluízio de Azevedo:

E viu a Rita Baiana, que fora trocar o vestido por uma saia, surgir de ombros e braços nus, para dançar. A lua destoldara-se nesse momento, envolvendo-a na sua coma de prata, a cujo refulgir os meneios da mestiça melhor se acentuavam, cheios de uma graça irresistível, simples, primitiva, feita toda de pecado, toda de paraíso, com muito de serpente e muito de mulher. Ela saltou em meio da roda, com os braços na cintura, rebolando as ilhargas e bamboleando a cabeça, ora para a esquerda, ora para a direita, como numa sofreguidão de gozo carnal num requebrado luxurioso que a punha ofegante; já correndo de barriga empinada; já recuando de braços estendidos, a tremer toda, como se fosse afundando num prazer grosso que nem azeite em que se não toma pé e nunca se encontra fundo. Depois, como se voltasse à vida, soltava um gemido prolongado, estalando os dedos no ar e vergando as pernas, descendo, subindo, sem nunca parar com os quadris, e em seguida sapateava, miúdo e cerrado, freneticamente, erguendo e abaixando os braços, que dobrava, ora um, ora outro, sobre a nuca, enquanto a carne lhe fervia toda, fibra por fibra titilando (AZEVEDO, 1997, p. 67).

\section{O teatro de revista - Oba!}

O teatro de revista no Brasil surge em $1859^{28}$, com As surpresas do Sr. José da Piedade de Justino de Figueiredo Novaes, atinge o começo do seu apogeu em $1883^{29}$ com a revista O Mandarim, trazendo a dupla de 
irmãos maranhenses - os revistógrafos Arthur ${ }^{30}$ e Moreira Sampaio. Definida como uma forma ligeira de entretenimento, a revista musical ou teatro de revista contém:

elementos da comédia clássica, da dança popular coletiva e da dança interindividual dos salões aristocráticos, e dos autos populares profanos, representados nas feiras municipais francas da Idade Média, nos quais eventos do ano eram rememorados em canções humorísticas e alegóricas (PAIVA, 1991, p.30).

Apesar de a revista não exigir em sua estrutura uma linha narrativa, o modelo luso que nos serviu de inspiração trazia como figuras obrigatórias o compère e a comère. Já a revista de ano é uma criação francesa, tendo como característica passar em revista fatos acontecidos no cotidiano durante o ano, costurados por um tênue fio de enredo adornado por muitos personagens episódicos e/ou alegóricos, que em cena cantam e dançam depois de um breve diálogo com o personagem principal, que nunca sai de cena.

Esse gênero irreverente tinha como proposta artística passar em revista ${ }^{31}$ os fatos cotidianos acontecidos durante o ano, emoldurados por canções, mulheres bonitas com corpos e pernas bem torneadas, muita fantasia e tipos que desfilavam uma infinidade de situações costuradas por um texto ágil e de fácil agrado. Este gênero contribuiu de forma emblemática para a construção da intérprete/estrela no Brasil, além da padronização do formato apoiados em modelos importados da França, Itália, Portugal, Inglaterra e Espanha, e da considerável quantidade de empresários, autores, diretores, técnicos e artistas em sua grande maioria vindos de Portugal, e posteriormente da Itália, França, Espanha e Argentina.

Influenciada inicialmente pelo modelo francês - particularmente a partir da década de vinte - e transplantada de Portugal, a revista encontra no Rio de Janeiro ambiente perfeito para o seu florescimento. Alimentada por um público formado em sua grande maioria por lusos, espanhóis, franceses e italianos, exerce influências na construção de um gênero que começava a dar mostras de brasilidade. Ao contratar 
artistas brasileiros para confecção dos libretos, canções, e atuarem nos palcos como atores/cantores, coristas, que pudessem representar tipos "brasileiríssimos", os empresários lusos possibilitam a criação de tipos, que tinham na caricatura pessoal o ponto forte, já presente nas revistas portuguesas - diferentemente das revistas francesas, que tinham como preocupação maior o espetáculo bem coreografado, com números musicais costurando o frouxo enredo que servia para ilustrar as pernas e corpos esculturais das vedetes.

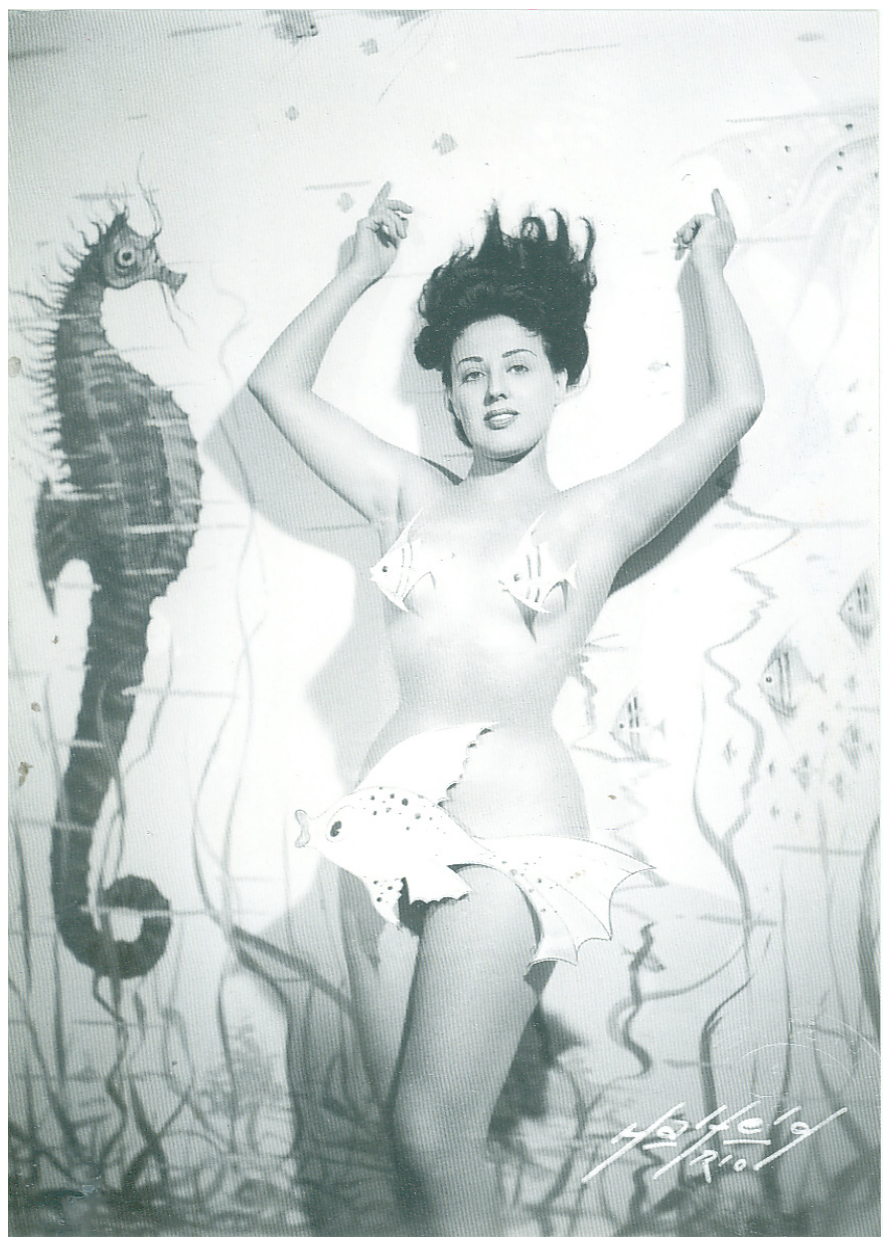

Figura 1 - Virgínia Lane. Cedoc-Funarte [1940] 
A atuação destes empresários na contribuição e fomento deste tipo de espetáculo que levava grandes públicos em cada audiência, motivados pelo artista que mostrava no palco sua marca registrada, pela música que ecoava pela boca do povo ou pelas partituras vendidas em cada esquina, ou ainda pelos revistógrafos famosos capazes de captar situações curiosas de caráter político, social, cultural que pudessem ir à cena, apesar por vezes da forte censura na época, foi um dos fatores que corroborou para o surgimento desta intérprete/ atriz no cenário da música brasileira.

Paiva (1991) destaca que a população brasileira contabiliza, em 1890, 14.199.00o brancos (os índios e negros não contavam). Só no palco do Rio de Janeiro neste período, das 137 companhias estrangeiras instaladas no país, 11 são inglesas. As temporadas constantes destas companhias não só portuguesas como também italianas, francesas, espanholas, etc, apresentavam em seu elenco cada vez um maior número de estrangeiros, chegando a ponto de haver um movimento no sentido de preservar dois terços do pessoal para os artistas nativos.

O teatro de revista pode ser responsabilizado como grande fornecedor do mercado da música que, a partir de 1900, a casa Edison, representante da fábrica Odeon no país, se encarregou da difusão. No entanto, temos nos cafés cantantes e chopes berrantes outros importantes meios de propagação e criação musical a partir do século XIX, estendendo-se até meados da década de trinta do século $\mathrm{xx}$, tendo como um dos maiores representantes o Alcazar Lyrique, de propriedade do francês Joseph Arnaud. A novidade chegada da França trazia em sua bagagem, segundo Joaquim Manoel de Macedo (1878), "teatro de trocadilhos obscenos, dos cancãs e das exibições de mulheres seminuas" (apud TINHORÃO, 1998, p.213). Os diversos setores ocupacionais gerados pela revista se tornam um espaço de negociações de que tomam parte autores, diretores, empresários, técnicos e artistas oriundos inicialmente de Portugal e, em seguida, de espanhóis, italianos e franceses; os brasileiros, por sua vez, vão tomando espaço em um segundo momento. 
Os tipos brasileiros retratados pelos revistógrafos nos palcos nesta época por autores como Arthur Azevedo, Moreira Sampaio e Oscar Pederneiras se inspiravam nos tipos comumente presentes na paisagem urbana do Rio de Janeiro, diferentemente das revistas portuguesas, que retratavam estes mesmos tipos de forma exótica, deliberada ou involuntariamente.

Pelo visto, o ano de 1889 pode ser considerado um marco em vários aspectos no que tange a construção de uma nacionalidade. A primeira delas, sem qualquer grau de importância, se refere à proclamação da República, no sentido de tornar o Brasil um país moderno e independente, na busca de um sentimento nativista e uma consciência nacionalista. Nos palcos, observamos o surgimento de tipos que se tornariam símbolos de nacionalidade, como a baiana, a mulata, o compadre, o português, o caipira, dentre outros; além do aproveitamento do Carnaval como motivo nas revistas teatrais.

Nos palcos, o teatro musicado continua influenciando e sofrendo influências, principalmente a partir da chegada da companhia de Lisboa de Sousa Bastos, em 1892, com a revista Tim-Tim por Tim-Tim. Como já apontado, a invasão da mão-de-obra portuguesa nos palcos das revistas era incômoda para a "classe artística" de uma maneira geral, tendo em vista que faltava, além de know how, condições econômicas para enfrentar em igualdade de condições a concorrência européia, visto que os portugueses e seus descendentes de primeira geração, entre os habitantes do Rio de Janeiro, eram muito numerosos.

Entretanto, é com O Tribofe, de Arthur Azevedo, segundo críticos do gênero, que o teatro de revista atinge sua plenitude dramatúrgica, contando no elenco com Ana Manarezzi, Xisto Bahia e Aurélia Dellorme - segundo especialistas em revista, a precursora do teatro rebolado, pois dançava maxixe com graça singular. Esta revista foi um marco na dramaturgia brasileira, mas sua popularidade sequer se aproximou daquela alcançada por Tim-Tim por Tim-Tim. Tanto no palco quanto na plateia, a presença de portugueses era muito numerosa. Havia empresas que empregavam mais portugueses que nativos. Como aponta Ruiz (1984): 
Essa presença maior de artistas, diretores e empresários lusos em nosso teatro, nos nossos palcos, até quase a metade do nosso século, uma predominância dos falares lusos na linguagem teatral, que só lentamente foi sendo deixada de lado, num trabalho de quase cem anos de persistência, até que se impusessem os modismos coloquiais nativos. (apud PAIVA, 1991, p. 106 ).

Este gênero teatral já se constituía num empreendimento bastante lucrativo e tecnicizado. Com uma estrutura profissional administrada por empresários donos de companhias, em sua grande maioria estrangeiros, uma indústria do entretenimento composta de revistógrafos, coreógrafos, artistas, cenógrafos, coristas, compositores e maestros trabalhavam para colocar em cena espetáculos que permaneciam em cartaz com até mais de cem apresentações, sucesso absoluto para os moldes da época. Quando o espetáculo não levava um grande público, era imediatamente substituído por outro, basicamente com o mesmo elenco. Companhias como a de Pascoal Segreto (italiana) Souza Bastos (portuguesa), Madame Rasimi (francesa) ocuparam os palcos cariocas. Enfim, era um dos negócios mais lucrativos da época.

O fato é que os grandes revistógrafos da época já carregavam na tinta ao construir estes tipos tão bem recebidos pela audiência. Dentre eles, destacamos um que se imortalizou e vem se re-processando ao longo das décadas como um dos ícones de representação da sociedade baiana/brasileira: a baiana.

Estudiosos do teatro de revista no Brasil afirmam que a subida no palco do tipo a baiana acontece em 189o, com a estreia, a 26 de março, no Teatro Variedades Dramáticas, com a revista musical A República, de autoria dos irmãos maranhense Arthur e Aluísio Azevedo, cuja trama era uma crítica ao establishment. Tendo como pano de fundo o Rio de Janeiro, a peça tinha um prólogo e três atos divididos em 13 quadros, com peças de Charles Lecocq (autor de inúmeras operetas), Offenbach (outro grande autor do mesmo gênero) e Francisco Manoel da Silva, dentre outros, além do maestro Carlos Gomes e Adolfo Lidner, este último, responsável pela compilação e regência do espe- 
táculo. Entretanto, apesar de grandes nomes da música dita erudita, segundo os pesquisadores deste gênero, os números que obtiveram maior sucesso foram as modinhas cantadas por Xisto Bahia, além da atriz e soprano grega Ana Manarezzi ${ }^{32}$, cantando um tango que o país inteiro aprendeu, As laranjas de Sabina. Pode-se afirmar que o "tanguinho se constitui no maior sucesso popular de música divulgada pelo teatro no fim do século XIX" (PAIVA, 1991, p. 92) Esta mesma peça foi gravada dez anos depois pela casa Edison, na voz de Manoel Evêncio da Costa Moreira, conhecido popularmente como Cadete.

O tango interpretado por Ana Manarezzi tratava de uma arbitrariedade cometida por um delegado de polícia, que havia mandado prender a negra Sabina, baiana que vendia laranjas à porta da Faculdade de Medicina do Rio de Janeiro. Consta que, durante a passagem de D. Pedro II pela frente da Faculdade, os estudantes, em manifestação de repúdio, atiraram-lhe laranjas. A polícia, então, prendeu a vendedora, em vez de os próprios estudantes, acusando-a de incitá-los a este gesto. O caso resultou em passeata de protesto dos estudantes; estes, empunhando suas espadas tendo na ponta uma laranja enfiada, na porta da delegacia, exigiam que fosse solta a negra e demitido o delegado. Reivindicações atendidas, a vendedora ambulante voltou para o seu antigo posto e ainda foi glorificada no teatro e na boca do povo, que cantou o tango durante um longo tempo. Vejamos uma parte da canção, da autoria de Arthur Azevedo:

Sou a Sabina

Sou encontrada todos os dias

Lá na carçada da Academia de Medicina

Um senhor subdelegado

Home muito resingueiro

Me mandou por dois sordado

Retira meu tabuleiro

Ai!... 
Sem banana macaco se arranja

E bem passa o monarca sem canja

Mas estudante de Medicina

Nunca pode

Passar sem laranja da Sabina!

Os rapazes arranjaram uma grande passeata

E, deste modo, mostraram

Como o ridículo mata

Ai!...

As laranjas de Sabina. Arthur e Aluísio Azevedo (1999).

Barros (2005), estudioso da História da Cia. Negra de Revista, aponta que o tipo da baiana estreou no Teatro de Revista efetivamente em 1898, tornando-se um personagem recorrente da revista, dividindo juntamente com o compère e a comère, o português, o policial, o malandro,o coronel, o arsenal dos tipos indispensáveis a este gênero de teatro ligeiro. Diz o autor:

Há certa controvérsia quanto à primeira baiana e quem representou, mas certamente foi uma européia, branca em qualquer caso, e que deveria ser, desde o princípio, uma negra ou mulata, para atender a fidelidade histórica, porque assim eram as baianas do Rio, com os seus tabuleiros armados nas vias principais, constituindo-se em personagens importantes da cultura baianocarioca, tão especialmente forte na Capital Federal, por toda a Belle Èpoque, e ainda depois. (BARROS, 2005, p. 28)

Lafayete Silva (1989, apud Barros, 2005, p. 29) aponta a brasileira Aurélia Dellorme, nome artístico de Constância Cândido Cardoso Sanchez, como a primeira baiana/brasileira a se apresentar nos palcos cariocas na Cia. Dias Braga, no Teatro Variedades Dramáticas, em 1889, estrelando a revista O Bendegó, de Oscar Pederneiras e Figueiredo Coimbra, referente ao famoso meteorito caído no ser- 
tão baiano. Contrariando a informação contida em Barros, Paiva (1991, p.88-89) atribui este feito a Rosina Bellegrandi. Para este último, Aurélia Dellorme assumiu o papel criado pela colega e rival Bellegrandi no Teatro Recreio, em fevereiro de 1900, depois de superar cem apresentações na primeira montagem. Aurélia, então, poderia ser considerada

A criadora do teatro rebolado, mais tarde enriquecido com estrelas do tipo de Ana Manarezzi, Déo Maia, Aracy Cortes e Eloína, sabendo tirar lundu, maxixe ou samba não somente no pé como também nas ancas. [...] A celebridade de Aurélia advinha dos quadris avantajados que possuía, nádegas de tanajura, que ela utilizava com maestria e muita graça (PAIVA, 1991, p.79).

Neste sentido, Giacominni (1992), aponta, baseada em entrevistas a candidatas a mulata profissional em espetáculos contemporâneos, que um dos pré-requisitos para a obtenção do certificado é ter "o corpo de violão" que se configura por determinados contrastes de volume - cintura de vespa e a parte inferior e traseira do corpo, tem que ser "grandinha e empinadinha" (relato de uma das entrevistadas). Assim, a própria criação do tipo a baiana se confunde por vezes com a criação da mulata.

Considerando sua especial importância neste processo, destacamos alguns elementos do perfil de uma artista singular da história da revista, vinda das terras de Homero.

A figura da atriz grega Ana Manarezzi, que aparece nos elencos das revistas "nacionais", consta pela primeira vez em dados imprecisos obtidos na revista Mercúrio, de autoria de Arthur Azevedo em 1887, cujo elenco era composto de nomes já consagrados como Xisto Bahia e Correia Vasquez, um dos maiores comediantes da época, além do maestro Adolfo Lindner.

Ainda em 1887, Ana Manarezzi sobe ao palco para mais uma atuação na revista de nome Cobras e Lagartos, da autoria de Augusto Fábregas. Este espetáculo estreou em 17 de dezembro do mesmo 
ano e, segundo críticas da época, a peça era menos venenosa do que se anunciava.

Em 3 de janeiro de 1888, como se vê, não muito tempo depois, Ana Manarezzi sobe ao palco em outra revista da autoria de Arthur Azevedo e Moreira Sampaio: O Homem. Mais uma vez, a atriz e cantora integra o elenco ao lado de Xisto Bahia, Augusto Mesquita e João Colas, com partitura contendo motivos de Offenbach e Suppé e música popular do Norte.

Também em 1888, a nossa "grega-baiana" sobe mais uma vez ao palco para encenar a revista Fecha! Fecha!, de Soares de Sousa Jr, tema que se referia ao horário estabelecido para o fechamento do comércio. Depois deste espetáculo, a atuação de La Manarezzi na revista que iria transformar sua atuação num marco da dramaturgia com a "sua" Sabina das laranjas em 189o. Em 1891, aparece na revista de Arthur Azevedo Viagem ao Parnaso, com peças de Adolfo Linder, Franz von Suppé, Offenbach e outros, ainda num certo descaso com relação ao que era "unicamente nacional". Neste sentido, dava-se um jeito de equilibrar o local com o importado.

Enfim, o estudo da figura da baiana nos permite afirmar que a construção da identidade baiana/brasileira passou inclusive pelo talento de uma grega que se vestiu de baiana e vendedora de laranjas na revista República... Isto nos oportuniza retomar o tipo a baiana também nesta perspectiva das artes cênicas.

Colocadas estas notas sobre a importância das tias baianas e do teatro de revista, bem como as interseções entre suas trajetórias. Traçamos dois perfis especialmente relevantes aos efeitos de nossa construção. Trata-se de Araci Cortes e Carmem Miranda.

\section{Araci Cortes, ou simplesmente, Linda Flor}

Nascida no Rio de Janeiro em 31 de março de 1904, Araci Cortes entra para o teatro de revista em 31 de dezembro de 1921, no Teatro Recreio na Companhia de João de Deus. 
A novata Araci, em cinqüenta dias, tomara parte em três revistas diferentes, numa das quais conhece Sinhô que seria autor de um dos seus maiores êxitos como intérprete, em todos os tempos - Jura! Fora, sem dúvida, uma estreia auspiciosa e definitiva (RUIZ, 1984, p. 32).

Podemos observar que o teatro de revista se configurava como um grande veículo de concentração e difusão de artistas e seus respectivos produtos como a voz, a canção, o corpo, o dom que era aplaudido efusivamente pela audiência que comparecia às apresentações. Araci surge para o grande público num momento singular. Em 1922, comemora-se o centenário da Independência, além de acontecer a Semana de Arte Moderna; esta, ironicamente, deixa de fora uma das manifestações artísticas de caráter mais nacional na época: o teatro de revista. A primeira transmissão radiofônica do País, em 7 de setembro do mesmo ano, dá o pontapé inicial para capturar o discurso sonoro da brasilidade. As ondas do rádio se constituem, então, como veículo que se transformaria em grande fenômeno de comunicação de massa, configurando um novo momento no cenário cultural nacional.

Outro elemento de fundamental importância na construção da estrela/intérprete brasileira que começava a se plasmar foi a chegada da companhia francesa $\mathrm{Ba}$-ta-clã dirigida por madame Rasimi, nos palcos cariocas. Sua inovação vinha de trazer algo de novo para os palcos brasileiros: a féerie, onde a fantasia era primordial, associada a corpos praticamente nus, exibidos em pernas longilíneas e nuas, sem as grossas meias cor da pele como normalmente eram usadas pelas coristas brasileiras.

Neste sentido, novos padrões estéticos se sobrepõem às coristas roliças e generosamente dotadas que passam a ser chamadas de girls. Assim:

Com esse novo figurino, a revista cresce, pois não abre mão de seus textos espirituosos e da contundente crítica política, agora emoldurados por fantasia cuidada e renovadas exigências 
quanto à participação feminina. É o começo de uma excelente fase para o gênero, fase que iria exigir novos talentos. Araci Cortes não podia ter escolhido melhor ocasião para a sua triunfal entrada em cena (RUIZ, 1984, p. 39).

É o começo do surgimento da estrela nos palcos brasileiros, que, "copiando" os modelos francês, espanhol e italiano (a Cia. Velasquez aporta no Rio de Janeiro vinda da Espanha em 1923, trazendo em sua bagagem proposta artística semelhante), busca construir sua singularidade a partir do padrão importado. As trocas culturais nos palcos continuam não só no que se refere à forma das coristas e solistas se apresentarem; o papel das coristas assume outras funções que não se resumem unicamente em passos em conjunto, mas em coreografias elaboradas que só um corpo com predisposição e dom, na acepção de Morin (1987), podem dar conta. Araci então se revela como uma artista ideal para reproduzir o protótipo importado, imprimindo, no entanto, toda a graça e malemolência presente em sua performance.

Assim, torna-se uma atriz e intérprete de grande estofo, atuando em papéis cômicos e cantando e dançando "cheia de dengues e pernosticismo" (RUIZ, 1984, p. 44). Apresentando raro talento para a dança, torna-se uma grande divulgadora do sapateado norte americano difundido por algumas atrações estrangeiras que por aqui se apresentavam e mais tarde seria visto nos primeiros filmes sonoros norte americanos. Estes, além do sapateado, traziam em suas telas ritmos e canções como o ragtimes, foxtrotes e shimmies, convivendo com choros, maxixes e sambas.

Convivia-se assim, nos palcos, num hibridismo cultural (CANCLINI, 2003) com gêneros musicais de caráter nacional e estrangeiro, que através do teatro de revista - já que o rádio ainda não atingia as grandes massas - se fazia presente interpretado por uma quantidade infinita de artistas nacionais e estrangeiros que, cambiando informações musicais, proporcionava nova síntese no gênero. 
O Carnaval foi outro fator importante para o teatro, cujos autores e empresas transformavam em veículo de sucesso o que o povo iria cantar nas ruas durante a folia. Isto provocava uma corrida crescente de compositores que queriam ver a sua música interpretada pelos 'astros' da época, garantia inicial de sucesso definitivo (PAIVA, 1991, p. 50).

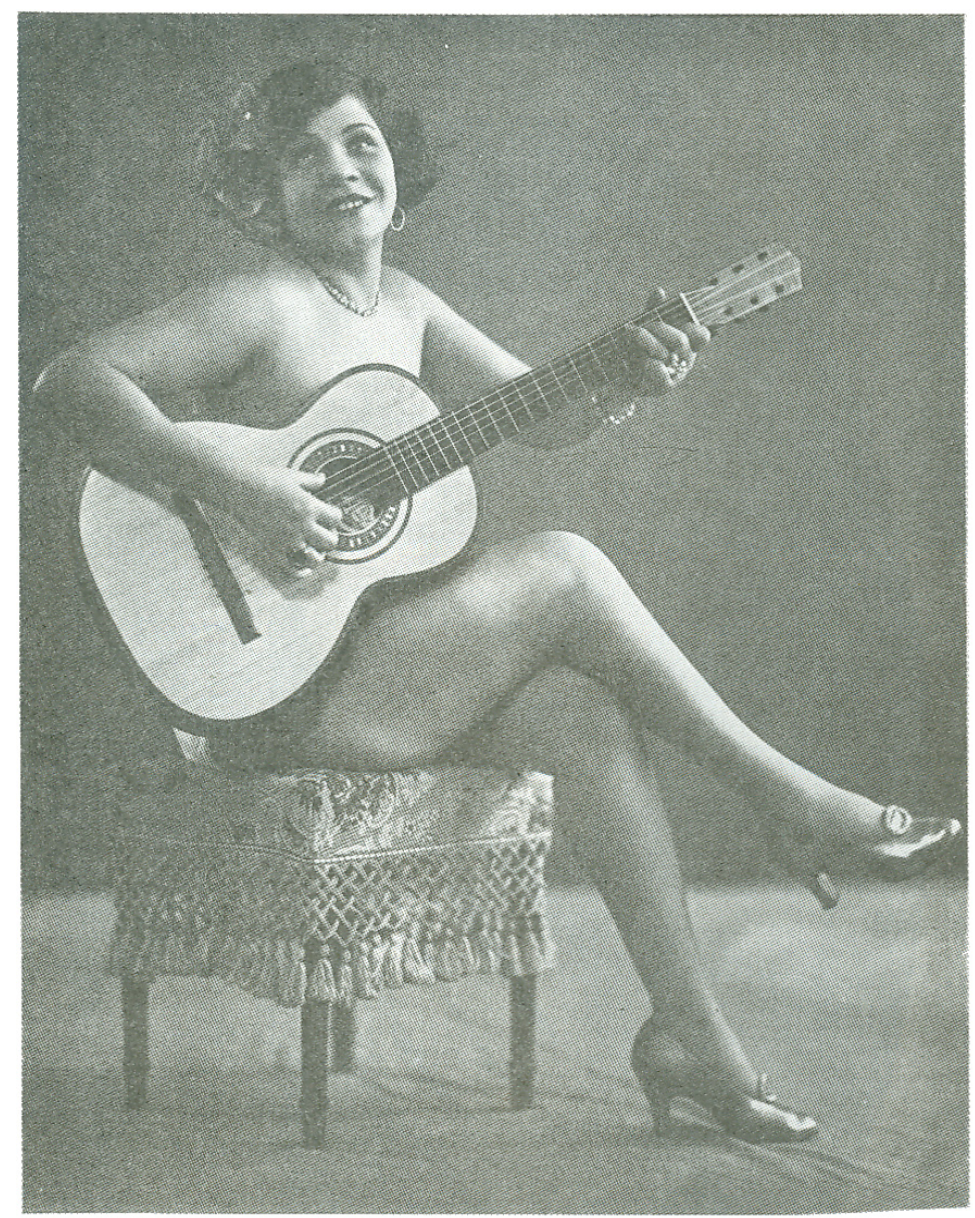

Araci em 1924, inicio da carreira no teatro de revista

Figura 2 - Araci Cortes 
Assim, começam a despontar compositores do porte de Sinhô, que só no Carnaval de 1925 apresentou cinco sambas nos palcos dos teatros. Um deles foi Dor de cabeça, que, mesmo depois da folia momesca, continuou divulgado pelos palcos das revistas.

Estas peças musicais transitavam em diversos ambientes indo dos teatros para as ruas em diversos gêneros como a marcha - este sempre com muito sucesso no período do Carnaval - repleta de alusões e críticas a acontecimentos do momento. Assim o cotidiano ia sendo passado em revista, não mais nos palcos dos teatros, mas também nas ruas, já em forma de peça musical, seja em formato de partitura, seja na boca do povo, alastrando-se de forma vertiginosa.

Se o espetáculo do teatro ligeiro era considerado pelos intelectuais da época um gênero menor, sem profundidade, unicamente feito para divertir com graça, música, luz e cores, e obviamente com mulheres bonitas no elenco, sua relação com o Carnaval configurava, assim, um binômio perfeito para o mercado da música.

Temos então o ambiente ideal para o surgimento da estrela/vedete com plumas, as pernas à mostra, pela influência das companhias de Velasco (espanholas) e Madame Rasimi (francesa). Com esta empresária, vem a estrela da companhia, a vedete Mistiguetti, provocando na população masculina carioca um inusitado rebuliço. Arma-se, então, a companhia rival brasileira, a Tro-lo-ló. "Além das girls havia a necessidade, desde logo, de escolher uma 'estrela', a primeira figura feminina da companhia, alguém marcante, decisiva, dona de interesse popular, sucesso garantido a partir do nome na fachada" (PAIVA, 1991, p. 62).

O nome de Araci Cortes foi o escolhido para estrelar a companhia de Jardel Jércolis e de José do Patrocínio, uma vez que a vedete era portadora dos predicados enumerados acima. Estreia com estrondoso sucesso, carregando para o palco todos os adjetivos que a faziam uma estrela. Parte então para criar sua própria companhia, tornando-se assim artista/empresária, gerenciando-a numa longa trajetória no teatro de revista com sucesso bombástico no final da década de 30 , enquanto, nas ondas do rádio, lançava e regravava em discos sucessos de autores que consagrou. É o caso das canções Jura! e Ai iô iôô3 . 
De sua performance entre 1922 e 1961, atuou em 153 espetáculos musicais, entre revistas, burletas e operetas. À frente de sua companhia, realizou turnês de sucesso também em Portugal, França e Argentina. Atuou também em programas de rádio. Dizendo-se cansada do teatro e das atividades artísticas em geral, retira-se de cena em 1942, retornando dez anos depois, em virtude da insistência do empresário Miguel Khair.

Pode ser interessante ler um testemunho da reação da plateia diante destas duas grandes representantes do teatro musicado:

Viu, então, o público, duas versões distintas da estrela: a vedete emplumada, maliciosa, capaz de descer com donaire as célebres escadas que tanto valorizavam as aparições de Mistiguett; e a estrela da revista autenticamente à brasileira, dominando nos seus sambas, sapateando e capaz de fazer qualquer papel, do dramático ao mais extremo cômico (RUIZ,1984, p. 206).

Araci contribuiu para imortalizar autores do porte de Assis Valente, Noel Rosa, Sinhô, Vicente Paiva, e outros. Foi homenageada por este último com um samba que arremata a sua vida nos palcos, transcrito em Ruiz (1984, p. 206).

Nasci sambista

Nasci artista

E até hoje

Não me arrependi

Público amigo

Que não me esquece, Quem te agradece É a Araci!

Aclamada pela crítica e pelo público, Araci Cortes torna-se uma grande representante do teatro musicado e da música brasileira, servindo inclusive de modelo para grandes nomes, a exemplo de Carmem Miranda. 


\section{Carmem Miranda: a Pequena Notável}

Maria do Carmo Miranda da Cunha nasceu em Várzea de Ovelha, Portugal, em 9 de fevereiro de 1909. Seu pai, José Maria Pinto da Cunha, barbeiro de profissão, imigrou para o Brasil no mesmo ano. No ano seguinte, sua mãe, Maria Emília, também vem ter ao Brasil com as filhas - a pequena Carmem, com apenas 18 meses de idade, e a filha mais velha, Olinda. A família cresceu por aqui com o nascimento de mais quatro filhos, inclusive Aurora.

Com 15 anos, Carmem começa a trabalhar como balconista numa loja de roupas femininas. Mais tarde, aprende a confeccionar chapéus, o que lhe foi muito útil na confecção dos seus trajes.

Desde pequena gostava de cantar nas festinhas de amigos e acompanhava os programas através do rádio. Uma de suas artistas favoritas, e a quem mais gostava de imitar, era Araci Cortes.

Descoberta por Josué de Barros, depois de interpretar uma canção de sua autoria num festival beneficente, estreia em disco com duas canções deste autor. Só faz sucesso, entretanto, ao gravar Ta-hí - pra você gostar de mim, de Joubert de Carvalho, com 36 mil cópias vendidas. Carmem se lança para a indústria da música e do cinema em 1932, com a estreia do filme Carnaval cantado no Rio.

Desde o seu primeiro sucesso, Carmem consolida sua carreira no Brasil ${ }^{34}$ de maneira inusitada. Em apenas nove meses de sucesso, de janeiro a setembro, a gravadora Victor, à qual pertencia, lhe dera mais "28 músicas - quatorze discos - para gravar. Era um investimento inédito de uma gravadora brasileira numa só artista. Significava que a cada dezoito dias de 1930, saía um disco novo de Carmem Miranda" (CASTRO, 2005, p.6o).

O que mais interessa no perfil de Carmem, aos efeitos desta pesquisa, é sua identificação com o tipo da baiana. Vamos, então, à sua parceria com Dorival Caymmi.

O cantor e compositor baiano ilustra no filme Banana da terra, através da voz de Carmem Miranda, a canção O que é que a baiana tem?. Sua descrição de toda a indumentária da baiana começa pelo torço. Assim, imortaliza-se não só o traje, mas a própria performance 
da pequena Carmem. Pesquisadores afirmam que foi Caymmi quem ensinou os trejeitos e olhares maliciosos contidos na performance de Carmem a partir da gravação desta canção. Eis a letra da canção.

O que é que a bahiana tem?

Que é que a bahiana tem?

Tem torço de seda tem.

Tem brinco de ouro tem

Corrente de ouro tem

Tem pano-da-costa tem

Tem bata rendada tem

Pulseira de ouro tem

Tem saia engomada tem

Sandália enfeitada tem

Tem graça como ninguém

Como ela requebra bem.

Quando você se requebrar caia por cima de mim

Caia por cima de mim, caia por cima de mim

O que é que a bahiana tem?

Que é que a bahiana tem?

[...]

Dorival Caymmi. O que é que a bahiana tem (1939).

Com o sucesso da música de Dorival na voz de Carmem, ocorre um fenômeno bastante curioso de intercâmbio cultural. O primeiro deles se refere à emigração do compositor baiano para o Rio de Janeiro, levando consigo elementos para a construção de uma identidade cultural bastante singular, não só na forma de compor, mas, principalmente, nas temáticas: o mar, o pescador e seu ambiente, a festa, a religião, a culinária, o samba, o dengo, a malemolência e sensualidade da mulher baiana etc. 
Já o mineiro Ary Barroso, que seria o compositor escolhido com a música Na Baixa do Sapateiro e Boneca de pixe, recusara-se a participar com suas músicas no filme no último instante, por não concordar em receber apenas os honorários de cinco contos de réis que haviam sido combinados. O mineiro pleiteava dez contos de réis. O produtor americano Wallace Downey, "um americano que vivia no Brasil havia pelo menos dez anos, considerou absurda a pretensão de Ary Barroso e recusou pagar o que o compositor pedia" (CAYMMI, 2001, p. 129). O compositor Aloysio de Oliveira resumiu assim o significado destes encontros:

Este incidente mudou definitivamente o destino de três pessoas: o de Caymmi, o de Carmem e o meu. O Caymmi conheceu o seu primeiro sucesso, partindo para muitos outros. A Carmem se apresentou vestida pela primeira vez de baiana no Cassino da Urca logo a seguir foi contratada para a Broadway. E eu, com o Bando da lua, que se apresentou pela primeira vez junto com Carmem no Brasil, também parti para os Estados Unidos. Graças ao Ary Barroso (CAYMMI, 2001, p. 129).

Stella Caymmi (2001), entretanto, contrariando o depoimento de Aloysio de Oliveira, afirma que Carmem já havia se apresentado no Cassino da Urca, em dezembro de $1938^{35}$, vestida de baiana, cantando $\mathrm{Na}$ Baixa do Sapateiro ${ }^{36}$. A diferença entre sua primeira aparição com o referido traje é que, até sua primeira aparição, o traje era unicamente decorativo, tornando-se, a partir do samba de Caymmi, "parte indissociável da personalidade artística da Pequena Notável (p.130).

Sua "descoberta" pelo citado magnata se deu no Cassino da Urca. O traje vestido pela cantora foi o mesmo usado no filme Banana da Terra, cuja saia foi confeccionada com o auxilio de um figurinista. Por que Carmem se apresentou mais uma vez vestida de baiana? E de onde teria surgido este traje estilizado desta figura que a imortalizaria?

Primeiramente, seria interessante relatar que a baiana de Carmem foi inspirada na letra da canção de Dorival Caymmi - O que é que a baiana tem? -, cujo conteúdo descreve com detalhes, da cabeça aos 
pés, como se veste uma baiana, começando pelo torço usado na cabeça, que tanto pode servir para enfeitar como para cobrir as filhas de santo iniciadas nos cultos de candomblé - que têm a cabeça raspada. Ao mesmo tempo, esta indumentária indica, conforme o modo que é dobrado no candomblé, divindades e hierarquias carregadas não só nos seus trajes, mas no seu jeito de ser e interpretar singularidades.

Neste sentido, considerando a música popular brasileira como um processo híbrido de organização de narrativas identitárias, o relato acima pode nos servir de ilustração para afirmar que a brasilidade se processa de forma fluida e múltipla (HALL, 2002), em trânsito constante (GILROY, 2001), bem como sincrética (CANEVACCI, 1996). Mais uma vez percebemos, portanto, que esse texto identitário se constrói não unicamente por baianos, e muito menos por brasileiros.

Por outro lado, a baiana "estilizada" criada por Carmem Miranda difere e muito das pinturas capturadas pelo olhar de Jean Baptiste Debret $^{37}$ e de Johan Moritz Rugendas, representando cenas cotidianas da paisagem brasileira do século XIX, tendo nestas representações a presença do traje da baiana ${ }^{38}$, bem antes, portanto, deste traje ser capturado pelas imagens exibidas nas salas de projeção; bem como das descrições contidas nos romances $O$ cortiço e Memórias de um sargento de milícias.

Entretanto, Carmem não deixa de se constituir numa representante autêntica desta figura, mesmo sem manter qualquer vínculo com a tradição religiosa afro-baiana. Neste sentido, a baiana (re)apresentada por Carmem, tanto nos filmes quanto em shows no Brasil e nos Estados Unidos, se configura numa bricolagem, numa re-invenção. Para a construção de "sua" baiana, a artista utiliza tecidos brilhantes e de brocados, numa referência muito próxima àquelas das estrelas de cinema de Hollywood; em lugar de batas rendadas, faz uso de mini blusa com a barriga de fora, sem, no entanto, mostrar o umbigo; em lugar de sandálias de dedos, "sobe" em saltos tipo plataforma para compensar sua baixa estatura $-1,55 \mathrm{~cm}$ ! Vejamos então, mais um pouco da trajetória da Pequena Notável. 


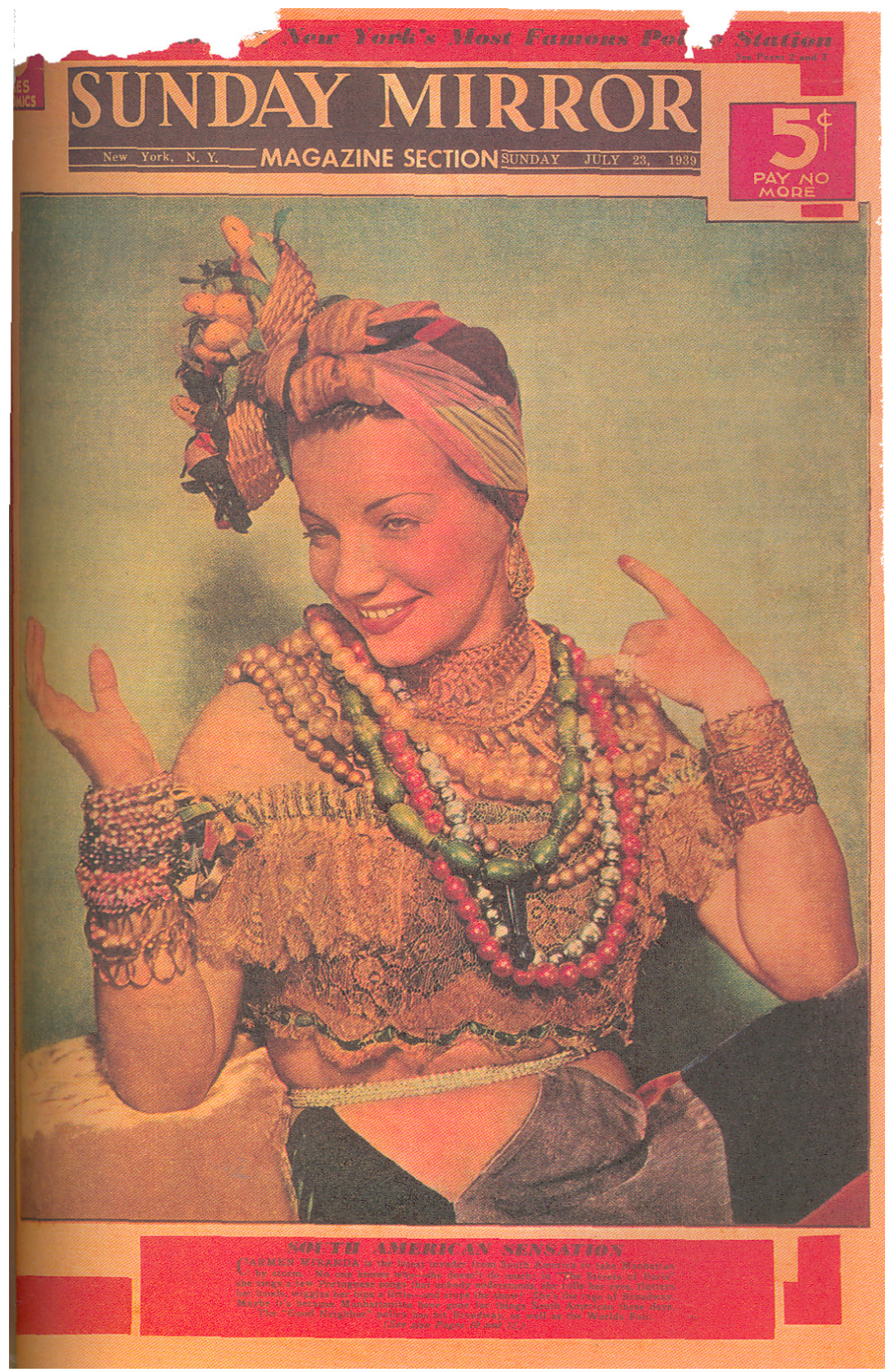

Figura 3 - Carmem Miranda no Magazine Sunday Mirror (July, 1939) 
A construção do sucesso de Carmem Miranda como uma das grandes intérpretes do Brasil não foi como se divulgou durante muito tempo, uma "invenção" da política da "boa vizinhança" 39 dos Estados Unidos com os países da América Latina, que, através do cinema, contribuiu de forma caricata para uma polêmica erotização da mulher latino-americana. Sua aparição na indústria cinematográfica de Hollywood proporcionou aos espectadores tomarem conhecimento não só dos sucessos musicais veiculados, mas pela vida pública e privada dos astros e estrelas que alimentavam a indústria do entretenimento com suas fofocas e fãsclubes, tornando-se assim um dos primeiros ídolos brasileiros produzidos pelos meios de comunicação de massa. Carmem contribuiu de forma emblemática para a divulgação da música brasileira, bem como dos "tipos" estereotipados das mulheres latinoamericanas, como também no que se apresentaria como mais próprio do Brasil, configurado nos trajes, malícia, alegria e performance que a transformaria na brasileira mais famosa do século Xx. Sua carreira nacional e internacional é uma referência de singular importância para a compreensão do processo de construção do sucesso.

A mudança do sistema de gravação mecânica para a elétrica foi outro fator relevante. O rádio, como um veículo de integração nacional, proporciona o surgimento de uma nova geração de intérpretes e compositores, que contribui de forma determinante para o surgimento e difusão da música popular brasileira.

Carmem Miranda reinou no Brasil e nos Estados Unidos dos anos trinta aos cinquenta do século $\mathrm{XX}$, trazendo-nos uma baiana estilizada impressa nas fotos, revistas, filmes e discos da época que deram origem a este emblema de brasilidade-latinidade. Desde o seu sucesso com Ta-hí, em 1930, até a sua partida para os Estados Unidos nove anos depois, quando foi convidada pelo magnata do show-business norteamericano Lee Schubert, Carmem soube transmitir com graça, talento e outros atributos a brasilidade latino-americana que tinha como lugar de origem a Bahia e sua referência de mulher nativa, a baiana.

Sua trajetória artística se confunde, por vezes, com a própria representação da figura da baiana imortalizada pela artista, que, ao 
longo deste movimento, vem se transformando também com a ajuda de figurinistas de Hollywood. Estes a transformam pouco a pouco em rumbeira, e os famosos turbantes de frutas, em monumentos ambulantes com motivos que passavam de pequenas sombrinhas, pirulitos e até um farol (substituído imediatamente por outro motivo, por parecer em determinados ângulos um símbolo fálico) carregado de brilhos e pedras. A interpretação de sambas, marchinhas e emboladas provocou na artista o "estigma da cantora/atriz latina cômica e destemperada" (CASTRO, 2005, p. 284).

Por outro lado, pela leveza e destreza com que se equilibrava nas sandálias-plataformas de $13 \mathrm{~cm}$, além dos turbantes e todo o traje, era considerada exímia dançarina. Assim, a "baiana" construída por Carmem ao longo de sua trajetória se revela para o mundo como uma embaixadora do samba, segundo declarações da própria aos jornais da época: "Eu quero que o americano conheça o samba e compreenda que o samba não é rumba" (CASTRO, 2005, p.97).

Neste sentido, a artista já apresentava uma preocupação em distinguir um ritmo desconhecido ainda para o mundo, de forma a torná-lo singular e territorializado, que pode ser observado também através da letra de Al Dubin em inglês e espanhol, traduzida por Aloysio de Oliveira para o português, que conservou a palavra espanhola pregoneiro e o refrão inglês na canção South american way, com melodia de Harry Warren. Paradoxalmente, esta canção "recebeu uma pequena transfusão de samba pelo Bando da Lua ${ }^{40}$ para disfarçar o rebolado rumbeiro" (CASTRO, 2005, p. 205).

Assim, a Brazilian bombshell ${ }^{41}$ se lança nos palcos e tela americana com um repertório preparado especialmente para a sua revista musical de estreia, Streets of Paris, formada pelas canções South American Way, O que é que a baiana tem?, Touradas em Madri e a embolada Bambu de bambu. Durante esta última, em pré-estreia em Boston, com apenas seis minutos de apresentação, a artista arranca aplausos e críticas que a fazem fechar o ato da revista, fato considerado quase inédito para uma apresentação tão rápida. 
Assim, Carmem se torna uma "febre" para os empresários, que a transformam em garota propaganda de produtos como um carro da Ford, creme dental Kolynos e cerveja Rheingold, além de sua indumentária se tornar moda, exibida nos manequins com seu rosto e gestos das vitrines da loja Saks, cujas poses foram dirigidas pela própria para o vitrinista.

Não somente os empresários ${ }^{42}$ e publicitários exigiam a presença de Carmem. A imprensa também fazia o seu papel no sentido de solicitar entrevistas e fotos para publicação. Em seis meses, desde a sua chegada aos EUA, subiria profissionalmente ao palco 416 vezes. Com o excesso de trabalho, suas noites de sono ficavam cada vez mais comprometidas, chegando por vezes a duas horas, fato que contribuiu para a dependência de substâncias psicoativas ${ }^{43}$, o que levou ao seu falecimento em agosto de 1955, quando contava 45 anos.

Por outro lado, o público norteamericano via a artista muito mais como uma comediante do que como uma cantora de discos, o que a levou a uma produção cinematográfica de 14 filmes, muito mais expressiva que a discográfica - 16 discos -, considerando que os discos continham duas canções, boa parte destas interpretada nos filmes. Em seis anos de contrato com a Fox, de 1940 a 1946, a artista atuou em dez produções cinematográficas; no Brasil, atuou em seis; trabalhou depois como free lancer em outros longas e shows.

Sua maior preocupação era enaltecer a música popular brasileira, adornada pelo traje de baiana que, a cada produção cinematográfica, se assemelhava a uma rumbeira pelas mãos da figurinista de Hollywood Ivonne Wood, descoberta pela artista. Ironicamente, quando a artista coloca enfim a canção $O$ que é que a baiana tem? no filme norte-americano Serenata Boêmia, rodado entre 1943/1944, enverga a roupa de rumbeira. Assim, sua preocupação em enaltecer e diferenciar o Brasil dos outros países latinos servia cada vez mais para estereotipar - Hollywood era especialista nisto - os tipos interpretados pela artista, carregados de comicidade em nomes que se confundiam com mexicanos tais como Chiquita, Rosita, dentre outros, que retratavam as latinas como mulheres instáveis e infantis, 
de temperamento forte e sempre com ombros de fora, falando alto e rápido, incendiárias. Assim, declarava a própria Carmem para um amigo: "Antes de o pessoal no Brasil desgostar dos meus filmes, eu já me aborreço com eles" (CASTRO, 2005, p.377).

A artista era muito bem informada sobre o que se publicava no Brasil a seu respeito e quanto à sua participação estereotipada nos filmes em que atuava. Por outro lado, não era a única a quem Hollywood tratava assim. Fred Astaire seria sempre o dançarino que atuava, não o ator; Laurence Olivier jamais seria um cowboy, e sim sedutor. Por outro lado, a artista sabia que seu potencial não seria bem aproveitado na Fox, e muito menos em qualquer outra companhia cinematográfica americana. Assim, mesmo percebendo que estava se exaurindo, a artista se afunda cada vez mais em contratos e turnês exaustivas que a levam a diversas estafas, que culminam em sua morte.

Ao tempo em que a estrela sobe, existe um preço a pagar que a indústria do entretenimento cobra alto. Neste sentido, na busca incessante da artista de enaltecer e divulgar o que para ela seria o símbolo da identidade brasileira, reforçada pela ideia de brasilidade dos norteamericanos, empenha-se cada vez mais em se tornar uma profissional perfeita, sempre pronta a honrar os inúmeros compromissos assumidos, mesmo que para isto sacrifique a sua saúde. Por outro lado, é importante observar que a trajetória de Carmem nos Estados Unidos não se apresenta para o leitor desavisado de forma tão ingênua quanto possa parecer. A artista, ao optar em embarcar para os Estados Unidos, buscava sim um reconhecimento internacional para o seu trabalho, bem como tornar-se a embaixadora de música popular brasileira para os norteamericanos. A padronização imposta pela indústria do entretenimento no sentido de veicular a imagem da mulher latina, não importando se vinha do México, de Cuba ou do Brasil, servia para divulgar um tipo criado pelos cosmopolitas yankees para retratar a mulher dos trópicos, cheia de sensualidade e luxúria, mas também difícil de ser "domada"; nem por isto, menos atraente.

Esta imagem não se plasma tão somente pelos "vizinhos civilizados". Em nossa terra brasilis, os compositores brasileiros também se 
incubem de divulgar a imagem da mulher brasileira de forma estereotipada, estigmatizada, seja pela cor, seja pela sensualidade, seja ainda pela malícia, dentre outros predicados.

Colocadas estas reflexões sobre tantas baianas, é possível, então, ensaiar uma compreensão mais geral sobre o perfil que se constituiu em torno deste tipo, tanto no teatro de revista como, logo depois, no cinema.

\section{Quem é mesmo a baiana consagrada na ribalta?}

A constituição da baiana como personagem-tipo acontece diferentemente da forma como se deu com os outros personagens com que os revistógrafos povoaram a paisagem urbana do Rio de Janeiro. Contrapondo-se aos personagens-tipos cuja característica básica é a personalidade frágil e rasa, a baiana tem personalidade forte, mostrando-se decidida nas ações, além de carregar corporalmente o "lado" brejeiro, a sedução, a malícia; enfim, era "capaz de todas as habilidades do palco e exibicionista quase sempre, para não dizer também que era frequentemente a rainha do duplo sentido e da luxúria" (BARROS, 2005, p.28).

A descrição anterior refere-se ao caráter, à personalidade do tipo baiana. Sua aparência era outro fator importante em sua composição. Inspirada na África Ocidental, no imaginário da tradição dos orixás, a baiana vestia-se nos palcos com roupas cheias de rendas e babados; enfeitava-se com colares ${ }^{44}$ de muitas voltas e cores (numa alusão aos orixás), além de chinelas delicadas deixando os pés quase nus à mostra; na cabeça, turbantes.

Neste sentido, o traje da baiana apresentado nos palcos pode ser considerado uma re-invenção do que era cotidiano na antiga capital da província, bem como no Rio de Janeiro. Assim, a baiana, no palco, torna-se estilizada, diferentemente daquela descrita por Caymmi em $O$ que é que a baiana tem?. Trata-se de uma re-invenção baseada no mundo do entretenimento, cujo modelo podia ser visto pelos tecidos brilhantes e glamourosos das estrelas de cinema, copiados 
ou mesmo trazidos pelas estrelas estrangeiras em suas companhias de revista. Garcia (2004) aponta que a baiana de Carmem Miranda não apresentava vínculo mais forte com a tradição baiana, além da proximidade com o samba. Assim, Carmem imprime uma bricolagem criativa, "acrescentando à sua baiana outras partes, outros pedaços sem deixar de ser baiana, pois o que a priori a particulariza é justamente essa não unidade, essa diversidade proveniente de diferentes origens" (p. 111).

O México também já teve sua baiana através do cinema norteamericano, representada pela atriz Dolores Del Rio no filme Voando para o Rio, no ano de 1934, ao lado do ator brasileiro Raul Rolien, numa produção da RKO, de Nelson Rockfeller, investindo no mercado latinoamericano (GARCIA, 2004, p.116). Antes, portanto, de Carmem Miranda se tornar a maior representante do "tipo" no mundo. No entanto, é com a Pequena Notável que acontece a estilização e a internacionalização da indumentária juntamente com a personagem/tipo. Assim, o traje, antes "estigmatizado como a indumentária que vestia as mulheres negras” (p. 116.) invade os salões a partir de 1939, ganhando ascensão social e registro nas páginas da revista O Cruzeiro, em 1940.

As bahianas [sic] tiveram maioria no Carnaval carioca. A sugestão de Carmem Miranda e seu sucesso em Nova York inspiraram as cariocas na escolha de sua fantasia. Em todos os bailes, encontramos dezenas de bahianas com suas saias de roda e balangandãs vistosos (apud GARCIA, 2004, p. 116).

Paiva (1991), por sua vez, aponta que a estilização do traje da baiana e sua representação no palco se inicia na companhia portuguesa de Sousa Bastos, que desembarcou no Rio de Janeiro em 1892 com a revista Tim-Tim por Tim-Tim. No elenco, destacava-se a atriz espanhola Pepa Ruiz, que interpretava 12 papéis, dentre eles a baiana, que cantava um lundu de nome Mungunzá, da autoria de F. de Carvalho, com arranjo de Nicolino Milano. Estava criado o primeiro arquétipo pelo teatro de revista no Brasil. Transcrevemos o seu comentário a respeito do fato: 
Começou ali o império da baiana estilizada, iconizada, mumificada como símbolo da mulher do povo, mulata, mestiça de raízes luso-africanas, analfabeta, mística, lasciva e familiar a cada espectador até por atavismo: era o predomínio do espírito patriarcal da casa-grande. Daí a empatia imediata que despertava na plateia, e desperta até hoje, mesmo nos mais sofisticados shows. Literalmente, este pode ter sido o cerne de uma deturpação, de uma caricatura, de uma invenção que historicamente apagou e substituiu para sempre a imagem real de um tipo popular, a baiana de rua, vendedora de quitutes, na imaginação e na consciência do homem comum. [...] O abstrato venceu o concreto a partir do momento em que Pepa Ruiz levantou a barra da saia e cantou as qualidades gastronômicas do prato de milho com leite de coco, açúcar e canela. Manjar tropical de um Baco moreno, ébrio de calor, de sexo olímpico? Baiana dengosa de cultos sincréticos, carnações opulentas, cantares pitorescamente onomatopaicos a ouvidos europocentrados, meneios luxuriosos, mistérios gestuais? Difícil precisar os porquês da identificação imediata, eletrizante, da assistência com a baiana branca fingindo de preta (PAIVA, 1991, p.107).

Vários pontos podem ser alinhavados no decorrer da citação. O primeiro, quando o autor se refere à figura da baiana como uma "mulher do povo", analfabeta e mestiça de raízes lusoafricanas, no sentido de se preservar este senso comum, como se a figura da baiana não pudesse ser estilizada, como se fosse algo sagrado a preservar; os estrangeiros, ao querer imitá-la, estariam cometendo um sacrilégio, uma profanação a um tipo popular que se tornou praticamente um mito. Na citação acima, afirma-se que "era o espírito patriarcal da casa grande". Ou seja, a mulher mestiça só poderia servir para a luxúria... O autor coloca a imitação como o cerne de uma caricatura, de uma invenção que historicamente apagou e substituiu para sempre a imagem real de um tipo popular que, por ser uma branca pintada de preto, não poderia jamais servir de ilustração para uma cena deste tipo.

Ao mesmo tempo em que Paiva (1991) acirra os ânimos a respeito desta "profanação", ele mesmo responde quando afirma que se trata 
de uma "invenção". Se se trata de uma invenção que foi substituída, esta invenção continua acontecendo, atualizando-se de forma intermitente, seja na figura de outras "estrangeiras" como a própria Carmem Miranda quase 50 anos depois, que além de reinventar a baiana, "reinventou os seus trajes, bricolados em novas versões de acordo com tempo e espaço determinados" (GARCIA, 2004, p.111), seja mesmo em brasileiras não baianas, como Clara Nunes, com uma indumentária que chega mais próxima dos trajes tradicionais, seja ainda Ivete Sangalo sobre um trio elétrico, numa bricolagem que funde a rumbeira com a baiana também encontrada nas chanchadas da Atlântida.

Por outro lado, o que mais nos intriga em relação à asseveração do autor citado é o fato de que, mesmo sendo uma invenção, o público se identifica com o tipo; mesmo sabendo que, além de não estar em cena uma baiana "autêntica", ela ainda não é negra, ou seja, é branca pintada de preto. E por que a audiência se encanta com a sua performance? Provavelmente porque existem sentimentos, sensações e apropriações artísticas que não se explicam unicamente pelo senso comum dos intelectuais convencionais e de certa faixa de público. Outros fatores deverão ser levados em consideração, tais como o talento, a graça, a picardia, a criatividade e principalmente, o dom na acepção já apontada por Morin (1989).

Podemos afirmar que a baiana de Pepa Ruiz é menos autêntica do que a de Ana Manarezzi, Aurélia Dellorme, Araci Cortes, ou mesmo Carmem Miranda e tantas outras que subiram ao palco com a indumentária em questão? Segundo Aurélio Buarque de Holanda Ferreira, o vocábulo autêntica se refere "ao que é do autor a quem se atribui, de origem ou qualidade comprovada, genuíno, legítimo” (1986, p. 202). Como negar a autenticidade destas baianas/ não brasileiras se o próprio Paiva (1991) descreve e se intriga com o poder de hipnose provocada na plateia pela sua entrada em cena? Neste sentido é pertinente buscar o que se convencionou caracterizar por tradição em autores como Hobsbawm e Ranger:

Por tradição inventada entende-se um conjunto de práticas, normalmente reguladas por regras tácita ou abertamente acei- 
tas; tais práticas, de natureza ritual ou simbólica, visam inculcar certos valores e normas de comportamento através da repetição, o que implica, automaticamente, uma continuidade em relação ao passado (HOBSBAWN; RANGER, 2002, p. 9).

A negra Sabina, interpretada pela cantora e atriz grega Ana Manarezzi, é menos autêntica que a própria vendedora de rua que serviu de protótipo para esta invenção? Mas como definir uma cultura inventada? Esta cultura estaria indissociável do desejo de ser diferente, singular, único... A "baiana inventada" por Ana Manarezzi, por Pepa Ruiz, por Aurélia Dellorme, pela nossa representante maior, Carmem Miranda - com a ajuda inestimável de Dorival Caymmi - é menos autêntica do que as baianas Daniela Mercury e Margareth Menezes e Ivete Sangalo? No campo da música, o que diferencia estas artistas é justamente a maneira com que cada um "inventa" o seu fazer artístico, usando da criatividade.

Neste sentido, estas tradições não se reportam necessariamente a um passado tão remoto e distante quanto podemos supor; por outro lado, não significa que estas mesmas tradições não tenham sido construídas e formalmente institucionalizadas num passado recente e se estabelecido com impressionante rapidez.

As tradições se processam na relação passado/comunidade/identidade, reconfigurando-se e convivendo com a modernidade. Paul Gilroy (2001) propõe repensar o conceito de tradição discutindo a ideia de afrocentricidade, reconfigurando o conceito de tradição e modernidade não de forma excludente. A perspectiva que o autor apresenta para as identidades negras se constitui no trânsito África-Europa-América de maneira a apontar uma negritude não somente africana, mas centrada no próprio trânsito pelo Atlântico. O centro da Negritude, para Hall (2003) seria então o meio, na acepção mesma tanto de meio geográfico/geofísico como de meio cultural e histórico.

O samba, eleito como um dos ícones centrais da configuração identitária nacional brasileira, foi sendo criado concomitantemente à sua nacionalização. Assim, o que é considerado hoje tradicional 
pode ter sido inventado ou mesmo construído paulatinamente pela perseverança, pela repetição. Gilberto Freyre (1984), ao propor a mestiçagem brasileira como a síntese de um povo, via aí a possibilidade de transformação constante e de adequação à diversidade. Neste sentido, a fundamentação da nacionalidade brasileira no orgulho de ser mestiço pode corresponder à representação do "tipo da baiana" encenada nos palcos cariocas do final do século XIX até os dias atuais e que se constitui em pactos sempre renegociáveis. Ao se apresentar pintada de preto nos palcos cariocas para representar a "nega Sabina", Ana Manarezzi, naquele momento, representava sim aquela baiana homenageada; assim como a espanhola Pepa Ruiz, ao exibir nos seus "requebros e maneiras" no lundu $O$ mungunzá, trazia toda a graça e sedução da mulher brasileira em construção.

Hermano Vianna (2002) traça, a partir do samba, uma construção de identidade nacional brasileira:

Como todo processo de construção nacional, a invenção da brasilidade passa a definir como puro ou autêntico aquilo que foi produto de uma longa negociação. O autêntico é sempre artificial, mas, para ter "eficácia simbólica", precisa ser encarado como natural, aquilo que "sempre foi assim" (p. 152).

Parece que o termo usado por Vianna - "autêntico como artificial" - refere-se ao fato de ter sido uma invenção, ou mesmo uma "descoberta" de algo que já existia e que foi revelado para a comunidade como algo antigo e ancestral. Vale ressaltar que este "antigamente" é datado do final dos anos vinte do século xx. Neste sentido, as tradições podem ser modificadas com o diálogo dos setores populares e eruditos. Segundo Canclini (2003, p. 204-20):

O popular não é monopólio dos setores populares [...] O popular não é vivido pelos sujeitos populares como complacência melancólica com as tradições [...] a preservação pura das tradições não é sempre o melhor recurso popular para se reproduzir e reelaborar sua situação. 
Continuando a discussão sobre a construção da estrela/intérprete brasileira, indissociável da figura da baiana, ou ainda da mulata ${ }^{45}$, não percamos de vista os tipos representados nos palcos das revistas musicais, nos romances de Jorge Amado, nos quadros e gravuras de Rugendas e Debret, nas fotografias de Pierre Verger, ou ainda nas telas do argentino-baiano Carybé, e das mulatas de Di Cavalcanti, só para citar alguns, bem como as personagens baianas exibidas nas chanchadas da Atlântida ou da Vera Cruz, ou ainda na teledramaturgia.

\section{A representação da figura da baiana pelos compositores}

A representação da figura da baiana também está presente na obra de compositores brasileiros de diversas gerações, tendo em Caymmi um representante destacado. Para continuar usando o Buda Nagôo ${ }^{46}$ como referência, temos outros exemplos de elaboração, como a canção Lá vem a baiana, que, ao descrever sua chegada, inicia mais uma vez descrevendo seu traje: Lá vem a baiana de saia rodada sandália bordada ... Lá vem a baiana coberta de contas, pisando nas pontas [...].

Mais adiante, mesmo ao afirmar que ela pode "invocar o seu santo e jogar o seu quebranto", diz ele: não vou porque não posso resistir à tentação se ela sambar. Continuando a descrição, Caymmi compara o jeito de sambar da baiana com o diabo, dizendo: esse diabo sambando é mais mulher, e que, com o samba no corpo da baiana, ele fica à sua mercê. E seu eu deixar ela faz o que bem quer. Então, numa analogia à Odisséia de Ulisses, que, para resistir ao canto da sereia, entope os ouvidos dos escravos com cera e lhes pede que o amarrem ao mastro do navio, o autor diz não vou nem amarrado porque sei, se ela sambar... O Buda Nagô não conclui com discurso convencional; o resto do verso é hum hum hum hum hum hum hum hum... Deixa, então, que o ouvinte e/ou intérprete deduzam o que efetivamente acontecerá.

Assim, a figura da baiana em Caymmi, de maneira específica, e da mulher na sua obra em geral, reflete um padrão de sensualidade e 
luxúria, mulatez e dengo também observados em Dora, rainha do frevo e do maracatu; ninguém requebra nem dança melhor do que tu. Segundo Chediak (1994), e outras fontes, Caymmi revela que Dora foi inspirada numa passagem rápida por Pernambuco em sua primeira turnê nacional, em 1941. Pela frente do hotel em que ficou hospedado no centro do Recife, passou num rancho em que lhe chamou a atenção a forma com que uma das pastoras dançava. Dizia ele: no meu pensamento, te vejo requebrando pra cá, ora pra lá, meu bem. Os clarins da banda militar tocam para anunciar sua passagem. A Dora descrita por Caymmi já não é baiana e muito menos dança samba; é uma pernambucana. Diz ele: Dora, rainha do frevo e do maracatu, Dora rainha cafuza de um maracatu. Mais adiante, localiza sua origem: Te conheci no Recife dos rios cortados de pontes, dos bairros das fontes coloniais. Assim, além de abordar a origem étnica de Dora - cafusa -, situa a rainha do frevo e do maracatu geograficamente, além dos gêneros musicais em que a rainha se mostra: o frevo e o maracatu de Recife.

Estes dois exemplos servem para ilustrar que não só a baiana carrega em seu corpo, em sua dança, em seu jeito, os predicativos da luxúria, mas, de maneira geral, a mulher brasileira, e de maneira particular, a nordestina. O Caymmi buliçoso, malicioso, etnográfico se revela em outras composições cuja figura feminina se encontra presente carregada de double sens, ilustrada em composições tais como O dengo que a nega tem, A vizinha do lado, Vestido de bolero, Balaio grande e Acontece que eu sou baiano.

A malemolência do ritmo - e os próprios requebros e interjeições verbais do cantor/autor - lubrifica a libido dos versos, que podem ainda conjugar a mulher e a terra como única celebração. Em Balaio grande, o duplo sentido impresso no samba de roda alude ao balaio da nega, referindo-se à sua parte traseira, também denominada de cadeira.

Oi a nega do balaio grande

Oh do balaio

Oh do balaio grande

Oh do balaio

[...] 
No balaio dessa nega não se sabe o que é que tem

Essa nega tem segredo que não conta pra ninguém

Olha a nega...

Lá na feira aparece

Muito cesto e samburá

Mas balaio assim, ô nega!

Todos dizem que não há.

Nega do balaio grande. Dorival Caymmi e Osvaldo Santiago (1941).

Assim, Caymmi se refere aos atributos físicos da nega, apontando os segredos não revelados, obscuros, escondido no balaio. Podemos observar que o próprio tratamento conferido de forma jocosa à nega não sugere conotação discriminatória, mesmo porque, na obra de Caymmi, o elemento étnico não se apresenta como discussão. Nossa etnicidade, como apontado em Moura (2001) ${ }^{47}$, soa naturalizada para os outros brasileiros e para os não brasileiros:

A cor é um tema ou uma questão, o que não se vê em Caymmi, porquanto a própria etnicidade não se colocava como questão no seu tempo. E a cor como cromaticidade, pigmentação da epiderme, coincide com a etnicidade na sua dimensão de estigma, ou seja, enquanto cor da pele. Contudo, tal como em Caymmi, o natural - seja o moreno, o mestiço, o negro dito sem problematização, seja o plural cromático - é percebido numa atitude de êxtase e deslumbramento, e isto tem importância fundamental no texto da baianidade (MOURA, 2001, p. 150).

Continuemos, pois, a ilustrar, nos cancioneiros do Brasil, a representação da figura da baiana, agora com Geraldo Pereira, que jocosamente põe em cheque a autenticidade da baiana na canção Falsa baiana, gravada inicialmente por Ciro Monteiro em 1944. O autor, sem jamais ter vindo à Bahia, inicia a canção anunciando que a baiana que entra no samba e só fica parada, portanto, não samba, não mexe, não bole nem nada, não sabe deixar a mocidade louca, não é verdadeira. Mais 
adiante, afirma que a verdadeira baiana é aquela que entra no samba de qualquer maneira, que mexe remexe, dá nó nas cadeiras, deixando a moçada com água na boca.

Retomando, o compositor afirma que a falsa baiana, quando entra no samba ninguém se incomoda, ninguém bate palmas, ninguém abre a roda, ninguém grita Oba!, salve a Bahia, senhor. Assim, a audiência não se manifesta quando percebe que aquela é uma baiana falsa. Então, o compositor enuncia o que a audiência gosta. Mas a gente gosta quando uma baiana samba direitinho de cima embaixo, revira os olhinhos e diz: eu sou filha de São Salvador. Assim, o "revirar os olhinhos", o "sambar direitinho" são características corporais para ser uma "autêntica baiana". A autenticidade da baiana, assim como a da mulata referida, está no jeito de o corpo sambar e seduzir a audiência que percebe, pelo jeito de corpo e do olhar, sua autenticidade, bem como da localidade. Ou seja, a baiana autêntica teria que ser de São Salvador.

Além do corpo sensual, o olhar como construção da figura da baiana é bastante presente em obras de compositores desta geração. Sabemos que o jeito de "revirar os olhinhos" ensinado por Dorival Caymmi, que se tornou uma das marcas registradas de Carmem Miranda, pode ser considerado uma das características da construção corporal da baiana/mulata.

Na canção Mulata assanhada, de Ataulfo Alves, registrada em 1968 na voz de Elizeth Cardoso, em gravação que se fez muito famosa com Jacob do Bandolim, Zimbo Trio e o conjunto Época de Ouro, representa a mulata fingindo de inocente, tirando o sossego da gente, demonstrando toda a malícia contida no corpo, no jeito, no comportamento da mulata que finge que não sabe que tem feitiço no olhar. Neste sentido, o olhar também se configura como um dos códigos de sedução e de construção desta baiana/mulata.

Ary Barroso, contemporâneo de Caymmi, pode ser considerado um compositor que se esmerou em termos de temáticas baianas, imortalizadas também na voz de Carmem Miranda, como em No tabuleiro da baiana, em dupla com Luiz Barbosa, em setembro de 1936; Quando eu penso na Bahia, em dupla com Sylvio Caldas, em setembro de 1937; 
e Na Baixa do Sapateiro, em outubro de 1938, que contribuíram de forma emblemática para a organização de referências da brasilidade/ baianidade. Contando as canções de Ary Barroso, num intervalo de menos de dois anos, Carmem gravara mais de 7 canções "baianas". Já o tema sobre a mulata É luxo só, em parceria com Luiz Peixoto, pode ser conferido, também, na gravação de duas baianas: Gal Costa, em Aquarela do Brasil (1980), um álbum em homenagem ao autor e, mais tarde, Rosa Passos, em Pano pra manga (1996). Aí, os compositores se reportam à mulata dizendo que esta mulata quando samba é luxo só. O samba, mais uma vez, como gênero genuinamente brasileiro, serve para ilustrar a sensualidade de um corpo mulato, mestiço, não branco, que quando todo seu corpo se embalança é luxo só. Mais do que balançar, o corpo se embalança, numa alusão de que o balançar se refere mais a sacudir do que propriamente a embalar, dando assim a ideia de molejo; para usar um vocabulário mais musical e atual, é o swingue.

Mais adiante, os autores apontam que a mulata tem um não sei quê que faz a confusão. Seria esse "não sei quê" alusão a um dom naturalizado para enlouquecer a audiência masculina "sem compaixão"? Ainda mais adiante, os autores apontam exatamente o ponto do corpo que provoca a confusão - as cadeiras. Assim, a mulata, quando mexe as cadeiras e revira os olhinhos, tem a parte inferior, a traseira do corpo, como um padrão que se estabelece pelo tamanho avantajado, que se pressupõe um corpo "de violão". Quanto aos olhos, é a audiência que fica embevecida com "o requebrado (que) me maltrata".

Neste sentido, a construção da identidade da baiana/mulata no imaginário brasileiro/baiano e global passa pelo vetor da ideia de abundância, pela cor, pela malícia do olhar, pelo suingue no corpo e na naturalização em saber dançar samba, como apontado por uma das entrevistadas de Giacominni (1992), que afirma: "se você já nasceu, já quer sambar". Sendo assim, neste depoimento, saber sambar seria intrínseco à pessoa, o que poderia ser extensivo ao que Morin (1989) denomina de dom.

A esta altura, podemos observar que a construção da figura da baiana se confunde com a própria construção da mulata, da morena, da cabrocha, da nega, da cafusa, e em menor escala, da cabocla. 
Vejamos como o mineiro Ary Barroso representa a baiana/mulata. Na canção No tabuleiro da Baiana, denominada originariamente de batuque e não de samba, Ary Barroso descreve as iguarias contidas no tabuleiro da baiana, que se confundem com o coração da baiana cheio de sedução. Destacamos um trecho.

No tabuleiro da baiana tem

vatapá caruru mugunzá tem umbu pra ioiô

Se eu pedir você me dá

o seu coração seu amor de iaiá

No coração da baiana também tem

canjerê, sedução, ilusão, candomblé pra você...

Ary Barroso. No tabuleiro da baiana. (1936).

Assim, a representação da figura da baiana/brasileira na música pode ser configurada sobretudo pela corporeidade, que também se expressa na cor. Este corpo também pode ter um cheiro que exala sensualidade e malícia. Isto também está presente na obra de Ary Barroso, na canção Os quindins de Yayá, gravada por Emilinha Borba e César de Almeida em 1954. Em Bororó, o corpo moreno, cheiroso e gostoso o autor atribui ao pecado que tem cor - a cor morena.

Caymmi também utilizou artifício semelhante para dar conta da receita impressa no samba-receita Vatapá, gravado por Gal Costa em 1976, num álbum dedicado ao compositor:

Quem quiser vatapá ô

Que procure fazer

Primeiro o fubá, depois o dendê

Procure uma nega baiana , ô

Que saiba mexer, que saiba mexer..

Bota castanha de caju

Um bocadinho mais

Pimenta malagueta

Um bocadinho mais 
Amendoim, camarão, rala o côco

Na hora de machucar

Sal com gengibre, cebola Yayá

$\mathrm{Na}$ hora de temperar

Não parar de mexer

Que é pra não embolar...

Vatapá. Dorival Caymmi (1976).

Assim, Caymmi vai descrevendo todos os ingredientes necessários para a confecção do vatapá, sem esquecer que o ingrediente mais importante é a nega baiana que saiba mexer. Mexer diz respeito tanto à sensualidade presente no corpo da baiana quanto ao ato de fazer o vatapá, que necessita de braços fortes: não parar de mexer que é pra não embolar.

A própria construção desta figura nos palcos cariocas e do Brasil aponta para a indissociabilidade entre os pratos típicos e a sensualidade, como vimos no lundu Mungunzá, da autoria de F. de Carvalho, com arranjo de Nicolino Milano, apontado antes na performance da cantora/atriz espanhola Pepa Ruiz no segundo ato da revista portuguesa Tim-tim por Tim-tim.

No entanto, é com Araci Cortes que "o personagem encontrou adequação perfeita, tendo a atriz physique de rôle ideal" (BARRos, 2005, p.29). Ainda segundo Barros, com a morte da criadora do tipo - Aurélia Dellorme -, Araci assume o posto em 1921, confundindo-se desde então com o papel da mulata, numa síntese em que o "natural" da baiana se apresenta na cor mulata.

Voltemos, pois, à representação desta personagem/tipo com compositores da atualidade. O não baiano Alceu Valença fez sucesso nos anos noventa com o xote Morena tropicana, imprimindo na cor morena um gosto especial. O pernambucano compara o gosto da morena a frutas tropicais como "jabuticaba, caju, umbu-cajá”, dentre outras. Assim, vai descrevendo partes do corpo da morena que lembra a pele macia, ai, carne de caju; saliva doce, doce mel, mel de uruçu. 
Este procedimento pode ser considerado usual em temas recorrentes do cancioneiro nacional, metaforizando a mulher em objetos, sobretudo frutas tropicais, e traçando referências às suas partes íntimas de maneira por vezes dúbias, como é bastante recorrente em compositores do Nordeste. É o caso de Genival Lacerda e João Gonçalves, autor de Severina Xique Xique, que fez grande sucesso com composições desta natureza, utilizando o duplo sentido.

Por outro lado, a figura da baiana, da mulata, da nega, é também representada de forma que poderia ser considerada pejorativa no cancioneiro popular, com canções como $O$ teu cabelo não nega, bem como Mulata assanhada, só para lembrar algumas mais emblemáticas. Para ilustrar esta fala, vale ressaltar que, no ambiente do Carnaval de Salvador e da axé music, Luiz Caldas e Paulinho Camafeu, ao retratar em Deboche (1987) a nega do cabelo duro que não gosta de pentear, sofreram represálias por parte da imprensa e críticas dos movimentos de afirmação étnica, sobretudo o Movimento Negro Unificado - MNU, quanto ao caráter presumidamente racista da canção.

Como exemplo ainda mais próximo, na década de noventa, podemos encontrar este traço no grupo de pagode É o Tchan. Leme (2003) aponta o grupo como representante da vertente maliciosa da música produzida no Brasil desde os tempos da colônia, como demonstra a autora ao resgatar o Lundu da marrequinha, composição de Francisco Manuel da Silva e do tipógrafo Francisco de Paula Brito, datada de 1853, apud Leme (2003, p.84).

Os olhos namoradores

Tão engraçada iaiazinha

Logo me fazem lembrar

Sua bella marrequinha ${ }^{48}$

Iaiá, não teime,

Solte a marreca,

Senão eu morro

Leva-me a breca.. 
Passemos a ilustrar agora, de forma sucinta, a contribuição do grupo É $o$ Tchan na construção da representação desta baiana/mulata a partir de suas letras cheias de malícia e duplo sentido. Isto se verifica no perfil de suas dançarinas, particularmente Carla Perez, que aponta um modelo de baiana fora dos padrões de representação da etnicidade, imprimindo assim um diferencial no grupo. Sendo duas as dançarinas - uma negra e uma loura -, esta última obtém um estrondoso sucesso também por dançar como uma negra, cheia de sensualidade e lascívia, comum entre as mestiças, segundo aponta o senso comum. Vejamos como aparece a figura de Carla Perez na formação do grupo de forma casual.

O Gera Samba estava fazendo um show na Casa d'Itália, que é uma casa que fica no centro de Salvador. Nos domingos à tarde, eles faziam os chamados "ensaios do Gera Samba", e Beto viu as meninas dançando. Carla dançando no meio do público. E ele sempre teve o costume de chamar o público, quem estava dançando melhor, para subir ao palco com a banda. Chamando Carla, sentiu que o público teve uma reação muito positiva. O produtor do Gera Samba naquele momento (Cal Adam) sentiu que era um gancho forte de imagem. Uma loura dançando samba como uma morena. E aí pegaram uma morena que já estava mais ou menos próxima do grupo (Débora Brasil) e colocaram as duas no palco. E o resultado foi melhor do que ele esperava. (RANGEL, 2001 apud LEME, 2003, p.104).

Não é foco único do presente estudo buscar a figura da baiana na construção de uma representação de artistas femininas no palco de maneira geral, e na música de forma particular. No entanto, a presença deste tipo em diferentes ambientes sociais revela-se muito rica para se deixar de levar em consideração alguns aspectos concernentes a esta categoria. Podemos, assim, destacar o contexto do Carnaval e o surgimento da axé music nesta construção.

Com isso, reunimos elementos suficientes para afirmar que a construção da figura da baiana/mulata nos palcos e no cancioneiro popular 
aponta para a sensualidade, que abrange o duplo sentido e as danças impressas nos corpos sensuais e olhares; para a etnicidade, impressa nas matizes que vão da preta, morena, mulata, cabocla, cafuza, dentre outras; e para a culinária, indissociável da sensualidade e do duplo sentido das letras; para a indumentária, carregada de significados religiosos que vão se diluindo à medida que vão se re-inventando; e para a performance. Temos como ambientes propícios para esta construção, além do Carnaval, o cinema, os palcos e as atrizes e intérpretes do cancioneiro popular.

Entretanto, esta construção normalmente se estende ao próprio tipo da mulher brasileira, construído de fora para dentro e de dentro para fora como uma figura dotada de sensualidade e malícia "naturalizada", bem como um corpo dotado dos ingredientes também encontrados na construção da figura da baiana.

\section{A axé music e a construção de uma identidade cultural baiana/brasileira}

Na segunda metade da década de oitenta, mais um acervo de imagens da Bahia se plasma pelo ritmo da axé music e do samba reggae preconizada nas vozes de Luiz Caldas, Sarajane e a banda Chiclete com Banana, que, associados ao Carnaval, representam Bahias plugadas no mundo sem perder de vista o local. É o que discutiremos nesta seção.

A música é uma das expressões artísticas de grande importância na difusão, aceitação e legitimação da cultura negra na diáspora. Gêneros ou estilos musicais como o jazz nos Estados Unidos; o reggae na Jamaica; a salsa em Cuba; e o samba-reggae na Bahia se difundiram e propagaram pelos quatro cantos do mundo não só através de intérpretes, compositores e instrumentistas negros, como também de artistas brancos, a exemplo de Daniela, Ivete Sangalo, Cláudia Leitte e tantas outras.

Vejamos o que vem a ser axé music na acepção de Moura (2001, p. 215): 
Chamo axé musicà interface do repertório musical e coreográfico que se desenvolveu basicamente a partir do encontro entre a tradição do trio elétrico e o evento afro, que por sua vez recapitula a tradição da musicalidade negra do Recôncavo em conexão com outras vertentes estéticas da diáspora. (MOURA, 2001, 215).

Para o autor, a axé music não se configura nem num estilo ou mesmo um gênero musical, mas sim uma interface que, dialogando aspectos formais diferentes num determinado espaço ou ambiente, se constitui naquele momento como tal.

Goli Guerreiro em A trama dos tambores (2000) percebe a axé music oriunda do encontro da música dos blocos de trios com a dos blocos afro. É um hibridismo musical, caracterizado por sonoridades harmônicas e percussivas.

Podemos observar que há graus de similitude nas definições dos autores citados, que apontam o diálogo entre os tambores dos blocos afro e o trio elétrico como uma característica desta música. Entretanto, há divergências entre ambos quando o primeiro distingue esta coleção/seleção musical como uma interface, enquanto a segunda a denomina de síntese.

Além dos pesquisadores que se debruçam sobre o fenômeno axé music e a produção musical soteropolitana, gostaríamos de reproduzir a fala de alguns artistas que participa(ra)m deste processo para que possamos compreender como esta identidade é veiculada através da mídia de forma a contribuir na configuração de um modelo da imagem da Bahia. Outra pergunta relevante é como a permanente reconstrução de um texto identitário regional/local pode, por sua vez, se refletir na música que carrega em suas características um caráter urbano, tradicional e popular, o que aponta para o reconhecimento de um ethos soteropolitano cuja elaboração da vida social pode ser reconhecido de forma vigorosa, particularmente a partir da explosão de Luis Caldas, de Sarajane e de Gerônimo, se quisermos retroceder no tempo e compreender o que efetivamente vem se transformando ao longo destes 20 anos de existência. Vejamos o que nos tem a dizer 
o cantor e compositor Gerônimo (2005, p. 5) sobre o que vem a ser axé music:

O axé é uma mistura. Um movimento que começou a partir da década de oitenta. Nós não sabíamos que estávamos fazendo esse movimento, que é uma mescla de ritmos afro-baianos com afro-caribenhos. Daí, os músicos baianos começaram a adotar elementos de ritmos do Nordeste, surgindo assim, o axé.

O artista aponta um novo elemento na construção deste gênero híbrido, um novo dado: a influência do Caribe e dos ritmos nordestinos, a exemplo do galope e do próprio frevo. Assim, o próprio frevo baiano seria uma síntese do frevo pernambucano, tocado em seu nascedouro com sopros e percussão, que sofre uma transformação na Bahia ao introduzir o pau elétrico em sua sonoridade, com podemos observar neste trecho do frevo Vassourinha elétrica, do novobaiano Moraes Moreira:

E o frevo que é pernambucano

Sofreu ao chegar na Bahia

Um toque, um sotaque baiano

Pintou uma nova energia

Vassourinha elétrica. Moraes Moreira. (1995)

Passemos, pois, ao ambiente da contemporaneidade para ilustrar as transformações sofridas pelas intérpretes, buscando situá-las no ambiente do Carnaval e da axé music, sintonizadas com novas tecnologias, proporcionando assim novas sínteses musicais/culturais que, de maneira geral, passam a representar novos modelos através de nomes como Daniela Mercury, Margareth Menezes e Ivete Sangalo . Suas trajetórias podem servir de modelo na análise do fenômeno das estrelas nas práticas musicais da atualidade, bem como na construção da baiana contemporânea.

Importante traçar de forma sucinta o panorama sócio-cultural que propiciou o aparecimento desta intérprete brasileira/baiana 
no Brasil/Bahia, indissociável, portanto, do período de transição sócio-cultural presente na Bahia e no Brasil de forma geral e da autonomização da produção da música popular brasileira/baiana no ambiente do Carnaval, bem como dos novos modelos de blocos de trio, propiciando assim o aparecimento da intérprete baiana nos moldes em que foi construído.

Vejamos como se colocam intérpretes que estão hoje no topo do sucesso, a exemplo de Ivete Sangalo, Daniela Mercury e Margareth Menezes e que no passado foram vocalistas de grandes blocos. Ivete esteve à frente da banda Eva; Daniela também, ainda como vocalista de Ricardo Chaves, depois como puxadora do bloco Eva, Pinel e Os Internacionais, já como integrante da Companhia Clic; já Margareth Menezes teve uma experiência efêmera como puxadora de blocos como o $20 \mathrm{~V}$ e o Simpatia quase amor.

Para Margareth, o axé é:

Uma denominação criada como identidade para a música baiana popular contemporânea, que nada mais é do que o afropopbrasileiro. E o axé não vai acabar. Ele pode se transformar, mas o sotaque da música alegre, de verão, de Carnaval, vai ser difícil de acabar ( 2005).

Margareth imprime um rótulo sobre o já existente, fazendo uma prospecção de que não é perecível, mas aponta que é uma música sazonal, e que tem a alegria como característica.

Vejamos o que Ivete Sangalo tem a dizer sobre o mesmo rótulo. "Alegria acima de tudo! O axé é toda uma manifestação de cultura e ritmos que, hoje, se sobrepôs a qualquer rótulo!" (2005). A estrela nos aponta também a alegria como um sentimento emanado desta música e amplia o seu significado para a cultura, colocando esta acima do rótulo.

Vejamos agora o depoimento de Daniela Mercury a respeito:

Axé é uma palavra que significa sorte, é uma saudação no candomblé e como aqui tudo vem das origens afro, esse nome foi dado à música feita na Bahia principalmente relacionada ao 
Carnaval. Só que a música feita no Carnaval é uma música cheia de influências porque, como eu lhe disse, o Carnaval da gente é como se fosse um grande concerto, é como se você fizesse um Rock in Rio dançante, um festival de música dançante. Então mistura-se reggae, rock, funk, música eletrônica, eu acho que talvez a síntese seja o que eu falei do Carnaval. A música axé, a essência dela seja a alegria e a dança. Agora com muitos ritmos que envolvem este gênero. $O$ brasileiro ainda não sabe dizer exatamente o que seja o axé. Hoje em dia é assim. Tudo que sai da Bahia é axé. (2003c).

São semelhantes os depoimentos de Daniela, Margareth e Ivete. As três caracterizam a axé music com um sentimento comum - de alegria. Ao mesmo tempo em que relacionam este sentimento com o Carnaval enquanto festa cheia de influências, Daniela aponta uma nova configuração para a realização desta música no Carnaval, já como um grande concerto ao ar livre, um festival cujos gêneros distintos e semelhantes transitam em todos os ambientes, cuja essência é emanada pela a alegria da música e do corpo. Ao mesmo tempo, Daniela, em consonância com Gerônimo (2005), Moura (2001), Mercury (2003c) e Guerreiro (2000), aponta a matriz afro presente nesta construção.

Assim, as representações sobre a Bahia e sua capital se constroem no trânsito entre a tradição/modernidade, buscando na ancestralidade africana as matrizes de nossa nacionalidade, na remissão às divindades de origem africana, bem como na ostentação estetizada da afrodescendência, principalmente no que se refere ao plano da sensualidade, em parte retomada pela auto-estima da população negra dos bairros populares da cidade, acentuada sobretudo no verão, quando o fluxo turístico aumenta consideravelmente, aumentando também o turismo sexual. Desta forma, pode-se perceber uma configuração do imbricamento das "dimensões étnica, religiosa, sensual, etária e histórica, organizadas numa narrativa de forte apelo estético e turístico" (MOURA; GUERREIRO, 2004, p.8).

Esta tradição representacional, entretanto, não corresponde de forma coesa, linear, a este universo. Vejamos como esta dinâmica se 
processa na construção desta baianidade que, na acepção de Moura (2001), é uma tessitura baseada nos valores da familiaridade, religiosidade e sensualidade. Tomamos, novamente, como referência desta construção o binômio tradição/modernidade na representação do que seria a Bahia no Brasil no âmbito da música na obra de Daniela, Margareth e Ivete. Que Bahias são essas representadas por estas estrelas que se legitimam em termos de discurso pela cultura da mídia veiculada através das ondas sonoras do rádio, em imagens veiculadas pela TV, DVDs, propagandas, capas de álbuns etc?

Estas artistas representam atualmente, perante o Brasil e o mundo, a imagem de uma Bahia ancestral que originou a formação cultural brasileira e que, perante o Brasil, conserva seu posto inaugural mesmo quando se dá a transferência da capital para o Rio de Janeiro e mais tarde para o Centro-Oeste. Por outro lado, também uma Bahia contemporânea, pop, cosmopolita, cujo ambiente permite trânsitos e trocas culturais, que se torna cada vez mais difícil de rotular como este ou aquele nome.

Como pudemos observar nas seções anteriores, as narrativas identitárias que se remetem à Bahia nas vozes/corpos e no figurino destas intérpretes não necessariamente baianas encontram-se impressas de ancestralidade, etnicidade e sensualidade, percebidas também na obra de Caymmi e de Ary Barroso. Tais narrativas ecoam nas décadas seguintes, relativizando as fronteiras entre o tradicional e o moderno na forma de releitura por intérpretes baianas.

Vale a pena transcrever o que diz Oliveira (2005, p. 149) acerca desta proximidade:

Gal grava um álbum em 1992 - Gal - com peças do espetáculo anterior e a inclusão de É d'Oxum (Gerônimo/Vevé Calasans) e Raiz (Roberto Mendes/Jota Velloso), promovendo encontro das Bahias afro-moderna e épica dos blocos afro de Salvador e da Bahia mítica dos orixás, no caso, numa homenagem mais explícita ao orixá Omolu, que Gal assume como seu. O disco se inicia e conclui com uma vinheta de atabaques e voz da cantora entoando cânticos tradicionais de terreiro, em yorubá. 
Neste sentido, podemos eleger as intérpretes brasileiras de forma geral e as baianas de forma particular como grandes representantes da construção de um texto identitário nacional e local perante o público e a mídia. Dito isso, convém aproximar a lente para o acontecimento do Carnaval de forma geral e, particularmente, o surgimento das estrelas/intérpretes da nova música que se associa também ao aparato tecnológico e ao novo modelo de blocos de trio, sendo a alavanca para a subida da nova música afro-baiana ao palco do trio elétrico. A percussão produzida a partir de instrumentos heteróclitos realiza um som que, se não bem equalizado e mixado, não permite a audibilidade da voz do (a) intérprete.

$O$ repertório correspondente a este movimento é que se denomina então, axé music. Moura (2001) afirma que não se trata de um gênero musical na acepção técnica usual, ou seja, um conjunto relativamente homogêneo em termos de formas musicais associado a uma geração, um grupo originário de autores ou intérpretes ou mesmo uma região. A axé music, enquanto repertório, integra seus sucessos pelo próprio fato de terem sido colocados ali na cena, enquanto enunciado, referência ou acervo. Esta nova música produzida na Bahia trouxe consigo inúmeras mudanças de ordem comportamental, econômica, social e artística, mudando por vezes o foco artístico-cultural do Centro-sul para o Nordeste.

Daniela Mercury alcança muito sucesso com uma canção de sua autoria e de Tote Gira:

A cor desta cidade sou eu

O canto dessa cidade é meu

O Gueto, a rua, a fé

Eu vou andando a pé

Pela cidade bonita

O toque do afoxé,

E a força de onde vem

Ninguém explica, ela é bonita

Uô, ô 
Verdadeiro amor

Uô, ô

Você vai aonde eu vou

Não diga que não me quer

Não diga que quer mais

Eu sou o silêncio da noite

O sol da manhã

Mil voltas o mundo tem

Mas tem um ponto final

Eu sou o primeiro que canta

Eu sou o carnaval

A cor dessa cidade sou eu

$\mathrm{O}$ canto dessa cidade é meu

Canto da Cidad.e Daniela Mercury e Tote Gira. (1992)

Quando Daniela anuncia que a cor dessa cidade sou eu, o canto dessa cidade é meu, bem como eu sou o primeiro que canta, eu sou o carnaval, concretiza-se a polifonia vocal e étnica no sentido de se apropriar Daniela, "bonita e branca" (MASSON e FERNANDES, 1997, p. 83) de um texto (MOURA, 2001) que representa Salvador e seu entorno não unicamente formados por negros e mestiços, mas também de uma branca cantando um canto que também é seu - um canto que se faz seu no ambiente do Carnaval. Dizendo "eu sou o primeiro que canta", torna-se protagonista de um novo momento que se inicia para a música carnavalesca, que sempre sofreu certo preconceito. Tal preconceito não vem só da mídia, como também dos intelectuais de classe média, justamente o meio de onde provém Daniela. Assim, não é difícil entender porque boa parte desses intelectuais se recusa a reconhecê-la como sujeito de um trabalho cultural que merece valor, para além do estereótipo.

Neste sentido, a representação de uma mulher branca, cantando um ritmo gestado num território negro, com danças que se remetem aos orixás, em temáticas que exaltam as belezas de Salvador e um 
Carnaval cada vez mais pop, em que gêneros cada vez mais híbridos se interfaciam e convivem em cima do trio, indo do samba reggae do Olodum à batida eletrônica do trio Tecno de Daniela Mercury, a partir de 2000, causa estranheza refletida pela mídia, ou por artistas não baianos que se sentem incomodados com mais uma invasão.

Assim, a Bahia tradicional/contemporânea retoma algumas características e adquire nova configuração, tendo o Carnaval de Salvador como ambiente. É a etnicidade nos moldes diferentes do que foi constituído nas décadas passadas, já em diálogo com elementos pop presentes no reggae jamaicano bem como no pop americano de Michael Jackson. É a ancestralidade presente nas batidas do candomblé, bem como em algumas coreografias e a tecnologia que permite a amplificação destas vozes que se tornam expressão de identidade impressa numa atitude de comando. Diferente, portanto, da baiana tradicional que, encharcada de sensualidade, torna-se por vezes instrumento de desejo, de luxúria, mas nem por isto menos interessante.

Continuemos a pontuar a axé music de forma a compreender seu papel no ambiente local/nacional na construção de uma Bahia plugada no mundo.

O surgimento da axé music no Brasil, no final dos anos oitenta, coincide com a ascensão da música sertaneja, com quem divide as atenções da mídia radiofônica e televisiva, bem como uma grande fatia do mercado na venda de CDs. A axé music se torna, então, a representação do Carnaval contemporâneo de Salvador, já sendo denominada por revistas especializadas como pop/axé, enquanto suas representantes como Ivete Sangalo e Daniela Mercury assumem o lugar de intérpretes no cenário pop. A própria Margareth Menezes fala em termos de afropopbrasileiro.

Transformada em fenômeno de mídia, a axé music se posiciona no mercado de forma cada vez mais representativa, representada por bandas como a Reflexu's e Banda Mel (já extintas), Chiclete com Banana e artistas como Luiz Caldas, Sarajane, Netinho e outros. Entretanto, é com três representantes femininas da atualidade que a axé music e o próprio Carnaval, enquanto ambiente que serve para espetacula- 
rização de formação social, assume novos contornos no cenário pop local/nacional/global, alavancado também pelos novos modelos dos blocos de trio, pelo mercado da música pop, da indústria fonográfica e midiática e do turismo, que se utiliza deste exotismo musical como recurso de propaganda, principalmente no verão.

Neste sentido, a década de noventa e o início do novo milênio se constituem num momento emblemático desta nova configuração que a cada ano apresenta transformações cada vez mais velozes. Referimonos ao convívio entre o samba reggae presente no Olodum e a batida do Ilê Aiyê, em consonância com o ícone da negritude tradicional, com a batida grunge da Timbalada, que enaltece a negritude contemporânea. Entretanto, todos estes representantes podem ser considerados pontas de lança do movimento afropop brasileiro. Por outro lado, o galope do Chiclete com Banana (que já apresenta um refluxo no mercado), bem como a banda Asa de Águia, a banda Rapazzola, a banda Cheiro de Amor, apresentam características distintas do modelo de outras bandas que denominamos vertente axé e suas variações; além do pagode, que vem refluindo nos últimos anos, mas não deixa de representar esta fatia no Carnaval em grupos como Fantasmão, Parangolé, dentre outros; desembocando em representantes de maior expressão nacional como Ivete Sangalo em primeira escala em termos de vendas, seguida de Daniela Mercury e Margareth Menezes.

Assim, percebemos que o próprio Carnaval, enquanto ambiente de negociações, apresenta em seu repertório tanto temáticas consideradas ícones da negritude, quanto a presença de sonoridades ligadas ao mundo das pistas de dança mais global. Neste sentido, a reconfiguração do local pelo global (HALL, 2003) também se apresenta no que podemos denominar de Carnaval contemporâneo.

Assim, partindo do nascedouro da axé music, veremos que a representação da sociedade baiana/soteropolitana veiculada dentro e fora do seu território está cada vez menos ligada ao Carnaval e a Salvador como o lugar paradisíaco, mas cada vez mais especializado em organizar e produzir festa. Observamos que as temáticas presentes nas canções, ao longo dos 20 anos de existência da axé music, também 
vão se transformando. Assim, não se desenvolvem mais tanto temáticas relativas a aspectos da experiência soteropolitana da cidade, a exaltação ao sentimento e da presença da pessoa amada, de forma até explosiva, eufórica.

A experiência do amor é sempre um encontro. A pessoa amada não está ausente, ela está junto a quem canta a música [...] O encontro entre os amantes se dá em geral sob condições especiais, que podem ser elementos da natureza (a praia, o luar) ou a própria cidade de Salvador (ARAÚJO, 2000, p.138)

Neste sentido, é especialmente interessante o que pode ser observado na canção Beleza rara, interpretada por Ivete Sangalo (1996), ainda como vocalista da Banda Eva.

Eu não posso deixar que o tempo te leve jamais para longe de mim

Pois o nosso romance, minha vida, é tão lindo

[...]

Hoje sou feliz e canto

Só por causa de você

A exaltação, a alegria, a festa, o estar junto também são um tema bastante recorrente neste primeiro momento como pode ser observado em Daniela com a canção Música de rua: Esta alegria é minha fala que declara a revolução; ou em Festa, interpretada por Ivete Sangalo: E vai rolar a festa... o povo do Gueto mandou avisar; ou ainda em Margareth, cuja interpretação o tema alegria é associado à cor da pele em Alegria da cidade:

A minha pele de ébano é

A minha alma nua

Espalhando a luz do sol

Espelhando a luz da lua

[...]

Eu sou o sol da Jamaica 
Sou o sol da Bahia

$[\ldots]$

Apesar de tanta dor

Que nos invade somos nós

Alegria da cidade

Apesar de tanta marginalidade

Somos nós alegria da cidade.

Alegria da Cidade. Lazzo e Gileno Félix (1988)

A alegria, tema tão recorrente para retratar um estado de espírito, de celebração neste ambiente, não se refere unicamente ao Carnaval. É possível reconhecer nesta palavra significados múltiplos, como pode ser observado na canção Alegria, de Assis Valente, ou ainda em Alegria alegria, canção emblemática de Caetano Veloso. Entretanto, antes de entrarmos na análise temática, a partir do repertório destas estrelas do Carnaval, passemos pois a compreender como os aspectos técnicos e profissionais são importantes neste processo, podendo alavancar o sucesso.

\section{Notas}

1 Uma das grandes fases da música popular brasileira, que durou de 1930 a 1950, trouxe uma considerável diversidade musical e a criação de novos ídolos: os cantores e as cantoras de rádio. Ver Pimenta (2003) e Avancini (1996).

2 Morin (1998, p. 216) aponta que o "bem estar" aparece com mais clareza "com os bens de consumo e de uso produzidos pela economia industrial - e precisa-se como um estilo de vida ligado à habitação, aos transportes e aos lazeres modernos"

3 Maiores informações a respeito das transformações do samba neste período em Sandroni (2001).

4 Fred Góes (2006) traça uma pequena história da presença das mulheres no Carnaval brasileiro desde o entrudo, passando pela marchinha 
carnavalesca Oh Abre Alas, de Chiquinha Gonzaga, chegando à também precursora D. Ivone Lara, como mulheres compositoras num ambiente eminentemente masculino. O autor refere-se também a Elza Soares, puxadora do Salgueiro em 1969, "até desembocar contemporaneamente nas rainhas dos trios elétricos baianos, Margareth Menezes, Daniela Mercury e Ivete Sangalo. Representantes portanto, de uma já longa dinastia de mulheres bandeirantes a desbravar territórios muitas vezes dominados pela figura masculina para neles fazer surgir, luminosa, a presença da mulher". (p. 109)

5 Fez parte do cast da Rádio Nacional durante 27 anos, e foi campeã de correspondência durante 19 anos consecutivos pela mesma emissora; e mais de 50 vezes foi capa da Revista do Rádio.

6 Pode ser considerada como um novo jeito de cantar (o canto falado, sussurrado, com texto bem pronunciado) em contraposição ao bel canto, a "grande voz". Outra característica marcante da Bossa Nova é a forma como se toca o samba, particularmente ao violão num diálogo entre o canto e este instrumento recheado de acordes dissonantes para a época, enriquecido pelas letras de temas mais leves. Vale ressaltar o crédito da invenção da batida da Bossa Nova a João Gilberto, bem como seu canto "falado". Tom Jobim, Roberto Menescal, Carlos Lyra, Johnny Alf, Nara Leão, dentre outros, são também grandes representantes da Bossa Nova.

7 O disco de ouro se refere à quantidade de álbuns vendidos do artista que ultrapassa um número estipulado pela indústria fonográfica, atingindo novos recordes.

8 "Surgiu na cena artística a partir de 1967, com a proposta de exercer uma intervenção crítico-musical na cultura brasileira". (ALBIN, 2004, p. 290) Liderado pelos músicos e compositores Caetano Veloso e Gilberto Gil, agregando outros artistas a exemplo de Tom Zé, os poetas Torquato Neto e Capinan, os maestros Julio Medaglia, Rogério Duprat; o grupo Os Mutantes, Gal Costa, o artista plástico Rogério Duarte, entre outros artistas, sua estética "ressaltava os contrastes da cultura brasileira, como o arcaísmo convivendo como o moderno, o nacional com o estrangeiro, a cultura de elite com a cultura de massa" (p. 191) absorveu diferentes gêneros como baião, samba, bolero, frevo, jovem guarda, apropriando-se de diferentes temáticas que iam de Carmen Miranda à palhoça, dentre outros.

9 Elis Regina, juntamente com César Camargo Mariano, seu marido na época, e mais seu advogado e o seu irmão Rogério, criam a Trama, 
empresa que passaria a produzir espetáculos musicais, retomada atualmente por João Marcelo Bôscoli, seu filho mais velho com Ronaldo Bôscoli, seu primeiro marido, A gravadora Trama - cujo sucesso é cada vez maior - lança nomes que se convencionou denominar de Nova MPB, além de relançar títulos como Elis e Tom, dentre outros.

10 Esta canção foi gravada no seu álbum Saudade do Brasil. Seu último álbum, gravado em 1980, é dedicado a Rita Lee. Vejamos a dedicatória. "Dedico este disco a meu ídolo, minha amiga e colega de internato, Rita Lee. (ECHEVERRIA, 1994, p. 215).

11 Ao observar o gestual das intérpretes brasileiras ao longo das décadas, pode-se constatar que o rompimento do movimento com os braços e pescoço à frente do microfone (ainda com o pedestal de suporte) se rompe com Elis Regina. Gal Costa e Maria Bethânia também participam deste novo momento.

12 Sandroni (2004) aponta para três acontecimentos em relação a esta sigla: "Servia ao mesmo tempo como categoria analítica (distinguindose da música erudita e da folclórica), como opção ideológica e como perfil de consumo" (p. 31).

13 Como na canção Divino, maravilhoso (bordão utilizado pelo empresário da artista na época, Guilherme Araújo), de Gilberto Gil e Caetano Veloso, defendida no Festival de Música da TV Record em 1968. Esta atitude vocal de Gal Costa não se encontra isolada de sua transformação visual impressa pelos cabelos black power, colares e roupas coloridas e nos gritos da canção: "é preciso estar atento e forte/ não temos tempo de temer a morte..."

14 Este álbum foi considerado "censurado" para os padrões vigentes da época, vindo embalado numa capa de plástico por mostrar a artista com uma sumária tanga e veste indígena. Sobre a liberação sexual da MPB, consultar Faour, (2006).

15 Ver ilustrações das páginas iniciais de Faour (2006).

16 Elis dizia que o talento da compositora "só podia ser encosto" (apud ECHEVERRIA, 1994), pois era muito jovem para compreender de forma tão profunda o sentimento e o pensamento feminino.

17 Ver Néder (2007).

18 Com este álbum, a artista atinge a marca de 80 mil cópias vendidas.

19 O prêmio Sharp é dedicado à música, com várias modalidades de premiação, em diferentes categorias. Movimentou bastante o mercado da música, sem, no entanto, ter uma ligação direta com o mercado 
fonográfico. Criado pelo empresário José Augusto Machiline, carregava em seu cerne a segregação dos artistas do centro sul em relação à "periferia" com categorias como artista regional, banda regional, dentre outros. Daniela, Ivete, Margareth e Elba já receberam inúmeras vezes prêmios na respectiva categoria. O prêmio Tim de música procede de maneira semelhante.

20 Curiosamente, com este álbum, Marisa Monte é premiada como melhor cantora de samba no prêmio TIM de música 2007, concorrendo com Alcione.

21 A revista Veja de 11 de abril de 2007 traz a matéria A nação das cantoras - p. 120-127, apontando que do preconceito inicial que as interpretes carregavam, tornaram-se hoje as maiores representantes do mercado de disco comandando "a tradição de canto da música popular brasileira" (MARTINS,2007, p. 121).

22 Diz-se da forma específica de tocar um instrumento musical, sobretudo a guitarra e o baixo, associada a um determinado estilo.

23 A influência do canto de Elis Regina nas intérpretes de axé music é também citada nesta mesma matéria na Veja on-line; "Cronologia: a MPB na voz das mulheres, disponível em http://veja.abril.com.br/ cronologia/index.shtml, 2007. De maneira depreciativa., diz ele: "Daniela, assim como Ivete Sangalo, Carla Vizi (do Cheiro de Amor) e outras intérpretes desse gênero, são uma versão mais gritada - e algumas vezes menos afinada - de Elis Regina"

24 Importante destacar a performance da intérprete baiana Rosa Passos, cuja influência confessa em João Gilberto pode ser observada em sua obra. A artista, mais conhecida no Japão, Europa e EUA do que no Brasil, carrega em seu canto a sutileza, a emissão precisa e sintética da voz do mestre.

25 Em Clara Nunes, particularmente em Salvador, podemos observar duas representantes que sofreram influência da artista mineira: Tetê da Bahia e Mariene de Castro.

26 Refere-se também à proteção aos recém-chegados e órfãos da vizinhança, além do costume de promover festas em suas casas, geralmente mais espaçosas que aquelas outras da vizinhança. Este modelo familiar matrilinear, em que o sobrinho é quase que um filho, segue a estrutura familiar africana, com pequenas diferenças conforme a região, passando assim o controle da casa a essas mulheres, "explicando a predominância dessas negras senhoras da comunidade baiana no Rio de Janeiro" (TINHORÃO, 1998, p. 276). 
27 Referido por Vianna (2002, p. 112).

28 Chiaradia (1990) aponta esta mesma revista de José Figueiredo como sendo em 1854; enquanto Veneziano (1996) aponta o ano de 1859.

29 Ainda Chiaradia (1990) destaca o surgimento da revista O Mandarim em 1884, além de apontar como co-autor Arthur Azevedo não o seu parceiro usual, Moreira Sampaio, e sim Lino Assunção.

30 Para maiores informações sobre a obra de Arthur Azevedo, ver Martins (1988).

31 Maiores informações sobre o teatro de revista: Barros (2005); Paiva (1991); Veneziano (1991, 1997); Ruiz (1984); Silva (1999); Tinhorão (1998).

32 Barros (2005) grafa o nome da artista grega como Monarezzi e não Manarezzi, como Tinhorão (1998) e Paiva (1991).

33 Esta canção passou por diversas modificações até chegar a uma gravação definitiva cunhada em sua voz, com letra de Luiz Peixoto. Isto imortalizou o seu nome nos sulcos dos álbuns em acetato e, posteriormente, em vinil.

34 Sobre o período que a intérprete desenvolveu sua carreira no Brasil, ver Kerber (2002).

35 Nesta apresentação, assistida pelo ator de cinema americano Tyrone Power, Carmen usou o figurino da baiana desenhado pelo estilista J. Luiz e fez uso de uma maquiagem no rosto mais escura (CASTRO, 2005, p. 173). Quando ela lhe pediu que desenhasse uma baiana, não imaginava que, sem querer, Jotinha iria abrir o caminho para todas as liberdades tomadas pelos estilistas que lhe sucederiam trabalhando com Carmen. [...] A bata e saia foram feitas em material e cores diferentes. A saia era agora de veludo, com retalhos de losangos de várias cores, num eco modernista de Di Cavalcanti. O turbante começou a crescer, passando a acomodar duas cestinhas, e as frutas deram lugar a arranjos de folhas ou do que quisesse. [...] A baiana tornou-se apenas um veículo para o que se quisesse pôr em cima dela

36 Ary Barroso conheceu a Bahia em 1929, quando integrava como pianista a orquestra de Napoleão Tavares. Em entrevista à Manchete em 1962 disse: "Eu me descobri na Bahia. Os seus ritmos, seus candomblés, suas capoeiras, sua gente [...] foram uma revelação para mim. Fiquei de tal modo impressionado que o jeito foi exteriorizar a minha admiração através da música”. Depoimento extraído do site cifrantigaz.blogspot. com/2006/o4/-na-baixa-do-sapateiro.html. 
37 As aquarelas e gravuras de Debret "datam de 1816 (quando chega ao Rio de Janeiro com a Missão Francesa) a 1831 (quando retorna à Europa), ou seja, antes da migração baiana para o Rio de Janeiro por ocasião da proibição do tráfico negreiro em 1850" (GARCIA, 2004, p. 148).

38 Há uma semelhança muito grande entre o traje descrito tanto na música de Caymmi e aquele presente nas gravuras dos pintores citados acima, o que pode ser explicado pela religiosidade afro-brasileira que preserva sua tradição em torno dos seus mitos, como é apontado por Lipovetsky: "inteiramente centrada no respeito e na reprodução minuciosa do passado coletivo, a sociedade primitiva não pode em nenhum caso deixar manifestar-se a sagração das novidades, a fantasia dos particulares, a autonomia estética da moda" (1987, p. 7).

39 Como afirma Eneida Maria Souza (2004, p. 75): "Durante o período da política da Boa Vizinhança, programa instaurado pelo governo americano para tornar próximas as relações com a América Latina, uma artista é escolhida como símbolo do continente: Carmen Miranda. Já Ruy Castro (2005) afirma que a imagem de Carmen Miranda é indissociada da política da Boa Vizinhança, criada pelo magnata Nelson Rockfeller, cujo objetivo era "estimular negócios comerciais" (p. 264) através do Office of the cordinator of inter American Affairs, não aconteceu como divulgado maciçamente pela imprensa da época; ao contrário, os planos de Rockfeller só foram aprovados em 16 de agosto de 1940. Neste período, Carmen já havia aportado nos EUA e terminado as filmagens do seu primeiro filme pela Fox - Serenata Tropical, com direção de Darryl F. Zanuck e já fazia estrondoso sucesso na Broadway. É bem verdade que o diretor decidiu rodar este filme ainda em 1939, ano em que Carmen embarcou do Brasil para os EUA. No entanto, segundo Castro, em meados de 1939, ainda não havia "uma política da Boa Vizinhança em ação, muito menos comandada por um birô. (Na verdade, não havia nem a guerra)" (p. 265). Já Tânia Garcia (2004) situa o início da política da Boa Vizinhança em 1933, com a produção do filme Flyng down to Rio "intencionando agradar o público latino americano e expandir o mercado da região" (2004, p. 143). Para o papel principal, a atriz mexicana Dolores Del Rio fazia uma brasileira de nome Belinha, que, em viagem a Miami apaixona-se por um americano.

40 O Bando da Lua é uma referência fundamental na construção da baiana e do samba de Carmen em terras do Tio Sam. Formado inicialmente pelos músicos Aloysio de Oliveira (que acompanhou Carmen em todos os momentos de sua carreira, tornando-se também seu amante durante longo tempo), os irmãos Osório, Ivo, Hélio e Vadeco, o Bando, que 
almejava mais a carreira como grupo autônomo, não conseguiu, contudo, se estabelecer como tal. Viajaram com Carmen para os EUA, por exigência e precaução da artista, que não confiava no acento do samba tocado pelos norteamericanos. Assim, o Bando embarca com Carmen com seis membros que seriam substituídos por outros integrantes ao longo do tempo, com um cachê de 35 dólares por semana para cada integrante, ficando Carmen responsável de repassar o pagamento para cada um.

41 Um dos adjetivos aplicados a Carmen na sua pequena aparição na revista Streets of Paris. Foi cunhado pelo crítico Earl Wilson do jornal Daily News. Além deste, outros como The siren from South América, The pearl of the pampas, The latin lollapalooza, para citar os mais inusitados. Alguns destes foram enumerados pelos críticos para ilustrar o que para eles seria a razão do verdadeiro sucesso da aparição de Carmen na revista musical: sua aparição. Uma performer, enfim.

42 O empresário Lee Schubert, que a levou para os EUA em 1939, aceitava todos os convite para a presença da artista, que se desdobrava em atender a todas as solicitações, além de fazer sete apresentações por semana de Streets of Paris às 20:30 de segunda a segunda, e mais duas às 14:30 nas matinês de quartas e sábados, além do programa de Rudy Vallèe às quintas por quatorze semanas seguidas. Durante três anos, Carmen permaneceu sob a tutela de Shubert, inicialmente com contrato de $50 \%$, depois $30 \%$ para ele, até chegar a $25 \%$. Posteriormente, em 6 de agosto de 1942, a artista passa a administração de sua carreira para as mãos do empresário George Frank, levada pelas mãos do ator Don Ameche.

43 Não se sabe ao certo quem ofereceu à artista a anfetamina Benzedrine pela primeira vez. O fato é que, após extenuante jornada de trabalho, a artista desmaia no set de filmagem da Fox, onde gravava sua participação no filme Serenata tropical, e é levada ao médico, que recomenda repouso e o remédio. Entretanto, Benzedrine era considerada uma cápsula mágica no meio artístico e até pelos médicos que não tinham a dimensão dos efeitos por vezes irreversíveis causados ao organismo. Para contrabalançar os seus efeitos, utilizava dos barbitúricos Seconal e Nembutal, que serviam para amenizar os efeitos de se passar dias sem dormir (CASTRO, 2006).

44 Araci Cortes se apresentava com jóias verdadeiras no palco.

45 Importante observar por vezes a analogia empregada entre a baiana e a mulata. Podemos considerar o rótulo de ambas como meio irmãs. 
Vale citar Giacominni (1992), cuja abordagem de uma categoria racial torna-se ocupacional a partir da pergunta a 14 candidatas a mulata profissional - "O que é ser mulata"? A partir das respostas das candidatas (está na cor, está no sangue, está no corpo, ser profissional), a autora constrói seu texto de forma bastante ilustrativa, apontando a afirmação da identidade da mulata profissional que passa por um diálogo defensivo, dependendo do desempenho particular de cada aluna, para se livrar do estigma da prostituição, buscando um reconhecimento como dançarina, mesmo observando que o ingresso da mulata profissional na capacitação de dançarina não detém algumas das características exigidas para a profissão.

46 Expressão criada por Gilberto Gil, na faixa homônima com participação de Nana Caymmi, do disco Parabolicamará, lançado pela WEA em 1991.

47 Maiores informações sobre a baianidade impressa na obra de Caymmi consultar Moura (2001, p.146-149) e Risério (1993).

48 Acessório usado no vestido. Um laço ornamentado colocado sobre as nádegas. 


\section{4}

\section{Aspectos artísticos, técnicos e profissionais na construção da carreira das estrelas/ intérpretes da axé music}

As novas relações do mercado da cultura que se estabelecem entre os atores sociais no ambiente da axé music, envolvidos na produção, criação, divulgação e consumo deste produto podem ser utilizadas como referências para a análise da construção do sucesso das intérpretes baianas nesta teia em que artistas, produtores, patrocinadores, mídia e público intercambiam poder e bens culturais.

O que é necessário para ecoar som e imagem destas agentesestrelas, que gravitam em diferentes espaços, convivendo com suas diferenças? Talento, beleza, juventude, punch? Normalmente, estas características não são suficientes para dar conta de inquietações deste tipo. No entanto, no campo da música, tais características são indissociáveis de outros elementos que podem elucidar a perspectiva do sucesso destas estrelas.

O avanço tecnológico vem possibilitando uma transformação avassaladora no ambiente da música de cunho carnavalesco na Bahia a partir do fenômeno axé music. Primeiro, pelo próprio diálogo que se pôde travar com instrumentos a princípio incompatíveis, como a percussão e instrumentos eletroeletrônicos, associados à potência da voz captada por microfone, que possibilitou uma nova ortofonia ${ }^{1}$ tanto para a voz quanto para a música. 
À medida que a tecnologia avança, novas possibilidades de experimentação tornam-se possíveis para que o espetáculo possa continuar cada vez mais limpo e sem ruídos, fazendo dialogar de forma harmoniosa instrumentos de diferentes timbres e intensidades num ambiente ao ar livre, possibilitando, assim, diálogos possíveis entre, por exemplo, um piano acústico, uma banda com instrumentos de percussão, instrumentos eletroeletrônicos e a voz humana, em cima de um trio elétrico ${ }^{2}$.

As condições técnicas, bem como os operadores de tecnologia e técnicos/engenheiros de som podem contribuir de forma determinante para a reprodução e reprodutibilidade dos aspectos sonoro e visual destas estrelas/intérpretes. Entretanto, o processo de autonomização destas agentes não se dá de forma isolada. É em meio a uma série de transformações que esta autonomia faz sentido. Para Bourdieu (1991), estas transformações se processam na constituição de um novo público consumidor socialmente diversificado, num aumento de produtores e empresários de bens simbólicos e na multiplicação e diversificação das instâncias de consagração.

Já para José Carlos Durand (1989), este processo de autonomização se realiza no bojo de mudanças sócioeconômicas no Brasil a partir da década de sessenta, impulsionado assim o meio artístico que se (trans)formava. A concorrência entre os agentes também se faz presente na busca de patrocínio, e consequentemente de espaço, na obtenção de recursos públicos ou privados para a realização de suas práticas artísticas.

Pode ser interessante aqui reportar uma matéria publicada no Jornal A Tarde de 2 de fevereiro de 2005, como ilustração deste processo: Empresários preferem o mundo axé. Vejamos o depoimento de Eduardo Santana, Coordenador do Departamento de Educação do bloco afro Malê Debalê: "As perspectivas dos empresários no Carnaval de Salvador estão é no público axé, que está no circuito Barra-Ondina, onde não há blocos afro. Nosso trabalho, que não é só a festa, o desfile, dura 365 dias no ano".

No mesmo jornal, na coluna Sotaque Baiano, em entrevista com Bell Marques - vocalista e baixista da banda Chiclete com Banana, o 
repórter Sandro Lobo pergunta sobre a solução para a falta de patrocínio dos blocos afro. Bell responde: "Isso vem acontecendo há mais de vinte anos, ninguém tem culpa. Acho que os blocos afros deveriam se profissionalizar para acabar com esse problema. Todo ano é a mesma coisa; garanto, que se eu estivesse lá, isso não estaria acontecendo".

Neste sentido, Bourdieu e Haacke assinalam que os artistas são difíceis de serem mobilizados, pois "não têm consciência de possuir problemas de interesse comum e se limitam à defesa dos interesses particulares, que são concorrentes com os dos outros" (1995, apud NUSSBAUMER, 2000, p. 39).

Assim, o processo da autonomização da produção artística de forma geral se realiza de forma individual, sendo os mais beneficiados aqueles que mais se identificam ou se submetem à lógica do mercado. São os chamados artistas executivos. Isto não significa, porém, que esta autonomização se efetivará. Buscamos na relação entre artistas, patrocinadores, agentes e mídia, a explicação da construção do sucesso desta agente-intérprete no tocante ao ambiente da axé music e sua confluência que se derrama em outros ambientes do mercado da cultura.

Para que as intérpretes do Carnaval baiano sejam "eleitas" representantes da produção musical recente entre nós, redes de interesses e conexões se fazem necessárias para a construção desse sucesso que se estende para além do Carnaval. É instigante o que Claude Mollard (1994, apud NUSSBAUMER, 2000) denomina de jogo das quatro famílias que constituem o sistema cultural no qual artistas, públicos, financiadores e mídia se relacionam e se estruturam por dois eixos:

[...] artistas e públicos podem jogar juntos, mas financiadores e mídia nutrem-se da presença dos primeiros. [...] Em torno desse eixo dos artistas e dos públicos, estabelece-se o conjunto de trocas que constitui o mercado da cultura. Em torno do eixo dos financiadores e da mídia, constrói-se o conjunto de intervenções que condicionam cada vez mais as relações entre artistas e público, ou seja, o mercado (p.19-20). 
Assim, as relações entre os artistas e públicos se transformam, na medida em que crescem as intervenções entre os financiadores e a mídia, mudando, desta forma, o sistema de artístico para cultural. Entretanto, para Nussbaumer, ainda citando Mollard, a relação que se estabelece entre os "participantes deste jogo" não se dá unicamente de forma biunívoca. Os atores podem participar de várias famílias ao mesmo tempo. $\mathrm{O}$ artista pode ser produtor e financiador de outros artistas, assim como o jornalista pode ser empresário; assim, vão se formando teias de relações e serviços no ambiente do mercado da cultura, que ampliam o trânsito e o poder destes agentes circularem no mercado, como "vencedores do jogo".

Nussbaumer (2000), além dos quatro elementos propostos por Mollard (1994), inclui um quinto: os agentes culturais. Para a autora, este quinto elemento é importante como mediador entre o produtor e o financiador, também denominados de produtores executivos, relações públicas, dentre outros. Gostaríamos, aqui, de substituir a denominação "agente" por produtor cultural, pois este último termo, mais próximo do mercado da cultura baiana, se configura também como mediador entre o artista e o patrocinador.

A ocasião do sucesso surge de forma relacionada a circunstâncias nem sempre previsíveis e muito menos premeditada, não só por parte do produtor cultural. Examinemos o que nos tem a dizer Edgar Morin (2003) sobre este item. Utilizando a noção de acaso/incerteza no conhecimento científico, Morin nos revela que enfrentar a incerteza faz parte da vida. Contudo, isto não significa uma resignação ou mesmo um ceticismo generalizado, para aguardar o incerto e o inesperado, traçando estratégias e desafios. Para o autor, "uma estratégia traz em si a consciência da incerteza que vai enfrentar e, por isso mesmo, encerra uma aposta. Assim, deve-se estar plenamente consciente da aposta, de modo a não cair em uma falsa certeza" (p. 62).

Assim, a consciência de que a vida humana é uma aventura, uma incerteza em que a estratégia e a própria sorte são artifícios fundamentais na tentativa de êxito, pode se configurar numa descrição de elementos fundantes na construção do sucesso. 


\section{Aspectos propriamente artísticos: o artista como intérprete e criador}

Passemos a considerar o artista como intérprete e criador, buscando nesta consideração o conceito de intérprete na acepção de Paul Zumthor (1993): Intérprete se refere aos "portadores da voz poética" (p. 57). Estes portadores se estendem não somente a cantores, músicos, trovadores, menestréis, compositores, jogralescos, dentre outros detentores do dom da oratória. Segundo o autor,

[...] o que os define juntos, por heterogêneo que seja seu grupo, é serem (analogicamente, como os feiticeiros africanos de outrora) os detentores da palavra pública: é, sobretudo, a natureza do prazer que eles têm a vocação de proporcionar: o prazer do ouvido; pelo menos de que o ouvido é o órgão. O que fazem é o espetáculo (p. 57).

O intérprete ao qual Zumthor se refere é aquele da Idade Média na Europa. Baseado em Faral3 (1964), pesquisador da Idade Média cuja obra foi reeditada quase meio século após o seu desaparecimento, o autor conclui que nos intérpretes "se apreciava, sobretudo uma espécie de universalidade nas artes do divertimento e, se ele dizia ou cantava a poesia, com igual maestria nos diversos gêneros" (p. 57). Já Menendez Pidal (apud zUMTHOR, 1993) se contrapõe à opinião de Faral e afirma que o intérprete se sustenta pelo instrumento musical que o acompanha.

As possibilidades de distinguir o músico do cantor e do recitador eram muito pequenas. Neste sentido, a especialização na arte de interpretar não se constitui em regra neste período. No entanto, a depender do gênero recitado, a interpretação se tornava mais especializada. Estes cantores "de gesta", como eram chamados, apresentavam-se nos “jograis", e muitos deles eram cegos.

Onipresente, insistente, agitada, a massa dos intérpretes não tem delimitações fixas nem precisas. Socialmente heterogênea, 
recruta-se em todos os setores não camponeses da população e dá provas de uma mobilidade que, de um dia para o outro, pode modificar a condição do indivíduo; fazer do cavaleiro um errante miserável, do clérigo um saltimbanco, do recitador popular um cantador introduzido nas altas rodas (ZUMTHOR, 1993, p. 59).

O intérprete teria o dom da vocação da palavra e do canto originando uma elite de porta-vozes (p. 6o).

Estas diversas práticas, apresentadas de diversas formas em lugares diversos, se estendiam também a leitores profissionais que, em voz alta, narravam o conteúdo de várias modalidades de textos verbais impressos. Romances, poemas e outros gêneros eram lidos por intérpretes especializados que, a partir da demanda, formavam-se cada vez mais rápido. Estas leituras normalmente se transformavam em espetáculo, não importando para os ouvintes as diferenças sociais, sexuais, econômicas; sua atuação não era considerada uma atividade marginal. Apesar de não estarem situados socialmente em classe alguma, é difícil localizar sua posição. Zumthor (1993), destaca que:

Eles não se assentam, propriamente falando, em nenhum lugar; distinguem-se; situam-se em contraste com os outros "estados do mundo"; muitos se enfeitam com roupas chamativas ou excêntricas, tratam a si próprios ironicamente de loucos. Por um lado, manifestam o caráter carnavalesco dessa cultura, mas por um lado somente (p. 63).

Estes intérpretes ligam-se às vezes a uma corte ou mesmo a um poeta que não dispõe da mesma competência para a arte de dizer. Assim como a aristocracia, a Igreja também se valia destes artistas para publicidade junto aos peregrinos. Esta ilustração pode ser reportada aos cantos de romaria.

Outra característica destes porta-vozes do mundo medieval era certo nomadismo. Circulando por toda a Europa, estas migrações não eram bem vistas nas regiões que as recebiam, chegando a ponto de limitarem a quantidade de jograis que podiam circular e estabelecer re- 
sidência em algumas cidades. Fossem cantores, recitadores ou leitores, a depender do estilo de vida que levavam, no modo como se inseriam na ordem feudal ou urbana, só cabia a estes profissionais "uma modalidade de integração social: a que se opera pelo lúdico” (p. 66).

Podemos observar, a partir do relato de Zumthor (1993), que estes profissionais intérpretes medievais carregam graus de similitude com o que costumamos denominar de intérprete da canção popular brasileira/baiana, nos moldes da indústria da música contemporânea.

O construto desta nova intérprete, como já apontado no capítulo anterior, pode ser reportado às transformações operadas no ambiente da música popular brasileira, principalmente a partir da década de vinte do século $\mathrm{xx}$, quando da passagem do sistema de gravação mecânica para o de gravação elétrica; e o aparecimento e expansão do primeiro veículo de comunicação de massa: o rádio. Isto não significa deixar de apontar também o teatro musicado como palco desta construção, não só pelas atrizes e cantoras brasileiras, mas por estrangeiras que aqui passaram com suas respectivas companhias portuguesas, francesas, gregas, espanholas e brasileiras.

As intérpretes que se apresentavam nos palcos das revistas musicais do início do século $\mathrm{xx}$, passando pelas estrelas que se constituem a partir do advento da era radiofônica mecanográfica, com Araci Cortes, e depois da era elétrica, com Carmen Miranda, passando pela fase da música popular brasileira que durou da década de trinta até a década de cinquenta, a Época de Ouro 4 , trazendo renovação musical e criação de novos ídolos, como Marlene, Emilinha, Dalva e Ângela Maria, dentre outras; atingindo o auge da MPB já na década de sessenta e setenta com Elis Regina, Gal Costa e Maria Bethânia; e os nomes da nova música brasileira, como Marisa Monte, Vanessa da Matta, Cássia Eller, Adriana Calcanhoto e Maria Rita, desempenham um importante papel na construção de uma identidade nacional, suplantando por vezes o próprio discurso dos compositores que de certa maneira passam a ter uma participação mais ativa na década de setenta, principalmente no período dos festivais da canção, que coincide com o período da ditadura militar no Brasil. 
Aproximando mais o foco, apontamos para as intérpretes surgidas no seio do Carnaval de Salvador, que, de forma semelhante às estrelas/ intérpretes surgidas em épocas anteriores, retomam o espaço também como criadoras da canção, não no sentido de compor a canção nos moldes em que se compreende o senso comum, mas suplantando por vezes o seu criador, sendo elas próprias também criadoras, já que decalcam o seu canto impregnado de significados não apenas referidos ao vocal, como também ao corporal, tudo isto relacionado à criação de tecnologias de som e de imagem, aumentando assim o leque de possibilidades da performance destas intérpretes na mídia 5 .

Este rápido panorama só nos serve para situar o objeto em questão. Apresentamos como algumas intérpretes baianas se pronunciam acerca deste conceito, a partir de sua experiência.

Márcia Short afirma que a intérprete é:

Aquele personagem que traduz todo sentimento do compositor. Toda invenção do compositor, e que, sobretudo, a emoção da banda traduz em palavras o que a banda, o compositor, o que a música diz. Na minha visão, é este o papel do intérprete (Entrevista à autora em 25 jan. 2005).

Podemos observar que a artista afere à intérprete o papel de personagem que traduz de maneira geral o sentimento. Neste sentido, ela representa alguém que não é ela mesma, pelo menos no momento em que interpreta a canção. Márcia Freire, diferentemente de Márcia Short, distingue a intérprete da cantora pelo tipo da canção interpretada. No entanto, destaca, como a primeira, de que forma a emoção impressa é um ingrediente indispensável na composição da mesma.

Que pergunta, essa... Normalmente, quando a gente sente a música, que a música entra na alma, a gente consegue interpretar, nem sempre a gente é uma intérprete no caso da gente que canta no trio, no Carnaval, que faz aquele baile de 7, 8 horas e é claro que a emoção anda solta. Mas, tem aquela música que você consegue se dar mais, porque ela entra na sua alma, então você consegue interpretar essa música. Eu me lembro de 
quando eu estava no estúdio gravando aquela música de Benito de Paula, Eu amei. Foi uma emoção, pois desde pequena eu ouvia aquela música. Então, quando eu gravei aquela música, eu gravei do fundo da minha alma. E a coisa mais interessante é que consegue passar isso pro público. O público consegue distinguir quando você canta uma música de alma e quando você está cantando porque simplesmente está cantando. (Entrevista à autora em 25 jan. 2005).

Morin (1998) afirma que, na ética cultural da intelligentzia, há uma diferença entre melodia e canção. A primeira releva da arte e a segunda, do consumo. Assim, a canção carrega uma dose de frivolidade, enquanto a melodia, uma dose de nobreza. Este esquema se refere especificamente à canção francesa. Entretanto, pode nos servir para traçar um rápido perfil desta construção poética do intérprete e suas várias nuanças de interpretações.

Assim, voltamos a levantar o problema da criação artística no sistema industrial. O critério de "qualidade" parece não se referir ao sistema industrial-comercial como linha de demarcação entre a arte e a não-arte. Morin (1998) aponta que a canção tem um caráter multidimensional, pois carrega em si a dupla substância musical e verbal:

A própria música é algo de sincrético na canção. Comporta o tema melódico, o ritmo, o arranjo musical, o acompanhamento e orquestração. Se o tema musical é o maior refractário à analise conceptual e ao estudo sociológico, o arranjo e o ritmo inserem-se em gêneros, estilos, modas. Assim, a substituição de uma guitarra (normal) por outra (elétrica) marca a passagem do yê yê para o gênero neofolclórico (p. 236).

A história da canção se confunde com a individualidade criativa das intérpretes e dos gêneros musicais. Neste sentido, situando a canção de maneira multidimensional, podemos nos reportar à indissociabilidade desta com relação à dança. Ambas se misturam de tal forma a gêneros tais como o rock, o twist, ao bolero, o samba, a valsa, o tango, o charleston, a axé music, só para citar alguns, que o 
artista, ao fazer parte do espetáculo, seja em teatro ou em música, exibe seus dotes não só vocais, mas físico/corporal/coreográficos, e mesmo teatrais, na medida em que se apropria do texto do autor para decalcar de forma mimética o pensamento da personagem.

Assim, no conjunto música/palavra, a primeira é arrastada pela dança, enquanto a segunda, pelo teatro. E o conjunto das duas se reporta ao caráter da canção moderna de forma multidimensional, na medida em que a "mesma está empenhada no processo econômicoindustrial-técnico-comercial" (MORIN, 1998, p. 237), apontando assim os problemas da indústria cultural, que desemboca na contradição entre produção e criação. Por outro lado, podemos pensar no caráter singular da indústria da canção, que tem na intérprete uma das grandes representantes; tem o disco além do palco, o satélite da canção. “Toda canção moderna tornou-se um satélite da indústria do disco" (p. 237). Contudo, não significa afirmar que a aura (BENJAMIN, 1983) impressa no software, ou seja, suas condições de gravação cada vez mais limpa, sem ruídos, não possa produzir, transmitir sentimentos e sensações de diversas naturezas no ouvinte/espectador.

Por outro lado, ao imprimir sua voz num software, a intérprete já não precisa dispor de uma voz potente para este tipo de registro, visto que o microfone funciona como um amplificador da voz, bem como um mediador entre a intérprete e o público. Entretanto, o processo de tecnicização da canção necessita de um sistema de sonorização que integre cada vez mais tecnologia de ponta, para que possa captar a voz sem ruídos e sem defeitos. Assim, ao mesmo tempo em que o microfone subjuga a voz da intérprete às condições do estúdio e de uma apresentação ao vivo, proporciona, como já apontado, amplificar vozes de timbres agradáveis, mas destituídas de intensidade, bem como pequenos defeitos que se tornam estilos interpretativos.

Como exemplo deste fenômeno, podemos citar duas grandes vozes da música brasileira: Carmen Miranda e João Gilberto. Com uma extensão vocal relativamente pequena e de pouca intensidade, Carmen se vale de uma interpretação brejeira e peculiar, enriquecida pela sua performance corporal e pela sua indumentária, que proporciona 
um conjunto performático seguido até hoje no show bussiness por artistas como Daniela Mercury, Ivete Sangalo, Margareth Menezes e Marisa Monte, dentre outras, para dar conta de uma singularidade interpretativa projetada para além da voz.

Examinemos o depoimento da artista à revista O Cruzeiro, em 1935.

Repórter [...] E você para cantar estuda muito a música? Carmen: Não! Eu não entendo nada de música! Canto por vocação. Assim, quando me dão a letra, peço para tocar e, lendo os versos, dou a expressão que se torna necessária. Aliás, isto não sucede só comigo. Todas estas canções populares são assim fáceis, dependendo apenas de uma cousa, de alma, mas alma de gente carioca, expressiva, viva, espontânea. (apud GARCIA, 2004, p.31).

Quando Joubert de Carvalho - autor de Ta-hí, quis ensinar-lhe a marchinha com voz de seresteiro e tentando orientar sua interpretação, ela retrucou dizendo: "Não precisa me ensinar, não, que, na hora da bossa, eu entro com a bossalidade" (CASTRO, 2005, p.52).

Assim, nos dois exemplos, podemos perceber a "intuição" da intérprete como tônica na construção de uma forma própria de interpretar sambas, marchas e demais canções brasileiras. Assim sendo,

A soprano de voz afinadíssima, com uma diç̧ão de cristal, não alcançava a extensão de Aracy [Cortes] nos agudos, mas tinha mais peso na voz e capacidade de trabalhar igualmente nos médios. Isso indicava seu potencial para cantar numa variedade de ritmos e estilos. E Carmen tinha a interpretação, a bossa da cantora de rua - um talento para enxergar nas entrelinhas das frases, tomar liberdade com a melodia e surpreender o ouvinte com seus achados. Não precisava ser vista para agradar - embora quando isso acontecesse, nas fotos e nas apresentações em público, sua beleza e vivacidade e o fato de cantar sorrindo pudessem torná-la muito popular. (CASTRO, 2005, p.50). 
João Gilberto ${ }^{6}$ contribui de forma emblemática numa nova performance vocal interpretativa, cujo diálogo com o violão torna-se referência de "qualidade" numa síntese do canto falado, só tornado possível em virtude da apropriação de uma nova tecnologia de captação da voz e de instrumentos tanto em estúdios quanto em concertos ao vivo, denominada ortofonia. João e seu violão configuram emblematicamente a interface entre a música erudita e a popular no sentido de exigência auditiva e conhecimentos técnicos por parte do público que de maneira sutil possa captar os acordes dissonantes do seu violão com a divisão rítmica do canto proporcionando assim diálogos antes inimagináveis, captados pela tecnologia.

João tem uma declarada preocupação em projetar a voz de maneira clara e delicada, com uma diç̧ão impecável e sem um pronunciado sotaque de baiano... Em seu perfeccionismo, emite cada palavra com o peso inteiro de seu significado e de sua sonoridade. (MELLO, 2001, p. 43)

Guardadas as devidas proporções ambientais e artísticas, observamos que o mesmo fenômeno tecnológico é possível na captação da voz da intérprete no trio elétrico, em diálogo com instrumentos harmônicos e percussivos. Assim, a técnica vocal é indissociável de novas tecnologias de captação que proporcionam uma emissão vocal de menor intensidade, oferecendo assim uma saúde vocal longeva, bem como o surgimento de novos estilos que se distanciam cada vez mais.

Margareth Menezes revela, em entrevista ao jornal A Tarde, sobre o tema em questão, à época do lançamento do seu CD Pra você, em 2005, pela gravadora Universal.

Não sou cantora nem de trio nem de Carnaval. - Carnaval é um momento na minha carreira. E esse CD é uma maneira de expandir mais o meu trabalho, para que percebam minha interpretação, meu timbre de voz. É uma proposta de novidade. Claro que o Carnaval tem o seu valor, mas não é a minha essência. O que me liga ao Carnaval é a música; a participação é de momento. Agora chegou a vez de me mostrar mais. Sequei mais o som, coloquei pouca percussão para que sobressaísse 
esse meu lado, para mostrar minhas possibilidades. Porque, para ser sincera, não me vejo cantando no Carnaval eternamente. E o Carnaval, mesmo, precisa se renovar... estão surgindo outras bandas... Tô aí, mas não sei até quando. (BASTOS, 2005, p. 1).

A artista, ao se "excluir" como intérprete do Carnaval, demonstra de certa maneira a "limitação interpretativa" que o Carnaval impõe, já apontado anteriormente por Márcia Freire, no sentido de não permitir que a essência da intérprete seja percebida, captada pelo público. Margareth demonstra em seu depoimento que o diálogo com muitos instrumentos, particularmente a percussão, "pode prejudicar" a performance interpretativa do artista em poder transmitir sua "essência". Entretanto, com a criação e difusão de instrumentos eletroeletrônicos, as possibilidades de variedades tímbricas da voz humana se ampliam consideravelmente, proporcionando assim milhares de variedades antes consideradas ruído, tais como soprosidades, gritos, rouquidão, sussurros, em diálogo com distorções, microfonias, delays, computadores, samplers, reverber, etc. Assim, os ruídos ${ }^{7}$ passam a ser incorporados esteticamente, tornando-se música, como uma representação do caos sonoro da contemporaneidade, sonorizada por buzinas de carros, sirenes, betoneiras etc. Rompe-se assim o binômio beleza/pureza.

Margareth Menezes considera a "intérprete uma mensageira que extrai o sentimento da canção, permitindo assim que as pessoas sonhem". A intérprete sente a música dessa maneira. Por outro lado, pontua a integração entre a melodia e a letra, além da observação e percepção dos limites. "Tem todo um perceber. Você percebe os limites quando você tenta. Daí pra cá eu não vou. Eu posso ir até aqui. Acho que isso a gente acha o caminho" (Entrevista à autora em 5 out. 2005).

Assim, a intuição está presente no ato interpretativo, bem como o sentimento impresso na poesia que se torna música. "A palavra convertida em música. A música expressa em palavra” (SANT'ANNA, 2001, p. 11). Na mesma obra, Sant'Anna enumera quatro tipos de ex- 
pressão musical: a música que canta (privilegia a melodia); a música que fala (privilegia o texto); a música que corporifica (transforma o corpo num elemento de expressão tanto da música quanto do texto); a música que visualiza (espetaculariza). De acordo com esta classificação, o autor também enumera, na mesma ordem: a Bossa Nova como a primeira categoria; o rap e os repentes como a segunda; as músicas de cunho popular, carnavalesco, pagodes e sambas, concertos de rock e pop como a terceira; e finalmente, os videoclipes como a quarta categoria, enquanto gênero sonoro/visual, bem como os DVDs.

De certa maneira, Margareth Menezes e Márcia Freire seguem a classificação número um de Sant'Anna (2001), ao considerar a intérprete como uma profissional que valoriza a melodia da canção. Entretanto, acrescentaríamos, aos gêneros enumerados por Sant'Anna, a MPB transitando nas duas primeiras classificações. Por outro lado, tanto na música quanto em outras práticas artísticas, os gêneros não se configuram em classificações estanques, podendo transitar de um gênero a outro sem necessariamente pertencer unicamente a um ou a outro. Neste sentido, o ambiente do Carnaval também pode figurar em performances que na classificação de Sant'Anna seria representada pela música que corporifica, mas também em música que "canta" e que "fala".

Ivete Sangalo considera ser possível não só "interpretar o segmento, mas o sentimento" Para ela, em entrevista à autora:

A intérprete é aquela que se sente íntima de uma canção. [...] Você tá lá na prateleira de música, isso é possível, da mesma maneira que é possível só interpretar bacana, determinadas canções. Intérprete não é só aquele que chega, grita e canta, se dilacera, ou então se joga no chão, não. De repente, eu já vi milhões de interpretação iguais, idênticas, de diferentes momentos. Então, eu acho que é isso. A pessoa está pronta para assumir aquela música, caso contrário, ele tem direito de dizer não, esta canção não é para mim, por ele ser intérprete (SANGALO, 2005). 
Ivete aponta o bom senso como medida para se tornar uma intérprete. Conhecendo assim seus limites, o artista vai poder errar menos.

E assim, a voz enquanto força interpretativa da canção extrapola sua materialidade física e orgânica, assumindo contornos não só estéticos/artísticos quando, ao sair do papel, imprime uma materialidade sonora que difere da voz que fala, pelo menos no cotidiano. A educação de uma voz cantada enriquecida pela técnica possibilita um domínio maior do material vocal do intérprete, possibilitando assim matizes de uma construção vocal compatível com um instrumento de composição cuja tessitura, timbre, fraseado, articulação, emissão, ritmo, pode imprimir múltiplas possibilidades de interpretação numa identidade vocal múltipla, sincrética, híbrida.

Vejamos o que Daniela Mercury tem a pontuar sobre o seu conceito de intérprete. Paralelo ao canto, enumera outros pilares que alicerçam a carreira da intérprete:

Domínio do que se quer fazer com a música, pesquisa musical com escolhas conseqüentes (boas ou ruins), direção artística dos espetáculos. Eu sempre tive a idéia do que quero. A intérprete no palco com dança, repertório, detalhe de arranjo, iluminação, quem trazia a proposta era eu, e cada vez mais. (MERCURY, 2003b).

Assim, a intérprete em Daniela não se resume ao ato de interpretar uma canção; configura-se num espetáculo multidimensional cujos elementos técnicos e artísticos contribuem para alicerçar, enunciar uma mensagem do artista performático contemporâneo ${ }^{8}$. Esta característica é bastante presente em espetáculos de música pop, cujo público de proporções gigantescas, impossibilitados de ver de perto o seu ídolo, se contentam não só em vê-lo através do telão; o espetáculo oferecido pela iluminação e efeitos cenográficos/coreográficos possibilita uma assistência visual/sonora de enormes proporções. O público quer ver/participar de um espetáculo, seja dançando, cantando. Por outro lado, a música pop imprime uma gestualidade indissociável 
da voz, na medida em que a relação corpo/voz, enquanto linguagem, também passa pelo vetor da percepção.

Assim, podemos pontuar que, de maneira multidimensional, Daniela aponta para uma intérprete que dialoga com recursos técnicos/tecnológicos, performáticos, de forma a encarar sua prática artística como uma mediadora cultural que imprime no seu corpo/ voz sua mensagem poética. Ivete e Margareth também podem servir de exemplo para esta configuração, bem como o nosso primeiro mito contemporâneo - Carmen Miranda -, que associa a performance ${ }^{9}$ corporal/gestual/visual para dar conta de uma pequena extensão vocal compensada por estes outros atributos.

Concordamos com Martins (2004), quando afirma que:

[...] a voz ocupa seu lugar simbólico na linguagem, constitui e é constituinte da cultura, por sua capacidade comunicativa corpóreo-perceptiva. A corporeidade da voz ultrapassa a função lingüística ao criar ambientes sonoros que nos circundam e nos põem em estado de imersão sensória (p.141).

Neste sentido, uma nova ortofonia se apresenta para compactuar com o Carnaval, que também pode ser um ambiente bastante fértil para observar a atuação destas intérpretes. Estas, aliadas à tecnologia, podem ecoar os seus respectivos cantos de forma a refletir um novo estilo interpretativo, que carrega grandes transformações, não só na emissão vocal brusca e percussiva, pelo próprio estilo que a axé music e os gêneros afins imprimem, como nas tonalidades mais graves para a tessitura feminina, que, ao dialogar com instrumentos heteróclitos, busca uma ressonância peitoral laríngea, bem como a hiponasalidade e a metalização do timbre. Importante observar que a transformação da extensão da voz feminina no cenário da música popular passa por questões socioculturais bastante emblemáticas que de certa maneira pode levar a novas experimentações vocais em regiões mais próximas da fala. Utilizando regiões mais graves, é possível imprimir uma voz de comando, para ambos os sexos, a depender das tonalidades das canções, e assim o público pode cantar junto os sucessos executados ao vivo ou nas emissoras de rádio. 
Estamos hoje diante de uma androginia vocal cuja audição à primeira vista pode confundir o ouvinte acerca de quem canta, um intérprete ou uma intérprete. Importante observar, particularmente no ambiente do Carnaval, como este fenômeno nas intérpretes femininas imprime timbres e tonalidades mais próximos do masculino, enquanto que os intérpretes masculinos o fazem em tonalidades mais próximas do feminino. Para ilustrar, podemos observar o "jeito" do cantar de Netinho, de Luiz Caldas e de Bell Marques. Entretanto, cabe lembrar que quem imprimiu no Carnaval de Salvador este canto andrógino masculino foi Zé Honório, o então vocalista do bloco Trás os Montes.

Dessa forma, munidos de depoimentos diversos das referidas artistas, podemos afirmar que nestas intérpretes, seja no ambiente do Carnaval, seja fora dele, vibram em suas cordas vocais o comando da "massa", a sensibilidade, a percepção, a mensagem poética, o domínio técnico, o bom senso, a performance, apontando para um conceito mais estreito, bastante discutido, de que a interpretação é indissociável de determinados gêneros mais "calmos", compactuando com o binômio beleza/pureza, mas também apontando para um visão mais ampla, pela qual a intérprete carrega no seu canto historicidade, a identidade do lugar e do povo de onde se canta, bem como a juventude, a beleza, o punch e o dom da estrela.

Para concluir esta seção, tomemos o depoimento de uma intérprete brasileira considerada uma unanimidade nacional: Elis Regina. Em entrevista ao programa Roda Viva na TV Cultura, re-apresentada no programa Metropólis, na mesma emissora, quando do vigésimo quinto aniversário de sua morte (19 de janeiro de 2007), a artista diz que "a função do intérprete é procurar autores". Assim, aproveitamos o depoimento de outra unanimidade nacional - Milton Nascimento-, no mesmo programa, para exprimir o pensamento de um artista compositor em relação à intérprete: "Todas as canções que eu fiz eram para ela cantar".

Voltemos ao nosso ambiente para capturar a fala de dois compositores baianos, Ramon Cruz e Gilson Babilônia, a respeito do 
processo de criação e como tais intérpretes emprestam suas vozes a estas canções.

Ramon Cruz guarda uma forma muito própria de compor:

Geralmente eu falo de amor e mostro pras pessoas que eu gosto e que gostam do trabalho. Daniela, Ivete, Cláudia Leitte são três intérpretes que eu vejo minhas músicas nas vozes delas e é uma forma de divulgar o trabalho também e pela qualidade do trabalho delas. Mas não especificamente prá elas. Mas por coincidência, às vezes casa perfeitamente, como Bola de Sabão, com Cláudia Leitte; com Quando a chuva passar, com Ivete; e com Feijão de Corda, com Daniela. Eu mostrei o refrão pra ela e ela disse: que lindo, faça o resto da música e ficou legal. Mas eu faço sem compromisso, também. (Entrevista à autora em $1^{\circ}$ jan. 2007).

Gilson Babilônia aponta que, ao compor, pensa no povo. "Na alegria do povo. Depois da música pronta é que eu vejo qual a cantora que mais se aproxima daquela música. Me inspiro na vivência, no contato com os artistas e no paraíso que é Salvador". (Entrevista à autora em 9 ago.2005).

Quanto à sensação de ouvir sua música na voz destas intérpretes, o compositor anteriormente citado diz: "Elas transformam em pérola o que canta. E o que elas cantam vira sucesso. É uma emoção muito grande ouvir sua música na voz de cantoras deste porte”.

Ainda para Ramon Cruz,

A sensação é a melhor possível. E melhor ainda é a resposta do público. Vê-las cantando, interpretando e tal, é sensacional. Ver um arranjo legal em cima da composição é também maravilhoso. Agora, ver o público cantando a sua música, aí não tem o que falar. Ver a galera... Essa resposta é o melhor resultado do trabalho. O público gostando.

Assim, podemos observar que estes compositores apontam o reconhecimento do trabalho mediante o retorno dado pelo público, tendo 
como porta-vozes estas intérpretes, que funcionam como divulgadoras destes talentos. Passemos então para a próxima seção, observando a relação destas artistas com os profissionais que proporcionam uma conexão mais próxima com o mercado da música.

\section{As intérpretes e seus músicos, arranjadores e diretores musicais}

A abertura do mercado de trabalho proporcionado pelo mercado da axé music, do Carnaval e dos estúdios de gravação provocou a profissionalização dos músicos em segmentos como arranjadores, diretores musicais, vocalistas, percussionistas, músicos de sopro e compositores. Com o aquecimento do mercado, aumenta a profissionalização, oferecendo-se, assim, uma mão de obra mais especializada. A própria diversidade no âmbito da música profissional provoca este aquecimento de músicos saídos de vários segmentos. Da música (dita) erudita à música popular, o trânsito se torna cada vez maior.

São absorvidos pelo mercado da axé music: profissionais vindos da Escola de Música da UfBA, bem como da Orquestra Sinfônica da UfBA e Orquestra Sinfônica da Bahia - OsBA; artistas premiados pelo Troféu Caymmi; autodidatas que têm sua formação nos bares, tocando jazz e música brasileira, dentre outros gêneros; músicos de países vizinhos, a exemplo da Argentina, que também contribui de forma significativa na forma(ta)ção do gênero: nomes como Ramiro Musotto, percussionista e produtor artístico de vários álbuns de Daniela Mercury; Guimo Migoya, baterista; Nestor Madrid, baixista e sócio de Wesley Rangel; Alejandro Fuentealba, guitarrista; Pedro Giorlandini, guitarrista, são alguns dos músicos argentinos que contribuíram na formatação da axé music.

Podemos perceber, assessorando as intérpretes como diretores musicais os instrumentistas e arranjadores Gerson Silva, Cesário Leoni, Adson Santana e Alexandre Lins, músicos autodidatas, além de Letieres Leite e Radamés Venâncio, estes com uma formação 
acadêmica que exercitam sua criação artística nos CDs e nos shows ao vivo das intérpretes. Podemos nos referir também a instrumentistas de sopro, além de percussionistas e vocalistas que, pela atuação profissional no mercado da axé music, também foram absorvidos em outros segmentos da música, como Leonardo Reis, Gustavo di Dalva e Peu Meurray, percussionistas baianos; os dois primeiros tocaram com Gilberto Gil e o terceiro, com Marisa Monte. Podemos citar também as vocalistas Ângela Lopo, Silvinha Torres e Tita Alves, que cantaram com Luiz Caldas, Ricardo Chaves, Claúdia Leitte e Gilberto Gil. Outros nomes são Roney Scott, Fred Dantas, Joatan Nascimento, que também tocaram com Daniela Mercury e Caetano Veloso, bem como os argentinos Guilhermo Migoya, Ramiro Musotto e Nestor Madrid, (este último sócio por um longo período da WR e diretor musical e baixista de Margareth Menezes), para citar alguns.

Em entrevista à autora, Letieres Leite, criador da Orkestra Rumpilezz, saxofonista e flautista da banda de Ivete Sangalo, além de arranjador e diretor musical de artistas como Daniela Mercury e da própria Ivete Sangalo, ressalta o aspecto mais determinante neste ambiente da axé music:

É a percussão com suas variantes e a sua organização. O que eu quero deixar neste depoimento é que ela é muito organizada, ela é sistemática. Você precisa se debruçar sobre ela para ter o impacto que eu tive como arranjador. Como eu tive que lidar com estes elementos. Eu acho que o cantor tem uma participação secundária, é um erro histórico quando se faz uma reunião com cantores para discutir a história da axé music. [...] Quer dizer, o que determina é o ritmo. Botou o swingue... Se Michael Jackson cantou com o Olodum, então ele é um cantor de axé? Então, tá na composição, vamos ver se tá? Tudo se resume em cinco grandes grupos [...] Ou as claves saem do llê Aiyê; ou vêm do Olodum, ou vêm dos frevos e caboclinhos, que vêm de Recife e dos blocos de trio; dos ijexás, com os filhos de Gandhy; e a última é a Timbalada, que vem da música negra americana, do funk, misturada com os tambores e o hip hop. Com estes cinco, o grande tronco é o candomblé. As claves todas vieram do candomblé. (LEITE, 2005). 
Seu posicionamento refere-se não ao local de onde veio, mas onde está se gerando a música dentro da axé music, de modo que sua crítica se dirige à própria postura do músico em dominar com mais propriedade, e não de forma aleatória à formatação desta música, para que haja um respeito da própria imprensa, da "alta cultura" sobre a importância desta música produzida por negros. O soprista aponta a fragilidade associada à própria etnicidade que esta música carrega, e cita como exemplos o próprio rock e o jazz como gêneros preteridos pela intelligentzia e que se tornaram tão importantes na história da música.

Como sugestão, ele aponta a organização destes artistas "negros" não só como artistas, criadores, mas como aqueles que geram os meios de produção, e aponta como grande empreendedor desta natureza o percussionista, compositor e empresário Carlinhos Brown.

Se tivesse dez Browns na Bahia, talvez a gente tivesse falando de maneira diferente. Ter um Brown que consegue gerar o próprio mercado financeiro... Ele não precisa se associar a alguém que vai gerir a carreira dele e investir no trabalho dele. Então, se todos os grandes cantores negros tivessem essa independência, talvez a gente tivesse falando de uma maneira diferente. De uma Bahia mais cultural, mais criativa. Eu não tenho nada contra empresário, nem produtor, eu não vou criar nada contra essas pessoas. Mas eles estão aqui prá ganhar dinheiro. O cara que quer ganhar dinheiro, ele faz isso como se faz para vender sabão em pó. Isso é uma coisa difícil de conviver. A gente precisa combater isso (LEITE, 2005).

Para Leite, os músicos devem deter os seus meios de produção e assim gerir seu próprio negócio. Neste sentido, Letieres não considera estas intérpretes enquanto músico ${ }^{10}$ que administram suas carreiras. Parece que a relação músicos/intérpretes/empresários soa de maneira conflitante para o instrumentista que não se sente representado por estas profissionais nem artisticamente, nem etnicamente.

Destacamos, ainda, como o profissional contratado como diretor musical e arranjador concebe o seu ofício. Letieres afiança que reuni- 
ões são fundamentais para compreender o conceito artístico do trabalho. Ouvir outros trabalhos do artista, também, para que possa ser influenciado e se sentir "dentro" do trabalho do artista contratante.

Particularmente, com Ivete fica mais fácil. Como eu toco na banda, a gente sabe a reação, como ela gosta e como a música tem que atingir o público dela. Nesse nível, você tem que pensar em tudo... Na questão estética da música, mas tem que pensar também na música ter um resultado. As pessoas terem uma empatia. Então, tem certos truques que a gente aprende com o tempo, que vai dar certo. Não quero dizer com isso que você vai trabalhar na mesmice, na redoma, não é isso. Mas você equilibra seus conceitos criativos com conceitos técnicos e também de como embalar o produto para que chegue ao mercado, ao público, de maneira adequada.

Letieres assinala para o equilíbrio da padronização/individuação sem, no entanto, se eximir da criatividade. É o que Morin (1969) aponta, quando afirma que a divisão do trabalho não se incompatibiliza com a individuação da obra. Entretanto, na mesma obra, Morin assinala também para o fato de a individualidade do autor ser esmagada pela da estrela. Assim, esses "criadores" se sentem por vezes preteridos pela indústria da música, que os contrata pelo talento, sem, no entanto, utilizarem deste artifício para o mercado. Referindo-se à sua contratação por outra estrela, Letieres Leite (2005) afirma, ainda: "Daniela é muito explícita no que ela quer, com ela não tem meio termo. Ela deixa bem claro: 'eu quero assim'. Então, fica fácil trabalhar desse jeito".

Também em entrevista à autora, Gerson Silva, diretor musical de Daniela Mercury e arranjador da intérprete e de outros artistas, a exemplo de Ivete Sangalo e Banda Cor de Mel, declara que o papel do diretor musical e arranjador é conhecer o projeto do artista que contrata seus serviços.

Por exemplo, eu tive uma experiência de fazer a abertura da novela América com Ivete Sangalo cantando, e eu tinha que 
conhecer o roteiro da novela, o diretor, o que eles queriam com a abertura da novela, então, tinha que ser uma abertura mais alegre. E ao mesmo tempo era uma música complicada para mexer, pois um monte de artista regravou, mas a novela falava da coisa latina. Então você tinha que pegar esta informação do tema, proposta da novela, e colocar o trabalho do artista junto. Isto é que é o mais complicado. Pois às vezes você pensa que é bacana para a novela, mas não tem nada a ver com o artista. Eu tive sorte de conseguir fazer isso. Inclusive, Alexandre Pires me convidou para fazer um arranjo para o disco dele depois que ouviu a abertura da novela. Então, o ponto de partida é conhecer o trabalho, o projeto, acho que é por aí (SILVA, 2007).

O instrumentista, arranjador e diretor musical Gerson Silva (2007) fala sobre Daniela Mercury:

Daniela é muito inteligente. Eu achava isto mesmo antes de tocar com ela. É uma inteligência de visão. O que acontece é pegar como ferramenta de conceito, o llê Aiyê, por exemplo, é uma coisa de uma artista extremamente inteligente. A clave, o ritmo, a dança, o que surgiu a partir do Ilê Aiyê. O que antigamente já vem do candomblé. Então, você descobrir que aquela manifestação rítmica só existia aqui foi uma grande sacada. $\mathrm{E}$ aí, você vê que a carreira de Daniela foi se desenvolvendo em cima do bloco afro, das características do Ilê, seja na dança, na música, na poética. O Ilê tem aquela coisa maravilhosa que é o orgulho de ser negro, você defender sua raça. Então, eu acho muito importante, e Daniela sacou isso. Se você for pegar arranjadores mais experientes. Com o próprio ritmo do llê você faz rock, funk, jazz, tudo. É só você ficar atento à questão rítmica, da clave, então, pra mim a inteligência dela vem daí, somando com tudo o que ela viveu com música e com a dança, que também é importante pra caramba. Mas, esta questão do llê é uma referência.

Quanto ao mercado da música, Gerson aponta que é "bastante democrático, onde tem a formação dos músicos de tendências diferentes 
como jazz, rock, MPB, samba" o que enriquece a sonoridade desta música; afirma ainda que o conhecimento musical não se limita unicamente à "academia, mas de tudo. De estilo, de tendência, de técnica, timbragem, porque isso é que dá a característica do mercado".

Assim como Letieres, Gerson Silva critica o caminho que o mercado da axé music sugere e cita como exemplo a criatividade de Brown.

O mercado é uma coisa complicada, porque, se você for observar do lado administrativo, a indústria do axé se desenvolveu muito. Eles às vezes compram um formato de trabalho achando que só aquilo vai chegar ao público, e não é verdade. Tanto não é verdade que Brown é todo dia uma em cima da outra. Tanto com Marisa Monte, (que escreve sua carreira antes e depois do Brown), Brown com Enrique Iglesias, dentre outros, provando que você não tem que ter medo de arriscar e colocar suas idéias. Acho que falta isso, pra não ficar tudo padronizado. A indústria que assimilou isso é que quer ganhar dinheiro com isso. E ganha (SILVA, 2007).

O pianista e diretor musical de Ivete Sangalo, Radamés Venâncio comenta sobre sua atuação na banda da estrela.

Ivete é uma pessoa muito fácil prá se trabalhar, porque ela é uma intérprete. Quando ela quer um trabalho dela, a gente entende muito bem o que ela quer e se torna fácil fazer os arranjos. Quando a gente está fazendo um arranjo de uma música, ela diz o que ela quer, o que ela pensa e fica fácil, porque ela sempre demonstra o que ela quer em forma de arranjo, de percussão dentro da música.(VENÂNCIO, 2005).

Assim, Radamés afere a Ivete o rótulo de intérprete, algo não muito usual no mundo dos músicos. Estes, em sua grande maioria, responsabilizam as intérpretes/cantoras pela falta de reconhecimento do trabalho destes artistas no mercado da música, não percebendo, porém, que os empresários, bem como as majors, os utilizam como força de trabalho para alicerçar a carreira da intérprete/cantor. 
Por outro lado, estes mesmos músicos/instrumentistas parecem não possuir/perceber o poder de administrar uma carreira solo, ou mesmo enquanto arranjador, diretor musical etc. Os que conseguem são normalmente criticados pelos seus pares, que os taxam de mercenários e oportunistas.

A própria categoria não se sente representada nem pelas intérpretes, nem pelos músicos empreendedores que conseguem um espaço no mercado seja como empresário (com escolas, fazendo arranjos de encomenda etc), seja fazendo parte de bandas de artistas de sucesso.

O cenário musical do Carnaval de Salvador, com seus representantes, se apresenta de forma bastante heterogênea no que se refere aos objetivos da categoria. Os blocos afro não se sentem representados pelos músicos que atuam nos blocos de trio, que não se sentem representados pelas intérpretes que puxam os respectivos blocos, que em sua grande maioria não têm autonomia para "escolher" repertório e profissionais cujas afinidades possam contribuir para o enriquecimento do trabalho criativo da música.

Pode-se observar, também, que muitos músicos se tornaram empresários e abandonam suas respectivas carreiras no palco para gerenciar blocos e artistas, de maneira a competir no mercado de forma mais profissional; é o caso de Jonga Cunha e Alexandre Lins. Podemos também apontar outros músicos que conseguem conciliar o fazer musical com o empresarial, enquanto sócios da Academia de Música da Bahia - AMBAH; nesta categoria, encontram-se Letieres Leite e Gerson Silva, bem como o percussionista argentino Ramiro Mussotto, que, além de produzir outros artistas, desenvolve seu trabalho solo como instrumentista e compositor.

Passemos então a analisar empresários e produtores na carreira destas intérpretes. Daniela Mercury, Ivete Sangalo e Margareth Menezes administram suas respectivas carreiras através de suas produtoras, representadas por seus empresários e produtores contratados ou em sociedade com cada um deles. 


\section{Empresários e produtores culturais: os intermediários da cultura}

A função do produtor no ambiente da cultura de forma geral, e na música de forma particular, tem grande importância como intermediador, negociador entre artistas, financiadores, mídia e público consumidor. Este profissional se configura no ambiente cultural como de suma importância para o bom funcionamento do mercado. Sendo uma profissão ainda recente no mercado, mas com um grande crescimento a partir dos anos setenta, transforma-se por vezes em descobridor de talentos, na medida em que o interesse crescente das iniciativas privadas em vislumbrar a arte como negócio busca parceiros que possam dialogar de forma semelhante neste ambiente das práticas artísticas.

Para se obter patrocínio no ambiente da cultura, preparo e estratégias de ação na interação com as diversas áreas das empresas patrocinadoras, os produtores são peças chave. Crescem cada vez, em número e em proporções, as empresas especializadas no setor de eventos, assessoria de imprensa, produção de espetáculos, captação de recursos, propaganda, elaboração e produção de projetos e eventos para atender à demanda do mercado, seja pela quantidade de artistas que aparecem de forma cada vez mais veloz no mercado, seja por algum gênero que estoura nas FMs, provocando uma corrida de todo o sistema cultural que se mobiliza no sentido de dar conta destes fenômenos.

A axé music, de forma geral, e o Carnaval da Bahia, de forma particular, se configuram num ambiente bastante rico de informações no que diz respeito à atuação dos produtores culturais. Primeiramente, é importante destacar a posição de Mollard (1994) apud Nussbaumer (2000), no sentido dos diálogos possíveis entre os agentes/jogadores deste ambiente do sistema cultural. Assim, o produtor/empresário ${ }^{11}$ se constitui normalmente em sócio do artista ou vice e versa. O artista como sócio de empresário/produtor. Este foi o caso de Daniela Mercury em início de carreira solo, que, ao lado de Jorginho Sampaio, 
gerenciava sua carreira ficando com um montante de 50\% de tudo que se produzia.

Sócio da Banda Eva, Jorginho é uma figura bastante emblemática no ambiente do mercado da música baiana. Convidado por Daniela para empresariar sua carreira ainda enquanto integrante da Companhia Clic, produz os dois álbuns do grupo e acompanha Daniela na saída para a carreira solo em 1990. Sua função na produtora era redigir contratos, vender shows, traçar estratégias de ação com relação à carreira e buscar parcerias em voos mais altos, como o show do vão do MASP, que propiciou a alavancada nacional da carreira da artista, em parceria com Poladian - empresário carioca que agenciou nomes da música brasileira como Paulo Ricardo, RPM, Jorge Benjor e outros. Poladian se configurava num agente - vendedor de shows que contava com estrutura de palco, iluminação, sonorização e uma equipe de produtores executivos e assessoria de imprensa, dentre outros serviços para a realização de grandes eventos. O empresário/ agente propulsionou a careira da intérprete ajudando-a a "invadir" o Brasil ao oferecer para a Rede Globo o especial exibido em 8 de dezembro de 1992, ficando com a artista até 1994, quando lançou seu terceiro álbum solo, Música de Rua. (ver AneXo A).

Foi a própria Daniela quem o convidou para gerenciar sua carreira. Todas as estratégias e passos no sentido de alcançar êxito/sucesso eram discutidos entre ambos. Segundo a intérprete, a preocupação maior de Jorginho Sampaio, mais do que gerenciar uma carreira artística, era otimizar lucros. A intérprete, para baratear custos e conseguir realizar no palco o que pretendia, coreografava seus trabalhos e confeccionava os figurinos com a sogra, arranjando assim soluções baratas e criativas para viabilizar seus projetos artísticos. No que se refere ao repertório, o empresário tinha uma preocupação maior com o Carnaval do que com os shows enquanto espetáculo cênico, trazendo o feedback dos programadores de rádio no que se refere à vontade do público.

Assim, havia certa divergência entre empresário e intérprete no que concerne aos objetivos e gerenciamento de uma carreira artística. 
"Mas ele acatava o que eu queria", pontua a intérprete. "Se no barzinho eu cantava o que eu queria... Nunca me vendi por dinheiro. Eu tinha a dimensão de minha auto-estima e o respeito com o que fazia e faço". (Entrevista a SILVA (2006), gentilmente cedida à autora). "Eu sou a patroa do meu empresário. Mas eles também são meus parceiros", continua Daniela.

Jorginho Sampaio se configura em Salvador, pelo menos até o final da década de 9o, em empresário bem sucedido no mercado da música e do Carnaval, gerenciando não somente a carreira de Daniela Mercury, como também de Ivete Sangalo, Simone Moreno, Araketu, Banda Eva (também como sócio do bloco) e outros.

Depois de Jorginho Sampaio, Daniela é gerenciada pelo então marido Zalter Póvoas, fundando em 1993 a sua produtora Canto da Cidade, ficando o gerenciamento com o empresário Luiz Laborda durante oito meses. Com a saída de Laborda, Cacau Blaicker, Cacilda Póvoas e Nely (que havia trabalhado com o empresário carioca Poladian) assumem o gerenciamento de sua carreira, que tinha como política empresarial dialogar, traçar estratégias de carreira e "invadir" o Brasil. Com a saída de Nely e Cacilda Póvoas, Cacau continuou. Saindo Cacau, Nely volta e assume junto com Conceição/Cony Lopes. Com a saída de Zalter, entra a irmã de Daniela, Kitty Mercury, permanecendo à frente, ao lado de Conceição/Cony. A primeira se transfere para o Rio, o que dificulta o gerenciamento, e culminou com a sua saída. Durante um curto período, Kitty permanece à frente da carreira da irmã, até pedir o desligamento, pois seria mãe em breve, assumindo o cargo o seu marido, Clínio, que por sua vez trabalhou com a artista até junho de 2006. Kitty volta depois do nascimento do filho, mas assume de forma diferente a carreira da irmã, ficando à frente Clínio, que gerencia sua carreira nacional e o seu bloco Crocodilo. Na Europa e América, Daniela é representada pela sua agente internacional - Letícia, que a empresaria e vende shows pela Europa e EUA.

Clínio Bastos atesta a respeito do papel do empresário na carreira do artista/intérprete. 
Eu não gosto de dizer que eu sou um empresário artístico, porque não me envolvo nas questões artísticas, principalmente com uma artista que tem uma formação tão densa como Daniela, que sabe muito bem o que quer e como quer fazer a sua música. Então, eu me coloco mais como um instrumento pra pegar a musicalidade dela e fazer com que esta arte seja até comercializada. [...] A minha função é efetivamente de um executivo que, obviamente, por ter um envolvimento com arte, como um marchand, requer uma sensibilidade para estar atento. Às vezes, você não é necessariamente sensível à música, você pode ser um ignorante musical e um excelente empresário artístico, mas você tem que entender as nuanças e as sensibilidades. Isto é que é mais importante, até mesmo para que você sobreviva executivamente. (BASTOS, 2005).

Neste sentido, Clínio se coloca como marchand, não no sentido concebido ao termo no universo das Artes Plásticas, de introduzir um artista em um círculo de clientela de sua intimidade, bem como de buscar novos clientes para aquisição de suas obra, fazendo-o assim circular num ambiente propício ao seu reconhecimento e importância enquanto artista. Há traços de similitudes entre estes profissionais. Ambos, enquanto intermediários culturais, cujo papel maior é fomentar a carreira do artista no sentido administrativo, além de fazer crescer o público potencial, buscam ampliar o raio de ação do artista para que o consumo do seu produto seja cada vez maior e mais valorizado no mercado.

Retomemos ao depoimento de Clínio, no sentido de compreender o artista como um produto; entretanto, um produto artístico que difere, portanto, de outros...

Porque eles são emoção, eles são arte, são pessoas. Então, como eu, por exemplo, que tenho uma formação administrativa... Eu fui administrador, trabalhei 22 anos no comércio de varejo. [...] Então, nós trabalhávamos com saco de feijão, lata de salsicha, peixe, etc. Comprávamos produtos nem sempre perecíveis, 
mas que não têm uma opinião. Então, há uma diferença muito grande. Feijão não reclama da prateleira que está. $O$ artista, ele percebe que você não o colocou no lugar ideal. [...]. A minha função é colocar ela no local em que esteja nas condições ideais. E obviamente, sempre ficar atento ao que ela pensa e o que quer da carreira dela.

Assim, a função do empresário/produtor é atuar como intermediário entre os artistas e outros agentes do mercado da música, no sentido de viabilizar condições adequadas procurando atender suas exigências. Por outro lado, o empresário funciona como um termômetro no sentido de relatar a realidade do mercado.

Às vezes, é diferente o que o empresário quer e o que o artista quer. Então, a gente interfere passando um cenário do que está acontecendo no mercado quando a gente está comercializando show, disco, para que o artista também tenha uma pessoa que tenha a função pragmática. Porque, infelizmente, a gente não vive de arte, a gente vive de bussiness, e isto é um negócio. Daniela deixa de ser em algum momento um produto cultural, vamos dizer assim, e se transforma em produto de consumo. Pra que esse produto de consumo gere recursos. Para que ela faça a arte dela da melhor forma possível. Pelo menos é assim que funciona na história da cultura no mundo inteiro (BASTOS, 2005).

Este termômetro auxilia a manter o artista em seu voo criativo sem, no entanto, perder o foco do que se quer atingir em termos mercadológicos. Continua Clínio:

Então, eu acho que o equilíbrio entre o empresário e o artista é que, se em algum momento os dois voarem, a base poderá ter problemas. Eu acho que eu me preocupo com o bussiness, porque sei que tenho uma artista que tem preocupações artísticas. Ela tira de letra no direcionamento artístico e qualitativo que ela quer fazer e como ela vai fazer, efetivamente. 
Com este depoimento podemos perceber que profissionais deste porte têm a clareza do seu papel no mercado da música, funcionando como grandes intermediários/termômetros com os artistas, buscando assim somar esforços no sentido de perpetuar um negócio que cresce de forma cada vez mais organizada. Para Silva, pesquisadora do perfil artístico de Daniela:

Atualmente [2007], Daniela é dona de uma empresa chamada Canto da Cidade Produções, localizada na cidade do Salvador, que sedia, além de seu escritório no Brasil, uma editora de música (Páginas do Mar) e um estúdio de ensaio/gravação. A empresa trabalha com uma equipe reduzida, composta por: empresário, assessor do empresário, financeiro, uma pessoa responsável pelos fãs clubes, uma gerente da editora, uma pessoa responsável pelas pautas em programas de rádio e televisão, um técnico de estúdio, produção, duas recepcionistas (que se revezam em dois turnos de trabalho), um motorista, um office boy e serviços gerais.

Os músicos que acompanham Daniela Mercury, apesar de não estarem cotidianamente na empresa, também compõem o quadro de profissionais que acompanham a artista e fazem uso da estrutura física da empresa, principalmente do estúdio. Há, também, os serviços que são terceirizados como a assessoria de comunicação, trabalhos de cenografia, publicidade, serviços jurídicos e contabilidade.

Eventualmente, são contratados outros profissionais para projetos específicos. (SILVA,2006,p.48).

Vejamos agora a estratégia de Margareth Menezes, que por sua vez, torna-se sócia de duas amigas para, juntas, alavancar sua carreira com o bloco de Carnaval Os Mascarados, criado em 2000, retornando assim à cena do Carnaval e, consequentemente, ao mercado da música de forma mais competitiva. Atentemos à maneira como se comporta a intérprete-estrela no gerenciamento de sua carreira.

Diferentemente de Daniela e Ivete, Margareth "invade" a cena da chamada "música baiana" ao largo do Carnaval, dialogando com 
o teatro, cantando em bares noturnos e como crooner da orquestra do Maestro Vivaldo Conceição no Circo Troca de Segredos. Durante um período, foi produzida pelo sócios Dalmo Perez e Lu Barreto. No entanto, foi através do empresário Daniel Rodrigues (empresário de Gilberto Gil durante um período) que foi apresentada a David Byrne, abrindo sua turnê internacional antes mesmo de ser conhecida nacionalmente.

Com uma carreira bastante irregular em termos de gerenciamento, prejudicando assim seu reconhecimento em nível nacional, a intérprete fica sem gravadora durante sete anos, só voltando a gravar de forma independente em 2000, quando ressurge no cenário musical de forma mais visível pelas mãos do Carnaval, quando da comemoração dos 500 anos do descobrimento do Brasil - tema do Carnaval daquele ano, que a conduz de maneira criativa para este ambiente, já com o embrião do bloco Os Mascarados, que viria a se consolidar no ano seguinte.

A partir deste momento, a carreira e a visibilidade da artista tomam um novo rumo. Margareth é assessorada por mais duas sócias, que abrem a produtora Central de Produção e que têm como produtos a editora Estrela do Mar, os blocos Os Mascarados e o movimento e bloco Afropopbrasileiro, além de sua carreira solo. Conferimos o depoimento da empresária da intérprete, Jaqueline Azevedo, a respeito do papel deste profissional na carreira da artista. "O empresário é aquele que planeja e executa as estratégias da carreira do artista, respeitando, é claro, as tendências e as peculiaridades dele". (Entrevista à autora em 10 set. 2006).

Quanto aos produtos relacionados anteriormente, que a Central de Produção administra, a empresária afirma que:

A Central só trabalha com produtos que, além da festa e da alegria, tenham conteúdo cultural. Temos o bloco Os Mascarados, único bloco à fantasia da cidade, que busca e vem conseguindo o resgate da fantasia e das alegorias do Carnaval; temos o movimento Afropopbrasileiro, que visa a integração dos principais 
grupos afros da cidade: Ilê Aiyê, Muzenza, Filhos de Gandhy, Cortejo Afro, Olodum e Malê Debalê; além de projetos encaminhados às leis de incentivos Rouanet e Fazcultura, de ações sócio-culturais durante o ano corrente.

Quanto à equipe que forma a produtora, Jaqueline Azevedo diz: "Faz parte da nossa filosofia de trabalho manter uma estrutura pequena, terceirizando profissionais por cada evento" e a equipe que acompanha Margareth em viagens nacionais e internacionais, a empresária declara que "depende da formação do show, somos bastante flexíveis nas nossas negociações".

Para a pesquisadora, torna-se difícil, por vezes, mapear efetivamente os custos operacionais para manter e administrar uma carreira artística, visto que algumas informações de caráter econômico são omitidas, tais como valor de cachê, valor de captação de recursos, dentre outros itens importantes para se compreender efetivamente como funciona a máquina administrativa/econômica destas artistas/ empresárias.

Por outro lado, Margareth, ao mesmo tempo em que se vale de um produto padronizado (bloco de Carnaval) para ocupar a cena do Carnaval, se diferencia da própria cena ao retomar de forma criativa o uso da fantasia no Carnaval, permitindo assim o exercício da criatividade aos associados do bloco, que escolhem o que vestir, sendo identificados por uma pulseira, de forma diferente, portanto, dos abadás padronizados exibidos pelos associados dos outros blocos.

Buscando conquistar mais espaço neste ambiente competitivo, a intérprete cria o movimento Afropopbrasileiro em 2005, no sentido de fortalecer as entidades e blocos afro da cidade, respeitando suas respectivas singularidades. Com ensaios itinerantes, normalmente nas quadras dos respectivos blocos ou em espaços que possa agregar estes ensaios, ela se apresentou ao lado dos vocalistas da banda anfitriã da noite. Por exemplo, em janeiro de 2007, na Praça Tereza Batista, no Centro Histórico, ao lado dos vocalistas das bandas Olodum, Malê de Balê, Muzenza, Cortejo Afro, Ilê Aiyê e Filhos de Gandhy. 
Com vários produtos tais como o selo Estrela do Mar, possui dois blocos promovendo as festas d'Os Mascarados, e os bailes que leva para o Brasil inteiro. Exemplo disto são os espetáculos na casa noturna Canecão, no Rio de Janeiro, que em 2005/2006 promoveu ensaios com a artista. Em sua quarta edição, o ensaio d'Os Mascarados no Rio de Janeiro ocupou as terças-feiras de janeiro de 2007 no Circo Voador, com participações especiais de vários artistas como Zélia Duncan e Tony Garrido, dentre outros. Então, como gerenciar uma carreira solo?

Em depoimento à autora, em relação à sua carreira como empresária, pontua Margareth:

Não sou eu só. Tenho uma equipe, que são pessoas valiosas pra mim. Minha empresária, Jacqueline Azevedo, está comigo há mais de treze anos. E nesse processo a gente vem amadurecendo, eu não me sentia muito à vontade na questão do mercado aqui na Bahia, muito fechado. Então, eu não me sentia inserida em algumas coisas e acabei nesse tempo criando a minha panela. Aí eu consegui amadurecendo, vendo o que é que a gente pode melhorar, eu acho que é uma questão de maturidade. Todo mundo percebe que existe coisa boa prá gente fazer, que a gente tem um filão interessante, que ninguém dominava, e o que é que precisa. Vamos amadurecer isso, para ficar cada vez melhor. Hoje eu tenho uma equipe maravilhosa, profissionais de primeira linha e me sinto super bem. Hoje eu me sinto muito mais madura, porque o meu processo é muito do dia-a-dia mesmo. Eu tenho minha equipe: Jacqueline, Rita Martins, tem o selo Estrela do Mar, lançamos dois produtos, mais tarde eu pretendo movimentar melhor o selo, temos o bloco Os Mascarados, o Afropopbrasileiro e a Central de Produção, que é que me representa. (MENEZES, 2005).

Quanto à inserção da artista no mercado, continua Margareth:

Às vezes o mercado significa o quê? Por onde a gente pontua ele? Porque têm coisas que estão acontecendo no Norte e Nordeste lá em cima e que a gente aqui não sabe nem o que 
está acontecendo. Vender por exemplo 300 mil cópias lá. Ou no Rio Grande do Sul que o cara vai lá e vende 100, 200 mil cópias. Então, o mercado é muito relativo. Ainda mais em relação a uma questão mais nacional. Existem poucas oportunidades de você divulgar o seu trabalho nacionalmente e é restrito a poucos artistas também. Se se consegue cair nas graças dessa ciranda... A gente vê constantemente que durante anos e anos são os mesmos artistas, os mesmos programas, as mesmas performances. Na verdade a gente percebe que existe ali um certo domínio e eu acho que a única forma do artista que faz o circuito, uma performance mais independente, é ele perceber que o Brasil funciona por regiões. Por exemplo, no meu trabalho a gente começou a entender isso. Então vamos aí. Na região Norte e Nordeste, foi o primeiro filão maior em relação ao meu trabalho. Depois começamos a ir pro Norte fazer divulgação para as rádios, e isso, ao longo desse tempo, foi dando resultado. Hoje a gente tem um trabalho, posso dizer nacional, onde a gente faz show no Rio de Janeiro, bota 30 mil pessoas. Em São Paulo a gente tá começando a conquistar um mercado, mas a gente começa com um nome já na memória das pessoas. Minas Gerais. Então, a gente não tem que ter assim assombro com esse glamour todo que a gente vê na televisão. Porque, na verdade, ali favorece a uma fatia pelo menos para mim, relativamente pequena. Vamos ver. São 180 milhões de brasileiros. Por que o mercado nacional, de grandes destaques nacionais escolhe 20 artistas para maximizar a situação e estes tantos outros cento e tantos milhões de brasileiros consomem o quê?

O depoimento um pouco extenso serve para ilustrar em linhas gerais como uma artista que busca gerenciar e administrar sua carreira tem que compreender a lógica, a dinâmica do mercado e do público que se pretende atingir, buscando para isto um diferencial que possa atrair uma determinada fatia do mercado, e com isso, oferecer seu produto de forma diferenciada.

O gerenciamento da carreira de Ivete Sangalo acontece de forma diferenciada. Em início de carreira, Ivete Sangalo, assim como Daniela 
Mercury, também foi produzida/empresariada pela produtora Perto da Selva, de Jorginho Sampaio. Ivete iniciou sua carreira ainda como solista, cantando em bares e boites, onde foi reconhecida e premiada pelo Troféu Caymmi, e produzida por Jonga Cunha. Este a conduz para o posto de vocalista da Banda Eva, atingindo estrondoso sucesso durante os anos em que permaneceu à frente do bloco/banda, até 1999, quando decide alçar voo solo. Seus irmãos, Jesus e Ricardo Sangalo, assumem então o gerenciamento de sua carreira através da produtora Caco de Telha, de sua propriedade, que ao longo de dez anos de existência, completados em 2005, amplia seu raio de ação como Caco de Telha Entretenimento.

Enquanto vocalista da banda Eva, Ivete recebia um cachê diferenciado dos outros integrantes da banda - em média três mil reais por apresentação -, até alçar o voo num show solo para a imprensa e fãs na área verde do Bahia Othon Palace, em 1999. Em entrevista a Cleidiana Ramos ao Jornal A Tarde, seu depoimento enquanto empresária revela:

Minha experiência como empresária é muito mais lúdica. $\mathrm{Na}$ verdade, eu sou uma mentora intelectual. Vou dando as coordenadas em termos de filosofia de trabalho, dentro da minha empresa, que é a conduta, a que me proponho. Mas as ideias no âmbito empresarial, de fechar negócio, de fechar contrato com gravadora, abrir produtora, comprar blocos, essas coisas vêm dos meus irmãos, que partindo dos meus princípios, da minha filosofia de trabalho, desenvolveram isso muito bem Agora, a minha negativa é importante pra eles. Se eu disser que é não, é não. E se eu disser que sim e eles disserem que não, aí a gente discute pois muito me interessa a opinião deles. Às vezes há coisas que eu não quero realizar, e eles me convencem, ou coisas que eles não querem que eu faça, e eu os convenço. Na verdade, a gente vai batendo uma bolinha (RAMOS, 2002, p.1).

Quanto aos produtos que formam a Caco de Telha: 
A empresa tem o bloco Cerveja e \& Cia. No caso do bloco Os Corujas, fomos contratados por um bom tempo, quase oito anos, o que não deixa de ser uma sociedade. Tenho que trabaIhar a favor desse bloco, que não é da nossa propriedade, mas a gente tem percentual, tem uma série de regalias, de coisas boas que vão me estimulando a divulgar o bloco, a tratar dele com mais carinho. Temos a produtora Caco de Telha, que, além dos meus shows, produz os de outras pessoas a exemplo de Sandy e Júnior, Jorge Aragão e tantos outros. A gente acabou de promover o Carnaval de Juazeiro, levando artistas que não estavam ligados a blocos. A gente vai batendo essa bola, fazendo a ponte de determinados artistas.

A notícia acima, veiculada há cinco anos, já não reflete a realidade atual da empresa fundada em 1996 com o objetivo de desenvolver e administrar a carreira solo da estrela/intérprete. Em 2007, a Caco de Telha possuía variados selos como a Caco discos, Caco produtora, Caco eventos, Caco formatura, Axé mix, Novas promoções, Caco eventos corporativos e Bar mix. A assinatura da marca está associada a mais de 500 eventos por ano. Com uma sede em Salvador e outra no bairro de Pinheiros, em São Paulo, consta em sua diretoria a família San galo ${ }^{12}$.

Uma das características mais recorrentes no gerenciamento da carreira de Ivete são os eventos produzidos para uma grande quantidade de público, como o show comemorativo dos dez anos de carreira orçado em $\mathrm{R} \$ 800$ mil, realizado em 19 de dezembro de 2003 no Estádio da Fonte Nova, em Salvador, que gerou o primeiro DVD da artista, lançado em abril de 2004 pela MTV, com vendas que ultrapassaram a marca de 350 mil cópias.Vejamos um registro da imprensa na época do evento.

Ivete Sangalo espera receber cerca de cem mil pessoas no mega show comemorativo que realiza domingo, a partir das $18 \mathrm{hs,}$ no Estádio da Fonte Nova. Há dez anos, quando se revelou para o público baiano no comando da Banda Eva, ter aos pés uma platéia tão numerosa era praticamente impensável, exceto 
no Carnaval, é claro. Mas Ivete está podendo. Com grande carisma, conquistou e vem mantendo uma popularidade capaz de lotar o espaço onde estará recebendo vários convidados para festejar uma década de sucesso e os cinco anos de projeto Sua Nota é um Show. Nos dias atuais, nenhum outro artista surgido na cena da axé music terias uma audiência dessa dimensão.

A "brodagem" de Ivete Sangalo também se reflete na relação com os artistas. Todos os que foram chamados para participar da festa têm uma relação muito afetuosa com a cantora "Eles são muito importantes na minha vida". [...] "No convívio profissional, é importante contar com pessoas amigas, que tenham energia boa, troquem opiniões e façam a gente se sentir a vontade. Ivete é uma delas", elogia Margareth Menezes.

Duetos - chuvas de fogos de artifícios e três telões gigantes situados em pontos estratégicos da Fonte Nova são recursos que demonstram o porte do investimento da festa, orçada em torno de $\mathrm{R} \$ 800$ mil.

Mas de mil seguranças foram contratados para atuar na área interna do estádio, além de efetivos das polícias civil e militar. O diretor musical do show, Alexandre Lins, adianta que Ivete fará a abertura, e em seguida, receberá os artistas. "Ela cantará músicas em dueto com os convidados e cada um fará seu número solo", acrescenta.

“Daniela é uma referência de profissionalismo, além de ter me dado o maior apoio quando fui fazer carreira solo. Já Margareth me confia todos os seus segredos, sem falar que tem um vozeirão", enaltece Ivete Sangalo.

Em clima de revisão de carreira, ela preparou um repertório de hits, incluindo sucessos da fase Banda Eva (como Arerê, Alô paixão, Levada Louca e Beleza Rara) e os mais recentes da carreira solo (o atual carro chefe Sorte Grande, a romântica Se eu não te amasse tanto assim e a indispensável Festa. O show da Fonte Nova atende a um antigo desejo da cantora (e torcedora do vitória), de se apresentar em um espaço de grandes dimensões. (UZEL; MARTINS, 2003, p. 4). 
Três anos depois, a artista/empresária mais bem sucedida da música pop brasileira da atualidade (segundo a revista Rolling Stone. dez. 2006, p. 60) repete o mesmo êxito de forma ainda mais grandiosa ao gravar em 16 de dezembro de 2006, no Estádio do Maracanã, no Rio de Janeiro, um especial para o canal Multishow (afiliado à TV Globo), que resultou num DVD e num CD com lançamento em março (CD) e abril (DVD) de 2007. Segundo dados da revista Rolling Stone:

A estrutura do show é gigante e envolve uma equipe de 350 pessoas, palco de 19,8 metros de comprimento por 17,6 de profundidade e um telão LCD de 15X6 metros, o maior já usado no Brasil $O$ público esperado, 80 mil pessoas. O custo do evento: $R \$ 2$ milhões. (CUNHA; SCHIRILÓ, 2006, p. 70).

Ivete, a primeira mulher brasileira a se apresentar no grande estádio carioca, segundo dados do Jornal A Tarde de 18 de dezembro de 2006, leva 55 mil pessoas num show que contou com as participações especiais do vocalista do grupo Skank, Samuel Rosa, de Buchecha, Durval Lelys e do cantor espanhol Alessandro Sanzs, com a duração de mais de três horas, devido à queda de energia que esfriou um pouco os ânimos da plateia. No Carnaval 2009 Ivete Sangalo foi a cantora que mais apareceu nas transmissões de TV, segundo informação colhida no Navii Informação Inteligente.

Assim, ao longo de suas carreiras, cada uma das três intérpretes foi alçando voos solo, de forma a assumir o seu negócio como "dona", criando blocos, produtoras, para que pudessem gerenciar mais de perto o seu produto artístico. Enfim, tornaram-se artistas/empresárias, não só gerenciando suas carreiras individuais, mas outros grupos e outros negócios não necessariamente situados no ambiente da música.

Neste sentido, estes produtores/empresários contratados para gerenciar as respectivas carreiras destas artistas/empresárias tornam-se parceiros, mas não sócios (a não ser no caso específico de Margareth), ou seja, estes profissionais se configuram em intermediários do artista com o patrocinador, de forma que os interesses do primeiro 
sejam também o seu próprio interesse. Entretanto, é importante ressaltar que o diálogo entre os produtores e patrocinadores se processa de forma comercial e contratual. Isto pode coincidir com uma boa amizade, mas não se identifica necessariamente com relações afetivas de proximidade e intimidade.

\section{As donas do canto}

O artista, enquanto dono do seu próprio negócio na história da música popular brasileira, não é um fenômeno recente e muito menos localizado. Podemos apontar como uma das precursoras deste empreendimento a compositora e pianista Chiquinha Gonzaga, que já no século XIX ousava vender suas composições e partituras para o teatro de revista e se torna uma lutadora feroz pelos direitos autorais de sua própria obra, sendo neste período uma das criadoras de uma associação para defender os direitos do artista, a Sociedade Brasileira dos Autores Teatrais - SBAT. Aponta-se também, a visão empreendedora de Araci Cortes, que, numa atitude pioneira, monta uma Companhia de Revista na década de trinta, associada ao diretor artístico Luís Iglesias e ao compositor Freire Junior.

Araci empresária foi, por isso mesmo, um capítulo importante no tempo, como exemplo de empresa sólida, duradoura e bem conduzida, além, é claro, além de bafejada pelo interesse popular, já que Araci há muito se constituíra em sólido argumento de êxito de uma revista, ainda mais que o tino do grupo fazia com que se cercasse de outros consagrados valores da cena revisteira [...] Araci não só lançou muitos compositores; na função de empresária, ao lado de dois autores, Iglesias e Freire, não deixou de dar ensejo a que novos valores surgissem também nesse campo, obstinando-se em obter sempre algo de novo na rotina de seu trabalho (RUIZ, 1984, p. 181). 
Este exemplo nos serve para ilustrar que a indústria do entretenimento e o mercado da cultura não se encontram unicamente vinculados aos meios de comunicação de massa, tais como o rádio e a televisão. Podemos ilustrar a partitura e um de seus reprodutores, o piano, como uma das origens da "música de massa".

Patrice Flichy aponta a importância deste instrumento musical nos lares de classe média, no final do século passado, na sociedade européia. O piano não estava destinado apenas à execução de música clássica, e as edições de partituras indicavam uma grande variedade de canções populares, já segmentadas em vários estilos (religiosos, patrióticos, baladas sentimentais, canções cômicas) e com tiragens numerosas. (DIAS, 2000, p. 33).

Obviamente, a crescente mercantilização da cultura, também impulsionada pela indústria do entretenimento fomentada por estes veículos, provoca uma nova lógica numa sociedade contemporânea em que o processo de produção, viabilização, divulgação e consumo exigem artistas que saibam lidar com esta lógica de forma a competir no mercado "num jogo de poder no qual é necessário que cada um dos atores sociais envolvidos esteja consciente do seu papel e de sua posição neste campo" (NUSSBAUMER, 2000, p.86).

Continuemos, pois, a pontuar outros exemplos em períodos distintos do processo de autonomização da produção artística na contemporaneidade. Tomemos como exemplo alguns artistas que, ao longo de suas respectivas carreiras, assumem o timão do seu fazer artístico, de forma a manter uma autonomia não só do próprio fazer, como também das relações que se estabelecem com outros agentes que contribuem para a circulação e consumo deste produto artístico; bem como a própria mudança que se opera na organização e produção da indústria fonográfica que a partir dos anos setenta toma um novo rumo, impulsionada também pela "mundialização da cultura" (ORTIZ, 1994).

Citemos como exemplo desta transformação a intérprete Maria Bethânia, uma das pioneiras a produzir os seus próprios álbuns, escolhendo desde o repertório até o arranjador e músicos do disco; Ivan 
Lins, que, ao lado do seu parceiro Vitor Martins cria a gravadora Velas, lançando desde seus próprios álbuns solo ao de artistas como Rosa Passos, dentre outros.

Entretanto, na década de 1990, outro modelo de autonomização se faz presente, se considerarmos que alguns artistas detêm o direito de seus respectivos fonogramas, como é o caso de Marisa Monte e Daniela Mercury, que podem dispor destes produtos e disponibilizar por determinado período a gravadoras para comercialização. Motta (2007) pontua que "Marisa só faz o que quer, quando quer e com quem quer. É dona de sua gravadora e de todos os masters de seus discos, de sua editora, tem controle absoluto da carreira" (apud CORREA; PAGANINI, 2007, p. 81).

Assim, podemos observar que, por mais que a lógica da indústria cultural tenda a homogeneizar e padronizar determinados modelos de negociação entre o artista e seu produto, existem formas de se driblar a imposição do mercado, ou ainda, aliar-se a ele de forma a se tornarem "artistas executivos" (NUSSBAUMER, 2000, p. 87).

Podemos conferir como se processa a organização destas artistas executivas no ambiente do Carnaval de Salvador e seus respectivos staffs. Normalmente, cada artista, com sua empresa, faz circular em média 40 a 50 profissionais em seu staff. Em viagem a Portugal, em 2005, Ivete Sangalo levou em sua equipe 50 pessoas, somando técnicos de som, de luz, músicos, dançarinos e produtores, dentre outros.

No Carnaval de 2003 a equipe de apoio de Daniela Mercury contava com 27 pessoas que se desdobravam em sua equipe pessoal, fornecedores, imprensa, transporte aéreo e local, make up, artistas convidados, músicos, dançarinos e camarote. Além do camarote, o espólio de Daniela conta com sua produtora Canto da Cidade, equipada com um estúdio onde produz seus álbuns e ensaia; a editora Páginas do Mar; o bloco Crocodilo, de sua propriedade, administrado pela Central do Carnaval; além de sua carreira nacional e internacional, esta gerenciada, como já mencionado, pela produtora norteamericana Letícia.

O seu camarote, situado próximo ao Farol da Barra, na Avenida Oceânica, em funcionamento desde 1995, é organizado anualmente 
pela promoter Lícia Fábio e sua sócia Nil Pereira, cuja parceria com patrocinadores culminou com o lançamento de um livro-álbum ${ }^{13}$ contando a história dos dez anos de seu funcionamento. O camarote de Daniela é um desdobramento de sua atuação no Carnaval, necessitando de uma equipe específica para fazê-lo funcionar de forma plena nos cinco dias de folia. Lícia e sua equipe, composta em média por cinquenta pessoas entre produtores executivos, designers, músicos do camarote, garçons, lista de convidados, empresa que confecciona as camisetas, dentre outros itens, se constitui numa estrutura à parte, porém subjacente à empresa Canto da Cidade.

A cada ano, com temas diferentes, o "Camarote da Rainha"14 se torna uma referência, além de signo de distinção (BOURDIEU, 1991) para quem circula em seus cinco dias de funcionamento com as camisetas padronizadas. Artistas, personalidades, políticos e amigos da estrela circulam no ambiente cujo acesso é restrito a convidados, que podem desfrutar de cardápio diversificado, que a cada dia é oferecido por um restaurante "badalado" da cidade, bem como bebidas e drinques que vão de cerveja (que patrocina cotas para o funcionamento do espaço), uísque a champanhe, além de distribuição de brindes e souvenires, e podem também desfrutar de música ao vivo, bem como boite com música eletrônica e lounges para o descanso dos convidados, entre uma e outra passagem de bloco.

Lícia Fábio, administradora do camarote, destaca:

Hoje, estamos na décima edição desse espaço, que se tornou um case de sucesso no maior Carnaval do mundo. Nele, presenciei espetáculos e emoções. E são tantas emoções... Encontros memoráveis da fina flor da música popular brasileira. Cantores sertanejos, da MPB, da música baiana, do segmento pop/rock, todos dividindo o microfone com a artista. (MERCURY, 2005, p. 8).

A ambientação do camarote com temas ${ }^{15}$ que mudam a cada ano, estando sempre à frente deste empreendimento o artista plástico João Pereira, o arquiteto Luiz Humberto Carvalho, os hostess Graça e Paulo Borges. 
Numa estrutura que a cada ano se vê mais sofisticada, o camarote conta com banheiros climatizados, sala de massagem, maquiagem, e até uma pequena sala de cinema como em 2006, que exibia durante todo o tempo cenas de filmes nacionais de diferentes épocas. A partir de 2008 Daniela firma parceria com a revista Contigo, e amplia a recepção e visibilidade das celebridades que por lá circulam. Em 2009 o camarote recebeu a intelectual norteamericana Camille Paglia, que, encantada com a performance da artista, afirma ser Daniela a diva que Madonna gostaria de ser.

Quanto aos patrocinadores para fazer funcionar a "Casa da rainha", a equipe conta com o patrocínio desde a primeira edição do Shopping Iguatemi, além de outras empresas que vão se revezando ao longo dos anos de funcionamento como Credicard, Renault, Cerveja Brahma, Primus, telefonia Vivo e Tim.

Para ilustrar a importância do camarote na carreira de Daniela, capturamos o testemunho da estrela a respeito deste espaço.

O camarote é como a minha casa. Para acolher, para abraçar, cheio de prazer, amizade e música, com vista para o mar. É aqui que eu quero morar, no Carnaval da Bahia, onde toda a alegria é possível, onde tudo é permitido, onde tristeza não há. Onde o Brasil olha para o próprio umbigo e perde-se a se admirar. [...] O camarote é um presente para minha cidade, um espaço que nasceu para divulgar o Carnaval, tornou-se uma referência e inspirou uma mudança na estética e na organização da festa. (MERCURY, 2005 p.7).

Neste sentido, a estrela mais uma vez prenuncia o que efetivamente acontece no espaço do Carnaval de Salvador, que a partir de 2000 de forma cada vez mais acelerada ocupa novos espaços formado por camarotes que se destinam a oferecer conforto e comodidade a um sem número de foliões que se interessam cada vez menos pelo espaço da rua e se deleitam em assistir ao desfile de blocos recheado de estrelas, embalados não só pelas suas vozes, mas pela melhor bebida, comida, paquera, a preços ao gosto do freguês. 
Quanto ao camarote de Ivete Sangalo que passa a ocupar a Casa d'Itália em 2005, e em 2006 ocupa tanto a Avenida Sete quanto o circuito Barra-Ondina, não se constitui num espaço para se receber convidados, mas um estabelecimento comercial cujo objetivo único é obter lucro. Diferente, portanto, do Camarote da Rainha.

Já Margareth recebe seus convidados nos ensaios que promove a cada ano em espaços diferentes, tornando-se anfitriã no palco, mas não dispõe de um espaço no Carnaval que receba seus convidados. Por outro lado, a concentração do bloco Os Mascarados, que antes se situava no estacionamento do Mar Azul Hotel, na Barra, e a partir de 2005 passou a funcionar na Associação Atlética da Bahia, vem se constituindo como um local onde acontece concurso de fantasias e encontros de amigos e associados que saem em cortejo puxados por uma banda de sopros, que arrasta os foliões até o encontro do trio, onde a estrela puxará o bloco.

Neste sentido, Daniela pode ser considerada a pioneira no gerenciamento de sua carreira solo, quando resolve assumir o controle do seu produto, separando-se do seu então sócio Jorginho Sampaio.

O mesmo acontece com Ivete Sangalo quando se lança na carreira solo em 1999, ao sair da banda Eva, tendo como parceiros seus irmãos e criando a produtora Caco de Telha para gerenciar sua carreira e seus respectivos produtos. Estima-se que os produtos de Ivete tenham lucrado, em 2006, 40 milhões de reais, tornando-a assim uma das artistas mais ricas do Brasil, constando no seu espólio particular dois aviões, inúmeros imóveis, criação de gado e carros importados, trio elétrico - Demolidor3 -, que custou a artista no Carnaval 2009 a quantia de $\mathrm{R} \$ 2,5$ milhões, além de blocos. Isto sem considerar os shows vendidos no Brasil, na Europa e nos Estados Unidos, carnaval temporão e micaretas.

Importante considerar outros fatores que também levam ao sucesso empresarial, como o próprio mercado do Carnaval, que se profissionaliza cada vez mais, se tornando um negócio lucrativo tanto para os empresários quanto para as instituições do âmbito municipal e estadual, que capitalizam em benefício próprio o sucesso da axé 
music e do Carnaval de Salvador. O próprio momento do mercado da axé music é um fator importante a ser considerado, bem como a autonomia cada vez maior de alguns artistas com relação à indústria fonográfica.

Assim, a fragmentação da indústria fonográfica também provocada pela mundialização da cultura e a cada nova tecnologia percebe cada vez mais que a saída para as vendas é digital. ${ }^{16}$ Só em 2006, a queda de vendas de discos chegou a 25,5\% ultrapassando a marca de 2005. Mesmo assim, as multinacionais obtiveram lucro. No entanto,

[...] a venda de música digital cresceu 100\%, num total de 2 bilhões de dólares, segundo a Federação Internacional da Indústria Fonográfica (AIFPI)... A previsão é que, em 2010, a música digital represente $25 \%$ do mercado mundial de música. Segundo a AIFPI, em 2006, foram 795 milhões de downloads legais, $89 \%$ a mais que 2005. (MATOS, 2007, p. 4)

Margareth, que passou sete anos de sua carreira sem gravadora, retoma a relação com a gravadora EMI, assinando contrato em 2005 com o álbum Pra você, com duras críticas por parte da imprensa quanto à proposta estética do álbum como pode ser conferido na matéria de Eduardo Bastos no jornal A Tarde:

Embora Margareth Menezes afirme que teve independência para trabalhar, Pra você é indisfarçavelmente um disco moldado por gravadora. Há a intenção óbvia de pegar o diamante bruto que é Margareth Menezes e transformá-la numa cantora de maior popularidade. Em consequência tem-se uma artista quase irreconhecível. [...] A ousadia de misturar batidas tribais com sons eletrônicos, uma das marcas de seu autodenominado estilo afropopbrasileiro, deu lugar à melosidade efiêmica de canções como Versos de amor, Contra o tempo (esta de Vander Lee), Mesmo assim e Só eu e mais ninguém cantada como o co-autor Cláudio Zoli.

[...] No mais, Pra você é disco em tom menor, meloso, feito para consumo em larga escala. (BASTOS, 2005, p.1) 
Vejamos a opinião de Margareth, em entrevista à autora, a respeito desta relação com a gravadora.

Isso vai depender do artista, né? Do grau de maturidade do artista, e da questão da confiança também. Por exemplo, no meu caso, a gravadora veio atrás de mim. Eu passei 7 anos sem gravar, eu tenho 17 anos de carreira, então gravei cinco CDs, fiquei 7 anos sem gravar, depois abri um selo, lancei 2 $\mathrm{CDs}$, por este selo. A gente conseguiu vender mais com meu selo independente do que quando estava em gravadora. Aí eu recebi um convite, sério, de uma gravadora como a EMI, o presidente veio até aqui em Salvador conversar comigo e fez uma proposta muito legal. Então, eu tenho autonomia. O CD está com as músicas que eu selecionei; a gravadora me trouxe duas sugestões que eu achei ótima que foi a música que eu gravei com Ivete e a que eu gravei com Cláudio Zoli, talvez a música mais diferente do $C D$, que é um pop soul. E eu gostei de ter essas músicas no $C D$. Mas o resto do repertório foi opção minha. Fiz uma seleção de 30, depois a gente ouviu junto aí compomos essa parceria. (MENEZES, 2005).

Se a gravadora proporciona ao artista uma estrutura que possa veicular sua música de forma massificada nas rádios, isto não significa, porém, atestar a venda significativa de CDs. A intérprete aponta a relação das gravadoras com as rádios:

Hoje em dia, as coisas estão um pouco conturbadas com essa questão da música na rádio. Tudo funciona movido a muito petróleo. É verdade, isso é uma realidade, a gente não vai ficar se iludindo com isso não. Eu já estive no mercado independente de música, tenho um selo, sei como é que funciona. Também existe essa possibilidade, você chegar com uma música massa, como Dandalunda, ou Toté de Maianga e o cara na rádio não tem como barrar aquilo. Então, é a força da música também que chama. Agora, se você tem uma gravadora que investe na rádio, ajuda o trabalho. Porque um artista independente não consegue dominar uma rádio, essas grandes rádios ele não 
consegue dominar. É uma área mais difícil. A gravadora grande é boa para você tocar na grande rádio.

Quanto à trajetória de Daniela Mercury perante as gravadoras, foram muitas as negociações ao longo de sua carreira. A artista grava o seu primeiro álbum solo por uma gravadora nacional pequena - a Eldorado -, que já tinha gravado seus dois álbuns ainda como vocalista da Companhia Clic. Com o primeiro álbum solo, que alcançou venda estrondosa, a gravadora não tem condições de sustentar o prestígio alcançado pela artista, que passa para a Sony Music, ficando na multinacional até o álbum gravado ao vivo, Elétrica, quando migra para a $B M G$, com quem produziu alguns álbuns, além da Som Livre e da EMI como distribuidoras dos produtos CD e DVD.

O sonho da artista - deter os direitos de todos os fonogramas dos seus álbuns já gravados - se concretiza em 2005, podendo assim negociar diretamente com cada gravadora que queira reeditar ou relançar cada um deles com contrato por tempo determinado; ou ainda, negociar novos produtos. Silva (2006) sobre esta conquista, afirma:

No caso de Daniela Mercury, mais recentemente, em menos de um ano ela lançou três produtos distintos e com qualidades reconhecidas pelos principais críticos e conhecedores do assunto.

Em agosto de 2005 foram lançados, pela gravadora Som Livre, o CD e o DVD Clássica, com gravações de grandes canções da música popular, que rendeu à cantora elogios de grandes especialistas da área.

Em novembro deste mesmo ano foi lançado, pela gravadora EMI, seu CD de carreira - Balé Mulato -, que, desde a capa (com fotos do prestigiado Mário Cravo Neto) ao conteúdo, demonstra toda a preocupação estética e conceitual da artista. O resultado é que a obra está sendo muito bem recebida pela crítica especializada.

Para finalizar, no mês de fevereiro de 2006, foi lançado, também pela EMI, o DVD Baile Barroco, todo gravado em cima 
do trio elétrico (feito inédito no Brasil), durante o carnaval de 2005 que comemorou os 20 anos da axé music. Neste DVD, pode ser conferida a festa do carnaval de Salvador (que entrou para o Guiness Book como a maior festa popular do mundo), como se você estivesse ao lado da cantora, como um convidado especial (SILVA, 2006, p.40).

Ao longo de suas carreiras, cada uma foi alçando voos solo, de forma a assumir o seu negócio como "donas", criando blocos e produtoras para que pudessem gerenciar mais de perto o seu produto artístico. Tornaram-se artistas-empresárias, não só gerenciando suas carreiras individuais, mas outros grupos e outros negócios fora do ambiente da música.

Nesta seção, tratamos do estágio de profissionalismo atingido pela indústria da música baiana e seus respectivos profissionais, que buscam, no aperfeiçoamento deste know how, sua sobrevivência e perpetuação, em constante diálogo com patrocinadores, mídia e público.

\section{Os patrocinadores}

Para compreender o processo de produção do sucesso no âmbito musical, pode ser interessante traçar um panorama da geração de riqueza e mercado de trabalho que tem na produção cultural sua matriz, numa coexistência cujos benefícios sociais e econômicos podem ser traduzidos não só numa melhor qualidade de vida para os indivíduos diretamente ligados à atividade, como para a própria cidade que passa a arrecadar mais tributos com o aumento do fluxo turístico, bem como do poder aquisitivo da população.

O Carnaval de Salvador desemboca sua sonoridade para uma parte do mundo, atraindo "olhares" nesta "espetacularização identitária", possibilitando assim, realização de business, tendo a música como principal produto; por outro lado, aponta para um abismo social cada vez maior na geração de renda da maioria da população, que se vale 
do mercado não oficial de trabalho, impulsionado também pela proliferação de ensaios e festas que de alguma forma estão relacionadas ao Carnaval. Aumenta consideravelmente, neste período, o índice de prostituição e exploração de menores, bem como de doenças sexualmente transmissíveis, estimulado pelo aumento do fluxo de turistas.

Num mercado altamente competitivo, associar o seu produto à cultura pode se tornar um diferencial na solução de estratégias para a conquista de público consumidor. Neste sentido, o marketing cultural se torna um instrumento de comunicação na busca de uma identidade que favoreça o diálogo das empresas junto ao seu público.

Por um lado, o investimento em cultura não significa um retorno financeiro para a empresa. Entretanto, associar o seu produto à cultura torna-se cada vez mais um negócio lucrativo para ambas as partes: o Estado revela que, em 1997, a participação da cultura em ações de comunicação e marketing atinge 53\% das preferências das empresas pesquisadas, em detrimento de outras áreas de investimento como científica, educacional, esportiva, meio ambiente, saúde e turismo, dentre outras, tornando-se o marketing cultural o meio mais procurado pelas empresas para investimento em busca do mercado consumidor (MigueZ OLIVEIRA, 2002, p. 215).

Segundo Cândido Mendes Almeida (1994)

[...] a atividade cultural configura-se dentro de duas representações básicas: o produto e o evento. O produto cultural é um múltiplo. A partir de uma matriz, ele se multiplica em tiragens predeterminadas por intermédio de canais de distribuições. Múltiplos culturais são os livros, discos, vídeos ou reproduções artísticas. Os produtos se distinguem pela sua tangibilidade e por se destinarem, quase sempre, a um consumo individualizado. [...] O evento, em contrapartida, é essencialmente volátil, concluindo o seu ciclo ao final de cada apresentação. Dirigido a grupos de pessoas que podem variar de uma audiência restrita de um recital de poesia ao público presente a um mega show de rock, o evento permite impacto simultâneo da comunicação em ambos os casos. O evento cumpre seu ciclo com certa ve- 
locidade: de uma apresentação única a uma temporada de um ano, a transitoriedade é a sua marca principal (p. 31-32).

O mesmo autor diz: "a combinação correta entre evento ou produto e ação institucional ou de vendas é fundamental para o sucesso da estratégia de marketing cultural. A vantagem do evento em permitir a atuação concentrada em um volume de pessoas contrapõe-se à desvantagem do seu alcance local" (p.33). Entretanto, isto depende da própria estratégia traçada pelo patrocinador. Como exemplo podemos citar a aparição da top model Gisele Bundchen no camarote de Daniela com patrocínio da Credicard, em 2004. Gisele Bundchen, com a camiseta com a logomarca da empresa no trio de Daniela, provoca uma veiculação formidável em canais de TVs, revistas, jornais e outros periódicos de grande circulação.

Neste sentido, o Carnaval se constitui num dos espaços de maior disputa de patrocinadores que antes se limitavam a patrocinar - particularmente as cervejarias - camarotes institucionais, como os da Prefeitura. Atualmente, vêem-se cada vez mais outros anunciantes, a exemplo de empresas de telefonia celular, shopping centers e empresas de eletrodomésticos, dentre outros. O trio elétrico tornou-se um anunciador ambulante de produtos não só artístico-musicais, mas, principalmente, de produtos que vão de tintura de cabelo a cartão de crédito, tendo como modelo as estrelas, sua imagem e o seu corpo.

Por outro lado, esta possibilidade deve-se também às leis de incentivo à cultura em nível estadual e federal, que possibilitam deduções em impostos, além da estratégia do empresariado no sentido de associar seu produto a artistas que estão em evidência, associando assim a marca de sua empresa como apoiador e incentivador da arte e proporcionando-lhe retorno institucional. Assim, uma cidade que tem como cartão de visita a alegria para receber turistas e promover festa pode cooptar para si os olhares de empresários que vêem no Carnaval o seu stand e suas representantes - no caso desta pesquisa, as intérpretes - para servir de garotas- propaganda na difusão e venda do seu produto. 
Assim, a "fabricação" da estrela no cenário da axé music se constitui não apenas como sujeito, mas também como objeto da publicidade, podendo multiplicar a utilidade ou funcionalidade desta estrela de diversas formas. Seja Ivete Sangalo apresentando shampoos e tintura de cabelo da Garnier, usando a sandália da Grendene, com o celular da Vivo, ou ainda tomando cerveja Schin; seja Daniela Mercury tomando cerveja Antarctica com Ray Charles ou ainda fazendo compras no Shopping Iguatemi com o Cartão Credicard, ou do Trio elétrico Paes Mendonça; seja ainda a mesma intérprete como embaixadora da UNICEF ou fazendo campanha para as Obras Sociais de Irmã Dulce.

Tudo o que a intérprete-estrela produz pode ser lançado no mercado, não só no âmbito da música, mas em todas as suas variantes. Morin afirma que "A multiplicação da sua imagem, ao invés de alterá-la, a torna ainda mais desejável" (1989, p. 76). Mantendo sua originalidade mesmo quando é partilhada, configura-se como um produto específico da contemporaneidade. Assim, pode ser considerada uma síntese de estrela-deusa e estrela-mercadoria.

Este tino comercial que percebemos em alguns artistas baianos para gerenciar sua própria carreira, tornando-se empresárias e produtoras, ampliando, portanto, seu raio de ação com os Carnavais fora de época e se consolida como uma expansão deste mercado. Já se contabilizam 40 Carnavais extemporâneos pelo Brasil, dentre eles o Micarande, em Campina Grande (primeira cidade a aplicar este modelo), Carnatal (Natal), Fortal (Fortaleza), Carnabelô (Belo Horizonte), Micarecandango (Brasília) e muitos outros mais, reunindo dezenas de milhares de pessoas, possibilitando um novo nicho no mercado da cultura e assim, uma maior negociação com patrocinadores que se aproximam deste diálogo.

O artista também pode se tornar um patrocinador em potencial, produzindo outros artistas e eventos que capitalizam para si dividendos e lucros cada vez mais vultosos e menos revelados. Observa-se também que este mercado torna-se cada vez mais rentável, ampliando e modificando cada vez mais os circuitos de shows que chegam a reunir até 5 bandas numa noite em espaços que se ampliam para receber um número cada vez maior de público. 
Por outro lado, se a posição que estes artistas passam a ocupar no showbiz se torna cada vez mais rentável e concorrente, torna-se necessário associar o produto à lógica da indústria cultural na difusão e divulgação destes produtos.

\section{A mídia}

Tomamos por mídia, neste estudo, o conglomerado formado pelas emissoras de televisão (aberta e fechada) e rádio, bem como jornais e revistas que, de forma crescente, impõem a lógica da indústria cultural na produção e divulgação da cultura. Nesta perspectiva, a sede do poder comunicacional corresponderia ao seu suporte empresarial, que tem estado quase sempre concentrado em conglomerados como a Rede Globo, o SBT, BAND, Record e MTV, operando respectivamente no Rio de Janeiro e em São Paulo, passando as emissoras locais a simples receptoras ou retransmissoras, sem qualquer possibilidade de autonomia e interferência na programação, a não ser no noticiário e em poucos programas exibidos em horários de pouca audiência.

Este panorama, no entanto, não se apresentava da mesma forma em tempos mais remotos. Nos primeiros anos de funcionamento da TV Itapoan, o cast de funcionários, técnicos e artistas que por lá se apresentavam em programas passaram a uma dinâmica local, como recorda Rubim para ser "incorporada por uma lógica de indústria cultural, estranha e exterior à sociedade baiana" (2000, apud MIGUEZ OLIVEIRA, 2002, p. 237).

Por outro lado, a lentidão com que se deu a implantação de outro canal de Televisão além da TV Itapoan, em atividade a partir de 1960, se verifica no fato de que apenas em 1969 se estabeleceu a competição, com a entrada no ar da TV Aratu. Esta última incorporou sua programação à grade da Rede Globo e da TV Bandeirantes em 1974, tornando-se transmissora do canal homônimo.

Assim, Rubim (2000, apud MIGUEZ OLIVEIRA, 2002) aponta que a insipiência da mídia baiana corria por conta 
de sua inscrição em uma sociedade com forte desigualdade e exclusão sociais, vinda de uma recente paralisia econômica, com uma tênue industrialização e uma população majoritariamente rural, e uma modernização circunscrita espacialmente, em um Estado que comportava ainda muitas dimensões arcaicas (p.237).

Outro elemento relevante deste jogo do sistema cultural se processa pela influência da mídia na difusão e divulgação do produto artístico e seus desdobramentos. Estamos na "era da mídia" e, para tanto, o artista e qualquer celebridade só se torna visível pelo poder que a mídia tem de promover o sucesso. Para o artista, além do espaço, é importante o reconhecimento e a aceitação do seu trabalho pela crítica "especializada".

Em Salvador, o fenômeno axé music provocou por parte da imprensa "especializada", uma rejeição e campanha combatida à exaustão pelos cadernos de cultura dos principais jornais de maior circulação que tinham em "críticos", como Hagamenon Brito, atacante feroz do Carnaval e da axé music. Diz ele a Ceci Alves, do jornal A Tarde:

A axé music hoje não existe. Entre 97 e 99, até 2000 - que foi o seu auge -, o estilo chegou a representar, como segmento, $13 \%$ do mercado de venda de discos no Brasil. Hoje - e há quatro anos tem sido assim -, ele representa $1 \%$ das vendas, só empatando com a música erudita. Então, a realidade é que a axé como segmento, não tem mais representatividade.

[...] Hoje em dia não se vê renovação, não se tem mais artistas em vários escalões, que fazem shows. A axé não tem mais aquela força, nem no rádio baiano. Se ainda tivesse, não teria nem surgido o arrocha, que é apenas uma onda que veio na tentativa de ocupar o espaço vazio do axé music. (ALVES, 2004, p.1)

No entanto, pode-se ler o nome do jornalista e crítico Hagamenon Brito circulando em press releases de artistas como Margareth Menezes, no CD gravado ao vivo em 2004. Destacamos trecho do seu comentário: 
A era 2000 tem feito muito bem à cantora. Ela se reconciliou com o que tem de melhor - forte performance de palco, com atitude e sensualidade, e uma musicalidade afro-pop que não dispensa o samba e o ijexá. Intérprete potente e intuitiva, Margareth honra a tradição de vozes negras femininas da MPB (Clementina de Jesus, Carmen Costa, Elza Soares, Sandra de Sá, etc).

Como vemos, Hagamenon se reconcilia com "esta música", usufruindo agora da própria hostilidade que ele imprimiu quando segundo algumas fontes, rotula de forma pejorativa esta música como axé music. Podemos conferir mais um de seus comentários, agora elogiosos, sobre Daniela Mercury, no livro sobre os dez anos do camarote da artista:

[...] Dez anos de camarote. Vinte e cinco anos do primeiro álbum (ainda como vocalista da Companhia Clic), milhões de discos vendidos em todo o mundo. Elogios da crítica de toda a parte. Respeito entre os colegas e os profissionais do show bizz. Emoção e técnica, sentimento e disciplina. Tudo isso é Daniela Mercury, a tradução mais pop do Carnaval de Salvador. Os próximos passos? O futuro a Deus pertence, mas, em Entrevista à Isto é Gente, a cantora foi sábia ao analisar o Carnaval baiano atual. [Espero que ele continue absorvendo a diversidade, porque a cidade precisa de turismo, entretenimento e que isso gere muito emprego. Acho uma maravilha que a Bahia esteja explorando isso de uma forma mais profissional. Para sair no trio eletrônico, eu precisei de patrocinadores. Para fazer o camarote e convidar pessoas para irem lá, eu precisei de patrocinadores. Agora, eu não quero que o dinheiro, a ganância - o que não está acontecendo - sejam mais fortes que a espontaneidade da festa] (MERCURY, 2005, p. 93).

Como podemos notar, o poder da mídia e de seus representantes é tão determinante que o artista vê-se obrigado a dialogar com profissionais que se deixam seduzir pelos privilégios, que por vezes pode obter pela posição ocupada por eles em determinados veículos de comunicação. Trava-se, assim, um jogo de interesses entre os artistas 
e estes profissionais que chegam a trocar a redação para montar sua própria empresa de assessoria. Outros mantêm o seu posto e mesmo assim montam o seu próprio negócio e passam a usufruir deste espaço divulgando seus "produtos" artísticos, em detrimento de outros artistas que não têm assessoria nem guardam proximidades com o setor.

É sabido que foi de fundamental importância o rádio e seus respectivos programadores e radialistas na difusão desta música produzida na Bahia. Nomes como Cristóvão Rodrigues e Manolo Pousada, da Itapoan FM; Josenel, da Piatã FM; André Simões, da 104 A Tarde FM; Baby Santiago, da Itaparica FM; e Nailton Lantier, da Aratu FM, dentre outros, contribuíram de forma determinante na difusão desta música e seus respectivos artistas. É sabido que muitos deles se tornaram sócios de várias bandas e blocos. Uma prática comum é o jabá ${ }^{17}$ na divulgação dessas músicas por parte de alguns programadores e respectivos veículos. Este procedimento também se estendeu para o caderno de domingo do Jornal A Tarde - Lazer e Informação, já fora de circulação.

As emissoras locais de televisão também tiveram um papel determinante na difusão das imagens destes artistas pelos lares baianos. A pioneira mais uma vez foi a TV Itapoan. Sua programação aos sábados que lotava o auditório apresentando ídolos como Luiz Caldas, Sarajane, Banda Mel, Banda Reflexu's, Virgílio, Laurinha, Banda Cheiro de Amor, Margareth Menezes e Rey Zulú, dentre outros, sob a direção de Carlos Borges, que imprimia "uma cara da música da Bahia" que, por sua vez, chegava a inúmeros municípios baianos, estimulando assim o trânsito destes artistas por estes lugares. A TV Aratu também participava desta difusão com um programa num formato semelhante ao da TV Itapoan, porém com uma audiência um pouco menor.

A importância deste espaço na mídia, bem como o respaldo da crítica na divulgação da carreira do artista, é de fundamental importância para que este possa circular o seu produto e vender sua performance. Atentemos para o depoimento de uma repórter da TV Bahia, acerca do papel da mídia na carreira do artista. 
Não dá pra negar, né? Mas a gente ouviu muito artista quando está no topo dizer que não precisa da imprensa baiana pra nada. A imprensa é a imprensa, e a mídia é a mídia. A propaganda é a alma do negócio, né? Sem propaganda, sem divulgação, ninguém é nada. E nisso, eu acho que é incontestável o poder da mídia na divulgação daquilo que o artista está fazendo. Daniela, por exemplo, é uma artista que tá no mundo todo, mas alguém precisa saber, precisa noticiar. Então, todo o valor de Daniela a gente já conhece através da mídia. E ela sabe dar valor a mídia. Acho que a mídia é da maior importância, até porque eu faço parte da mídia. (ANA VALÉRIA, 2003).

A opinião de Ivete acerca do papel da mídia na carreira da intérprete/artista, em entrevista à autora, é:

Eu acho que é importantíssimo. Acho que é humanamente impossível você não revelar boas intérpretes a nível nacional. Das duas uma: ou a intérprete procura a mídia, ou a mídia procura a intérprete. $\mathrm{O}$ sucesso não está diretamente ligado a multidões. Mas se ela quiser levar a música dela para o grande público, ela vai ter que participar dessa mídia, que eu acho que é maravilhosa, imprescindível do ponto de vista geral, assim, lato sensu. A gente tem que pensar dessa maneira, porque são parcerias, não são pessoas [...] não é um movimento que vem para deteriorar, é pra perpetuar, pra registrar e divulgar. (SANGALO, 2005).

Para Margareth, também em entrevista à autora:

Eu acho que vai depender muito de como o artista dirige, como ele se comporta em relação à mídia. Eu acho que tem aquela mídia mais vampiresca, né? Que limita sua performance artística, a sua intimidade e tem também a mídia que realmente prestigia, que realmente quer mostrar um trabalho mais profundo. Eu acho que a gente tem que ter um jogo de cintura para caminhar no meio dessas duas diferenças de mídia. (MENEZES, 2005) 
Márcia Short, por sua vez, declarou à autora, em entrevista:

A mídia para mim é aquela velha história, que o dinheiro só vai prá quem tem dinheiro. Se você tem o dinheiro, você tem a mídia, se você não tem dinheiro, você tem amizade. Eu, por exemplo, não posso falar mal da mídia porque sou uma pessoa muito ajudada, graças a Deus, muito querida, e que tudo que eu faço os meus amigos noticiam. Mas isso não acontece com a maioria. Existem grandes feitos na Bahia, em Salvador, que ninguém sabe, que a mídia fica limitada a assessores de imprensa com a bunda numa cadeira de couro, recebendo um bom salário por mês pra divulgar as mesmas pessoas entra ano e sai ano, e o povo não fica sabendo das novidades... O povo tá de saco cheio, então está forçando a se apresentarem coisas novas, mais ainda, toda a estrutura de sucesso tem o seu adjacente, tem aquele onde ele aponta como bom e a mídia continua com a bunda sentada na cadeira de couro recebendo aquele salário pra divulgar as mesmas coisas. (SHORT, 2005)

Daniela afirma numa entrevista a Fabiana Silva, cedida à autora, que:

Não existem profissionais da mídia que tenham competência específica para cuidar da imagem do artista. Já estive a procura de publicitários que de certa forma trabalham de forma semelhante com políticos. Entretanto, o artista não ganha o suficiente para sustentar um profissional deste porte. Eu já levei assessores de imprensa para fora do país [...] Os meios de comunicação brasileira só dão retorno quando você paga para alguém sair do Brasil. Como eu tenho meus critérios éticos e sai muito caro levar vários correspondentes destes veículos, e eu, preocupada com o respeito da liberdade de imprensa. Este é um problema da ética do mercado bem como da pobreza dos jornais que não tem recursos para enviar estes correspondentes. [...] Falta à imprensa informação, acesso à informação. É um trabalho de reflexão do conhecimento do Brasil. Os repórteres fora do país que vêm falar comigo são formados em música, 
são cosmopolitas, a grande maioria tem conhecimento de onde estou inserida na música popular brasileira. (MERCURY, 2006)

Daniela aponta que o nível de informação da mídia acerca de sua carreira fora do Brasil se deve também ao fato da penetração que a música brasileira vem alcançando em outras sociedades. Este fenômeno pode ser creditado também ao desenvolvimento de novas tecnologias que desempenham um papel importante na difusão, circulação e consumo destes produtos proporcionados pela globalização da comunicação que fazem circular, através de cabos e satélites, bens simbólicos e informações de maneira cada vez mais veloz.

Assim, os meios de comunicação podem ser considerados novas formas de ação e interação com o mundo social entre os indivíduos e consigo próprio. Neste sentido,

[...] de um modo fundamental o uso dos meios de comunicação transforma a organização espacial e temporal da vida social, criando novas formas de ação e interação, e novas maneiras de exercer o poder, que não está mais ligado ao compartilhamento local comum (THOMPSON, 1998, p. 14).

Por outro lado, a visibilidade exposta através da mídia produz efeitos diversos na vida pública do indivíduo/artista. Neste sentido, a imprensa nem sempre serve unicamente para divulgar ou elogiar o trabalho destes artistas, visto que escândalos e gafes também servem para o mesmo fim. Temos como exemplo recente a própria "destruição" de Michael Jackson pela mídia, no que se refere ao escândalo por suposta prática de pedofilia.

A artista Madonna constrói sua imagem perante a mídia "subvertendo os limites do apropriado para mulher. Assim, desde o começo, Madonna foi um dos ícones femininos mais escandalosos do repertório das imagens que circulavam com a sanção da indústria cultural" (KELLNER, 2001, p. 341).. Esta foi a sua opção para atingir o estrelato. Obviamente, outros fatores determinaram esta construção, tais como: excelente dançarina, cantora, modelo, atriz de cinema... . 
Por outro lado, a noção de visibilidade e sua relação com o poder abordada por Thompson (1998), nos servem para tratar deste tema. Daí sua insistência na relevância da interação mediada, como forma distinta e não necessariamente oposta à interação face a face e à interação quase mediada. Em linhas gerais, o papel desempenhado pela mídia nas sociedades contemporâneas acontece como elaboração, criação de novas formas de interação nem sempre de forma a compartilhar locais em comum, mas sim no sentido de reformular a (trans)formação do self e do caráter mutável da sociedade.

Assim, as imagens destas intérpretes veiculadas pela mídia podem servir de modelo na construção de identidades e padrões ou modelos seguidos de diversas maneiras pelos seus fãs/seguidores.

Vejamos então, como se comporta o público diante destas estrelas que desfilam pelas telas e jornais e emitem seus trinados pelas ondas do rádio e no Carnaval. Tomamos como público os jovens e seus pares que consomem a axé music, que fazem parte, em sua grande maioria, dos fãs clubes destas intérpretes.

\section{O público: fãs clubes}

Quem é esta multidão postulada por Adorno e Horkheimer (1985) que, se "servindo" da indústria cultural, alimenta "indivíduos autômatos", incapazes de julgar e decidir conscientemente? Estes teóricos dão conta da teoria da recepção na medida em que usamos o seu contexto de origem na análise deste público. Ao analisar a configuração da cultura na contemporaneidade, outros teóricos traçam um novo perfil deste público consumidor dos produtos culturais que circulam neste ambiente. Vivendo num mundo múltiplo e fragmentado como este, diversos públicos cruzam formas de recepção destes produtos artísticos. No desenvolvimento da pesquisa no âmbito do sucesso, há que se tomar cuidado, pois os indivíduos, em sua totalidade, apresentam características distintas de acordo com transformações sofridas em 
inovações tecnológicas, em movimentos artísticos e outros acontecimentos que provocaram também mudanças na recepção.

Kellner afirma que "a cultura veiculada pela mídia induz os indivíduos a conformar-se à organização vigente da sociedade, mas também lhes oferece recursos que podem fortalecê-los na oposição a essa mesma sociedade" (2001, p. 11-12). Neste sentido, a reflexividade do agente de que fala Giddens (1991) é um instrumento interessante para distinguir que público é este, consumidor das estrelas de axé music.

Morin enuncia sobre a imagem provocada pelas estrelas sobre o público: "A estrela é padrão e é modelo" (1989, p.101). Assim, o padrãomodelo tanto determina a aparência exterior quanto serve de exemplo aos comportamentos da alma, ao mesmo tempo em que a palavra mais apta a traduzir a homogeneização de uma diversidade de conteúdo é o sincretismo. Ainda segundo Morin, para compreender o público que costuma consumir produtos da indústria cultural, tende-se a uma "unificação" entre dois setores da cultura industrial: o que se refere à informação e o setor literário, alimentando assim o duplo movimento do real com o imaginário. "Esse prodigioso e supremo sincretismo se inscrevem na busca do máximo consumo e dão à cultura de massa um de seus caracteres fundamentais" (1969, p. 39).

O cinema, bem como os periódicos e revistas a partir dos anos 30 do século XX, inicialmente nos Estados Unidos e Europa, derramando sua influência para outras fronteiras, tem como objetivo se dirigir a todos. Esta homogeneização temática, etária, social, tende a se fixar na juventude de forma geral e no público feminino de forma particular. Morin afirma que:

Não são apenas os jovens e os adultos jovens os grandes consumidores de jornais, revistas, discos, programas de rádio [...], mas os temas da cultura de massa (inclusive a televisão) são também temas "jovens". Assim, a cultura industrial tende a se desenvolver no plano do mercado mundial de maneira que as barreiras sociais, étnicas, nacionais, culturais, se tornem "universais" tendendo assim ao sincretismo-ecletismo e a homogeneização. (1969, p. 46) 
Neste sentido, podemos denominar este indivíduo da contemporaneidade como um homem imaginário (p.46) cuja identificação ou projeção servem para dar conta de uma linguagem composta de quatro instrumentos: imagem, som musical, palavra e escrita. Linguagem essa mais acessível, mais universal na medida em que a produção cria o público de massa, o público universal, ao mesmo tempo em que é determinada pelo próprio mercado e carrega singularidades, sendo um diálogo desigual entre produção e consumo.

Ao mesmo tempo, o modelo de projeção/identificação dos jovens, que tinha os pais como espelho, cede espaço na contemporaneidade para o ídolo.

O novo modelo é o indivíduo em busca de sua auto-realização, através do amor, do bem estar, da vida privada. É o homem e a mulher que não querem envelhecer, que querem ficar jovens para sempre [...] (MORIN, 1969, p. 158).

Assim, na cultura da mídia, a velhice está desvalorizada. A juventude e a beleza se derramam através das revistas, das telas de cinema, da TV, utilizando os artistas como protótipos a serem seguidos. Acelerados pelas indústrias do rejuvenescimento, há uma democratização da juventude eterna não só entre os jovens, mas entre aqueles que não querem envelhecer.

Por outro lado, o dilema sofrido, particularmente pelas mulheres de meia idade frente à ditadura da cultura da eterna juventude, leva a reflexões de gênero, geração e idade. Sardenberg (2002) convida a pensar o corpo como produto da história e não como algo dado "naturalmente" Neste sentido, a autora pensa o corpo como objeto e produtos de representações e práticas sociais diversas historicamente específicas.

As tecnologias do corpo se aplica a ambos os sexos, porém de forma diferenciada, na medida em que as mulheres, enquanto construção de objeto de desejo, "como é próprio às sociedades contemporâneas ditas ocidentais, resulta em investimentos maiores em seguir os padrões estéticos impostos ao seu sexo" (SARDENBERG, 2002, p.60). 
Neste sentido, o corpo ideal seria bonito, "saudável", aquele que segue os padrões estéticos atuais, os parâmetros do corpo jovem. Assim, as pressões sociais para se perpetuar e manter uma aparência jovem caem de forma muito mais avassaladora sobre as mulheres do que sobre os homens. Isto faz sentido não apenas no campo afetivo (menos capital simbólico no mercado afetivo), como também no campo da profissão. Particularmente àquelas que estão sob a mira do público e da mídia:

São constantemente cobradas no sentido de manter uma aparência jovem, estando expostas a críticas quando se recusam a valer-se de cirurgias plásticas ou de semelhantes tecnologias de modelagem do corpo: Brigitte Bardot, por exemplo. Ao mesmo tempo, ridicularizam-se aquelas que exageram nessa modelagem - como no caso de Dercy Gonçalves, Elza Soares, dentre outras. (p. 65).

Sardenberg (2002) propõe construir narrativas de meia idade, que desconstruam as imagens de envelhecimento como declínio. Neste sentido, a identificação/projeção também se perpetuaria?

O que diríamos do papel dos jovens adolescentes neste panorama?

As identificações imaginárias são fermentos para o mimetismo. Assim, as estrelas podem se tornar padrão modelo que afetam até o problema da personalidade humana que "nasce tanto da imitação quanto da criação” (MORIN, 1989, p.100).

$\mathrm{Na}$ adolescência e no início da juventude, os papéis ainda não estão cristalizados como máscaras endurecidas sobre os rostos. Em busca da autenticidade e integração no ambiente social, procura a "verdadeira vida" de forma intensa no ceticismo e nos fervores que podem ser percebidos através das relações de projeção-identificação entre a cultura de massa.

A cultura de massa tende a integrar os temas dissonantes da adolescência em suas harmonias padronizadas. Tende a instituir um "Olimpo dos menores de vinte anos". [...] A cultura de massa 
arremata a cristalização da nova classe de idade adolescente, fornece-lhe heróis, modelos, panóplias (MORIN, 1969, p. 162).

Assim, cai por terra o modelo da família, da escola, a valorização da velhice como acúmulo de saberes, enquanto assume o proscênio o modelo dos impressos, da TV, do cinema, das estrelas. Por outro lado, os temas identificadores da cultura da mídia como individualismo, amor, felicidade, valores privados, etc, despertam atenção com mais intensidade na juventude.

"Assim, pode-se dizer esquematicamente que esta cultura é criada pela adolescência, mas que ela é produzida pelo sistema. A criação modifica a produção e a produção modifica a criação" (MORIN, 1999, p.140). Morin evidencia que a cultura juvenil se apresenta de maneira ambivalente que ele denomina de ala esquerda e ala direita. A ala esquerda "a destruição supera o consumo, em que está muito perto da violência, das drogas fortes, das denúncias dos valores oficiais, da contestação política", a ala direita (a que particularmente nos interessa neste estudo), "é quase inteiramente integrada e integracionista, com culto das vedetes".

Ninguém melhor para representar estes mimetismos que as estrelas que conduzem diversos atos, gestos, atitudes, comportamentos, sensações, repetidos pelos fãs que se alimentam da imagem exibida nos veículos de comunicação. Além de representar o modelo para fornecer comportamentos e ações miméticas ao público, as estrelas propõem uma nova ética da individualidade - o ócio moderno.

Morin aponta o nascimento da ética do ócio a partir das novas necessidades do século Xx. Esta ética propõe uma "fuga" do trabalho em migalhas, propondo a afirmação da personalidade no sentido de exaltar atividades que façam esquecer o tédio da servidão. Assim, uma persona(lidade)gem como o campeão esportivo, as estrelas, "exprime os ideais da ética do ócio; mas além disso, lhes dá uma saída concreta ao apresentar o fruto mais delicioso, apaixonante e individualista, o mais imediatamente consumível de todos: o amor" (1989, p. 104).

Vejamos adiante, em linhas gerais, como podemos recorrer ao binômio identificação/projeção apontado por Morin (1969; 1989; 
1999), em entrevistas com alguns membros dos fãs clubes de Daniela Mercury.

Podemos perceber identificações práticas ou mimetismos que servem de ferramenta para traçar um perfil deste público. Inicialmente, o "parecer-se" com Daniela não se refere ao aspecto físico, e sim, principalmente, à sua postura profissional diante da carreira e a forma de se comportar no palco com seu canto e coreografias cheias de vigor. Isto sim encanta seus fãs. Todos querem dançar igual a ela. Buscam como espelho "serem profissionais competentes e plugados com o mundo". Isto é o que ela diz quando estão juntos. Daniela está no comando de sua carreira. Em todos os seus passos, percebe-se o domínio com que ela se lança em cada movimento. Assim, estando no comando de tudo, domina a todos que a cercam. Esses mimetismos de associação com o seu público possibilitam um "casamento" publicitário com alguns produtos, tornando esta estrela publicitária. Assim:

A estrela publicitária não é apenas um anjo da guarda que nos garante a excelência de um produto. Ela convida eficazmente a adotar os seus cigarros, a sua pasta de dentes, o seu baton, o seu barbeador favorito, ou seja, a identificarmo-nos parcialmente com ela. Faz com que se vendam combinações, sabonetes, geladeiras, bilhetes de loteria, romances - os quais impregna com sua virtude. É um pouco da alma e do corpo da estrela que o comprador irá apropriar para si, consumir e integrar em sua personalidade (MORIN, 1989, p. 98).

O número de fãs clubes de Daniela, no Brasil, divididos por regiões: na região Norte, apenas um no Pará; na região Nordeste, um total de 32, sendo 18 só na Bahia e sete em Salvador; no Centro-Oeste, o total de sete fãs clubes; no Sul são seis; não constam cadastrados no Sudeste, nem há fãs clubes pelo exterior. Os dados foram extraídos do seu site oficial, com acessos em 2006.

Em maio de 2007 os dados do site se atualizam com fãs clubes espalhados pelo Brasil e pelo mundo: constam no cadastro 11 no Rio de Janeiro, 12 em São Paulo, cinco no Rio Grande do Sul, um em Tocantins e em Manaus, dois no Distrito Federal, 32 na Bahia, 
dentre outros. Entre os países com fãs clubes cadastrados, constam Argentina, Itália, Rússia, Holanda, Inglaterra e Israel, cada um com uma filial com nomes Big Apple e Planeta Mercury; além de três filiais na Espanha e em Portugal, e duas na França.

Com Ivete, torna-se difícil a computação pela forma como a Central de Fãs está colocada no site que serviu de fonte, apesar de se tornar fácil localizar os países, capitais e cidades. Em linhas gerais, foi possível mensurar em Salvador 11 fãs clubes; em Alagoinhas, Santo Amaro, Vitória da Conquista, Ottenstein (cidade da Alemanha) e Lisboa, um; Feira de Santana, Maceió e Belo Horizonte, dois; em Manaus, três. ${ }^{18}$

Em Margareth, no seu site, a Central de Fãs, não disponibiliza para o internauta o contato com os cadastrados.

Coletamos depoimentos de alguns membros ${ }^{19}$ dos fãs clubes de Daniela Mercury da Bahia e do Brasil, no sentido de perceber identificações práticas ou mimetismos que servem de ferramenta para traçar um perfil deste público.

Bianca, do fã clube do Espírito Santo, afirma que a palavra que sintetiza Daniela Mercury é "amor. Porque o amor é tudo junto: é carinho, é amizade, é competição, é tudo junto”. Já Edwin Carvalho, presidente do fã clube Explosão de Alegria - RN, afirma que a palavra que sintetiza Daniela Mercury é: "vida. Eu acho que ela representa isso pros fãs. [...] ela traz uma energia que contagia. [...] o que eu sinto por Daniela, acho que já passou do estágio de fã. É como se ela fizesse parte de minha família [...] É uma coisa de irmão mesmo".

A transferência de sentimento que um fã tem pelo seu ídolo pode levá-lo a uma identificação como alguém da família, um irmão próximo que se divide os segredos, o afeto.

Tânia, presidente do fã clube de Itabuna, ao definir numa palavra quem é Daniela Mercury, diz: "Digamos que nós temos filhos e família. Mas, digamos que ela é o lado bom da nossa vida”. Neste sentido, Tânia, com 46 anos de idade, se constitui num perfil de uma fã que foge ao tipo ideal do fã jovem, que se deixa levar pela vida imaginária, pela fantasia do mundo das estrelas. Entretanto, credita à estrela uma razão para viver. 
Um fã bastante presente na carreira da estrela, que a acompanha desde 1994, ainda como puxadora do bloco Os Internacionais, é Cristiano, presidente do fã clube Dance Mercury, do bairro de Brotas, onde a cantora nasceu. Para ele, a palavra que sintetiza Daniela é humildade. Já Natália, natural da Argentina, pontua que no seu país não se tem costume de ter fã clube e a palavra que sintetiza Daniela é força. Bianca, presidente do fã clube de Feira de Santana Amor à primeira vista, pontua que a palavra que sintetiza Daniela é alegria.

Amor, vida, humildade, alegria, força são palavras que denotam em sua grande maioria várias formas de amar. Dos mais simples aos mais complexos, estes sentimentos cultivados pelos fãs/fiéis se configuram como mais do que simples objeto de admiração. São religiões laicas que se ramificam pelo mundo alimentadas pelas publicações especializadas que estimulam a fé tais como revistas de fofocas, fotografias, além de CD, DVD, shows, programas de TV, especiais, dentre outros; estes fãs/fiéis seguem passo a passo as carreiras de suas estrelas de maneira a conhecer sua vida privado-pública tendo como sede os fãs clubes, situados em sua grande maioria nos próprios quartos dos fãs, como aponta Bianca, a presidente do fã- clube de Feira de Santana, Amor à primeira vista.

Primeiro é incentivar o trabalho do artista e preservá-lo da melhor maneira possível, e a união. O fã clube é uma família, um vai tendo contato com o outro, um vai ajudando o outro. E aquilo que Daniela transmite prá gente passar para os outros. Ela transmite prá gente, amizade, solidariedade. Ela cede CDs autografados prá gente rifar. Então, a gente quer mostrar o que ela prega para várias pessoas do Brasil. (Depoimento à autora em 28 fev. 2003).

Já o depoimento de Tânia, de Itabuna, Bahia:

Nossa função é só diversão. Porque a gente se encontra, conversa, viaja. Sai por aí, passeando, leva o nome dela, conversa com as outras pessoas. De uma forma ou de outra, a gente 
está sempre informando as pessoas. Às vezes, as pessoas têm uma opinião errada sobre ela. A gente senta, reúne, conversa e é só diversão. Eu como sou a pessoa mais velha do fã clube de Daniela tanto na faixa etária quanto em acompanhar sua carreira, estou com ela desde 1992. [...] Eu tenho quase 11 anos com Daniela, ativa, correndo atrás mesmo. Colecionando fotos, materiais, etc. Juntei 13 álbuns sobre a vida dela inteira que ela me pediu emprestado. E está com ela, não me devolveu. É meu ato de diversão. (Depoimento à autora em 28 fev. 2003)

A relação adorador-adorado se processa ao desejo do fã ser amado por sua estrela, sem, entretanto, perder sua humildade.

Cristiano, presidente do fã clube Dance Mercury, diz:

Daniela pra mim é tudo. De tudo um pouco. Pra mim ela é assim [...] Mas ela realmente é muito talentosa, é profissional, então, adquire de tudo um pouco. Então, para mim ela é tudo.

Assim, o fã/fiel se coloca como um ser inferior diante do seu ídolo, imprimindo um caráter de culto, religioso. Esta adoração não recíproca não significa, contudo, que não busque uma recompensa que pode ser representada por um simples abraço, um aceno, ou mesmo um aperto de mão que de certa maneira o faça ser percebido pela estrela. Por outro lado, o fã consolida a imagem do ídolo, que, por sua vez, é uma construção relacional. Assim, o fã quer ter visibilidade na construção da fama do seu ídolo. Quer ser o ídolo.

Neste sentido, o caráter do ídolo se reflete para o fã, como uma pessoa boa, solidária, cujo amor não provoca ciúme ou mesmo inveja entre os associados. Ao contrário, o amor do fã/fiel é um amor partilhado, um amor adorador. Assim relata uma integrante do fã clube de Daniela, Alegria Sempre, de Porto Alegre, também em depoimento à autora, quando assiste a um show da estrela: "Eu fico paralisada. Eu não consigo dançar, só olhando os movimentos. Já fui em todos os shows dela em Porto Alegre. Já fui até Punta Del Leste assistir". 
Para o fã/fiel ir ao encontro de sua estrela, não existe barreira; há, sim, uma comoção coletiva, solidária, no sentido de partilharem juntos esta adoração. Ao passar em excursão por determinada cidade, os integrantes dos fãs clubes se mobilizam no sentido de viabilizar transporte, hospedagem, ficando às vezes na própria casa de algum dos integrantes, para assim, juntos, poderem desfrutar desta adoração, deste amor coletivo.

O Carnaval de Salvador é um ambiente bastante emblemático desta adoração. Os fãs- clubes de Daniela se comunicam via internet, telefones, blogs, dentre outros veículos, e, no Carnaval, normalmente alugam um apartamento no bairro da Pituba, próximo à produtora da estrela, e ficam à sua espera até saírem juntos para o circuito. Lá, ao se encontrarem com camisetas padronizadas (já que Daniela sai três dias puxando a "pipoca ${ }^{20 "}$ ) se reencontram e passam mais tempo assistindo a performance de Daniela em cima do trio do que propriamente pulando atrás do trio.

Interessante observar que estes fãs/fiéis se localizam na frente do trio e de frente para a estrela. Neste sentido, andam de costas para a multidão que está à sua frente. Eventualmente, a produção de Daniela os coloca dentro da corda, pois, cada dia se torna mais difícil disputar o espaço do Carnaval fora das cordas.

Fabiana Silva aponta a dificuldade encontrada para categorizar o público-alvo de Daniela Mercury tanto pela gravadora quanto pelas "pessoas da área de comunicação ligadas à música e nem a própria artista tem uma resposta categórica para definir esse público". (2006, p. 38).

Continuando, na mesma página, Fabiana diz:

Ao longo de toda sua carreira, esse público mudou e muda constantemente ao ponto de não ser viável dividi-lo por sexo, idade e afins. Pode-se dizer que o público da artista é identificado por um aspecto comportamental. Observa-se um predomínio de pessoas que gostam de dançar, apreciar um show plástico: com bailarinos, cenário e figurinos bem cuidados. É um público que, além do entretenimento, valoriza a informação cultural, independente do sexo, da idade ou condição social. 
O ambiente contemporâneo se revela cada vez mais de forma complexa no sentido da impossibilidade em definir público-alvo específico, sociedade esta "submetida a grandes paradoxos, que vê nascer um indivíduo mais individualista, mais presenteísta" (SILVA, 2006, p. 38). Coloca-se, então, a pergunta: Ora, como falar para um público que não se consegue definir categoricamente qual a melhor linguagem a ser utilizada?

Daniela constrói sua imagem como uma cidadã que assume um papel sociocultural, além de formadora de personalidades, já que imprime modelos de conduta para uma população de jovens que cada vez mais seguem seus ídolos de forma mimética, não no sentido físico, de copiar cabelos, modelos de vestes, maquiagem, etc, mas no sentido da personalidade e de posturas definidas com relação a questões polêmicas do mundo contemporâneo.

Neste sentido, a imagem de Daniela também é construída pelos seus fãs através de expressões simbólicas que têm o amor como sentimento maior. $\mathrm{O}$ amor ritualizado, adorador. Por outro lado, o adorador também quer ser adorado, e também quer ser estrela. Esta adoração do ídolo para com o fã/fiel é desigual, que caracteriza o amor religioso, uma adoração eventualmente recompensada com um autógrafo, uma foto com dedicatória, um aceno, um sorriso, etc.

Na relação da estrela com o seu público, diz Daniela:

Ao longo da vida, o que eu tenho tentado fazer é colocar uma pessoa no meu escritório para assessorar as pessoas que mandam cartas, e-mails e que estão sempre presentes, que acompanham a carreira, aquele povo fiel que está sempre dando um retorno. Eu estou tentando aperfeiçoar esta relação, dar mais atenção possível a eles e oferecer algumas vantagens que eu sempre faço. Reconheço que é um grupo que já está comigo há muito tempo. Dou ingressos, tenho um tratamento distinto, recebo com mais atenção porque eu conheço. E o escritório tem uma ação diante disso. A gente nunca conseguiu utilizar isto comercialmente. É muito mais uma relação humana do que comercial, apesar de termos muitas idéias e já termos feito 
algumas ações, não conseguimos efetivamente levá-las adiante [...] Por que não é muito simples você pegar um território brasileiro enorme e ainda monitorar o mundo e dar conta disso tudo. E não há como pagar as pessoas para fazer isto. Então, é caro manter duas, três pessoas profissionais para fazer isso. Por enquanto, temos buscado dar apoio a alguns trabalhos dos fãs. Por exemplo, eles fazem exposição que ajudam a divulgar o meu trabalho, mas eu não consigo mais do que posso dar, ofereço informações, roupas, etc. Eles têm a iniciativa e eu apoio, ajudo com dinheiro, dou camiseta, faço assim, ações pontuais, mas não tenho uma coisa sistematizada. (MERCURY, 2006).

Tanto a produtora $o$ Canto da Cidade, de Daniela Mercury, quanto a Caco de Telha, de Ivete Sangalo, contam com um pessoa responsável pelo contato com fãs clubes da Bahia, do Brasil e de outros lugares. Promovendo eventualmente encontros com suas respectivas estrelas e seu séquito de fãs/fiéis, as respectivas produtoras têm um papel fundamental de manter os termômetros das estrelas em altas temperaturas, em picos de consumo dos seus produtos seja em forma de CDs, DVDs, fotos autografadas, shows, blocos de Carnaval, dentre outros produtos. Assim, vejamos como se comporta a produtora Caco de Telha com os fãs clubes da estrela Ivete Sangalo.

Anualmente, há um recadastramento dos fãs clubes de Ivete com o propósito de conhecer um pouco do perfil dos fãs, bem como informar dos passos da carreira da estrela e mais profundamente saber a quanto anda sua popularidade e dos seus produtos colocados no mercado. Além disso, o site das artistas é um grande veículo de informação e comunicação entre os fãs/fiéis que trocam cartas em busca de amizade, troca de fotos, materiais referentes à sua carreira, dentre outros. Além do blog da artista, que se comunica diariamente com seus fãs, enviando fotos, mandando beijos, contando novidades e os passos do dia a dia. Além da produtora Caco de Telha, a Associação dos Fãs clubes de Ivete Sangalo - AFIS também promove encontros e reuniões com o objetivo de "resolver assuntos pertinentes sobre a referida associação” (AFIS, 27 ago 2001). O objetivo da AFIS é congre- 
gar todos os fãs clubes no sentido de apresentar novidades referentes à carreira da estrela.

Com um estatuto enumerando os direitos e deveres do associado, o fã clube Maderada, de Salvador, fundado em 2000, tem como uma de suas normas: "O integrante do fã clube ao ver o artista deve permanecer em estado normal, sem conter nenhum ato de esterismo" (transcrição idêntica ao original, s/d).

Quanto aos direitos dos associados do referido fã clube, destacamos um deles: "levar presentes a Ivete com o nome dos integrantes mais o nome do fã clube". Quanto aos deveres: "Ir sempre as reuniões; manter sempre os uniformes limpos, usar sempre a camisa do fã clube nos shows e eventos marcados, ser amigo de todos os fãs clubes".

Podemos observar que o culto à imagem dos integrantes dos fãs clubes é de fundamental importância para a reputação do seu ídolo, visto que seus admiradores são "monitorados" pelos presidentes sob pena de serem desligados caso cometam alguma infração que manche o bom nome do ídolo.

As correspondências trocadas entre os fãs clubes e seus integrantes podem servir de ilustração para observar os tipos de assuntos discutidos entre eles.

À Karina - Maderada

Tá tudo bem?

Eu faço parte de um fã clube de Ivete aqui em Fortaleza que é o Sangalo e Cia. Pois resolvi entrar em contato com outros fãs clubes para que possa nos corresponder para trocarmos fotos, informações, enfim, tudo de respeito à musa axé Ivete Sangalo.

Particularmente sou muito apaixonado pela Ivete, já venho acompanhando-Ihe há mais de três anos. Eu lhe admiro pela sua voz e a beleza inexplicável, sua forma de ser humilde e principalmente culta. Sempre que pode, tenta atender os seus fãs pelos hotéis, aeroportos, em qualquer hora e em qualquer lugar.

Acho a sua forma de agir com nós que somos fãs de carteirinha. 
Aqui em Fortaleza ela sempre faz uma hora de autógrafo, bate foto no hotel que ela esteja hospedada, se diverte como se fosse uma criança, mas não só ela e também às vezes que a Carol vem é do mesmo jeito que ela age.

Gostaria que você entrasse em contato comigo para trocarmos fotos e até ser mais um amigo no meu currículo de amigos. Fico muito grato de antemão.

Atenciosamente,

Fernando Rocha.

São Paulo, 21 de setembro de 2000

Olá, meu nome é Walquiria Lúcia do Amaral, tenho 22 anos, resido na Travessa Cláudio Guerin, n. 71 Bairro Jd. Ana Maria [...]

Sou uma grande fã da musa Ivete Sangalo, e gostaria de pedir por tudo, por Deus, qualquer coisa sobre ela: fotos, reportagens, gostaria de saber mais sobre ela. Carreira, família, shows, etc. Coisas que possa me aproximar dela, mesmo sendo de longe. Só a vi uma vez na minha vida, foi no show no Olympia dia 01/08/2000, que passou. Fiquei alucinada, pois ela é mais do que eu imaginava que fosse.

Já entrei em contato com o fã clube Beleza Rara de S.B. Campo - São Paulo. Mas por favor, se puderem se corresponderem (sic) comigo. Mande-me coisas sobre ela e se precisar pagar correspondências, fotos, reportagens, eu pagarei se for o caso com o maior prazer.

Já amo todos vocês por ter certeza de que todos vocês amam a nossa musa.

Aguardo mais que anciosa (sic) a resposta dessa dezesperada (sic) correspondência.

Uma graaaaaaaaande abraço.

Walquíria L. Amaral.

Itapuranga, 28 de março de 2001

Olá amigos,

É com muita emoção que eu Ihes escrevo, pois fico louco para me corresponder com pessoas que como eu, curtem a IVETE. 
Por isso resolvi lhes escrever, pois temos algo em comum.

Escrevo esta, pois aqui em Itapuranga .....

Estes relatos são alguns dos exemplos dos assuntos que norteiam o perfil de fãs clubes e seus integrantes, girando sempre em torno dos sentimentos que vão do amor ingênuo ao amor desesperado, que tem como objetivo maior ver o ídolo de perto, como ilustrado pelo depoimento acima, de Walquíria, que, ao ver seu ídolo pela primeira vez, reconhece que este superou as suas expectativas.

No entanto, esta reciprocidade de sentimento é demonstrada por cartas enviadas por Ivete para todos os fãs clubes como a ilustrada abaixo, logo no início de sua carreira solo.

Gostaria de agradecer todo carinho que vocês me dão, desde o inicio da minha carreira. Sempre sou bem recebida nos aeroportos, hotéis, das cidades por onde passo e, sem falar nos shows, os bichinhos, as cartas, nossos carinho e código. Recebo também através de Carol, muitos faxes, e-mails e cartinhas enviadas ao setor de cartas da Caco de Telha. Eu quero sempre poder levar esse amor e carinho para vocês com as melhores canções e o melhor de mim nos shows.

[...] Fiquem com Deus, e mais uma vez muito obrigada pelo carinho e por todas as orações [1999].

Esta via de mão dupla proporcionada pelo correio da estrela com os seus fãs sustentam o culto à sua imagem, que por vezes se confunde com um santo ou anjo da guarda pronto para dar conselhos, revelar segredos sentimentais e, principalmente, manter-se humilde, humana e com grandeza d'alma expressa com modéstia.

Ao mesmo tempo, o fã/fiel "sempre quer consumir o seu Deus" (MORIN, 1989, p. 60). Pois desde os primórdios os deuses são feitos para serem incorporados, assimilados. Assim, através da assimilação do conhecimento, o fã/fiel quer saber tudo sobre seu ídolo, que vai da fofoca, do mexerico, até a informação sobre a roupa e o sapato que a estrela usou na última festa do prêmio, o tipo de maquiagem e 
segredos de beleza, até mesmo o que está preparando no momento para lançar em breve. Observemos outro fragmento da mesma carta da estrela, onde ela relata o que tem feito:

Em abril eu começo a gravar o disco novo. Ele tá lindo, cheio de músicas boas. Penso em vocês a cada momento quando estou cantando, fico pensando: Será que eles vão gostar? Espero que sim, pois no meu disco estará a mais sincera prova e alegria da minha vida.

Assim, a declaração de amor é recíproca entre os adoradores e o adorado. Entretanto, o fã/fiel também processa e controla o adorador se algo não sai do seu agrado. Seja por um corte de cabelo que não lhe caiu bem, um namorado novo que não é do agrado da maioria ou ainda na falta de atenção com os fãs. Conferimos um exemplo deste fato numa convocação feita pelo fã clube Bota pra ferver, Santo Amaro - Bahia.

Santo Amaro, 22 de maio de 2002.

Olá, galera do fã clube.

É com imenso prazer que nós, do Fã clube Bota pra ferver, estamos convidando toda a diretoria desta entidade para uma reunião a ser realizada para colocarmos em pauta a falta de atenção da Central de Fãs para com os fãs clube, pois estamos mantendo contato com várias sedes e eles estão como os mesmos problemas de materiais, encontros e outras dificuldades. Nosso objetivo é fazer uma integração com todos os fãs clubes e associados de outras cidades. [...].

Neste sentido, os fãs "controlam" sim a carreira do seu ídolo de maneira a expressar sua insatisfação quando algo não ocorre do seu agrado. "Como os primitivos fazem com o deus que não acolhe suas preces, os fãs censuram as estrelas que não cumprem o dever da resposta, do conselho, da consolação" (MORIN, 1989, p. 62). Assim, toda informação é vital para manter acesa a curiosidade e o culto espontâ- 
neo e ingênuo que pode vir a se transformar em fetichismo. "O amor impotente quer fixar-se num pedaço, num símbolo do ser amado, na falta de sua presença real" (p. 61). Fotos e CDs autografados, cartas enviadas pela estrela, mexericos e fofocas, recortes de jornais podem tornar-se fetiches.

Retomando a noção de mímese podemos ilustrar em maior escala pelo menos no que se refere à associação de sua imagem a diferentes produtos, Ivete Sangalo como estrela mercadoria - quanto mais é partilhada, mais é desejada. Ilustrando produtos diversos qualquer um pode se tornar "Ivete Sangalo", tingindo o seu cabelo da cor Ivete da Garnier Fructis, calçando uma sandália da nova coleção Grendha, bebendo uma cerveja Schin para aplacar o calor, ou ainda mantendo o corpo em forma tomando o iogurte Corpus, os mimetismos de associação permitem tornar a estrela cada vez mais publicitária. Assim, todas as partes do corpo da estrela podem ser comercializados. Como numa versão contemporânea do Rei Midas, o que ela toca vira mercadoria de alto valor no mercado, pois vem assinado com sua griffe. Afinal, tudo o que a estrela usa lhe cai bem.

Com isto, não queremos afirmar que Daniela não tenha sido em momentos da sua carreira estrela-mercadoria. Ivete, entretanto, pela própria visibilidade que sua carreira vem alcançando nos últimos cinco anos, assume este papel de maneira plena.

Vejamos em linhas gerais como se constitui o público que acompanha a carreira de Margareth Menezes ${ }^{21}$.

Em consulta ao público da Concha Acústica do Teatro Castro Alves, em Salvador, em agosto de 2006, para prestigiar a gravação do DVD de Margareth, de cada dez entrevistados, nove estavam assistindo ao show por admiração à artista, mas não de forma idolátrica. Ao indagar qual o ídolo dos entrevistados, dirigiram-se as preferências entre Daniela Mercury e Ivete Sangalo; a simpatia era por Margareth.

A única pessoa entrevistada que conhece um pouco da trajetória da intérprete, de nome Noêmia, tem mais de 40 anos e se diz feliz com o momento atual da artista, que enfim se tornou re-conhecida pelo seu talento, sem, no entanto, deixar de registrar sua indignação 
pela falta de espaço na mídia do Centro-Sul. Neste sentido, o trânsito alcançado por Margareth no âmbito da música se manifesta mais vigorosamente no espaço local, em detrimento de sua presença no nacional/global. Sua presença não vem sendo frequente em programas de grande audiência nacional, o mesmo acontecendo com a execução de seu repertório pelas FM brasileiras.

Outro entrevistado presente na gravação do DVD na Concha Acústica, Sr. José, de 65 anos, afirma que estava presente para prestigiar a vizinha que conhece desde criança e acompanha sua carreira de forma esporádica pelo rádio e eventualmente vai a shows.

Assim, podemos afirmar que o público potencial de Margareth Menezes se constitui em sua grande maioria por pessoas curiosas, admiradores e familiares que de alguma maneira se identificam com a busca em demarcar espaços cada vez mais disputado neste ambiente, tornando assim um exemplo de resistência do espaço a ser mantido.

O perfil do público de Margareth se identifica com o seu fazer artístico também pela sua "luta" em ocupar o "seu" espaço que lhe é de "direito" nesta música, bem como na sua própria postura neste espaço. De qualquer modo, seu espaço foi (re)conquistado no Carnaval com o bloco Os Mascarados, atuando no nicho de agentes que não se sentiam pertencentes aos blocos de trio com abadás iguais a todos e preços não acessíveis. Margareth coopta este público de intelectuais e artistas - na sua grande maioria atores - e "moderninhos" que, numa atitude de cumplicidade espontânea, apóiam esta empreitada de customizar a sua própria fantasia tirada dos baús ou mesmo dos personagens encenados. Além deste público potencial de Margareth, o segmento GLS também se sente "em casa" quando sai num bloco que possibilita usar a criatividade e a contravenção própria do ambiente do Carnaval. Liberdade plena é o lema. Seja sexual, seja visual, enfim, no Carnaval e no bloco Os Mascarados, vale tudo, até falsificar pulseirinhas que dão acesso ao bloco. Vale ressaltar que as estrelas têm uma relação muito íntima com o público GLS, que se identificam de diferentes maneiras com o protótipo destas.

O público potencial de Ivete Sangalo se constitui em sua grande maioria de gente do povo, no sentido de popular. Interessante obser- 
var o passeio dado pela câmera do seu DVD gravado ao vivo em 2003 pela MTV na Fonte Nova, pelos dez anos de carreira, mostrando os pés do público e a amplidão que atinge a sua voz em todas as extensões etárias e sociais do público. Sua música agrada de $\mathrm{A}$ a $\mathrm{Z}$ e isto se traduz no próprio espaço escolhido para esta comemoração, um estádio de futebol com capacidade para mais de 50 mil pessoas, trazendo convidados do porte de Sandy e Júnior, Gilberto Gil e Daniela Mercury, dentre outros. Ivete se comporta como uma pessoa do povo, com linguagem coloquial. Utiliza-se disto de forma natural e chega com facilidade ao grande público que a elege como uma artista próxima e sem "frescura". Quem tiver a oportunidade de acompanhá-la no circuito do Carnaval pode perceber a sua proximidade com todos, sempre brincando e dialogando de forma debochada, o que lhe facilita o trânsito entre estes pares, como podemos ver nesta manifestação, registrada pelo jornal Correio da Bahia, de 22 dez. 2003.

Vocês vieram. Que felicidade. Sou a mulher mais feliz do mundo, esse é o sonho da minha vida, que estou realizando hoje, graças a vocês, que me acompanham com tanto amor. Vocês não sabem o que isso significa para mim. (UZEL; MARTINS, 2003, p. 4).

Mais adiante, a estrela retoma seu tom brincalhão de sempre e diz: "Isso aqui tá cheio de fãs meus! E sabe por quê? Porque eu sou um sucesso, e to feliz por isso.". Neste sentido, a artista, ao mesmo tempo em que credita o sucesso do seu trabalho aos fãs que a acompanham "com tanto amor", credita também a grande afluência do público, pelo seu sucesso alcançado. Segundo dados da Revista Rolling Stone:

Lá embaixo uma enorme quantidade de fãs está muito mais preocupada em se fazer notar para chegar a área vip. Entre eles, o público GLS - espalhafatosas drag queens, gays, lésbicas - que, em Belém elegeu Ivete como a sua musa e, de acordo com profissionais ligados ao evento, foi responsável por uma queda na procura de abadás para o seu bloco. Nos bastidores, a história que corre é que a presença de homossexuais acabou 
afastando os filhos bem nascidos da preconceituosa elite local, os maiores consumidores das micaretas na capital paraense (CUNHA; SCHIRILÓ, 2006, p. 71)

Em linhas gerais, este é o perfil do público que consome estas estrelas. Um público jovem, múltiplo, multifacetado, "antenado" com o que é sucesso, com perfil em sua grande maioria homoerótico, admirando o glamour emanado pelo figurino, pelas festas e aparições na mídia.

\section{O talento e o sucesso musical como cartão postal}

O desenvolvimento do turismo acompanha o ritmo da industrialização, modernização e urbanização que alcançou Salvador nos anos sessenta e se consolidou nos setenta. Queiroz (2001) apud Miguez Oliveira (2002) aponta o desenvolvimento deste setor em quatro fases. A primeira decorre entre os anos 1930 e 1962, quando o turismo se encontra ainda numa fase quase amadorística, restringindo a ofertas do seu serviço a Salvador a passageiros que, em passagem por estas vias em transatlânticos, se limitavam a visitar alguns pontos. Só na década de cinquenta, com a inauguração do Hotel da Bahia, no governo Otávio Mangabeira, o turismo dá seus primeiros passos.

Na segunda fase (1963-1971), o setor sai do marasmo anterior, impulsionado também pela criação em nível nacional da Empresa Brasileira de Turismo - EMBRATUR e do Conselho Nacional de Turismo - CNTur, alcançando o setor de turismo local, também impulsionado pela abertura da rodovia Brasil 116, a Rio-Bahia, bem como a criação em 1964 da Superintendência de Turismo de Salvador - SUTURSA, em nível municipal. Em nível estadual, o governo de Luís Vianna Filho funda a BAHIATURSA, em 1968, para promover a exploração industrial do setor.

$\mathrm{Na}$ terceira fase, a partir da década de setenta, um novo modelo começa a se configurar pelo incremento tanto no âmbito estadual quanto federal das ações institucionais de um novo modelo, cuja 
atividade se torna prioritária para a economia baiana do setor através do primeiro plano estadual do setor recomendado pelo Banco Interamericano de Desenvolvimento - BID. Em 1976, o governo cria a EMTUR, cuja finalidade é promover a interiorização do turismo e fomentar a construção de novas unidades hoteleiras, bem como aumentar a permanência do visitante. Em 1977, é fundada a CONBAHIA S/A, com o objetivo de administrar e explorar o Centro de Convenções da Bahia. A partir de 1979, Salvador começa a receber os primeiros voos internacionais, prenunciando o incremento que se efetivará a partir da década de oitenta, que aponta para o surgimento de novos pólos turísticos, começando assim a apontar a competitividade do turismo doméstico. Segundos dados da Bahiatursa, só nos anos entre 1979 e 1983, a BAHIATURSA chega a realizar mais de cem eventos promocionais em diversos países. Assim, o "produto Bahia" começa a fazer parte das ações de marketing em programas de TV e novelas, dentre outros veículos.

A quarta fase identificada por Queiroz (2001 apud MIGUEZ OLIVEIRA, 2002) inicia-se a partir de 1990. Neste período, a implantação do PRODETUR-NE, a partir de 1994, passa a integrar a política de turismo para a região Nordeste, recebendo recursos na ordem de US\$2 bilhões previstos para o período de 1991-2002. A partir de 1995, o setor se desvincula da Secretaria da Indústria, do comércio e do Turismo, passando a integrar a recém-criada Secretaria da Cultura e Turismo. A partir de então, a BAHIATURSA passa a concentrar suas atividades nas áreas de infra-estrutura turística, marketing, qualificação e capacitação da mão de obra e educação voltada para o turismo.

O "Produto Bahia" é redefinido e segmentado, tanto geograficamente, com a delimitação de sete áreas destino, quanto do ponto de vista dos interesses específicos que motivam os turistas que escolhem a Bahia (cultura, lazer, negócios, religião, etc.) (MIGUEZ OLIVEIRA, 2002, p. 248).

O fato é que, nesta década, a Bahia, de oitava colocada, passa a ocupar a segunda posição no ranking nacional dos destinos turísticos, 
embora seu impacto sobre o conjunto da economia baiana não seja tão expressivo assim, correspondendo a 3,6 do PIB estadual (p. 249).

Passemos a considerar, de forma sucinta, a transformação que se opera no adentramento do turismo em campo cultural, ele próprio produzindo ou mesmo co-produzindo bens culturais no bojo do que vem a compor o mix do Produto Bahia.

Esta teia de atividades envolvendo turismo e mercado cultural, que progressivamente se consolida subordinada a uma lógica de indústria cultural, desponta cada vez mais através não só do Carnaval, com também das técnicas do merchandising televisivo. Os resultados já podem ser vislumbrados pelo importante papel que o turismo vem representando na economia do entretenimento.

Neste sentido, Miguez Oliveira aponta que, a partir de 1993, o Carnaval "começa, então, a ser visto como um negócio estratégico pelos arranjos institucionais públicos e privados que se desenvolvem em seu entorno", exigindo do poder público municipal um maior "planejamento, organização, gerenciamento, montagem de infraestrutura e equipamentos, fornecimento de serviços, e disponibilidade de recursos" (p. 148). Esta atitude começa a se delinear na gestão da então prefeita Lídice da Mata, que passa a compreender o Carnaval como um setor estratégico para a economia municipal. Naquela gestão foi criada a Casa do Carnaval, administrada pela EMTURSA. Por sua vez, o cria a BAHIATURSA, que passa a assumir um papel importante na turistização da imagem da Bahia, envolvendo intensamente o Carnaval. O poder público passa a se utilizar da iconografia da Bahia e de seu "lugar" na configuração cultural brasileira, e associar sua própria imagem à ancestralidade africana que a cidade do Salvador representa para o conjunto da nacionalidade, conforme discutido no capítulo 3 .

Voltemos à administração do Carnaval pelos órgãos institucionais, particularmente a EMTURSA, que aponta que a participação do Carnaval na economia de Salvador entre 1998 e 1999 corresponde a 10\% do PIB de US $\$ 12$ bilhões. A organização da ordem dos desfiles dos blocos, limpeza e sanitários, bem como o policiamento, fiscalização 
de alimentos, postos médicos, dentre outros serviços a cargo da prefeitura municipal, se profissionaliza a cada dia, sem, no entanto, dar conta da complexidade que é organizar uma festa com proporções gigantescas.

Por outro lado, este processo se dá em meio a muitas contradições. Ao mesmo tempo em que o número de camarotes aumenta e se verticaliza, substituindo os modelos plasmados pelos clubes até a década de setenta/oitenta, o espaço livre para o folião comum é cada vez mais disputado, resultando em uma tensão notável em alguns pontos de estrangulamento da folia, tanto no centro da cidade como no trecho Barra-Ondina. Ao mesmo tempo em que se observa criatividade e inventividade nos âmbitos artístico e empresarial do Carnaval, pode-se notar que a expressão desse folião comum fica consideravelmente comprometida em meio ao poderio do modelo do bloco de trio, que toma quase todo o espaço da rua nas horas de pique da festa.

O Carnaval da Bahia vem se tornando uma atividade eminentemente lucrativa para os seus artistas e seus respectivos blocos, tornando-se um pólo de visibilidade para os mesmos e para a própria cidade.

Apoiada fundamentalmente nos elementos da conjunção musical afro-elétrico-Carnavalesca e na sua rica dimensão multicultural, passa a existir uma complexa e extensa rede de produtores de bens e serviços simbólico-culturais, que, inserida tanto no setor formal como informal da economia, alimenta um mercado praticamente permanente que extrapola os limites da cidade e do seu ciclo de festas de verão (MIGUEZ OLIVEIRA, 1998, p. 45).

A partir das afirmações destes pesquisadores, podemos nos perguntar: Como esta música foi derramada para além de suas fronteiras? Por que estas artistas conseguiram manter este espaço e outras não? O que as diferencia das demais no mesmo ambiente? São colocações que se conectam com a importância dos aspectos técnicos e profissionais na construção do sucesso de uma intérprete. 
Primeiramente, é preciso retomar a importância dos aspectos técnicos na construção do sucesso. Estas intérpretes carregam, nesta vertente de música originariamente carnavalesca, uma diversidade considerável de influências que podem ser traduzidas num jeito particular de se constituir como intérprete baiana. Esta identidade particular também pode ser remetida a outras intérpretes, não necessariamente de axé music, mas que de modo singular podem imprimir estas características próprias num jeito de cantar que extrapola fronteiras.

As agências da indústria do sucesso - sediadas ou não na Bahia associadas ao Carnaval, ao turismo, alicerçam o sucesso dessas intérpretes buscando este cimento na "tradicionalização do moderno" (ORTIZ, 1994b), processo em que o local se torna cada vez mais global, sendo a qualidade indissociável da quantidade.

Ivete Sangalo bate recorde de venda com a gravação do seu DVD ao vivo MTV (2004), com 350 mil cópias vendidas, ganhando CD de diamante pela sua gravadora - Universal Music; viajou para Portugal com uma equipe de 50 pessoas e se apresentou para um público médio de 100 mil pessoas. A intérprete faz em média 12 shows por mês com cachês não revelados. Com a carreira solo, atinge a marca de 6.500.00o discos vendidos, fez seis turnês internacionais e é a artista que mais aparece na tela da Globo, não só como apresentadora do programa dominical Estação Globo, já na sua segunda edição, como também nos programas Planeta Xuxa, Faustão e Caldeirão do Huck, além de participações em filmes produzidos pela Globo como Simão, o fantasma trapalhão, em 1998, ao lado de Renato Aragão, e o mais recente (2006/7), Xuxa Gêmeas, estrelado por Xuxa e elenco da Globo. Com coleção de troféus de melhor cantora, melhor DVD, ao longo de sua carreira, a artista declara à revista Rolling Stone:

O meu lado estrela fica em cima do palco. Quando desço para o camarim, muda tudo. A partir daí, minha vida é outra, o meu assunto é outro. Não dá para ser popstar o tempo todo. Tenho horror a essa história de ser diva, de dar piti, de atormentar a 
produção dos meus shows com exigências impossíveis (CUNHA; SCHIRILÓ, 2006, p.68).

Vale lembrar que Daniela Mercury recebe pelo seu Disco O Canto da Cidade em 1992, com dois milhões e meio de cópias vendidas, CD de platina e diamante. Em 2000 Daniela lança o projeto Por do Som no Farol da Barra, cuja proposta é fazer show no primeiro dia do ano recebendo artistas locais e nacionais. A partir de julho de 2005, embarca mais uma vez para a Europa para mais uma série de shows em Portugal, Itália, Holanda Bélgica e França. Computando mais de onze turnês internacionais entre Europa, EUA e Canadá, a estrela também coleciona um sem número de prêmios como pode ser conferido com o prêmio TIM de música 2006 com o CD Balé mulato de melhor cantora regional e melhor cantora pelo voto popular; bem como a indicação no Grammy Latino 2006 para melhor documentário longa com o DVD Baile Barroco.

Margareth Menezes também recebeu DVD de ouro, ao vivo, no Festival de Verão 2004. Com o maior recorde de público já registrado na Concha Acústica - 11 mil pessoas em dois dias -, em época da gravação do $\mathrm{CD}$ ao vivo, em 2005, a artista também coleciona um número significativo de prêmios como pode ser ilustrado com o prêmio TIM 2007 de melhor cantora regional; bem como contabiliza 14 turnês internacionais, sendo a pioneira entre as três grandes intérpretes do Carnaval baiano a fazer uma série de shows no Velho Continente e nos Estados Unidos a convite do cantor, compositor e produtor norte americano David Byrne, ficando 11 semanas em primeiro lugar na World Music americana com o álbum Elegibô, lançado também em 25 países.

É o desempenho dessas artistas diante de seus grandes públicos e a recepção que aí se realiza que arremata e dá sentido a toda essa malha de possibilidades, circunstâncias, definições, projetos, desejos, sedução e arte.

A espetacularização da cena carnavalesca baiana alicerça o sucesso destas intérpretes e, em contrapartida, tem no desempenho dessas estrelas um grande vetor de propaganda. Referências a seus nomes 
constam em pacotes turísticos que já incluem passagens, hospedagens e abadás durante o Carnaval, demonstrando uma profissionalização destes blocos de trio e suas produtoras, especializadas que são em vender sua mercadoria musical. Neste sentido, estas intérpretes buscam se associar a profissionais que possam, juntamente com as mesmas, gerenciar suas respectivas carreiras de forma empresarial e artística, seguindo uma divisão do trabalho que opera toda a máquina administrativa que extrapola o ambiente do Carnaval.

Vistas em tal perspectiva, as trajetórias de Daniela Mercury, Margareth Menezes e Ivete Sangalo compõem um quadro singular. Entretanto, só podemos compreender este processo mantendo presente que elas procuram assumir - com maior ou menor êxito - o gerenciamento de suas respectivas carreiras solo, administrando com uma equipe seus respectivos produtos: sua griffe de blocos, trios elétricos, shows, camarotes, de maneira empresarialmente organizada. Interessante observar o cast para botar o bloco na rua, com alto grau de profissionalismo, desdobrando-se em novas estratégias de administração do seu próprio negócio, tomando assim o timão de suas carreiras.

Enfim, a construção de três singularidades exitosas em termos de sucesso no complexo mundo da música será abordada no próximo capítulo.

\section{Notas}

1 Uma nova forma de captação da voz, usando da tecnologia.

2 Este fato aconteceu no Carnaval de 2005, com a subida do pianista erudito Ricardo Castro acompanhando a cantora Daniela Mercury em duetos como As Bachianas número 5 de Heitor Villa Lobos e Aquarela do Brasil de Ary Barroso, dentre outros números musicais, no percurso Barra-Ondina.

3 Tanto Faral quanto Menendez Pidal (filólogo espanhol) se debruçaram nas pesquisas para "esboçar um retrato falado de várias espécies de cantores, recitadores, atores, leitores, público aos quais (salvo raras 
exceções) a sociedade medieval confiou a transmissão e a 'publicação' de sua poesia" (apud zUMTHOR, 1993, p. 55)

4 Ver Pimenta (2003).

5 Não é objetivo deste estudo mergulhar de forma profunda nesta discussão. Ver Valente (2000).

6 Ver Mello (2001).

7 Ver Wisnik (1989).

8 Ver Setenta (2002).

9 Tomamos por performance a atuação gestual corporal e vocal apresentada em cena pelos artistas pop de maneira geral e as de axé music de maneira particular, associado ao aparato tecnológico presente na iluminação, no cenário, no figurino, enfim, nos efeitos especiais e objetos de cena que compõem um espetáculo de música pop contemporâneo. A performance pode ser considerada um acontecimento, um evento, levando em consideração o tempo, lugar, circunstâncias, contextos históricos, os indivíduos. Zumthor considera a performance "mais como ação do que pelo que ela possibilita comunicar. Captura expressão e fala juntas, no bojo de uma situação transitória e única" (1993, p.219). Já Goffman (2002) pontua que a performance ocorre onde se percebe a presença contígua de um ou mais indivíduos diante de um conjunto particular de observadores que sobre estes exerça alguma influência. Neste sentido, a presença do outro ou dos outros é elemento estético e órgão vital na performance.

10 É senso comum, no ambiente musical, que os instrumentistas considerarem a cantora ou intérprete como um profissional que "impede" de maneira geral a visibilidade do músico enquanto artista, esquecendo que o próprio mercado, bem como os músicos enquanto categoria, em sua grande maioria não organizada, não se posiciona no mercado de maneira a gerenciar o seu produto artístico e assim, poder ocupar espaço semelhante ao do cantor/intérprete.

11 Empresário aqui significa o profissional que administra a carreira do artista, não só vendendo shows, mas fazendo contratos, gerenciando e formatando um produto musical e artístico, de forma a competir no mercado com um produto composto de um staff que vai da recepcionista ao assessor de imprensa. Por outro lado, o produtor também por vezes pode se configurar num empresário e vice-versa. Entretanto, cabe ao produtor executar tarefas de forma supervisionada pelo empresário, que por vezes tem diversos produtos para administrar, delegando o 
produtor na execução de tarefas tais como arregimentar a banda para o show, pagamento de cachê e acompanhamento da montagem do palco, com toda sua estrutura de som, luz, cenário etc.

12 Grafado assim no site www.cacodetelha.com.br, formada por Jesus San galo, Cynthia San galo, Ricardo San galo, Luiz Paulo Nunes, Ricardo Martins, tendo em média 25 funcionários para dar conta de cada selo da Caco de Telha Entretenimento.

13 Mercury, Daniela. O canto da cidade: 10 anos do camarote Daniela Mercury. Salvador: Corrupio, 2005.

14 Em 2001 o camarote de Daniela teve como patrocinadores a Renault, Portal IG e shopping Iguatemi num investimento aproximado de $\mathrm{R} \$ 600$ mil reais, num evento só para convidados com capacidade para 1.000 pessoas, que consumiram 780 litros de whisky, 444 garrafas de champanhe, 25 mil unidades de salgadinhos, 8.40o latas de cerveja e 4 toneladas por dia de pratos quentes. Dados extraídos da Revista IstoÉ de 7 de março de 2001.

15 A cada ano, a artista busca temas distintos para homenagear no seu camarote. Em 2003, o tema foi o Camarote das flores; em 2004, foi o samba o homenageado, dedicando cada dia a um tipo de samba: na sexta-feira o samba tradicional; no sábado, samba bossa; no domingo samba rock; na segunda, samba enredo; e na terça samba reggae. Em 2006, foi a vez do cinema brasileiro. Em 2007, as tradições do Brasil com suas indumentárias, e culturas distintas.

16 Espaço ocupado pela Internet para venda de músicas, DVDs, CDs, Ipod, MP3, MP4.

17 Propina paga pelo artista ou seu empresário para veicular a música de trabalho. $\mathrm{O}$ valor pago varia pela quantidade de execução da música na programação, bem como o horário da execução. Murmura-se que alguns empresários pagavam ao responsável pelo programa para não executar as peças de determinado artista concorrente; no entanto, isto jamais chegou a ser comprovado.

18 Em consulta sistemática ao site da artista www.ivetesangalo.com.br observamos que, em sua cidade natal, Juazeiro, não consta fã clube cadastrado.

19 Os vários depoimentos com os fãs de Daniela Mercury: Bianca, Edwin, Tânia, Cristiano e Natália foram coletados pela autora em 28 de fevereiro de 2003, na produtora O Canto da Cidade. 
20 O termo pipoca se refere a foliões que saem pulando atrás sem serem associados dos blocos de Carnaval. Pulam fora da corda ou em trios independentes.

21 Em consulta periódica ao site da artista, pudemos perceber, em 20 de janeiro de 2007, que na atualização já constam links para cadastramento de fãs clubes, mas não se disponibilizam os nomes já cadastrados. 


\section{5 \\ A Singularidade das Intérpretes}

A voz, não puramente como materialidade física ou orgânica, mas como expressão, bem como a dona da voz e sua força interpretativa impressa numa canção, podem nos aportar possibilidades de interpretação do que poderíamos, aqui, denominar identidade. Este conceito, tal como proposto, parte da percepção da singularidade como um feixe representacional (MOURA, 2001). Seus elementos constitutivos podem ser pensados de forma embrionária, como representações construídas com sentido.

Entretanto, a presença artística no contexto social produz uma especialização do indivíduo como tal, que se destaca da e na coletividade, constituindo-se radicalmente como singularidade. Diversos autores contemporâneos insistem na mobilidade e instabilidade da configuração do indivíduo e de sua implantação na sociedade, cujos valores sofrem constantes alterações e se transformam, incessantemente, como numa festa móvel (HALL, 1992) hibridizando-se (CANCLINI, 2003), sincretizando-se (CANEVACCI, 1996), observando-se crescentemente a compressão tempo-espaço e acentuando-se progressivamente a reflexividade (GIDDENS, 1991), além da dissolução de fronteiras convencionais.

No sentido de construir uma plataforma teórica que dê suporte à discussão deste capítulo, podemos nos remeter a autores que ousaram tratar do tema polêmico sociedade e indivíduo de forma não dicotômica. Enquanto Norbert Elias (1994) imprime a noção de configuração para 
caracterizar a sociedade como um arranjo dinamizado pelas interdependências individuais; Bourdieu (2002) imprime a interiorização do exterior com a noção de habitus; e Giddens (1991) propõe, na teoria da estruturação, a noção de reflexividade do agente - os atores sabem o que fazem e como fazem; Edgar Morin (2003) caracteriza a unidade humana com base na tríade indivíduo/sociedade/espécie. Buscando no ser/no saber o cerne do seu pensamento complexo, Morin (2003) destaca o ser humano de forma multidimensional, contemplando assim aspectos desprezados pela grande maioria dos sociólogos, que não levam em consideração aspectos biológicos, psíquicos e emocionais na construção do indivíduo.

Para Morin (2003), o ser humano é ao mesmo tempo sujeito e objeto de sua construção do mundo, pois a unidade e a diversidade humanas estão inseparáveis, perpassando dimensões ou aspectos físicos, biológicos, psicológicos, sociais, mitológicos, econômicos, sociológicos e históricos, ativando assim a consciência reflexiva de si e do mundo a partir da crítica e da reflexão transformadora.

Neste sentido, alguns destes autores consideram o ator/agente como dotado de certa flexibilidade em determinados âmbitos sociais. Bourdieu (2002; 2004), por sua vez, contribui para o estudo das representações trazendo à tona as tensões/posições entre os campos, no ambiente das lutas simbólicas.

Podemos admitir que a interseção de campos, que no ambiente da música popular toma fôlego através dos veículos de comunicação, se dá no que Bourdieu (1991) denomina de espaço social. Este espaço pode ser representado por tais intérpretes que de alguma forma preenchem este requisito de representante de uma coletividade. É o caso de constituir-se como ícone da Bahia contemporânea, tradicional e pop perante o eixo Rio - São Paulo. Por outro lado, o espaço social é o espaço das concorrências e das reciprocidades, como também das lutas pelos recortes de sobrevivência e da ação. Estas intérpretes agenciam suas carreiras, seus repertórios, seus discursos veiculados pela mídia, considerando sua rede de interações apontadas por Claude Mollard (apud NUSSBAUMER, 200o, p.12) com o jogo das 
quatro famílias, já apontado no Capítulo 4, no qual o produtor cultural (artista), o agente cultural (produtor), a mídia e o público se unem para a construção do sucesso desses ídolos.

Tomemos então Daniela, Margareth e Ivete como singularidades representacionais de uma sociedade contemporânea que se chama Bahia, tanto no imaginário nacional quanto na relação Bahia/Brasil, no sentido de compreender de maneira multidimensional como:

[...] a voz assume o contorno semovente de lugar de apropriação. Isto corresponde a uma instância fronteiriça entre significações culturais, deslocando conceitualmente a força de seus sentidos para novos espaços de reflexão teórica e crítica (DINIZ, 2001, p.207).

Assim, podemos ilustrar, pelo corpo-voz, que as narrativas identitárias elaboradas no trabalho destas intérpretes se reconfiguram de maneira intermitente, tornando-se hegemônicas com relação a outras vozes, de forma que o feixe representacional impresso em suas respectivas trajetórias a partir da "força dessa voz incorporadora e rearticuladora de sentidos [...] pela leitura da releitura" perpassa a criação de uma personagem "que lance à cena a clivagem de uma visão teatral, propositalmente elaborada como representação, no estabelecimento da noção de espetáculo na voz encorpada e incorporada do intérprete" (DINIZ, 2001, p. 211).

A criação de uma personagem que lance à cena uma visão teatral elaborada como representação pode ser apontada na construção destas intérpretes, na sua própria relação com o público e na sua apresentação como um acontecimento dramatizado entre plateia e palco. Assim, a voz, como instrumento musical, pode servir em Daniela para demarcar de forma barroca, moderna e eletroeletrônica o mundo, o social, a festa; em Ivete, o drama identitário se apresenta na mistura do palco e vida cotidiana, na esculhambação, na esbórnia, cujo obsceno passa para a cena. ${ }^{1}$ Já a música/voz de Margareth Menezes funda-se no diálogo entre os elementos da natureza, mas de forma a apontar estes elementos como fonte de transformação de 
uma Marmelada em Alegria da Cidade. Trata-se de uma etnicidade em trânsito (GILROY, 2001), em que o drama histórico da estética afrobaiana torna-se um mosaico intrincado de significações e significados, qual um caleidoscópio que, a depender da maneira com que se olha, explodem diante dos nossos olhos novas cores, formas e imagens.

Assim, as interpretações da Bahia plasmadas nas obras/vozes das intérpretes Daniela, Margareth e Ivete podem ser elencadas também no âmbito do binômio tradição/modernidade. Entretanto, elementos inovadores particularmente veiculados pela mídia local, nacional e global, percebidos na vida sociocultural, se interfaciam de modo a contribuir para moldar uma Bahia local plugada no mundo.

Vejamos, então, como este caleidoscópio que pode ser representado por estas donas e suas vozes que viraram mercadoria joga com estas representações no âmbito da indústria cultural.

\section{Daniela Mercury: uma voz que dança}

E a gente dança a nossa dança (Daniela Mercury e Pierre Onasis)

A singularidade do trabalho de Daniela é, de acordo com a fragmentariedade do contemporâneo, um caleidoscópio de influências ressignificadas na sensualidade/etnicidade/ contemporaneidade plugada no "mundo", carregando, contudo, o elemento pop/eletrônico como um diferenciador de sua atuação artística. Com uma discografia composta de 12 álbuns² e quatro DVDs, Daniela aponta em cada álbum lançado no mercado suas principais influências - o samba reggae, a música pop, a música eletrônica e a MPB -, hibridizando gêneros e ritmos e incorporando assim novas sonoridades ao seu trabalho. A seguir, em linhas gerais, os seus traços biográficos.

Daniela Mercury de Almeida vem ao mundo em 28 de julho de 1965. Filha da assistente social Liliana Mercury, e Antônio Fernando de Abreu Ferreira de Almeida, português que veio para o Brasil com 
11 anos, mecânico industrial. Neta de italianos pelo lado materno, tem suas primeiras conquistas no palco pela dança, aos oito anos de idade, estimulada pela mãe. Mas é através do pai que a música se faz presente no gosto musical de nomes como Sarah Vaughan, Billie Holliday e Quincy Jones. Ao lado dos irmãos Tom, Cristiana, Vânia e Marcos, Daniela passa a infância no bairro de Brotas, em Salvador-Ba, onde nasceu e morou até a adolescência.

Aos 13 anos, ingressa num coral de igreja, destacando-se pela voz forte, presente e afinada, o que levou a cantora em pouco tempo a liderar o coro e passar a cantar em barzinhos, antes da maioridade. Aos 17 anos, tem sua primeira experiência no Carnaval, puxando um bloco pequeno de nome Kuka Fresca. "Passei então a fazer parte do desfile que tanto admirava" (MERCURY, 2005, p.7). Assim, sua trajetória vai se configurando de forma múltipla, dialogando com a dança, com os afazeres domésticos convencionais de mulher e com a dança, cuja passagem pelo grupo Salto também integra a multiplicidade de projetos e atividades.

Aos 19 anos, ingressa no curso de Dança na Universidade Federal da Bahia, investindo a partir daí também na profissionalização da música, cantando em bares (voz e violão) - ao lado da irmã (também cantora) Vânia Abreu - sucessos da MPB tais como Chico Buarque, Caetano Veloso, Gilberto Gil, dentre outros, e elegendo como ídolo a cantora Elis Regina. A carga de compromissos profissionais, por sua vez, inviabilizaria a conclusão do curso universitário.

Ainda aos 19 anos casa-se com o engenheiro Zalter Póvoas, com quem tem dois filhos - Gabriel (músico) e Giovanna (bailarina e estudante de Jornalismo), vindo a separar-se em 1996. Em 1985, aos oito meses da primeira gravidez, Daniela sobe no trio elétrico do bloco Cheiro de Amor para cantar e dançar. Em 1987, funda a Companhia Clic ao lado de músicos como Rudnei Monteiro, Jonga Cunha, Marcos Sampaio, Raul Carlos Gomes e Cezinha, futuramente substituído por Sérgio Henrique, cuja proposta musical era fazer música pop baiana. Com este grupo, Daniela recebe o Troféu Caymmi de melhor banda em 1998, estando a produção a cargo de Jorginho Sampaio. 
O grupo lança dois álbuns, em 1989 e 1990, e sai no Carnaval deste último ano puxando o bloco Pinel, o que dura pouco tempo diante da proposta da gravadora Eldorado (a mesma gravadora do grupo). Daniela parte então para a carreira solo, gravando o primeiro álbum em 1991. Neste álbum, produzido pela intérprete e por Wesley Rangel e agenciado pela DS produções, que tem Daniela e Jorginho Sampaio como sócios, interpreta compositores baianos como Saul Barbosa e Gerônimo (Meninos do Pelô), Roberto Mendes e Paquito (Ninguém atura), Rey Zulu e Cabral (Todo Reggae), Marinho e Daniela Mercury (Tudo de novo), Daniela Mercury e Durval Lelys (Vida é), Carlinhos Brown (Todo canto alegre), Dito (Maravilhê) e artistas "nacionais" como Herbert Vianna (Milagres) e Gilberto Gil na regravação de Geléia geral.

Neste primeiro álbum-solo Daniela já vislumbra que o samba reggae é a porta de entrada para o Brasil e para o mundo. Na música carro-chefe do álbum, Swingue da cor, de Luciano Gomes, o arranjo de percussão de Neguinho do Samba sugere um diálogo com a voz da intérprete que situa a Bahia nesta canção, não pelo tema romântico de súplica de não ser abandonado pelo amor, mas sim pela batida dos tambores do Olodum, presente na faixa título, bem como em assumir o traço do afro (no caso, trata-se do Muzenza ${ }^{3}$, outro bloco afro que tem o reggae no núcleo de sua proposta identitária). Esta canção se configura num primeiro diálogo com o étnico no seu trabalho.

Outra faixa emblemática deste álbum é o samba de roda Maravilhê, de Dito, que se tornou jingle de campanha publicitária da rede de supermercados Paes Mendonça. Sua garota propaganda, Daniela, se constitui numa figura emblemática da baianidade ao dizer: a gente pode ser feliz pelas ruas da Bahia, no trio elétrico independente patrocinado pela rede de supermercados.

Mas a intérprete já aponta para o ecletismo e a transgressão, vive uma inquietação intensa, com sua parceria com Durval Lelys na faixa Vida é:

Vida que vida é uma saída

Vida que vida é mudar a cara 
Vida é descer ladeira

É escolher um lado

É derrubar o muro

O amor é o culpado

Vida é. Durval Lelys e Daniela Mercury (1991).

Daniela aponta para outras mudanças quando afirma que "vida é mudar a cara", fazer escolhas nem sempre de forma diplomática, ou mesmo branda, mas sim "derrubando muro". Assim, a intérprete se mostra eclética no primeiro álbum, cantando reggae, samba reggae, balada, funk, samba de roda e axé, exprimindo vocalmente várias possibilidades de uma intérprete/compositora que tem no seu baixista Cesário Leone, também diretor musical durante a sua trajetória, bem como no seu contrarregra há mais de 15 anos, Vitor Jairo, figuras que a acompanham e que alicerçam sua carreira.

Utilizando também a dança ${ }^{4}$ como linguagem; tornando-se desde então uma artista que, além de carregar impressa no seu estilo de cantar uma voz metálica, nasal e vigorosa, compõe, cria arranjos e coreografias e produz seus próprios discos e shows, assumindo desde sempre não só a sua carreira artística no sentido estrito; enquanto gestora do seu próprio negócio, mas, também, seu campo de ação, como pode ser observado pelo seu camarote, o trio Tecno, diversos álbuns experimentais como Clássica e Carnaval eletrônico, dentre outros projetos.

Jussara Setenta (2002) analisa a dança presente na música de Daniela de maneira híbrida e singular a partir da análise de três shows bastante emblemáticos em sua carreira: Música de rua (1994) Feijão com arroz (1996) e Elétrica (1998), cujas características podem ser encontradas em:

[...] diversas matrizes estético-cultural tais como africanas, européias, indígenas, norte-americanas - vocabulários de dança afro, danças populares, ballet clássico, dança moderna e pós- 
moderna. Todavia, predominam princípios estéticos da dança afro baiana. (p. 7).

Destacamos o que o fenômeno Daniela Mercury provoca no Brasil com o lançamento do seu segundo álbum, Canto da cidade, lançado em 1992 pela multinacional Sony. Este álbum, segundo dados do seu site bateu todos os recordes de venda na época do lançamento, atingindo a marca de um milhão de cópias, o que lhe valeu, então, o disco de diamante.

O seu especial na Rede Globo de Televisão, neste mesmo período, bateu o recorde de 2 milhões de espectadores e o seu primeiro show em São Paulo, ao meio dia, no vão do MASP, parou a cidade com engarrafamento ao longo da Avenida Paulista, estendendo-se para o entorno e levando 20 mil pessoas num espaço que, depois do show, teve que ser interditado para outros eventos deste tipo. Um participante deste evento assim testemunhou:

Eu saí da USP mais cedo para poder assistir ao show do meio dia, que costumava acontecer no vão livre do MASP, às sextas feiras. Bem antes de chegar ao Parque do Ibirapuera, o trânsito já estava engarrafado. Assim como eu, inúmeros estudantes já tinham ouvido falar de Daniela. Todo mundo queria ver essa baiana; o nome dela já era conhecido. Muito ansiosos, descemos do ônibus ainda no parque, tendo que caminhar um bom pedaço para chegar até a Avenida Paulista, e aí chegar ao MASP. Foi um fenômeno, nunca vou esquecer. O show foi interrompido na segunda música, se não me engano. Em frente ao MASP, no Parque do Trianon, havia gente em cima das árvores, dos muros; foi um acontecimento. A Avenida Paulista interditada... Então ela se pronunciou assim: o show teria que ser suspenso, pois ela acabava de receber a informação de que algumas obras do museu poderiam ser danificadas em virtude da reverberação, e também porque estava causando descolamento de algumas coisas lá embaixo, no metrô, porque tinha muita gente pulando. Então, o show foi adiado para a USP, dois dias depois. Foi uma coisa linda, todo mundo admirado de ver 
o impacto que ela estava causando no centro financeiro do país (TUDELA-VIEIRA, 2007).

Neste segundo álbum solo da intérprete, que tem como música de abertura $O$ canto da cidade (Daniela Mercury/ Tote Gira), evidencia que "A cor dessa cidade sou eu", passando a ser chamada de rainha da axé music, contrapondo-se aos militantes de movimentos negros que não a "elegeram" como representante de identidades afro-baianas estetizadas no samba reggae, impulsionando assim o novo padrão musical baiano para o Centro-sul. A intérprete que usa o samba reggae já diferente do ambiente que o originou aponta para modernidades plasmada em sua obra fonográfica, no ambiente do Carnaval (como veremos adiante no Carnaval Eletrônico) e na própria coreografia presente em seu corpo, também sorvida nesta fonte das danças dos orixás transformadas esteticamente em performance nos palcos do show bussiness baiano/brasileiro.

Assim, o samba reggae se torna a síntese na sua prática artística com influências da música do Olodum, do Muzenza e do Ilê Aiyê, os mais emblemáticos, com elementos pop impresso nas levadas dos arranjos, bem como nos instrumentos eletroeletrônicos e a pluralidade de gêneros presentes nos seus álbuns. Vejamos o que nos aponta a intérprete a respeito da influência do samba reggae em sua prática artística:

Quando eu descobri o samba reggae, fiquei alucinada, apaixonada, emocionada com a sonoridade daquilo, aquelas letras, com todo o contexto, com toda a informação que vinha, com toda inserção social, que vinha no discurso anti-racismo e afirmativo da cultura negra e afro-brasileira

[...] E quando acabou aquela moda [da canção] Faraó, aqui em Salvador, eu pensei que as pessoas iriam largar de mão e eu vi nisso, depois do samba-rock de Jorge Benjor, a principal síntese rítmica brasileira estabelecida na contemporaneidade. Prá mim, são os três pontos: bossa-nova, samba-rock e samba reggae, porque isso eu já ouvi até repetido por outras pessoas, mas isso 
eu já comento desde que surgiu, que eu escolhi fazer samba reggae desde o Swingue da Cor. ${ }^{5}$

O diálogo entre tradição/modernidade se configura em sua trajetória de maneira não muito presente, mas não menos significativa em canções já citadas como $O$ canto da cidade. Ao modular sua voz nesta canção, Daniela se coloca também como baiana, mestiça, buscando afirmar uma Bahia não só étnica (no sentido do diferencial ou diferenciado) como também sincrética, sintética. Busca na batida do samba reggae sua identidade musical em diálogo com o eletrônico, num hibridismo (CANEVACCI, 1996) cujo nascedouro já se configurou no samba, inclusive na Bossa Nova, que tanto é influenciada pelo jazz como influencia o jazz. Assim, Daniela reconfigura posi (a) ções, abrindo espaço para o mundo a partir do lugar que ela ocupa na Bahia e no Brasil.

A carreira desta artista aponta em sua multiplicidade para uma Bahia conectada na tradição e na contemporaneidade, de forma que: "As tradições se mantêm porque são recicladas pela juventude, pela criatividade dos artistas que vivem aqui, que não têm pudor em misturar, mas têm amor por estas raízes" (MERCURY, 2003d).

Neste sentido, a tradição associada à ideia de passado na Bahia torna-se como que realidade presente, haja vista que o próprio samba, enquanto signo herdeiro da fala musical da Bahia e do Brasil, é representado na contemporaneidade por inúmeros grupos de pagode baiano e brasileiro, colocando assim no proscênio da contemporaneidade a preferência do grande público pelo gênero. Fato semelhante acontece com a síntese dos tambores dos blocos afro com os acordes das guitarras elétricas do trio, reconhecida tanto pela mídia como na linguagem do senso comum como axé music e samba reggae. 
A branquinha mais neguinha da Bahia ${ }^{6}$

A cor dessa cidade sou eu, o canto dessa cidade é meu

(Daniela Mercury e Tote Gira)

Fenômeno já discutido por autores como Guerreiro (2000), Miguez Oliveira (1996, 2002), Moura (1996, 2001), Godi (1997, 2002), Rubim (2000), Dantas (1994, 1996), procuramos focar nosso olhar nestas agentes/intérpretes. Através de suas vozes, ganham força e legitimam-se como representantes também deste fenômeno que poderíamos classificar como estético, tecnológico, midiático e/ou mercadológico na representação destas matrizes que, de forma nem sempre harmoniosa e/ou conflitante, conquistam espaços. Assim, o elemento étnico, bastante emblemático na estética musical de Daniela, sofre diversas "pressões" no ambiente dos movimentos negros. Sobre o assunto, a intérprete diz:

Foi uma conquista de muitos anos [...] Vovô do llê, em 1989, foi ao meu escritório e disse: a negrada gostou da branquinha, ela pode cantar na festa da Beleza Negra? Aí eu fui cantar [...] quando eu cheguei lá, eles ficaram todos de braços cruzados... A comunidade negra da região da Liberdade não me recebeu muito bem por eu ser branca... De repente, eu disse a eles: "Olha, eu sou filha dessa terra assim como vocês, danço afro desde pequena, sou bailarina de formação e minha primeira professora é negra, e eu aprendi um canto de orixá, queria que vocês me recebessem pois eu estou aqui pra cantar". Desarmei todo mundo e eles descruzaram os braços e começaram a cantar comigo. E eu cantei uma música que depois eu vim cantar no meu disco com a cantora Angelique Kidjo, do Benin, que é uma citação de um canto do candomblé [...] "Aiê a maianga"... Aí eu fui quebrando a resistência da comunidade de receber pessoas que não eram de cor, negros, eles foram vendo que eu era cúmplice da luta, que tinha um carinho enorme por isso tudo [...]. E é por isso que eu recebi este respeito e o ano 
passado [2002], depois de mais de dez anos de convívio com a comunidade do llê, eu fui, finalmente, convidada prá cantar com eles. Recebida e abraçada como alguém que é querido e respeitado dentro da comunidade, que pode cantar as músicas deles com a legitimidade também da comunidade. (MERCURY, 2003d).

Assim, o elemento étnico na trajetória de Daniela Mercury se configura não como uma apropriação indevida da "cultura do outro". Ao contrário, Daniela se constitui etnicamente também fazendo parte de uma cultura híbrida, sincrética, não só na sua música e na sua dança, como também na própria religiosidade ${ }^{7}$ transitando entre o catolicismo e o candomblé de maneira a poder conviver num ambiente negro-mestiço que também quer ver suas canções executadas nas emissoras dos rádios e, consequentemente, "na boca do povo". Nomes como Pierre Onasis, Guiguio, Jauperi, Tonho Matéria e Gilson Babilônia, dentre outros, se projetam nacionalmente também por conta de suas canções serem gravadas por Daniela e outros artistas que podem representar este gênero.

Esta via de mão dupla representa aspectos de um ambiente que pode ser ilustrado pela fala do compositor Gilson Babilônia: "é uma emoção muito grande ouvir sua música na voz de cantoras deste porte, pois elas transformam em pérola o que cantam. E o que elas cantam vira sucesso" (Entrevista à autora em 9 ago.2005). Neste sentido, podemos afirmar que a axé music reconfigura padrões sociais, estéticos e culturais numa cidade cujas negociações estão constantemente no proscênio. Assim, pode-se agir no sentido de administrar, aparar as arestas, as diferenças, não propriamente no sentido de resolver, mas de conviver ora de forma harmoniosa, ora de forma conflitante. O compositor Gilson Babilônia afirma, ainda na entrevista citada, que num país como o Brasil

Nenhuma profissão te dá uma renda satisfatória, mas o reconhecimento é grande. [...] Faço música porque gosto. Eu vivo para a música e não da música. Sobrevivo da música e vivo pra 
música. Eu pedi a Deus que não me fizesse escravo da música. Eu quero sempre poder escrever.

As intérpretes de maneira geral e Daniela, Margareth e Ivete de forma específica, contribuem para divulgar a imagem da Bahia como porta-vozes destes compositores saídos dos guetos da cidade; dificilmente, sem porta-vozes deste porte, atingiriam a grande mídia e consequentemente o sucesso. Com isso, contudo, não queremos afirmar que o sucesso destes agentes esteja unicamente condicionado à figura destas protagonistas; entretanto, o espaço conquistado pelas intérpretes também serve de abertura para outros artistas que virão a seguir.

Ainda para Daniela, esta "abertura" étnica, o diálogo inter-racial é uma conquista democrática:

Porque, no fundo, os blocos afros e alguns blocos que se organizaram dentro da história do Carnaval da Bahia, só os negros, como uma resistência porque eles não podiam entrar há muitos anos atrás, nos blocos de classe média alta de brancos. E aí, passou a ser uma questão social, política, uma luta em relação ao dia-a-dia também na cidade. A inserção dos negros na sociedade, o respeito aos negros, a luta contra o racismo é um sinal de que está se aproximando, que foi aberto também um espaço pela sociedade branca e classe média alta por causa da música e, principalmente, por causa do sucesso do Olodum e do llê, das músicas lindas que eles fizeram e que cativou a cidade inteira, a força do movimento afro e do samba reggae. [...] Eles também tinham que se desarmar um pouco, já não precisavam mais aquela coisa fechada, eles mesmos se excluem dessa forma. Mas eu entendo, é necessário também isso. (MERCURY, 2003d).

O discurso da etnicidade se configura também como uma questão cultural e de apropriação indevida por parte de não negros, pelo menos no que se refere à cor da pele. Entretanto, o discurso de Daniela em relação à questão da etnicidade passa pelo vetor do fato dela ser baiana. Continua Daniela: 
Por ser baiana, eu sou tão negra quanto eles. E os negros não necessariamente têm afeto pela cultura negra e originalmente africana... Isso independe da cor que nós tenhamos. Depende da afetividade, do respeito, da afinidade que se tenha e que se escolha. Porque eu acho que a cultura nossa, independentemente da cidade do Salvador ser uma cidade negra, é uma cidade também cosmopolita, que tem todo tipo de informação e a gente pode não querer ser tão relacionada às raízes dessa cidade. Alguém pode não querer ser, e eu procurei ser.

A legitimidade do discurso étnico em Daniela passa pelo vetor da localidade - o lugar de onde se é. Por outro lado, sabemos que a trajetória da música afro brasileira/baiana, não só de cunho carnavalesco, como também as perseguições sofridas pelos batuques, pode representar uma trajetória histórico/social/cultural da presença das tradições africanas percebidas nos blocos afros contemporâneos, bem como também na axé music e suas derivações. Este conflito, no entanto, além de étnico e social, se configura antes de tudo como estético, cultural. Assim, as proibições destas manifestações de negros escravos advindas dos poderes públicos, que se processaram desde a colônia até a república, se transformariam, por vezes, em negociações, "indicando que os contatos culturais engendrados no interior da vida social, iam além dos decretos daqueles que detinham o poder econômico e político" (SANTOS, 1996, p. 70).

Aos efeitos deste estudo, buscamos compreender os fenômenos sociais em que a presença da cultura negra e as articulações daí advindas podem guardar sutis estratégias de negociações com vistas à aceitação e legitimação de seus elementos estéticos, contribuindo assim para um pensamento não de apropriação ou mesmo assimilação da cultura negra pelos brancos, mas sim de negociações, sejam harmoniosas, sejam conflitantes.

Voltemos, pois, para o foco da discussão no que se refere ao êxito alcançado pela intérprete baiana/brasileira neste cenário.

No terceiro álbum de Daniela, Música de rua, lançado pela Sony Music em 1994, a intérprete continua com o discurso marcado por 
um tom de transformação, particularmente na faixa título, Música de rua, cuja autoria compartilha com Pierre Onasis. A canção aponta para uma alegria agora, agora e amanhã [...]. Refere-se a uma alegria que é minha, fala que declara a revolução, principalmente, através da dança e da música. Mas uma alegria também contida na arte de um povo que invade essas ruas de clave e sol e de multidão, que bem pode ter o Carnaval como representação desta alegria. Na faixa dois, Vulcão da liberdade (Tonho Matéria) a intérprete mantém o diálogo com o Ilê Ayiê numa canção cuja letra constrói a metáfora do Ilê como um libertador no combate à pobreza e à miséria. Na terceira faixa, Alegria ocidental, com letra da intérprete em parceria com Liminha (produtor deste álbum), mais uma vez presente em suas letras, a dança e a música são indissociáveis na Bahia e no Carnaval. Vivo dizendo que é bom/danço morrendo de rir/canto pra você me seguir/se quiser, se quiser. Em Tem Amor, também parceria de Daniela e Liminha, a programação eletrônica aparece ainda de forma tímida pelas mãos de Liminha e Ramiro Musotto. Em Batonga (Saudade) a moderna música africana se faz presente na composição da cantora e compositora nigeriana Angelique Kidjo, numa versão de Daniela.

Entretanto, em Rosa, de Pierre Onassis, a performance vocal de Daniela se apresenta de forma romântica para se declarar ao amor de uma Rosa embalada pela batida do Olodum - alegria cidade a cantar Salvador. Em O reggae e o mar, de Rey Zulu e Daniela, o samba reggae se faz presente numa analogia entre o reggae e o mar, já que ambos balançam o corpo. Em Rap repente, uma parceria com músicos da banda numa letra da intérprete, Daniela estetiza o rap num lugar chamado Bahia, mas circulando pelo Rio que samba no pé da baiana cujo mar de gente canta São Paulo. Aponta que o tempo samba na voz de João, referindo-se ao deslocamento rítmico provocado pelo seu canto falado em diálogo com o violão, bem como ao samba como ícone nacional e Carmen Miranda como representante da alegria e da tropicalidade. O Brasil pode ser uma banana; seu povo tem que plantar bananeira para sobreviver; quer outra coisa, a gente quer a música, a gente quer o samba, a gente quer o Brasil, diz ela num protesto escancarado. 
Em Domingo no Candeal ${ }^{8}$, de Lucas Santana e Quito Ribeiro, a letra faz uma brincadeira com a palavra Timbalada e outras de sons semelhantes, resultando numa rítmica bastante interessante, ao mesmo tempo em que descobre como se apresentam os timbaleiros com signos distintivos como tênis Reebok, relógio Shock, refletindo assim a imagem de Brown e seus discípulos timbaleiros espalhando espelhando a figura do Brown, que toca domingo de tarde no Candeal. Faz uma analogia entre o (Tim)baleiro e a baiana representada com seu tabuleiro carregando chocolate Chokito, Prestígio e (chiclete) Ploc.

Mais uma vez, Herbert Vianna comparece com uma balada, Sempre te quis, no álbum da intérprete, reforçando o diálogo com o pop nacional. A Bahia retorna na faixa Folia de Reis, de Carlinhos Brown e Alain Tavares, com um samba de roda elétrico com timbales e a programação de percussão de Ramiro Musotto, conferindo um vigor pop à canção. Finalizando o álbum, a artista mais uma vez reverencia seu (Por) amor ao Ilê, na composição de Guiguio, com participação especial do bloco afro-pop Vulcão da liberdade e dos filhos Gabriel e Giovanna no coro infantil.

A produção gráfica deste álbum, com fotos de Cláudio Elizabetsky e direção de arte de Carlos Garcia reflete Daniela laureada por uma pintura que pode nos remeter a uma aquarela cheia de cores, bem como a uma multidão. No encarte interno do álbum, percebemos pessoas comuns em fotos de crianças, casal, guarda, fotógrafo clicando modelos, cenas de rua. Na contracapa, Daniela aparece girando o corpo e sendo observada por diversas pessoas anônimas. É o que a artista considera música de rua.

Neste terceiro álbum, Daniela fecha uma trilogia e inicia uma outra que aponta para uma interface de gêneros em que se constitui a axé music, sem, no entanto, repetir os modelos já cunhados principalmente pelas bandas e seus respectivos blocos. É relevante observar que, a partir de 1993, Daniela passa a puxar o bloco Os Internacionais, primeiro da fila no desfile da Avenida, ficando até 1995, quando desce com o Crocodilo para a área conhecida como Barra-Ondina. Mas é em 1986 que a artista, como puxadora do bloco Eva entra para os circui- 
tos dos grandes blocos do Carnaval de Salvador. Daniela já assume o gerenciamento de sua carreira, sem a assessoria de Jorginho Sampaio, e funda a sua produtora $O$ canto da cidade, a editora musical Páginas do mar e seu estúdio Canto da cidade, onde parte deste álbum é gravada. Neste mesmo ano, 1993, faz sua estreia em solo europeu e nos Estados Unidos, cantando no The Ritz, em Nova York.

Já dona do seu próprio negócio e senhora do sucesso, Daniela parte para o seu quarto álbum solo, Feijão com arroz, em 1996, um divisor de águas em sua carreira, porquanto a crítica se rende ao seu talento e gerenciamento musical. O álbum chega com um orçamento generoso da Sony e pré-produção e arranjos de base e de sopro das mãos do maestro e tecladista Alfredo Moura9 .

O elemento percussivo é bastante presente neste álbum, em diálogo perfeito com o pop, o samba reggae e o samba e suas infinitas possibilidades, que se traduzem também em ritmos africanos como a soca. A faixa que abre o álbum - Nobre vagabundo, de Márcio Mello apresenta uma Daniela romântica, iniciando a faixa unicamente com sua voz, que desemboca num samba reggae romântico costurado por uma guitarra havaiana/caribenha, investindo assim num romantismo livre, sem amarras. A intérprete brinca com as notas musicais em oitavas, no grave e no agudo, pedindo: perdoa, meu amor, esse nobre vagabundo.

Em Rapunzel, de Carlinhos Brown e Alain Tavares, com arranjo de Alfredo Moura e Brown, Daniela/Brown faz uma analogia do amor de Julieta e Romeu igualzinho ao meu e o seu. A abertura com a guitarra trash de Roseval Evangelista, lembra os solos de Armandinho no trio elétrico. Com um naipe de sopros que vão do clarinete à tuba, instala-se um diálogo polifônico entre todos os instrumentos em momentos distintos. A interpretação de Daniela nesta canção exige muito vigor e controle vocal devido também à forma como as palavras se organizam na canção.

Com Rapunzel, Daniela/Alain/Brown conquistam o prêmio de melhor música do Troféu Dodô e Osmar (1996). A parceria entre Daniela e Brown normalmente aponta para sucessos mercadológicos e novas 
experimentações sonoras que se (re)configuram desembocando no Carnaval baiano. Na faixa Minas com Bahia, de Chico Amaral, Daniela trava um diálogo com Minas Gerais representada pela música pop de Samuel Rosa, vocalista do grupo mineiro Skank.

Em Feijão de corda ${ }^{10}$, do seu baterista Ramon Cruz, com arranjo de Daniela, Tony Mola e Letieres Leite, a intérprete encarna um samba de roda numa sonoridade tipicamente nordestina aportada pela sonoridade dos pífaros de Letieres, pelo flautista da orquestra sinfônica da Bahia, Tota Portela, e pelo acordeom de Cicinho. A percussão, também bastante presente nesta canção, bem como o violão de doze cordas, reflete a temática da letra numa analogia do feijão de corda, feira, com o amor. Nesta canção, o clipe exibido em canais como a MTV tem coreografia de Débora Colker ${ }^{11}$, mostrando uma Daniela brejeira, numa coreografia cheia de signos que remete à cultura popular do Nordeste.

Na gravação de Você abusou, da dupla baiana Antônio Carlos e Jocafi, Daniela participa também como arranjadora ao lado de Alfredo Moura e Ivan Huol no sentido de usar o samba reggae de forma a dialogar com a gafieira. Com um solo de bandolim de Armando Macedo, a canção enriquece em sonoridade, com um naipe de sopros dando o toque na introdução e no final e com o coro entoando o refrão. Ao dialogar com o naipe no final da música, Daniela imprime o canto barroco na axé music que será mais bem discutido ao final deste capítulo.

No samba de roda de Neguinho do Samba, Dona Canô, com arranjo de Neguinho, Daniela e da Banda Didá, que divide a instrumentação desta faixa com Armando Macedo, a artista se mostra à vontade numa reverência a Santo Amaro e sua famosa matriarca, mãe de Caetano e Bethânia. Mas é com a canção À primeira vista, do compositor paraibano Chico César, que Daniela invade a tela da Globo, fazendo parte da trilha sonora da novela $O$ rei do gado. Em Vestido de chita, de autoria da intérprete e do percussionista Ivan Huol, Daniela brinca com a palavras terminadas em "x" Marinex my baby fique relax, só vou no seu sex de jontex prá frentex, apontando para uma preocupação como o sexo seguro, campanha que depois fará parte do seu discurso como 
embaixadora do Fundo das Nações Unidas para a Infância - UNICEF. Ainda nesta canção, mais uma vez, aparece a voz de sua filha em duo com a artista, que na época contava dez anos.

Mais uma canção de Márcio Mello ${ }^{12}$ aparece neste álbum: Bandeira flor. Com arranjo de Alfredo Moura, um ijexá com participação de Pepeu Gomes ao violão, mais uma vez o naipe de sopros no arranjo de Alfredo Moura costura a canção, imprimindo diálogos com a voz da intérprete e a percussão.

Na última canção do álbum, Vide Gal, um samba-enredo carioca de Carlinhos Brown numa analogia da favela carioca Vidigal e Gal Costa, com arranjo de Rildo Hora e Alfredo Moura, Brown e Daniela apontam para um canto ufanista e ao mesmo tempo dramático do Rio que pode ser amortizado pelas belezas do lugar. Também nesta faixa aparece, no próprio arranjo, o diálogo entre o samba carioca e o samba baiano. No próprio "laiá laiá" de Ivan Huol, pode-se observar as "diferenças" culturais entre os dois tipos de samba, que convivem de forma harmoniosa nesta síntese musical.

Feijão com arroz é um marco em termos da entrada de Daniela no mercado internacional, tornando-se um fenômeno de vendas em Portugal. O encarte deste álbum, de Gringo Cardia, com fotos de Mário Cravo, assinala um diálogo inter-racial significativo na carreira da intérprete, denotado pelo próprio nome, alusão à mistura perfeita entre dois alimentos que se configuram no cardápio mais consumido no Brasil/ Bahia, mistura encontrada em toda casa de todas as classes sociais. No interior da capa, podemos perceber as fotos de bancos encontrados nas barracas das festas populares de Salvador, empilhados em cores e desenhos diferentes, além de fotos da intérprete exibindo parte do pescoço e do colo, bem como do modelo exibindo as costas. O que necessariamente se quer exibir são músculos femininos, numa alusão à força que o gênero encerra, independentemente do grupo étnico.

Neste álbum Daniela revela-se uma intérprete madura, segura. Sua performance cada vez mais irretocável atinge o máximo de profissionalismo que uma artista baiana/brasileira pode alcançar no ambiente do show bussiness nacional/internacional, chegando a 
despertar uma matéria do New York Times quando da passagem por lá com o Feijão com arroz, comparando Daniela a Janet Jackson, chamando a última de "batata quente" ao ver a performance da baiana brasileira no palco.

Assim, Daniela torna-se a segunda ${ }^{13}$ artista a receber o título de um novo ícone brasileiro. Em sua décima primeira turnê internacional em 2006 entre Europa, Estados Unidos e Canadá, e com mais de dez milhões de discos vendidos em todo o mundo.

Somente depois de consagrada no Brasil no início da década de noventa, Daniela amplia o reverberar do seu canto, inicialmente para a América Latina, tornando-se um fenômeno em vendas e execução, ampliando seu raio de ação para outros continentes, demonstrando a pretensão de atingir diversos públicos, num constante diálogo de referências identitárias tendentes aos trânsitos (GILROY, 2001).

Apontando sempre para o novo na busca incessante pela experimentação musical performática plugada no mundo e na ocupação de novos lugares, Daniela parte para mais uma transformação espacial ao "descer" com o bloco Crocodilo14 para a Barra-Ondina em 1996, momento que coincide com uma "nova" formatação organizacional do Carnaval, na gestão da Prefeita Lídice da Mata. Junto a outros segmentos de organizações carnavalescas, sindicatos, EMTURSA, BAHIATURSA, Polícia Militar, totalizando 24 representantes, a partir de 1993. "A administração municipal passa a privilegiar os espaços de articulação entre os diferentes atores do Carnaval, democratizando as relações institucionais e os processos relacionados com os festejos" (MigUeZ OLIVEIRA, 1996, p. 151).

Segundo ainda Miguez Oliveira (1996), os efeitos desta organização já podem ser percebidos no Carnaval de $1994^{15}$, coincidindo também com a abertura de vendas de espaços publicitários no sentido de captação de recursos para a viabilização da festa, bem como a ampliação do espaço da festa que a partir da década de noventa, com a expansão dos blocos de trios, "força" não só a ampliação do espaço fisco, criando o circuito Barra-Ondina, bem como a ampliação do calendário da festa que passa de quatro para 6/7dias. 
É neste ambiente que Daniela empreende mais uma de suas ideias ousadas: criar o Camarote ${ }^{16}$ da Rainha.

Em 1996, tive a idéia de fazer o meu desfile na Barra e convidei o bloco Crocodilo para esse desafio. Poucos trios e blocos faziam o percurso do Farol da Barra à Ondina, que para mim, sempre foi uma extensão natural da Avenida Sete. Queria convidar todo mundo para assistir ao novo desfile. E assim nasceu o camarote. (MERCURY, 2005, p.7).

Voltemos para a produção fonográfica da artista. O seu primeiro álbum gravado ao vivo no Solar do Unhão em 1998 - Elétrica, produzido também por Alfredo Moura, que assina a direção musical e os arranjos, assinala já na capa do álbum para uma Daniela mais sensual, mais mulher, com cabelos longos cacheados e revoltos ao vento e com fartos seios cobertos por um vestido branco transparente, desenhando as formas da baiana sensual e voluptuosa. Com Elétrica Daniela inicia a trilogia que segue com Eletrodoméstico, desembocando com Eletrônica. Numa homenagem ao frevo elétrico, este álbum busca a sonoridade do Carnaval baiano elétrico.

Regravando sucessos da carreira como $O$ canto da cidade, Música de rua, Swingue da cor, O mais belo dos belos e O reggae e o mar, Daniela continua assessorada pelos músicos que a acompanham desde o inicio da carreira solo, imprimindo mais uma vez neste álbum músicas inéditas cujo balanço do samba reggae, embebido de elementos pop, seja no timbre da guitarra de Alexandre Vargas, nos teclados de Mikael Mutti e Alfredo Moura, no baixo de Cesário Leony e na percussão de Beto Rezende, Gustavo de Dalva e Leonardo Reis, na bateria de Marcelo Brasil e nos sopros de Rowney Scott e Joatan Nascimento, coloca mais uma vez no topo do sucesso canções como Terra festeira, de Alain Tavares e Gilson Babilônia, que mais uma vez se reporta à Cidade da Bahia, Cidade da poesia, como uma cidade que canta e povo que dança/faz festa pro mar. Neste arranjo, o diálogo da guitarra com os sopros na introdução da música e a guitarra de Alexandre Vargas imprime um ritmo híbrido por vezes lembrando um galope em ritmo 
mais acelerado, por vezes um fricote, ou ainda a moderna música africana da juju music, trazida para nós pelo grupo Obina Shock.

No entanto, com a faixa título Elétrica, de sua autoria, num galope vigoroso, Daniela já demonstra o que será este álbum retrospectivo imprimindo pleno vigor vocal, controlado, associado ao vigor coreográfico que é característica desta "voz que dança”. Em pleno domínio, percebe-se uma menor emissão vocal para um maior controle de ar expiratório para manter a afinação aliada à coreografia. Na letra que mistura línguas como o alemão, inglês, italiano e português e mensagens distintas que se refere ao código e Micro, ao livre arbítrio, o clone e Deus termina suplicando: Bitte please, por favor Move your body.

Outras regravações presentes no álbum são: Você não entende nada ${ }^{17}$, de Caetano Veloso, presente no seu segundo álbum solo, e Toda menina baiana, de Gilberto Gil, comparecem como uma reverência a dois grandes ícones da música baiana/brasileira.

A homenagem da estrela prestada ao bloco Crocodilo se faz presente na parceria com o marido da artista na época, Marcelo Porciúncula; Alfredo Moura e Renan Ribeiro, para o frevo Trio metal, já apontando uma canção/sonoridade como um rock plugado no mundo inteiro, partindo do mundo, regionalizando o que é mundializado e mundializando o regional.

O frevo elétrico já prenunciado pela dupla de inventores/músicos Dodô e Osmar, ainda na década de cinquenta do século Xx, aponta para novas sínteses sonoras com o frevo pernambucano, cuja sonoridade de instrumentos se constitui de sopros e percussão. Com o frevo elétrico de Dodô e Osmar, transmitido de herança a Armandinho, Daniela diz: quero ver, quero ter o som do trio elétrico de Osmar e de Dodô e o som da guitarra de Armandinho. Esta canção poderia ser considerada uma síntese do Carnaval como um grande concerto, em que a tecnologia dos novos trios elétricos, palcos ambulantes com toneladas de watts reverberando pelas ruas da cidade, ecoam um rock prensado pro Carnaval balançando um povo inteiro na voltagem do Farol. Ao apontar na letra da canção no sentido de ter um futuro aquecido num gerador de estrelas, este gerador tanto pode se referir à máquina 
que gera energia para o pleno funcionamento do trio e sua parafernália eletrônica como ao trio elétrico e ao Carnaval como ambiente propício ao surgimento de estrelas do/no Carnaval.

Assim, Daniela vai se constituindo na rainha da axé music, eleita pelo séquito de fãs que a acompanham por diversos centros, no Brasil e no exterior, bem como pela imprensa especializada, que reconhece sua posição de destaque neste ambiente. Por certo, este título é também reivindicado pela primeira estrela considerada da axé music - Sarajane. Entretanto, quem efetivamente "abre as porteiras" deste gênero para o Brasil e para o mundo, segundo cronistas e uma parcela da crítica, é Daniela.

A rainha da axé music

Ela é dona do jogo

Ela é dona da banca

(Robson Pacífico/ Aleh)

Ao entoar para a Bahia e para o Brasil A cor dessa cidade sou eu, o canto dessa cidade é meu, Daniela já aponta para si um lugar de destaque no ambiente da axé music e do Carnaval da Bahia, transformando a folia num reinado de alegria, dança e som que pode ser percebido também na forma como recebe o povo e seus convidados no seu camarote. Uma rainha necessita de um espaço para receber seus súditos mais nobres em um reservado que possa aplaudi-la no momento em que, ao mesmo tempo em que se mostra para os nobres sempre com um convidado - também célebre - a tiracolo, ela os recebe com carinho.

Em $O$ canto do Carnaval $^{18}$ (2005), edição comemorativa dos dez anos do seu camarote, lançado em 2005, podemos traçar uma leitura descritiva do percurso da rainha, não só pelos súditos/célebres recebidos, como também pelos seus trajes de gala para o Carnaval, sempre assinado pelos estilistas mais prestigiosos do Brasil. No mesmo ano do lançamento do livro, Daniela brinca com o título de rainha do 
axé e convida vários estilistas para vestirem a rainha no Carnaval. Dentre estes, estilistas baianos como Márcia Ganem, Souddan e Kaveski, bem como estilistas nacionais como Glória Coelho e Walter Rodrigues, dentre outros.

Podemos observar, nessa edição, a diversidade de "coroas" ou similares, exibidas na cabeça da rainha ao longo dos anos de desfile. Estes adereços vão desde enormes tranças rastafari (capa) ao adereço em forma de estrela na página 3, como uma deusa inca adornada também nos braços e antebraços. Na página 6, podemos observar a rainha com uma coroa de canudos coloridos de refrigerantes, adornada com correntes que caem pelo lado da testa e bracelete também prateados, brincando com o próprio adorno que pode ser confeccionado de qualquer material, contanto que sirva para enfeitar a cabeça. Na página 10, ao lado do então ministro-artista Gilberto Gil, vemos a rainha adornada por um vestido marrom com tachas nos braços e ombros. Na cabeça, dentes e nós amarrados do mesmo tecido do vestido.

Na página 24, podemos perceber a rainha com uma espécie de cocar preto, também com correntes prateadas ao longo dos cabelos; com a irmã Vânia Abreu, Daniela se mostra na página 30 como se fosse uma deusa grega num adorno na cabeça discreto, mas presente; na página seguinte, ao lado da cantora Elba Ramalho, a estrela se veste de tecidos dourados e terra, com um adorno na cabeça, trançado de cores amarelo e vermelho.

Já na página 32, uma índia estilizada com um enorme cocar de penas que pende pelas costas mostra uma rainha moicana, numa alusão aos blocos de índios tão presentes no Carnaval da Bahia das décadas de sessenta/setenta. Na página 36, como que descida do Olimpo, a estrela deusa lunar se mostra embebida de beleza; não uma beleza cândida, mas sim uma beleza sensual preenchida por um grande decote no vestido vermelho e um par de "asas" vermelhas, como que pousando no Carnaval da Bahia. E, numa pose de agradecimento aos céus, reverencia com a mão direita, já que a esquerda se encontra preenchida pelo microfone. Mostra-se perfeita, sem defeitos, plena, estrela-deusa. 
Podemos observar na página 47 uma Daniela em seu camarote vestindo um tomara-que-caia dourado, com adereços adornando os braços e, na cabeça, uma pena também dourada. Mais uma vez, o motivo indígena presente em sua indumentária. Na página 67 , a estrela se exibe juvenil, límpida e serena num momento de "descanso" num vestido com motivos étnicos e acessórios tais como colares e pulseiras de búzios, numa alusão ao universo africano. Este é um dos raros momentos em que a rainha se apresenta sem coroa; talvez por ser um momento de descanso. Afinal, ser rainha também cansa... Entretanto, na página 69, como que revigorada, a rainha, da sacada do palácio/trio, agradece ao seu "povo", de braços abertos, inteira, plena e esfuziante como que demarcando seu espaço: "o samba é meu chão, meu hino nacional, minha forma de oração o meu Carnaval” (Quero ver o mundo sambar, de Daniela Mercury, 2004).

Emblemática é a aparição da intérprete ao lado da top model brasileira e internacional Gisele Bündchen em cima do trio elétrico, em $2003^{19}$. Usando figurino de Fause Haten, Daniela, com 1,60 metros de altura, e comparada à top, necessita de adereços que possam mostrar a artista com mais estatura. Isto se resolve pelo enorme cocar de moicano aplicado sobre sua cabeça, além de sandálias de enormes plataformas, usuais no seu figurino. Na página 79, abraçada ao poeta baiano Wally Salomão, a rainha do axé exibe trancinhas africanas enroladas em cordão, laureadas por uma discreta coroa dourada. Afinal, a estrela já não precisa ostentar coroas vistosas, pois o seu título já está conquistado.

Podemos observar o que nos aponta a foto da página 81 da mesma edição. A rainha desce do seu trono e se junta a outro rei das sínteses musicais/performáticas, Carlinhos Brown ${ }^{20}$ e seu camarote andante, e juntos "puxam" os súditos pela avenida afora "disfarçados" apenas por enormes óculos escuros. Já na página 85, em seu camarote, Daniela canta com um regional sambas e canções do seu repertório, envolta num vestido com enormes flores bordadas, e na cabeça uma discreta tiara preta com franjas caindo sobre a testa. 
Mas é na página 91 da edição que podemos observar a rainha através da foto, exibindo um/a discreto cocar/coroa estilizado/a, apontando para uma índia/rainha contemporânea, com discreto piercing no nariz e unhas pintadas de vermelho escuro, numa demonstração de que todos os signos são permitidos, sendo a mistura a tônica não só no que se refere à música, mas à própria indumentária, pois, segundo a rainha: "eu não tenho cenário no trio, a roupa tem que ser meio cenográfica, ela tem que enfeitar" (Entrevista coletiva para a imprensa gravada pela autora em 2 de março de 2003, no camarote da artista).

Assim, a "rainha" aponta para o papel do figurino na apresentação do Carnaval, tendo a função não só de enfeitar, como também de destacar, de distinguir, de chamar atenção para a roupa no corpo de uma rainha, pois o figurino serve para adornar este corpo perfeito, sem falhas ${ }^{21}$ (mesmo esculpido por cirurgias estéticas e lipoaspiração, próteses de silicone, maquiagens e adornos). O que os fãs/súditos/ foliões querem é admirar a rainha em sua perfeição apolínea, cuja noite serve para esconder/realçar os brilhos/opacidades desta figura emblemática que é a rainha da axé music, Daniela Mercury.

Passemos ao próximo álbum da artista, Sol da liberdade, gravado em 2000, que experimenta de forma mais declarada a sonoridade da música eletrônica, coincidindo também com a saída do trio tecno pela primeira vez no Carnaval de Salvador.

Em turnê deste álbum por 12 cidades norte-americanas, além da Europa, Daniela declara à Revista TV Guia, em Lisboa22: "a minha pulsação, a minha respiração, como cantora é no samba que a encontro" Ainda em Portugal, onde matérias em jornais e TVs demonstram a popularidade alcançada pela artista, podemos observar notas e críticas do show correspondente a este álbum tais como a do colunista português do Jornal 24h, Jacinto Velhote (2000), que comenta: "Mesmo quem não é fã de Daniela Mercury tem de lhe reconhecer mérito, pois conseguiu durante grande parte do concerto por os espectadores num estado de inquietação total". Ainda no mesmo jornal: "A brasileira usou e abusou de dotes de dançarina para cativar os 5 mil espectadores, num concerto em que rompeu com as sonoridades do passado" 
Nos Estados Unidos, a passagem do "furacão baiano" deixou rastros registrados pelo jornal americano Los Angeles Times, que comparou a cantora baiana a Tina Turner (performance), Catherine Zeta-Jones (classe) e Madonna (sensualidade) ${ }^{23}$. Na Alemanha, o álbum estreou em $13^{\circ}$ lugar da parada da revista Music Woche, tida como a Bilboard alemã.

Primeiro álbum gravado da artista pela BMG, depois de sete anos com a Sony, Sol da liberdade aponta para a via eletrônica, mas também para a tradicional MPB, segundo declaração da própria artista ao repórter Carlos Correia (200o), da revista portuguesa Nova Gente. Na mesma revista, Daniela fala deste álbum e da participação de Milton Nascimento dividindo os vocais com a intérprete na faixa de sua autoria, Sol da liberdade, cuja letra reporta a um verso do Hino Nacional brasileiro "onde se fala de uma democracia de uma maneira leve..." (p.111); além de uma canção de Caetano Veloso e explica que a música eletrônica na Europa não é uma novidade, "mas no Brasil sim. Gosto muito de música eletrônica, dos timbres e dos sons: fiquei com vontade de misturar" (p. 112).

Com este álbum Daniela aponta para uma nova sonoridade. $\mathrm{O}$ título do álbum pode traduzir esta liberdade não só de criar, experimentar, mas principalmente de ir-e-vir, ou até de trocar de gravadora, como declara a artista, na revista supracitada:

[...] foi a necessidade de mudar e por acreditar que, sendo uma companhia nova, me faria uma promoção muito boa. Também porque me foi prometido fazer-se um trabalho promocional em países que venho há uns sete anos tentando tornar conhecida a minha música (p.111).

Assim, Daniela acena para "um grito de liberdade" de expressão musical que pode ser descortinada também através das letras de algumas canções deste álbum, bem como da sonoridade mais plugada no mundo contemporâneo, sem, no entanto, perder de vista a Bahia e a batida do samba reggae, já impressa na primeira faixa do álbum, que prima por uma assepsia sonora no sentido de apontar cada vez 
mais para uma sonoridade glocal (RUBIM, 200o), presente cada vez mais nos seus álbuns subsequentes.

A baiana que Daniela apresenta para a Bahia/Brasil/mundo é uma baiana "groovada" (OLIVEIRA, 2004), com swingue que pode ser reconhecida na letra abaixo.

Quem quer levada tem

Quem quer cocada tem

A massa que rebola

Abará, coca-cola

Quem quer miolo tem

Quem quer crioulo tem

O plug, a lata d'água

Prêt-à-Porter, anágua

Ta no tabuleiro

Ponto com mundo inteiro...

Groove da baiana . Tenisson Del Rey/Paulo Vascon/Jorge Zarath. 2000

Um momento emblemático em sua carreira no período do lançamento deste álbum foi a participação no Rock in Rio, em 2001, ao lado de nomes consagrados como Gilberto Gil, James Taylor e Sting. Vejamos o que nos revela a artista na coletiva do evento, quando indagada pelo Jornal do Brasil, em 12 de janeiro de 2001, a respeito de novidades do show. "Novidade sou eu, que sou sempre uma novidade"24.Continuando a coletiva: "O povo dança com Gil, descansa com James Taylor. E depois eu entro. Estou mal intencionada. Acho que vou dar um jeito de todo mundo sair do chão". Com seis percussionistas em sua banda, afirma a intérprete que "o Brasil é minha matriz rítmica, mas haverá elementos eletrônicos". A grade da programação do palco Mundo, onde Daniela se apresenta, abre o evento às 18 horas, com a Orquestra Sinfônica Brasileira; em seguida, Milton Nascimento, às 19:20 horas; Gilberto Gil, às 20:40 horas; James Taylor, às 22 horas; Daniela, às 23:45 horas; fechando o evento, vem Sting, às 01:05 da manhã seguinte. Este, ao 
encontrar a artista num jantar em casa de Caetano Veloso, diz: "Ah, você é o meu problema de depois de amanhã?".

As críticas ao álbum Sol da liberdade apontam para uma intérprete madura, cheia de personalidade e sensível, segundo palavras do crítico musical e compositor Nelson Motta. Um trecho da crítica:

Uma guerreira romântica

Que Daniela é intérprete vigorosa, poderosa, guerreira, de voz afirmativa, não é novidade: sua carreira foi construída na base desses atributos. No disco, as canções mais alegres, animadas e dançantes, encontram a Daniela de sempre mais segura, mais precisa, com mais swingue ainda. Uma Daniela romântica? Sim, também mais romântica pop, sem melancolia ou sentimentalismo adulto e internacional, tecnológico e cheio de ritmo produzindo um romantismo contemporâneo, tão moderno e atual quanto o que mais o são. Este disco, talvez o melhor da sua carreira, abre novos caminhos para uma intérprete de grande sensibilidade e personalidade, para além das trilhas do samba, do reggae e dos infinitos ritmos e canções que nascem para alegrar, divertir e fazer dançar que a estão levando (e com ela a música e a diversidade brasileira aos palcos do mundo) (MOTTA, 2001).

Paradoxalmente, a capa deste álbum, também assinada por Gringo Cardia ${ }^{25}$, se apresenta como se o Sol estivesse escondido por entre os galhos distorcidos e carcomidos dos mangues. E Daniela se apresenta entre misteriosa e brotando do lodo. ${ }^{26}$

No álbum, Sou de qualquer lugar, gravado entre maio e agosto de 2001 e lançado pela BMG em 2002 Daniela inaugura, com este álbum, de maneira mais efetiva, as incursões no universo eletrônico.

Sou de qualquer lugar: a cor do som

Dialogando com a música pop e a música eletrônica brasileira neste álbum, Daniela grava nomes como Chico Science, Lenine, Gilberto 
Gil, Celso Fonseca, além de três canções de sua autoria, ao mesmo tempo em que carrega no seu canto e no seu corpo a força e o vigor de ser brasileira e internacional a partir da Bahia. Uma prateleira ${ }^{27}$ não é suficiente para atender suas necessidades musicais. Sua preocupação é artística, mas é importante sempre apontar para o novo no seu trabalho - uma Bahia inserida na territorialidade e em diálogo com o global/mundo.

A partir do Brasil e da Bahia, ela quer ser reconhecida no mundo com a sua música. Encontros internacionais têm sido comuns em sua trajetória: Ray Charles (EUA), Alejandro Sanz (Espanha), Rosário Flores (Espanha), Dulce Pontes (Portugal), Jovanotti (Itália), Cirque du Soleil (Canadá). Sua música carrega na sua voz e no seu corpo uma nação como pode ser conferida na canção de Lenine e Dudu Falcão: Eu sou brasileira, eu nasci assim..

Esta afirmação mostra-se perceptível já na capa do álbum, quando a intérprete exibe um visual pop/contemporâneo no corte e na cor do cabelo não mais longos e encaracolados, imprimindo uma latinidad, mas sim uma intérprete do mundo com cabelos em desalinho de mechas de cores diversas indo do castanho escuro ao louro médio, e uma maquiagem cujo olhar denota certo ar de mistério, ao mesmo tempo sensual ${ }^{28}$ através dos lábios entreabertos num batom cor de boca, carnuda, como a se oferecer para o ouvinte. No encarte do álbum, fragmentos de fotos como se estivesse, numa delas, no "topo do mundo", em outra, uma parte de um avião se mostra como um meio de transporte para qualquer parte do mundo; em outra ainda, uma antena parabólica se mostra como instrumento de captação e transmissão de sua imagem/voz para "qualquer lugar", sem ruídos; em outras fotos, o seu corpo também serve de ilustração para um "não" lugar determinado, assim como a foto de um retrovisor, bem como de uma estrada vista de dentro do carro. Onde daria esta estrada? Ou ainda, para que serve esta estrada? Para ligar um lugar a outro, sem fronteiras.

Ainda no interior do encarte, podemos observar um cartaz com palavras em diferentes línguas que podem ser decodificadas como 
"local, nacional, internacional", etc; na contra-capa do encarte observamos uma Daniela numa foto "em qualquer lugar" exibindo suas pernas perfeitas, mas com o rosto encoberto pelos cabelos, como que encobrindo uma identidade. No compartimento interior do álbum, onde o CD é guardado, apresentam-se duas fotos em posição de valete, exibindo o corpo/pernas desnudo/(en)coberto por um tecido azul, em um olhar carregado de mistério exibido pela maquiagem pesada e escura, encoberta por uma semi-franja que cai em cima de um dos olhos. Para finalizar a análise das fotos deste álbum, observamos duas fotos do compartimento exterior, exibindo Daniela em foto da cintura para cima de biquíni preto e coleira prata colada ao pescoço e cabelos longos em desalinho que se "mostra" impassível, longe, mas imponente.

Atentamos, então, para a análise de algumas letras/músicas/vozes deste álbum. A canção que abre o álbum pode servir e ilustração para que possamos compreender um pouco da proposta estética/artística/ identitária deste álbum. Daniela anuncia ser a própria nação.

Sou de qualquer lugar

Sou minha nação

Tenho somente o sonho

E o mapa do mundo em minhas mãos

Por onde eu passar

Vão lembrar de mim

Finco minha bandeira

Eu sou brasileira, eu nasci assim...

Sou de qualquer lugar. Lenine e Dudu Falcão (2002).

Segundo relato da artista, esta canção

Foi um arranjo feito por minha banda junto com o produtor da faixa ${ }^{29}$. É um funk com harmonização bem característica de Lenine, até um pouco triste a harmonia, lembra o repente nordestino, é uma característica de um tipo de Música brasileira 
que a harmonia é um pouco tristonha, e uma música vibrante. Sou de qualquer lugar é um rap com a harmonia que Lenine me mandou. E a guitarra é de Davi Moraes, que vem pesquisando esta sonoridade baiana e que pra mim dá um colorido bem diferente de timbragem (MERCURY, 2003a).

Em Baiana havaneira, de Carlinhos Brown, o arranjo para uma letra cheia de metáforas mostra que a influência cubana é também presente em nossa música. A descrição de Daniela a respeito do processo de produção/gravação desta faixa:

A gente no Brasil tem uma influência da música latina de Porto Rico, de Cuba, da música caribenha desde o começo da música popular brasileira. $\mathrm{O}$ tango influenciou a música brasileira desde que houve um tipo de intercâmbio entre a música latina e brasileira. Eu sei que o ritmo de Baiana havaneira é do século passado, chamado maxixe. Nós aqui temos a dança de salão chamada de gafieira, e maxixe é um gênero de música de salão com influência latina. [...] quando eu recebi a música das mãos de Carlinhos Brown era uma guajira. Então, chamei o maestro Fred Dantas e ele disse: “Dani, dá pra colocar um maxixe?" E Baiana havanera foi feita assim. O baixo, o teclado, os pratos, a guitarra são tudo da estrutura do maxixe; a única intervenção que nós fizemos mais atual foi da percussão que entra nos espaços, e depois, eu fiz uma pós-produção mudando os timbres de voz, botando um som mais envelhecido, diferente, prá ficar divertido aquilo e soar mais contemporâneo, mais novo, não soar revival. A gente utilizou carrons para dar outros sons de percussão (2003a).

Já a faixa 3, Praieira, de Chico Science, criador do movimento Mangue Beat, cuja síntese do rock com o maracatu e o coco, para citar alguns ritmos mais emblemáticos da nordestinidade, se constitui em divisor de águas na nova música pernambucana. Com produção de Ramiro Musotto, esta faixa, segundo a intérprete, tem uma reação muito positiva nos shows fora do país. Com coreografia vigorosa que 
por vezes lembra o maracatu e o frevo, imprime uma performance vocal/corporal de palco característica no que se refere também à própria divisão rítmica do texto.

Vejamos o relato da intérprete acerca da produção/gravação da canção Praieira.

[...] é um samba reggae. Eu brinco dizendo que é um samba reggae de branco. A gente pegou a célula principal (eu já venho a alguns anos pesquisando se a gente precisa pra fazer um ritmo de todos os elementos que compõem o chamado samba reggae, por exemplo). Se o Olodum toca o samba reggae original, com surdos, vários repiques fazendo desenhos diferentes, mais o tarol que é igual, então, a gente já não repete muitas vezes, com toda essa estrutura. A gente bota meio surdo, pois já temos o baixo. Pois se eu botasse a quantidade de surdos, esses desenhos, eles ocupam muito espaço de graves, ficando sacrificados na hora de colocar os instrumentos harmônicos. A voz, às vezes, fica "afundada" por conta dos graves, então não é muito fácil repetir o samba reggae como ele é (2003a).

Assim, o samba reggae de Daniela se mostra para o ouvinte de forma diferenciada, valorizando células rítmicas contidas no gênero, mas que de maneira sutil se apresenta em suas canções, buscando assim construir uma sonoridade local/global cuja experimentação e sutileza se faz presente de maneira especial para determinados ouvintes que conhecem mais a fundo os códigos musicais presentes no universo da música pop baiana/brasileira.Vejamos, mais uma vez, o relato da intérprete acerca deste processo de criação.

Ao longo dos meus discos, fui fazendo o samba reggae de várias formas diferentes. Construí nele o elemento principal, que é o balanço dele. Cada hora um instrumento fazendo um elemento, mas não um instrumento que tradicionalmente, originalmente faça. E até outros comportamentos, com outras interferências que não originárias, que não são da estrutura do samba reggae. (2003a). 
Em Beat lamento, mais uma vez, Daniela grava um dos seus compositores baianos favoritos, presente em outros álbuns: Márcio Mello, que mistura a palavra beat (batida) com lamento, fazendo uma analogia da batida do coração com o eletrônico. Assim, até as canções românticas entoadas por Daniela se referem ao universo musical/ eletrônico. A primeira parceria com o filho Gabriel se apresenta em Aeromoça, canção que se reporta às concessões feitas ao amor sem, no entanto, deixar de voar. Entretanto, a faixa Mutante, regravação de uma canção de Rita Lee e Roberto de Carvalho com bastante repercussão na mídia, pois é a música de trabalho do álbum, torna-se tema de personagem de novela da Rede Globo e ganha o prêmio de melhor música de 2001, no Prêmio TIM.

Ainda neste álbum, podemos observar um diálogo mais próximo, ainda que eletrônico, com ritmos reconhecidos como nordestinos como o xote de Gilberto Gil Quem puder ser bom que seja. Outro compositor que também está presente neste álbum é Carlinhos Brown nas faixas Baiana havaneira, já citada, e Bora morar. A presença do guitarrista Celso Fonseca também com arranjos de base nas faixas 4,11 e 13, esta última de sua autoria - Nossa música -, revela bastante domínio no uso do seu instrumento, bem como dos timbres elétrico/ eletrônico. Fechando o álbum, Daniela canta um xote de sua autoria, com citação da marcha rancho de Chiquinha Gonzaga Ô abre alas, num arranjo de Letieres Leite.

O que Daniela efetivamente aponta no bojo sonoro/poético deste álbum é a busca de experimentar sons híbridos em diálogos cada vez mais íntimos com o vocabulário da e-music em batidas house, trance, lounge, dentre outras. Assim, retomando a canção Praieira, a intérprete relata que pediu ao produtor que fizesse um samba reggae para pista, para as pessoas dançarem, mas também

Algo meio roqueiro. Nós temos esse sentimento forte, de ataque, é uma música contundente, agressiva, masculina. Depende da forma como ele é tocado, fica mais feminino, mais malemolente, 
mais marcha. Depende da canção, se a canção passeia em cima. Para ele (o autor, Chico Science), é uma música cantada ríspida, quase um rap. Então, ela também colabora pra deixar ainda mais dura sua estrutura. Se ela fosse ligada, faria um contraste. As guitarras fazem riffs com coisas que normalmente não se vê na MPB, (2003a).

Neste sentido, a trajetória da interprete, com pleno domínio do seu processo criativo, aponta para o samba reggae e suas variações, que podem ser observadas também no conhecimento e exigências técnicas/tecnológicas comum em seus álbuns, permitindo assim diálogos e trânsitos no universo da música do mundo - ou como preferem os norteamericanos, world music.

Enfim, em Sou de qualquer lugar, Daniela aponta a diferença deste álbum em relação aos outros na "cor dos sons". Descrevendo como se processa seu fazer artístico, diz:

Eu faço as bases dos meus discos assim: pego a canção, canto a canção várias vezes com a minha banda. Toco a música como ela veio do compositor e a gente vai espontaneamente descobrindo qual o seu sentimento com relação àquela canção. Então, às vezes ela muda do ritmo original que o compositor me manda, para um ritmo que é mais próximo do meu universo. Então, eu posso pegar uma música em inglês, por exemplo, e vou encontrar uma batida pra base que eu me sinta a vontade pra cantar em cima. Então, esta é uma forma intuitiva, espontânea, não é pensada. [...] Normalmente, são criadas as bases com as percussões junto, e eu vou dirigindo o arranjo. [...] Buscando na verdade, sempre me recriar, mesmo sendo do meu domínio, é do domínio intuitivo. Então, tudo acontece naturalmente. É impossível por exemplo, eu cantar um pouco um funk, sem um pouco da divisão do samba. Eu não faço funk como o americano faz. O meu sentimento já é outro em relação a divisão, como eu vou colocar a letra naquele contexto. Espontaneamente, intuitivamente, eu vou fazendo (2003a). 
A criação desta intérprete passa pelo vetor da experimentação, da textura, da vibração, do sentimento transmitido pela canção de forma natural, espontânea, mas com domínio do que se busca, propondo novos caminhos na direção da autonomia no campo da arte, sendo característica a busca por esta autoridade sobre a obra. Alguns fatores são adjacentes para a concretização deste feito, principalmente no que se refere à sua posição perante públicos, empresários, mídia, o poder governamental, a indústria fonográfica, bem como os produtores/ divulgadores desta indústria que permite que o perfil desta artista que gerencia sua obra seja plenamente exercido.

Atentemos para o comentário do divulgador da BMG, Zeca Souza, a respeito dos critérios de escolha de determinadas canções para veiculação em emissoras de rádio no período do Carnaval e fora do período momesco.

São vários critérios. Um critério que eu observo muito é o refrão. Se o refrão for fácil, eu digo, ah, essa vai ser fácil. No caso de Daniela, ela está com duas músicas hoje que o refrão é muito bom. Olha o Gandhy aí e Meu pai Oxalá, que inclusive tem dois refrões muito fortes. Então eu acho que vai muito do refrão. No caso de Daniela, é diferente dos outros artistas da Bahia. Ela já é uma artista que está com a carreira consolidada, internacional. Então, o critério para escolher uma música é muito complicado. A gente não pode observar só o Carnaval, tem que ser uma música pro mundo. Então, Daniela tem muito essa preocupação, de escolher uma música que vai tocar no mundo todo. Que não precisa ser comercial, também não precisa ser muito chique, entendeu? Mas que agrade gregos e troianos (Entrevista à autora em 1 jan. 2005).

Gravado ao vivo em janeiro de 2003 e lançado no mesmo ano, o álbum MTV ao vivo Eletrodoméstico, em parceria com a MTV, num pacote que incluiu CD e DVD, Daniela se cerca de estrelas locais (Carlinhos Brown, Ilê Ayiê e Olodum), grupo de dança do Ilê Ayiê e internacionais: Lorenzo Jovanotti (Itália), Dulce Pontes (Portugal), Rosário 
Flores (Espanha) e grava um álbum/DVD contemporâneo, com uma linguagem pop, também presente no cenário, que por vezes se reportava a uma imensa TV ao fundo, e trocas constantes de figurinos e cenários de maneira ágil, além do piso branco cobrindo todo o espaço da Concha Acústica do Teatro Castro Alves, em Salvador. Produzido por Nelson Motta e pela intérprete, esta álbum fecha o ciclo como já apontado aqui antes, iniciado com Elétrica.

O álbum possui onze gravações inéditas. São 25 músicas no DVD e 18 no CD. Assim, regrava canções de álbuns anteriores como $\AA$ primeira vista, Ilê pérola negra (o canto do negro) e Nobre vagabundo. Como inéditas a intérprete grava compositores considerados da nova geração como Falcão e Marcelo Yuka numa canção que dá título ao álbum, Eletro-doméstico cujos versos cheios de revolta podem ser conferidos: Eletro-doméstico/ eletro Brasil/ eletro selvagem/ futuro que ninguém viu[...]Vem aí um baile movido a novas fontes de energia/ Chacina, política e mídia/ Bem perto da casa que eu vivia; além de Dona da banca de Robson Pacífico e Aleh. Com a canção Mutante, de Rita Lee e Roberto de Carvalho, também gravada neste álbum ganha o prêmio Multishow de melhor música.

Nas palavras de Nelson Motta, "duas artistas brasileiras teriam condições de empunhar uma carreira internacional: Marisa Monte e Daniela Mercury"30 (OLIVEIRA, 2004, p.6).

Neste álbum e DVD, Daniela se consagra artista pop nacional/ internacional, sem perder de vista o samba reggae e seus desdobramentos, apontando assim para um momento especial no cenário da axé music/pop, dialogando com outros lançamentos local/nacional/ global em obras impressas nos trabalhos de Margareth Menezes e Ivete Sangalo, que apontam para uma nova estética musical/sonora produzida na Bahia com sonoridades que flertam com o tecno/eletrônico como vetores da prática artística no axé: Ivete, a partir de Beat beleza (2000); Margareth, a partir de Afro pop brasileiro (2001); e Daniela, a partir de Sol da liberdade (2000).

Assim, estas três artistas baianas/brasileiras plugadas no mundo elétrico/eletrônico refletem caminhos apontados pelo mundo pop 
que, mesmo sendo passageiro, "padronizado", acaba por marcar as idiossincrasias como parte das obras artísticas.

Vejamos depoimentos de Daniela à autora acerca do lançamento do Eletrodoméstico, em março de 2004.

Eletrodoméstico segue um pouco Sou de qualquer lugar, tem uma pesquisa de timbres, mas a pós-produção no estúdio não é tão radical quanto Sou de qualquer lugar. O eletrodoméstico volta a mesclar um pouco a sonoridade de discos anteriores.

\section{O Carnaval eletrônico da Rainha}

Quero ver o mundo sambar

Seja aqui ou seja lá (Daniela Mercury)

Se traçarmos uma analogia entre a revolução musical/espacial proporcionada pela dupla de inventores/músicos Dodô e Osmar na eletrificação do frevo e a "eletronização" do Carnaval de Salvador por Daniela Mercury, podemos observar que o ambiente do Carnaval também pode se mostrar propício a inovações sonoras/espaciais.

Parece que a chegada do novo milênio, especialmente o último ano do século Xx, é bastante emblemático no ambiente do Carnaval soteropolitano e consequentemente na cena musical da axé music. Nesse ano, como já dito, Ivete desponta com o álbum Beat Beleza; Margareth Menezes cria o bloco Os Mascarados e se lança no mercado dos blocos de Carnaval com o diferencial no uso da fantasia em substituição ao abadá, além de lançar o álbum produzido por Carlinhos Brown e Alê Siqueira, Afropopbrasileiro; e Daniela Mercury lança o álbum Sol da liberdade, inovando no Carnaval de Salvador com o trio Tecno e enchendo o trajeto Barra/Ondina com canções antes executadas apenas nas boites e raves: a $e$-music.

Segundo a intérprete, a ideia do trio tecno se apresenta quando de sua participação no Love Parade em Berlim/Alemanha. Saindo aos do- 
mingos no Circuito Barra-Ondina, o trio arrebata um grande número de foliões na "pipoca da rainha" ${ }^{31}$, transformando as ruas do circuito Barra/Ondina numa enorme pista. A artista considera o trio tecno uma "verdadeira jam session onde ela e os músicos experimentam o tempo todo" (MERCURY, 2003a).

Quatro anos depois, em 2004, Daniela lança o álbum Carnaval Eletrônico ${ }^{32}$, espalhando suas ondas sonoras/tecno/digitais, que declara de forma inovadora o registro de canções diversas remixadas pelos maiores DJs brasileiros da atualidade. Tendo como carro-chefe a canção Maimbê Dandá (Carlinhos Brown/Mateus Aléluia ${ }^{33}$ ), Daniela transforma em hit eletrônico uma canção cujo tema transita no universo do candomblé como Maimbê, Oyá, Cosme e Damião, revelando para o mundo contemporâneo adornado pela batida tecno, numa interface entre samba, ponto de macumba e ritmos caribenhos, as diversas possibilidades locais/globais. Estas se encontram sintetizadas também no "samba" eletrônico de sua autoria Quero ver o mundo sambar, cuja proposta é diluir barreiras e fronteiras embalados pelo beat do DJ Renato Lopes.

O samba é meu chão

Meu hino nacional

Minha forma de oração

O meu Carnaval

Todo mundo na palma da mão...

Quero ver o mundo sambar, seja aqui, seja lá...

Quero ver o mundo sambar

Quero ver o mundo sambar. Daniela Mercury. 2004

Este álbum se revela como mais um momento de experimentação em sua trajetória, apontando para a busca incessante, "mutante", de novos registros num ambiente como o Carnaval, cujas experimentações podem se constituir em risco. Ao mesmo tempo, o Carnaval se configura num ambiente propício para a espetacularização do 
cotidiano de vetores da sociedade baiana, também operada em sua música. Assim, Daniela cunha sua singularidade testando sempre um novo híbrido.

Neste sentido, Daniela imprime um aspecto conceitual em seu trabalho, ao mesmo tempo em que recarrega as energias do "seu" samba reggae ao investir na música eletrônica, imprimindo assim, na vida sociocultural da cidade de Salvador, transformações operadas no encontro de tradições culturais diversas, num trânsito que pode ser reconhecido na postura da intérprete diante de sua prática artística, buscando novas formas de fazer música no Carnaval, atuando assim no sentido de se distinguir no campo da música de forma geral, e da axé music de forma particular, atuando com destaque, podendo dessa forma intervir nos rumos da música, sendo também identificada como agente dessas mudanças.

Em Carnaval Eletrônico, a intérprete aponta também para um mercado diferenciado da música, extrapolando fronteiras do/no Carnaval, imprimindo um registro do que vem sendo sua atuação nesta cena, transformando o ambiente do Carnaval numa imensa pista ao ar livre, alimentada pela batida eletrônica do seu trio tecno.

O "teste" final para a "aceitação" deste novo som híbrido apontado pelo eletrônico por Daniela se plasma no Festival de Verão, em $1^{\circ}$ de fevereiro de 2004, quando apresenta este trabalho para um público "acostumado" a outras sonoridades. Sob aplausos de uma plateia entre surpresa e desconfiada, a intérprete revela mais uma vez sua capacidade inquieta e mutante de ir ao encontro da incerteza, do risco e da novidade.

Assim, a música eletrônica fechada nos guetos das boites e raves parte para o ar livre, levado pela "rainha" que, mais uma vez, intervém nos rumos da sonoridade da música popular, apontando para a quebra de limites de gêneros musicais, de espaço ${ }^{34}$, de negociações, contribuindo na transformação do Carnaval num grande concerto pop ao ar livre para uma média de dois milhões e meio de pessoas. Assim, o trio tecno de Daniela, que sai sem as cordas de isolamento no domingo de Carnaval, aponta para a reconfiguração do elétrico de 
Dodô e Osmar, bem como a fusão entre brasilidade/globalidade já apontadas em outros gêneros musicais híbridos aportados no Brasil, como o próprio rock e o reggae.

A interferência do trio tecno na cena do Carnaval de Salvador já é notícia registrada não só nos veículos de comunicação de massa, bem como na carreira da artista que aponta para fusões cada vez mais diferentes, como pode ser conferido na canção Maimbê Dandá.

Corre, Cosme chegou

Doum Alabá

Damião Jaçanã

Pra levar e deixar

Alegria de Erê

É ver gente sambar.

Maimbê Dandá. Carlinhos Brown e Matheus Aleluia. 2005.

\section{Clássica: o retorno}

Já conheço os passos dessa estrada (Chico Buarque/Tom Jobim)

Ao ser convidada para um show seleto no projeto Credicard Vozes no Bourbon Street Music Club em São Paulo, Daniela vai "para o futuro e para o passado. E obviamente vivendo o presente, intensamente, como sempre" (encarte do DVD Clássica, 2004). Gravado ao vivo em 7 de outubro de 2004, pela Som Livre, recebendo como convidados Vânia Abreu e Marcelo Quintanilha, Daniela parte para a escolha do repertório "a partir do meu coração", e mergulha num tempo em que cantar na noite era um exercício de pleno prazer e experimentação. O seu depoimento no mesmo encarte:

Foi com esse repertório que eu comecei a cantar, que descobri que tinha uma voz bonita, e meus amigos me deram este in- 
centivo. E agora eu tenho outros amigos que me incentivaram a rever essa minha trajetória e trazer para o público esse show (MERCURY, 2005).

Com a capacidade de se reinventar, Daniela parte do eletrônico para o acústico, experimentação que também pode ser compreendida levando-se em consideração o próprio trânsito da intérprete por entre outros gêneros, que lhe permite adotar posições artísticas a partir do reconhecimento de sua singularidade pelo público, pela mídia e pelos empresários ${ }^{35}$. Assim, com tiragem limitada, tanto o álbum Carnaval Eletrônico quanto o Clássica apontam "para um projeto especial de uma intérprete já consciente de que a pluralidade é o seu espaço mais apropriado" (BRITO, 2005).

A essa altura, a própria axé music, já aponta para uma nova configuração que extrapola cada vez mais o ambiente único do Carnaval. Daniela Mercury, como uma das figuras mais emblemáticas deste gênero, transita na interface entre o elétrico/eletrônico/acústico, buscando novas formas de fazer música fora das fronteiras do Carnaval. A própria performance/corporal/vocal de Daniela em Clássica revela uma artista também introspectiva, concentrada, cool, diva, cujo repertório exige uma postura desta natureza, posto que os clássicos da MPB como Chico, Djavan, Gil, Jobim, João Bosco e Roberto Carlos convivem de forma harmoniosa com autores contemporâneos como Lenine, Carlinhos Brown, Carlos Lima e a própria Daniela em parceria com o filho Gabriel.

Assim, a intérprete, como aponta Morin (2003), se mostra multidimensional, multifacetada, privilegiando, neste caso, unicamente a canção e o coração - o seu próprio e o de quem ouve canções de amor. O DVD Clássica, numa tiragem bastante reduzida, também distribuído como brinde em seu aniversário de 40 anos [2005], celebra mais um estágio singular da vida desta artista, marcada pelo signo da inquietação.

Passemos então para a análise sucinta do álbum lançado em 2005/2006 pela BMG, Balé Mulato. No encarte do DVD, a intérprete diz: 
O Balé Mulato é uma forma de identificar o Brasil. Eu descobri que mulato era uma palavra que só existia no português do Brasil e que não tinha tradução em nenhuma língua, no máximo uma forma diferente de pronunciar. Mas a palavra tinha uma relação forte com o Brasil. Eu vivo numa cidade que é antropofágica, que olha pro umbigo do Brasil. Desde pequena, tive sempre esse desejo de fazer algo brasileiro, mas completamente aberto pra receber todo tipo de linguagens novas, musicais, estéticas. E eu não me contento com uma só. Como fazer pra sintetizar novas coisas? Tinha que misturar de tudo, estar aberta a tudo. E a cultura brasileira é assim. Ela absorveu a influência européia estética do Barroco. Na maioria do tempo de existência do Brasil, temos predominantemente o estilo Barroco como característica da arte brasileira. E esse palco, pra mim, é um teatrinho mambembe.

No álbum, mais uma vez Daniela se cerca de profissionais como Ramiro Musotto - produção fonográfica, que divide com Alê Siqueira; Gringo Cardia e Mário Cravo, respectivamente capa do álbum e fotos (os mesmos de Feijão com Arroz); e apresenta uma capa que se reporta ao samba enquanto ícone de identidade nacional, misturando o morro com a cidade, as escolas de samba como o samba reggae. Este álbum é considerado por setores da crítica e pela artista como o terceiro volume de uma trilogia começada com Feijão com Arroz (1996) e seguida de Sol da Liberdade (2000).

Vejamos inicialmente a crítica de Márcia Ferreira Luz do jornal A Tarde a respeito do lançamento deste álbum no Canecão - Rio de Janeiro.

Elementos cênicos, instrumentos improvisados, como tampas de panela, baldes e bacias, além de bailarinas que também tocam e interpretam canções com passos e movimentos precisos. No palco, uma rainha que canta, dança, ensaia ginga de capoeira e interpreta cada palavra com uma firmeza visceral que deixa o público extasiado. Nesse clima, com cenário do artista plástico Joãozito e iluminação de Irma Vidal, a baiana 
Daniela Mercury mostrou anteontem e ontem no Rio o espetáculo Balé Mulato em turnê nacional, aberta em São Paulo dia 11. A direção cênica é de Antrifo Sanches e a geral, da própria cantora (LUZ, 2006, p.3).

Este show apresentado pela intérprete já havia sido lançado no Festival de Verão de 2006, em Salvador. No entanto, nem todos os recursos cênicos foram utilizados, por força da própria estrutura do evento, de caráter coletivo. A repórter pontua ainda que:

Apesar de considerada muitas vezes elitista e pouco popular, Daniela mostra, com o espetáculo, que tem intimidade com o que vem das ruas da Bahia e dos morros cariocas, que já serviram de cenário para as fotos do encarte do disco (EMI), produzido por Ramiro Musotto, e do videoclipe. A plasticidade de Balé Mulato ganha força nos detalhes e nos adereços: músicos aparecem de cara pintada, máscara de baile; dançarinas usam saias feitas de bacias de alumínio e aproveitam para tirar som daí com o auxilio de baquetas.[...] Logo na abertura da apresentação, quando se levantaram as cortinas de chita com estampas do morro ao som de Aquarela do Brasil, ela prestou uma reverência à capoeira, com berimbau e muito gingado, para mostrar Levada brasileira (melhor música do Carnaval baiano, 2005). [...] Balé Mulato é um show que cresce na medida em que Daniela se entrega ao público. Tem muita técnica e qualidade, a única coisa que se sente falta é um pouco mais de comunicação verbal da cantora com a plateia no inicio, embora isso se resolva ao longo do espetáculo.

Em Balé Mulato, mais uma vez Daniela transita entre o local e o global quando reverencia o samba ufanista brasileiro do compositor mineiro Ari Barroso, Aquarela do Brasil, em ritmo de chula, trazendo o Brasil para o Recôncavo e para o Nordeste com os pífanos ao fundo, e com vocais de filhas de santo do candomblé do bairro do Candeal, dando a impressão de lavadeiras cantando. O som do berimbau também se faz presente em alguns momentos, bem como o violoncelo 
costurando a canção, ao mesmo tempo em que passeia com o eletrônico em Quero ver o mundo sambar, presente também no álbum Carnaval Eletrônico, numa síntese do samba carioca e o samba baiano, com sutileza na percussão, ao mesmo tempo em que imprime uma levada de samba funk, apontando sínteses já experimentadas na música brasileira. A intérprete, transitando no ambiente sonoro da influência musical afro brasileira, tendo o candomblé como fonte maior, grava Levada Brasileira e Olha o Gandhy aí, já demarcando o "seu" Carnaval eletrônico. De Vinícius de Moraes grava Meu pai Oxalá, apontando fontes que servem de inspiração e que renovam o seu repertório.

As canções que falam de amor e das contradições da vida e do cotidiano também estão presentes em compositores já gravados em outros álbuns, como Lenine com Nem tudo funciona de verdade; Chico César com Pensar em você, presente na trilha da novela Belíssima, da Globo e Márcio Mello com Toneladas de amor. Outras canções, como Topo do mundo, já gravada pelo grupo Cidade Negra, torna-se a música de trabalho deste álbum, revelando mais uma vez onde a artista pretende levar "sua" música, que pode ser metaforizada como o seu grande amor ao afirmar que eu subo o alto da torre só por você... Buscamos na crítica de Hagamenon Brito (2005) uma maior compreensão do projeto deste álbum.

Balé mulato soa como a atualização de Feijão com arroz. O próprio espírito de mix rítmico, de miscigenação do disco de 1996, está presente no projeto gráfico de agora, assinado por Gringo Cardia, com fotos de Mário Cravo Neto. [...] Balé Mulato mostra que Dona Daniela continua com a saudável mania de tentar conciliar mercado e qualidade (BRITO, 2005).

Contratada como atração principal na comemoração dos 60 anos do SESC, Daniela apresenta o show do CD homônimo Balé Mulato no Farol da Barra, em 17 de setembro de 2006, lugar demarcado pela intérprete no evento que promove desde 2000 para celebrar o primeiro pôr-do-som do ano. Nesse show Daniela grava, ao vivo, o DVD do álbum ${ }^{36}$, apresentando também canções pontuais de sua carreira. $\mathrm{O}$ 
público que compareceu ao local do evento, estimado em 30 mil pessoas, segundo nota do jornal A Tarde, se manteve morno e distante.

Entre os pontos altos do espetáculo, esteve o esteio da carreira de Daniela: seu repertório. Bem escolhido, entre representativos compositores baianos da nova geração e da velha guarda, o set list do show Balé mulato fez um elegante apanhado da trajetória da diva e introduziu os sucessos do CD do mesmo nome.[...] Pena que o público recebeu Daniela friamente, e durante o espetáculo - salvo o sempre animado gargarejo, composto preponderantemente por membros do fã clube - não levantou fervura, por mais que La Mercury se esforçasse. A plateia era a figuração do DVD, dirigido por Lírio Ferreira, e agiu como tal: às vezes, até apática e de costas para o palco (ALVES, 2006a, p. 8).

Mesmo priorizando neste momento a carreira internacional, com várias turnês anuais pela Europa, EUA e Canadá, Daniela recebe em 2006 o prêmio TIM de música de melhor cantora regional e melhor cantora pelo voto popular.

Ainda em 2006, lança pela EMI o DVD ao vivo Baile Barroco, inteiramente gravado no Carnaval de Salvador de 2005. Com indicação ao Grammy Latino de melhor vídeo musical versão longa, o registro faz uma homenagem aos 20 anos da axé music pontuados por sucessos da intérprete e do "gênero", em canções como Chame gente e Fricote (com participação especial de Luiz Caldas), passando por Baianidade nagô, gravada inicialmente pela Banda Mel; O canto da cidade, grande sucesso na voz da artista; Pout pourri do Olodum, e, do álbum Trio eletrônico; além de Maimbê Dandá, grande sucesso da intérprete no álbum Carnaval Eletrônico.

O DVD conta também com participações especiais de Fernanda Porto, Banda Kaleidoscópio e Ramiro Musotto. Entretanto, a grande novidade deste registro está na participação do pianista erudito Ricardo Castro, que, ao lado da intérprete, executa clássicos da música como As Bachianas n. 5, de Heitor Villa Lobos, além de trechos da obra de Bach. 
Em estúdio desde fevereiro de 2008 compondo, fazendo arranjos e selecionando repertório para o novo álbum com previsão de lançamento no segundo semestre de 2009, Daniela experimenta neste álbum canções que vêm vendo executadas desde o Carnaval como Oyá por nós em parceria com Margareth Menezes e o Sol do sul em parceria com seu filho Gabriel Póvoas; além de regravações como Tico tico no fubá - esta em homenagem aos 100 anos de Carmen Miranda - O que será, pout-pourri de canções de Dorival Caymmi, dentre outras. Com arranjos de Alfredo Moura e Ramiro Musotto, a artista pretende intitular o álbum com o nome de Canibália.

Assim, Daniela Mercury manifesta sua expressão afirmando categoricamente que a nuclearidade do seu trabalho "é nascida e inspirada na música dos blocos afros da Bahia. O que eu faço é axé, um gênero ainda novo que alcançou respeito nacional e internacional e ainda está em fase em construção, portanto, aberto a novas influências" (ARAÚJO, 2006. p. 40). Neste sentido, as negociações apontadas entre o perfil singular desta intérprete e as instituições/estruturas por onde transita(ou) podem servir para compreender o caráter sutil e difuso da relação entre singularidade e coletividade, bem como o cenário do Carnaval e seus desdobramentos na discussão, tanto no que se refere às práticas artísticas quanto sobre práticas sociais em âmbito mais geral.

Como o Carnaval pode se configurar como ambiente para negociações simbólicas que, por sua vez, podem acontecer a partir de diversos gêneros da cultura pop - afro, reggae, MPB, frevo eletrizado, eletrônico, dentre outros -, Daniela pode ser considerada, neste ambiente, como uma estrela lunar. Este brilho necessita de plena escuridão para se destacar, para que seus contornos traçados de forma detalhada em performances corporais e vocais cheias de técnica e vigor possam efetivamente brilhar em luz e espaço milimetricamente afinados, cujo foco é a própria estrela. Por outro lado, a lua pode se configurar, de maneira metafórica, num referencial rico e múltiplo, cujas fases podem refletir momentos singulares que de maneira hologramática, podem refletir as partes cuja soma é muito mais que o todo. 
Daniela é um mito midiático que, através de suas práticas artísticas, pode se configurar como referência no quadro de representações da sociedade baiana/brasileira contemporânea. Neste sentido, as novas configurações musicais presentes de forma cada vez mais emblemática e transformadora em sua obra assinalam o redimensionamento da dinâmica cotidiana na cidade do Salvador, não só no período específico da festa carnavalesca, como na reconfiguração de textos/tessituras em torno das quais se organiza o ethos baiano/soteropolitano.

\title{
Margareth Menezes: a força que vem da Terra
}

\author{
A minha pele de ébano é \\ a minha alma nua \\ (Lazzo e Gileno Félix)
}

Nascida na Cidade Baixa, precisamente no bairro da Boa Viagem, em 1962, Margareth Menezes, filha de Dona Diva e Seu Adelício, com 4 irmãos - Aline, sua vocalista, César, produtor musical, Rita e Osmar, percussionista, contabiliza 14 turnês internacionais e 8 trabalhos lançados (IVANOV, 2005). Transitando pela música desde criança, sob influência do avô paterno, dos tios e do pai que cantava jovem guarda, Margareth também se diz influenciada pelas serenatas que aconteciam nas imediações da sua casa, além de ter cantado no coral da Congregação Mariana da Boa Viagem. Afirma também que seus pais adoravam forró. Aos 15 anos, recebe da mãe um violão de presente, envolvendo-se cada vez mais com a música.

O teatro também foi muito importante para a sua performance no palco. Começou a se exercitar na Escola Luis Tarquínio, ainda na Cidade Baixa, onde se formou em Artes Gráficas, indo depois para o teatro amador. Diz a intérprete, para Ivanov (2005): "Todas as coisas que eu aprendi no teatro eu uso no palco. No teatro, aprendi a ter domínio de palco, concentração, elaborar repertório, direção. Dirijo meus shows". Afirma ainda que os personagens que encenava 
tinham que cantar sempre alguma coisa. Entretanto, por força dos compromissos com a música, o teatro viria a ser relegado. Margareth ganha em 1985 o Troféu Caymmi de melhor intérprete com o show Banho de Luz - registrado num disco duplo coletivo com os demais ganhadores. Em 1987, ganha o troféu de melhor show. Entretanto, segundo palavras da intérprete, "o primeiro registro de verdade aconteceu em 198737" quando gravou Faraó - também gravada pela Banda $\mathrm{Mel}$ - tornando-se então um divisor de águas em sua carreira. Gravada juntamente com Djalma Oliveira, este samba reggae era tocado inicialmente pelos blocos afro, já misturando a percussão com instrumentos eletroeletrônicos.

Ainda na década de oitenta, era pequena a sua participação no ambiente do Carnaval de Salvador. Antes mesmo de gravar Faraó, o que lhe proporcionou visibilidade no mercado da música baiana, Margareth participa como backing vocal da banda de Sarajane, e logo após puxa o bloco $20 \mathrm{~V}$ e o Simpatia quase amor, formado por hóspedes do hotel Meridien. Entretanto, só em 1998 Margareth sai com um trio independente, patrocinado na época pelo Banco do Estado da Bahia - BANEB. Com o trio todo prateado, ladeado por homens seminus pintados também de prata, numa alusão ao futurismo, Margareth consegue uma grande repercussão na mídia local levando seu som afropop, reunindo um repertório com muito samba reggae, funk, soul e MPB.

Margareth destaca também como um grande divisor de águas em sua carreira de intérprete seu encontro com Gilberto Gil em 1989 no Rio e em São Paulo, além do seu momento de maior visibilidade no mundo através do convite feito por David Byrne ${ }^{38}$ para abrir o seu show - Rei Momo - pelo mundo, totalizando 42 shows entre Estados Unidos, Japão e Europa. Além dessas participações com artistas de renome, que de alguma forma ajudaram a impulsionar sua carreira, Margareth destaca como um fato inesquecível em sua carreira "ter ficado 11 semanas em primeiro lugar na World Music americana com o disco Elegibô. Esse disco foi lançado em 25 países" (PRESTES; CANCINI, 2005, p.36). 
São 10 álbuns lançados e 2 DVDs. O primeiro DVD é lançado pela Som Livre em 2004: Margareth Menezes ao vivo no Festival de Verão, que recebe o DVD de ouro. O segundo é lançado pela EMI Music em outubro de 2006, Brasileira ao vivo: uma homenagem aos 20 anos de samba reggae.

Podemos observar a influência em Margareth da música e do teatro do próprio bairro ao qual ela se reporta, sempre de maneira carinhosa e respeitosa, convivendo com a comunidade local, seja na escola, na comunidade religiosa, através da congregação Mariana da Boa Viagem, ou mesmo pela sua localização; é o ponto de saída e retorno da procissão do Nosso Senhor dos Navegantes. Sua ligação com o mar é fundamental para a construção do habitus primário (BOURDIEU, 1991) para o cotidiano desta intérprete. A Cidade Baixa ${ }^{39}$ parece ter vida própria e, de certa maneira, se diferencia da Cidade Alta pelo modelo de tradicionalidade, familiaridade e religiosidade impressa na sua arquitetura, em suas tradicionais igrejas, com suas festas sincréticas tais como a do Bonfim, a da Boa Viagem e mesmos aquelas cada vez mais combalidas, como a de Santa Luzia, da Conceição e da Ribeira, etc. O bairro ainda carrega a tradição de aos domingos ainda se colocarem cadeiras à frente da porta para se apreciar o movimento dos transeuntes que passam na avenida Beira Mar, ou que vão tomar sorvete na tradicional Sorveteria da Ribeira. As regatas e saveiros atracados conservam ainda hoje sua condição de uma "cidade" próxima do mar, não acompanhando, portanto, o crescimento urbano a partir dos anos sessenta com o surgimento das avenidas de vale, construção de diversos shoppings centers ou mesmo um acesso rápido ao aeroporto, rodoviária e demais vias de acesso à saída e entrada da cidade. Isto sem falar na proximidade com a Suburbana, pista que dá acesso aos demais pontos periféricos da cidade, cuja ligação se fazia principalmente pela Viação Férrea Federal Leste Brasileira e pelas canoas e saveiros.

Assim, abrir mão do convívio em família aos 18 anos para morar com artistas na Cidade Alta, e poder seguir a carreira inicialmente de teatro, foi um passo importante para Margareth, no sentido de 
buscar um diálogo com o que havia de mais expressivo acontecendo no cenário local, como grupos de teatro, a música de forma mais profissional e o convívio em teatros e bares da Cidade Alta, que de alguma maneira lhe oportunizou uma visibilidade maior. Bares como Banzo, no Pelourinho; a Orquestra de Vivaldo Conceição, no Circo Troca de Segredos; a participação no grupo de teatro Amora lá em casa, de Shirley Pinheiro e Antônio Moreno; e o Troféu Caymmi foram passagens importantes na constituição do perfil desta intérprete que encontra um terreno bastante fértil para semear e colher sonoridades musicais e performances teatrais na construção de sua trajetória..$^{40}$

Seu primeiro álbum - Margareth Menezes -, gravado em 1988 pela Polydor, lhe rende o título pelo Troféu Imprensa do canal de TV SBT de melhor intérprete, bem como uma série de shows em Buenos Aires, representando a Bahia. Entre as canções deste primeiro álbum, destacamos Elegibô e Tenda do amor (Magia).

Entre as três artistas destacadas nesta pesquisa, Margareth foi a primeira a tentar alçar voo nacional e internacional no sentido de ocupar espaços da mídia. Contabiliza aproximadamente 20 turnês em sua trajetória internacional. Autodenominando-se afropopbrasileira - uma mistura de ritmos de raízes afrobrasileiras misturando sonoridades pop mundiais como o rock, o reggae, o funk e o samba reggae, dentre outros, Margareth pontua desde o primeiro álbum o diálogo com a mãe África e a ancestralidade, como podemos ver na canção Uma história de Ifá (Ejigbô), de Ythamar Tropicália e Rey Zulu; na canção Muzenza, de Edil Pacheco e Paulo César Pinheiro; e na canção Planeta África Brasil de Paulo

Debétio e Paulinho Resende, dialogando com o ancestral e com o cósmico, mais precisamente com as forças da natureza - terra, água e ar, que pode ser observada também através das canções Correnteza do amor, de Cardan Dantas, e Natureza mãe, de Djalma Oliveira e Tonho Matéria.

Mais dois grandes sucessos podem ilustrar o seu primeiro álbum, que leva o nome Margareth Menezes, o já citado Uma história de Ifá e um hit que se perpetua: Alegria da Cidade, de Lazzo e Jorge Portugal, já citada em outra seção. 
Em 1989, a intérprete lança seu segundo álbum - Um canto pra subir. Este álbum é lançado em mais de 25 países pelo selo americano Mango/Islands Records, da gravadora Polygram. Neste mesmo ano, a intérprete assina contrato com a gravadora inglesa Polydor. Diante das diferentes temáticas abordadas nas canções que interpreta, notamos aí uma preocupação com o lugar do étnico - das diferenças na sua fala, em canções como Marmelada:

No começo desilusão

Mais tarde dor no coração

E depois vinha a certeza

De passar mais uma noite num alçapão

Em vão, em vão

$[\ldots]$

Púna-púna naná negro!

Puna-púna nana negro!

Amaha-amaha negro!

E jaz na lama jaz

Tem mais, tem muito mais

[...]

Nunca se deixe nunca confundir

Nunca se deixe nunca se enganar

Nunca se deixe nunca se iludir

Nunca se deixe teleguiar

Marmelada, "tô comendo nada"

Marmelada, "tô comendo nada"

Um canto pra subir. Margareth Menezes: George Décimus, versão Vilator Valakiá (1989).

Esta canção se reporta a um lampejo de esperança de um futuro melhor, ao mesmo tempo em que é importante a reflexividade do agente (GIDDENS, 1991) no sentido de perceber o subtexto de quem fala. Assim: 
Nunca se deixe se subtrair

Nunca se deixe se descontrolar

Nunca se deixe se substituir

Nunca se deixe se desinformar...

Outras canções deste mesmo álbum que dialoga com preocupações étnicas são Negro Menino (Lazzo e Gileno Félix) e Negra Melodia (Waly Salomão e Jards Macalé), bem como Maravilha morena (Jorge Portugal e Roberto Mendes). Também neste álbum Margareth já dialoga com o cósmico em canções tais como Hino das águas (Buziga e Haroldo Medeiros).

Águas dos rios, braços do corpo mar

São simplesmente águas

Em suas profundezas

Poços e pérolas

Ondas, a reação das águas

Movidas por força do vento

É demais

Onde as águas deságuam no pranto

De um povo sofrido

São simplesmente águas

Chuvas banhando a terra

Favorece ao lavrador

Homem do campo de mãos calosas

Agradece ao criador

Águas dos lagos dos vales dos mares

Das poças dos rios e bicas

Água caída parada

Água doce ou salgada

[...] 
São águas que brotam dos olhos dos recém-nascidos

Águas que sustentam o pão das pobres lavadeiras

Olhem estas pobres mulheres o que ganham

Mal dá para comer

Hino das águas. Buziga/Haroldo Medeiros (1989).

Sua preocupação em retratar o socialmente excluído também se faz presente no decorrer do seu discurso, que de certa maneira pode ser minimizado pelo contato com o cósmico. Outro grande sucesso deste álbum é a canção Ifá ${ }^{41}$, um canto pra subir.

Se é batifum de fé (e é)

Ijexá canto pra subir

Pra casa do senhor

Rumpi, ele é agogô

Sim, sim, sim eu vou

Eu vou, eu vou

Sim eu vou

Caminhando andando sem parar

Eu sei de onde vim

Pra mim todo mato é caminho

Se questão de adivinhar

(E é)

Clarear a vida de Kelé

Um homem e a mulher...

Ifá, um canto pra subir. Vevé Calazans e Walter Queiroz. (1989).

Prá encerrar este álbum, outra canção que retrata o universo afrobrasileiro é Tenda do Amor: magia (Carlos Pita). Diz assim: 
Moro numa cidade azul

Bem pra cá do Equador

Sou guerreira sou Caribe

Eu sou magia, eu sou magia

Africana Apofundá

Rastafari Olodum

Sou da tribo eu sou mais um

Eu sou magia, eu sou magia

Mexe na dança que eu quero inventar

Mexe no gozo da tenda, Olorum

Zanzibar do mar do amor

Afluente do prazer

Sou ioruba e male

Eu sou magia, eu sou magia

Trança de Deus do Ifá

Um colar de pedra e cor

Sou da raça eu sou o amor

Eu sou magia, eu sou magia

Tenda do amor:magia. Carlos Pita (1989).

Nesta canção, Margareth se localiza espacialmente, delimitando seu território, sua origem, e sua força de guerreira que vem dos povos Yorubá e Malê.

Gostaríamos de pontuar a noção do étnico presente na obra de Margareth, a partir da noção de stigma em Goffman (1963), que mapeia o conceito em três fases situadas historicamente. Ainda antes da Era Cristã, referia-se a um desvio. Na Idade Média, dois níveis de metáfora podem ser apontados: sinais corporais de graça divina e por distúrbio físico. $\mathrm{Na}$ atualidade, "o termo é amplamente usado de maneira um tanto semelhante ao sentido literal original, porém, é mais aplicado à própria desgraça do que a sua evidência corporal" (p.11). 
O étnico pode soar culturalmente "apoiado sobre o suporte fenotípico" (MOURA, 2001). Para o autor, o étnico se constitui não de forma unicamente genética, mas da maneira como é delineado, principalmente pelo elemento branco, supostamente ou pretensamente ocidental, também pelo pátrio de uma província. Assim, não só pelo fenótipo, mas pelo lugar de onde se origina o étnico, o estigma se imprime praticamente de forma irreversível, tomando assim uma predisposição para um discurso vitimizado da pessoa estigmatizada, que busca se corrigir baseada em modelos hegemônicos, seja em comportamentos, na estética, no discurso ideológico, para com isso galgar reconhecimento da forma como os indivíduos ditos "normais" o identificarão e o reconhecerão.

O fenômeno da incerteza pode ser um importante fator nesta interação, na medida em que não se pode prever "aquilo que os outros estão realmente pensando de si” (GOFFMAN, 1963, p. 23), de maneira que comportamentos tanto agressivos ou retraídos podem ser frequentes, tornando por vezes a interação angustiada ou ainda tímida para ambos os casos. Por outro lado, o estigmatizado pode se configurar como representante dos seus pares com um pouco mais de oportunidade de se expressar, tornando-se com isso mais conhecido ou mais relacionado que os seus companheiros e podendo, assim, ter poderes de representar a sua categoria.$^{42}$

A predisposição para a autocompreensão é outro fator presente nos ditos indivíduos "normais", diante do estigmatizado; ou ainda, pode-se considerar um conjunto de indivíduos também "estigmatizados" no que se refere a outros estigmatizados (homossexuais, artistas marginais, dentre outros), ou ainda, os "informados" (jornalistas, políticos, intelectuais), que podem considerar o estigmatizado uma pessoa comum. Ou seja, o estigmatizado aceito pelos "normais" pode fornecer um modelo de "normalização que mostra até que ponto podem chegar os normais quando tratam uma pessoa estigmatizada como se ela fosse igual" (GOFFMAN, 1963, p. 40).

Por outro lado, o esforço constante do estigmatizado em se apresentar como uma pessoa comum, mesmo carregando impresso no 
seu corpo o estigma, pode ser amenizado pelo símbolo de prestígio que tem o poder de despertar a atenção e o reconhecimento dos "normais" diante do estigma. Assim, Margareth pode se considerar entre os "estigmatizados" e os "normais" reconhecidamente uma pessoa "normal", contanto que traduza em seu trabalho artístico uma correspondência ao seu fenótipo, por vezes de forma estereotipada. Neste sentido, depoimentos de artistas convidados e contratados da intérprete em shows e álbuns lançados revelam uma visão, ainda que velada, do estereótipo.

Observemos o depoimento de Fernanda Abreu sobre Margareth Menezes.

Margareth é uma mulher muito autêntica, eu acho que ela é a personificação. O que eu acho bacana é que no Brasil às vezes existe um preconceito muito grande, um racismo com o negro. E o negro tem tanta facilidade de chegar na mídia, nos grandes veículos, quanto uma branca, bonita etc. E a Margareth eu acho que é bacana, não só a Margareth, mas por exemplo, o Cidade Negra, o Garrido, e tal. Eu acho muito importante que os negros tenham tanta importância como Margareth está tendo agora na mídia e na música brasileira. [...] A música dela ultrapassa fronteiras porque ela é muito moderna também, é uma pessoa muito antenada e sintonizada com as coisas que acontecem no mundo. Mas me parece que traz na essência dela uma raiz muito profunda da identidade brasileira, da coisa do negro, do que é que o negro trouxe de bom pro Brasil, que foram coisas muito importantes, muito impressas na cultura brasileira de maneira definitiva, mas que a gente percebe que às vezes fica uma coisa escamoteada, e vira uma coisa do branco. E eu acho que a Margareth traz isso no palco. Eu acho que a Bahia ta mostrando assim que o que eu acho legal é que as pessoas dizem: Ah, a Bahia é axé, Carnaval, eu acho isso uma redução, mas isso não é só na Bahia. Ah, São Paulo é a cidade da garoa, o Rio é samba... (ABREU, 2005).

Assim, a pele de ébano de Margareth soa compatível com o modelo plasmado da intérprete étnica, que é reconhecida pelos "nor- 
mais" como sua representante maior, bem como entre seus pares, que a utilizam como modelo de gerenciamento e negociações entre os "normais". O depoimento da intérprete pode servir para ilustrar atitudes de ocupar também este espaço do Carnaval e do artista empreendedor.

A questão do mercado aqui na Bahia é muito fechado, então eu não me sentia inserida em algumas coisas e acabei nesse tempo criando a minha panela. Aí eu consegui amadurecendo, vendo o que é que a gente pode melhorar, eu acho que é uma questão de maturidade. Todo mundo perceber que existe coisa boa pra gente fazer, que a gente tem um filão interessante, que ninguém dominava, e o que é que precisa (MENEZES, 2005).

Este espaço, entretanto, ocupado por Margareth no Carnaval, se configura ainda para a artista de forma efetiva só a partir de 2000, quando da criação do Bloco Os Mascarados, que teve o seu embrião no desfile no Carnaval de comemoração dos 450 anos da cidade do Salvador, sendo o desfile patrocinado pelo Governo da Bahia.43

Voltemos em linhas gerais a traçar o percurso desta intérprete no seu terceiro álbum, Kindala ${ }^{44}$, lançado pela Polygram em 1991, que inicia turnê em São Paulo. No ano seguinte, leva em turnê este show para os Estados Unidos, Europa e Japão. Neste álbum, a artista se apresenta já na capa de forma pintada como se fizesse parte de alguma tribo africana, com os lábios realçados por tinta vermelha. A canção Kindala, que dá título ao álbum, é uma parceria de Lazzo e Capinan. Os temas étnicos estão presente nas canções Negro nagô, de Luís Bacalhau, e Brilho de Beleza, de Nego Tenga, que se misturam com os temas ancestrais presentes na regravação do seu primeiro sucesso, Faraó, de Luciano Gomes; Uma história de Ifá, Depois que o Ilê passar, de Miltão; e Deus do fogo e da justiça, de Carlinhos Brown.

Entre sucessos já conhecidos do público, Margareth regrava Fé cega faca amolada, de Milton Nascimento e Ronaldo Bastos, e Mosca na sopa, de Raul Seixas. Entretanto, mais um sucesso na voz da artista se plasma com a canção Me abraça, me beija, de Jimmy Cliff, Lazzo 
e Gileno Félix, cuja letra aponta para o encanto presente no corpo e na voz de uma pessoa que foi levada pela onda do mar. Mais uma vez fazem-se presente os elementos da natureza, particularmente a água (do mar).

Seu quarto álbum, Luz dourada (1993), é lançado também pela Polydor. Dentre as canções contidas no repertório podemos destacar Vou mandar, de Fôca; Raça negra, de Dito e Jorge Zarath, que diz: $O$ grito da terra se expande por todo universo / no verso da mão calejada que afaga o rebento / o amor relampeja quebrando a semente da guerra / sagrada é a força da terra brilhando num só pensamento. Nestes versos, podemos observar a síntese do seu discurso impregnado de mensagem de justiça para um planeta que clama por atenção, além da presença do étnico. Na canção que dá nome ao álbum, Luz dourada, do compositor tocantinense Juraildes da Cruz, a mensagem se repete numa comunhão do ser humano com a natureza: Quando é tempo de chover / se alegram flores, bichos, gado / eu ainda hei de ver /o mundo sem guerras, de homens honrados / então sairei por aí / de pés no chão, despreocupado / sou menino, sou guri / tupy guarani, dourado. Ainda neste álbum, podemos observar a presença do compositor e cantor Lenine, na canção Olho no Farol, e Caetano Veloso, em Chegar à Bahia; a produção da intérprete como compositora se faz presente através das canções Vai mexer, Mar de amor e Até rir o mar.

Em 1996, Maga lança seu quinto álbum, Gente de festa, já pela gravadora Warner Music, contando com a participação de Maria Bethânia na canção Sou Araketu, de Evany; grava também Ilê que fala de amor, de Fôca e Gilberto Timbaleiro, presente até hoje em seu repertório, além da regravação de Vestido de prata, de Jorge Alfredo, que revela uma baiana com novos signos que pode ser observado nos versos: Precisa fazer pra baiana um vestido de prata... Presentes também no repertório deste álbum estão composições da intérprete como Reggae a vida e Requebra no vatapá, uma versão da canção Panamá, além de Caetano Veloso como participação especial.

O ano de 1999 traz mudanças no Carnaval de Salvador num evento especial pelos 450 anos da Cidade, promovendo um desfile de fantasias, 
trazendo a alegoria dos antigos carnavais ao som do seu trio elétrico, também alegórico. Este acontecimento resultou na criação do bloco Os Mascarados em 2000, tornando-se um sucesso não só dos foliões baianos ditos moderninhos, mas também pelos artistas famosos que "aproveitam" o Carnaval da Bahia para um pouco mais de visibilidade na mídia do Centro-sul. A recíproca, entretanto, é verdadeira.

Seu sexto álbum, Afropopbrasileiro, gravado em 2001 e lançado em 2002, cinco anos depois do Gente de festa, foi produzido por Carlinhos Brown e Alê Siqueira e distribuído pela Universal Music. Neste álbum, por orientação do próprio Brown, Margareth explora mais a sua dimensão de compositora, gravando de sua autoria as canções Preciso, Moderninha, Despertar (preconceito de cor), Pelo mar the mando flor e a parceria com Brown para a canção Nego doce. Além da presença de Brown em quase todas as faixas como percussionista, Margareth fecha o álbum com participação preciosa de Daniela e Ivete, que dividem os vocais com a artista no samba Cai dentro, de Paulo César Pinheiro. Entretanto, quem mais uma vez coloca um hit no mercado da música é Brown, com a canção Dandalunda na voz de Maga, que volta a se tornar sucesso de público e execução nas rádios, ganhando o troféu Dodô e Osmar de melhor música do Carnaval 2003. O Afropopbrasileiro 45 é lançado pelo selo da artista Estrela do Mar em 2002 e distribuído pela Universal Music.

A Margareth compositora aparece neste álbum, particularmente nas canções Pelo mar lhe mando flor, que diz:

Toda essa água sagrada não importa a fonte de onde brotou Água, pureza divina, fina, cristalina é benção do amor

Nossa senhora do reino das águas vem lavar as mágoas desse orador

Ê Bahia, pelo mar lhe mando flor

[...]

Nasce nos olhos da gente, corre pela face imitando um rio Água mistério profundo, tesouro abundante do nosso Brasil

Dona que banha meu corpo e me limpa e lava as chagas de nosso senhor 
E Bahia, eu pelo mar lhe mando flor

Pelo mar lhe mando flor. Margareth Menezes (2002).

Numa apologia ao elemento água, tema já presente nos álbuns anteriores, a intérprete/compositora clama pela força e poder curativo deste elemento que tem a Bahia como localidade deste clamor; a fonte de onde brota esta água não importa, mas sim o seu poder curativo que tanto pode vir da água doce, quanto da água salgada.

Na parceria com Brown para a canção Nego doce, Margareth brinca com os sabores presente no nego doce que a água do mar lhe trouxe, já que a água do mar é salgada:

Vem nego doce

Vem que o que eu tenho

É pra te dar

A água do mar lhe trouxe

Nego doce

Vem me namorar

Nego doce. Carlinhos Brown e Margareth Menezes (2002)

Ainda neste mesmo álbum, na faixa Desperta (preconceito de cor), a intérprete/compositora retoma o discurso da etnicidade de forma que podemos compreender pelo viés da noção de estigma (GOFFMAN, 1963), utilizando como pano de fundo sentimentos de amor e ódio, seja pelo outro, seja pelo mundo, bem como a noção de identidade/ diferença.

Por preconceito de cor você perdeu esse amor

Você parou a canção que tocou no coração

[...]

Não é porque eu sou preto que todo mundo é preto

Não é porque eu sou branco que todo mundo é branco 
Não é porque eu sou índio que todo mundo é índio

Por preconceito de cor morrem todo dia mil

A fome, a violência, descaso e impaciência

Há ódio a cada segundo, se afunda mais esse mundo

[...]

Por preconceito de cor, se é pobre já é ladrão

Mas o doutor que roubou nunca vai para a prisão

Policial matador tem preconceito de cor

Por preconceito de cor se espalha a ignorância

Não se oferece ajuda, outros perderam a esperança

É tanto tempo perdido e um Deus pai esquecido

Desperta: preconceito de cor. Margareth Menezes (2002).

Com o álbum Tête-à-Tête, lançado em 2003, Maga sedimenta sua carreira em Salvador ao gravar este álbum ao vivo na Concha Acústica do Teatro Castro Alves em dois dias, com um público recorde de 11.000 pessoas. A gravação contou com as participações especiais de Carlinhos Brown e da banda Cidade Negra e o álbum saiu pelo selo da artista, Estrela do Mar. Regrava sucessos de álbuns anteriores como Alegria da Cidade, Pout pourri de samba reggae, Marmelada, Faraó; além do pout pourri sempre presente no desfile de abertura do bloco Os Mascarados: a Noite dos Mascarados, de Chico Buarque, e Eu quero botar meu bloco na rua, de Sérgio Sampaio. De canções inéditas, grava Vitalunda, de Brown; Jeito Cativo, de Bira Marculino; Chuviscado, de sua autoria; e Toté de Maianga, de Gerônimo e Saul Barbosa, que se torna o novo sucesso da intérprete.

Seu primeiro DVD, gravado no Festival de Verão realizado em janeiro de 2004, integrando a programação de sua sexta edição, traz como convidados Alcione e a bateria da Escola de Samba Estação Primeira de Mangueira. Com direção geral de Aloysio Legey e direção artística de Márcio Meirelles, direção musical de Adson Santana, distribuido pela Som Livre, e com um repertório eclético que contempla compositores locais, nacionais e internacionais, além de inúmeros 
pout pourris e dos sucessos de sua trajetória; a intérprete mantém o diálogo com o telúrico em canções como Do mar, do céu, do campo, de Belchior; da ancestralidade africana presente em toda a sua trajetória, em canções como Toté de Maianga, de Gerônimo e Saul Barbosa; Odé negrume da noite, de Paulinho do Reco e Cuiuba; Cavaleiro de Aruanda, de Toni Osanah; Uma história de Ifá (Elegibô), de Ythamar Tropicália e Rey Zulu.

O diálogo com a etnicidade está presente nas canções Alegria da cidade (Lazzo e Jorge Portugal), Depois que o Ilê passar (Miltão) e Eu sou negão (Gerônimo); e da MPB presente nas canções que impreterivelmente abre o desfile dos Mascarados. De sua autoria, interpreta Preciso e a emblemática Passe em casa, presente no álbum dos Tribalistas em parceria com Arnaldo Antunes, Marisa Monte, Carlinhos Brown.

Maga: o senso de justiça

Por preconceito de cor, se é pobre já é ladrão Mas o doutor que roubou nunca vai para a prisão

(Margareth Menezes)

Margareth passou cinco anos sem lançar um álbum e, segundo ela mesma afirma, não parou de trabalhar durante este período. Entretanto, por mais que seu discurso acerca do seu "lugar" no ambiente da música baiana se constitua pela relação com a ancestralidade africana e o pop, Margareth refuta o rótulo de cantora de axé music, considerando-o reducionista para o seu trabalho, não se configurando assim numa intérprete de axé music com as características estigmatizadas pela grande mídia.

O discurso capturado pela fala de Margareth pode retratar uma forma de ver o mundo com otimismo, respeito e justiça. Diz ela em entrevista à revista GoWhere Bahia:

Eu penso assim, o que eu não quero para mim eu não quero para os outros. Respeito é uma coisa primordial, independente- 
mente se ela é branca, preta, azul ou rosa...Mas também tem o contrário. Se a pessoa afrontar, você tem que revidar no mesmo nível (IVANOV, 2005, p. 20).

Adepta da religião espiritualista como lastro no enfrentamento de dificuldades de diversas naturezas, a fé é o seu alicerce na busca da paz interior. Quanto ao candomblé, em entrevista à revista Raça Brasil, diz ela:

Não sou do candomblé diretamente. Mas tenho respeito e faço as minhas reverências. Candomblé é uma religião milenar e, se está há tanto tempo aí, vivo, alguma coisa tem. O que me atrai na religião é a ligação com a força da natureza, isso é muito importante. (CAMPOS, 2005, p.61).

Ao ser questionada sobre o fato de sua música trazer muito da religião de origem africana, Margareth responde: "Essa é uma relação mais cultural. Canto porque faz parte da realidade, da cultura e da formação do povo brasileiro" (CAMPOS, 2005, p. 61). Parece haver uma preocupação da intérprete em separar o que personaliza em sua voz e o que ela segue enquanto crença. Ainda na mesma entrevista, percebe-se uma preocupação em delimitar o seu trânsito entre o que canta e o que crê. Como exemplo, a canção Dandalunda, do álbum Afropopbrasileiro, que provocou sua retomada à cena artística com mais vigor.

Seu zumbi é santo sim que eu sei

Caxixi, agdavi, capoeira

Casa de batuque e toque na mesa

Linda santa iansã da pureza

Vira fogo, atraca, atraca, se chegue

Vi Nana dentro da mata do Jejê

Brasa acesa na pisada do frevo

Arrepia o corpo inteiro

Coquê 
Dandalunda maimbanda

Coque

Dandalunda. Carlinhos Brown (2001).

Sobre esta canção, diz a artista, ainda ao repórter da Raça Brasil:

Na música Dandalunda, de Carlinhos Brown, ele conta a história do Candeal e de um terreiro das duas nações, Angola e Ketu, o que é muito raro. Dandalunda é uma representação de Oxum que pertence ao legado de Angola, que é a rainha do ouro, do mineral, que mora na cachoeira. Tudo isso foi Brown que me contou. É uma música linda, com uma força e energia muito grande. Essa composição acabou resgatando um pouco dessa linguagem dentro da música baiana. (CAMPOS, 2005, p.61).

Margareth faz questão de ressaltar a fonte que lhe informou a origem de Dandalunda: seu próprio autor. Assim, escolhe interpretar uma canção mais por proximidade cultural do que por fé no que está contida na letra. Neste sentido, a busca pelo diálogo com a sua cultura é unicamente artístico; não uma questão de crença, mas sim de respeito.

É uma constante nas entrevistas coletadas das intérpretes uma preocupação em se autodenominar uma cantora de MPB ou mesmo afropopbrasileiro. Diz: "Muitas pessoas têm a visão de que todos da minha geração são cantores de axé music. Canto afropopbrasileiro e o que está presente na minha música são as misturas de raiz com o contemporâneo" (BASTOS, 2005, p.1).

Assim Margareth define o rótulo que a consagrou, negando que no rótulo de axé music está contido todo este caldeirão sonoro de influências caribenha, africana, latina e brasileira. Na busca de definir um rótulo para a sua música, Maga utiliza a tradição da religiosidade africana com a sonoridade/efemeridade do pop contemporâneo, também retratada no seu último sucesso do Carnaval de 2004, Toté de Maianga (Saul Barbosa/Gerônimo): 
Vinha passando pela Mata Escura

No bate folha ouvi uma canção

Que é pro santo poder sair da aldeia

E pra chamar o ancestral dessa nação

Com o balanço do mar eu vim

Com o balanço do mar eu vou

$\mathrm{E}$ a inkisse que vovó me ensinou

Eu vou cantar pra chamar o meu amor

Toté, toté de maianga

Maiangolê

Toté de maianga. Saul Barbosa e Gerônimo (2004).

Seu discurso carrega em seu cerne uma religiosidade de origem africana singular, não sendo de entendimento direto, por vezes, de alguém que não mantenha familiaridade com o meio do candomblé. Neste sentido, as tradições que de certa forma são reportadas nestas canções podem ser "essencialmente um processo de formalização e ritualização, caracterizado por referir-se ao passado, mesmo que apenas pela imposição da repetição" (HOBSBAWM; RANGER, 2002, p.12). O místico, particularmente nos moldes afro-baianos, se configura na estética musical de Margareth de forma bastante presente, reforçado pela sua voz forte e marcante, com uma sonoridade vocal posterior no que se refere à ressonância, imprimindo por vezes um canto gutural e "escuro", muito particular e próprio para o estilo musical que a consagrou.

Desde o início de sua carreira, computada a partir do sucesso do samba reggae Faraó, que celebrou 20 anos de carreira em 2007, Margareth trilha uma estética afropopbrasileira, cuja negação de proximidade com o axé, que também bebe na mesma fonte, pode soar por vezes como mágoa e desprezo, ou mesmo estigmatizada pela própria intérprete. Vejamos o que nos revela a artista numa entrevista a Marcos Case, no jornal $A$ Tarde, quando dos preparativos para a gravação do DVD comemorativo dos 20 anos de carreira. 
Quando o axé estourou, eu não tive a mesma projeção que os outros baianos exatamente porque não era o tipo de música que fazia. Essa é a minha diferença, eu sou realmente diferente dessa leitura. Porque nem tudo que se faz na Bahia é axé music só por ser dançante e ter percussão. (CASÉ, 2006, p.4).

Neste sentido, a intérprete não se sente representada e nem representando o que se convencionou denominar axé music, diferenciando-se assim deste caldeirão sonoro e híbrido que é a música feita na Bahia, rotulada de axé music pelos críticos de jornais de forma quase sempre pejorativa, nos primeiros anos. Assim, Margareth se autodiferencia deste modelo criticado pela imprensa, distanciando-se desta carga pejorativa e imprimindo para si como o "outro" deve reconhecê-la, e não como o "outro" efetivamente a vê.

Em entrevista com o público na gravação do DVD comemorativo dos 20 anos de carreira, o reconhecimento apontado em sua grande maioria pela audiência se referia à dificuldade encontrada pela intérprete em ocupar o "seu" espaço, ou ainda, um reconhecimento pela mídia nacional, principalmente a Rede Globo, no que se refere à participação em sua programação musical, bem como à execução de suas músicas nas emissoras de rádio. Assim, o discurso assinalado pelo público entrevistado aponta para o reconhecimento pela grande mídia do talento de Margareth como representante não da axé music nos moldes em que foi se constituindo perante a mídia, mas do samba reggae - "sua" representante de direito, por ter sido a pioneira em plasmar sua voz/corpo/performance num gênero reconhecidamente calcado nas raízes afro/brasileiras. Sendo assim, a representante "autêntica" por direito se configura no discurso subliminar da própria intérprete. "Fui a primeira a levar o estilo para o resto do país e fora dele. A minha carreira se mistura com o desenvolvimento do samba reggae". (CASÉ, 2006, p. 4).

Percebemos, eventualmente, no discurso de Margareth e no do público que a acompanha, uma necessidade latente de apontar o reconhecimento da artista não unicamente pelos méritos artísticos, mas 
sim - e principalmente - pelo ato solidário de reconhecê-la como real representante do samba reggae, como se somente uma negra pudesse fazê-lo de forma autêntica, verdadeira.

Por outro lado, ainda coletando opiniões acerca da trajetória da intérprete no evento citado, de cada dez entrevistados, um verdadeiramente acompanhava a carreira da intérprete. Os demais foram assistir ao show porque gostam de sua música, porque admiram sua performance ou por curiosidade; não propriamente porque acompanham sua trajetória enquanto fã.

Margareth traça o início de sua trajetória a partir da gravação, aos 23 anos, do samba reggae Faraó, de Luciano Gomes, num primeiro momento de ebulição do que se convencionou denominar axé music. Margareth se aponta como sendo uma das pioneiras na gravação deste "gênero", afirmando que pouca gente tinha experimentado o samba reggae como ele é. Tratava-se, contudo, de um momento de ebulição na música baiana, creditando para si o pioneirismo de ter sido a primeira intérprete a assumir como porta voz do gênero que se formatava e ganhava fôlego no Brasil, mas que efetivamente explodiu em termos nacionais com a ascensão e reconhecimento pela mídia e pelo público brasileiro de Daniela Mercury, como representante deste novo gênero.

Neste sentido, Margareth torna-se cúmplice dos elementos da natureza e da batida do samba reggae, louvando a raça negra e proclamando temas marcados pelos elementos religiosos de origem africana. A carreira da intérprete reflete hiatos significativos no que se refere à aparição e registro em álbuns, sem, entretanto, deixar de dialogar ano a ano com o global, como faz em turnês internacionais desde o convite de David Byrne. Com um discurso por vezes carregado de ressentimento, ao mesmo tempo em que de luta e desafios travados com o mundo da mídia, Margareth vai aos poucos (re)conquistando novos espaços, empresarizando sua carreira de forma cada vez mais profissional, constituindo-se em um exemplo de obstinação e força impressa não somente na voz, como também no discurso para atores que veem na intérprete um modelo comportamental a ser seguido e admirado. 
Artistas que ao longo de sua carreira participaram de eventos realizados pela produtora da intérprete, como o cenógrafo e diretor gaúcho Gringo Cardia, que confeccionou o cenário do show de lançamento do álbum Pra você, comenta a respeito de sua performance:

Eu acho que o legal dela é essa força vital que ela tem na voz, uma negritude. A força da voz dela é incrível, porque ela carrega a terra pela boca, entendeu? E eu acho que o bacana dela é que ela traz essa cultura toda afro com um canto do pop, do contemporâneo, de desfolclorizar o afro. [...] Eu acho que ela carrega muito bem essa bandeira afrobaiana, para um lado do contemporâneo, do moderno, do dia a dia. Então, isso é muito bacana no trabalho dela, entendeu? (CARDIA, 2005).

Retomando a noção de étnico apontada por Moura, "Soamos étnicos para os outros brasileiros, para os não brasileiros e para nós mesmos porquanto somos o espelho contrastivo do si mesmo absoluto que se pretendem os ocidentais" (2001, p.169).

Afropopbrasileira

Dandalunda maimbanda coquê (Carlinhos Brown)

As formas sociais e estéticas impressas na obra de Margareth Menezes podem revelar formas espetaculares impressas nas matrizes ancestrais que poderosamente se impõem no espaço do Carnaval na contemporaneidade baiana, de forma a revelar uma inquietação ainda que tímida em beber em fontes do pop, bem como da MPB, como relata a intérprete à autora:

Toda essa mistura que a gente tem, perpetuando essa ancestralidade, isso é que nos dá o diferencial do resto do Brasil, que é o diferencial do mundo também. $E$ a gente preserva isto. $E$ também tem a nossa influência externa, nossas misturas que a gente faz. (MENEZES, 2005). 
Margareth acentua a ancestralidade como a matriz maior de suas influências, bem como a Tropicália como "o coração de todas essas expressões, de liberdade de modernidade que existe no Brasil". Assim, Margareth se consolida como uma intérprete reconhecidamente como representante desta ancestralidade que para ela se resume no sentimento afropopbrasileiro.

Transitando entre o "ancestral" e o moderno, a diferença substancial apontada por Margareth em relação à sua negação de fazer axé music passa unicamente pela temática impressa em suas letras, que se reportam em sua grande maioria aos elementos da natureza, bem como às temáticas de cunho afro religiosos e étnico. Isto, entretanto, se mostra bastante difuso no seu álbum Pra você, gravado pela Universal Music em junho de 2005. Aí, a intérprete se revela mais romântica pop, que foge do que se convencionou denominar axé music, afropop, samba reggae, dentre outros rótulos, a começar pelo encarte do álbum, revelando uma Margareth "casual", bem como nas letras e nos arranjos, impressos por temáticas reportando-se ao amor, como pode ser observado na canção Como tu, versão de Carlos Vivas com participação de Ivete Sangalo, que diz: Nada existe parecido com as estrelas assim como tu... Não há nada que eu queira como tu a vida inteira [...] E as sete maravilhas reunidas não são como tu.

$\mathrm{Na}$ segunda faixa do álbum, o tema romântico continua com uma voz suave na canção Versos do amor (Alexandre Leão e Manuca Almeida), canção que fala de amor e dos encontros. Falei das flores, falei dos sonhos, de tudo aquilo que a vida tem pra dar; na faixa Prá você, de Saul Barbosa e Pierre Onasis, que dá nome ao álbum, Margareth assume o samba exaltação, cujo tema gravita sobre o amor nos moldes plasmados por intérpretes como Simone e Alcione. Diz ela: Me olha assim comendo com os olhos e eu me derreto toda pra você, contrastando com o reggae Miragem na esquina (Tom Deike e Esquisito). Nesta última canção, o amor que desapareceu provoca uma miragem no amor abandonado, que diz: Quando te encontrar, vai ser gostoso pra valer, eu vou te amar com todo meu prazer. Já na canção Contra o tempo, de Vander Lee, o tema telúrico/cósmico, como estrela e vento, retoma a cena para compor a saudade do amor que se foi. 
O samba ufanista Boléia Brasil, de autoria da artista, passeia pelos estados brasileiros numa clara homenagem à brasilidade, cheia de nuanças e idiossincrasias, que serve de ilustração para o amor que ficou na terra natal. Atua dividindo os vocais com Cláudio Zoli na canção/ soul Só eu e mais você, de Vinícius Cantuária, e com declamação própria: Ainda há um pedaço de lua e um resto de estrela [...] Agora você está em minha companhia [...] Ficar contigo depois que a onda passa, não penso mais em nada, numa alusão a uma noite em que "amar é preciso".

Mas é na última faixa do álbum, Abanaê, de Clóvis Cruz, Alain Tavares e Gilberto Timbaleiro, um galope / ponto de macumba, uma canção carregada de significados simbólicos que pode ser interpretado pelos elementos da natureza vento e fogo - Abanaê, abanaê, abana. Abana o fogo que é pro fogo esquentar... - que Margareth apresenta todo o seu vigor vocal.

Neste álbum, Margareth busca novos diálogos musicais que possam ser absorvidos pelo mercado da música, de forma a poder transitar em emissoras de rádio que têm o pop como marca. Entretanto, apresenta também a possibilidade de experimentar e criar independente de rótulos. Vejamos o que nos tem a dizer a artista em entrevista a Martins ${ }^{46}$ acerca do lançamento do álbum.

Este CD serve para eu expandir meu campo de ação e causar surpresa às pessoas e a mim mesma. As pessoas tendem a me enquadrar como uma artista que canta a Bahia com percussão. Mas com esse disco eu estou resgatando a Margareth que sempre gostou de cantar várias coisas. (2005).

O seu décimo álbum e segundo DVD, Uma brasileira ${ }^{47}$, foi gravado ao vivo na Concha Acústica do Teatro Castro Alves em 3 e 4 de agosto de 2006 pela EMI, em homenagem ao samba reggae e em comemoração aos seus vinte anos de carreira, e lançado em outubro do mesmo ano.

Nestes registros em áudio e vídeo, apresenta os sambas reggae mais emblemáticos de sua carreira, tais como Faraó, Elegibô e Canto pra subir, além da inédita Rasta, que provocou polêmica entre os reggaemen ao enunciar na letra Reggae, este cara dança reggae, meio 
maluco mas um homem bom. Gravou com a participação especial de um dos maiores expoentes da música afro baiana da década de setenta, Mateus Aleluia, as canções do grupo Os Tincoãs: Cordeiro de Nanã, Deixa a gira girar e Atabaque chora, também com a presença do violonista e compositor Saul Barbosa; além de Lenda Iorubá, com a participação especial do Cacique Carlinhos Brown.

Grava também a canção bastante presente em seus últimos shows, A luz de Tieta, de Caetano Veloso, bem como Toté de Maianga. Neste álbum e DVD, a artista se apresenta com uma produção visual cheia de ícones, como uma deusa do ébano em dourado e branco e muitos acessórios como pulseiras e brincos, e saias que se superpõem umas às outras, retiradas no momento em que canta Povo, vem ver. Com cenário e figurino de Alberto Pitta (um dos donos do bloco Cortejo Afro), O DVD demonstra uma intérprete com trânsito seguro no ambiente do samba reggae, bem como no palco, em movimentos corporais que têm como marca sempre movimentos laterais e jogadas e quebradas de perna, bem como a mão quando aparece em primeiro plano e demonstra um símbolo de atenção em cotovelos flexionados. As danças dos orixás também estão presentes em sua performance corporal de forma alegorizada, diluída, bem como o samba.

$\mathrm{Na}$ época do lançamento, em outubro de 2006, a imprensa comenta o clima morno que pairou na gravação do DVD/CD:

[...] quem levar para casa o lançamento chancelado pela major EMI pode ficar tão desapontado quanto quem saiu de casa para prestigiar sua gravação em agosto, na Concha Acústica do TCA. Produzida por Adson Santana, a dobradinha Brasileira ao vivo não faz jus ao calor do gênero que conduziu a cantora ao caminho da consagração em 1987, ano marcado pelo feliz encontro de sua voz vigorosa com a inspirada letra de Faraó, divindade do Egito. (Correio da Bahia, 22 out. 2006) ${ }^{48}$.

No entanto, na mesma matéria, a intérprete afirma que:

Sou muito exigente e acho que a proposta, que era registrar a riqueza musical do samba reggae, está ali. Reinterpretamos to- 
das as levadas para mostrar a eficiência do samba reggae como música popular brasileira, tanto que escolhemos canções diretamente relacionadas a outras que interagem com essa idéia.

Com o álbum Naturalmente lançado em outubro de 2008 pela MZA e produzido por Marco Mazzola, Margareth finca mais ainda o pé na MPB regravando canções de Chico Cesar Por que você não vem morar comigo? De Gilberto Gil Mulher de Coronel, de Amelinha Foi Deus que fez você; além de canções de Nando Reis, Marisa Monte, Zeca Baleiro, dentre outras.

Continua assim o percurso iniciado com o álbum Prá você de um álbum que busca na atmosfera da MPB reforçar o desejo de uma artista que se alimenta do trânsito entre o étnico e a MPB como experimentações de um processo de amadurecimento artístico.

\section{O Carnaval e o bloco Os Mascarados}

Quem é você diga logo que eu quero saber (Chico Buarque)

Percebemos que o discurso de Margareth no que se refere à sua participação no Carnaval reflete um certo desconforto em se inserir na folia momesca. Vejamos o que ela diz a respeito em entrevista à revista Raça Brasil:

Raça - você costuma cantar no Carnaval também?

Margareth - Existe esse movimento na MPB que é o momento do Carnaval. E na Bahia, nessa hora, o artista consegue ampliar seu universo, divulgar e quebrar algumas barreiras. $O$ trabalho que desenvolvo no Carnaval é diferenciado. Não tenho um bloco oficial. Não gosto de nada muito enquadrado ou de ser limitada. Acho que as pessoas têm que ter espaço para criar e descobrir coisas. No trio elétrico, colocamos uns negros bonitos pintados de dourado como estátuas. Nos 450 anos de 
Salvador, fizemos uma linda homenagem à cidade. O bloco Os Mascarados fez quatro anos e agora lançamos o Afro pop brasileiro. (CAMPOS, 2005, p. 61)

Neste discurso Maga ratifica sua preocupação de demarcar o seu rótulo e o seu território, quando afirma que "o Carnaval é apenas um momento em minha carreira". De certa maneira, isto parece procedente, pois o calendário do Carnaval é sazonal. Entretanto, o seu retorno à mídia se deu pelas mãos do Carnaval e não só, mas, sobretudo, pela criação do bloco Os Mascarados. Margareth nos diz, sobre o Carnaval:

Claro que o Carnaval tem seu valor, mas não é a minha essência. O que me liga ao Carnaval é a música; a participação é de momento. [...] Porque, para ser sincera, não me vejo cantando no Carnaval eternamente. E o Carnaval mesmo precisa se renovar, estão surgindo outras bandas... Tô aí, mas não sei até quando. (ALVES, 2005, p.1)

Neste sentido, podemos perceber que o gerenciamento de sua carreira e a abertura de sua produtora possibilitaram um retorno à mídia de forma mais efetiva e administrada. Passemos agora a uma análise mais detalhada do seu bloco como forma de gerenciar uma carreira não só para o Carnaval, mas tendo como eixo os ensaios e bailes à fantasia não só na Bahia mas em outros espaços do Centro-sul.

O bloco Os Mascarados consistia no desfile de foliões fantasiados ao som do trio elétrico puxado pela intérprete. A receptividade foi tão positiva pela mídia e pelo público que no segundo ano, 2000, Margareth e sua empresária e sócia, Jacqueline Azevedo, resolveram fundar o bloco com a proposta de resgatar os antigos Carnavais, em que as pessoas saíam fantasiadas às ruas numa brincadeira de se transformar em "outro" no uso da máscara, que, ao mesmo tempo em que esconde o rosto, enuncia, denuncia. Assim, sair "mascarado" no Carnaval, pode suscitar inúmeras atitudes permissíveis por conta do uso da mesma. 
O desfile do bloco se dá no circuito Barra-Ondina. Segundo dados da revista Carnasolo (2004) o bloco já desfilou no primeiro ano com 2000 mil associados. Com um público bastante diferenciado, seus foliões são jornalistas, artistas plásticos, atores, homossexuais, empresários, músicos, dançarinos, intelectuais, professores e "moderninhos", dentre outros.

O jornal Correio da Bahia registrou, em forma de entrevista, o perfil de um folião que sai no bloco desde 2000:

CB - Quanto cada um de vocês gasta em média com a fantasia? $A B$ - Este ano, estamos gastando $R \$ 1800$ cada. Ano passado, a fantasia completa custou $R \$ 1400$.

CB - Vocês contam com a ajuda do bloco, já que, saindo juntos, vestidos iguais com fantasias caras, contribuem para a beleza do mesmo?

$A B$ - Ano passado, um amigo conseguiu que o bloco liberasse dois kits para a gente. Dois de nós tiveram que pagar. Nos outros anos, todos pagamos.

$\mathrm{CB}$-Você tem alguma crítica ao bloco?

$A B$ - Acho o cinturão de "cordeiros" frágil. Há poucos "cordeiros" para a quantidade de foliões dentro da corda. Por conta disso, a pipoca às vezes puxa adereços, fantasias. Outra coisa: os olheiros ${ }^{49}$ do bloco não conseguem barrar a entrada de pessoas sem pulseiras de identificação, principalmente aquelas que estão fantasiadas. É uma injustiça com quem pagou caro para estar dentro da corda. Mas tudo isso pode ser corrigido e não apaga o fato de que "Os Mascarados" é a melhor coisa do Carnaval da Bahia. (BARROSO, 2003, p.7)

Neste depoimento, concedido pelo professor de literatura portuguesa da UFBA, Ângelo Barroso, 36 anos, observamos o perfil do público que frequenta o bloco Os Mascarados. Entretanto, há uma divergência em relação a este perfil, tanto por parte de uma das suas mentoras, Margareth, quanto por parte do público GLS que reclama para si a participação hegemônica do bloco. Luiz Mott, presidente do GGB - Grupo Gay da Bahia, levanta a polêmica no sentido de aferir 
o sucesso do bloco ao público GLS, que, com sua presença, fomenta e dá vida ao mesmo. Contrapondo-se a esta visão, Margareth rebate o rótulo e afirma que o bloco não é GLS, e sim democrático. O fato é que, no Carnaval, as fronteiras entre estas discussões se tornam mais tênues, dificultando assim, uma definição fechada no sentido de caracterizar um único tipo de folião que frequenta estes ambientes.

A jornalista Suzana Varjão em nota no jornal A Tarde diz: "Irretocável o desempenho de Margareth Menezes no quesito segurança. Policiais, 'cordeiros' mascarados e 'pipocas' que ensaiaram o 'argumento' da força bruta foram contidos pela artista" (2002, p.8).

Como podemos observar, as opiniões divergem no que se refere à segurança, ao tipo de folião que frequenta o bloco ou mesmo quanto ao valor do carnê. Em 200o, como já relatado, o bloco saiu unicamente na quinta-feira de Carnaval, e a partir de 2001 passou a desfilar às quintas e no sábado, até voltar a desfilar só às quintas em 2007.

No primeiro ano, os ensaios do bloco aconteceram no Rock in Rio, sempre com convidados. Depois, passaram para o Candeal e para o Armazém da Companhia das Docas do Estado da Bahia - CodebA e finalmente, para a casa Espetáculo, na Boca do Rio. Voltando ao seu lugar de origem, o Rock in Rio, os ensaios dos Mascarados aconteceram normalmente no verão, até desembocar no Carnaval, sempre às sextas-feiras, recebendo convidados ilustres tais como: Caetano Veloso, Ivete Sangalo, Edson Cordeiro, Sandra de Sá, Fernanda Abreu, Tatau, Márcia Short, Márcia Freire e Targino Gondin, dentre outros. Em 2005, os ensaios passaram a ser quinzenais, abrindo sempre com um baile à fantasia no clube Associação Atlética da Bahia, ponto de concentração do bloco desde 2005. Antes disso, a concentração se dava no estacionamento do Marazul Hotel, também na Barra. Nessa ocasião, inúmeros serviços são oferecidos para o folião, desde maquiagem até desfile de fantasias, com eleição da melhor da noite.

Ainda no Carnaval de 2005, um momento simbólico na carreira de Maga foi o desfile como atração do bloco Os Internacionais, cuja fusão com Os Mascarados, unicamente nesse ano, passou a se chamar Inter Mascarou. Trata-se de um momento em que os trânsitos/negociações 
de espaço se mostraram de forma emblemática, não vindo a se repetir em anos posteriores.

A partir de 2005, Margareth passa a levar os ensaios para a casa de shows Canecão, no Rio de Janeiro, sempre às terças-feiras, também recebendo convidados como Ivete Sangalo e Cláudia Leitte, e em Costa do Sauípe, complexo hoteleiro no litoral norte de Salvador, às quintasfeiras. Porto Seguro também foi palco de alguns de seus ensaios.

Em 2006, na coletiva convocada para anunciar as novidades do Carnaval, Margareth afirmou:

A concentração tem sido tão boa que temos até dificuldade
em sair", brincou Margareth, referindo-se ao bochicho prévio,
quinta e sábado, com direito a concurso de fantasia, show,
discotecagem e afins. Entre as novidades, está a presença, no
primeiro dia, do cantor Eduardo Dusek, estreante no Carnaval
baiano, e a homenagem à cantora Carmen Miranda (PEREIRA,
2006).

Em 2007, o ensaio em Salvador aconteceu quinzenalmente; no Carnaval, o bloco Os Mascarados saiu unicamente na quinta-feira, enquanto o Afropop se apresentou dois dias, domingo e terça feira. Em 2008 a artista fecha parceria com o Jornal A Tarde, instituindo o uso da fantasia obrigatória como passaporte para o acesso dos foliões dentro das cordas.

Em 2009 a parceria continua possibilitando assim o acesso de todos que queiram participar da folia momesca fantasiado.

\section{Afropopbrasileiro: o bloco}

A partir do Carnaval de 2005, Margareth lança outro bloco, o Afropopbrasileiro, cujo objetivo é unir entidades e artistas negros. São eles: Muzenza, Olodum, Ilê Ayiê, Malê de Balê, Cortejo Afro, Filhos de Gandhy. Em 2005/2006, Margareth propôs a estas entidades promoverem ensaios do bloco nas quadras dos respectivos "parceiros"; de forma itinerante, portanto. 
Para o Carnaval 2006, o Afropopbrasileiro, que contou com patrocínios da TIM, Insinuante, LG, Q-Boa e Shopping Center Iguatemi, desfilou com camisetas assinadas por Alberto Pita e alas de dança e cantores do Ilê Ayiê, Olodum, Malê de Balê, Muzenza, Filhos de Gandhy e Cortejo Afro, além do cantor e percussionista Peu Meurray. A partir de 2007, o bloco passou a desfilar dois dias na Barra, domingo e terça. Para a artista:

A ideia é de união. Todo mundo bebe na fonte dos afros e dos compositores da comunidade, mas o retorno para eles é muito pequeno. Essa é a minha maneira de colaborar, de aumentar a visibilidade para os afros na avenida [...] Seria uma pessoa inútil se não ajudasse em nada. Não quero fazer discurso racista, mas o negro não pode ser apenas o carvão que move a máquina. (PEREIRA, 2006).

A artista busca "unir forças" para dar conta da assimetria de oportunidades entre negros e brancos no mercado do Carnaval. Ainda no Carnaval de 2007, a intérprete desfilou no domingo no Bloco da Cidade, no circuito Osmar.

No Carnaval de 2009 Margareth e o Bloco afropopbrasileiro reuniu os maiores representantes da música afro da Bahia em cima do trio dividindo os vocais como Chico do Malê debalê, Altair do Ilê Aiyê, Isaac dos Filhos de Gandhy, e Nen Tatuagem do bloco Muzenza.

Esta forma de gerenciar um produto artístico acontece de maneira cada vez mais frequente num ambiente com predisposição para se organizarem festas. Salvador tem cultivado, ao longo das décadas, a "vocação" para organizar e receber turistas, como afirmam seus governantes. Prova disso são os dados exibidos nas revistas especializadas, que acusam um número cada vez maior de turistas que deságuam na cidade durante o verão, intensificando-se esta afluência no período de Carnaval.

Buscando em Gilroy (2001) a perspectiva da identidade negra que se constitui no trânsito África-Europa-América, a intérprete Margareth Menezes - e o seu diálogo em trânsito neste ambiente - se 
autodenomina uma artista que navega no afropopbrasileiro. Com este rótulo, ela sintetiza suas influências estético-musicais que passeiam pela versão de Marmelada a Dandalunda. Suas referências identitárias se confundem com a África, com a Bahia e com o mundo. Ao mesmo tempo em que a sua identidade se constrói no local para se tornar global, ela se processa múltipla (HALL, 2003), em trânsito (GILROY, 2001) e sincrética (CANEVACCI, 1996). Assim a intérprete afirma: "Minha casa é a Bahia, mas o mundo é meu lugar" (apud ALMADA, 2007, p. 54-55).

Neste sentido, já dispomos de subsídios suficientes para afirmar que a tipologia ideal para Margareth Menezes se refere à estrela telúrica, cujos elementos da terra são bastante presentes nas composições que compõem seus álbuns, no decorrer de sua trajetória. Seu discurso é também carregado do elemento étnico, ancestral, numa perspectiva pop, contemporânea; como ela denomina, é o afropopbrasileiro.

\section{A trajetória de Ivete Sangalo: liberdade na voz dela que ecoa ${ }^{50}$}

Ivete Maria Dias de Sangalo, filha de pai galego (falecido em 1988) e mãe baiana (falecida em 2001), nasceu em Juazeiro-Bahia, em 27 de maio de 1972, caçula de seis irmãos. Ainda em sua cidade natal, quando criança, era levada pelos pais para serenatas que aconteciam pelos arredores da cidade. Com a morte precoce do pai, a mãe mobiliza a família para vender marmitas a domicílio. Àquela altura, Ivete contava quinze anos e dividia a venda de marmitas e os estudos com desfiles como modelo nas passarelas. Logo desistiu de ser modelo: "Eu não tinha estampa de top model. Sempre fui grande demais" (LIRA NETO; FAISSAL, 2006, p. 66). O negócio familiar das marmitas faliu e Ivete, que aprendeu a tocar violão quando criança, parte para cantar na noite, levada pelas mãos da irmã Mônica, também cantora.

Entretanto, sua trajetória musical pode ser traçada a partir do primeiro prêmio conquistado - picolé grátis por um ano em uma sorveteria de Salvador - no programa infantil de TV, de Mara Maravilha, 
ao dublar Nika Costa na canção On My Own. Entretanto, ao receber o prêmio de melhor intérprete feminina do Troféu Caymmi em 1992 - “aquilo foi a glória para mim!" (LIRA NETO; FAISSAL, 2006, p. 66) -, Ivete recebe um convite para cantar no trio elétrico na Micareta em Morro do Chapéu e é vista pelo produtor, percussionista e fundador da banda Eva, Jonga Lima, que a convida para puxar o bloco.

Estava aí firmado um pacto com a axé music, pontuada por uma discografia iniciada com a banda Eva em 1993, com 35 mil cópias vendidas, seguida em 1994 com o álbum Prá abalar, com 6o mil cópias vendidas; em Hora $H$, Ivete, ainda como vocalista e puxadora do Bloco/Banda Eva, atinge a cifra de 170 mil cópias; mas é com Banda Eva ao vivo, lançado em 1997, que atinge a maior cifra de vendas junto à banda - dois milhões de cópias vendidas, com os sucessos registrados ao longo de sua trajetória como vocalista/puxadora. Seu último álbum como vocalista da banda é o Eva, você e eu, lançado em 1998, com 420 mil cópias vendidas.

De vocalista a empresária

\author{
Já não se sabe o momento \\ exato de partir \\ (Gigi/ Fabinho O’Brian)
}

Seguindo a trilha iniciada por Daniela Mercury, Ivete, ao lado dos irmãos Jesus, que administra seus negócios; Ricardo, o seu empresário; e Cynthia, sua produtora, cria a produtora Caco de Telha para administrar a sua carreira, reunindo em 2005 um patrimônio orçado em 30 milhões de reais.

No entanto, sua saída da Banda Eva, segundo declaração da artista, "não foi uma separação fácil. Era como se um casamento tivesse chegado ao fim" (LIRA NETO; FAISSAL, 2006, p. 66). Assim, com uma trajetória pessoal/familiar marcada por perdas (pai, mãe, irmão, namorados e marido) e a opção profissional no sentido de gerenciar o seu produto com todos os riscos que um mercado da música pode 
trazer, a intérprete opta pela carreira solo em 1999 e grava o primeiro CD - Ivete Sangalo. O álbum é gravado pela Universal Music com direção artística de Marco Mazzola, em abril, maio e junho de 1999, no estúdio Impressão Digital, Rio de Janeiro (bases, sopros e vozes) e no estúdio WR, Salvador (vocais e percussão), e mixado em Los Angeles no Castle Oaks \& Bay. A artista fala sobre esta parceria, em entrevista à autora:

Minha filha, eu não posso falar de gravadora. Eu queria tanto poder reivindicar coisas com gravadora. Eu não tenho esse problema. Primeiro, os nossos contratos são muito esclarecedores, todas as cláusulas e tudo o que eu quero. Acho que nós temos que pensar mutuamente. Não é por que eu sou uma artista e que estou brilhando que a gravadora não tenha que lucrar com isso. Tem. Ela é veículo, e eu sou produto. Então, temos que ter as duas partes parecidas para que trabalhemos em conjunto, felizes. Quem trabalha de graça é relógio. Eu tenho livre arbítrio de ter ou não uma gravadora. [...] Também tem a conduta da gravadora e a minha conduta diante deles. Nós nos respeitamos muito e já que eles confiam em mim, eu confio neles, no trabalho deles. (SANGALO, 2005).

Assim, Ivete se posiciona como uma intérprete/empresária que tem clareza acerca da relação empresarial que se estabelece entre ela, enquanto produto artístico, e a gravadora no papel de divulgar e lucrar assim como ela com este produto. Vejamos o seu primeiro álbum solo a partir do seu canto/música/letra e imagem.

A capa do seu primeiro álbum solo já remete ao ícone de uma intérprete que se constrói também pela imagem cheia de beleza e juventude embalada como uma flor plena de viço, perfazendo uma imagem de Bahia que não corresponde ao modelo da mulher baiana representada em sua grande maioria nas novelas da Globo, nos romances de Jorge Amado, nos palcos teatrais da Bahia e do Brasil.

Para Kellner:

[...] na contemporaneidade, a moda é um componente importante da identidade, ajudando a determinar de que modo cada 
pessoa é percebida e aceita. [...] Moda e modernidade aliam-se para produzir personalidades modernas à cata de identidade em constantes renovações e atualizações de roupas, aparências, atitudes e estilos, com medo de estar desatualizadas e fora de moda (2001, p. 337).

Neste sentido, no seu primeiro álbum, Ivete rompe com este modelo, representando no encarte do álbum uma baiana clean, até mesmo como uma imagem de santa, como pode ser observado na segunda foto da capa do álbum. Na terceira foto, já se apresenta uma imagem brejeira, mais ainda num sorriso tímido e um olhar inocente. $\mathrm{Na}$ foto do centro, podemos observar uma quebra desta imagem com a foto dos seus lábios tomando toda a extensão da capa, que se oferece para o ouvinte como se pudesse sorvê-lo com a sua voz, ou ainda encantá-lo com a boca cheia de brilho. A quarta e a quinta fotos do álbum mostram uma Ivete mais sóbria e, ao mesmo tempo, plena de beleza e juventude. Posa para a foto como se fosse um catálogo de moda da revista Vogue. Na última foto da capa, aparece a estrela, envolta em plumas com a mão sobre a testa, como se estivesse protegendo do sol a sua pele de pêssego.

A estrela se exibe plena e bela, perfeita, sem defeitos, numa embalagem pronta para ser consumida por uma infinidade de fãs/fiéis que quer(er)iam ser Ivete. 410 mil cópias foi o número de álbuns vendidos na sua estreia como solista. Continuemos a consumi-la agora de forma musical/vocal/poética. Interpretando no seu álbum de estreia, em sua maioria, compositores baianos, grava um repertório eclético com samba reggae, balada, funk, salsa, axé, frevo, galope e samba. Por este viés, poder-se-ia compreender a axé music como uma interface de repertório (MOURA, 2001), de composições que, tomadas no seu conjunto, configurariam um estilo - ou, como também se diz comumente, um gênero.

A primeira faixa deste álbum, Canibal, é um axé com letra e clima que nos remete às marchinhas de Carnaval de Braguinha, como $O$ pirata da perna de pau e Alá lá ô, dentre outras. Entretanto, o que de 
fato se retrata na letra da canção é o amor de um índio que trazia alegria à sua amada. A faixa dois Tá tudo bem, de Alexandre Peixe (percussionista que se tornou intérprete em virtude do número considerável de sucessos nas vozes de outros artistas baianos), um samba reggae romântico cujo tema continua sendo o coração e as brigas e pazes que permeiam a união a dois. Carlinhos Brown e Luiz Caldas comparecem na faixa três com uma regravação realizada por Ivete, cuja percussão de timbaus/timbalada demonstra, na interpretação da artista, um domínio rítmico que vem sendo cada vez mais aperfeiçoado pela sua performance vocal ao longo de sua carreira. $\mathrm{Na}$ faixa quatro, composição de Davi Sales, Música prá pular brasileira, a introdução se reporta ao frevo Índio quer apito, de Milton de Oliveira e Haroldo Lobo, num frevo baiano/pernambucano; nesta faixa, Ivete se autodenomina portadora da alegria do Carnaval e convida todos a cair na brincadeira até o dia raiar.

$\mathrm{Na}$ faixa cinco, comparece com Monsieur Samba, de Gal Sales e Jamoliva, num pagode baiano cujo convite - em francês - a cair no samba consiste na descrição das partes do corpo que vão sendo tocadas, do queixinho ao joelhinho. Ivete, nesta faixa, demonstra o que vem acontecendo no decorrer de sua carreira, que é o diálogo com todos os ritmos, inclusive o pagode baiano. Mesmo o arrocha, evitado por quase todos os artistas que não se proclamam arrocheiros, em virtude de sua emblematização como brega, integra o seu repertório, de maneira a apresentar o panorama musical radiofônico, fonográfico carnavalesco, não só da Bahia, mas do Brasil.

A passagem por toda esta diversidade musical, traduzida pelo swingue de sua voz, lhe permite esta mobilidade rítmica e melódica, de forma que podemos apontá-la, dentre as intérpretes aqui estudadas, como a única que canta pagode tanto nos shows quanto nos álbuns, demonstrando com isso livre trânsito por ritmos considerados ou não "baianos".

As outras faixas, de autores baianos, também comparecem com temas românticos, a exemplo de Medo de amar, de autoria própria, e de Tô na rua, de Gal Salles e Xexéu, além da regravação de Bota prá 
ferver, de Durval Lelys. Os autores nacionais que comparecem no álbum são João Bosco, com Tenho dito, em cujo arranjo, à la Timbalada e salsa, a cantora brinca imitando a voz do autor; da dupla carioca Antônio Adolfo e Tibério Gaspar, regrava Sá Marina, já demonstrando a intimidade com a soul music brasileira de Wilson Simonal, Tim Maia e Cassiano. Num arranjo latino que mistura bolero e big band com naipe de sopros, teclado e percussão, Ivete desliza o seu canto percussivo/sonoro pela cama preparada pela banda, que a deixa livre para voar com sua voz.

Em seu álbum de estreia, Ivete já demarca o que pretende com a música - experimentar sonoridades que, ao mesmo tempo em que carregam o rótulo de axé music, o que para ela não se configura em problema, lhe permite sofrer influências e influenciar gerações com desenvoltura. Para a intérprete, em entrevista à autora, a Bahia de sua música "é a Bahia permissiva musicalmente. A Bahia absorve tendências, influências, traduz sempre de maneira diferente a sua cultura, o seu folclore, a sua força. A Bahia que eu povoo é a Bahia da liberdade" (SANGALO, 2005).

Para finalizar, Ivete grava, assim como Daniela no seu primeiro álbum solo, uma balada romântica de Herbert Vianna e Paulo Sergio Valle. Desta vez, a balada romântica Se eu não te amasse tanto assim, prenunciando uma cantora que tem um trânsito livre pelo romantismo nas canções que se tornarão bastantes presentes nos próximos álbuns. Isto demonstra que a versatilidade interpretativa impressa em sua voz quente, forte e grave permite esta flexibilidade rara na maioria das intérpretes, que busca um modelo mais impresso no estilo musical que nas possibilidades vocais que o intérprete pode experimentar.

Partimos para o seu segundo álbum solo, Beat Beleza, gravado em 2000 na Ilha dos Sapos (estúdio de Carlinhos Brown) em Salvador, no estúdio AR e Cia. dos Técnicos, no Rio de Janeiro, sendo mixado também neste último. Neste álbum, a partir da capa, podemos captar a pretensão, mesmo que subliminar, da artista e da Universal Music no sentido de transformar a intérprete em uma autêntica representante 
latina da música, sem precisar sair do seu local. Por outro lado, ao se observar a capa do álbum, assim como o primeiro e todos os posteriores, não se reconhece aí o que se convencionou assinalar como características carregadas de signos como a morenice, a sensualidade e outros ingredientes que possam localizar espacialmente sua origem. Pelo contrário, podem-se identificar ícones globais de intérpretes de qualquer parte do mundo. Estes ícones, impressos nas capas, podem ser observados pelas argolas (brincos) descomunais de aro, camiseta branca, jeans, ou mesmo camiseta preta cheia de tachas, formando o desenho de uma águia; para ampliar um pouco esta leitura, podemos observar em seu braço esquerdo uma pulseira prateada amarrada, em que se prende um grande crucifixo, ícone do maior ídolo feminino pop mundial - Madonna. Assim, Ivete dialoga não só como música de forma global cantando salsas, samba reggae, axé, baladas, etc; sua imagem também carrega estes ícones identificados em qualquer parte do mundo que tenha sido engolfado pela música pop.

Sua imagem, embalada pela sua música/letra/voz, se oferece aos ouvintes e espectadores de maneira a embalar com A lua que eu te dei, de Herbert Vianna, a dançar a salsa Tanta saudade, de Djavan e Chico Buarque, que termina com uma batida de candomblé, ou ainda na faixa três, Pererê, de Augusto Conceição, um frevo com levada da Timbalada. Nesta faixa, ela imprime o bordão que carrega até hoje - miseravão. Em Balanço black de Cassiano André, Ivete divide os vocais com Gilberto Gil num arranjo de Letieres Leite, cujo diálogo do eletrônico com o funk faz sentido no Carnaval de Salvador e ainda vira um rap.

No encarte deste álbum, Ivete demonstra o quanto se sente agradecida por ter contado com a presença de Gil dividindo os vocais da canção acima com ela. Diz a intérprete:

[...] Prá você que está lendo este encarte, é importante para mim que compartilhe de alguns nomes. A Deus, por me permitir realizar tantos sonhos. O sonho de ter GILBERTO GIL (grifo da intérprete) no meu CD. A ele, por tudo o que ele é: meu amigo, meu ídolo, meu bailarino predileto. 
Ivete demonstra que o ídolo também tem ídolos que se torna admirador e parceiro em outros negócios que extrapolam a música, como na parceria com o seu camarote em 2005 no Farol da Barra. Ainda neste álbum, Ivete interpreta Postal, do cantor de soul brasileiro Cassiano, além de baladas como A lua que eu te dei, que compôs a trilha da novela global Kubanacan, e Meu abraço, de sua autoria com Marquinho de Carvalho, que também fala de lua. As três canções que mais se aproximam da temática do axé music são Pererê e Bug bug bye bye, ambas de Augusto Conceição, e Empurra empurra, de Alain Tavares e Gilson Babilônia, um frevo que usa a levada da Timbalada bastante presente no seu trabalho. Nesta canção, Ivete inicia brincando com o sotaque carioca, iniciando com "dá licença"!

Podemos perceber, pela vendagem do álbum - 200 mil cópias, quase metade de vendas do seu álbum de estreia -, que houve um estranhamento por parte do público, que provavelmente esperava algo mais voltado para o universo local, ou mesmo do Carnaval. É no ano seguinte, em 2001, com o álbum Festa, que a intérprete atinge o Brasil, consolidando-se como uma grande estrela da música baiana/ brasileira, tornando-se referência e presença em todos os programas de música, em revistas, prêmios nacionais de melhor cantora regional como Multishow ${ }^{51}$ e MTV, bem como musa da Copa de 2002 com Festa (Poeira), de Anderson Cunha, que se tornou o hino da vitória do Brasil neste evento esportivo. Vejamos, a partir do repertório do álbum, como a intérprete sedimenta sua singularidade.

O álbum gravado na Ilha dos Sapos, em Salvador, traz o repertório quase todo de compositores baianos que circulam no ambiente da axé music, à exceção do também artista baiano Gilberto Gil, com Assimétrica, e Nando Reis, com E tudo mais. Ramon $\mathrm{Cruz}^{52}$, autor da primeira faixa do funk/reggae com pitadas no eletrônico, a começar pela abertura, com Ivete cantando em inglês com a voz distorcida pelo protools a canção Ruas e rios, que fala do amor na cidade da Bahia, fazendo uma analogia entre o calor do verão e o amor que ferve na cidade, cuja topografia poderia ser transitada de canoa. 
Entretanto, o grande sucesso deste álbum da intérprete é a faixa título, Festa. Com arranjo de Letieres Leite, "misturando o mundo inteiro" de ritmos e influências, parece um funk com iê iê iê e soul, vamos ver o que é que dá:

Hoje tem festa no Gueto

pode vir, pode chegar

Misturando o mundo inteiro

Vamos ver no que é que dá

Vem gente de toda cor

Tem raça de toda fé

Guitarras de rock'n roll

Batuque de candomblé, vai lá

Pra ver a tribo balançar

O chão da terra tremer

Mãe preta de lá mandou chamar

Avisou, avisou, avisou

Que vai rolar a festa, vai rolar

O povo do Gueto mandou avisar

Festa. Ivete Sangalo. (2001)

A festa à qual Ivete se refere acontece no Candeal Ghuetho Square, ambiente criado por Carlinhos Brown para os ensaios da Timbalada ${ }^{53}$ que acontecia aos domingos, mas que os moradores, organizados em virtude do incômodo produzido pelo volume do som, conseguem proibir. Nesta mesma festa, organizada pela mãe preta, que tanto poderia corresponder à África quanto a uma mãe de santo, a intérprete se propõe a misturar sons, cores, fé, para ver no que resultaria sem reservas esta mistura. Antropofagicamente, tudo pode ser combinado; o que importa não é o resultado, mas o prazer de poder experimentar. Se observarmos o clipe exibido nas emissoras MTV e no canal fechado Multishow, aparece a anfitriã, Ivete, recebendo convidados vindos 
de todos os lados, de famosos "globais" como Vera Fischer, Carolina Dieckmann, a anônimos, todos com o intuito de fazer uma festa. Ao final, uma abelha intrusa é abatida pela anfitriã de forma cômica e displicente.

As outras faixas, em sua grande maioria, têm o amor e a relação a dois como tema, tudo em clima de festa. É um álbum dançante, que também apresenta os ritmos com que a intérprete se identifica, como baladas, funks, soul, axé e frevo, dentre outros. Observemos o frevo $O$ grande chefe, de Chiclete/André Fanzine e Cassiano Faleta. Nos frevos gravados por Ivete, observa-se que, ao mesmo tempo em que está impresso um clima ingênuo que remete à imagem alegórica de índio, associada à alegria, o axé está presente não só na letra, mas no clima do Carnaval. A interprete dialoga com muita intimidade por estes ritmos, ao se apropriar como uma personagem em cada ritmo/letra/melodia/voz. O mesmo acontece com o samba reggae do percussionista Leonardo Reis e do baterista Marcelo Brasil Tum tum goiaba, cuja letra descreve as frutas tropicais que podem ser provadas "na boquinha". Ao enumerar as frutas - bago de jaca, manga, pinha-, além de deslocar o acento prosódico da palavra bago, estas palavras soam aos nossos ouvidos como onomatopéias, sem, no entanto, causar estranheza, pois tão importante quanto a letra e a melodia é o ritmo materializado pela voz/corpo.

Medeiros (2001, p. 136) propõe observar a interpretação do texto como fenômeno também externalizável, por meio da voz. Assim, mesmo se referindo ao poema, a autora afirma que o trabalho com canções num curso de poesia, como forma de compreender e, assim, apropriar-se das nuanças do universo dos sons e da voz, pode enriquecer um diálogo mais efetivo com outras disciplinas, especialmente a música, a etnomusicologia e a antropologia. Partindo da letra Pipoca moderna, de Caetano Veloso, a autora propõe o estudo da canção no sentido de devolver a voz ao poema. Podemos observar que a axé music, com sua diversidade rítmica/sonora, pode imprimir diferentes nuanças numa análise desta natureza, no sentido de poder compreender a interface entre letra, música, voz, corpo e identidade. 
Vale ressaltar que o álbum Festa, assim como todos os seus álbuns até então, são produzidos por Alexandre Lins, percussionista que pertenceu à banda da intérprete, vindo a se tornar produtor de discos, particularmente os de Ivete e Banda Eva. Na contracapa deste álbum, Ivete agradece especialmente ao músico "que me ajudou a concluir mais esse projeto, num momento tão difícil” ${ }^{34}$. Com a música Festa bastante executada em várias capitais do Brasil no período do seu lançamento, Ivete recebe o prêmio Multishow de melhor cantora.

Vejamos como aparece a imagem de Ivete neste álbum. A concepção da capa é da própria Ivete, que convida estilistas famosos do Brasil, dentre eles Marcelo Sommer, Fause Haten, Glória Coelho, Renato Kerlakian, Tufi Duek e Walter Rodrigues, para criar modelos exclusivos para vestir a "boneca" que se exibe na capa. No encarte, podemos recortar os modelos para vestir a boneca com a roupa que escolhermos para ela ir à festa. "Brincando" de modelo de capa de revista, Ivete se exibe na capa do álbum, linda e sensual num micro vestido dourado fosco e sandálias de salto agulha, num jogo entre sensual e moleca, entre esconder e mostrar, de forma a deixar o fã/ fiel, o consumidor do produto entre perplexo, admirado ou cúmplice desta "brincadeira" de ser modelo/cantora.

Ivete brinca com sua imagem de todas as maneiras, fazendo beicinho, mostrando as pernas, detalhes da sandália, exibindo a boca sensual (lembrando em algum momento Gal Costa no álbum Fa-tal, que traz sua boca vermelha se oferecendo, como uma fruta). De certa maneira, Ivete exibe todo o seu corpo para aquele que quer consumi-la, quer ser igual a ela, ou melhor, quer ser ela. "Não tem jeito, sou exibida mesmo. Sempre fui grandona, espaçosa. Eu gosto de ser notada", afirma em entrevista à Revista Contigo (LIRA NETO, 2006, p.64). Morin (1989) afirma que a estrela, quanto mais é consumida, mais é partilhada. Então, sua boca, pernas, pescoço, corpo, olhos, tudo pode ser desejado, e até recortado e colado do jeito do "freguês". É só usar a tesoura e a cola, colocar o CD para tocar e "se sentir Ivete Sangalo".

Para concluir a análise deste álbum, os motivos impressos na capa nos reportam também ao universo da moda, com tesouras e riscos de moldes, próprio deste ambiente. 
O seu próximo álbum, Se eu não te amasse tanto assim, lançado em 2002, é uma coletânea de canções românticas, com vendas acima do esperado em relação aos álbuns anteriores: 120 mil cópias.

\section{A sorte grande de (piri)guete Sangalo}

A minha sorte grande foi você cair do céu minha paixão verdadeira.

(Lourenço)

O quarto álbum solo - Clube Carnavalesco Inocentes em Progresso ${ }^{55}$ veio dois anos depois de Festa. Lançado em 2003, com 180 mil cópias vendidas, gravado e mixado na Ilha dos Sapos nos meses de junho e julho de 2003, o álbum traz 14 faixas e direção de Alexandre Lins, exceto a faixa Eu e você, você e eu, dirigida por Davi Moraes.

É possível que a artista tenha sido influenciada por Davi Moraes, seu então marido, na maturação deste álbum. Ivete teria se lançado num processo criativo coletivo, em que os músicos experimentavam, tocavam juntos, dialogavam, de forma a construir um produto musical maturado, cuja intimidade e propriedade se realiza antes de ir para o estúdio registrar.

A intérprete descreve o processo de construção deste álbum, à repórter do jornal A Tarde: "Por um mês e meio, meus músicos iam à minha casa, a gente almoçava e tocava na varanda onde criamos tudo. Quando percebemos, tinha funk e afoxé, até merengue" (LIMMA, [2003]).

No jornal Correio da Bahia, a respeito do processo de criação deste álbum, diz Ivete:

O resultado foi sendo maturado bem à baiana: chamava a galera para bater um feijão lá em casa e depois reunia todo mundo na varanda para ensaiar. Nunca tive tanto tempo parada em prol de um projeto e acho que isso faz mesmo a diferença. Conseguimos extrair todas as possibilidades das músicas selecionadas. Foi 
Festa que abriu minha visão, me fez enxergar novos elementos para usar com a música baiana. (MIRANDA, [2003]).

No entanto, em entrevista à autora, Ivete descreve o ponto de partida para a intérprete conceber um álbum...

Primeiro, a minha energia com a música. Coisa de intérprete. De ouvir. Às vezes eu ouço a música, eu nem me deparo com letra, com melodia, é uma loucura isso. Quando eu ouço de novo eu digo. Vixe! Dizia isso? Eu posso gravar uma música [canta] chão, pé, pé, chão, cabeça, árvore, chão, pé. Chão, pé, cabeça, árvore, céu, choveu, molhou. Se isso me tocar, eu gravo. Isso é muito bom em $99 \%$ das vezes. Só que eu corro risco, de alguma maneira, de me trazer prejuízos, porque as pessoas criam conceitos a respeito da gente. A gente não pode estar todo dia na televisão, dizendo: "Olhe, eu sou assim, eu sou assado, eu só gosto de amarelo". Isso é humanamente impossível. Mas o meu ponto de partida é a minha alegria particular, que naturalmente isso leva pras pessoas. Se eu tô fazendo um negócio "satisfetcha", o povo vai estar "satisfetcho" comigo. Na verdade, você canta uma música ali porque um produtor mandou você cantar. E eu também tenho a sorte de ter conseguido galgar a minha carreira sem tantas interferências, porque, não sei como, sempre parecia, prá mim e prá quem trabalha comigo, que eu sei exatamente o que eu quero. É uma dúvida. A gente nunca sabe o que quer exatamente. Depende do dia, da hora, mas eu consigo concluir os meus trabalhos dessa maneira. E tenho muita tranquilidade. (SANGALO, 2005).

A imagem que Ivete imprime perante os músicos ${ }^{56} \mathrm{com}$ os quais trabalha e perante a mídia que a veicula sugere uma segurança do que quer e do que faz, de maneira que esta mesma imagem se plasma pela própria intimidade com que a intérprete transita em cada canção que lhe sai da boca/corpo.

Ao ouvir o álbum, percebemos um romantismo explicito no repertório cheio de títulos sugestivos, como Sorte grande, Faz tempo, Vai 
dar certo, Você e eu, eu e você, Só pra me ver, a regravação de Retratos e canções de Michael Sullivan e Paul Massadas e a versão Somente eu e você. Assim, a intérprete canta para o mundo que está apaixonada, não só através destas canções, mas também pelo projeto gráfico do álbum: uma Ivete rodeada de flores na capa e com um sorriso de orelha a orelha. Folheando o encarte, observamos uma Ivete que mais parece "Alice no país das maravilhas" vislumbrando "a casa no campo" - ou será "uma casinha de sapé", ao lado do seu amado? Mais adiante, podemos observar o retorno da "modelo exibida" que se comporta como uma detetive. Ou será uma cantora pop, com todos os ícones que isto possa representar: argolas enormes, corrente prateada no pescoço, chapéu...

Entretanto, o mais interessante pode ser observar, além da medalha em que está impressa Banda do clube, com o nome dos músicos que a acompanha no álbum, uma fotografia que pode ser tomada como chave: ao fundo, meio desfocado, um dos ícones maiores de Salvador - o Elevador Lacerda. Ivete está localizada. Em primeiro plano, com um olhar entre maroto e apaixonado, exibe um canário ${ }^{57}$. Entretanto, mais que o canário, o que efetivamente se exibe é a espessa aliança no dedo, numa afirmação de que Ivete está casada com a música, com o sucesso e com Davi Moraes. Efetivamente, o que está em primeiro plano, nesta foto, é a aliança de casamento.

$\mathrm{Na}$ contracapa, um cocar colorido cheio de penas que remete à sua obra. Vide a citação de índio quer apito na canção Música prá pular brasileira no seu álbum de estreia, ou ainda, no álbum Festa, o frevo $O$ Grande chefe. Ivete ratifica seu trânsito no Carnaval em canções como Ritmo gostoso, Verdadeiro Carnaval e Pan americana. Vejamos como se mostra a Ivete no Clube Carnavalesco.

O pop associado ao Carnaval pode ser observado na faixa Brasileiro, cuja remissão ao senso comum é evidente:

Fim de semana todo brasileiro gosta de fazer um som uma cerveja bem gelada violão de madrugada 
samba e futebol

Eu trabalho o ano inteiro

De janeiro a janeiro e não me canso de plantar

Ô ô ô ô

Passa boi passa boiada ${ }^{58}$

Debruçada na janela que vontade de cantar

Eu sou brasileiro

Índio, mulato, branco e preto

Brasileiro. Augusto Conceição/Duller/Fábio Alcântara. (2003).

Apesar de as duas primeiras faixas do álbum ser em ritmo de funk, é na faixa três, Sorte grande, de Lourenço, que Ivete se "revela". Depositando a sorte no amor do outro, a intérprete "levanta poeira de prazer" com o seu amado, que atinge todo o Brasil. O hit se configura na síntese do álbum, que tem na sonoridade da guitarra de Davi Moraes o seu eixo sonoro, associado à percussão à la Timbalada, e à sonoridade eletrônica. Trata-se de um álbum eminentemente pop.

Letieres Leite, saxofonista e arranjador da intérprete desde seu álbum solo, em inúmeras faixas, declara em entrevista à autora:

O pop está muito ligado ao conceito da indústria fonográfica [...] A palavra pop está muito vinculada a isso, à música de consumo, de massa. [...] Prá mim, a música pop é sinônimo de música que entra nas entranhas da indústria fonográfica de grande produção, de tocar no rádio. Então, ela ganha essa estampa de pop. É porque ela segue os trâmites pra tocar no rádio, ela cumpre uma série de regras. Pop está ligada a negócio. (LEITE, 2005)

Portanto, se o pop é um modelo musical que carrega em sua construção características padronizadas no sentido de ser consumido em larga escala, os ingredientes que o constituem não se resumem unicamente em timbres, ritmos, mensagens poéticas, tempo de duração para a execução nos rádios. Também constam de imagens exibidas em 
videoclipes, em programas de TV, cujo impacto produzido junto ao público jovem, sendo que os efeitos culturais que o provocam podem ser percebidos pelas estratégias de marketing, cujo objetivo é vender a imagem do artista embalada com todos os ingredientes para o consumo em larga escala.

Para ilustrar esta afirmação, observemos o lançamento do álbum anteriormente citado com entrevista convocada pela gravadora Universal, no Rio de Janeiro, com representantes dos maiores veículos da mídia impressa no país. O jornal A Tarde, representado pela jornalista Neyse Limma, participou da coletiva. Segundo esta, o detalhe mais importante a ser destacado era o hiato de dois anos de Ivete sem gravar, dando assim possibilidade de uma maior experimentação deste novo álbum. Alguns trechos da crítica da jornalista ao álbum:

Ivete mantém o vocal afetado e outros cacoetes axezeiros, que acabam desvalorizando um timbre que podia ser bacana. As letras também são meio melhor deixar pra lá (grifo da jornalista). Mas a cantora dá sérias mostras de que quer tentar coisas novas, embora siga afirmando que continua "na praia do axé" (grifo da jornalista), por via das dúvidas. Axé, assim, como dizer... clássico, tem Só pra me ver e Azul da moda, esta última parceria com o cunhado Ari Moraes. O resto é basicamente pop, com algumas caídas para o funk, um estilo que a cantora já frequentava bem antes de ficar famosa na Banda EVA.

Em Clube Carnavalesco, ela faz cover de Tim Maia Eu e Você, você e eu (juntinhos) e outra do soulzinho Retratos e canções, também imortalizado pelo síndico. A maior parte das outras faixas também segue a linha dançante, seja no approach bregoso da candidata a hit Sorte Grande, com aqueles tecladinhos chatos de Radamés Venâncio, seja na pegada mais, digamos, Marisa Monte (sem insinuações, por favor) das canções assinadas por Gigi, baixista da banda - Faz tempo e Devagar e sempre. No mais, é Novos Baianos na veia, a suingada Brasileiro às composições dos herdeiros da trupe de Morais e Baby - tipo Pedro Baby e o próprio Davi com a irmã Ciça, em Verdadeiro 
Carnaval. Considerando que Novos Baianos soa muito melhor que axé clássico e resumindo tudo bem direitinho, conclui-se que Ivete Sangalo está de fato apaixonada. E que fica bem melhor assim. (LIMMA, [2003]).

Já a repórter Dóris Miranda, do jornal Correio da Bahia, afirma:

Diferente... e como sempre, em seu novo disco, Ivete reafirma o interesse pelo pop, ensaiado em Festa, e mantém as raízes carnavalescas. [...] $\bigcirc$ disco que chega às lojas, depois de dois anos de intervalo, traz a mesma Ivetinha de sempre, porém um pouco diferente, se é que isso é possível. Em nenhum momento, deixa de lado o Carnaval que a projetou, tanto que presta uma homenagem à folia resgatando o nome do primeiro bloco carnavalesco de que se teve notícia em 1900. Mas agora se utiliza de outras formas de expressão também, numa tentativa mais consistente, já esboçada em Festa, de fazer música pop.

Aliadas às já tradicionais levadas de samba reggae, galope, frevo, salsa e merengue que, misturadas, se apresentam como a mais genuína do trio elétrico, Ivete Sangalo juntou suas descobertas. Sorte Grande, a música de trabalho, já recordista em execução (é a mais executada em 2003, com cerca de 350 execuções em todas as rádios do Brasil), resume o estilo Ivete de ser. É festiva, com aquela cadência característica do samba reggae mais contemporâneo, já mesclado com as outras referências. Ela segue na mesma linha em Brasileiro e Só pra ver. [...] Resgata as origens (antes mesmo da Banda EVA) com uma salada de samba-soul-rock (Verdadeiro Carnaval e Devagar e sempre), revigora o ancestral axé com pitadas de funk e renova o espírito com bases eletrônicas, como em Vai dar certo e Ritmo gostoso, que traz de volta os compositores Gilson Babilônia e Alain Tavares, autores de alguns dos grandes sucessos anteriores de Ivete, como Levada Louca e Arerê. [...] No fim, amansa o clima com umas baladinhas como Somente eu e você, que inspira a personagem de Danielle Winnitis na novela das sete, Kubanacan. ${ }^{59}$ (MIRANDA, [2003] ). 
A intérprete, no entanto, diferentemente da afirmação da jornalista Neyse Limma, revela por telefone ao jornal Correio da Bahia: "Não quero ser consumida apenas e isso requer paciência e reflexão. [...] Não sei se o meu disco vai dar certo ou errado. O que me interessa é que ele me deixa muito feliz. Por isso vou fazer uma festa para o lê povon se acabar". Ainda na mesma entrevista, a artista declara que "a superexposição é perigosa quando você perde o fio da meada". Assim, as críticas que norteiam a carreira de uma artista de forma geral, e desta intérprete de maneira particular, aponta cuidados com a visibilidade (THOMPSON, 1998), de forma a calcular os passos a serem dados a cada momento que se lança um produto novo.

Tomemos em linhas gerais o que Thompson (1998) aponta como a relação da modernidade "com diferentes formas de interação entre os indivíduos" (p. 7). Considerando três tipos de interação, que denomina face a face, mediada e quase interação mediada, analisa o papel da mídia na formação das sociedades modernas. Na quase interação mediada, derivada da ideia de distanciamento espaço-temporal em Giddens (1991), o autor aponta as transformações de interações operadas pela mídia entre os indivíduos.

As construções midiáticas das imagens podem apresentar fragilidades de conteúdo simbólico, tornando-se necessário apontar os efeitos provocados pela visibilidade no indivíduo público - neste caso, o artista - no sentido de preservar, perpetuar a mediação desta imagem em longo alcance. Assim, ao adquirir um álbum de um artista, vê-lo na televisão, ir ao seu show, vê-lo de perto no Carnaval ou até mesmo sair no bloco "puxado" por este artista, por vezes pode confundir o receptor, no sentido de nos soar familiar aquela imagem acessível através de um veículo (rádio, TV, CD, DVD, etc.). "Por outro lado, a transformação da natureza da visibilidade através destes veículos transforma também a relação de forma dicotômica entre o público e o privado" (THOMPSON, 1998, p. 109).

Thompson aponta dois sentidos desta dicotomia. O primeiro "tem a ver com a relação entre o domínio do poder político institucionalizado, que cada vez mais era exercido por um estado soberano, 
por um lado, e o domínio da atividade econômica e das relações pessoais, que fugiam ao controle direto do poder político, por outro lado" (1998, p. 110).

O segundo sentido se refere ao que é público enquanto observável, ou mesmo realizado na frente dos espectadores para que estes vejam ou ouçam. O privado, no entanto, é o que está fora da cena, o que se esconde da vista dos outros. Assim, Thompson (1998) aponta que o sentido dicotômico se opera pela "publicidade versus privacidade, com abertura versus segredo, com visibilidade versus invisibilidade" (p. 113). Neste sentido, o ato público se refere ao que é feito abertamente, e o privado se refere àquele que é realizado de forma secreta, invisível.

Como exemplo, podemos ilustrar a segunda gravidez da artista - já que a primeira, perdeu o bebê - como espetacularização da vida privada. Disputada por quatro grandes programas da rede Globo: Serginho Groisman, Xuxa, Faustão e Fantástico no anúncio público de sua gravidez, a artista vê sua disputa desmoronar com o equívoco do compositor e cantor Toquinho que ao participar ao lado da estrela do show de Andrea Bocelli em São Paulo em abril de 2009, anuncia para o público a gravidez da estrela, revelando assim o segredo que todos já sabiam.

Assim, Ivete transforma a vida privada em pública, até como estratégia de marketing no gerenciamento de sua carreira, de forma a se exibir como eu-mercadoria, plena, inteira, de biquíni, de maillot, com sutiã à mostra, abraçada a todos os namorados famosos que completam sua lista, ao lado dos familiares, ao lado de celebridades de todas as áreas, vendendo tanto produtos de toda natureza não produzidos pela estrela (shampoos, sandálias, iogurtes, cervejas, tintura de cabelo) como produzidos com sua marca (CDs, DVDs, vídeo clips, blocos de Carnaval, etc.). Até o seu espólio é exibido publicamente nos magazines como Contigo, Quem, Caras. Podemos considerar também declarações de famosos como Xuxa, Suzana Vieira, Carolina Dieckmann, Serginho Groisman e Hebe Camargo, que a enchem de elogios como pessoa e como artista. 
Ainda que a crítica "especializada" não seja unânime em considerá-la um talento (vide críticas do seu álbum Clube Carnavalesco...), o que importa para o grande público e para a estrela é ser "consumida" de todas as maneiras. No programa Marília Gabriela Entrevista, exibido na GNT em 20 de maio de 2007, a artista diz:

Meu lance é com o público. A crítica é mais relacionada ao segmento. Você agradar a todos é uma tentativa ridícula. Eu acho que o crítico tem que emitir sua opinião com a mesma liberdade que eu tenho de criar. A crítica não me movimenta. A capa do jornal de hoje enrola o peixe de amanhã (SANGALO, 2007).

Só pra me ver, de sua autoria, Seja por meio de fofocas e escândalos, seja através de sua música, seja ainda pela sua imagem, pela sua voz, pelo seu corpo, pelas suas declarações a respeito da música e de como manter a forma, etc...

A canção neste álbum pode servir de ilustração de um processo de construção de uma identidade própria:

Me deixa cantar que a banda é boa

Me deixa cantar

Me deixa cantar que a vida é boa

Me deixa cantar

Primeiros acordes na avenida

E o povo se junta pra ver

Uma banda famosa da terra

Hoje vai ter

A gente toca música boa

Que o povo gosta de cantar

Liberdade na voz dela que ecoa

E balança

Sou, sou, sou eu, sou eu

Quem carrega a galera

Que dança, que passa

Que fica que espera pra ver 
Só pra me ver

Sou eu, sou eu, sou eu

Que carrega a negada

Que dança, que passa

Que fica parada pra ver

Só pra me ver

Primeiros tambores na avenida

Me deixa cantar que a banda é boa

Me deixa cantar

Me deixa cantar que a vida é boa

Me deixa cantar...

Só pra me ver. Ivete Sangalo (2003).

Esta canção define em linhas gerais o que significa para a intérprete/compositora transitar no mundo da música. Ao mesmo tempo em que pede para cantar por ter "uma banda boa", pede também "porque a vida é boa". Ao mesmo tempo em que a intérprete usa o pronome pessoal na terceira pessoa e no feminino - ela - para se referir a qualquer cantora, mais abaixo se apropria do fato de que "sou eu que carrego a galera que passa, que fica e que espera pra ver, só pra me ver" (grifo da autora), dando mostras de que a galera vai para a avenida "para vê-la", não importando de que maneira. Parada, cantando com ela, dançando, de todas as maneiras, "todos" querem desfrutar de sua presença/imagem/voz.

Neste sentido, Ivete Sangalo pode ser considerada um fenômeno da música baiana/brasileira, uma pop star cuja trajetória também pode ser vista como um sucesso de marketing. Exibida, é uma intérprete baiana/brasileira que gosta de se (a) mostrar, se exibir. Kellner (2001), ao analisar o fenômeno Madonna como um construto, aponta que:

Mesmo recorrendo aos métodos convencionais dos Estudos Culturais, com a análise do texto e sua recepção pelo público, argumentaremos que um componente geralmente negligenciado dos estudos culturais - a economia política e a produção 
da cultura - é uma importante chave para a compreensão do fenômeno Madonna, pois o sucesso de Madonna é em grande parte um sucesso de marketing, e a música, os vídeos, outros produtos seus e sua própria imagem, são triunfos de estratégias extremamente bem sucedidas de produção e marketing (p. 342).

A partir da afirmação podemos perceber graus de similitude do construto da pop star americana com as intérpretes baianas/brasileiras, de maneira geral, e Ivete Sangalo de forma particular.

O eu-mercadoria

Não quero dinheiro

Só quero amar

(Tim Maia)

As estratégias de marketing também deflagraram o sucesso provocado pelo lançamento do sexto álbum solo da intérprete - Ao vivo MTV -, completando dez anos de carreira, lançado em CD e DVD em 21 de dezembro de 2004 no estádio da Fonte Nova, em Salvador, para 80 mil pessoas. Podemos observar que, assim como o sucesso de Madonna (KELLNER, 2001), guardando as devidas proporções, o sucesso de Ivete é também, em grande parte, um sucesso de marketing. Conforme declaração da intérprete ao repórter Osmar Martins a respeito do convite para gravar Ao vivo MTV, diz a intérprete:

Eu já tinha recebido o convite, mas não aceitei por achar que não estava preparada e precisava sedimentar minha carreira. [...] Participei de todo o projeto e foi bacana porque a gente gravou tudo num único dia, com o estádio cheio, e a banda não errou uma nota. Eu amei o resultado (MARTINS, 2004).

Observamos, com esta declaração, as estratégias necessárias para se gerenciar uma carreira com sucesso. Ivete cercada de profissionais 
talentosos e competentes, como ela mesma não economiza reiterar, pela sua produtora Caco de Telha, que montou uma infra-estrutura mobilizando uma enorme equipe de mais de mil seguranças especiais, além de efetivos das polícias civil e militar, fast food, serviço médico, infraestrutura de som, luz, palco e banheiros químicos; a parceria com a prefeitura de Salvador também foi de fundamental importância na realização deste evento, colocando à disposição da população transporte urbano, bem como policiamento para a segurança do público; uma parte da renda foi revertida para o hospital infantil Martagão Gesteira, em Salvador, e para a campanha Sua nota é um show ${ }^{60}$, dentre outros.

Os patrocínios também foram fundamentais para a realização de um evento desta proporção. A parceria se estabeleceu com a Arisco, Vivo, Nova Schin, Insinuante, Iguatemi e Pestana Bahia. Como convidados, Daniela Mercury, Sandy \& Junior, Gilberto Gil, Davi Moraes, Tatau e Margareth Menezes. A MTV gravou um especial ao vivo que originou um CD e um DVD. Na coletiva para a divulgação do megaevento, que aconteceu no hotel Pestana, Ivete, ao lado do seu produtor executivo Ricardo Martins, além de ter mostrado toda a infraestrutura descrita acima, divulgou parte do repertório. Declarou ela: "trago canções que viraram sucesso na época em que eu integrava a banda Eva, mesclando com hits que fazem parte da carreira solo, além de uma música inédita de minha autoria" (MIRANDA, [2003]). Produzido pela Universal Music e dirigido por Alexandre Lins e Ivete Sangalo, o evento para a gravação do álbum e do DVD contou com uma equipe reunindo em média 70 a 80 pessoas, para por de pé um evento orçado em torno de $\mathrm{R} \$ 800 \mathrm{mil}$. Assim, o modo como Ivete gerencia sua carreira, indissociável de sua imagem, incorporando públicos diferenciados, possibilita tornar-se uma superstar pop.

Assim, com um repertório eclético e variado, recheado de hits jamais esquecidos pelos fãs, Ivete segundo seu diretor musical Alexandre Lins, "fará a abertura e em seguida receberá os artistas" (MIRANDA, 2003), com canções que fizeram parte do seu repertório ainda como vocalista/puxadora da banda Eva como Alô Paixão, Beleza Rara, Levada Louca, Vem meu Amor, Eva; grandes hits de álbuns solos 
como Carro Velho, Empurra-empurra, Sorte Grande, Festa, To na rua, Faz tempo, A lua que eu te dei, Se eu não te amasse tanto assim, e duas agradáveis surpresas: a primeira, a regravação da canção imortalizada na voz de Carmen Miranda, Chica Chica boom chic, uma rumba apreciadíssima, cheia de ufanismo; a segunda, a lambada Chupa toda, de Ronaldo Marcel, em dueto com o ministro artista Gilberto Gil, cuja interpretação termina de certa forma engolfada pela da sua parceira.

No álbum, além de Gil se fazem presente Sandy, com a balada Se eu não te amasse tanto assim, e Davi Moraes, com a guitarra em Astral. Quanto ao DVD, todos os outros artistas que não puderam entrar no álbum estão presentes. Segundo declaração da gravadora, "por motivos mercadológicos, entre as 30 músicas gravadas, foram selecionadas 18. Isso porque, a partir desse número, o projeto teria que se transformar em um CD duplo, o que acabaria por elevar o preço do CD ao vivo Ivete Sangalo" (MARTINS, 2004).

Para um álbum gravado ao vivo num estádio da proporção da Fonte Nova, o resultado técnico é satisfatório, captando todos os instrumentos com uma sonoridade agradável, bem como o "coro" dos fãs e do público presente em quase todo o álbum. Percebe-se na voz da intérprete uma soprosidade excessiva, talvez pela própria captação ao vivo, possibilitando assim um tipo de emissão vocal diferente de um registro em estúdio, que utiliza outro tipo de microfone, mais sensível e consequentemente, mais eficaz em maquiar alguns problemas técnicos.

Quanto à performance de palco, rodeada por um grupo de dançarinos, pode-se dizer que Ivete praticou com eles diversas coreografias, trocando cinco figurinos no decorrer do show, confeccionados por Pat Zufa e seu braço direito Higor, maquiada por Tom Reis "ele me deixou com cara de mulher famosa!!!", com cenário elaborado pela irmã Mônica Sangalo, Ivete ainda conta no palco com sua banda, que a acompanha durante este tempo. Vejamos o que nos diz a intérprete a respeito destes profissionais no encarte deste álbum (2004). 
A banda e os bailarinos são de fazer gosto. Ô capacidade, ô balanço, ô meu Deus! Todos lindos, tocando e dançando muito... aí eu não aguento... Guiga, diretor musical, Letieres, Ferreirinha, Cara de Cobra, Márcio Brasil, Fabinho O'Brian Dú e Jô, Radamés, Toinho Batera, Gigi, Juninho, Rudney, Paty, Maria e Juju, Kalunga (engenheiro de som - super PA).

Por outro lado, para se gravar um álbum ao vivo, é necessário maturidade e segurança vocal, para que o registro efetivamente seja agradável tanto para o público como para a crítica; o artista, ao se expor desta maneira, pode se revelar frágil em determinados aspectos. Assim, tanto vocalmente quanto em termos de performance - ver o DVD do mesmo evento com 350 mil cópias vendidas - Ivete Sangalo atinge sim uma maturidade e segurança plena ao comemorar dez anos de carreira com estes dois tipos de registro. Neste sentido, a intérprete credita a competência deste registro a Marcelo Sabóia (som), Flávio Sena (mixagem) e Carlinhos Freitas (masterização).

A cobertura do evento foi assim narrada pelo repórter Jairo Costa.

Por volta das 19h, um espetáculo de fogos de artifício encheu de luz e cor o céu sobre a Fonte Nova, levando o público ao delírio. Foi a senha para o início da festa protagonizada pela cantora juazeirense, mas que contou com uma verdadeira constelação como coadjuvante.

[...] gritos histéricos ecoam pelo templo sagrado do futebol baiano. De vestido branco com detalhes prateados, aparece Ivete, precedida pelo canto uníssono de parabéns pra você. Ao ver o imenso público presente ao evento, a cantora chora, engole as lágrimas e solta sua voz tarimbada por uma década de carreira levantando multidões pelo país afora. Aos acordes do hit Eva - sucesso da banda Rádio Táxi durante os anos oitenta, mas que se eternizou nos vocais de Ivete - a multidão incendeia a Fonte Nova.

[...] A primeira parte do show é composta de canções que 
fizeram parte da carreira da cantora no comando da banda EVA. Nesse instante, ficam evidente a dimensão da empatia que Ivete tem junto ao seu público e o domínio adquirido ao longo de sua carreira. O palco é sua casa, onde ela passeia com desenvoltura.

Até mesmo a mega-estrutura montada para o espetáculo anunciada com pompa semanas atrás [...] - parece pequena diante da força de Ivete. Ela sim é a senhora absoluta do show. A cada passo de coreografia, o público acompanha, hipnotizado [...]

À medida que os convidados se sucediam no palco, o público delirava. [...] Mesmo no momento das já tradicionais baladas, os ânimos do público não se arrefeceram. Continuaram acelerados, em puro êxtase. Ao final do evento, a Fonte Nova parece, enfim, voltar a sorrir (COSTA, 2003. p. 8).

Em linhas gerais, o repórter coloca Ivete como uma artista que chegou para ficar. Para arrematar este registro, Ivete credita o sucesso do seu trabalho de maneira geral aos fãs que a acompanham durante estes dez anos de carreira. Na contracapa do álbum MTV ao vivo (2003), assina do próprio punho a seguinte declaração:

Quando eu era pequena, sonhava em ser cantora. O tempo passou e hoje faço 10 anos de carreira. Deus realizou o meu sonho e encheu minha vida de música e do carinho do meu público. O mesmo sinto por vocês. Somos uma coisa só: eu, a música e os meus fãs. Me sinto hoje como quando eu era pequena. Posso cantar e ser feliz porque estou em casa e tenho o amor de vocês.

Passemos ao lançamento do álbum As Super Novas, em 2005, pela Universal Music. Este álbum soa como uma sequência dos álbuns anteriores, interrompido pelo MTV ao vivo. Funks, baladas, axé, samba reggae, lambadas, são ritmos presentes no álbum que, curiosamente, apresenta o menor número de canções até hoje gravadas pela intérprete numa única edição - apenas 12. 
Várias razões podem ter levado a esta redução quantitativa. Uma delas, a falta de tempo para pesquisar repertório, ou para entrar em estúdio e registrar mais canções, em virtude da agenda superlotada, ou a falta de material compatível com a proposta estética do álbum, ou ainda a queda vertiginosa de vendas causada pela disseminação aberta da pirataria, diante do que não vale a pena investir mais tanto recursos na gravação de um álbum que pode ser comprado em qualquer esquina por $\mathrm{R} \$ 5$ reais, ou ainda ser capturado na Internet sem ônus para o ouvinte.

As Super Novas foi lançado no mesmo período em que Ivete aceita convite da Rede Globo para apresentar quatro programas musicais/ temáticos aos domingos - Som Brasil, cada um deles com um tema diferente: Mulheres do Brasil, Sabores do Brasil, Modos e modas do Brasil e Paisagem do Brasil. Ivete recebeu artistas do Brasil inteiro, além de sempre fazer também um número musical buscando emplacar hits do novo álbum. Soy Loco por Ti América foi o primeiro sucesso deste álbum, mesmo porque já vinha sendo executado na novela do horário nobre - América. Abalou (Gigi) foi a segunda, além de bastante executada no Carnaval de 2006, ao lado de A galera. O tema da novela das sete, Cobras e Lagartos, exibida em 2006 pela Rede Globo conseguiu manter o álbum à venda, principalmente com a canção de Ramon Cruz, Quando a chuva passar. Este álbum teve a tiragem inicial de 650 mil cópias, das quais 500 mil comprados pela indústria de cosméticos Avon.

Os temas recorrentes nas canções da artista continuam apontando para o amor a dois, como pode ser observado na canção Abalou: Bastou você entrar na minha vida prá ficar tudo bem/Não quero desgrudar de vocêlé bom parar o tempo/tem tudo pra dar certo nós dois/já sei que não tem jeito ta feito/você me ganhou. O refrão arremata este amor ideal com: abalou, abalou, sacudiu balançou/coração é só felicidade/Abalou, abalou isso sim é amor de verdade.

O crítico Hagamenon Brito diz:

As Super Novas vol 1 não decepciona quem acompanha a carreira da cantora. Sobretudo após Clube Carnavalesco Inocentes 
em Progresso, influenciado pelo então namorado Davi Moraes. Com o álbum de 2003, Ivete encontrou uma estética sua, uma discotecagem pop variada que mescla baianidade percussiva, Caribe, reggae, romantismo, etc. (BRITO, 2005).

Ao observar a capa deste álbum, podemos nos reportar às coletâneas dos vinis da década de setenta/oitenta, As 14 mais, com as capas exibindo mulheres/modelos jovens em trajes sumários em cima de motos ou exibindo seus corpos perfeitos, sem falhas. Ivete, de jeans, top, sandálias altíssimas e brincos com pena de pavão, quase que deitada em cima da moto com as nádegas arrebitadas, parece uma pin up ilustrando o rótulo de um produto - no caso dela, o seu produto. $\mathrm{Na}$ coletiva de lançamento, ao ser indagada sobre por que resolveu fazer o tipo "gostosona”, a artista respondeu:

Eu queria aparecer belíssima, bem sensual. Adoro aparecer bonita. Sou mulher. Além disso, quando resolvi fazer a capa do $C D$, eu me lembrei das capas nas quais Rose di Primo (famosa modelo/atriz dos anos setenta) aparecia de biquíni. Só que a mamãe aqui não está podendo. (MARTINS, 2005).

A intérprete mantém a imagem do eu-mercadoria, que lança mão de todos os acenos no sentido de que o consumidor leve o seu produto. Trata-se de uma imagem que começa a se construir nos tempos de vocalista da Banda Eva, ladeada pelos músicos, dividindo assim as atenções, passando, a partir do primeiro álbum solo da garota pudica, límpida, envolta numa espécie de capa/copo de leite, à garota plugada no mundo pop do segundo álbum exibindo, à la Madonna, crucifixos e camiseta com taxas, passando para sua grande guinada com o álbum Festa, assumindo o corpo/pernas enquanto objeto de desejo masculino/feminino; no quarto álbum, resguarda-se envolta em flores e figurino romântico com listras cor de rosa e flores ao redor, até como mensagem subliminar de estar casada, portanto, comprometida.

No álbum MTV ao vivo ${ }^{61}$, continua casada com o músico e compositor Davi Moraes, mas a capa do álbum retrata um momento de 
celebração entre o seu público e ela, como que agradecendo o sucesso, comungando juntos. No álbum As Super Novas vol.1, Ivete se mostra "disponível" para o largo consumo. Sua mão no queixo e a boca meio entreaberta, outra marca de seus álbuns (seus lábios exibidos como uma fruta a ser devorada), assim como um olhar distante, (re)velam códigos sexuais de disponibilidade. Assim, a sexualidade latente em Ivete se desnuda não de forma acintosa ou mesmo vulgar; ao contrário, de forma brincalhona e "sacana", sua singularidade vai se construindo, se metamorfoseando, como uma camaleoa que muda de cor a depender do ambiente onde esteja, como um jogo de esconde/ mostra, de forma que o "leitor" não leve muito a sério o que está à mostra; ao contrário, é tudo um faz de conta, mas com controle de sua imagem, do que quer e como quer mostrar para o público.

A imagem construída por Ivete ao longo de sua trajetória é de quem "brinca" com estes códigos morais, éticos, estéticos, como se a vida para ela fosse um contínuo jogo de exibicionismo, não no sentido em que se emprega normalmente, pejorativamente; ao contrário, como ela mesma revela na capa da revista Contigo: "Nunca me senti tão bonita quanto agora". Soltando em seguida uma sonora gargalhada, brinca, faz caretas e adiante diz ela na terceira pessoa: "Abalou Ivete". (LIRA NETO; FAISSAL, 2006. p.61).

Este corpo transformado por plásticas ${ }^{62}$, ginásticas, maquiagem, figurinos, cortes de cabelo, dentre outros, serve de reforço na venda dos seus produtos. Assim, este corpo ideal pode servir de instrumento, de reforço de uma imagem construída de forma brincalhona, sem pretensão, pelo menos perante o público e a mídia, que a divulga também com esta imagem. Imagem esta que pode ser associada tanto a celebridades internacionais como Bono Vox (vocalista do grupo irlandês $U_{2}$ em dueto com a intérprete no Carnaval 2006), a apresentadora Xuxa, convidada pela intérprete para desfilar no Carnaval no trio elétrico do bloco Corujas, como foi veiculado na capa da Revista Quem de março de 2006, só para citar alguns famosos. O lançamento de As Super Novas vol. 1, ao lado de grupos populares massivos como Calcinha Preta, Said Bamba - como ela mesma anuncia, "misturando 
o mundo inteiro vamos ver o que é que dá" (Festa 2001) - se revela: Sou uma "artista popular e por isso quero chegar a todos os lugares, mas também quero imprimir um padrão de qualidade" (CASÉ, 2007b p, 21). Com este álbum, a artista chegou a 600 mil cópias e ganhou o prêmio Multishow de melhor cantora, assim como o troféu Dodô e Osmar na mesma categoria.

No Carnaval de 2007, a artista reinou absoluta, com os abadás dos blocos esgotados e vestida de vedete nos 5 dias de desfile. Ivete provou mais uma vez sua popularidade culminada com a gravação do $8^{\circ}$ álbum solo e $14^{\circ}$ trabalho da carreira. Em parceria com o canal Multishow, a artista gravou o CD e o DVD ao vivo no Maracanã, em dezembro de 2006, com 55 mil pessoas no estádio. Com tiragem inicial de 100 mil cópias do CD e 75 mil para o DVD lançados em abril de 2007, "a menina de ouro da Universal Music" está no topo da constelação de estrelas brasileiras, cuja crítica aponta que o maior mérito do CD é a capacidade de Ivete movimentar a massa.

Como convidados, a estrela recebeu Samuel Rosa, Alejandro Sanz, Saulo Fernandes, Durval Lelys, Mc Buchecha. Com a música inédita Deixo (Sérgio Passos e Jorge Papapá), a canção, com arranjo de Davi Moraes e guitarra nas mãos da própria Ivete, já em plena execução nas rádios do Brasil, Ivete pôde testar mais uma vez sua popularidade. "Como estava num estádio, pude sentir o clima como o de uma torcida. Mas era a torcida para um time só, o meu” (CASÉ, 2007a).

$\mathrm{O}$ CD/DVD apresenta um grande número de regravações pontuadas por apenas três inéditas, uma das quais gravada em estúdio - Dunas, com participação de outra intérprete baiana, Rosa Passos, também compositora da faixa, em parceria com Fernando de Oliveira.

Observemos agora um pouco do repertório presente no CD/DVD Multishow ao vivo: Ivete no Maracanã. O DVD programado para ser exibido em 10 de abril de 2007 no Canal Multishow foi adiado para o dia 24 de abril, para inibir a pirataria. Com duração de uma hora e 30 minutos, reúne 18 músicas entre inéditas e regravações. Entre as inéditas, destacamos a já citada Deixo, que mostra a Ivete romântica que sonha com o amor ideal: 
Lembro daquele beijo que você me deu

E que até hoje está gravado em mim

E quando a noite vem

Fico louca pra dormir

Só pra ter você nos meus sonhos

Me falando coisas de amor

Sinto que me perco no tempo debaixo do meu cobertor.

Deixo. Sergio Passos e Jorge Papapá (2007).

Cabe destacar o clipe desta música exibido nos canais de TV representando uma Ivete num vestido longo e vaporoso, com gaivotas ao redor, empunhando uma guitarra ${ }^{63}$ que contrasta com o clima ao mesmo tempo em que romântico, pop. Por outro lado, ao observarmos a capa do álbum e do DVD, percebemos uma pop star - ou será uma super heroína? Com um macacão justo de vinil confeccionado pelo estilista Alexandre Hercovitch. A indumentária lembra a mulher gato, cuja arma no combate à injustiça pode ser representada por um microfone que transmite ondas sonoras, levando adiante sonhos para uma verdadeira multidão em poder se tornar uma estrela ${ }^{64}$. Como já apontado por Morin (1987), qualquer jovem bonita e bela é uma estrela em potencial. Será?

Na capa do CD e do DVD, a artista é fotografada num momento do show, no palco, de maneira em que se podem observar ao fundo pontos de luz, como se estivesse gravitando entre as estrelas, ao mesmo tempo em que se torna a maior delas - a estrela solar. Continuemos com o repertório do álbum/DVD.

Dentre as inéditas, destacamos Dengo de amor (Ivete Sangalo/ Ramon Cruz), Completo (Ivete Sangalo/Gigi) e Ilumina (Sergio Passos, Jorge Papapá/Edu Casanova). Tanto Completo quanto Ilumina depositam no outro a felicidade, o que é recorrente em seu repertório, que ilustra com ícones como flores, jardim, estrela, etc. o sentimento do amor perfeito, eterno. O que importa aos olhos do outro é que o amor pregado pela intérprete seja intenso e verdadeiro, não importa 
se efêmero (como é recorrente em sua vida real). Já em Dengo de amor, acontece um fato curioso e pouco frequente na maioria de suas canções românticas. A artista deposita aí o centro da paixão do outro. Coisa boa é ver você chegar/Coisa boa é ver você dançar/Coisa boa é ver você cantar/ é ver você se apaixonar por mim.

As outras canções que compõem as duas peças são regravações de outros álbuns como Abalou, Festa, Sorte Grande, Flor do reggae, A galera e Chupa Toda. Dentre as participações especiais:

No palco, ela também recebe cinco convidados especiais, todos incluídos no especial do Multishow. Samuel Rosa, vocalista do Skank, divide os vocais na faixa Não vou ficar (de Tim Maia, sucesso na voz de Roberto Carlos); Saulo, que hoje cumpre a função de vocalista da Banda Eva, por onde a própria Ivete passou, participa em Não precisa mudar; o funkeiro Buchecha representa o Rio de Janeiro; Durval Lelys joga um clássico da axé music, Bota prá ferver, e o espanhol Alejandro Sanz coloca tempero gringo no show, com o sucesso Corazon Partió. (MAIA, 2007).

Com uma duração bruta de quatro horas, incluindo os extras, o DVD conta com 27 músicas, enquanto o CD conta com 18.

Em outubro de 2008 Ivete lançou o CD infantil, A Casa Amarela, com composições como o Funk do Xixi, Frufru, é bom viajar, Maria Flor, Bichos, A casa amarela, dentre outras. Foi todo composto e gravado pela cantora baiana com Saulo Fernandes e tem a participação de Xuxa.

Em abril de 2009 lança o CD e DVD Pode Entrar de duetos com nomes como Carlinhos Brown, Lulu Santos, Marcelo Camelo, Maria Bethânia e Vanessa da Mata. O projeto de duetos foi todo gravado nos meses de setembro até meados de outubro de 2008 - no estúdio construído por Ivete em seu apartamento, em Salvador.

É comum no meio artístico, de forma geral, e nas gravações de DVDs de maneira específica, bem como no ambiente do Carnaval, receber convidados da mesma gravadora, ou ainda o artista com quem o 
anfitrião se identifica, cujo trabalho admira. Neste sentido, podemos nos reportar à noção de familiaridade apontada por Moura (2001), que também pode ser observada no dia a dia da artista, como ilustrado a seguir:

Para quem reside ou passa próximo à sua residência, no Campo Grande, é corriqueiro ver Ivete fazendo caminhadas e corridas pelas ruas e praças. O motorista do ônibus pára e grita: “E aí, negona"? Um outro passa de carro e cumprimenta: "Diga lá, Ivetão!". "É uma maravilha", diz ela: "Não tenho problema com assédio de fã. Se estou correndo e alguém pede para fazer uma foto minha, fico pulando no mesmo lugar até a pessoa tirar a foto. Isso não me custa nada" (LIRA NETO; FAISSAL, 2006, p.66).

Assim, a artista estende para o palco a alegria e a proximidade com o público que já carrega do cotidiano, de forma a buscar nesta atitude o reconhecimento de uma artista que busca na aproximação com o seu público o diferencial. Assim, "todos" já tiveram e têm a oportunidade de falar com Ivete Sangalo, de forma a considerá-la como alguém muito próximo ou mesmo da família. Assim, Ivete transforma sua vida em obra de arte "inventando" um estilo muito próximo de sua vida pessoal para plasmar a sua arte.

Podemos arriscar uma afirmação no sentido de identificar Ivete Sangalo como uma personagem/tipo no sentido aristotélico. Para Aristóteles (1993), o ethos (caráter) e a diánoia (pensamento) são o princípio da caracterização da personagem de teatro, sendo estes elementos básicos para a sua construção. Por outro lado, segundo ainda o filósofo, a ação, elemento fundamental na construção da cena, supõe personagens que falam, agem.

Poderíamos, aqui, nos perguntar se a personagem, na tragédia grega, é dono dos seus atos ou refém das ações. Parece que a dualidade sujeito e vontade, objeto e determinação, agente e paciente, herói titular da ação e vítima da fatalidade da decisão dos deuses e dos golpes do destino, o personagem trágico toma sim suas decisões e age, 
em seguida, de acordo com elas. Entretanto, as personagens cômicas, são, via de regra, donas do seu nariz; não estão determinados por mitos que os apresentam enquanto prendem, não carregam os efeitos de maldições e vaticínios.

Gerard Gilles define personagem como um "homem portador de todos os signos próprios do emissor-homem, gesto e gestualidade (ou imobilidade, que também é gesto), som [...] mímica, guarda roupa, adereços e até cenário, porque uma personagem nunca se define sozinha" (1980 apud PALLOtTini, 1989, p. 14). Já Patrice Pavis deposita na recepção dos espectadores o que é verossímil ou não, adquirindo assim um tom cambiante e uma ótica subjetiva às coisas:

[...] o espectador sabe que, indo ao teatro, não poderá lá encontrar a pura verdade, o natural total; sabe, desde sempre, que vai ao teatro para encontrar uma ilusão, um fingimento, um faz de conta. Mas precisa de pontos de contato com o real, que lhe dêem apoio necessário, os elementos de ligação com o mundo em que vive, e que é o seu mundo conhecido. (2005, p. 21).

Neste sentido, poderíamos nos reportar a Morin (1969; 1989; 1998). Sua formulação de vida imaginária embebida de vida real e vida real embebida de vida imaginária pode ajudar a compreender a construção desta intérprete sujeito objeto no ambiente social.

Assim, a singularidade de Ivete vai se delineando, aprimorando seus papéis com total controle sobre os rumos do teu trabalho, não só artístico, bem como empresarial, de modelo bem sucedido, gerenciando ao lado da família, profissionalmente, seu patrimônio, demonstrando que arte e negócio podem andar de mãos dadas. A intérprete afirma ao jornal $A$ Tarde que gerencia seus negócios ludicamente, dando as coordenadas em termos de filosofia de trabalho junto aos seus irmãos, pontuando de que maneira pretende conduzir a carreira (RAMOS, 2002), mais como mentora intelectual do que propriamente como produtora, tarefa reservada à família.

A música que vibra em sua garganta e no seu corpo ecoa para o Brasil e para o mundo de forma cada vez mais latente. Isto pode ser 
ilustrado com a turnê bem sucedida em vários países da Europa e dos Estados Unidos e América Latina a partir de 2003.

A cidade de Santiago do Chile foi o ponto de partida da série de shows internacionais de Ivete Sangalo. "Será minha primeira excursão”, revela a cantora, que já tinha realizado shows na Europa e Estados Unidos com a Banda Eva. Do Chile, a próxima parada aconteceu no dia 6 de junho, em Portugal, onde Ivete participou da noite de inauguração do Rock in Rio Lisboa ao lado de Sting, Alejandro Sanz e Alicia Key. Em julho, retornou a Portugal para mais três shows, dias 13, 15 e 17. No mês de agosto, Ivete rumou ao Japão, apresentando-se em Nagoya, Hamamatsu, Saitama e Tóquio. Em seguida, atuou nos Estados Unidos, cantando de 16 a 22 em Miami, Nova York e Boston. Quando o assunto é carreira internacional, Ivete resolve tomar as rédeas: "eu me envolvo ainda mais, por isso só resolvi fazer essa excursão quando a gravadora tivesse condições de me acompanhar, [...] não queria me apresentar num lugar onde não tivesse um disco meu e as pessoas não conhecessem meu trabalho" (MIRANDA, [2003]). Em seu site, pode ser observada sua agenda de shows em países e cidades do mundo, tais como Alemanha, Itália, Portugal, Holanda, França e Espanha, dentre outros.

Com influência confessa de ídolos da brazilian soul music como Tim Maia (o que pode ser constatado no seu último álbum), Cassiano, além do baiano Gilberto Gil, da Timbalada e, em menor escala, dos blocos afro, Ivete promove a síntese desses artistas em seu canto de forma a não perder de vista a axé music e o Carnaval como ambiente que se traduz pela levada vigorosa de sua banda nos shows e turnês que realiza, bem como pelo contato constante com o público, seja através de brincadeiras por onde passa, seja de palavras de ordem e animação com a plateia. Dir-se-ia até que Ivete carrega no seu canto a noção de Povo no sentido de popular, falando uma linguagem próxima a este público que se identifica com sua fala, seu vocabulário.

Assim, a singularidade de Ivete se apresenta de maneira multidimensional (MORIN, 1998), buscando uma tradução da Bahia/Brasil em aspectos cujos sentimentos de alegria, festa, prazer, sucesso, 
bussiness, marketing, negociações, se apresentam de maneira nem sempre harmoniosa, nem sempre conflitante, mas nos permitem compreender como o sucesso se realiza numa dimensão cuja liberdade individual pode ser percebida pela confluência da noção de reticularidade (ELIAS, 1994, p. 29), habitus (BOURDIEU, 2002) e discursividade (GIDDENS, 1991).

A liberdade plasmada na vida e obra de Ivete Sangalo transcende a noção utópica e telúrica que o termo possa vir a ter. Ao contrário, esta liberdade "brincante" da artista é a base da construção do seu perfil enquanto pessoa e personagem, denotando assim a estrela solar que irradia de luz e cores tudo ao seu redor. Segundo seu próprio depoimento, "Sol é vida, energia, libido, perna de fora. É calor! E eu sou uma pessoa solar. O sol faz a minha fotossíntese" (KEDOUK; MORAES, 2006, p. 92).

Não é à toa que seus desfiles no Carnaval acontecem sempre à tarde, para que os fãs/súditos possam admirá-la em sua beleza solar, radiante.

\section{O canto barroco da axé music: Daniela, Margareth e Ivete}

Tanto a Fonoaudiologia quanto a Otorrinolaringologia, como especialidades da área de saúde que cuidam da voz, bem como professores de canto, de dicção e expressão vocal, e ainda estudiosos da área de comunicação oral vêm contribuído substancialmente para compreender os diversos aspectos da voz, não unicamente no aspecto fisiológico, como também estético, social e cultural.

Podemos pensar a voz enquanto força interpretativa de um determinado estilo musical - a axé music -, buscando múltiplas possibilidades na construção de referências móveis de identidade. A voz pode ser compreendida, então, como "contorno semovente de lugar de apropriação, instância fronteiriça entre discurso de significações culturais, deslocando conceitualmente 
a força de seus sentidos para novos espaços de reflexão teórica e crítica" (DINIZ, 2001, p. 207).

Diniz (2001) afirma que ao abandonar a "imaterialidade sonora do papel" (p. 208), as letras na voz do/a intérprete, quando expressas em melodia, apontam para o tripé constitutivo da canção: a letra, a melodia e "a voz que faz emergir do silêncio a palavra-canto" (p. 208). No entanto, a voz cantada, na contemporaneidade, assume contornos distintos, uma vez que a estética do canto popular urbano ocidental é indissociável das transformações tecnológicas da captação da voz. Instaura-se, assim, uma nova ortofonia ${ }^{65}$.

Com a transcrição eletromagnética dos sons capturada pelo microfone pelo registro fonográfico e sua difusão, a voz e a música se tornam mercadoria no Brasil quando o primeiro registro na voz de Baiano foi prensado. Por outro lado, a criação de instrumentos eletroeletrônicos possibilita uma maior variedade tímbrica da voz humana, valorizando sons, inclusive ruídos que outrora seriam considerados defeitos, como soprosidade, gritos e sussurros, dialogando com guitarras distorcidas, samplers, delays, "que passam a ser incorporados esteticamente, como representação do caos sonoro das grandes metrópoles, rompendo de vez com a equação beleza = pureza" (ABREU, 2001, p.109).

Assim, o canto popular contemporâneo pode determinar não só gêneros e estilos musicais, bem como determinados papéis sociais, denotando posições dantes difíceis de perceber, na medida em que o caráter da obra é determinado pelo/a intérprete, que tem o poder de interpelar o ouvinte com o seu canto.

A voz destas intérpretes da axé music pode caracterizar universos de incorporações e reinvenções; em releituras não unicamente presente em seus aspectos técnicos tais como afinação, pureza e riqueza de emissão, como também em outros níveis de percepção, no qual o poder imagético da voz, além de se apropriar de uma canção, transfigurando-a. Transmite, em seu canto, um lugar de onde este canto ecoa, incorporando e rearticulando sentidos. 
Neste sentido, o Carnaval de Salvador pode ser compreendido, aos efeitos desta pesquisa, como o espaço onde estas vozes se formataram para ecoar nos quatro cantos do mundo, de maneira a convidar os curiosos a perceberem uma força transformadora contida no canto barroco da axé music. Vejamos o que poderia significar aqui este termo. Usado pela primeira vez em francês, o vernáculo correspondente a barroco origina-se de um termo português que qualifica uma pérola de formato irregular; inicialmente, foi empregado para sugerir estranheza, irregularidade e extravagância, aplicando-se mais às artes plásticas do que à música. Somente no século XX o termo passou a se referir a um período da história da música (SADIE, 1994, p. 77). Denominamos de canto barroco, aqui, a extravagância/excesso vocal impressa no trabalho das intérpretes de axé music cuja emissão vocal de peito, brusca e percussiva, com um pitch vocal grave e voz levemente rouca, com excesso de vibrato nos finais de frase, salvo raras exceções, possibilitam um maior diálogo com os tambores e instrumentos harmônicos (guitarra, teclado, baixo). Estes, tocados simultaneamente, exigem voz forte, dotadas de grande domínio rítmico, já que as letras, em sua grande maioria, se superpõem, via de regra, à melodia. Risério aponta:

[...] o barroco como a arte do excesso, da exuberância, da desmesura; voluptuosa arte das volutas, das máscaras, dos arabescos; espaço pleno e repleno (horror ao vazio), reino de superabundância, transbordamento, prodigalidade, arte da soma, da sinonímia, da catalogação, da digressão e do desvio. Barroco $=$ a jogo; arte clássica $=$ trabalho (apud MIGUEZ OLIVEIRA, 1998, p. 50).

De acordo com Sant'Anna (2001), no barroco também pode se observar a convivência entre canto e palavra que para Dâmaso Alonso "mostrava como a sonoridade rítmica dos versos, os jogos fonéticos estavam sendo usados como elementos sedutores irracionais, já que o sentido claro do poema nem sempre se alcançava conscientemente" (apud Sant'Anna, 2001, p.18). Em relato ainda no mesmo artigo, 
Sant'Anna aponta para a capacidade "hipnótica", "narcotizante" do texto poético observada em festivais de poesia falada na Europa e América do Sul sobre ouvintes que se dispunham a ficar horas em pé a escutar os poetas a recitarem suas poesias, mesmo em línguas por vezes desconhecidas para estes ouvintes, que, embevecidos, recarregavam as energias a partir da sonoridade das frases emitidas.

Este sentimento de "torpor", "hipnótico", pode ser reportado aos estrangeiros que, estando em Salvador no período do Carnaval, mesmo sem entender a mensagem poética das canções entoadas em cima do trio elétrico, são tomados de igual sensação.

No período barroco propriamente dito, a voz se potencializa em grau nunca dantes observados, tornando-se a relação entre texto e música indissociável. Na Idade Média, o cantochão desenvolvia três estilos melódicos de canto: "O silábico, em que cada sílaba do texto corresponde a uma única nota musical; pneumático, em que duas a doze notas acompanham uma sílaba; e o melismático, em que sílabas isoladas podem ser cantadas sobre muitas notas" (SADIE, 1994, p.77). Os compositores Mozart e Rossini formam os maiores representantes do Melisma no Barroco, chegando a voz a um virtuosismo tamanho que a notação musical torna-se mais importante que o próprio texto. "Sobre uma sílaba ou sobre uma vogal, o cantor ou cantora tinha possibilidades de exercitar por certo tempo todas as virtualidades de sua glote, num estilo eminentemente ornamental, exagerado, às vezes mesmo cacofônico. É quando surgem efeitos conhecidos como o trilo, que era uma articulação da glote ao invés da utilização do diafragma, como ocorre hoje" ${ }^{66}$ (SANT'ANNA, 2001, p.19).

A partir deste período, a voz passa a ser construída, inventada, reconstruída baseada nestes princípios até atingir o canto operístico italiano. É também no período barroco que surgem os inúmeros castrati, bem como o aparecimento da mulher na cena musical. É também neste período que a bissexualidade vocal atinge o ápice com os castrati, reencontrada na contemporaneidade com cantores de rock como Boy George e do pop como Michael Jackson e Prince, dentre outros. Vindo para o ambiente da música brasileira, temos representantes desta voz 
em falsete tão comum no barroco em Milton Nascimento e Edson Cordeiro, além de Ney Matogrosso, que se apropria também do gestual homoerótico para dar conta deste canto castrati masculino/feminino.

Quanto às performances destes artistas, Sant'Anna (2001) aponta graus de similitude "nos grandes concertos de rock da atualidade, uma mistura de reencenação das grandes óperas píricas barrocas, com aquela formidável noção de cultura como espetáculo" (p. 19). Assim, os concertos de rock da atualidade, sobretudo no caso do heavy metal, com as performances vocais dos ídolos contemporâneos, cujo trato vocal transforma a voz gutural, rouca, gritos e urros em estilo, como parte da performance, num constante reinvenção não só vocal, mas principalmente corporal, podem ser vistos em oposição ao canto radiofônico e estático de um João Gilberto com seu banquinho e seu violão, ou de uma Marisa Monte com seu canto sussurrado e de pouca emissão, com concentração maior no rosto e na boca. Nos grandes concertos de música pop contemporânea, além da voz, da palavra, da dança, a reinvenção do corpo em movimento, principalmente do baixo corporal preconizado já nos anos cinquenta por Elvis Presley e tendo como grande representante, nos últimos anos, o grupo É o Tchan e suas bailarinas rebolando os quadris, bem como Daniela Mercury num corpo que dança, denotam o descongelamento do artista no palco. O espetáculo toma forma de show business. Neste momento, não só o corpo e a voz se movimentam, mas também o palco se torna móvel com a invenção do trio elétrico, telões ampliam detalhes do cenário e do corpo, a iluminação toma proporções descomunais e transformam a visibilidade de praticamente tudo... enfim, todo o visível é reconfigurado como espetáculo. A voz se torna a grande representação do novo formato do trio elétrico a partir do novo modelo de bloco de trios.

$\mathrm{Na}$ década de setenta, um caminhão com gerador, projetores de som e oito a doze amplificadores, além dos instrumentos elétricos, entre os quais a guitarra baiana, era a formação que dominava a cena do Carnaval. Entretanto, é Moraes Moreira já em carreira solo, egresso do grupo Os Novos Baianos, o primeiro cantor a amplificar 
sua voz no trio elétrico e embalar os foliões baianos com composições de sua autoria tais como Pombo Correio, Chão da praça e Assim pintou Moçambique. Neste período, a voz do cantor no trio, segundo Oliveira (2007, p. 85) "era leve, flexível, e melodiosa, acompanhando o andamento cada vez mais rápido imposto pelos dedos ágeis da guitarra elétrica [...] Voz e guitarra dialogavam enquanto os elementos percussivos eram menos destacados".

No final dos anos 70, amplifica-se a percussão, possibilitando assim uma modificação na forma de emissão e colocação da voz, que passa a repetir a marcação da percussão forte e volumosa. Mas adiante, com a projeção da axé music inicialmente nas vozes de Luiz Caldas e Sarajane, bem como do samba reggae, a percussão assume definitivamente o proscênio do gênero, em diálogo com teclados e sopros. O trio elétrico transforma sua sonoridade imediatamente seguida pela voz dos cantores de trio de ambos os sexos.

[...] independentemente destes recursos de amplificação da voz, o cantor de trio utiliza frequentemente aumento de loudness na voz cantada, forte intensidade na emissão de voz falada, nos intervalos e durante as músicas, como recurso para animar o público, promovendo desta maneira desgaste das estruturas do trato vocal quando executados de maneira inadequada, sobrecarregando [...] principalmente o músculo tireoaritenóideo, mais acentuadamente o feixe externo, solicitado em emissões vocais mais intensas (OLIVEIRA, 2007, p. 90).

Entretanto, no que se refere à diferença de gênero entre os/as intérpretes, percebe-se que, no sexo feminino, a emissão da voz que canta se situa na região mais grave da tessitura, com ressonância laringofaríngea, enquanto nas vozes masculinas a voz que canta se situa nas regiões agudas, com predomínio de ressonância faríngea, denotando, assim, inversões vocais no cotidiano. Assim, no caso específico da axé music, a emissão masculina se processa mais na região aguda e a feminina, na região grave, denotando assim uma tendência à androginia vocal que também pode estar associada aos papéis socioculturalmente construídos. 
Na axé music, então, a voz se caracteriza por uma canto percussivo, "duro", que, em diálogo com os tambores e instrumentos harmônicos, contribui para que o canto possa sobressair em letras ${ }^{67}$ quase onomatopaicas, percussivas, cujas sonoridades servem de referência para a dança e para o corpo que ao ar livre, portanto, um espaço sem delimitação prévia, pode "dificultar a emissão conforme sua direção" (OLIVEIRA, 2007, p. 91), nem sempre podendo contar com o vento como aliado na transmissão deste som.

A psicodinâmica vocal observada nas vozes de Margareth, Daniela e Ivete no que se refere especificamente à voz de peito - portanto, grave - observa-se no campo das representações. São vozes que denotam poder, domínio, comando, simbolicamente representadas em figuras tais como rainhas, guerreiras, sereias que enfeitiçam seus ouvintes não de maneira unicamente dócil, melodiosa, mas dialogando com mundos em trânsito cuja tradição e modernidade se hibridizam na acepção de reinventar sentidos e sensações. Pois: "Através da voz, a palavra se torna algo exibido e doado, virtualmente erotizado, e também um ato de agressão, uma vontade de conquistar o outro, que a ela se submete pelo prazer de ouvir" (ZUMTHOR, 1993, p. 8).

Podemos afirmar que o prazer de ouvir e o prazer de dançar - ainda que no mesmo lugar, pois o espaço público do Carnaval de Salvador encontra-se cada vez mais disputado pelos foliões e associados - é monitorado pela dona da voz e pela voz da dona. Esta dona da voz é oportunizada, circunstancializada, potencializada, legitimada pela indústria cultural, que a transforma em mercadoria; entretanto, pode ganhar força e impor negociações com a agência mais poderosa da cadeia do sucesso, qual seja, a gravadora. Torna-se cada vez mais fragmentário o conjunto das etapas de gravação, fabricação e distribuição do produto, chegando-se ao ponto em que se encontra hoje uma das três estrelas/intérpretes enfocadas nesta pesquisa: Daniela Mercury chegou a deter os direitos de propriedade dos seus fonogramas.

Voltemos, pois, à análise da voz em Daniela Mercury como uma construção que encontra matrizes em vozes da MPB, a exemplo de Elis Regina, cuja força interpretativa, que correspondia a um estilo pes- 
soal que se contrapunha ao ícone plasmado na voz de João Gilberto, transforma a voz numa explosão articulatória precisa e perfeita. Esta construção sacrifica por vezes um timbre suave e delicado comum nas vozes femininas da MPB, a exemplo de Gal Costa, Zizi Possi, Fátima Guedes, Marisa Monte e Vanessa da Matta, para citar algumas representantes da chamada MPB das últimas décadas, em detrimento de um timbre áspero, rasgado, metálico e anasalado pela força interpretativa impressa em cada canção.

O mesmo sacrifício do timbre pode ser observado na voz de Daniela, que ganha contornos singulares pela própria característica do repertório por ela registrado, bem como pelas transformações tecnológicas e espaciais que, impressas em seu canto, denotam a concepção da voz enquanto assinatura, ao mesmo tempo em que, repleta de máscaras identitárias que representam inúmeras possibilidades de recepção, pode se tornar um selo de identificação do lugar de onde se canta.

De maneira geral, as intérpretes de axé music e de maneira particular as intérpretes no trio elétrico podem ser comparadas a maratonistas que necessitam tanto de resistência quanto de força muscular para dar conta de uma atividade física/estética que exige, além de energia, grande preparo físico. No caso de Daniela, que se revela uma intérprete vigorosa não só corporalmente, em virtude da própria formação em dança, o que lhe facilita um maior domínio técnico do corporal/vocal, quanto no espaço cênico de sua performance, sua emissão vocal exige um maior controle no sopro expiratório, visto que o corpo inteiro participa da emissão, servindo de suporte e de ressonador na produção deste som.

Neste sentido, tanto em cima do trio elétrico quanto nos palcos de grandes proporções, exige-se muita movimentação por parte desta "maratonista vocal", imprimindo assim uma voz que, ao mesmo tempo em que é percussiva, brusca, imprime um excesso de vibrato laríngeo por vezes presente nas terminações frasais, por conta do movimento corporal/respiratório que exige controle constante. Este fenômeno também pode ser percebido com menor incidência em Ivete Sangalo e Margareth Menezes, cujo vibrato é também laringo-faríngeo, apesar deste recurso se apresentar com menor incidência em Margareth. 
Daniela imprime sua voz mutante, elétrica, eletrônica, no trio metal, sob o sol da liberdade que se dança, Música de rua, um Balé Mulato, À primeira vista, Por amor ao Ilê, Sou de Qualquer lugar. É a voz que dança, canta para dançar, como uma pop star que quer exibir suas inúmeras habilidades para um mundo cujo diferencial não se concretiza unicamente pelo dom, beleza e juventude, mas também pela linguagem do pop e do punch.

Podemos, então, continuar perscrutando os contornos do adjetivo pop. A característica maior do pop, além de padrões tais como sonoridade da canção e tempo de execução em três minutos no máximo para tocar no rádio, é atingir uma faixa etária de jovens que se identificam com as mensagens poéticas da canção, além da performance múltipla e eletroeletrônica em conexão com o global, sem transigir o esteio da tradição do Carnaval não mais eletrizado, mas eletronizado.

Em Daniela, as alterações vocais emitidas pela intérprete, ou ainda, as modificações tecnológicas provocadas de forma proposital pelo protools, samplers, reverbers ou qualquer outro aparelho que possa alterar a qualidade vocal podem servir de referência estética em seu trabalho artístico. A intérprete usa como recurso, sem máscara, a tecnologia que, no seu caso, está a serviço da experimentação artística. Podemos perceber de forma mais fecunda esta experiência em Sou de qualquer lugar (2001). Na própria expressão que nomeia a faixa título, a voz aparece como num alto falante, com excesso de frequências médias, em diálogo com percussão eletrônica e guitarras distorcidas de Alexandra Vargas e Davi Morais, e scratch de Marcos Almeida. É sintomático que, ao mesmo tempo em que a intérprete alardeia na letra da canção de Lenine e Dudu Falcão o "sou de qualquer lugar", marca uma sonoridade na canção que pode ser identificada como uma canção do mundo.

A voz de Daniela sugere uma associação íntima com os recursos da língua portuguesa, considerando-se-lhe a cadência e a nasalidade, bem como com a batida do samba reggae e suas variações, impressas no corpo e na música cheia de groove, swingue e beat, bastante comum no universo sonoro da música pop mundial contemporânea, sendo 
que o Carnaval já se encontra em consonância com este mercado. Assim, não se pode analisar sua voz unicamente pela emissão através da boca e ressonadores; é preciso considerá-la como evento através do corpo que se torna uma caixa vibratória não a serviço da voz apenas, mas em consonância indistinta corpo/voz/performance.

Em depoimento a Setenta (2002) a artista revela que "a dança sempre foi o motivo do espetáculo [...], ela rege inclusive a própria inspiração para o repertório" (p.6o).

No entanto, o conteúdo deste depoimento parece vir se diluindo através dos novos shows e álbuns apresentados pela artista, que demonstra cada vez mais um cuidado musical em primeira instância; sem abandonar propriamente a espetacularização coreográfica, recorre cada vez mais a bailarinas que executam as coreografias marcadas sem a participação constante da estrela no acompanhamento dos passos. A estrela fica, assim, mais solta, menos marcada. Podem ser observados gestos bastante recorrentes em sua performance corporal, como a mão esquerda sempre levantada com a palma para fora, bem como pivôs e piruetas com agilidade e controle sobre o corpo no espaço cênico. Os braços sempre abertos para o alto é também um gestual bastante característico em sua performance corporal.

Passemos em linhas gerais à análise da voz de Margareth Menezes.

Nesta intérprete, a performance vocal pode ser apontada, segundo depoimento de artistas e críticos, como uma voz de diamante bruto, cuja característica maior é também o ataque vocal brusco, seguida, no seu caso específico, de excesso de portamento para atingir a nota exata da melodia. Seria o que se convencionou denominar, no universo do jazz, de blue note.

Observa-se que, no canto negro de Margareth, a afinação, nos moldes em que se convencionou apontar o sistema temperado ocidental, composto de sete sons com a repetição do oitavo som numa oitava acima, deixa de ser levado em consideração, se considerarmos que a polirritmia dos tambores com a emissão da voz humana deixa de ser uma referência harmônica necessária para se constituir uma tonalidade 
harmônica. Assim, a percussão herdada dos terreiros de candomblé, que também utiliza estrutura semelhante em seus cânticos aos orixás, em que a voz é emitida antes mesmo do som dos tambores, guiando assim a marcação dos mesmos, propicia uma nova referência de tonalidade, sanada com a chegada de instrumentos eletroeletrônicos mais leves em termos de peso, que podem dialogar e galgar o palco dos trios elétricos conectados com novos aparatos tecnológicos.

Assim, a voz humana se põe a dialogar de forma mais ocidentalizada com tambores e instrumentos harmônicos, permitindo uma maior percepção por parte dos intérpretes da tonalidade em que se canta. Em Margareth, bem como em Marinês da Banda Reflexu's, em Márcia Short e Alobêned, vocalistas da segunda formação da Banda $\mathrm{Mel}$, pode-se notar graus de similitude em termos de qualidade vocal não só pelo aspecto fenotípico, como também pelo fisiológico, que, segundo profissionais da área de saúde, apontam características vocais pertinentes - "a raça negra, em virtude de sua tendência a apresentar um trato vocal com dimensões maiores, sendo reconhecida pelo seu grande volume vocal, pitch grave e voz levemente rouca" (OLIVEIRA, 2007, p. 89).

Por outro lado, "as características vocais e anatômicas mencionadas parecem ser mais marcantes nos negros africanos do que nos negros americanos. Essas variações talvez possam ser justificadas pelos efeitos da miscigenação, dialetos diferentes e características particulares de cada grupo" (PIMENTA; PINHO, 2003, 93).

Ao mesmo tempo em que alguns profissionais de saúde constatam uma singularidade fisiológica vocal dos negros - no caso, das negras -, podemos observar que as pregas vocais, sendo músculos, podem ser trabalhadas de forma a se adequar a um estilo musical, bem como o uso de ressonadores e de recursos tecnológicos na experimentação destas modalidades estéticas. Por outro lado, além da fisiologia do trato vocal, outros fatores importantes no canto popular, como o valor da palavra, a articulação do som de forma precisa, bem como a expressividade e estilo impresso pelo intérprete ao se apropriar de cada canção, também vêm a ser importantes na caracterização do trato vocal. 
Assim como em palcos de grandes proporções, o trio elétrico pode ser um espaço cujos recursos tecnológicos são grandes aliados na performance destas intérpretes. A mesa de som com os periféricos, amplificadores, compressores, reverbers e delays, bem como ear phones e microfones especiais para cantar ao ar livre, são ingredientes indispensáveis ao bom funcionamento da voz da intérprete, que necessita de um engenheiro de som que reúna competência e acuidade - enfim, um timing especial - para fazer a sua voz brilhar, acontecer em diálogo com outros instrumentos. Neste sentido, cada interprete carrega no seu staff, em média, dois engenheiros de som que cuidam para que toda a massa sonora possa ser ouvida com a máxima fidelidade, tanto por parte dos músicos no palco, que contam com um deles, quanto para o grande público, que responde, a depender do som, como está ouvindo o(a) intérprete e sua banda.

Voltemos em linhas gerais para a análise sucinta da estética vocal de Margareth e o samba reggae que, como já apontado, exige um diálogo bem mais potente com a voz. Vejamos um depoimento da intérprete acerca do impacto de cantar no trio elétrico. "A primeira vez que cantei, tive uma sensação de susto pela capacidade do trio de ampliar milhares de vezes o potencial sonoro e espalhar a música por uma distância imensa" (GÓES, 2000). Neste sentido, a referência auditiva fica comprometida pelos harmônicos graves emitidos pelos tambores que "afundam", sufocam o som dos instrumentos harmônicos.

Daniela, por sua vez, exemplifica o fato com o samba reggae do Olodum e o "seu" samba reggae.

Se o Olodum toca o samba reggae original, com surdos, com vários repiques fazendo desenhos diferentes, mais o tarol que é igual, então, a gente não repete muitas vezes, com toda esta estrutura. A gente já bota meio surdo, pois já tem o baixo. [...] A voz, às vezes fica afundada por conta dos graves, então, não é muito fácil repetir o samba reggae como ele é. Ao longo dos meus discos, eu fui fazendo o samba reggae de várias formas diferentes. Construí nele o elemento principal, que é o balanço. Cada hora um instrumento fazendo um elemento, mas não um 
instrumento que tradicionalmente, originalmente faça. E até com outros comportamentos, com outras interferências que não são originárias, não são da estrutura do samba reggae. (MERCURY, 2003a).

Assim, a partir da matriz do samba reggae, Daniela se apropria de alguns de seus elementos para reprocessar e compor o "seu" samba reggae. Como um padrão já constituído no mercado da música, a intérprete "brinca" com seus elementos de forma a construir novos protótipos que possam dar conta de suas experimentações musicais para constituir novos "sentimentos". Em entrevista concedida à autora, a intérprete revela ter experimentado essa sonoridade especialmente na canção de Chico Science - Praieira - do álbum Sou de qualquer lugar (2001). Para a intérprete, esta canção foi pensada para as pistas. ${ }^{68}$

Enquanto Daniela pensa em diluir cada vez mais a fórmula da batida do samba reggae em seu trabalho, Margareth retoma o samba reggae de forma cada vez mais contundente, inclusive homenageando o ritmo que a consagrou para o mundo na gravação do seu DVD de vinte anos de carreira, em 2006, computada a partir da gravação de Faraó, em 1987. Podemos observar que, ao longo dos seus 20 anos de carreira, o samba reggae em Margareth aparece ainda na forma como foi concebido em seu nascedouro, adaptando-se tão somente à quantidade de instrumentos de percussão em número menor e ao uso dos instrumentos harmônicos, também já adotados pelo Olodum.

Quanto à forma interpretativa, o canto gutural, rouco e forte da intérprete, associado a um timbre "escuro", demonstra certa "naturalização", segundo depoimentos do senso comum como "pertencente" ao fenótipo negro. Vejamos o que declara à autora a intérprete Fernanda Abreu (2005), em relação à voz e performance de Margareth Menezes: "Margareth, além de ser linda, tem uma voz poderosa, uma autenticidade muito grande. [...] No palco ela tem um vozeirão".

No depoimento da artista, observamos que o estigma ${ }^{69}$ se encontra presente em seu depoimento, bem como o binômio tradição/modernidade. Por outro lado, a noção de autenticidade se encontra presente 
na medida em que uma negra se legitimaria mediante a prática de cantar o ritmo do "seu" seu povo, não sendo, portanto, uma situação forjada pelos "brancos" que se "apropriam" da cultura de origem africana. Assim, o discurso se repete de forma a perpetuar que o "lugar do negro" e da "cultura negra" se legitima ou se impõe somente com a atuação do negro. Assim, o samba reggae encontra legitimidade imediata na voz da intérprete Margareth, diferentemente do discurso velado em relação a Daniela, que, para a grande maioria, se apropria do ritmo/gênero para dar conta do seu sucesso.

Num país híbrido e de configuração sócio-histórica complexa como o Brasil, o discurso da etnicidade se configura também como uma questão cultural. Para alguns críticos, seja em nome próprio, seja em nome de movimentos, esta apropriação da "cultura negra" seria, assim, "indevida" por parte de não negros, pelo menos no que se refere à cor da pele. Na contramão desta postura, o discurso de Daniela em relação à questão da etnicidade passa pelo fato de ser baiana. Diz a intérprete:

Por ser baiana, eu sou tão negra quanto eles. E os negros não necessariamente têm afeto pela cultura negra e originalmente africana.. Isso independe da cor que nós tenhamos. Depende da afetividade, do respeito, da afinidade que se tenha e que se escolha. Porque eu acho que a cultura nossa, independentemente da cidade do Salvador ser uma cidade negra, é uma cidade também cosmopolita, que tem todo tipo de informação, e a gente pode não querer ser tão relacionada às raízes dessa cidade. Alguém pode não querer ser, e eu procurei ser. (MERCURY, 2003d).

Voltemos, pois, à análise da estética vocal destas intérpretes, enfocando agora o caso de Ivete Sangalo. Diferentemente de Daniela e Margareth, mas guardando semelhanças no que se refere ao pitch vocal, ao ataque brusco, à região modal nas tonalidades e ao canto barroco, cheio de vibrato, o diferencial vocal encontrado na qualidade vocal de Ivete se refere mais a um canto sinuoso, menos "duro", mesmo sendo menos percussivo do que nas duas intérpretes já citadas. 
Nos álbuns de Ivete, percebemos de maneira frequente canções românticas contrastando com axé music e galopes frenéticos. Trata-se de uma característica comum a artistas que gravam álbuns anuais e pretendem dar conta de canções associadas a sazonalidades específicas.

O canto de Ivete pode ser considerado o mais barroco dos três analisados nesta seção. Ao imprimir uma interpretação mais romântica, sinuosa e ao mesmo tempo vigorosa, transita por outros estilos com segurança. Com uma musicalidade acima da média e uma inteligência musical que extrapola o conceito de melodia, ritmo e harmonia, num contraste vocal entre o ritmo suingado da palavra (frequentemente deslocada em suas interpretações; além de variações melódicas sobre a melodia original), Ivete demonstra, na interpretação da axé music e suas derivações, uma intimidade de improvisador de jazz, brincando de forma prazerosa tanto para o ouvinte e com o ouvinte quanto para si mesma e consigo mesma. A simplicidade presente nas harmonias e letras das canções se sofistica pela intimidade e apropriação com que embala o seu público.

O seu domínio rítmico beira o virtuosismo, tratando cada canção na reexposição. Por outro lado, podemos nos reportar a seus ídolos, tanto no Brasil quanto em outros países, que carregam em cada interpretação graus de similitude com a fã. Nomes como Tim Maia, Gil, Cassiano e Stevie Wonder, são alguns dos seus ídolos. Coincidências à parte, em sua maioria, todos eles negros e dotados de um domínio rítmico fora do usual. Outra coincidência, quem sabe... a intérprete é, conterrânea de João Gilberto, o inventor da batida da Bossa Nova no violão, do "canto falado" e da "divisão rítmica" ao transferir a batida do tamborim para o violão, numa síntese entre o canto e este instrumento. Ivete, de maneira semelhante e singular, transforma a axé music num estilo cada vez mais latino e caliente, buscando consonâncias também com a salsa e ritmos caribenhos, já presentes no cerne desta interface que é a axé music, principalmente nas composições de Gerônimo, já desde os anos oitenta.

Retomemos a definição de Medeiros: "O ritmo é um fator de respiração e da emissão da voz. É uma questão de quanto fôlego se aloca para 
cada segmento do poema e de como se distribuem os acentos fortes e fracos" (2001, p.130). A partir disto, podemos afirmar que Ivete imprime, pelo domínio do deslocamento do tempo forte de cada palavra, o que em termos musicais se costuma denominar de swingue.

Contrariando o senso comum, segundo o qual os negros seriam os únicos detentores deste domínio, Ivete parece se apropriar do que os negros já carregam em sua "essência". Podemos aproveitar e exemplificar a atuação de Margareth no âmbito do swingue, observando que seu canto duro e percussivo imprime, por vezes, esta característica em seu cantar, de maneira diferente daquele de Ivete, que brinca com a melodia e o ritmo da canção; enquanto Margareth trata a palavra de forma mais percussiva, não prolongando suas terminações frasais sob pena de sacrificar a afinação. Por sua vez, Daniela transita de forma mais movente por entre o ritmo da música, sem, no entanto, se apropriar deste swingue de forma tão contundente quanto Ivete; Daniela utiliza a voz mais como um instrumento de sopro em riffs e fraseados, seja na introdução, nos solos em diálogo com outros instrumentos, ou ainda na coda, quando termina a canção, sempre preenchendo os espaços. De maneira geral, tanto nos arranjos musicais quanto nos vocais, a pausa, tanto nos arranjos quando na interpretação, é muito pouco observada na axé music. Em Daniela, a pausa é muito rara, tanto no seu cantar quanto nos arranjos apresentados. Se pararmos para escutar calmamente cada canção registrada em seus álbuns, particularmente os primeiros de sua carreira, podemos observar interferências vocais constantes, num canto barroco que pode beirar o rococó para continuar em analogia com estilos arquitetônicos.

No que se refere ao vibrato, Ivete demonstra um domínio pleno deste recurso que, de forma adquirida ou não, se revela na interpretação de cada canção, provocando assim, no ouvinte, uma sensação de deleite e bem estar. De maneira mais acentuada nas interpretações românticas, podemos perceber em Ivete um vibrato longo e estável, diferentemente de Daniela, que apresenta um vibrato laríngeo, mas, a depender do movimento corporal, muda o padrão, sem no entanto sacrificar a afinação, sempre precisa. Por sua vez, Margareth o faz em 
menor escala; quando este recurso aparece no seu canto, aparenta ser de forma acidental e frequentemente provocando concessões na afinação.

Em linhas gerais, há que se levar em consideração que a performance vocal destas artistas se encontra indissociável da performance corporal, que funciona como um aporte no ajuste vocal. Ao mesmo tempo em que o corpo fala, a voz também emite sinais de canto/ palavra, um poder imagético/sonoro. Em Daniela e em Ivete, a voz pode ser considerada um instrumento de composição. Em Margareth, a voz se torna um instrumento de contestação, de apropriação. Nas três intérpretes, entretanto, o instrumento vocal/corporal se manifesta como um construto cujo espaço social pode revelar "feixes representacionais" tendo como representação musas - cuja palavra está ligada à música.

Procedamos a uma rápida digressão no sentido de ilustrar um pouco estas últimas considerações. Os gregos concebiam nove tipos de musas $^{70}$ : Clio, Euterpe, Tália, Érato, Melpômene, Terpsícore, Urânia, Polímnia e Calíope. Dentre elas, podemos destacar três aos efeitos de construir uma analogia com nossas estrelas-musas: Terpsícore, cujo prazer da dança e da música caminham juntas, podendo ter Daniela como representante num corpo que dança; Tália, aquela que traz alegria, que dirige a comédia, podemos ver representada em Ivete; e Clio, aquela que traz a glória, preside o canto épico e a historiografia, podemos ver personificada em Margareth.

As três estrelas/intérpretes da axé music podem ser contempladas como carregando em si características presentes dessas musas gregas. Isto não significa que uma estrela não possa transitar por características de mais de uma musa... Estas analogias são aqui aportadas no sentido de facilitar a percepção de singularidades. 


\section{Notas}

1 Como pôde ser observado pela autora, na quarta-feira de cinzas do Carnaval de 2006, em Salvador: ao flagrar um casal fazendo sexo na praia do Farol da Barra, Ivete torna público o ato, anunciando pelo microfone: "Gente, eles estão fazendo ozadia!".

2 Não estão sendo considerados neste estudo os dois álbuns lançados pela artista, ainda como membro da Companhia Clic.

3 Maiores informações sobre o bloco Muzenza, ver Veiga (1997).

4 Para maiores informações sobre a performance de Daniela no palco como dançarina e cantora ver Setenta (2002).

5 Entrevista a Carlos Oliveira em 14 de abril de 2004, cedida à autora.

6 Segundo a intérprete, este título lhe foi dado por um puxador do bloco Ilê.

7 Em pesquisa de campo no Carnaval de 2003, ao final do percurso de terça-feira para quarta-feira de cinzas, no retorno do trio elétrico da intérprete, na contramão, sentido Ondina-Barra, fui convidada pela equipe da cantora, formada pelo seu empresário Clínio, sua irmã Kitty, Lícia Fábio e Nil Pereira (responsáveis pelo camarote), Marcelo Dantas, para juntos agradecer pelo Carnaval tranquilo e organizado. O primeiro lugar a ser visitado foi o terreiro do Gantois, e em seguida, fomos em comitiva para a Igreja do Bonfim também agradecer pelo Carnaval.

8 Esta canção recebeu o prêmio de melhor música no Troféu Caymmi 1994, na categoria melhores do disco.

9 Músico emblemático na constituição da axé music. Foi um dos músicos da banda Acordes Verdes, da WR, bem como integrou a banda de Luiz Caldas durante o período da Banda Beijo, além de gravar e fazer arranjos para grandes nomes da axé music.

10 Em entrevista à autora em $1^{\circ}$ de janeiro de 2007, o músico relata que mostrou à artista o refrão da canção e que esta lhe pediu que a concluísse.

11 Dançarina, pianista, coreógrafa e diretora de movimento de atores, cantores tais como Fernanda Abreu, Kid Abelha, Adriana Calcanhoto e Daniela Mercury, Deborah Colker, com vários prêmios no currículo, funda sua própria companhia de dança em 1994 apresentando espetáculos como MIX, Casa, Velox, dentre outros. Maiores informações em http://.ciadeborahcolker.com.br/port/acia/index.htm. 
12 Compositor e cantor do cenário pop local que rejeita o rótulo axé music, sendo, entretanto, gravado em quase todos os álbuns de Daniela. Para ele Daniela não é cantora de axé music, e o axé é muito pequeno para ser representado por uma artista do seu porte (Depoimento no show de $1^{\circ}$ de janeiro de 2006, no Farol da Barra, como convidado da artista).

13 A primeira é Carmen Miranda, saindo do seu país e migrando para os Estados Unidos, onde constrói uma carreira internacional.

14 Neste primeiro ano de desfile no Barra-Ondina, o bloco desfilou com 2.500 participantes.

15 "São adquiridos, pelo Banco do Brasil, Brahma e Bahiatursa, cotas de patrocínio no valor respectivamente, US\$1,25 milhão, US\$ $400 \mathrm{mil} \mathrm{e}$ US\$750 mil, no conjunto, responsáveis por mais de 90\% dos US\$2.513 milhões arrecadados pela prefeitura com o Carnaval" (costA apud OLIVEIRA, 1995, p. 158).

16 Maiores informações sobre o Camarote no capítulo 2.

17 No clipe desta canção veiculado nos canais musicais como MTV, o partner da intérprete é Caetano Veloso, o autor da canção, que, numa cena lembrando a morena dengosa faceira e apaixonada, espera o seu "malandro" chegar em casa depois de um dia de trabalho. Daniela se apresenta neste clipe como uma personagem feminina dos livros de Jorge Amado, tal qual Dona Flor ou Tieta. Num vestido justo de flores tropicais, mostra-se como uma baiana morena e sensual à espera do seu amor para, além de comer a sobremesa e tomar coca-cola, se refere também ao ato sexual ao "botar fogo este apartamento, comendo você".

18 Todas as fotos analisadas neste tópico integram tal edição comemorativa.

19 Importante destacar que no Carnaval de 2003 os convidados presentes nos dias que a estrela desfilou na Barra-Ondina. Saindo no sábado com o trio independente, recebeu o grupo mineiro Berimbrown; no domingo, com o trio Tecno, teve como convidados o DJ Memê, o grupo Rouge e o Eletrosamba; na segunda feira, é convidado do Bloco Crocodilo com Ricardo Chaves como puxador, e recebe a modelo Gisele Bündchen; na terça feira, o trio acústico tendo como convidados Jorge Vercilo e Luiz Brasil. A cada trio em que a artista desfila, o repertório composto em média de 150 a 200 músicas sofre alterações, pois cada trio tem suas peculiaridades. Outra observação interessante é o mapeamento feito pela artista do repertório baseado no percurso a ser feito pelo trio com trechos que apresentam maior ou menor incidência de tumulto, violência, exigindo assim, músicas de acordo com a energia do folião. 
20 A dupla Carlinhos Brown e Daniela Mercury são em grande parte responsáveis pelos maiores sucessos do Carnaval nos últimos anos, numa parceria que pode ser ilustrada em novas sínteses musicais apontadas em Rapunzel e Maimbê Dandá. Carlinhos Brown também se apresenta, seja no ambiente do Carnaval, seja fora dele, sempre com imensos cocares em sua maioria feito de palha e pinturas no corpo - pinturas essas utilizadas pela Timbalada, bloco criado pelo mesmo ainda na década de noventa.

21 Consultar Morin (1989, p. 5)

22 Material cedido à autora pela produtora O Canto da Cidade.Declaração em 19 maio 2000

23 Revista Época 2 out. 2000.

24 Referência com entrada pelo título: É só o primeiro fim de semana.

25 Cenógrafo, diretor, artista gráfico. Trabalha há mais de dez anos com Daniela na confecção de cenários e capas dos seus álbuns como Feijão com Arroz (1995), Sol da liberdade (2000), Sou de qualquer lugar (2001), Eletrodoméstico (2003), Balé Mulato (2005). Em entrevista concedida à autora, Gringo destaca em Daniela a "força incrível de comunicação com as pessoas, porque ela vai além da voz, é o corpo inteiro, tem uma coisa de energia.[...] Daniela é dança e música. Então é uma coisa que é a essência do povo baiano, do povo brasileiro que é se mexer. Então, eu acho assim, ela sintetiza esses dois lados que eu acho muito legal. E é impressionante, eu já acompanho ela há mais de dez anos e eu vejo o carisma que ela tem em qualquer lugar do mundo que ela vá. É o carisma do povo brasileiro, da gente que tem essa coisa corporal muito forte, emocional, que vem do corpo" (junho de 2005).

26 Em conversa informal acerca da capa deste álbum, Daniela revela que não conseguiu realizar o que havia programado, transformando então com o fotógrafo o tema da capa .

27 Em entrevista à vendedora Verônica nas Lojas Americanas do Shopping Barra, em 5 de outubro de 2005, sobre o critério de arrumação dos CDs por gêneros na prateleira, esta me relatou que quem determina esta organização é o repositor da loja, baseado em critérios de procura dos clientes que vão às prateleiras respectivas dos gêneros que os artistas representam. Segundo ela, se colocar em outra prateleira que não seja a usual, os clientes não perguntam e muito menos procuram, pois acham que terminou o produto. Assim, ao procurar o álbum Clássica de Daniela Mercury na prateleira de MPB, encontrei-o na prateleira Axé, mesmo o repertório tendo sido só de MPB. Assim, quem determina o rótulo do produto a ser consumido é o consumidor. 
28 Importante observar nestas artistas, como aparece sensualidade de maneira distinta das baianas tradicionais apontadas no capítulo 3.

29 O produtor desta faixa foi o percussionista argentino radicado no Brasil/Bahia Ramiro Musotto, que também assina a produção do álbum juntamente com Daniela.

$30 \mathrm{Na}$ ocasião, o jornalista, crítico musical e letrista não vislumbrou que o mercado da axé music, produz/produziu outro grande potencial artístico que já vem se constituindo em sucesso internacional por onde faz shows: Ivete Sangalo.

31 Nome dado pelos fãs que a acompanham no Carnaval fora do bloco Crocodilo.

32 O trio tecno criado por Daniela tem o seu inicio em 2000 quando a mesma, depois de ter participado da Parada Gay em Berlin, na Alemanha, resolve experimentar um trio tecno em pleno Carnaval de Salvador, provocando reações diversas por onde desfilava.

33 Ex-integrante do grupo baiano Os Tincoãs, cuja matriz afro-brasileira se reportava aos elementos da cultura dos terreiros de candomblé nos anos sessenta/setenta,. Este grupo pode ser considerado um dos precursores da influência da matriz afro-brasileira/baiana na música axé music e no samba reggae, antes mesmo de outro grande nome também responsável por esta síntese - Moraes Moreira.

34 Os camarotes, cada vez mais sofisticados, transformaram-se num ambiente dentro/fora do Carnaval que se situa entre uma festa privé, com bebidas, comidas, massagens, música ao vivo, música mecânica - esta cada vez mais de caráter eletrônica, bem como num novo empreendimento empresarial cuja estrutura alcança considerável vulto.

35 Este DVD e o CD têm patrocínio do Credicard, um dos patrocinadores do seu camarote, bem como da edição referente aos dez anos do camarote. Esta troca se processa também pela propaganda veiculada durante o Carnaval com Daniela como garota propaganda da marca.

36 Em entrevista/matéria ao jornal A Tarde de 15 set. 2006 a artistas revela o repertório do show: Aquarela do Brasil, Levada brasileira, Meu Pai Oxalá, Olha o Gandhy aí, Nobre vagabundo, Só no balanço do mar, Feijão de corda, Água do céu (com participação da cantora Gil), Topo do mundo, Pensar em você, Dia branco, À primeira vista, Amor de ninguém, Toneladas de amor, Você não entende nada, Que bloco é esse, Balé popular, Ilê pérola negra, Maimbé Dandá, Dona Canô (com participação de Mariene de Castro e a banda Didá), Vidigal. Além de outras canções que a intérprete preparou como surpresa. 
37 É esta data que Margareth toma como referência para comemorar seus 20 anos de carreira, deixando de levar em consideração sua aparição no teatro como o grupo de teatro "Amora lá em casa", suas apresentações no circo Troca de Segredos às sextas feiras, como vocalista da Orquestra do maestro Vivaldo Conceição, e os prêmios conquistados do troféu Caymmi em 1985 e 1987, o que levou a intérprete a se apresentar na noite do Caymmi no Projeto Astral, sendo aí contatada pela Polygram para um futuro contrato; ratifica o seu comportamento diante de sua trajetória em negar fatos que de alguma maneira propicia o alavancamento de sua carreira. Outros aspectos, como a negação do grande fluxo de foliões homossexuais no bloco Os Mascarados, é outra polêmica provocada pelo seu perfil, bem como a sua iniciação no candomblé.

38 Cantor e compositor integrante do grupo Talking Head, que em carreira solo lança o álbum Rei Momo.

39 Vale lembrar que na Cidade Baixa moravam os inventores/músicos do trio elétrico, Dodô e Osmar, e todo o seu clã, assim como os artistas Book Jones, Janete e Jaciara (Banda Mel) e Era Encarnação, cantora famosa da década de setenta.. Localizada na Península de Itapagipe, tinha assim uma vida cultural bastante agitada.

40 Para mais informações, ver Silva (2002).

41 Deus da adivinhação.

42 Este fenômeno, no caso de Margareth, pode ser exemplificado com a criação do bloco Afropopbrasileiro em 2004, em cujo ambiente representantes das entidades dos blocos afros, liderados pela intérprete, promovem ensaios nas quadras dos respectivos blocos.

43 Tanto Margareth quanto artistas baianos de diversos gêneros e tendências musicais recebiam apoio sistemático do governo do Estado no fomento aos seus respectivos trabalhos, tanto para a gravação de CDs quanto em turnês pelo Brasil e fora do país, bem como em blocos alternativos e em desfiles no Carnaval. Assim, o governo do Estado da Bahia se torna o grande investidor destes artistas, que nas rodas de artistas são chamados de chapa branca.

44 Em yorubá, significa lábios grandes.

45 "Ser afropop não é uma invenção da minha cabeça. É uma proposta de comportamento, bem baiano e contemporâneo no modo de vestir, agir e pensar. Sinto uma certa responsabilidade pela referência de qualidade, mas sou um tipo de artista assim, não me atenho a só uma coisa, vivo na contemporaneidade e me identifico com este conceito" (Jornal A Tarde, 25 jul. 2006). 
46 Entrevista extraída do site www.correiodabahia.com.br/folhadabahia/ noticia_impressao.asp?codigo=80628.

47 Com este álbum, a intérprete recebe o prêmio TIM de música de melhor cantora regional 2006. Paradoxalmente, o título do álbum é "Uma Brasileira”.

48 Matéria não assinada. Nas Referências, entrada pelo título Margareth Menezes homenageia o samba reggae.

49 Olheiros são contratados para inspecionar, verificar se os foliões que estão no bloco possuem a credencial (no caso, específico, a pulseira de acesso) para permanecerem no mesmo.

50 Trecho da música Só pra me ver, de sua autoria, do álbum Clube Carnavalesco Inocentes em Progresso, lançado em 2003.

51 Prêmio instituído pelo canal fechado há 15 anos. Ivete recebeu, ao longo deste período, 17 indicações, reunindo as categorias show, cantora, música e DVD.

52 Ramon Cruz vem da geração do rock baiano dos anos oitenta/noventa, como compositor, cantor e baterista. Contudo, sua atuação se faz cada vez mais presente como baterista de Daniela Mercury e como compositor bastante gravado por Ivete Sangalo.

53 Em entrevista concedida à autora, em 6 de outubro de 2005, Ivete afirma que a Timbalada a transformou muito, musicalmente. "Eu posso dizer, depois da Timbalada eu tomei outro rumo nas minhas interpretações".

54 No momento em que Ivete selecionava o repertório para entrar em estúdio para a gravação deste álbum, sua mãe, Maria Ivete, sofre um acidente vascular cerebral e fica internada na UTI, vindo a falecer.

55 Nome de um préstito, entidade carnavalesca de Salvador nos anos 30 aos 40, sediada no bairro da Saúde.

56 Ver declaração, no capítulo precedente, de Radamés Venâncio, tecladista e diretor musical da intérprete.

57 Comumente, canário é um adjetivo pejorativo que os músicos utilizam para se referir ao cantor(a) que só faz reproduzir uma música sem imprimir personalidade.

58 Numa alusão ao poema Trem de ferro, de Manuel Bandeira

59 Desde o lançamento do seu primeiro álbum, Ivete aparece em trilhas de telenovelas da Rede Globo. Em 2003, com Somente eu e você; em 2005, com Soy loco por ti América - tema de abertura da novela América 
(que começou com na voz de Milton Nascimento, sendo substituída por Ivete, com arranjo de Gerson Silva); e em 2006 na novela Cobras e Lagartos, com Quando a chuva passar.

6o Projeto do Programa de Educação Tributária desenvolvido pela Secretaria da Fazenda do Estado da Bahia, que objetiva proporcionar aos cidadãos um maior acesso aos programas culturais e esportivos do Estado.

61 Um marco em termos de vendagem mundial, para a gravadora Universal Music, com 500 mil cópias do CD e DVD no ano de 2004.

62 Ivete colocou silicone nos seios em 2006.

63 Em depoimento da artista no seu blog (http://blog.ivetesangalo.com. $\mathrm{br} /$ ), Ivete credita sua performance com a guitarra à estrela pop que mais a influenciou - Marina Lima.

64 O programa Fama pode ser apontado como um modelo de fabricação de estrelas, bem como o Big Brother Brasil na fabricação de celebridades, só para citar os veiculados pela Rede Globo. É o caso também de Ídolos, veiculado pelo SBT.

65 Trata-se de uma nova técnica para captação da voz humana ao microfone, levando-se em conta novos recursos tecnológicos.

66 Pejorativamente, esses trinados eram chamados de "balido de cabra e de bode" (SANT'ANNA, 2001). Como exemplo desta técnica, citamos a coloratura da ária "A rainha da noite", na Flauta Mágica de Mozart. No Brasil, a cantora Elba Ramalho foi estigmatizada durante um longo período por cantar de forma semelhante ao balido de uma cabra, segundo comentários preconceituosos da época.

67 Se procedermos a um cotejamento do número de percussionistas compositores lançados no ambiente do Carnaval baiano e da axé music e samba reggae, podemos observar uma predisposição para sonoridade de palavras que tenham um efeito percussivo, a exemplo das composições de Carlinhos Brown, Peu Meurray e Leonardo Reis, para citar os mais emblemáticos.

68 Nome dado ao local onde as pessoas, na boite ou nas raves, dançam música eletrônica.

69 Ver subseção 5.2.1.

70 Ver Cheneider (1982) apud Sant'Anna (2001). 


\section{6 Acordes Finais}

A crescente mercantilização do Carnaval acarretada, entre outros fatores, pela organização dos blocos de trio a partir da década de 1990 e pela fragmentação do processo de produção do sucesso, proporcionou certa autonomia e o florescimento sem precedentes de um mercado musical local, provocando, assim, um fenômeno que traz graus de similitude com a indústria cinematográfica de Hollywood das décadas de trinta, quarenta e cinquenta: o fenômeno das estrelas.

Surgem, então, algumas questões: É possível fabricar uma estrela nos moldes em que a indústria do Carnaval se constitui a partir deste período? Se positivo, quais os ingredientes necessários para sua ascensão? De que maneira estas estrelas estabelecem graus de sociabilidade numa sociedade contemporânea cujo trânsito entre o local e o global pode ser veiculado através de novas autonomias mediadas pelo artístico cultural impresso na voz/corpo/performance destas estrelas/intérpretes do pop/axé, que, ao assumirem as rédeas de suas respectivas carreiras, imprimem perfis identitários perante o local e o global?

Foi sobre isto que nos debruçamos ao longo deste trabalho.

No capítulo 2, foi discutido o panorama musical de Salvador, que ocasionou a profissionalização de uma categoria que tem a axé music como fator de êxito mercadológico, tanto no ambiente local quanto nacional. Neste sentido, a própria organização empresarial do Carnaval e dos blocos de trio torna-se ambiente fértil para a ascensão de artistas; particularmente, neste estudo, para o surgimento da estrela do Carnaval de Salvador, que antes tinha no trio elétrico 
a grande sensação inventiva do Carnaval. Assim, as estrelas que se compõem de três elementos - beleza, juventude e dom (MORIN, 1989) - carregam neste ambiente mais um elemento em sua constituição - o elemento pop, que se constitui também como uma performance.

No capítulo 3, tratamos da construção de uma referência baiana no contexto da brasilidade/baianidade, inicialmente representada pelas tias baianas no Rio de Janeiro e pelas personagens de romances, bem como pelas estrelas-intérpretes no imaginário local, nacional, global, que tem em Carmen Miranda o seu maior ícone, contribuindo para plasmar imagens de Bahias calcadas na tradição. Isto é o que podemos observar no teatro de revista no final do século XIX e início do século Xx, com as vedetes brasileiras Araci Côrtes e Aurélia Delorme, dentre outras, além de estrangeiras como Ana Manarezzi e Pepa Ruiz, que se apresentavam principalmente nos palcos cariocas. Umas e outras mostravam uma baiana lasciva, sestrosa, brejeira, maliciosa, confundindo-se por vezes com diversas matizes étnicas que passeiam da mulata à morena, nega, cafuza, também representadas pelos compositores como um dos palcos desta construção.

A partir da Era de ouro, a constituição da intérprete baiana/brasileira abandona um pouco desta tradicionalidade, entrando em sintonia com a era do rádio e suas estrelas representadas por intérpretes que, para Zumthor (1993), se constituem em portadoras da voz poética, tendo o drama como tema recorrente nas vozes de Dalva de Oliveira e Ângela Maria. Como representantes de outras décadas, podemos citar uma infinidade de estrelas-intérpretes baianas e não-baianas que contribuem para plasmar modelos de imagens de Bahias não mais unicamente calcadas na tradição, mas num trânsito entre a tradição e a modernidade, como pode ser observada tanto em artistas baianas, como Gal Costa e Maria Bethânia, quanto não baianas, como Clara Nunes e Fafá de Belém. Entretanto, é a partir da segunda metade dos anos oitenta, com a axé music, que a construção de uma identidade cultural baiana/brasileira toma novo fôlego com as estrelas-intérpretes Daniela Mercury, Margareth Menezes e Ivete Sangalo. 
No capítulo 4, alguns aspectos foram elencados no sentido de compreender a construção das respectivas carreiras das estrelas-intérpretes, no que Claude Mollard (1994) denomina de Sistema Cultural, cujos aspectos artísticos, técnicos e profissionais são de importância fundamental para a construção do sucesso. Assim, o gerenciamento das respectivas carreiras de cada uma destas artistas se configura em teias de relações com as intérpretes-estrelas e seus músicos, arranjadores, diretores musicais, empresários e produtores, gravadoras, agências da mídia e público consumidor destes produtos artísticos, que neste estudo têm os fãs clubes como um foco especial.

No capítulo 5, abordamos minuciosamente a trajetória de cada uma das estrelas/intérpretes do Carnaval baiano. Cada uma destas estrelas, com suas particularidades, tocam suas carreiras de maneira distinta, configurando características próprias, seguindo em busca incessante de novos desafios dentro e fora do âmbito do Carnaval, gerenciando blocos, trios, produtoras e outros empreendimentos.

A singularidade destas intérpretes se constitui não só pelas práticas artísticas que se estabelecem entre o artista e o âmbito no qual se situa, como também pela sua própria vida enquanto construto. Por outro lado, cada uma destas intérpretes acima representa, a seu modo e em algum sentido, de maneira própria e intransferível, a atual música pop no Carnaval de Salvador.

As carreiras destas intérpretes podem ser tomadas como representações de diversas Bahias que se apresentam em suas respectivas obras, ora de forma harmoniosa, ora de forma conflitante, sempre mantendo o diálogo com o contemporâneo.

Em Daniela, a noção de etnicidade se refere a todas as vozes que porventura ousem cantar "a cor dessa cidade sou eu". Ao mesmo tempo que proclama que é a cor da cidade, a cor da cidade é de quem canta esta canção de autoria dela própria e Tote Gira. Poderíamos modular esta expressão a partir de duas perguntas: Que cor tem swingue? E que cor tem o swingue? Ou ainda: quem detém o swingue? Daniela se apropria não só do swingue da dança afro, já que sua formação em dança permite este trânsito, mas também do samba reggae e todas 
as influências advindas do elemento afro-baiano. Assim, a cidade que canta, que dança, faz festa pro mar, plasmada na voz de Daniela, é a cidade da Bahia, cidade da poesia; é a terra festeira de gente bonita, é a terra da felicidade. Não se trata de uma felicidade pura e simples cujo dinheiro e bens de consumo se tornam a tônica. Para a artista, na canção A Felicidade (2007), parceria entre ela e Manno Góes, a felicidade é querer trocar barracos por casas / e histórias prá contar / roupa bem lavada / e um colo pra ninar / massa feita em casa / por um fado pra cantar / paredes pintadas / e uma moça pra dançar.

Inquieta, profissional, inovadora, só para citar alguns adjetivos do que singulariza a carreira desta artista, podemos apontar que esta estrela lunar - posto que se notabiliza pelo desfile à noite no Carnaval, busca com o jogo de luz e sombra um brilho que mesmo para uma estrela que já carrega em si o brilho, se não bem localizado, situado, se torna obscuro. No caso de Daniela, seu espaço é o centro do palco laureado por convidados que, ao seu lado, tornam-se coadjuvantes ofuscados pelo brilho da rainha da noite (para lembrar a alusão da ária da Flauta Mágica de Mozart); suas vestes normalmente servem para esconder/revelar brilho e competência interior, acentuado pelos refletores e engenharia pirotécnica para transformar em sonho o lado obscuro dos plebeus que param para aplaudi-la à sua passagem em seu carro alegórico elétrico-eletrônico, numa performance corporal/ vocal marcada, coreografada, ensaiada.

Assim, a baiana encontrada na obra de Daniela Mercury é apolínea, moderna, elétrica e eletrônica. Mais que tudo isso, é pop. No entanto, o pop apresentado em sua performance se encontra carregado cada vez mais do signo da nova música brasileira contemporânea. Suas apresentações são cada vez mais híbridas, sincréticas, locais e plugadas no mundo. O tradicional encontrado na obra de Daniela se apresenta de forma tão diluída que só um olhar e ouvido mais atento pode perceber a ligação com o frevo baiano presente nas guitarras dos seus álbuns, na batida cada vez mais diluída do samba reggae e nas danças dos blocos afro, particularmente o Ilê Aiyê, reforçada pelas piruetas adquiridas pela sua formação em dança. Assim, a rainha da 
axé vai reconfigurando a baiana tradicional cheia de lascívia, dengo e malemolência, numa dança que pouco apresenta de sensual; ao contrário, apresenta movimentos vigorosos, marcados e nada sinuosos.

A estrela-intérprete singular construída por Daniela se revela vocalmente forte, poderosa, decidida, não só impressa nas tonalidades mais graves, mas na emissão vocal percussiva um canto barroco característico da axé music, num domínio da mensagem poética do seu discurso, que também ecoa através da dança como um elemento aglutinador do seu canto numa Bahia que se apresenta eminentemente pop, moderna, cosmopolita, eletrônica.

A baiana groovada que se constitui em Daniela é também cidadã (seja como embaixadora da UNICEF, UNESCO, Instituto Ayrton Sena, ALAS) seja em campanhas contra doenças sexualmente transmissíveis, seja contra a prostituição infantil.

Em Margareth, o ancestral africano se apresenta não só no revestimento étnico, no sentido estético, mas também religioso, sagrado, tribal, de certa forma estigmatizado. Entretanto, as sínteses que podem ser observadas na sonoridade do seu trabalho carregam o elemento étnico em sua própria performance corporal, nas danças alegorizadas que remetem aos orixás, bem como no seu jeito de sambar ou na própria pele. O vetor pop se faz presente no sentido de imprimir uma sonoridade híbrida na mistura entre instrumentos harmônicos, percussivos e eletrônicos; entretanto, a forma como o seu canto barroco passeia pelos arranjos impressos nos seus álbuns denota um intercâmbio tímido com o pop tal como considerado pelo mercado, dificultando assim sua penetração de forma massiva neste ambiente. Assim, a temática social/étnica que normalmente se desdobra e se impõe em suas canções, tais como Negra cor, Alegria da Cidade, Maravilha morena e Dandalunda se reportam também aos elementos da natureza, revelando assim uma estrela telúrica, a que se alimenta da terra e seus elementos, tirando daí o seu néctar sonoro, a sua força vibrante, indomável, até pela própria força motriz que a impulsiona de forma fremente para o palco, lugar onde transborda toda a sua catarse. 
Para a estrela telúrica, os elementos da natureza, particularmente a água e terra, demonstram também um trânsito pelo étnico já "naturalizado" pela própria cor de sua pele e pela proximidade cada vez maior com seus pares através do movimento afropopbrasileiro criado por ela a partir de 2005, que congrega ensaios e um bloco de Carnaval formado pelo Olodum, Ilê Aiyê, Male de Balê, Filhos de Gandhy e Cortejo Afro, servindo assim para se legitimar enquanto artista engajada na causa étnica.

A trajetória musical de Ivete Sangalo aponta para uma cantora pop-romântica que transita entre a soul music - como pode ser conferido nas canções Não quero dinheiro e Sá Marina - e a axé music, nas canções Empurra empurra, Tô na rua, De ladinho, Abalou; os ritmos latinos nas canções Céu da Boca, Corazón Partío, Chica Chica Boom, com a mesma desenvoltura com que se movimenta em baladas, como pode ser ilustrado nas canções A Lua que eu te dei, Se eu não te amasse tanto assim, Quando a chuva passar, dentre outras. Sua relação com o étnico se processa através do outro: "Quero meu negão do lado", como canta em Carro Velho. (ver ANEXo C).

Ao ser indagada pela repórter Cleidiana Ramos, do jornal A Tarde, acerca de que mensagem enviaria aos afrodescendentes homenageados no Carnaval de 2002, cujo tema foi Carnaváfrica, Ivete responde:

A África é uma das fontes inesgotáveis de coisas boas culturalmente. É um povo forte, determinado, sofrido, explorado, mas é uma fonte que a gente bebe diariamente, principalmente o Brasil e, indiscutivelmente, a Bahia, na cultura, no seu folclore, na sua música, na maneira de vestir, de se comportar, na miscigenação. Acho que é uma homenagem muito justa. A minha mensagem para os afro-descendentes é de agradecimento, um muito obrigada, por toda essa herança. Que Deus continue com os olhos voltados para a África que tem um povo muito sofrido, mas que sabe lidar com o sofrimento e transformar tudo isso em coisas boas. Que Deus nos permita usufruir cada vez mais dessa criatividade e dessa fertilidade que a África tem. (2002, p.1). 
Musa dos últimos verões do Carnaval e do Brasil, Ivete Sangalo é, no momento, o que Edgar Morin (1989) denomina de estrela mercadoria - quanto mais consumida, mais desejada. Sua singularidade se constrói com beleza, jovialidade, simpatia, dom, alegria, festa, numa Bahia do Carnaval, da molecagem, da brejeirice e da "esculhambação", além de um ingrediente que a coloca como heroína de sua geração e transforma a sua vida em obra de arte. Ao assumir publicamente sua vida privada, Ivete traz à tona os sentimentos e percalços por que passa uma estrela. É isso que pretende a estrela que, neste momento [2007], é a campeã de vendas na atual constelação da axé music. "Viver a vida" (MORIN, 1969) - é o que busca de forma descontraída, debochada, moleca e faceira. Desfrutar do sucesso, da fama, cantando e fazendo o que gosta, inclusive as negociações, natural no mundo da indústria da música.

Ivete assume publicamente - às vezes, escrachadamente - todas as suas atitudes e sentimentos que vêm desde a perda da mãe, as dificuldades de sobrevivência com a morte do pai, os casamentos e as traições, o espólio cada vez maior e sua aquisição de novos bens a cada dia, além de namoros fugazes e intensos, aborto espontâneo, gravidez, dentre outras superexposições. A mídia aproveita esta vocação para a superexposição, que por sua vez é re-aproveitada pela estrela, que, com estas aparições e no crescimento de sua visibilidade, resulta em mais vendas de discos, mais shows, contratos milionários como garota-propaganda e, consequentemente, investimentos como empresária em sua própria carreira e em outros negócios.

Também dona do seu próprio negócio, a cantora de voz caliente e pernas perfeitas -segundo a própria - vende a sua imagem embalada com música, beleza e alegria para os fãs-fiéis que a idolatram em centenas de fãs clubes que ajudam a perpetuar o sucesso de uma das estrelas da axé music.

Ivete veio de uma região árida, o baixo São Francisco, onde o sol brilha o ano inteiro. Sua vida já reflete a clareza/claridade de seus atos debochados, transparente, sem etiquetas. De forma debochada ela vai construindo sua performance como já apontado, calcada 
na esculhambação. Ela é o próprio espírito do Carnaval 365 dias no ano. Assim, Ivete é o que podemos denominar de estrela solar. Coincidências à parte, seus desfiles acontecem sempre à luz do dia, tanto no percurso Barra-Ondina, com o bloco alternativo Cerveja e Cia, quanto na Cidade Alta, com o bloco Os Corujas.

Assim, as interpretações da Bahia configuradas nas obras destas intérpretes no ambiente contemporâneo podem ser compreendidas a partir do binômio tradição/modernidade, em cujo âmbito as imagens de Bahia estão vinculadas a vetores de ancestralidade (em maior escala em Margareth), sensualidade (nas três intérpretes) e familiaridade (também nas três, mas em Ivete em maior escala), além do elemento pop. Este se encontra consubstanciado não apenas nos arranjos e formas musicais registrados nos álbuns destas intérpretes, como na própria indumentária e nos shows performatizados por coreografias e aparatos tecnológicos fartamente veiculados pela mídia, como que plugando a Bahia no mundo.

Por outro lado, as interpretações acerca da(s) Bahia(s) na obra destas intérpretes também passam pelo vetor de sentimentos psicoafetivos apontados por Morin (1969; 1989; 1999). Assim, o amor, a festa, a felicidade, a alegria retratam o sentimento presente em canções que têm o encontro, a celebração como tônica. Como um modus vivendi.

Quanto às temáticas presentes, particularmente nos álbuns das intérpretes, em Ivete Sangalo, o amor perdido ou encontrado é motivo constante para embalar festas e encontros de jovens. Em menor escala, Daniela também brinda seus fãs/ouvintes com temas românticos, como pode ser conferido em sucessos tais como: Só pra te mostrar, Rosa, Nobre Vagabundo e À primeira vista. Entretanto, este tema é povoado de metáforas como em Beat Lamento, canção de Márcio Mello, ou ainda Amor de ninguém, de Jorge Papapá, deixando o amor livre para amar, sem amarras. Além disso, o amor relatado na obra de Daniela é espacialmente delimitado, territorializado. Em Rosa, o Olodum serve de cenário; em Swingue da cor, o amor vai relaxar o calor no bloco Muzenza; ou ainda, em $O$ mais belo dos belos, o bloco 
Ilê Ayiê torna-se o motivo da separação ocasional porque o Carnaval se aproxima.

Paulatinamente, o discurso sobre o amor no decorrrer de sua obra vai sendo desterritorializado como em Topo do mundo (Jauperi e Gigi), Amor de ninguém (Jorge Papapá), Pensar em você (Chico César), ou ainda em Sem querer da autoria da artista. Entretanto, em Daniela, a Bahia e o Carnaval comparecem em temas sempre recorrentes como em Trio metal, cuja massa em lata invadia metida a heavy metal; assim como em eu sou o primeiro que canta, eu sou o Carnaval, ou ainda em Toneladas de amor (Márcio Mello), cujos versos diz: ao seu lado eu sou Carnaval e/ se ainda me quiser me quiser eu não vou the decepcionar; Em Axé axé de Caetano Veloso a declaração de amor se faz presente pela música, que é o que há de fazer eu me juntar a você e ver meu povo feliz. Assim, o amor da rainha do axé é elétrica, num Carnaval eletrônico. (ver ANEXO A).

O elemento romântico é menos frequente na obra de Margareth. Entretanto, como já apontado no álbum Pra você, a intérprete se revela romântica e telúrica, particularmente na canção Como Tu, de Cláudio Rabello, comparando o seu amor às estrelas, à primavera. Presente em sua obra, o elemento étnico impresso na pele de ébano de Alegria da cidade, em Maravilha morena, em Negro menino, Negra melodia e Nego doce, dentre outras, além dos elementos da natureza, particularmente a água do mar, como pode ser observado em Pelo mar lhe mando flor, Até rir o mar e Mar de amor, só para citar canções de sua autoria. (ver ANEXO B).

Entretanto, o que efetivamente distingue estas três estrelas da música produzida em Salvador a partir dos anos oitenta é o ambiente do Carnaval, o canto barroco e o elemento pop presente em suas respectivas carreiras. Daniela, com um investimento cada vez mais intenso e frequente do elemento pop/eletrônico; Margareth, com o samba reggae e o afropopbrasileiro; e Ivete com a axé music romântica, associada a pitadas pop temperadas de latinidade.

$\mathrm{O}$ ano 2000 poderia ser apontado como o divisor de águas em suas respectivas carreiras. Daniela, com o lançamento do trio Tecno, o álbum Sol da Liberdade e o projeto Por do Som; Ivete, com o álbum 
Beat Beleza; e Margareth, com o bloco Os Mascarados. As três apontam para uma nova configuração sonora/empresarial tanto no ambiente do Carnaval de Salvador, tornado então um imenso concerto ao ar livre, cujas experimentações e trocas sonoras se performatizam a cada ano, como aos olhos do mundo. Estes passam a encarar o Carnaval baiano não unicamente como uma festa local e de características singulares, mas como uma grande vitrine de estilos, ritmos e artistas locais, nacionais e globais que a cada ano afluem mais frequente e intensamente a este fenômeno de grandes proporções.

Ao mesmo tempo em que a Bahia destas intérpretes pode ser comparada àquela das tradições correspondentes às representações da baiana no século XIX ou associadas à figura de Carmen Miranda, carregada de etnicidade, sensualidade, historicidade, podemos também observar, no desempenho dessas estrelas/intérpretes, a consagração da Bahia/Brasil na mídia como reserva telúrica e étnica veiculada pelo discurso da burocracia governamental e do empresariado do turismo, fomentada principalmente a partir dos anos sessenta, tendo o elemento pop como grande diferencial desta construção.

As intérpretes Daniela, Margareth e Ivete sofrem também o estigma de carregar em seu canto/performance as referências culturais que costumam ser encerradas no termo baianidade, representadas por festa, folia, verão, Carnaval. Recuando um pouco no tempo, observamos que o perfil de Dorival Caymmi plasmado perante a mídia e o imaginário é construído em torno da reserva telúrica, do Éden. Uma cidade praieira, cujas reservas naturais se distanciam da temporalidade característica de uma sociedade urbana industrial moderna.

Entretanto, é também na voz deste trio de intérpretes, que tem o trio elétrico como um espaço de sua performance, da música contemporânea do ambiente do Carnaval da terra festeira, que um novo acervo de referências acerca da Bahia começa a se delinear no imaginário e na mídia local/nacional/global. Isto é indissociável de um Carnaval que não se organiza mais tanto de forma tradicional e regional, e sim como um grande festival pop que elasteceu o calendário das festas que o antecedem, como o Festival de Verão, os ensaios dos 
blocos e festas cujas misturas de gêneros e estilos são compactuadas para atingir o maior e mais diverso público possível.

Neste sentido, o Carnaval torna-se um aglutinador de gêneros e artistas de diversas vertentes que o utilizam como vitrine da pluralidade de possibilidades. Para Moura (2007), quem perde com isso é o próprio "Carnaval como um tempo especial de festa, a culminância do verão, o tempo do prazer, da sensualidade, do sol, do encantamento, do enlevo tropical". Para o autor, todos perdem com isso, tanto os blocos afros quanto os blocos de trio, que perdem espaço para outros artistas de outras vertentes como Jorge Vercilo, Ana Carolina e Calypso, dentre outros. Assim, "essas novidades não se integram; somam-se à parte”. Assim, na atualidade, a própria axé music não se constitui como única atração musical do Carnaval de Salvador. Isto sem apontar o crescimento dos camarotes, que também contratam bandas e artistas do porte de Nando Reis e Paula Lima para animar os "convidados". Bandas essas que, em sua grande maioria, praticam um repertório mais vinculado ao pop nacional. Outras vertentes da música pop baiana também são representadas por grupos como Diamba, Skambo e O Círculo, dentre outras.

A axé music encontra-se hoje cada vez mais associada à música pop no Brasil, sem no entanto carregar, na sua nuclearidade, "especificidades e especialidades da cidade do Salvador" (MOURA, 2007), como era mais comum no seu nascedouro, conforme pode ser observado na canção do publicitário Nizan Guanaes, We are Carnaval, bem como no depoimento da artista Fernanda Abreu.

A Margareth, Daniela, Ivete, também [...] que faz tão bem o axé como faz música pop, taí provado, o Brasil todo cantando as músicas da Ivete, elas provam que elas podem vir de uma essência do samba reggae né, da Bahia e tal mas que elas são realmente artistas cosmopolitas, elas falam do Brasil todo, falam do mundo todo, acho isso muito importante. (ABREU, 2005).

O Carnaval, nos moldes em que hoje é veiculado para boa parte do mundo, não se configura mais como uma festa sazonal animada unica- 
mente por artistas locais e temáticas auto-recorrentes. Ao contrário, o que se presencia no espaço do Carnaval, a partir da nova conformação gerada pelas negociações e parcerias dos empresários donos de blocos, patrocinadores de grande porte locais e nacionais, o governo (nos âmbito municipal, estadual e federal) e os artistas também donos de blocos que movimentam uma fábula, economicamente só comparável a grandes concertos internacionais, gera uma competitividade cada vez maior e uma padronização crescente de produtos cada vez mais parecidos entre si a serem oferecidos aos públicos.

Por outro lado, estas estrelas-intérpretes da música pop baiana/ brasileira podem se configurar, aos nossos olhos, como modelo para novos protótipos em gestação, demonstrando que a capacidade para gerir seu próprio negócio - não somente do ponto de vista artístico, como também empresarial - pode se tornar um diferencial na construção do sucesso, bem como na formatação de novos modelos de representação social.

Daniela Mercury, Margareth Menezes e Ivete Sangalo compõem um quadro privilegiado. Entretanto, só podemos compreender este processo no momento em que elas procuram assumir - com maior ou menor êxito - o gerenciamento de suas respectivas carreiras solo, administrando com uma equipe seus respectivos produtos: griffes de blocos, trios elétricos, shows camarotes, etc, de maneira empresarialmente organizada. É interessante observar o cast para botar o bloco na rua, com alto grau de profissionalismo, desdobrando-se em novas estratégias de administração do seu próprio negócio, tomando assim o timão de suas carreiras.

Assim, a diferença fundamental entre as intérpretes que ocupam o primeiro plano como objeto desta pesquisa - pois tiveram a ousadia de aproveitar as oportunidades e ocasiões, no sentido de comandar, além das massas no Carnaval, suas trajetórias artísticas, assumindo os riscos que uma carreira solo pode encerrar - e outras intérpretes de axé music é que estas últimas se mantêm atreladas, contratadas, gerenciados por empresários e donos de blocos que as utilizam de forma efêmera, descartável, qual mercadoria perecível. 
Por outro lado, o acúmulo de papéis em que estas intérpretesempresárias se desdobram lhes deixa sujeitas às circunstâncias e vicissitudes do consumo de shows e de CDs, envolvendo a escolha do repertório e arranjos contidos em cada número a ser lançado no mercado, a relação com o fotógrafo, o maquiador e o figurinista, que as deixarão belas e vendáveis. Porém, como uma das características da estrela-intérprete é a inquietude e a busca incessante da perfeição técnica e emocional, associada à distribuição e consumo desses produtos, ninguém melhor que as próprias donas e suas vozes para discernir como perenizar, comandar e quem sabe perpetuar o sucesso diante da mídia e dos grandes públicos, ao mesmo tempo emprestando seu fenótipo e suas cordas vocais ao acervo de imagens e sons da Bahia e do Brasil.

Assim, estas estrelas-intérpretes lançam-se constantemente ao encontro de novidades em termos de oportunidades e recursos e mostram competência para gerenciar e vender seu próprio negócio; ou seja, colocar o seu tabuleiro de baiana na esquina do sucesso e vender seu próprio negócio; vender suas iguarias musicais e performáticas, utilizando quase os mesmos ingredientes, cada uma com seu tempero próprio. Por outro lado, estas estrelas-intérpretes se relacionam com o ambiente de forma multidimensional, não se configurando como superagentes.

Assim, o sistema cultural/social em que estão imersas pode ser compreendido como uma teia de relações que conspiram de forma a fomentar e perpetuar, ou não, o seu sucesso, pelo menos até que outras estrelas estejam prontas para atingir o Olimpo, como pode ser observado no modelo que começa a conquistar espaço cada vez maior na mídia - Cláudia Leitte - que aponta para a construção de uma estrela teen para uma estrela mãe.

Estas estrelas se propõem a sair do local rumo ao macro-planetário (MORIN, 1998, p.167) com a sua arte. Seu lugar são todos os lugares a partir da Bahia. Sua identidade é construída pela capacidade de agir reflexivamente e criativamente sobre suas práticas, aproveitando decididamente as oportunidades que surgem com as transformações 
no âmbito da tecnologia, da gestão e da perspectiva dos negócios, imprimindo novos padrões no próprio ambiente em que foram plasmadas. Assim, na pele de Daniela Mercury, Margareth Menezes e Ivete Sangalo, a baiana tradicional encontrada no século xIX torna-se, na contemporaneidade, pop. Pop-eletrônica em Daniela, afropopbrasileira em Margareth Menezes e pop-romântica em Ivete Sangalo. 


\section{Lista de Abreviaturas e Siglas}

ACBEU - Associação Cultural Brasil-Estados Unidos AFIS - Associação dos fãs-clubes de Ivete Sangalo AIFPI - Federação Internacional da Indústria Fonográfica ALAS - Fundação América Latina em Ação Solidária AMA - Academia Música Atual AMBAH - Academia de Música da Bahia AMUSA - Academia de Música de Salvador BAHIATURSA - Empresa de Turismo da Bahia S/A BANEB - Banco do Estado da Bahia S/A BID - Banco Interamericano de Desenvolvimento CNTUR - Conselho Nacional de Turismo CNIC - Comissão Nacional de Incentivo à Cultura CODEBA - Companhia Docas do Estado da Bahia CONBAHIA - Bahia Convenções COPene - Companhia Petroquímica do Nordeste S/A EMBRATUR - Empresa Brasileira de Turismo EMTUR - Empreendimentos Turísticos da Bahia EMTURSA - Empresa de Turismo de Salvador ICBA - Instituto Cultural Brasil Alemanha GGB - Grupo Gay da Bahia MASP - Museu de Arte de São Paulo MPB - Música Popular Brasileira OSBA - Orquestra Sinfônica da Bahia PRODETUR/NE - Programa de Ação para o Desenvolvimento do Turismo no Nordeste SBAT - Sociedade Brasileira de Autores Teatrais SESI - Serviço Social da Indústria SUTURSA - Superintendência de Turismo de Salvador TCA - Teatro Castro Alves UCSal - Universidade Católica do Salvador UNESCO - Organização das Nações Unidas para a Educação, a Ciência e a Cultura UNICEF - Fundo das Nações Unidas para a Infância USP - Universidade de São Paulo 


\section{Referências}

ABREU, Felipe. A questão da técnica vocal: ou a busca da harmonia entre música e palavra. In: MATOS, Cláudia Neiva de; MEdeiros, Fernanda de; TRAVASSOS, Elizabeth (Org.). Ao encontro da palavra cantada. Rio de Janeiro: 7 Letras, 2001. p.104-112.

ABREU, Thareja Fernandes. A vida como obra de arte Leila Diniz: um mito no Brasil contemporâneo. 1997. 133 f. Dissertação (Mestrado em Comunicação e Cultura Contemporânea) - Faculdade de Comunicação, Universidade Federal da Bahia.

ABREU, Fernanda. Entrevistadora: Marilda Santanna. Salvador, 1 jan. 2005. 1 cassete sonoro (6o min). Entrevista após o show de Daniela Mercury no projeto Por do Som, no Farol da Barra.

ADORNO, Theodor. O fetichismo na música e a regressão da audição. In: BENJAMIN, Walter; HORKHEIMER, Max; HABERMAS, Jurgen. Textos escolhidos. 2 ed. São Paulo: Ática, 1983. p. 165-191.

; HORKheIMer, Max. Dialética do esclarecimento. Rio de Janeiro: Jorge Zahar, 1985.

ALBIN, Ricardo Cravo. O livro de ouro da MPB: a história de nossa música popular de sua origem até hoje. Rio de Janeiro: Ediouro, 2004.

AlmadA, Sandra; PRAde, Priscila. Maga pop. Raça Brasil. São Paulo: Símbolo, v. 11, n. 106, jan. 2007. p. 52-5.

ALmeida, Candido José Mendes de. A arte é capital: visão aplicada do marketing cultural. Rio de Janeiro: Rocco, 1994. 101 p.

ALmeida, Manuel Antônio de. Memórias de um sargento de milícias. Barcelona: Sol 90, 2004.

ALMeIDA, Tereza Virginia de. A materialidade da voz feminina: o timbre de Elza Soares. 18 maio 2007. Instituto Memória Musical Brasileira. Jornal Musical. Niterói, RJ. Disponível em http://www.jornalmusical.com.br/ 
textoDetalhe.asp?iidtexto=1320\&iqdesecao=1 . Acesso em: 24 maio 2007. (Especial para o Jornal Musical).

ANA VALÉRIA. Entrevistadora: Marilda Santanna. Salvador, 2 mar.2003. 1 cassete sonoro (6o min). Entrevista no camarote de Daniela Mercury.

OS ALtos e baixos de quem foi notícia. Época. p. 92, 2 out. 200o. (Montanharussa).

ALves, Ceci. O axé morreu. Viva o axé. A Tarde, Salvador, 17 out. 2004. p. 1. Caderno 2.

Ficou tão quente o farol que pegou fogo. A Tarde, Salvador, 19 set. 2006a. Coluna Sotaque Baiano, p. 8. Caderno 2.

Carnaval é um momento na minha carreira. A Tarde, Salvador, 15 jun. 2006. p.1. Caderno 2.

ARAúJo, Carlos Alberto Ávila. Balançando o Brasil: a emergência da axé music e do pagode nos anos 90. 2000. 290 f. Dissertação (Mestrado em Comunicação Social) - Faculdade de Filosofia e Ciências Humanas, Universidade Federal de Minas Gerais.

ARAúJo, Marco Antônio. Daniela Mercury: a rainha do axé ousou levar música eletrônica para o carnaval. Revista Planeta Carnaval, ano1. n. 1, p. 38-40, 2006.

ARIstóteles. Poética. Tradução Eudoro de Souza. São Paulo: Ars Poética, 1993. $149 \mathrm{p}$.

ASsIs, Machado de. Obra Completa. Organização Afrânio Coutinho. Vol. III. Rio de Janeiro: Nova Aguilar. [s/d]

AUtÊnTICA. In: FERREIRA, Aurélio Buarque de Holanda. Novo dicionário da língua portuguesa. 2. ed. Rio de Janeiro: Nova Fronteira, 1986. p. 202.

AVANCINI, Maria Marta Picarelli. Nas tramas da fama: as estrelas do rádio em sua época áurea, Brasil anos 40 e 50. 1996. Dissertação (Mestrado em História) - Universidade Estadual de Campinas.

AXÉ Mix. Disponível em: <http://www.axemix.com.br/> .

AZevedo, Aluízio de. O cortiço. São Paulo: Moderna, 1997.

AZevedo, Arthur; Azevedo, Aluízio. As laranjas de Sabina. Intérprete: Maricenne Costa. In: Como tem passado!! Faixa 2 ( 2 m 56 s) CPC-UMES, 1999. Registro CPC 026. (Com Izaías e convidados).

AZEVEDO, Jaqueline. Entrevistadora: Marilda Santanna. [mensagem pessoal]. Mensagem recebida por < marilda_santanna@yahoo.com.br > em 10 set. 2006. 
BABADO Novo. Disponível em < http://www.babadonovo.com.br/portal_babado/self_print.asp?id=227> Acesso em: 28 abr. 2007.

BABILÔNIA, Gilson. Entrevistadora: Marilda Santanna. Salvador, 9 ago.2005. 1 cassete sonoro (6o min). Entrevista na produtora O Canto da Cidade.

BALOGH, Ieda Rodrigues da Silva. Operários da alegria: motivações, circunstâncias, êxitos e dificuldades na carreira profissional da axé music em Salvador, Bahia. 1999. 87 p. Monografia (Trabalho de Conclusão do Curso) - Ciências Sociais, Universidade Federal da Bahia, Salvador.

BARbosa, Marco Antonio. O triunfo da vontade de Ivete Sangalo. Instituto Memória Musical Brasileira. Jornal Musical. Niterói, RJ. 29 mar. 2007. Disponível em: <http://www.jornalmusical.com.br/textoDetalhe. asp?iidtexto=1092>. Acesso em: 22 abr. 2007.

BARroso, Ary. Aquarela do Brasil. Intérprete: Gal Costa. In: Aquarela do Brasil. Polygram/Philips, 1980. 1 LP. Faixa 12. Registro 6485.216.

. Na baixa do sapateiro. Intérprete: Carmen Miranda. EMI Odeon Brasil, 1996. In: Álbum 4. Faixa 18 (3 min 5 s). Registro 8347072.

. No tabuleiro da baiana. Intérprete: Carmen Miranda EMI Odeon Brasil, 1996. In: Álbum 2. Faixa 18 (2 min 36 s). Registro 8347052.

Quando eu penso na Bahia. Intérprete: Carmen Miranda. In: Álbum 3. EMI Odeon Brasil. , 1996. 1 CD. Faixa 19 (2 mim 42 s). Registro 8347062 .

; PeIXoto, Luiz. É luxo só. Intérprete: Rosa Passos. In: Pano pra manga. Velas, 1996, 1 CD. Faixa 9. Registro 11-V145.

BARroso, Carlos. Foliões mascarados. Correio da Bahia. Salvador, 28 de nov.2003.p.7

BARros, André Luiz; SimÕes, Eduardo. A dona da voz. Revista Bravo, n. 14, p. 72-9, nov. 1998.

BARros, Orlando de. Corações de chocolat: a história da Companhia Negra de Revistas, 1926-7. Rio de Janeiro: Livre Expressão, 2005.

BAstos, Eduardo. Daniela solta o canto. A Tarde. Salvador, 15 set. 2006. Fim de semana, p.1. Caderno 2.

. Margareth mais pop. A Tarde. Salvador, 23 set. 2005. p. 1. Caderno 2. BAStos, Cline. Entrevistadora: Marilda Santanna. Salvador, 7 out. 2005. 1 cassete sonoro (6o min). Entrevista na produtora O Canto da Cidade. 
BENJAMIN, Walter. A obra de arte na época de suas técnicas de reprodução. In: ADORNo, Theodor; HABERMAS, Jurgen; HORKHEIMER, Max. Textos escolhidos. 2ed. São Paulo: Ática, 1983. p. 3-28. (Os pensadores).

BHABHA, Homi K. O local da cultura. Belo Horizonte: UFMg, 1998.

BORGES, Kátia. Estamos sendo devorados. A Tarde. Salvador, 22 out.20oo. Caderno 2. p.8.

BOURDieU, Pierre. O poder simbólico. Rio de Janeiro: Bertrand Brasil, 2002. A economia das trocas simbólicas. São Paulo: Perspectiva, 1991.

BRITO, Hagamenon. Opinião/As super novas. Correio da Bahia. Salvador, 27 out. 2005. Disponível em: <http://www.correiodabahia.com.br/folhadabahia/noticia_impressão.asp?codigo=82003>. Acesso em: 24 abr. 2007.

Daniela Mercury acerta na mistura. Correio da Bahia. Salvador, 16 nov. 2005. Disponível em <http://www.correiodabahia.com.br/discomania/noticia_impressao.asp?codigo=51046>. Acesso em 24 abr 2007.

BUSSAB, Mariana de Oliveira. A celebridade e seus fãs: contribuição ao estudo de comunidades de marca no setor do entretenimento. 2004. $191 \mathrm{f}$. Dissertação (Mestrado) - Fundação Getúlio Vargas, São Paulo.

cAco de Telha. www.cacodetelha.com.br .

CAMpos, Djalma Leite. Margareth Menezes: de corpo e alma. Raça Brasil. São Paulo: Símbolo. n.89, ago. 2005. p.61. (Perfil).

CANCLINI, Nestor Garcia. Culturas híbridas: estratégias para entrar e sair da modernidade, São Paulo. EDUSP. 2003.

CANEVACCI, Massimo. Sincretismos: uma exploração das hibridações culturais. São Paulo: Studio Nobre, 1996.

CARDIA, Gringo. Entrevistadora: Marilda Santanna. Salvador, 10 jun. 2005. 1 cassete sonoro (6o min). Entrevista no lançamento do álbum Pra você, de Margareth Menezes, no hotel Pestana.

CAsÉ, Marcos. 20 anos de samba reggae. A Tarde. Salvador, 25 jul. 2006. Caderno 2, p.4

. No topo com Ivete Sangalo. A Tarde. Salvador, 29 mar. $2007 a$. Caderno 2, p. 8.

Ivete Sangalo lança novos CD e DVD. A Tarde. Salvador, 28 mar. 2007b. Caderno Brasil, p.21. 
CAStro, Rui. Carmen: uma biografia. São Paulo: Companhia da Letras, 2005 .

CAYMmi, Stella. Dorival Caymmi: o mar e o tempo. São Paulo: Ed. 34, 2001. $627 \mathrm{p}$.

CAYMMI, Dorival. Depoimento no catálogo de premiação do Troféu Caymmi. ano 1. 8 mar. 1986.

. O dengo que a nega tem. Intérprete: Carmen Miranda. EMi Odeon Brasil, 1996. In: Álbum 5. Faixa 23 (2 min 37 s). Registro 8347082.

. O que é que a baiana tem? Intérprete: Carmen Miranda. EMI Odeon Brasil, 1996. In: Álbum 4. Faixa 25 (3 min 12 s) Registro 8347072

. Lá vem a baiana. Intérprete: Rosa Passos. Lumiar Discos, 1999. In: Morada do Samba. Faixa 9. Registro LD 42-03/99.

; SANTiago, Osvaldo. Balaio grande. Intérprete: Dorival Caymmi. Odeon. 1954. In: Canções Praieiras. LP de 10 polegadas.

CENTRAL do Carnaval. Disponível em: < http://home.centraldocarnaval. com.br/ >.

CHEDIAK, Almir. Song Book Dorival Caymmi. Rio de Janeiro. Lumiar. 1994. V. 1.

CHIARAdiA, Maria Filomena Vilela. Revendo os bastardos de outrora. 1990. Monografia (Trabalho de Conclusão de Curso) - Universidade Federal do Rio de Janeiro.

Correa, Ademir; PAganini, Gui. Senhora Monte. Revista Rolling Stone. Brasil. 07 abr. 2007. p. 74-81.

CORREIA, Carlos. Daniela Mercury:sempre fui uma pessoa com muita força. Revista Nova Gente. Lisboa. 24 maio, 2000. p. 110-112.

costa, Jairo. Levantando a poeira. Correio da Bahia. Salvador, 22 dez. 2003. p. 8.

CRONOLOGIA: a MPB na voz das mulheres, disponível em http://veja.abril. com.br/cronologia/index.shtml . Acesso em 24 abr 2007.

CRUZ, Ramon. Entrevistadora: Marilda Santanna. Salvador, 1 jan.2007. 1 cassete sonoro (6o min). Entrevista no camarim, após o show de Daniela Mercury no projeto Por do Som, no Farol da Barra.

CUNHA, Vladimir; schiliró, André. Ivete Sangalo, ouro baiano. Revista Rolling Stone. São Paulo: Spring Publicações Ltda. n.3, dez 2006, p.63-73. 
CUnHA, Jonga. Entrevistadora: Marilda Santanna. Salvador, 18 maio 2005. 1 cassete sonoro (6o min). Entrevista na Escola de Administração da UFBA.

DANIELA Mercury: a energia e o movimento. Revista TV Guia. Lisboa 15 maio 2000, p.83.

.Sempre fui muito elétrica. Revista TV Guia. Lisboa. 19 maio 2000, p.22-24.

DANTAS, Marcelo. Olodum: de bloco afro a holding cultural. Salvador: Grupo Cultural Olodum/Casa de Jorge Amado, 1994.

. Gestão, cultura e leadership: o caso de três organizações afrobaianas. Revista Análise\&Dados. Salvador. 5, n. 4, mar. 1996.

DIAS, Márcia Tosta. Os donos da voz: indústria fonográfica brasileira e mundialização da cultura. São Paulo: Editorial Boitempo, 2000.

DINIZ, Julio. A voz como construção identitária. In: MATOS, Cláudia Neiva de; Medeiros, Fernanda Teixeira de; travassos, Elizabeth (Org.). Ao encontro da palavra cantada. Rio de Janeiro: 7 Letras, 2001. p. 207-16

DUARTE, Rodrigo. Adorno/Horkheimer \& a dialética do esclarecimento. Rio de Janeiro, Jorge Zahar, 2003. (Passo-a-passo).

DURAND, José Carlos. Arte, privilégio e distinção: artes plásticas, arquitetura e classe dirigente no Brasil. São Paulo: Perspectiva, 1989.

É só o primeiro fim de semana. Jornal do Brasil: Rio de Janeiro. 12 jan.2001. p.21. Revista Programa.

ECHEVERRIA, Regina. Furacão Elis. Rio de Janeiro: Globo, 1994.

ELIAS, Norbert. A sociedade dos indivíduos. Rio de Janeiro: Jorge Zahar, 1994 .

FAOUR, Rodrigo. História sexual da MPB: a evolução do amor e do sexo na canção brasileira. Rio de Janeiro: Record, 2006.

FeAtherstone, Mike. O desmanche da cultura: globalização, pós-modernismo e identidade. São Paulo: UNESP, 1991.

ferraroti, Franco. Histoire et histoire de vie: le méthode biografique das les sciences sociales. Paris: Librarie des Meridiens, 1983.

FOLlONI, Daniela. Ivete Sangalo: 30 x melhor. Revista Nova. set. 2003. p.142-5.

FREIRE, Márcia. Entrevistadora: Marilda Santanna. Salvador, 25 jan. 2005. 1 cassete sonoro (6o min). Entrevista no camarim, após o show de Margareth Menezes na casa de show Espetáculo. 
FREITAS, Verlaine. Adorno \& a arte contemporânea. Rio de Janeiro: Jorge Zahar, 2003. (Passo-a-passo).

FREYRE, Gilberto. Casa-grande \& senzala: formação da família brasileira sob o regime da economia patriarcal. 23 ed. Rio de Janeiro: José Olympio Editora, 1984.

GARCIA, Canclini Néstor. Culturas híbridas: estratégias para entrar e sair da modernidade. São Paulo: USP, 2003.

GARCIA, Tânia da Costa. O "it" verde e amarelo de Carmen Miranda-1930...1946. São Paulo: Annablume/Fapesp, 2004.

GASPAR, Marina Monarcha. As exigências técnicas da música contemporânea para o intérprete/cantor. 1993. Mestrado (Música) - Universidade Federal do Rio de Janeiro.

GERÔNIMO. Depoimento coletado no especial dos 10 anos do Troféu Caymmi exibido pela TV Educativa em 31 mar.1995.

GiAcominni, Sônia Maria. Aprendendo a ser mulata: um estudo sobre a identidade da mulata profissional. In: costA; Bruschini (Org). Entre a virtude e o pecado. Rio de Janeiro: Rosa dos Tempos, 1992. p. 213-46.

GIDDEns, Anthony. As conseqüências da modernidade. São Paulo: UnEsP, 1991.

GILROY, Paul. O atlântico negro: modernidade e dupla consciência. São Paulo: Ed. 34; Rio de Janeiro: Universidade Cândido Mendes. Centro de Estudos Afro-Asiático, 2001.

GODI, Antônio J. V. dos Santos. Música afro carnavalesca: das multidões para o sucesso das massas elétricas. In. SANSONE, Lívio; SANTOS, Jocélio Teles dos (Org.). Ritmos em trânsito: sócio antropologia da música baiana. São Paulo: Dynamis Editorial; Salvador: Programa a cor da Bahia e projeto S.A.M.B.A, 1997.

. Presença afro carnavalesca soteropolitana. In: CERQUEIRA, Nelson et al. Carnaval da Bahia: um registro estético. Salvador: Omar G., 2002. p.94-111.

GóES, Fred. 50 anos de trio elétrico. Salvador: Corrupio, 2000.

. Elas abrem alas. Cultura Brasileira Contemporânea. Rio de Janeiro: Fundação Biblioteca Nacional, ano 1, n.1, p. 109-15, nov. 2006. Música Popular Brasileira.

GOFfmAN, Erving. Estigma. Tradução por Leonor Guinsberg. Buenos Aires: Amorrortu, 1963.

. A representação do EU na vida cotidiana. Petrópolis: Vozes, 2002. 
Gomes, Tiago de Melo. Revista Brasileira de História. São Paulo, v. 21, n. 42, p. 525-30. 2001.

GUERREIRO, Goli. A trama dos tambores: a música afro-pop de Salvador. São Paulo: Ed. 34, 2000, v. 1. (Todos os Cantos).

HALL, Stuart. Identidade cultural na pós-modernidade. 5.ed. Rio de Janeiro: DP\&A, 1992.

Da Diáspora: identidades e mediações culturais. Belo Horizonte: UFMG, 2003.

HOBSBAWM, Eric; RANGER, Terence, (Org). A invenção das tradições. São Paulo. Paz e Terra, 2002.

IVANOv, Ricardo. Quarteto fantástico. Revista Go Where? Bahia. ago - set. 2005. p.20-6.

Kedouk, Márcia; Moraes, Nana. 13 coisas que me fazem assim. Revista Nova, ano 34, n. 3, p. 90-3, mar. 2006.

KELLNER, Douglas. A cultura da mídia: estudos culturais: identidade e política entre o moderno e o pós-moderno. Bauru, São Paulo: EDUSC, 2001.

KERBER, Alessander Mário. O que é que a baiana tem? Representação das nações brasileiras nas canções interpretadas por Carmen Miranda na década de 30. 2002. Dissertação (Mestrado em História) - Universidade do Vale dos Rios dos Sinos.

LEITE, Letieres. Entrevistadora: Marilda Santanna. Salvador, 6 out. 2005. 1 cassete sonoro (6o min). Entrevista no Teatro Castro Alves,antes do show Tributo às Divas em comemoração aos 20 anos da TV Bahia.

LEME, Mônica Neves. Que tchan é esse? indústria e produção musical no Brasil dos anos 90. São Paulo: Annablume, 2003.

LIMMA, Neyse. Uma nova baiana. A Tarde. Salvador, [2003].

LIPOVETSKy, Gilles. O império do efêmero: a moda e seu destino nas sociedades modernas. São Paulo: Companhia das Letras, 1989.

LOBO, Sandro. Empresários preferem o mundo axé. A Tarde, Salvador, 2 fev. 2005. Coluna Sotaque Baiano, Caderno 2. p. 8.

LOPES, Nei. Sambeabá: o samba que não se aprende na escola. Rio de Janeiro: Casa da Palavra: Folha Seca, 2003.

LIRA Neto; fAISSAL, Rogério. Abalou Ivete! Revista Contigo: São Paulo, p. 6o-7, jun. 2006.

LISBOA JUNIOR, Luis Américo. A presença da Bahia na música popular brasileira. Brasília: Musimed/Sobrindes, 1990. 
LuZ, Márcia Ferreira. Mulato, musical e cênico. A Tarde. Salvador, 18.mar.2006, p.3.Caderno 2.

MAIA, Leonardo. O gol de placa de Ivete Sangalo. Correio da Bahia. Salvador, 24 abr.2007. Folha da Bahia. Disponível em http://www.corrreiodabahia. com.br/folhadabahia/noticia_impressao.asp?codigo=126836 Acesso em 24 abr. 2007.

MARgareth Menezes homenageia o samba-reggae. Correio da Bahia. Salvador, 22 out. 2006. Folha da Bahia. Disponível em: < http://www.correiodabahia.com.br/> Acesso em 26 out. 2006.

MARIA RITA. Segundo. Warner Music, 2005. 1 CD. Registro 256462675-2.

MARTIN BARBero, Jesús. 2.ed. Dos meios às mediações: comunicação, cultura e hegemonia. Rio de Janeiro: Editora da UFRJ, 2003.

Martins, Antônio. Arthur Azevedo: a palavra e o riso. Rio de Janeiro: Perspectiva, 1988.

MARTINS, Janaina Trasel. A relação entre o texto escrito e a vocalidade no teatro:contribuições a partir de Paul Zumthor. Revista Urdimentos. Florianópolis: UDESC: p. 141-150, 2004.

MARTins, Sérgio; VitAle, Paulo. A nação das cantoras. Veja, ano 40, n. 14, p. $120-7,11$ abr. 2007.

. Axé music S/A. Veja, ano 40, n. 16, p. 130-1, 25 abr. 2007.

MARtins, Osmar. Na marca do pênalti. Correio da Bahia. Salvador, 1 abr. 2004 .

. Esse CD serve para causar surpresa. Correio da Bahia, 16 jun. 2005. Folha da Bahia. Disponível em: http://correiodabahia.com.br/folhadabahia/noticia_impressao.asp?codigo=80628. Acesso em 24 abr. 2007

. Ivete Sangalo para abalar: cercada de expectativa, cantora lança o CD 1 As super novas, pela Universal Music. Correio da Bahia, 27. out. 2005. Folha da Bahia. Disponível em http://www.correiodabahia.com.br/folhadabahia/noticia_impressao.asp?codigo=82003. Acesso em 24 abr. 2007.

MASSini; CAgliari, Gladis. Acento e ritmo. São Paulo: Contexto, 1992. (Coleção Repensando a Língua Portuguesa).

MAsson, Celso; fernandes, Manoel. Carnaval: a sexo music. Veja, Rio de Janeiro, p. 82-5, 12 fev.1997.

matos, Luciano. A música do futuro. A Tarde. Salvador, 23 jan. 2007. Caderno Dez! p.3.

Mello, Zuza Homem de. João Gilberto. São Paulo: Publifolha, 2001. 
Medeiros, Fernanda Teixeira de (Org). Pipoca moderna: uma lição - estudando canções e devolvendo a voz ao poema. In: MATos, Cláudia Neiva de; TRAVASsos, Elizabeth (Org.). Ao encontro da palavra cantada: poesia, música e voz. Rio de Janeiro: 7 Letras, 2001. p. 128-40.

MEnEZES, Margareth. Discografia. Disponível em: <http://cliquemusic.uol. com.br/artistas/margareth-menezes.asp.> Acesso em: 29 maio 2007.

. Disponível em: http://www.memoriamusical.com.br/ discografia.asp. Acesso em: 13 jun. 2007.

Entrevistadora: Marilda Santanna. Salvador, 5 out. 2005. 1 cassete sonoro (6o min). Entrevista no Teatro Castro Alves, no ensaio geral do show Divas na festa dos 20 anos da TV Bahia.

$\mathrm{br} />$.

Site oficial. Disponível em: < http://www.margarethmenezes.com.

MERCURY, Daniela.(Org.) O canto do carnaval. Salvador: Corrupio, 2005.

. Depoimento coletado no especial dos 10 anos do Troféu Caymmi exibido pela TV Educativa em 1 mar. 1995.

Discografia. Disponível em: <http://www.memoriamusical.com.br/ discografia.asp > Acesso em: 29 maio 2007.

. Disponível em : < http://cliquemusic.uol.com.br/artistas/ ivete-sangalo.asp > Acesso em: 15 abr. 2007.

. Disponível em: < http://discosdobrasil.com.br >. Acesso em: 29 maio 2007.

Entrevista ao canal Argentino Entertainment Television. Salvador, 1 mar. 2003d. 1 cassete sonoro (6o min). Coletada por Marilda Santanna, simultaneamente.

. Entrevista coletiva com a imprensa. Salvador, 2 mar.20oze. 1 cassete sonoro (6o min). Coletada no camarote por Marilda Santanna, simultaneamente.

MERCURY, Daniela. Entrevistadora: Fabiana Silva. Salvador, 2006. 2 CDs sonoros. Cedida à autora.

Entrevistadora: Marilda Santanna. Salvador, 24 fev. 2003b. 1 cassete sonoro (6o min). Entrevista na produtora O Canto da Cidade.

Salvador, mar. 2004. 1 cassete sonoro (6o min). Entrevista na produtora $\mathrm{O}$ Canto da Cidade.

.Entrevista a TV Italiana. Salvador, 1 mar. 2003c. 1 cassete sonoro (6o min). na produtora O Canto da Cidade.Coletada por Marilda Santanna simultaneamente 
. Entrevistadora: Pesquisadora alemã. Salvador, 27 fev. 2003a. 1 cassete sonoro (6o min). Entrevista na produtora O Canto da Cidade coletada por Marilda Santanna simultaneamente.

Site oficial. Disponível em: http://www.danielamercury.art.br/.

MIRANDA, Dóris. Diferente...e como sempre. Correio da Bahia.Salvador. [2003]

Mollard, Claude. L'ingéniere culturelle. Paris: Presses Universitaires de France, 1994.

MORAIS, Tuca de. Entrevistadora. Marilda Santanna. Salvador. 10 de dez. 2005 .

MOREIRA, Morais. Vassourinha elétrica. Intérprete: Moraes Moreira. In: Moraes Moreira Acústico, Virgin , 1995, 1 CD. Faixa 14. Registro 8409532. MORIN, Edgar. As estrelas: mito e sedução no cinema. Rio de Janeiro: José Olympio, 1989.

. Cultura de massa no século xx: o espírito do tempo. 2.ed. Rio de Janeiro: Forense, 1969.

.Cultura de massas no século Xx: necrose. Rio de Janeiro: Forense Universitária, 1999.

. O método 5: a humanidade da humanidade. Porto Alegre: Sulina, 2002.

- Sociologia: do microssocial ao macroplanetário. Portugal: Publicações Europa-América, 1998.

. A cabeça bem feita: repensar a reforma, reformar o pensamento. Rio de Janeiro: Bertrand Brasil, 2003.

. Os sete saberes necessários à educação no futuro. São Paulo: Cortez, 2002.

. Meus demônios. Rio de Janeiro: Bertran Brasil, 2000.

motтA, Nelson. [mensagem pessoal]. Mensagem de Armando Oliveira recebida por < marilda_santanna@yahoo.com.br> em 10 set. 2001.

MOURA, Milton. Produtora, mercadora, mercadoria: uma cidade para o carnaval. In: FICHER, Tânia (Org.). Carnaval baiano: negócios e oportunidades. Brasília: SEBRAE, 1996.

. Quem quer comprar a cara desta cidade. Bahia Análise e Dados, v.

1, p. 25-32, 1998. 
Carnaval e baianidade: arestas e curvas na coreografia de identidades do carnaval de Salvador. 2001. 364 f. Tese (Doutorado em Comunicação e Culturas Contemporâneas) - Faculdade de Comunicação. Universidade Federal da Bahia.

O transcaráter do carnaval. Revista Análise e Dados, Salvador, v.1, p. 93-100, 1996. Entrevista a Análises \& Dados.

O carnaval de Salvador no final do século XX. In: CERQUeIRA, Nelson et al. Carnaval da Bahia: um registro estético. Salvador: Omar G, 2002. p.124-53.

Entrevistadora: Marilda Santanna. Salvador, 13 jan.2007. 1 cassete sonoro (6o min). Entrevista na residência do entrevistado.

.; GUerreiro, Goli. Criatividade e trabalho no cenário musical da Bahia. Relatório Parcial do CULT-Centro de Estudos Multidisciplinares em cultura. UFBA. 2004.

MOURA, Roberto. Tia Ciata e a Pequena África no Rio de Janeiro. 2.ed. Rio de Janeiro: Secretaria Municipal de Cultura, 1995.

MOLlard, Claude. L'ingénierie culturelle. Paris: Presses Universitaires de France, 1994.

nascimento, Regina Célia Oliveira. A trajetória de uma identidade. 1994. Dissertação (Mestrado em Sociologia) - Universidade de Campinas.

NEDER, Álvaro. Um homem pra chamar de seu: de como as mulheres encontram posições de poder dentro da MPB. Instituto Memória Musical Brasileira. Jornal Musical. Niterói, RJ. 18 abr. 2007. Disponível em < http:// www.jornalmusical.com.br/textoDetalhe.asp?iitexto $=1163$ \&iqdesecap $=1>$. Acesso em: 22 abr. 2007.

NERY, Joaquim. Entrevistadora: Marilda Santanna. Salvador, 18 maio 2005. 1 cassete sonoro (6o min). Entrevista na Escola de Administração da UFBA.

NETO COSTA. Entrevistadora: Marilda Santanna. Salvador, 25 jan.2005. 1 cassete sonoro (6o min). Entrevista no camarim, após o show de Margareth Menezes na casa de show Espetáculo.

Nussbaumer, Gisele Marchiore. O mercado da cultura em tempos (pós) modernos. Porto Alegre: UfSM, 2000.

oliveira, Carlos Antônio Barros de. Doces e bárbaros: um estudo sobre construções de identidades baianas. 2005. Dissertação (Mestrado em Ciências Sociais) - Universidade Federal da Bahia. 
OLIVEIRA, Carlos Antônio Barros de Maimbê e o carnaval eletrônico: música e identidade na Bahia contemporânea. Texto escrito como base para comunicação no seminário sobre o carnaval da Bahia realizado na Escola de Administração da UFBA em abr.2004.

Oliveira, Paulo César Miguez. Carnaval baiano: as tramas da alegria e a teia de negócios. 1996. 234 f. Dissertação (Mestrado em Administração) Escola de Administração, Universidade Federal da Bahia.

A contemporaneidade cultural na cidade da Bahia. Bahia Análise e Dados, v. 1, p. 50-3, 1998.

A organização da cultura na cidade da Bahia. 2002. 346 f. Tese (Doutorado em Comunicação) - Faculdade de Comunicação, Universidade Federal da Bahia, 2002.

OliveirA, Valéria Leal. A qualidade vocal na axé music.Temas em voz profissional. RJ: Revinter, 2007, p. 85-105.

ORTIZ, Renato. A moderna tradição brasileira. 5.ed. São Paulo: Brasiliense, 1994.

. Cultura brasileira e identidade nacional. 5.ed. São Paulo: Brasiliense, 1994 .

PAIVA, Salviano Cavalcanti de. Viva o rebolado: vida e morte do teatro de revista brasileiro. Rio de Janeiro: Nova Fronteira, 1991.

PAllottini, Renata. Dramaturgia: A construção da personagem. São Paulo: Ática, 1989.

PAVIS, Patrice. A análise dos espetáculos. São Paulo: Perspectiva, 2005.

Pereira, Ana Cristina. As alternativas de Margareth Menezes. Correio da Bahia. Salvador,16 fev. 2006. Folha da Bahia. Disponível em http://correiodabahia.com.br/folhada bahia/noticia_impressao.asp?codigo $=82587$. Acesso em 24 abr. 2007.

PETRAGLIA, Izabel Cristina. Edgar Morin: a educação e a complexidade do ser e do saber. Petrópolis, RJ: Vozes, 1995.

PRESTES, Lígia; CANCInI, Daniel. Musa afropop. Revista Go Where? Bahia, p. 34-6, ago./set. 2005.

PIERRY, Marcos. Artistas aplaudem de pé a volta do Troféu Caymmi. Gazeta da Bahia.p. 6, 22 mar. 1999.

Pimenta, Fátima Maria Conti. Mulheres de letras: imagens femininas em canções da "Era do Rádio" no Brasil (anos 30 a 50). 2003. Dissertação (Mestrado em Comunicação) - Universidade Paulista. 
PIMENTA, Janaína; PINHO, Sílvia Maria Rebelo (org). A voz do negro. Tópicos em voz. RJ:Revinter, 2003, p. 89-95.

RAMOS, Cleidiana. A música baiana não está morrendo. A Tarde, 10 fev. 2002. Caderno 2 p.1

Rezende, Marcelo; Meirelles, Murilo. O samba é pop. Revisto Bravo, p. 24-30, abr. 2006.

RISÉRIO, Antônio. Carnaval ijexá: notas sobre afoxés e blocos do novo carnaval afrobaiano. Salvador, Corrupio, 1981.

Caymmi: uma utopia de lugar. São Paulo: Perspectiva; Salvador: COPENE, 1993. (Debates).

RUBim, Antônio Albino Canelas. Comunicação, mídia e cultura na Bahia contemporânea. Bahia Análise e Dados. Salvador, t. I, v.9, n. 4, p. 74-89, mar. 2000.

RÜDIGER, Francisco; HOHLFERDT, Antonio (Org.). Teorias da comunicação: conceitos, escolas e tendências. Petrópolis, RJ: Vozes, 2001.

RUIZ, Roberto. Linda flor: Araci Cortes. Rio de Janeiro: FUnARTE/InM/ Divisão de Música Popular, 1984.

SÁ, Simone Pereira de. Onde o Rio é mais baiano: tradição e tradução na invenção dos balangandãs. Textos de Cultura e Comunicação. Salvador, n. 41, 2001.

SADIE, Stanley: ed. Assistente; LATHAM Alison. Dicionário Grove de Música: edição concisa. Tradução Eduardo Francisco Alves. Rio de Janeiro: Jorge Zahar, 1994.

SANDRONI, Carlos. Adeus à MPB. In: CAVAlCANTE, Berenice; STARLing, Heloisa; EISENBERG, Jose (Org.). Decantando a república: inventário histórico e político da canção popular moderna brasileira. Rio de Janeiro: Nova Fronteira; São Paulo: Ed. Fundação Perseu Abramo, 2004. p.26-36. v. 1.

Feitiço decente: transformações do samba no Rio de Janeiro (1917

- 1933). Rio de Janeiro: Jorge Zahar / Editora da UFRJ, 2001.

SANGALO, Ivete. Blog oficial de Ivete Sangalo. Disponível em: <http://ego. globo.com/Entretenimento/o\%2C\%2CCUCo-7742\%2Coo.html >

Discografia. Disponível em: <http://www.memoriamusical.com.br/ discografia.asp >. Acesso em: 28 maio 2007.

Disponível em: <http://cliquemusic.uol.com.br/artistas/ ivete-sangalo.asp > . Acesso em: 28 maio 2007.

. Disponível em: <http://www.discosdobrasil.com.br/> . Acesso em: 27 maio.2007. 
. Entrevista coletiva pela volta do Troféu Caymmi no restaurante Barbacoa. Salvador, 2001. Depoimento coletado por Marilda Santanna. SANGALO, Ivete. Entrevistadora: Marilda Santanna. Salvador, 6 out. 2005. 1 cassete sonoro (6o min). Entrevista no Teatro Castro Alves, após o show As Divas em homenagem aos 20 anos da TV Bahia.

- Entrevistadora: Marília Gabriela. Programa Marília Gabriela Entrevista. GNT. 20 maio 2007. 22h.

. Site oficial. Disponível em: http://www.ivetesangalo.com.br/2007/ principal.html

SANSONE, Livio; SANTOS, Jocélio Telles (Org.). Ritmos em trânsito: socioantropologia da música baiana. São Paulo: Dynamis, 1998.

SANTOS, Antônio Jorge Victor dos. Raízes e traições da música afro carnavalesca contemporânea. 1996. 217 f. Dissertação (Mestrado em Comunicação)

- Faculdade de Comunicação, Universidade Federal da Bahia.

SANTOS, Verônica. Entrevistadora: Marilda Santanna. Salvador, 5 out.2005. Vendedora das Lojas Americanas do Shopping Barra.

SARdenberg, Cecília Maria Bacellar. A mulher frente à cultura da eterna juventude: reflexões teóricas e pessoais de uma feminista cinqüentona. In: FERREIRA, Silva; NASCIMENTO, Enilda Rosendo (Org.). Imagens da mulher na cultura contemporânea. Salvador: UFBA/FFCH/ NEIM, 2002.

SeVeriano, Jairo; Mello, Zuza Homem de. A Canção do tempo: 85 anos de música brasileiras. São Paulo. Ed. 34, 1998. v.2:1958-1985.

SANT'ANnA, Affonso Romano de. Canto e palavra. In: MAtos, Cláudia Neiva de; Medeiros, Fernanda Teixeira de; TrAvAssos, Elizabeth. Ao encontro da palavra cantada. Rio de Janeiro: 7 Letras, 2001. p.11-22.

SAntanA, Rosane. Antônio Carlos dos Santos, Vovô: presidente do bloco Ilê Ayiê. In: CERQUeIrA, Nelson. Carnaval da Bahia: um registro estético. Salvador: Omar G, 2002, p.94-111.

SCHAeber, Petra. Música negra nos tempos de globalização: produção musical e management da identidade étnica - o caso do Olodum. In: SANSONE, Livio; SANTOS, Jocélio Teles dos (Org.). Ritmos em trânsito: sócio antropologia da música baiana. São Paulo: Dinamis Editorial; Salvador, BA: Programa A Cor da Bahia e Projeto S.A.M.B.A., 1997.

SHORT, Márcia. Entrevistadora: Marilda Santanna. Salvador, 25 jan. 2005 na casa de shows Espetáculo, após participação especial no show de Margareth Menezes. 
SILVA, Fabiana Jacinto da. Só é seu aquilo que você dá: a indústria cultural e o mundo da música - desafios para uma assessoria em comunicação. 2006, 71 f. Monografia (Especialização em Comunicação) - Faculdade de Comunicação e Biblioteconomia. Universidade Federal de Goiás.

SILVA, Gerson. Entrevistadora: Marilda Santanna. Salvador, 1 jan. 2007. 1 cassete sonoro (6o min). Entrevista após o show de Daniela Mercury no projeto Por do Som, no Farol da Barra .

SILVA, Marilda de Santana. O canto das sereias: as intérpretes baianas como mediadoras culturais no universo ibero-americano. In: Diálogos possíveis. Revista da Faculdade Social da Bahia, Salvador: FSBA ano 1, n o, jul - dez. 2002.

Sorriso de mulher: tipos de comicidade em personagens femininas de comédias musicais baianas. 1999. 185 f. Dissertação (Mestrado em Artes Cênicas) - Escola de Dança, Escola de Teatro,Universidade Federal da Bahia.

SetentA, Jussara Sobreira. Corpos musicais: a dança na cena artística de Daniela Mercury. 2002. Dissertação (Mestrado em Artes Cênicas) Universidade Federal da Bahia.

souzA, Eneida Maria de. Carmen Miranda: do kitsch ao cult. In: CAVALCANTe, Berenice; StARling, Heloísa; eisenberg, José (Org.). Decantando a república: inventário histórico e político da canção popular moderna brasileira. Rio de Janeiro: Nova Fronteira; São Paulo: Ed. Fundação Perseu Abramo, p. 63-87. v.2.

SouzA, Zeca. Entrevistadora: Marilda Santanna. Salvador, 1 jan.2005. Entrevista após o show de Daniela Mercury no projeto Por do Som no Farol da Barra.

A TARDE. Salvador, 9 jan.2007. Caderno 2, p. 4 (Sotaque Baiano).

Nunca foi tão fácil mostrar um trabalho: o difícil é ser notado. $A$ Tarde, Salvador, 16 set. 2006b, p. 8. Caderno 2. (Entrevista com Nelson Motta).

THOMPson, John B. A mídia e a modernidade: uma teoria social da mídia. 3.ed. Rio de Janeiro: Vozes, 1998.

Ideologia e cultura moderna: teoria social crítica na era dos meios de comunicação de massa. 4.ed. Rio de Janeiro: Vozes, 2000.

TINHORÃo, José Ramos. Música popular teatro e cinema. Rio de Janeiro: Vozes, 1972.

O samba agora vai...: a farsa da música popular no exterior. Rio de Janeiro: JCM, 1969. 
. História social da música popular brasileira. São Paulo: Ed. 34, 1998.

A trajetória da Maga. Carnasolo: a revista de quem faz o carnaval da Bahia. Salvador, ano I, n. 1, p. 7-8, fev. 2004. Distribuição gratuita junto ao kit do bloco Eu vou.

TUdelA-VIEIRA, Sílvio. Entrevistadora: Marilda Santanna. Salvador, 27 jan.2007.

uzel, Marcos; Martins, Osmar. Festa na Fonte Nova. Correio da Bahia. Salvador, 19 dez. 2003. p.4

valente, Heloísa de Araújo Duarte. As vozes da canção na mídia. 2000. Doutorado (Comunicação e Semiótica) - Pontifícia Universidade Católica de São Paulo.

VARJÃo, Suzana. A Tarde. Salvador, 12 fev. 2002. Caderno 2. p. 8.

VASCONCelos, Luiz Paulo. Dicionário de teatro. Porto Alegre: L\&PM, 1987

Velhote, Jacinto. Hipnotizados pela energia. Jornal 24 h. Lisboa, 2 jul. 2000.

VEIGA, Ericivaldo. O errante e apocalíptico Muzenza. In: SANSONE, Livio; SANTOS, Jocélio Teles dos (Org.). Ritmos em trânsito: sócio antropologia da música baiana. São Paulo: Dynamus Editorial; Salvador: Programa A Cor da Bahia e Projeto S.A.M.B.A., 1997.

VENÂNCIO, Radamés. Entrevistadora: Marilda Santanna. Salvador, 6 out. 2005. Entrevista no Teatro Castro Alves após o show As Divas, em comemoração aos 20 anos da TV Bahia.

VENEZIANO, Neyde. Não adianta chorar: teatro de revista brasileiro, oba! . Rio de Janeiro: UNICAMP, 1996.

. O teatro de revista no Brasil: dramaturgia e convenções. São Paulo: UNICAMP, 1991.

VIANNA, Hermano. O mistério do samba. Rio de Janeiro: Jorge Zahar, 2002.

WISNIK, José Miguel. O som e o sentido: uma outra história das músicas. São Paulo: Companhia das Letras, 1989.

ZUMThOR, Paul. A letra e a voz: a literatura medieval. São Paulo: Companhia das Letras. 1993. 


$$
\text { Anexos }
$$




\section{ANEXO A \\ Daniela Mercury: discografia}


ARTISTA(S):

Daniela Mercury

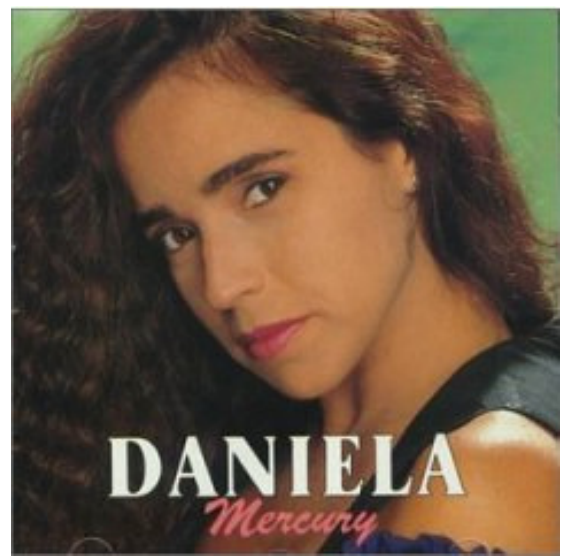

\section{FONOGRAMAS:}

1. Swingue da Cor (Luciano Gomes)

Participação: Olodum

2. Ninguém Atura

(Roberto Mendes / Paquito)

3. Milagres

(Herbert Viana)

4. Todo Canto Alegre

(Carlinhos Brown)

5. Geléia Geral

(Gilberto Gil / Torquato Neto)
6. Menino do Pelô

(Saul Barbosa / Gerônimo)

7. Todo Reggae

(Rey Zulu / Cabral)

8. Vida $\hat{E}$

(Durval Lelys / Daniela Mercury)

9. Tudo de Novo

(Marinho Assis / Daniela Mercury)

10. Doce Esperança

(Roberto Mendes / J. Velloso)

11. Maravilhê

(Dito)

\section{DADOS ADICIONAIS:}

Produção: Daniela Mercury e Wesley Rangel

Músicos: Cesário Leone (Baixo), André Santana (Teclados), Toni Augusto (Guitarra, Violão aço), Ramon Cruz (Bateria, Percussão), Beto Resende (Percussão) e Théo Oliveira (Percussão)

Participações: Luisinho Assis (Teclados), Roberto Mendes (Violão), Rowney Scott (Saxofone), Ramiro Mussotto (Percussão), Pedro Giorlandini (Teclados), Julio Moreno (Guitarra) e Giba (Percussão) 


\section{O CANTO DA CIDADE}

(1992) Sony Music 177.287/1-4644348

$\operatorname{ARTISTA(S):~}$

Daniela Mercury

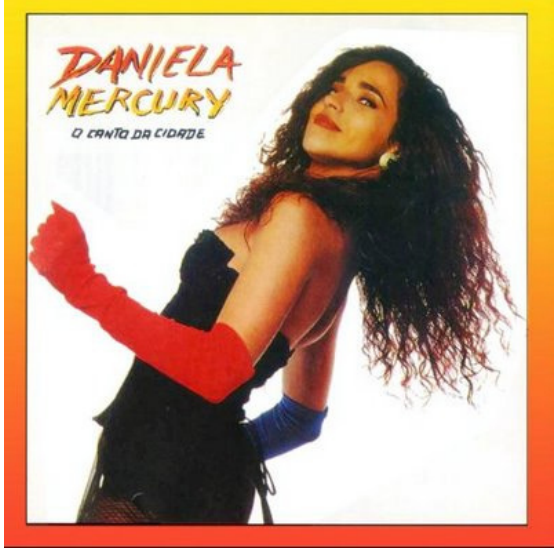

\section{FONOGRAMAS:}

1. O Canto da Cidade (Tote Gira / Daniela Mercury)

2. Batuque

(Rey Zulu / Genivaldo Evangelista)

3. Você Não Entende Nada

(Caetano Veloso)

Mus. Inc. "Cotidiano" (Chico

Buarque)

4. Bandidos da América (Jorge Portugal)

5. Geração Perdida (Daniela Mercury / Ramon Cruz / Toni Augusto)

6. Só pra te Mostrar (Herbert Viana)

Participação: Herbert Viana
7. O Mais Belo dos Belos (A Verdade do Ilê)

(Guiguio)

O Charme da Liberdade

(Adailton Poesia / Valter Farias)

8. Rosa Negra

(Jorge Xaréu)

9. Vem Morar Comigo

(Daniela Mercury / Durval Lelys)

10. Exótica das Artes

(Armandinho Macedo / Edmundo

Carôso)

11. Rimas Irmãs

(Carlinhos Brown)

12. Monumento Vivo

(Moraes Moreira / Davi Moraes) 


\section{MÚSICA DE RUA}

(1994) Epic/Sony Music 758.209/2476287

ARTISTA(S):

Daniela Mercury

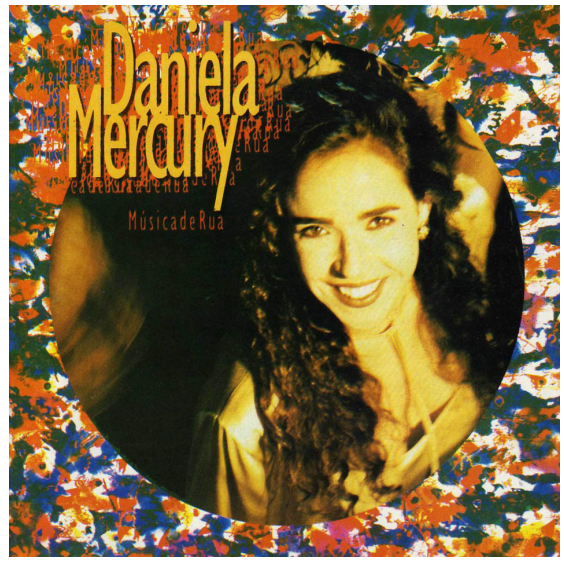

\section{FONOGRAMAS:}

1. Música de Rua (Daniela Mercury / Pierre Onassis)

2. Vulcão da Liberdade (Tonho Matéria)

3. Alegria Ocidental (Daniela Mercury / Liminha)

4. Tem Amor (Daniela Mercury / Liminha)

5. Saudade (Batonga) (Angelique Kidjo / John Hebrail)

6. Rosa

(Pierre Onassis)
7. O Reggae e o Mar (Rey Zulu / Daniela Mercury)

8. Rap Repente (Daniela Mercury / Beto / Cesário / David / Ramiro / Toni)

9. Domingo no Candeal (Lucas Santana / Quito Ribeiro)

10. Sempre Te Quis (Herbert Viana)

11. Folia de Rei (Carlinhos Brown / Alain Tavares)

12. Por Amor ao llê (Guiguio) 


\section{FEIJÃO COM ARROZ}

(1996) Sony Music 758.290/2.479372

ARTISTA(S):

Daniela Mercury

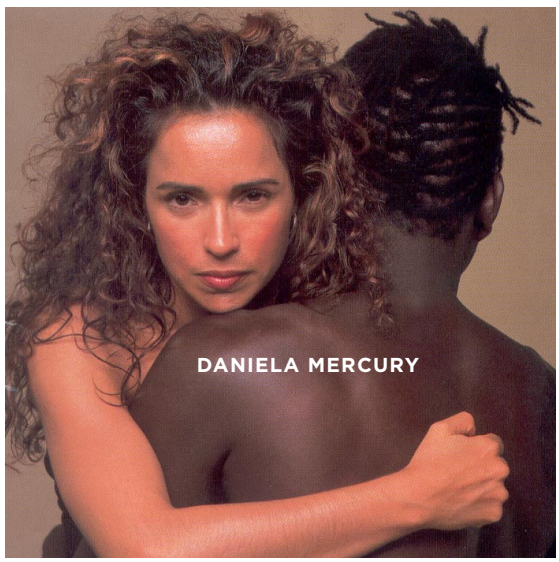

FONOGRAMAS:

1. Nobre Vagabundo (Márcio Mello)

2. Rapunzel

(Carlinhos Brown / Alain Tavares)

3. Minas Com Bahia

(Chico Amaral)

Participação: Samuel Rosa

4. Feijão De Corda

(Ramon Cruz)

Participação: Bragadá

5. Você Abusou

(Antônio Carlos Marques / Jocafi)

6. Dona Canô

(Neguinho do Samba)

7. Bate Couro

(Gilson Babilônia / Alain Tavares)
8. À Primeira Vista

(Chico César)

9. Rede

(Gilson Babilônia / Alain Tavares)

10. Musa Calabar

(Guiguio)

11. Vai Chover

(Boghan Costa / Gustavo de Dalva)

12. Vestido De Chita

(Daniela Mercury / Ivan Huol)

13. Do Carinho

(Boghan Costa / Gustavo da Dalva)

14. Bandeira Flor

(Márcio Mello)

15. Vide Gal

(Carlinhos Brown) 


\section{ELÉTRICA}

(1998) Sony Music 789.162/2-492216

ARTISTA(S):

Daniela Mercury

- Gravado ao vivo no Solar do Unhão Salvador, em agosto de 1998

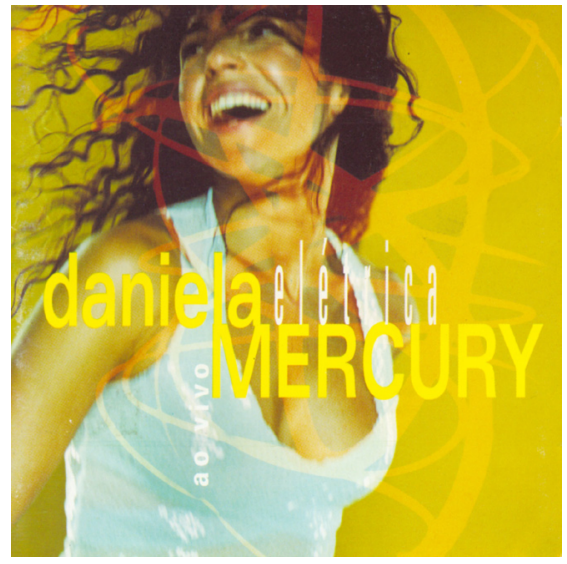

\section{FONOGRAMAS:}

1. Elétrica

(Daniela Mercury)

2. Swingue $\mathrm{Da}$ Cor

(Luciano Gomes)

3. O Canto Da Cidade

(Daniela Mercury / Tote Gira)

4. Salve-se Quem Puder (Ramon Cruz)

5. Abraço

(Daniela Mercury)

6. Música De Rua

(Daniela Mercury / Pierre Onassis)

7. Terra Festeira

(Alain Tavares / Gilson Babilônia)

8. Feijão De Corda

(Ramon Cruz)

9. Tua Lua

(Daniela Mercury / Alfredo Moura)

10. Vulcão Da Liberdade

(Tonho Matéria)

Faraó Divindade Do Egito

(Luciano Gomes)

Uma História de Ifá (Elegibô)

(Ythamar Tropicália / Rey Zulu)

Madagascar Olodum

(Rey Zulu)
11. O Mais Belos Dos Belos (A

Verdade Do llê)

(Guiguio / Adailton Poesia / Valter

Farias)

Por Amor Ao llê

(Guiguio)

12. Você Não Entende Nada

(Caetano Veloso)

13. Trio Metal

(Daniela Mercury / Marcelo

Porciúncula / Alfredo Moura /

Renan Ribeiro)

14. O Reggae E O Mar

(Rey Zulu / Daniela Mercury)

Venha Me Amar

(Rey Zulu)

Batuque (Tá No Batuque)

(Rey Zulu / Genivaldo Evangelista)

15. Rapunzel

(Carlinhos Brown / Alain Tavares)

16. Toda Menina Baiana

(Gilberto Gil) 


\section{DADOS ADICIONAIS:}

Músicos: Cesário Leony (Baixo), Alexandre Vargas e Alfredo Moura (Guitarra), Alfredo Moura (Violão 12 cordas), Beto Rezende, Gustavo da Dalva e Leonardo Reis (Percussão), Marcelo Brasil (Bateria), Mikael Mutti e Alfredo Moura (Teclados), Vittor Santos e Ferreira Filho (Trombone), José Canuto (Sax alto), Flávio Melo (Trompete) e Tita Alves, Silvana Torres e Paulo Caldas (Vocais)

Músicos Convidados: Orlando Costa e Márcio Victor (Percussão), Rowney Scott (Sax tenor), Henrique Baud (Sax barítono), Joatan Nascimento (Trompete) e Henrique Bocão (Trombone)

Produção, Direção Musical e Regência: Alfredo Moura

Arranjos: Cesário Leony

Direção Artística: Ronaldo Viana 
SOL DA LIBERDADE

(2000) BMG Brasil 7432173818-2

ARTISTA(S):

Daniela Mercury

- Acompanha um CD single com a faixa

"Como Vai Você"

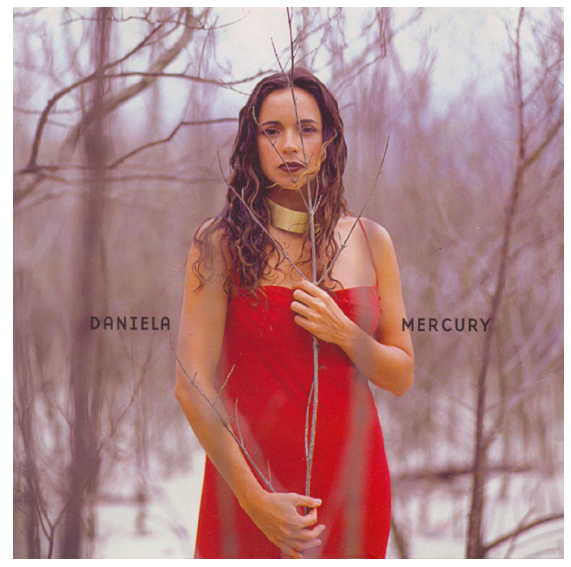

\section{FONOGRAMAS:}

Disco: 1

1. Sol Da Liberdade (Daniela Mercury)

Participação: Milton Nascimento

2. Groove da Baiana

(Tenisson Del Rey / Paulo Vascon / Jorge Zarath)

3. Ilê Pérola Negra

(René Veneno / Guiguio)

4. Santa Helena

(Márcio Mello)

8. Dara

(Daniela Mercury)

Participação: Angelique Kidjo

9. Funk Da Decepção

(Márcio Mello)

10. Só No Balanço Do Mar

(Lenine / Dudu Falcão)

11. Viagem

(Vanessa da Mata)

5. Axé Axé

(Caetano Veloso)

Citação: "Chão da Praça" (Moraes Moreira / Fausto Nilo)

6. Itapuã Ano 2000

(Lucas Santana / Quito Ribeiro)

12. De Tanto Amor

(Roberto Carlos / Erasmo Carlos)

13. Crença E Fé

(Beto Jamaica / Ademário)

14. Ilê Pérola Negra

(René Veneno / Guiguio)

7. Sou Você

(Caetano Veloso) 


\section{SOU DE QUALQUER LUGAR}

(2001) BMG Brasil 74321876482

ARTISTA(S):

Daniela Mercury

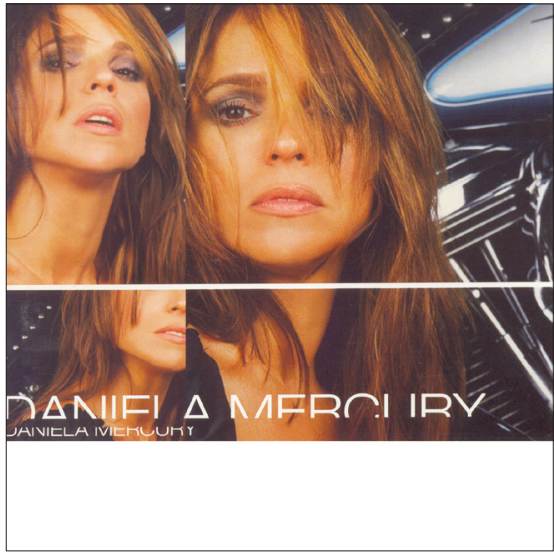

\section{FONOGRAMAS:}

1. De Qualquer Lugar (Lenine / Dudu Falcão)

2. Baiana Havaneira (Carlinhos Brown)

3. A Praieira (Chico Science)

4. Beat Lamento (Márcio Mello)

5. Aeromoça (Daniela Mercury / Gabriel Povoas)

6. Estrelas (Tenisson Del Rey / Carlos Neto) Participação: Toni Garrido

7. Ata-me (Daniela Mercury)
8. Mutante

(Rita Lee / Roberto de Carvalho)

9. Um Tempo de Paixão (Dalmo / Cláudio Rabello)

10. Bora Morar (Carlinhos Brown)

11. Quem Puder Ser Bom Que Seja (Gilberto Gil)

12. Janela

(Kiko Furtado / Daniel Gonzaga)

13. Nossa Música (Celso Fonseca)

14. Nina

(Daniela Mercury) 


\section{MTV AO VIVO - ELETRODOMÉSTICO}

(2003) BMG Brasil 74321988632

\section{$\operatorname{ARTISTA(S):~}$}

Daniela Mercury

- Gravado ao vivo na Concha Acústica do Teatro Castro Alves - Salvador, nos dias 24 e 25 de janeiro de 2003

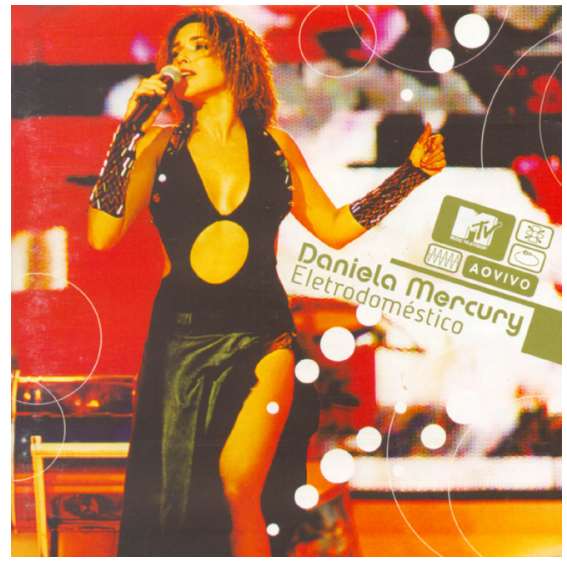

\section{FONOGRAMAS:}

1. Eletro-doméstico

(Falcão / Marcelo Yuka)

2. Temporada Das Flores (Leoni)

3. Dona Da Banca (Robson Pacífico / Aleh)

4. Ive Brussel (Jorge Ben "Jorge Benjor") Participação: Jovanotti

5. Baby

(Caetano Veloso)

6. Meu Plano (Lenine / Dudu Falcão)

7. À Primeira Vista (Chico César)

8. To Remember (Carlinhos Brown / Arnaldo Antunes) Participação: Carlinhos Brown

\section{Riqueza (Tour)}

(Carlinhos Brown / Vrs. Carlinhos Brown / Vrs. Angel Diez) Participação: Rosário Flores
10. It Ain't Over 'till It's Over (Lenny Kravitz)

11. Milagre Do Povo (Caetano Veloso) Participação: Dulce Pontes

12. Nossa Gente (Avisa Lá) (Roque Carvalho)

13. Umbigo Do Mundo (L'ombelico Del Mondo)

(L. Cherubini / P. Foschi / M. Centoze / S. Celani / Vrs. Nelson Motta) Participação: Olodum

14. Ilê Pérola Negra (O Canto Do Negro) (Miltão / René Veneno / Guiguio)

15. Mutante (Rita Lee / Roberto de Carvalho)

16. Nobre Vagabundo (Márcio Mello)

17. Só Pra te Mostrar (Herbert Viana)

18. Pára de Chorar (Alexandre Peixe / Beto Garrido / Daniela Mercury / Nelson Motta)

\section{DADOS ADICIONAIS:}

Músicos: Alexandre Vargas (Guitarra, Violão, Guitarra portuguesa), Gerson Silva (Guitarra, Violão), Zito Moura (Teclados), Mikael Mutti (Programação, Teclados), Cesário Leony (Baixo), Marcelo Brasil (Bateria), André Becker (Sax, Flauta, Vocal), Daniela Penna, Fabricio Scaldaferri, Rudson Daniel e Peu Meurrahy (Percussão) e Aninha Oliveira, Joelma Silva, Gil Alves, Paulinho Caldas e Ramon Cruz (Vocal) 


\section{MTV AO VIVO - ELETRODOMÉSTICO}

(2003) BMG Brasil 82876502309

ARTISTA(S):

Daniela Mercury

- Gravado ao vivo na Concha Acústica do Teatro Castro Alves - Salvador, nos dias 24 e 25 de janeiro de 2003

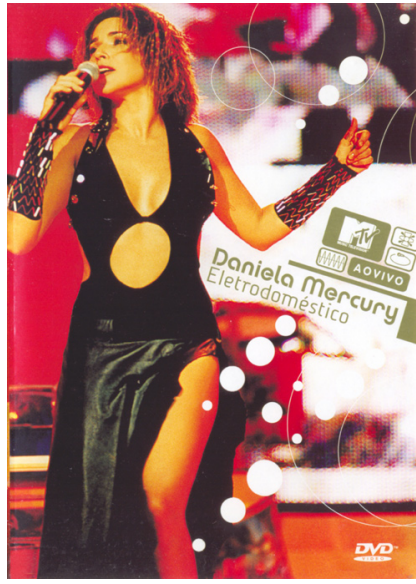

\section{FONOGRAMAS:}

1. Eletro-doméstico (Falcão / Marcelo Yuka)

2. Mutante (Rita Lee / Roberto de Carvalho)

3. Temporada Das Flores (Leoni)

4. A Praieira (Chico Science)

5. Nobre Vagabundo (Márcio Mello)

6. Ive Brussel (Jorge Ben "Jorge Benjor") Participação: Lorenzo Jovanotti

7. Minas com Bahia (Chico Amaral)

8. Você Não Entende Nada (Caetano Veloso)

9. Dona da Banca (Robson Pacífico / Aleh)

10. Meu Plano (Lenine / Dudu Falcão)

11. À Primeira Vista (Chico César)

12. Baby (Caetano Veloso)

13. Só pra te mostrar (Herbert Viana)
14. To Remember (Carlinhos Brown / Arnaldo Antunes) Participação: Carlinhos Brown

15. It Ain't Over 'till It's Over (Lenny Kravitz)

16. Nossa Gente (Avisa Lá) (Roque Carvalho)

17. Milagre do Povo (Caetano Veloso) Participação: Dulce Pontes

18. Pára de Chorar (Alexandre Peixe / Beto Garrido / Daniela Mercury / Nelson Motta)

19. Riqueza (Tour) (Carlinhos Brown / Vrs. Carlinhos Brown / Vrs. Angel Diez) Participação: Rosário Flores

20. Ilê Pérola Negra (O Canto Do Negro) (Miltão / René Veneno / Guiguio)

21. Umbigo do Mundo (L'ombelico Del Mondo)

(L. Cherubini / P. Foschi / M. Centoze / S. Celani / Vrs. Nelson Motta) Participação: Olodum

22. Swingue da Cor (Luciano Gomes) Participação: Olodum 
23. Rapunzel

(Alain Tavares / Carlinhos Brown)

24. Trio Metal

(Daniela Mercury / Marcelo

Porciúncula / Alfredo Moura /

Renan Ribeiro)

25. O Canto da Cidade

(Tote Gira / Daniela Mercury)

\section{DADOS ADICIONAIS:}

Músicos: Alexandre Vargas (Guitarra, Violão, Guitarra Portuguesa), Gerson Silva (Guitarra, Violão), Zito Moura (Teclados), Mikael Mutti (Programação, Teclados), Cesário Leony (Baixo), Marcelo Brasil (Bateria), André Becker (Sax, Flauta, Vocal), Daniela Penna, Fabricio Scaldaferri, Rudson Daniel e Peu Meurrahy (Percussão) e Aninha Oliveira, Joelma Silva, Gil Alves, Paulinho Caldas e Ramon Cruz (Vocal) 


\section{CARNAVAL ELETRÔNICO}

(2004) BMG Brasil 8287658708-2

ARTISTA(S):

Daniela Mercury

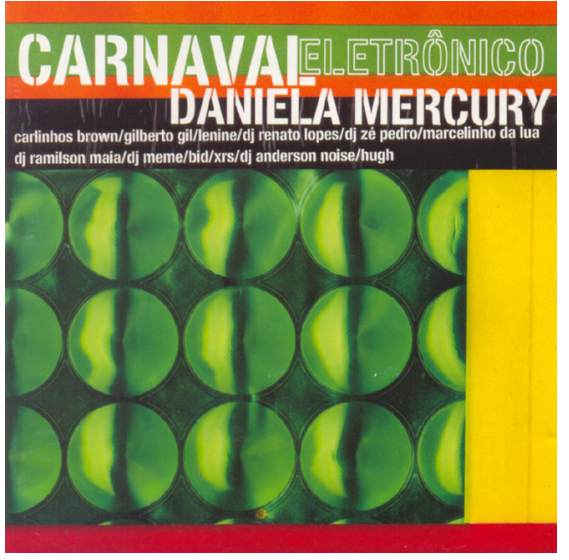

\section{FONOGRAMAS:}

1. Maimbê Dandá

(Carlinhos Brown / Mateus)

Participação: Carlinhos Brown

2. Quero Ver O Mundo Sambar

(Daniela Mercury)

Arranjo: DJ Renato Lopes

3. Vou Batê Pá Tu

(Orlandivo / Arnaud Rodrigues)

Arranjo: DJ Zé Pedro

4. Que Baque é Esse?

(Lenine)

Arranjo: Marcelinho da Lua

Participação: Lenine

5. A Tonga da Mironga do Kabuletê (Toquinho / Vinicius de Moraes) Arranjo: DJ Ramilson Maia

6. O Canto da Rainha (Daniela Mercury / DJ Marcelo Mansur)

Arranjo: DJ Memê

\section{Amor de Carnaval}

(Gilberto Gil)

Participação: Gilberto Gil

8. Por trás da Fantasia

(Marcelo Quintanilha)

Arranjo: DJ Zé Pedro

9. Preto e Branco

(Dudu Fagundes / Santos Dinis)

Arranjo: Xrs

10. Charles Ylê

(Carlinhos Brown)

Arranjo: Carlinhos Brown

11. Ago Lonan

(Tradicional / Adpt. Daniela

Mercury)

Arranjo: DJ Anderson Noise

12. Quero Voltar Pra Bahia

(Paulo Diniz / Odibar)

Arranjo: Hugh 


\section{CLÁSSICA}

(2005) Som Livre 0185-2

ARTISTA(S):

Daniela Mercury

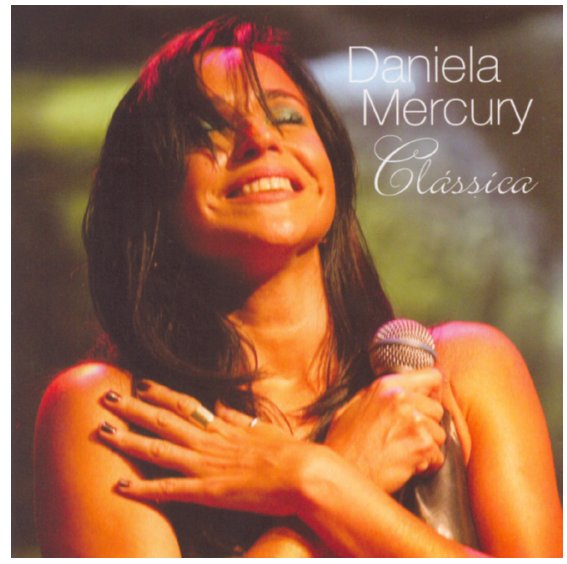

\section{FONOGRAMAS:}

1. And I Love Her

(John Lennon / Paul McCartney)

2. Covered Saints

(Carlinhos Brown)

3. Maria Clara

(Daniela Mercury)

4. Retrato em Branco e Preto (Chico Buarque / Tom Jobim)

5. Brigas Numca Mais (Tom Jobim / Vinicius de Moraes)

6. Atrás da Porta (Chico Buarque / Francis Hime)

7. Serrado (Djavan)

8. Derradeira Primavera

(Tom Jobim / Vinicius de Moraes)

\section{Sua Estupidez}

(Roberto Carlos / Erasmo Carlos) Participação: Vânia Abreu

10. Aeromoça (Daniela Mercury / Gabriel Povoas)

11. Vapor Barato (Wally Salomão / Jards Macalé)

12. Se Eu Quiser Falar Com Deus (Gilberto Gil)

13. Corsário (João Bosco / Aldir Blanc)

14. Divino Maravilhoso

(Gilberto Gil / Caetano Veloso) 


\section{BAILE BARROCO - \\ DANIELA MERCURY NO \\ CARNAVAL DA BAHIA}

(2005) EMI Music 3528089

ARTISTA(S):

Daniela Mercury

- Gravado ao vivo num trio elétrico, durante o Carnaval de Salvador, nos dias 05 a 08 de fevereiro de 2005

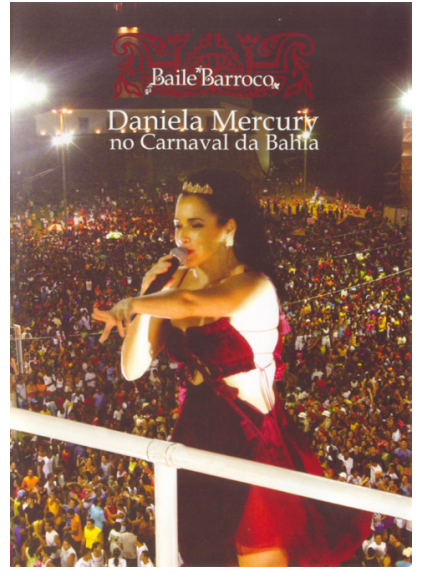

\section{FONOGRAMAS:}

1. Baianidade Nagô (Evany)

2. Trio Metal (Daniela Mercury / Alfredo Moura / Marcelo Porciúncula / Renan Ribeiro)

3. Prefixo de Verão (Beto Silva)

4. Maimbê Dandá (Carlinhos Brown / Mateus)

5. Ladeira do Pelô (Betão)

Faraó Divindade do Egito

(Luciano Gomes)

Protesto do Olodum (E Lá Vou Eu) (Luciano Gomes)

6. Vamos Fugir (Gilberto Gil / Liminha) Participação: Gilberto Gil

7. Meu Pai Oxalá (Vinicius de Moraes / Toquinho)

8. Olha O Gandhi Aí (Tonho Matéria / Jó Vieira)

9. Força do Ilê (Paulinho Laranjeira)
10. Ilê Pérola Negra (O Canto Do Negro)

(René Veneno / Guiguio)

11. Aquarela do Brasil

(Ary Barroso)

Citação: "Na Baixa do Sapateiro"

(Ary Barroso)

Participação: Ricardo Castro

12. Axé Axé

(Caetano Veloso)

Participação: Ricardo Castro

13. Fricote

(Paulinho Camafeu / Luis Caldas)

Participação: Luis Caldas

14. Rapunzel

(Carlinhos Brown / Alain Tavares)

15. Chame Gente

(Moraes Moreira / Armandinho Macedo)

16. O Canto da Cidade (Daniela Mercury / Tote Gira) Participação: Ricardo Castro

17. O Trenzinho do Caipira (Villa-Lobos)

Participação: Ricardo Castro 
18. Prelúdio $\mathrm{N}^{\circ} 2$ BWV 847 em Dó

Menor (do Cravo Bem Temperado)

(Johann Sebastian Bach)

Participação: Ricardo Castro

19. Aria - Cantilena ( $N^{\circ} 1$ das

Bachianas Brasileiras $N^{\circ}$ )

(Villa-Lobos)

Participação: Ricardo Castro

20. Expresso 2222

(Gilberto Gil)

Participação: Ricardo Castro

Eu Só Quero Um Xodó

(Dominguinhos / Anastácia)

Participação: Ricardo Castro

Asa Branca

(Luis Gonzaga / Humberto Teixeira)

Participação: Ricardo Castro

21. Pot-pourri:

La Danza Del Tezcatlipoca Rojo

(Ramiro Musotto)

Intérprete(s): Ramiro Musotto

Roda Viva

(Chico Buarque)

Intérprete(s): Fernanda Porto

Tem Que Valer

(Janaina Lima / Tchorta Boratto /

Gui Boratto / Samuel Braga)

Intérprete(s): Kaleidoscópio

\section{DADOS ADICIONAIS:}

Músicos: Alexandre Vargas (Guitarra, Direção Musical), André Becker (Sopro), Ramon Cruz (Bateria), Cesário Leony (Baixo), Rudson Daniel e Fabrício Scaldaferri (Percussão), Zito Moura (Teclados) e Gil Alves, Joelma Silva e Ramon Cruz (Vocal) 


\section{BALÉ MULATO}

(2005) EMI Music 3452342

ARTISTA(S):

Daniela Mercury

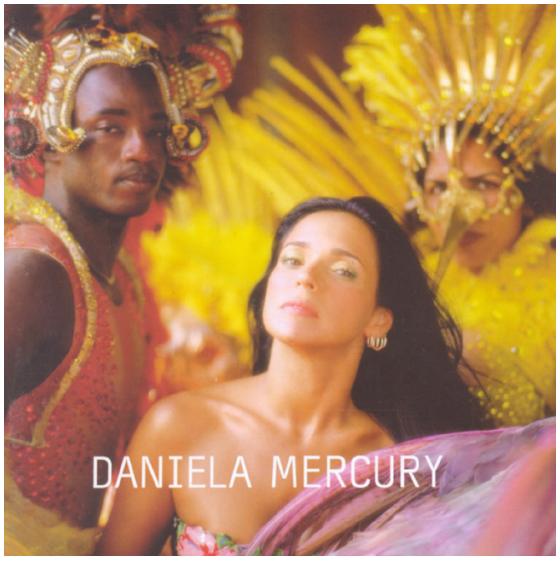

\section{FONOGRAMAS:}

1. Topo Do Mundo (Jauperi / Gigi)

2. Levada Brasileira (Pierre Onassis / Edilson)

3. Amor De Ninguém (O Amor) (Jorge Papapá)

4. Balé Popular (Pierre Onassis / Edilson)

5. Toneladas De Amor (Márcio Mello)

Poema: "Amor Santo", de Márcio Mello

Participação: Márcio Mello

6. Nem Tudo Funciona De Verdade (Tenisson Del Rey / Gerson Guimarães)

7. Pensar em Você (Chico César)
8. Quero Ver o Mundo Sambar (Daniela Mercury)

9. Aquarela Do Brasil (Ary Barroso)

10. Meu Pai Oxalá (Toquinho / Vinicius de Moraes)

11. Eu Queria (Pierre Onassis / Xel Guima / Edilson)

12. Sem Querer (Daniela Mercury)

13. Olha O Gandhi Aí (Tonho Matéria / Jó Vieira)

14. Água Do Céu (Daniela Mercury / Jorge Zarath) 


\section{BALÉ MULATO}

(2006) EMI Music 3792829

ARTISTA(S):

Daniela Mercury

Gravado ao vivo no Farol da Barra Salvador, no dia 17 de setembro de 2006

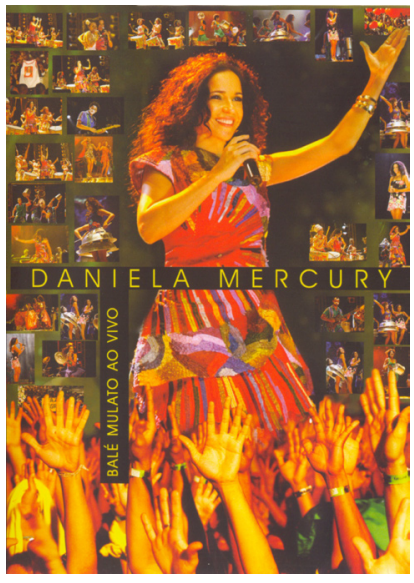

\section{FONOGRAMAS:}

1. Aquarela do Brasil (Ary Barroso)

2. Levada Brasileira (Pierre Onassis / Edilson)

3. Meu Pai Oxalá (Toquinho / Vinicius de Moraes)

4. Olha O Gandhi Aí (Tonho Matéria / Jó Vieira)

5. Nobre Vagabundo (Tonho Matéria / Jó Vieira)

6. Baianidade Nagô (Evany)

7. Prefixo de Verão (Beto Silva)

8. Só No Balanço do Mar (Lenine / Dudu Falcão)

9. Feijão De Corda (Ramon Cruz)

10. Toneladas de Amor (Márcio Mello) Citação: Poema"Amor Santo" (Márcio Mello) Participação: Márcio Mello
11. Topo Do Mundo (Jauperi / Gigi)

12. Pensar Em Você (Chico César)

13. Dia Branco

(Geraldo Azevedo / Renato Rocha)

14. Amor de Ninguém (O Amor) (Jorge Papapá)

15. Você Não Entende Nada (Caetano Veloso)

16. Ciranda das Panelas

(Daniela Mercury / Antrifo Sanches / Osvaldo Rosa)

Adaptação das obras "Ciranda de Lia" e "Sai Piaba" (Domínio Público)

17. Ilê Ayê (Que Bloco É Esse?) (Paulinho Camafeu)

18. Dona Canô (Neguinho do Samba) Participação: Mariene De Castro / Didá Banda Feminina 
19. Balé Popular

(Pierre Onassis / Edilson)

Participação: Didá Banda Feminina

20. Não Chore Mais (No Woman no

Cry)

(B. Vincent / Vrs. Gilberto Gil)

21. Ilê Pérola Negra (O Canto Do

Negro)

(Guiguio / René Veneno / Miltão)

22. Água do Céu

(Daniela Mercury / Jorge Zarath)

Participação: Gilmelândia

23. Maimbê Dandá

(Carlinhos Brown / Mateus)

DADOS ADICIONAIS:

Músicos: Ramon Cruz (Bateria, Vocal), Cesário Leoni (Baixo), Alexandre Vargas e Gerson Silva (Guitarra, Violão), Rudson Daniel, Cacau Alves, Enio Taquari e Emerson Taquari (Percussão), Gil Alves, Joelma Silva e Aninha Oliveira (Vocais)

Participação Especial: Daniela Penna (Percussão)

- Apresenta como bônus os videoclipes das músicas "Quero a Felicidade", com participação de "Jammil e Uma Noites" e "Topo do Mundo" 


\section{CANIBÁLIA (2009)}

ARTISTA(S):

Daniela Mercury

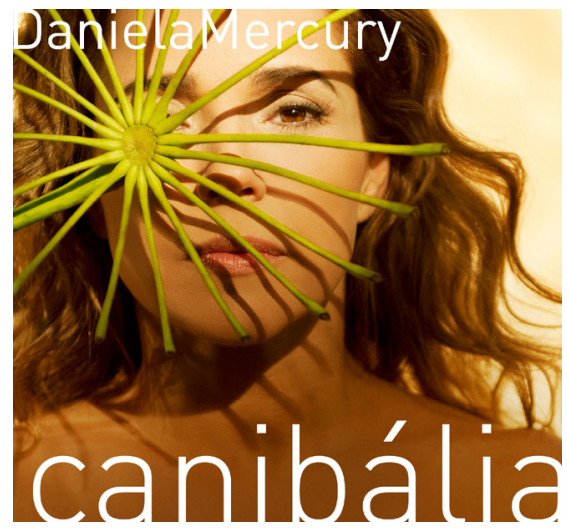

\section{FONOGRAMAS:}

1. Sol do Sul

(Daniela Mercury e Gabriel Póvoas)

2. Dona desse lugar

(Daniela Mercury)

3. Trio em transe

(Daniela Mercury)

4. Preta

(Jota Velloso e Mariene de Castro)

5. Samba da benção/Samba da minha terra

(Vinicius de Morais e Dorival Caymmi)

6. O que será

( Chico Buarque)
7. A vida é um Carnaval (Célia Cruz. Versão de Daniela Mercury)

8. One Love ( Sara Tavares)

9. Life is beautiful (Wyclef Jean)

10. O que é que a baiana tem? (Dorival Caymmi)

11. Tico tico no fubá (Zequinha de Abreu)

12. Oyá por nós( Daniela Mercury e Margareth Menezes) 
ANEXO B
Margareth Menezes: discografia 


\section{MARGARETH MENEZES}

(1988) Polydor 837 459-1

ARTISTA(S):

Margareth Menezes

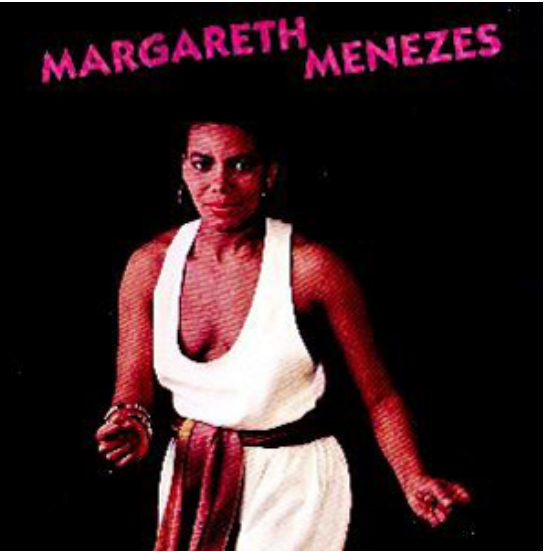

\section{FONOGRAMAS:}

1. Uma História de Ifá (Ejigbô)

(Ythamar Tropicália / Rey Zulu)

2. Mãe Lua

(Jorge Zarath / Marco Lobo)

3. Você Virou Fumaça

(Paulo Debétio / Paulinho Resende)

4. Alegria da Cidade

(Lazzo / Jorge Portugal)

5. Devastação

(Luis Caldas)

6. Natureza Mãe

(Djalma Oliveira / Tonho Matéria)
7. Tenda do Amor (Magia)

(Carlos Pita)

8. Muzenza

(Edil Pacheco / Paulo César Pinheiro)

9. Planeta África Brasil

(Paulo Debétio / Paulinho Resende)

10. Correnteza do Amor

(Cardan Dantas)

11. Janela das Viagens

(Geraldo Azevedo / Capinan) 


\section{UM CANTO PRA SUBIR}

(1989) Polydor 841 561-1

ARTISTA(S):

Margareth Menezes

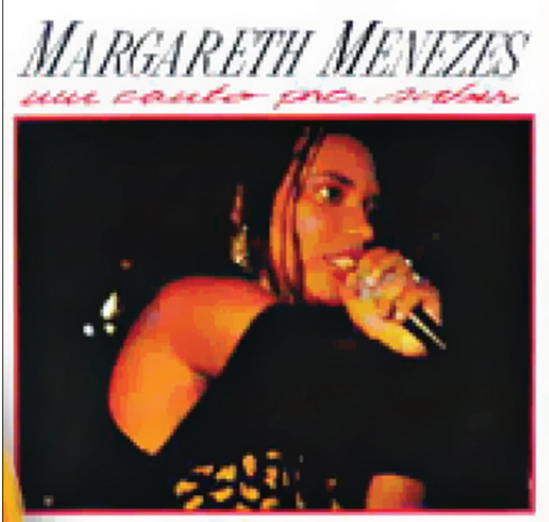

\section{FONOGRAMAS:}

1. Marmelada [Bas moin Laia] (G.Decimmus)

2. Negro menino (Gileno Félix - Lazzo)

3. Negra melodia [Soul train domingueira] (Jards Macalé - Waly Salomão)

4. Co-brador (Carlinhos Brown)

5. Dark secrets (David Rudder - Jeff Vincent - Paul Pesco - Andy Paley)
6. Ifá , um canto pra subir (Walter Queiroz - Vevé Calasans)

7. Hino das águas (Aroldo Medeiros - Buziga)

8. Maravilha morena (Jorge Portugal - Roberto Mendes)

9. Tudo à-toa (Peri Albuquerque)

10. Abra a boca e feche os olhos (Dito - Gerônimo) 
KINDALA

(1991) Polydor 849 441-2

ARTISTA(S):

Margareth Menezes

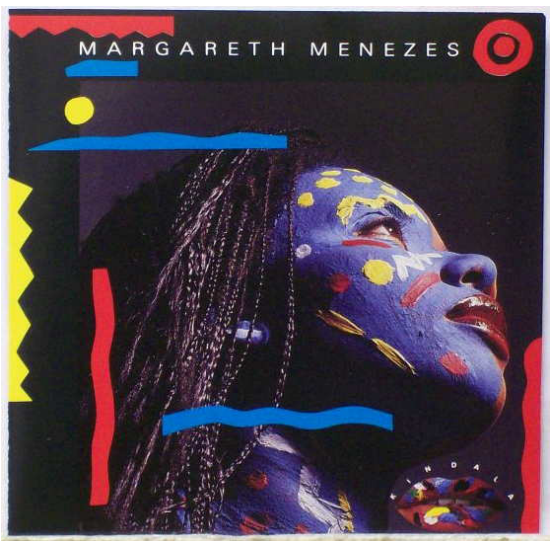

\section{FONOGRAMAS:}

1. Fé cega, faca amolada (Milton Nascimento - Ronaldo Bastos)

2. Paz no mundo [Pwazon rat] (D.Beaubrun - Vs. Margareth Menezes - E.François - T.Beaubrun Jr. - M.Beaubrun)

3. Mosca na sopa (Raul Seixas)

4. Negrume da noite (Paulinho do Reco - Cuiuba)

5. Jet ski (Margareth Menezes)

6. Negro nagô (Luiz Bacalhau)

7. Me abraça e me beija (Jimmy Cliff - Gileno Felix - Lazzo)
8. Repique romântico (Silas Henrique)

9. Kindala

(Lazzo - Capinan)

10. Menina Dandára (Paulo Debétio - Paulinho Rezende)

11. Vendaval temporal (Gerônimo)

12. Praga do céu (Alain Tavares - Carlinhos Brown)

13. Pot-pourri "Samba Reggae": • Faraó divindades do Egito (Luciano Gomes)• Brilho de beleza (Nego Tenga)• Depois que o llê passar (Miltão)• Deus do fogo e da justiça (Carlinhos Brown)• Uma história de Ifá (Ejigbô) (Ythamar Tropicália-Rei Zulu) 


\section{LUZ DOURADA}

(1993) Polydor 519 537-1

ARTISTA(S):

Margareth Menezes

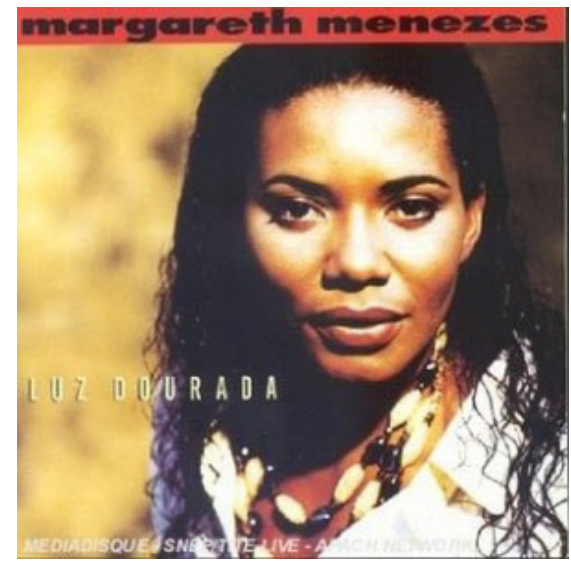

\section{FONOGRAMAS:}

1. Vou Mandar (Fôca)

2. Black Show (Fôca)

3. Luz Dourada (Juraildes da Cruz)

4. Vai Mexer (Margareth Menezes)

5. Novos Rumos (Jota Maranhão)

6. Mar de Amor (Margareth Menezes)

7. Raça Negra (Dito / Jorge Zarath)
8. Desabalada (Jean Garfunkel / Paulo Garfunkel / Prata)

9. Club do Brown Benjor (Carlinhos Brown)

10. Até Rir o Mar (Margareth Menezes)

11. Olho do Farol (Lenine)

12. Chegar à Bahia (Caetano Veloso) 
GENTE DE FESTA

(1995) Warner Music C0063011109-2

ARTISTA(S):

Margareth Menezes

\section{MWKGAKEIS NENEZES}

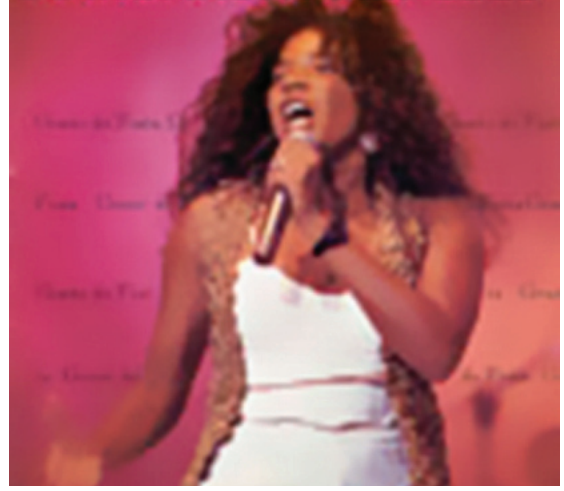

\section{FONOGRAMAS:}

1. Ilê Que Fala De Amor (Fôca / Gilberto Timbaleiro)

2. Rataplan (Joccy Lee / Silvio Almeida)

3. Love Of My Life (Freddie Mercury)

4. Vestido De Prata (Jorge Alfredo) Participação: Caetano Veloso

5. Viola Festeira (Rafael Júnior / Luis Segrob)

6. Reggae A Vida (Margareth Menezes) Participação: Cássio Calazans

7. Sou Araketu (Evany)
8. Requebra no vatapá (Panamá) (D. Rudder / P. Goddard / Vrs. Margareth Menezes)

9. Libertar (Roberto Mendes / J. Velloso) Participação: Maria Bethânia

10. Swingueira Baiana (Dito)

11. Música Do Mundo (Dalmo Medeiros / Carlos Pita) Citação: "O Que" (Arnaldo Antunes)

12. Cavalo Alado (Margareth Menezes)

13. Altiplano (Margareth Menezes)

14. Das Terras De Cabral (Lenine) 


\section{AFROPOPBRASILEIRO}

(2002) Universal 325912004032

ARTISTA(S):

Margareth Menezes

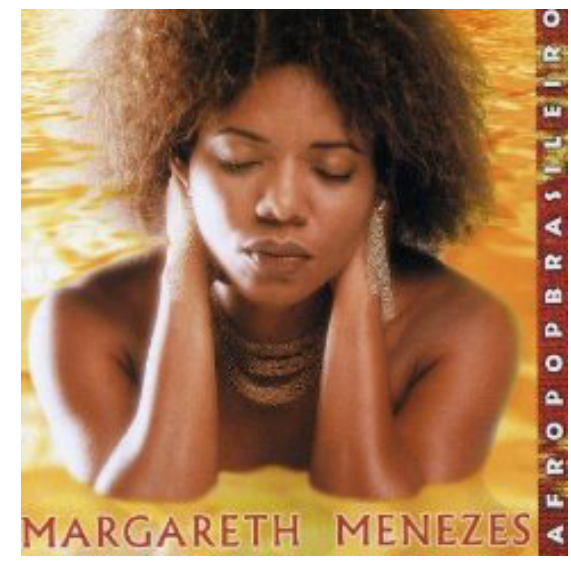

\section{FONOGRAMAS:}

1. Pelo mar lhe mando flor (Margareth Menezes)

2. Preciso (Margareth Menezes)

3. Desperta (Preconceito de cor) (Margareth Menezes)

4. Mamãe querida (Humberto do Maracanã)

5. Do mar, do céu, do campo (Belchior)

6. Nego doce (Carlinhos Brown - Margareth Menezes)

\section{Dandalunda}

(Carlinhos Brown - Refrão de domínio público)

8. Cai dentro (Baden Powell - Paulo César Pinheiro)

9. Moderninha (Margareth Menezes)

10. Mãe de leite (Zeca Baleiro)

11. Lua candeia (Paulo César Pinheiro - Lenine) 


\section{TETE A TETE MARGARETH}

(2003) Independente SOL0001

ARTISTA(S):

Margareth Menezes

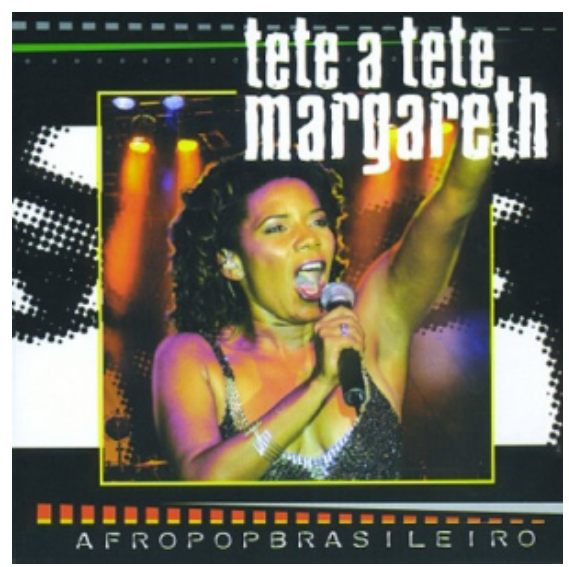

\section{FONOGRAMAS:}

1. Estrela Ardente e Poderosa (Humberto Barbosa Mendes)

2. Dandalunda (Carlinhos Brown)

3. Do Céu do Mar e do Campo (Belchior)

4. Alegria da Cidade (Jorge Portugal / Lazzo Matumbi)

5. Marmelada (George Decimmus / Veloto Walakiar)

6. Me Abraça e Me Beija (Lazzo Matumbi / Gileno Félix) Citação: "Ao Capazes" (Bernardo / Biro / Da Gama / Mozão)

7. Vitalunda (Carlinhos Brown)

8. Toté de Maiangá (Saul Barbosa / Gerônimo)

9. Jeito Cativo

(Bira Marculino)

10. "Pot-pourri de Bloco": Noite Dos Mascarados (Chico Buarque) Eu Quero É Botar Meu Bloco Na Rua (Sergio Sampaio)
11. "Pot-pourri de Samba Reggae": Odé (Paulinho do Reco / Cuiuba) Negrume da Noite (Paulinho do Reco / Cuiuba) Depois Do llê Passar (Miltão)

Eu Sou Negão

(Gerônimo)

Aeiou

Alfabeto do Negão Madagascar Olodum (Rey Zulu) Uma História de Ifá (Elegibô) (Ythamar Tropicália / Rey Zulu) Citação: "Na Baixa do Sapateiro" (Ary Barroso)

12. O Quereres (Caetano Veloso)

13. Chuviscando (Margareth Menezes)

14. Blowing In The Wind (Bob Dylan / Adpt. Diana Pequeno)

15. Carinhoso (Pixinguinha / João de Barro)

16. Faraó (Luciano Gomes) 


\section{FESTIVAL DE VERÃO \\ SALVADOR - DVD AO \\ VIVO}

(2004) Som Livre 0131-2

ARTISTA(S):

Margareth Menezes

- Gravado ao vivo no Festival de Verão -

Salvador, em 2004

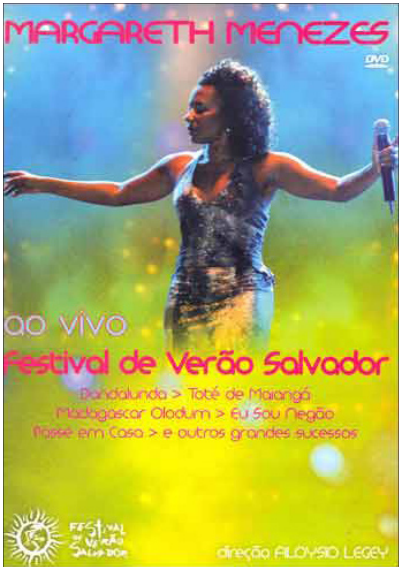

\section{FONOGRAMAS:}

1. Estrela Ardente e Poderosa

(Humberto Barbosa Mendes)

Toté de Maiangá

(Gerônimo / Saul Barbosa)

Cavaleiro de Aruanda

(Tony Osanah)

2. Do Mar, do Céu, do Campo (Belchior)

3. Alegria da Cidade (Lazzo / Jorge Portugal)

4. Me Abraça e me beija (Lazzo / Gileno Félix)

5. Odé / Negrume da Noite (Paulinho do Reco / Cuiuba)

Depois que o llê passar

(Miltão)

Eu Sou Negão

(Gerônimo)

Madagascar Olodum

(Rey Zulu)

Uma história de Ifá (Elegibô)

(Ythamar Tropicália / Rey Zulu)

\section{Passe em Casa}

(Marisa Monte / Arnaldo Antunes /

Carlinhos Brown)

7. A Resposta está no ar (Blowin' In The Wind)

(Bob Dylan / Vrs. Diana Pequeno)

8. Preciso

(Margareth Menezes)

9. A Loba

(Paulinho Resende / Juninho)

Participação: Alcione

10. Jamaica a São Luis

(Gerude / Ciba Carvalho)

Participação: Alcione

11. Noite dos Mascarados

(Chico Buarque)

Eu Quero é botar meu bloco na rua (Sergio Sampaio)

12. Faraó divindade do Egito

(Luciano Gomes)

13. Dandalunda

(Carlinhos Brown)

\section{DADOS ADICIONAIS:}

Músicos: Adson Santana (Guitarra), Erick Firmino (Baixo), Jorge Wallace (Percussão), Geg Patrocínio (Percussão), Marcio Diniz (Bateria), Luciano Silva (Sax, Sampler e Teclado), Adilmar Borges (Guitarra e Vocal), Jacilene Santos (Vocal) e Aline Menezes (Vocal) 
PRA VOCÊ

(2005) EMI Music 8638152

ARTISTA(S):

Margareth Menezes

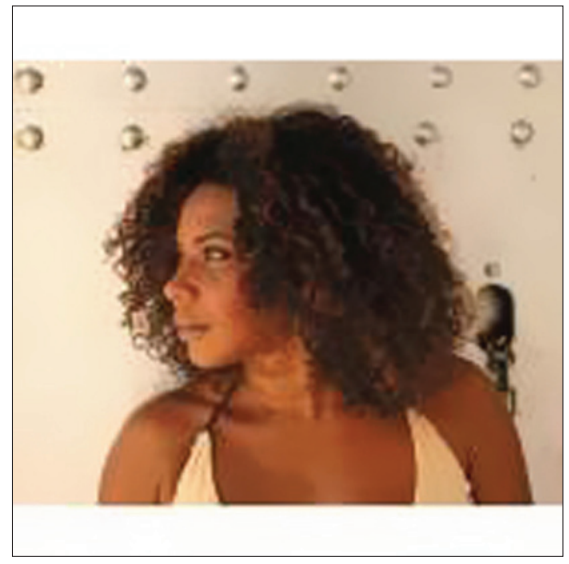

\section{FONOGRAMAS:}

\section{Como Tu}

(Carlos Vives / Carlos Ivan Medina / Adpt. Cláudio Rabello)

Participação: Ivete Sangalo

2. Versos de Amor (Manuca Almeida / Alexandre Leão)

3. Pra Você

(Saul Barbosa / Pierre Onassis)

4. Miragem na Esquina (Ton Duque / Esquisito)

5. Contra o Tempo (Vander Lee)
6. Boléia Brasil

(Margareth Menezes)

7. Só Eu e Mais Ninguém

(Margareth Menezes)

Participação: Cláudio Zoli

8. Mesmo Assim

(Fernando Noronha / Jair Luz)

9. Chame Ele

(Margareth Menezes)

10. Abanaê

(Clóvis Cruz / Alain Tavares /

Gilberto Timbaleiro) 
BRASILEIRA AO VIVO

(2006) EMI Music 3747022

ARTISTA(S):

Margareth Menezes

- CD gravado ao Vivo na Concha Acústica do Teatro Castro Alves Salvador, nos dias 3 e 4 de Agosto de 2006.

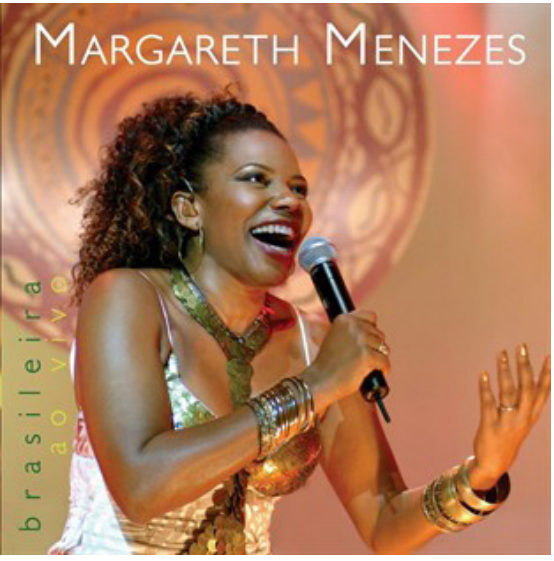

\section{FONOGRAMAS:}

1. Faraó divindade do Egito (Luciano Gomes)

2. Uma História de Ifá (Elegibô) (Ythamar Tropicália / Rey Zulu)

3. Na ponta do pé (Gilberto Timbaleiro / Clóvis Cruz)

4. Tempo Sara (Margareth Menezes)

5. Rasta Man (Fábio Alcântara / Augusto Conceição)

6. Miragem na Esquina (Tom Duque)

7. Cordeiro de Nanã (Matheus / Dadinho) Participação: Mateus Aleluia / Saul Barbosa

Deixa a Gira Girar

(Matheus / Dadinho)

Participação: Mateus Aleluia / Saul

Barbosa

Atabaque, Chora

(Matheus / Dadinho)

Participação: Mateus Aleluia / Saul

Barbosa
8. Salvador não inerte (Bobôco / Beto Jamaica) Guerrilheiros da Jamaica (Rumpilé) (Ythamar Tropicália / Roque Carvalho) Alfabeto do Negão (Ythamar Tropicália / Rey Zulu)

9. Ritmo do Coração (Gigi / Ivete Sangalo)

10. Swingue Bom (Roberto Moura / Binho Nunes)

11. Lenda Yorubá (Carlinhos Brown / Alain Tavares) Participação: Carlinhos Brown

12. A Luz de Tieta (Caetano Veloso)

13. Caminhão da Alegria (Elivandro Cuca / Fábio Alcântara / Augusto Conceição)

14. Toté de Maiangá (Saul Barbosa / Gerônimo)

\section{DADOS ADICIONAIS:}

Músicos: Adson Santana (Guitarra, Cavaquinho, Violão, Três Cubano, Sampler), Erick Firmino (Baixo, Baixolão), Jorge Wallace, Orlando Costa, Bóka e Osmar Purificação (Percussão), Allan Amaral (Bateria), Luciano Silva (Sax), João Teoria e Vanilson Lemos (Trompete), Adimar Borges (Teclado, Guitarra), André Santana (Teclado, Sanfona) e Aline Purificação, Gisley Maia, Andréa Costalima e Paulo Silva (Vocal) 
BRASILEIRA AO VIVO DVD

(2006) EMI Music 3747039

ARTISTA(S):

Margareth Menezes

- DVD gravado ao Vivo na Concha Acústica do Teatro Castro Alves Salvador, nos dias 3 e 4 de agosto de 2006.

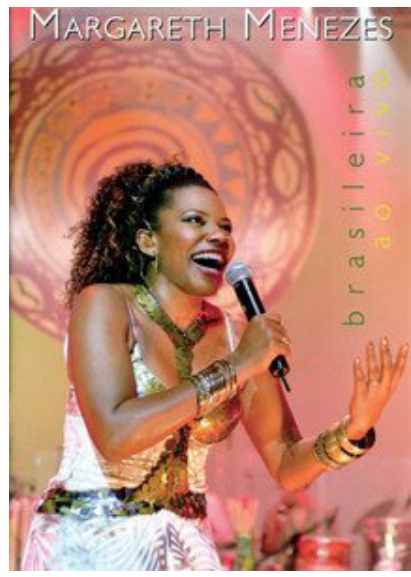

\section{FONOGRAMAS:}

1. Voz Guia

(Roberto Mendes / Jorge Portugal)

2. Faraó Divindade do Egito (Luciano Gomes)

3. Uma história de Ifá (Elegibô) (Ythamar Tropicália / Rey Zulu)

4. Na Ponta do Pé (Gilberto Timbaleiro / Clóvis Cruz)

5. Dez Poemas Diferentes (Marrom Brasileiro)

6. Tempo Sara (Margareth Menezes)

7. Rasta Man (Fábio Alcântara / Augusto Conceição / Duller)

8. Miragem na Esquina (Tom Duque / Esquisito)

9. Cordeiro de Nanã (Matheus / Dadinho) Participação: Mateus Aleluia / Saul Barbosa

\section{Deixa a Gira Girar}

(Matheus / Dadinho / Eraldo)

Participação: Mateus Aleluia / Saul Barbosa

Atabaque, Chora

(Matheus / Dadinho)

Participação: Mateus Aleluia / Saul

Barbosa

10. Salvador Não Inerte

(Bobôco / Beto Jamaica)

Guerrilheiros da Jamaica (Rumpilé)

(Ythamar Tropicália / Roque

Carvalho)

Alfabeto do Negão

(Ythamar Tropicália / Rey Zulu)

11. Povo Vem Ver

(Clóvis Cruz)

12. Ritmo do Coração

(Gigi / Ivete Sangalo)

13. Swingue Bom

(Roberto Moura / Binho Nunes) 
14. Lenda Yorubá

(Carlinhos Brown / Alain Tavares)

Participação: Carlinhos Brown

15. A Luz de Tieta

(Caetano Veloso)

16. Malê-debalê

(Edil Pacheco / Paulo César Pinheiro)

Ajeumbo

(Aloísio Menezes / Portela)

Agô do Pé

(Pepeu Gomes / Paulinho Camafeu)

17. Caminhão da Alegria

(Elivandro Cuca / Fábio Alcântara /

Augusto Conceição / Duller)

18. Toté de Maiangá

(Saul Barbosa / Gerônimo)

\section{DADOS ADICIONAIS:}

Músicos: Adson Santana (Guitarra, Cavaquinho, Violão, Três Cubano, Sampler), Erick Firmino (Baixo, Baixolão), Jorge Wallace, Orlando Costa, Bóka e Osmar Purificação (Percussão), Allan Amaral (Bateria), Luciano Silva (Sax), João Teoria e Vanilson Lemos (Trompete), Adimar Borges (Teclado, Guitarra), André Santana (Teclado, Sanfona) e Aline Purificação, Gisley Maia, Andréa Costalima e Paulo Silva (Vocal)

Direção Musical: Adson Santana. 


\section{ELLEGIBÔ (Coletânea)}

ARTISTA(S)

Margareth Menezes

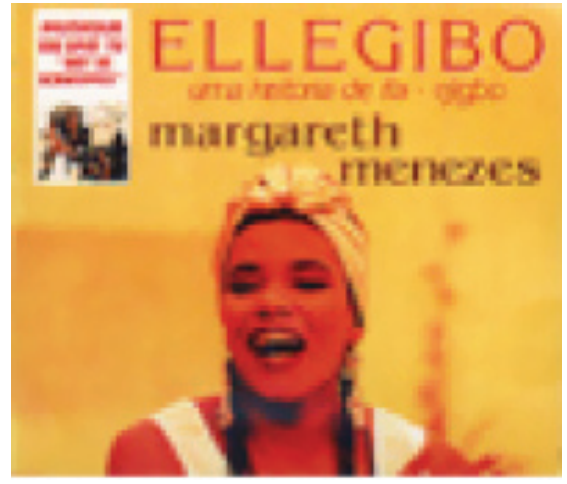

FONOGRAMAS:

1. Elegibô

2. Fé cega faca amolada

3. Paz do mundo

4. Mosca na sopa

5. Negrume da noite

6. Jet Ski

7. Negro Nagô

8. Me abraça e me beija

9. Repique romântico

10. Kindala

11. Menina Dandara

12. Vendaval temporal

13. Praga do céu

14. Samba reggae 


\section{ELEGIBO (Coletânea)}

(1990) Mango (USA) 162-539855-2

ARTISTA(S):

Margareth Menezes

- Coletânea para o mercado americano, produzida por David Byrne, que reúne seus dois primeiros discos "Margareth Menezes", de 1988 e "Um Canto Pra Subir", de 1990

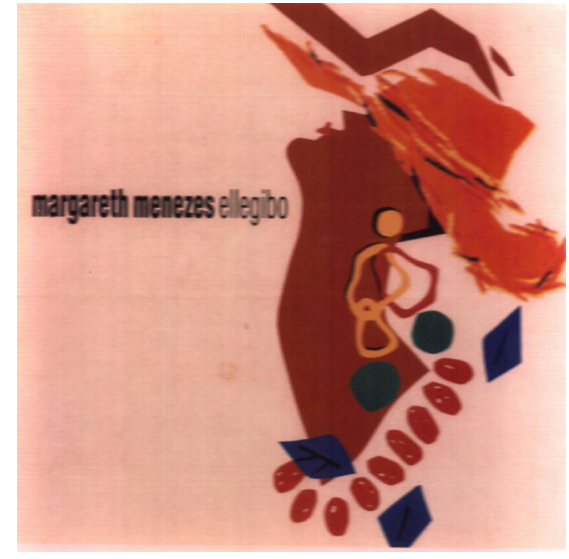

\section{FONOGRAMAS:}

1. Elegibô (Uma História de Ifá)

2. Tenda do Amor (Magia)

3. Negra Melodia

4. Natureza Mãe

5. Marmelada (Bas Moin Laia)

6. Abra a Boca e Feche os Olhos

7. Hino das Águas

8. Alegria da Cidade

9. Ifá Um Canto Pra Subir

10. Tudo à Toa

11. Maravilha Morena

12. Muzenza 
NATURALMENTE

(2008) MZA

Margareth Menezes

ARTISTA(S):

Margareth Menezes

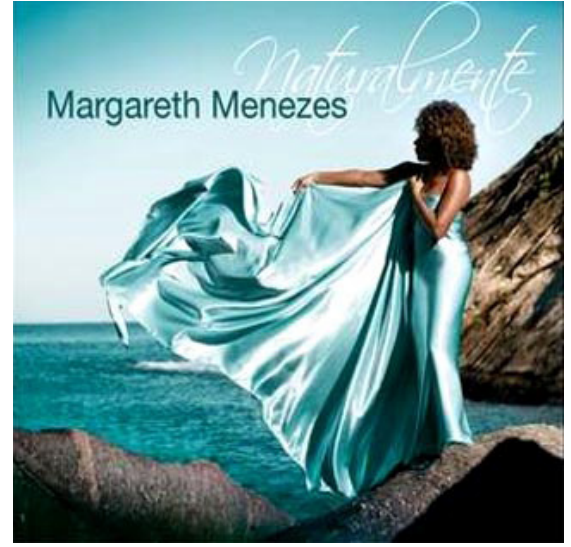

FONOGRAMAS:

1. Mulher de Coronel

(Part. especial: Gilberto Gil )

2. Gente

(Arnaldo Antunes, Marisa Monte e Pepeu Gomes)

3. Cego do Castelo (Nando Reis)

4. Porque Você Não Vem Morar Comigo ?

(Chico Cesar)

5. Lua No Mar

(Margareth Menezes e Robson Costa)

\section{Abuso de Poder}

(Marquinho PQD e Carlito

Cavalcante)

7. O Perdão

(J. Veloso e Roberto Mendes)

8. Febre

(Zeca Baleiro e Lúcia Santos)

9. Matança

(Jatobá)

10. Foi Deus Quem Fez Você (Zé Ramalho)

11. Um Caso a Mais

(Part. especial: Luis Represas) 
Ivete Sangalo: discografia 
IVETE SANGALO

(1999) Universal Music 546 255-2

ARTISTA(S):

Ivete Sangalo

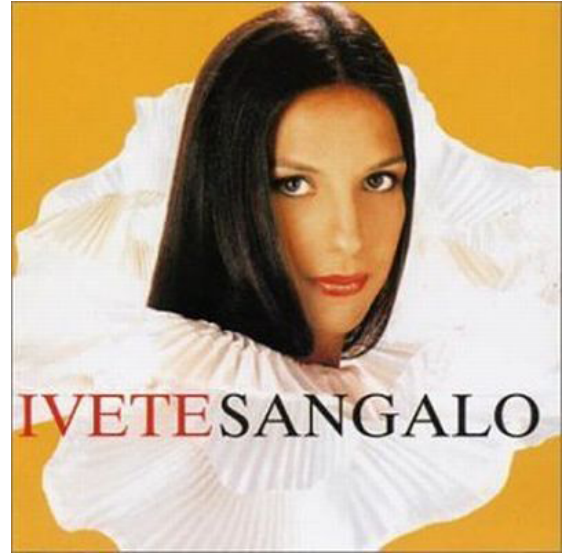

FONOGRAMAS:

1. Canibal (Ivete Sangalo)

2. Tá Tudo Bem (Alexandre Pires)

3. 100 o Seu Amor

(Carlinhos Brown / Luis Caldas)

4. Música Pra Pular Brasileira (Davi Salles)

5. Monsieur Samba (Gal Sales / Jamoliva)

6. Medo De Amar (Ivete Sangalo) Participação: Ed Motta

7. Eternamente (Davi Salles)
8. Tô Na Rua

(Gal Sales / Xexéu II)

9. Chuva De Flor (Marquinhos Carvalho)

10. Tenho Dito (João Bosco)

11. Destino (Gal Sales / Jamoliva)

12. Sá Marina (Antônio Adolfo / Tibério Gaspar)

13. Se Eu Não Te Amasse Tanto Assim (Herbert Viana / Paulo Sergio Valle)

14. Bota Pra Ferver (Durval Lelys) 


\section{BEAT BELEZA}

(2000) Universal Music 60121593902

ARTISTA(S):

Ivete Sangalo

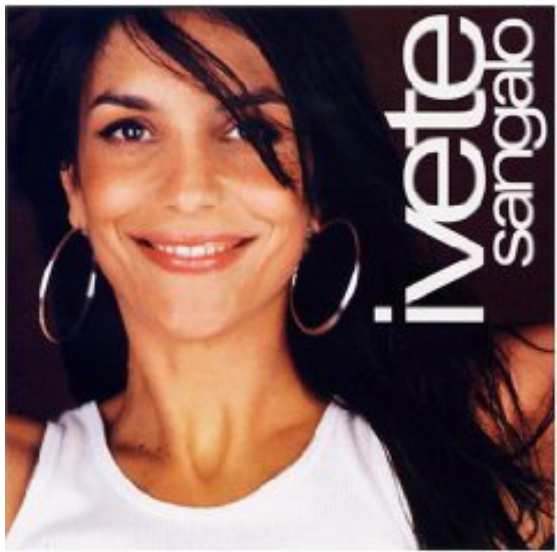

\section{FONOGRAMAS:}

1. Me Deixe Em Paz (Can You Read My Mind)

(B. McKnight / B. Barnes / J. Lorber / Vs. Ivete Sangalo)

2. Tanta Saudade (Djavan / Chico Buarque)

3. Pererê (Augusto Conceição / Chiclete)

4. Rosa Roseira

(Alain Tavares / Gilson Babilônia) Lambada Da Delícia (Gerônimo / Bego)

5. Bug, Bug, Bye, Bye (Augusto Conceição / Chiclete / Rayala)

6. A Lua Que Eu Te Dei (Herbert Viana)

7. Balanço Black (Chiclete / Cassiano / André Fanzine) Participação: Gilberto Gil
8. Postal

(Cassiano)

9. Beat Beleza

(Boghan Costa / Ruben Tavares)

10. Vira, Vira

(Pierre Onassis / Paulo Jorge / Gal Sales / Roberto Ramos)

11. Quer Que Eu Vá (Léo Bit Bit / João Paulo / Juliana Montal)

12. Meu Abraço (Ivete Sangalo / Marquinhos Carvalho)

13. Romance Muito Louco (Jamoliva / Silvio Almeida / Joccylee)

14. Empurra-empurra (Alain Tavares / Gilson Babilônia) 


\section{FESTA}

(2001) Universal Music 04400162852

ARTISTA(S):

Ivete Sangalo

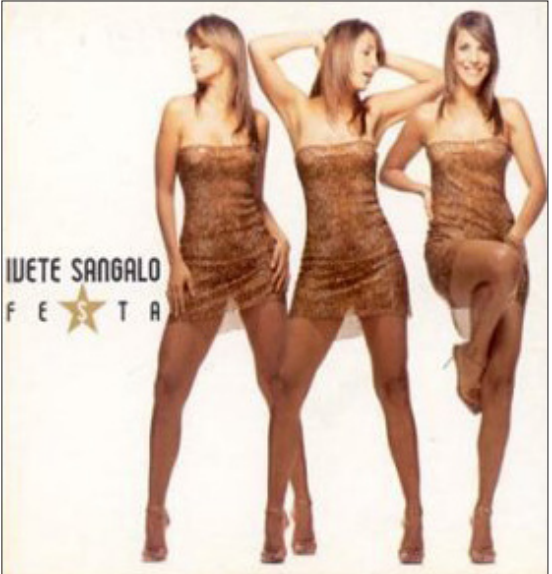

FONOGRAMAS:

1. Ruas E Rios

(Ramon Cruz)

2. Festa

(Anderson Cunha)

3. Astral

(Gustavo di Dalva / Cláudio Martins)

4. Penso

(Gigi / Fábio O'Brian)

5. Meu Maior Presente (Ramon Cruz)

6. E Tudo Mais (Nando Reis)

7. O Grande Chefe

(Chiclete / André Fanzine / Cassiano Faleta)
8. Tum, Tum, Goiaba

(Leonardo Reis / Márcio Brasil)

9. Aqui Vai Rolar (Leonardo Reis / Peu Meurrahy)

10. Pop Zen

(Alexandre Leão / Manuca Almeida / Lalado)

11. Em Mim, Em Você (Ivete Sangalo / Gigi)

12. Assimétrica (Gilberto Gil)

13. Narizinho (Ivan Lins / Vitor Martins)

14. Back At One (Brian McKnight / Vrs. Ivete Sangalo) 


\section{CLUBE CARNAVALESCO INOCENTES EM PROGRESSO}

(2003) Universal Music 60249808705

\section{ARTISTA(S):}

Ivete Sangalo

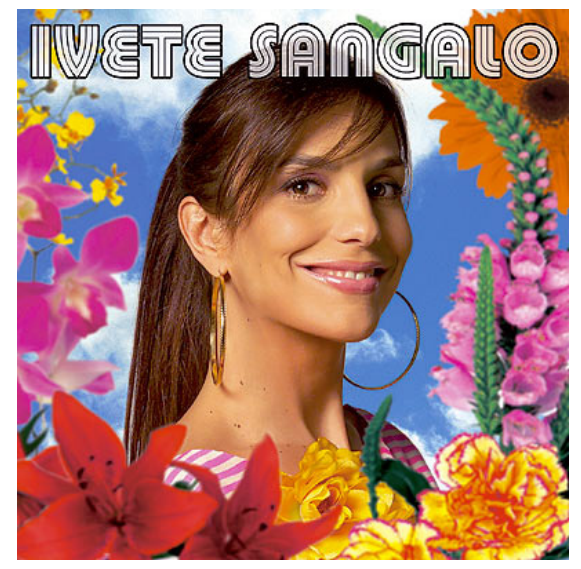

\section{FONOGRAMAS:}

1. Brasileiro (Augusto Conceição / Duller / Fábio Alcântara)

2. Rítmo Gostoso

(Alain Tavares / Gilson Babilônia)

3. Sorte Grande (Lourenço)

4. Verdadeiro Carnaval (Davi Moraes / Quito Ribeiro / Pedro Baby / Betão Aguiar / Ciça Morais)

5. Só Pra Me Ver (Ivete Sangalo)

6. Pan-americana (Betão Aguiar / Ari Morais / Fefê Gurman)

7. Faz Tempo (Gigi / Fabinho O'Brian)

\section{Retratos E Canções}

(Michael Sullivan / Paulo Massadas)

9. Devagar E Sempre (Gigi / Rudnei Monteiro)

10. Vai Dar Certo (Peu Meurray / Leonardo Reis)

11. Azul Da Moda (Ivete Sangalo / Ari Morais)

12. Você E Eu, Eu E Você (Juntinhos) (Tim Maia)

13. Natural Collie (F. McGregor / Smith)

14. Somente Eu E Você (Moonglow) (W. Hudson / E. Delange / I. Mills / Vrs. Dudu Falcão) 


\section{MTV AO VIVO - IVETE SANGALO}

(2004) Universal Music 60249816564

\section{ARTISTA(S):}

Ivete Sangalo

- Gravado ao Vivo no Estádio da Fonte Nova - Salvador, no dia 23 de dezembro de 2003

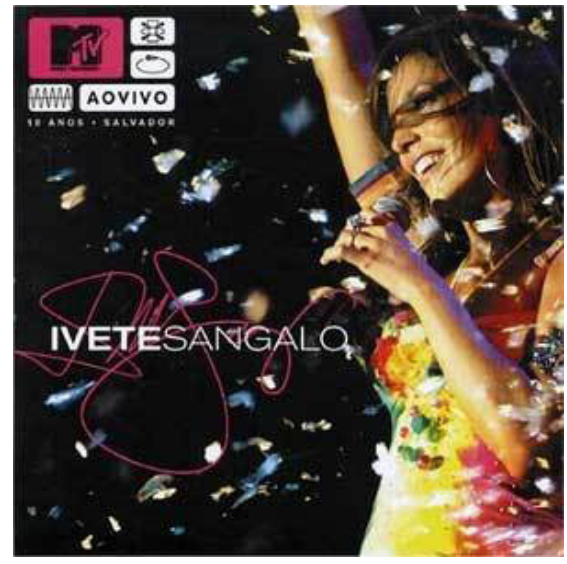

\section{FONOGRAMAS:}

1. Eva

(Giancarlo Bigazzi / Umberto Tozzi /

Marcos Ficarelli)

Alô Paixão

(Jorge Xaréu)

Beleza Rara

(Ed Grandão)

2. Vem Meu Amor

(Silvio / Guio)

Nossa Gente (Avisa Lá)

(Roque Carvalho)

3. Flor Do Reggae

(Ivete Sangalo / Gigi / Fabinho O'Brian)

4. Carro Velho

(Ivete Sangalo / Ninha)

5. Tô Na Rua

(Gal Sales / Xexéu II)

6. Empurra-empurra

(Alain Tavares / Gilson Babilônia)

7. Céu Da Boca

(Reinaldo Marcel)

Participação: Gilberto Gil

8. Chica Chica Boom Chic

(Harry Warren Mack Gordon)
9. Só Pra Me Ver

(Ivete Sangalo)

10. Sorte Grande

(Lourenço)

11. Festa

(Anderson Cunha)

12. Astral

(Gustavo di Dalva / Cláudio Martins)

Participação: Davi Moraes

13. Faz Tempo (Gigi / Fabinho O'Brian)

14. A Lua Que Eu Te Dei (Herbert Viana)

15. Se Eu Não Te Amasse Tanto Assim (Herbert Viana / Paulo Sergio Valle) Participação: Sandy

16. De Ladinho (Léo Bit Bit / Gustavo di Dalva / Boghan)

17. Pererê (Augusto Conceição / Chiclete)

18. Canibal

(Ivete Sangalo)

\section{DADOS ADICIONAIS:}

Músicos: Gigi (Baixo), Toinho Batera (Bateria), Juninho Costa e Rudney Monteiro (Guitarra), Radamés Venâncio (Teclados), Márcio Brasil, Cara de Cobra, Fabinho O'Brian, Du e Jó (Percussão), Letieres Leite (Sax, Flauta), Ferreirinha (Trombone), Guiga Scott (Trompete, Flugel, Vocal) e Marya Bravo, Juju Gomes e Patrícia Sampaio (Coro) 


\section{MTV AO VIVO - IVETE SANGALO}

(2004) Universal Music 60249816565

\section{ARTISTA(S):}

Ivete Sangalo

- Gravado ao Vivo no Estádio da Fonte Nova - Salvador, no dia 23 de dezembro de 2003

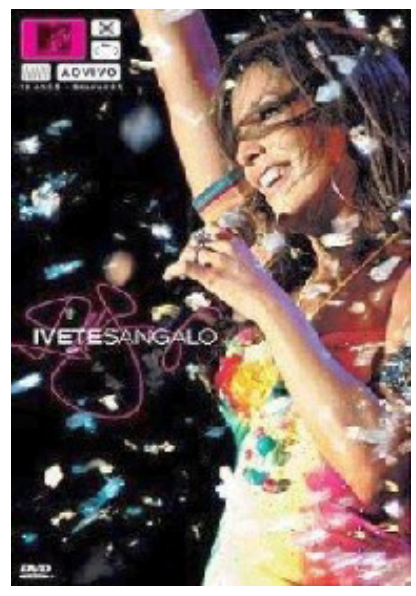

\section{FONOGRAMAS:}

1. Abertura

Eva

(Giancarlo Bigazzi / Umberto Tozzi / Marcos Ficarelli)

Alô Paixão

(Jorge Xaréu)

Beleza Rara

(Ed Grandão)

2. Vem Meu Amor

(Silvio / Guio)

Nossa Gente (Avisa Lá)

(Roque Carvalho)

3. De Ladinho

(Léo Bit Bit / Gustavo di Dalva / Boghan)

4. Arerê

(Alain Tavares / Gilson Babilônia)

Participação: Tatau

5. Carro Velho (Ivete Sangalo / Ninha)

6. Tô Na Rua (Gal Sales / Xexéu II)

7. Empurra-empurra (Alain Tavares / Gilson Babilônia)

8. Chica Chica Boom Chic (Harry Warren Mack Gordon)

\section{Pan-americana}

(Betão Aguiar / Ari Morais / Fefê

Gurman)

Participação: Daniela Mercury

10. Chão da Praça

(Moraes Moreira)

Participação: Margareth Menezes

11. Sorte Grande

(Lourenço)

12. Festa

(Anderson Cunha)

13. Astral

(Gustavo di Dalva / Cláudio Martins)

Participação: Davi Moraes

14. Só Pra Me Ver

(Ivete Sangalo)

15. Ilê Ayê

(Paulinho Camafeu)

Participação: Gilberto Gil

16. Céu Da Boca

(Ronaldo Marcell)

Participação: Gilberto Gil

17. Faz Tempo

(Gigi / Fabinho O'Brian)

18. A Lua $Q$ Eu Te Dei

(Herbert Viana) 
19. Se Eu Não Te Amasse Tanto Assim

(Herbert Viana / Paulo Sergio Valle)

Participação: Sandy

20. Desperdiçou

(Liah / Dani Monaco / Rique

Azevedo)

Participação: Sandy e Júnior

21. Coleção

(Cassiano / Paulo Zdanowski)

22. Flor Do Reggae

(Ivete Sangalo / Gigi / Fabinho

O'Brian)

23. Pererê

(Augusto Conceição / Chiclete)

24. Canibal

(Ivete Sangalo)

25. Levada Louca

(Gilson Babilônia / Lula Carvalho /

Alain Tavares)

\section{DADOS ADICIONAIS:}

Músicos: Gigi (Baixo), Toinho Batera (Bateria), Juninho Costa e Rudney Monteiro (Guitarra), Radamés Venâncio (Teclados), Márcio Brasil, Cara de Cobra, Fabinho O'Brian, Du e Jó (Percussão), Letieres Leite (Sax, Flauta), Ferreirinha (Trombone), Guiga Scott (Trompete, Flugel, Vocal) e Marya Bravo, Juju Gomes e Patrícia Sampaio (Coro)

Legendas: Português, Inglês, Espanhol e Cifras. 


\section{AS SUPER NOVAS}

(2005) Universal Music 60249885448

ARTISTA(S):

Ivete Sangalo

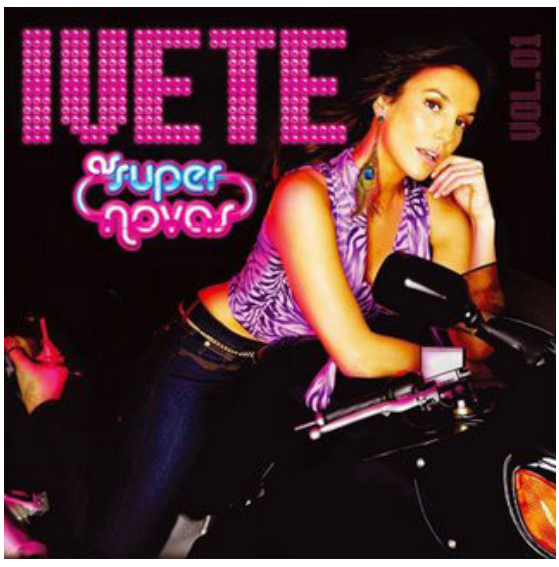

\section{FONOGRAMAS:}

1. Abalou (Gigi)

2. Poder (Ivete Sangalo / Gigi / Radamés)

3. Pra Sempre Ter Você (Eva Cavalcante)

4. A Galera (Augusto Conceição / Fábio Alcântara / Elivandro Cuca / Rayala / Sá Trindade)

5. Eh! Maravilha (Gigi)

6. Zum Zum $\hat{E}$ (Augusto Conceição / Fábio Alcântara / Elivandro Cuca) Participação: Carlinhos Brown

\section{Cadê Você?}

(Márcio Brasil)

8. Quando A Chuva Passar (Ramon Cruz)

9. Na Bahia (Ivete Sangalo / Gigi)

10. Mega Beijo (Lourenço)

11. Soy Loco Por Ti América (Gilberto Gil / Capinan)

12. Chorando Se Foi

(Ulisses Hermosa / Gonzalo Hermosa / Vrs. José Ari / Vrs. Márcia Freire)

Ao Vivo 


\section{MULTISHOW AO VIVO - IVETE NO MARACANÃ}

(2007) Universal Music 60251720826

ARTISTA(S):

Ivete Sangalo

- Gravado ao vivo no Estádio do Maracanã - Rio de Janeiro, no dia 16 de dezembro de 2006

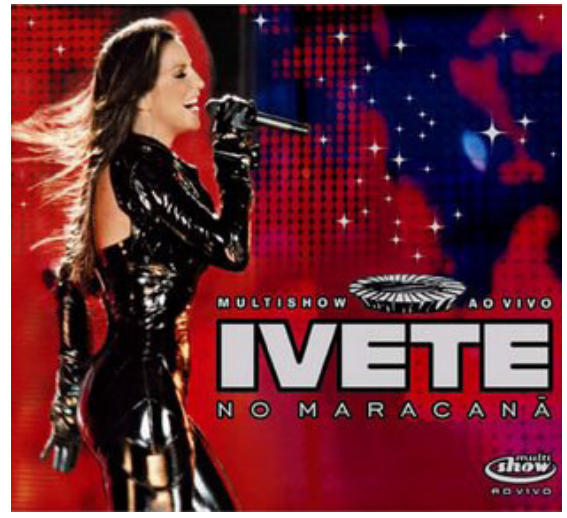

\section{FONOGRAMAS:}

1. Pot-pourri:

Never Gonna Give You Up

(Kenneth Gamble / Leon Huff / Jerry

Butler)

Abalou

(Gigi)

2. Não Quero Dinheiro (Só Quero

Amar)

(Tim Maia)

3. Berimbau Metalizado

(Dória / Miro Almeida / Duller)

4. Corazon Partio

(Alejandro Sanz)

Participação: Alejandro Sanz

5. Ilumina

(Sergio Passos / Jorge Papapá / Edu Casanova)

6. Não Me Conte Seus Problemas (Ivete Sangalo / Camila San Galo)

7. Não Precisa Mudar

(Gigi / Saulo Fernandes)

Participação: Saulo Fernandes

\section{A Galera}

(Augusto Conceição / Fábio

Alcântara / Elivandro Cuca / Rayala / Sá Trindade)

9. Dengo de Amor

(Ivete Sangalo / Ramon Cruz)

10. Chorando Se Foi (Llorando Se Fue) (Ulisses Hermosa / Gonzalo Hermosa

/ Márcia Ferreira / José Ari)

Preta

(Beto Barbosa)

11. Bota Pra Ferver

(Durval Lelys)

Participação: Durval Lelys

12. Quando a Chuva Passar

(Ramon Cruz)

13. Deixo

(Sergio Passos / Jorge Papapá)

14. Não Vou Ficar

(Tim Maia)

Participação: Samuel Rosa 
15. Nosso Sonho

(MC Buchecha)

Participação: MC Buchecha

Conquista

(MC Buchecha)

Participação: MC Buchecha

Poder

(Ivete Sangalo / Gigi / Radamés

Venâncio)

Participação: MC Buchecha

16. País Tropical

(Jorge Ben "Jorge Benjor")

Arerê

(Gilson Babilônia / Alain Tavares)

Taj Mahal

(Jorge Ben "Jorge Benjor")

17. Completo

(Ivete Sangalo / Gigi)

Faixa bônus gravada em estúdio

\section{DADOS ADICIONAIS:}

Músicos: Radamés Venâncio (Teclados, Piano), Gigi (Baixo), Juninho Costa (Guitarra), Toinho Batera (Bateria), Letieres Leite (Sax, Flauta), Gilberto Júnior (Trompete), Ferreirinha (Trombone), Márcio Brasil, Gustavo Di Dalva, Fabinho O'Brian, Cara de Cobra (Percussão), Patrícia Sampaio, Tito Bahiense, Danilo Back (Coro). 


\section{SE EU NÃO TE}

AMASSE TANTO ASSIM (Coletânea)

(2002) Universal Music 044001735028

ARTISTA(S):

Ivete Sangalo

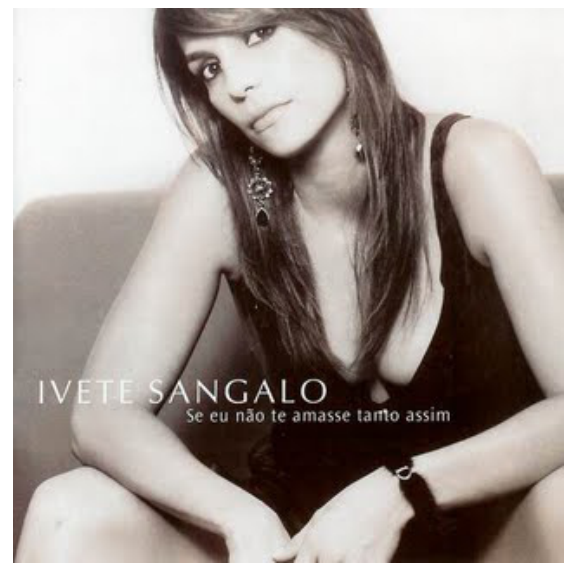

FONOGRAMAS:

1. Se Eu Não Te Amasse Tanto Assim

2. A Lua Que Eu Te Dei

3. Coleção

4. Back At One

5. Frisson

6. Medo De Amar

7. Meu Abraço

8. Fullgás Ao Vivo

9. O Sal Da Terra

10. Em Mim, Em Você

11. Postal

12. Por Causa De Você, Menina

13. Meu Maior Presente

14. Loucuras De Uma Paixão 


\section{A CASA AMARELA}

(2008) Universal Music

$\operatorname{ARTISTA(S):~}$

Veveta e Saulinho

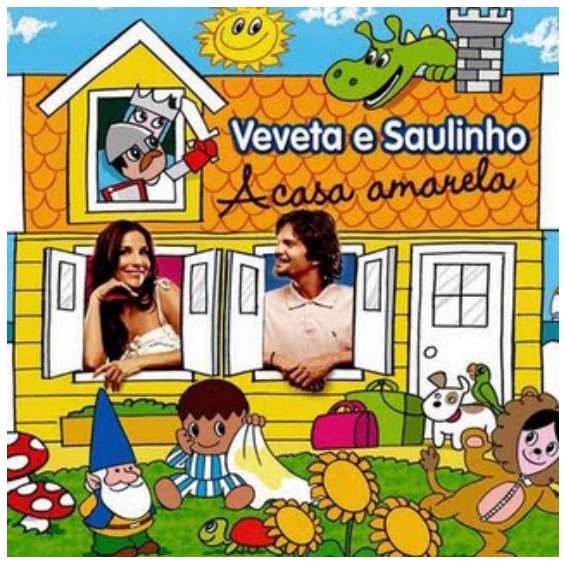

\section{FONOGRAMAS}

1. Bicho

2. Fantasia

3. Fruru

4. A Casa Amarela

5. Mundo de Lela

6. Sensacional

7. É Bom Viajar

8. Funk do Xixi

9. Maria Flor

10. Sono

Participação Especial: Xuxa

11. Enfim Vencer 
PODE ENTRAR

(2009) Universal Music

ARTISTA (S):

Ivete Sangalo

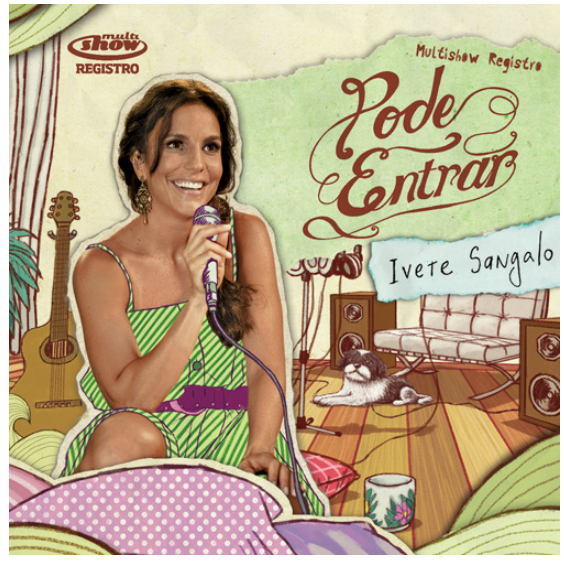

\section{FONOGRAMAS:}

CD

1. Balakbak

2. Cadê Dalila

3. Teus Olhos

Part. Esp.: Marcelo Camelo

4. Agora Eu Já Sei

5. Brumário

Part. Esp.: Lulu Santos

6. Meu Segredo

7. Completo

Part. Esp.: Monica de San Galo

8. Eu Tô Vendo

9. Na Base do Beijo

10. Sintonia e Desejo

Part. Esp.: Aviões do Forró

11. Oba Oba

12. Viver com Amor

13. Vale Mais Part. Esp.: Saulo Fernandes

14. Meu Maior Presente

15. Quanto ao Tempo Part. Esp: Carlinhos Brown

16. Muito Obrigado Axé Part. Esp.: Maria Bethânia

17. Não Me Faça Esperar
DVD

1. Balakbak

2. Eu to Vendo

3. Brumário Part. Esp.: Lulu Santos

4. Agora eu Já Sei

5. Teus Olhos Part. Esp.: Marcelo Camelo

6. Meu Maior Presente

7. Completo Part. Esp.: Monica de San Galo

8. Na Base do Beijo

9. Cadê Dalila

10. Sintonia e Desejo Part. Esp.: Aviões do Forró

11. Oba Oba

12. Viver com Amor

13. Vale Mais Part. Esp.: Saulo Fernandes

14. Quanto ao Tempo Part. Esp: Carlinhos Brown

15. Muito Obrigado Axé Part. Esp.: Maria Bethânia

16. Fã

17. Não me Faça Esperar 
Formato $18 \times 25 \mathrm{~cm}$

Tipografia Chaparral Pro e Syntax LT

Papel Alcalino $80 \mathrm{~g} / \mathrm{m}^{2}$ (miolo)

Cartão Supremo $250 \mathrm{~g} / \mathrm{m}^{2}$ (capa)

Impressão Setor de reprografia da EDUFBA

Capa e acabamento Cartograf

Tiragem 500 exemplares 